\title{
مذذاكرات زنسو
}

48

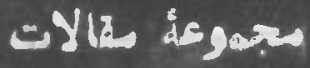

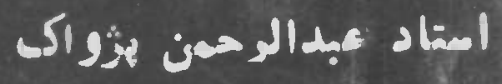

كمل

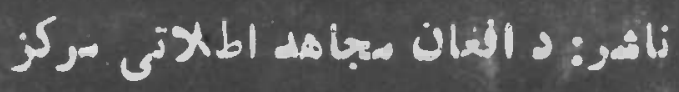

1 Fั4. 


$$
\begin{aligned}
& \text { hLal/ Yrbl } \\
& \text { 7" : }
\end{aligned}
$$

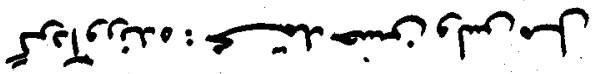

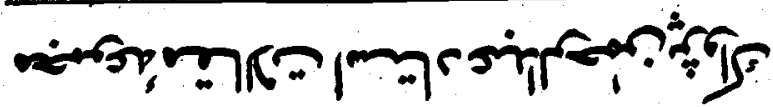
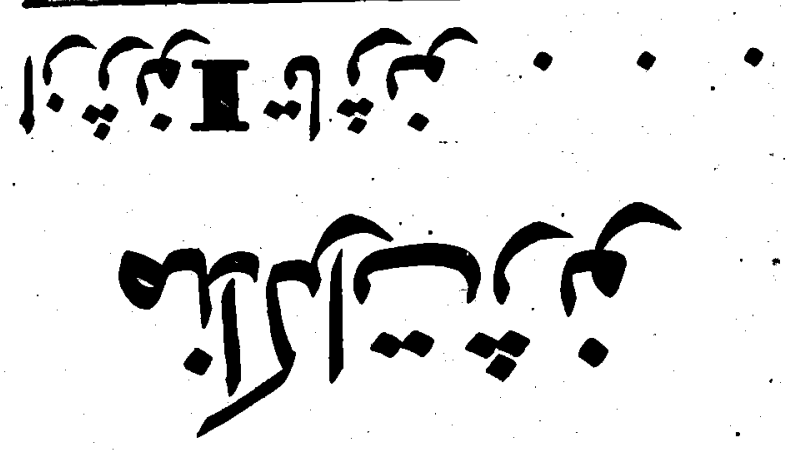


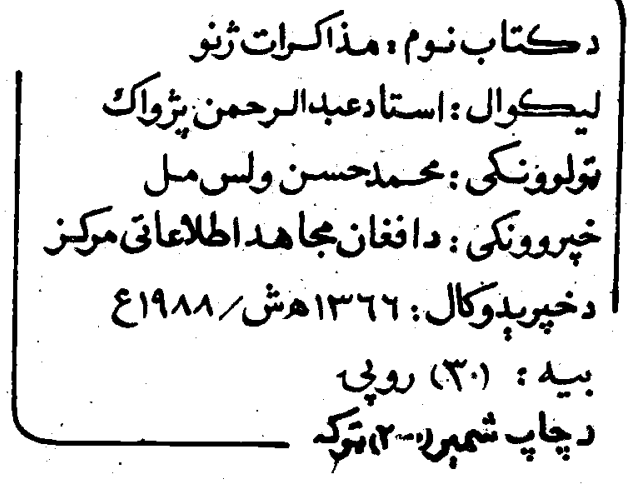




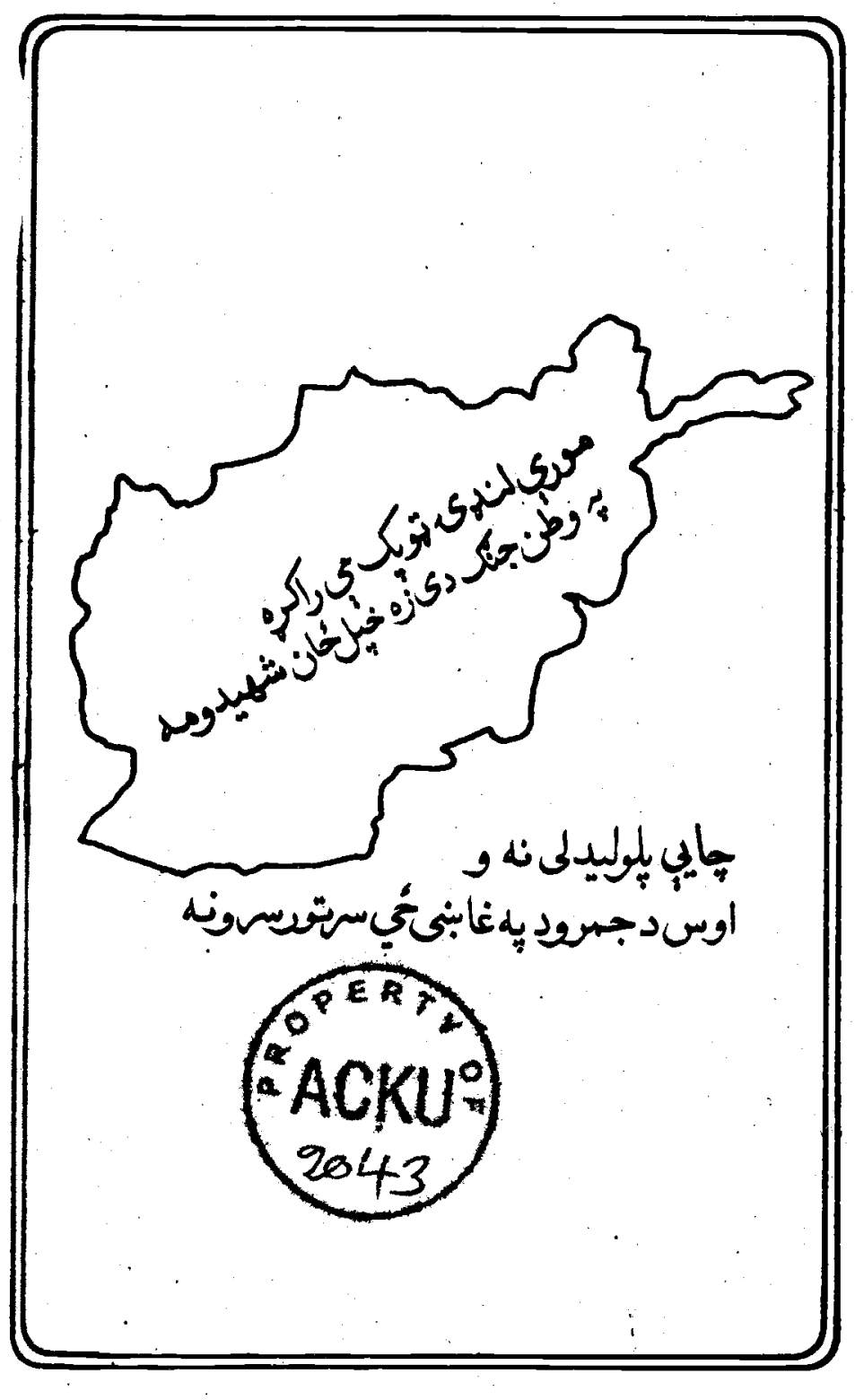




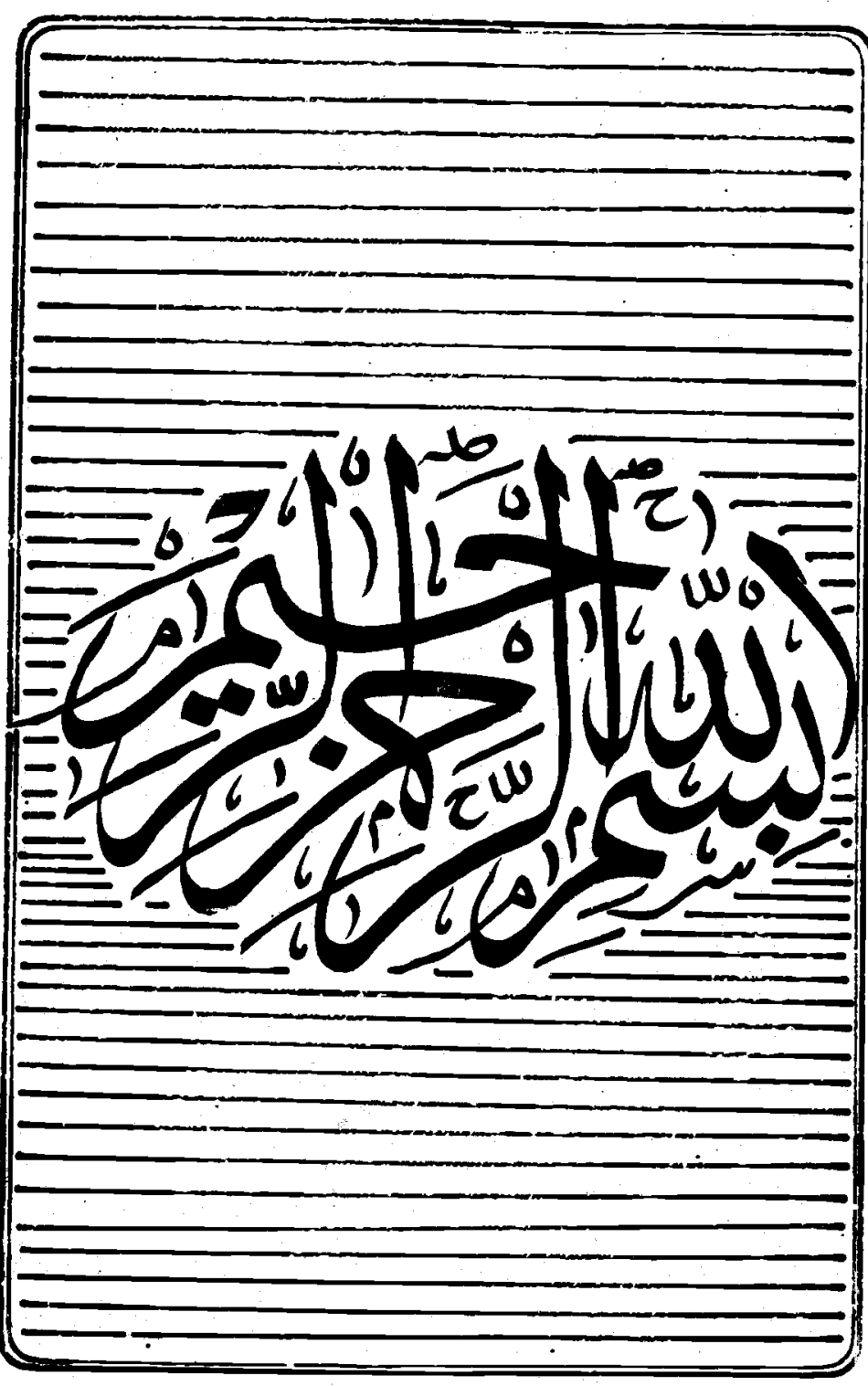




\section{مترنوخندو سونو!}

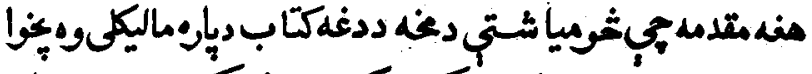

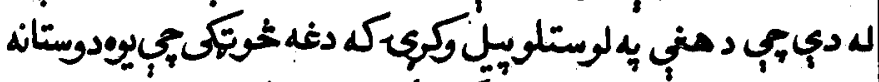

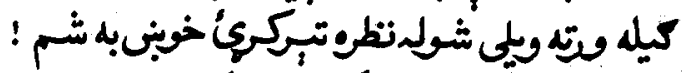

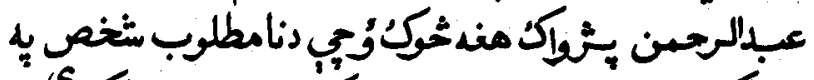

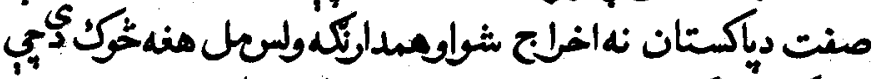

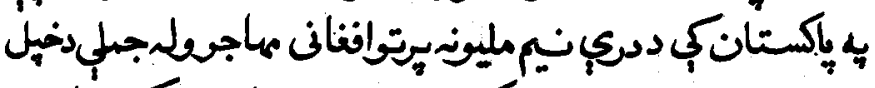

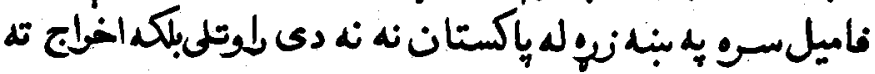

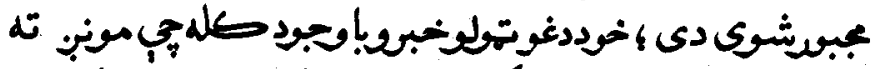

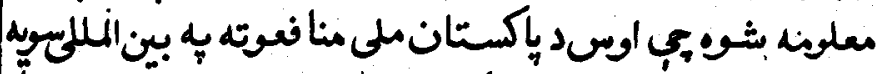

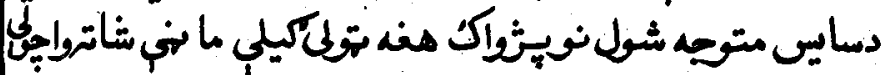

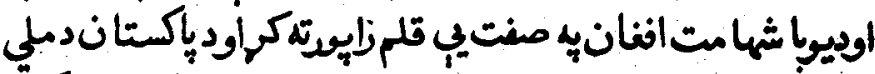

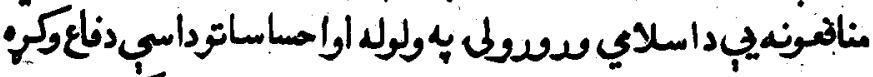

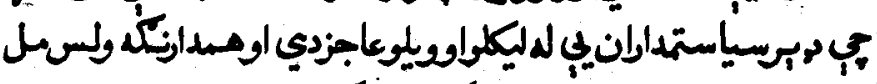

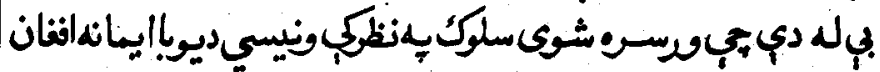

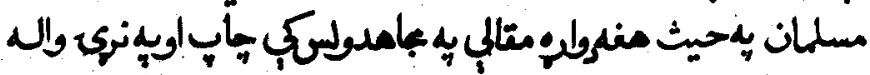

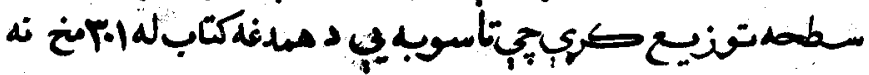

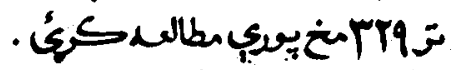

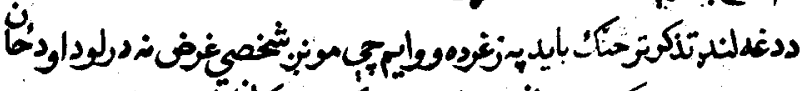

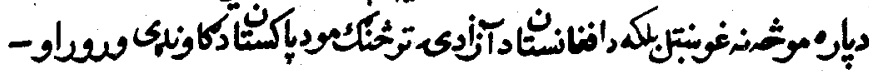

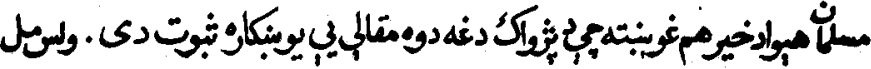
AV-I.-TV 


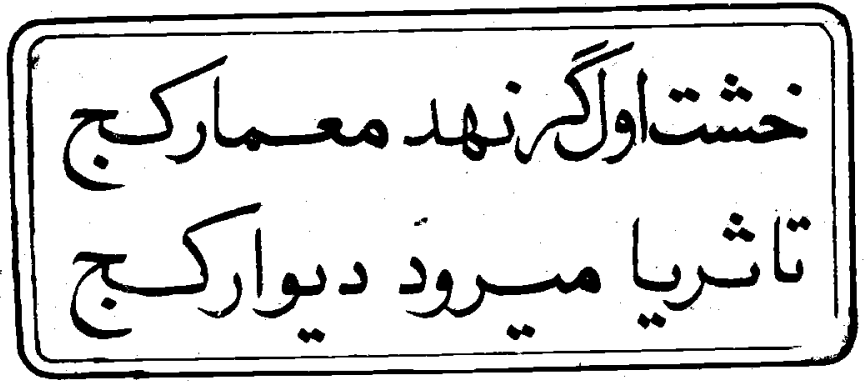

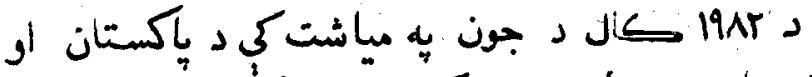

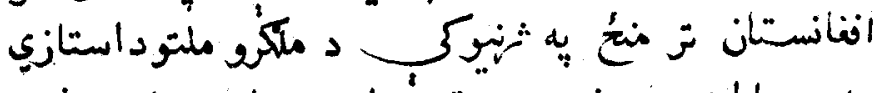

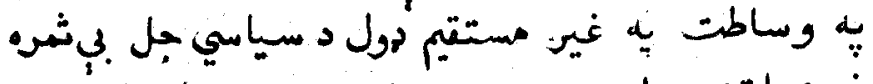

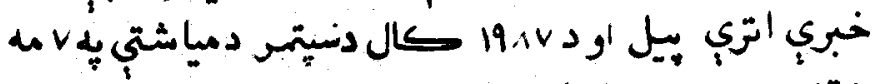

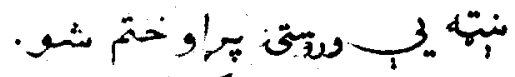

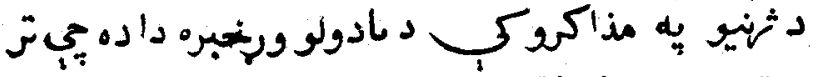

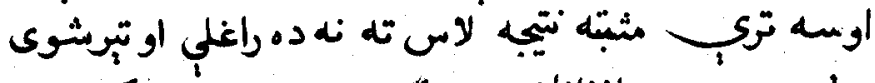

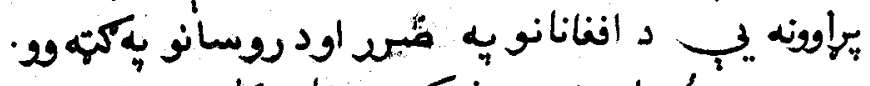

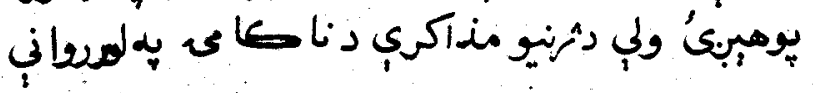




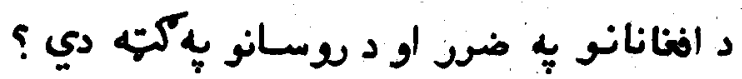

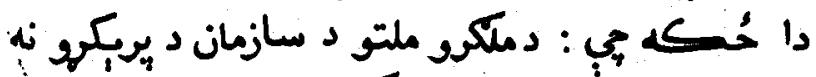
د مذا كک

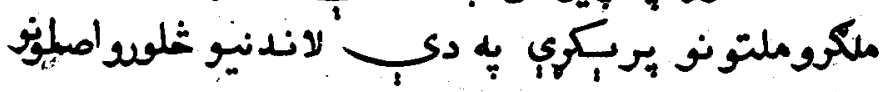

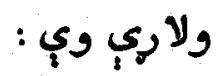

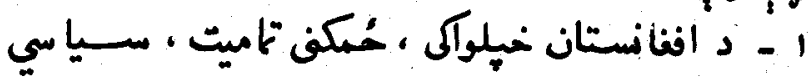

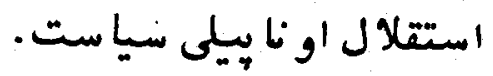

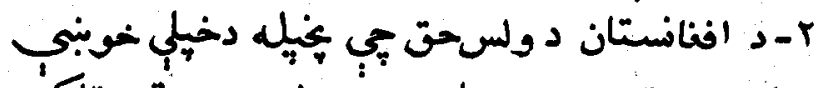

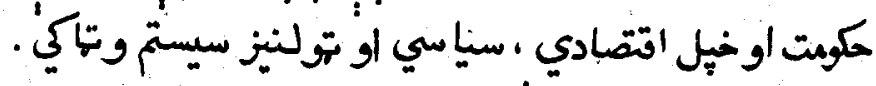

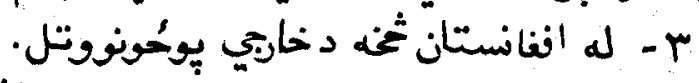

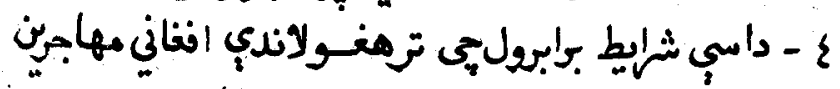

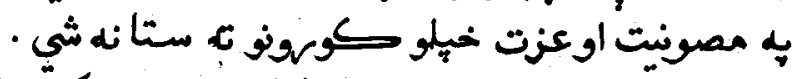

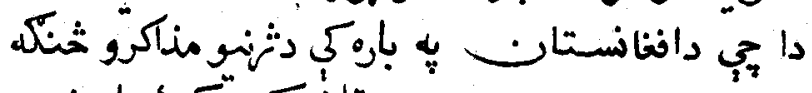

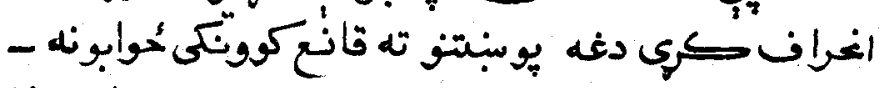

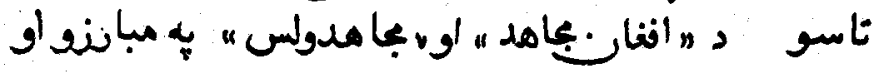

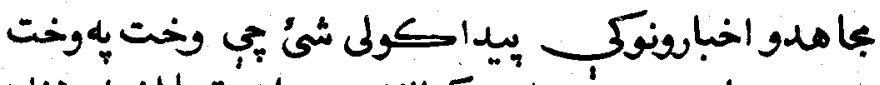

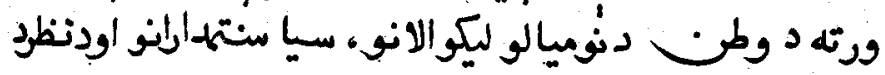

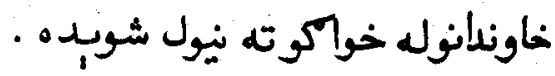

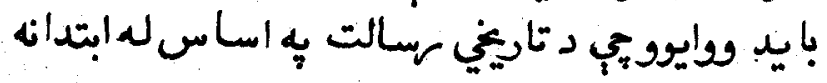

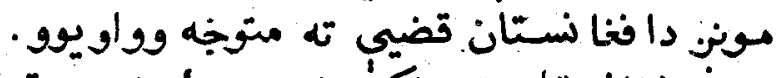

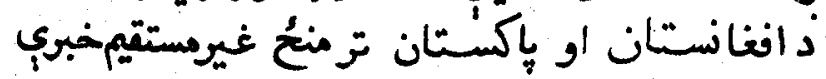




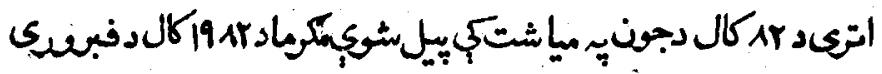

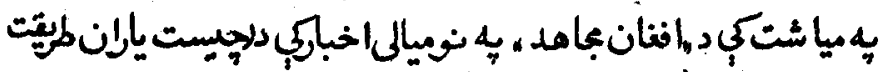

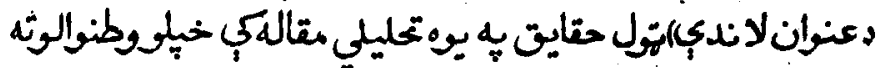

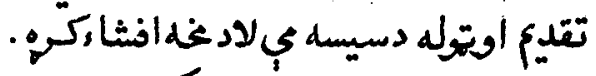

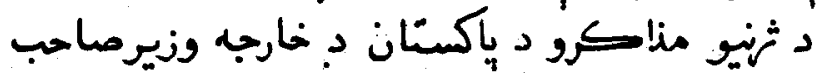

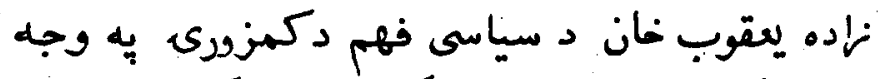

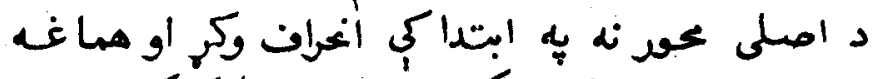

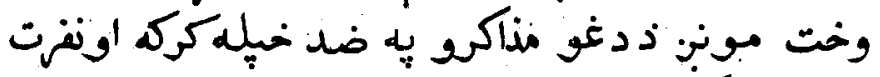

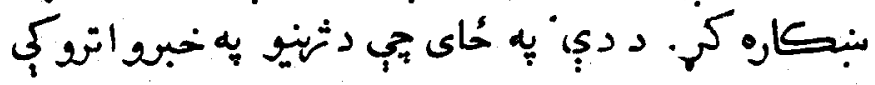

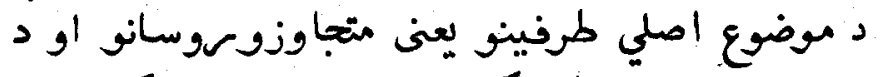

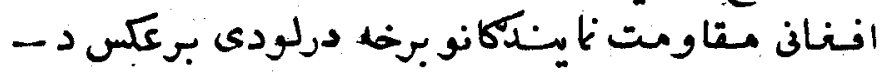

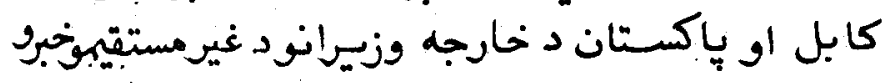

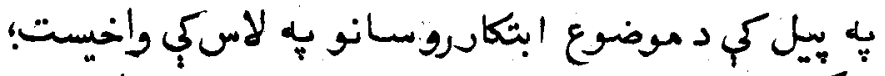

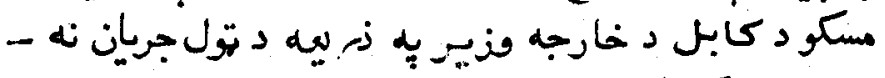

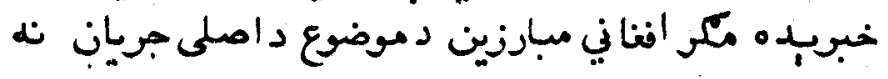

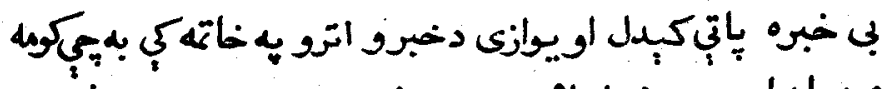

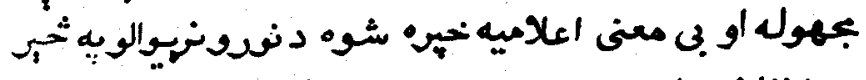

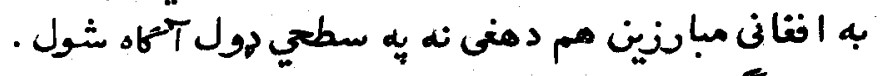

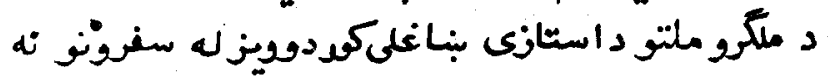

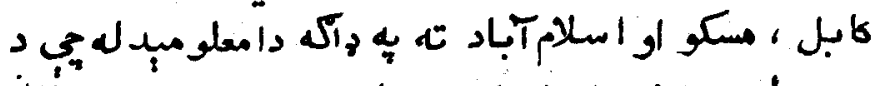

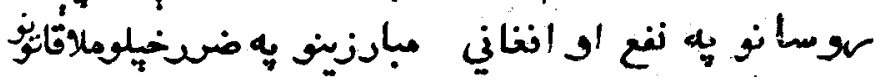




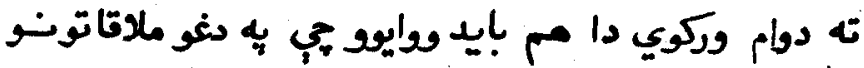

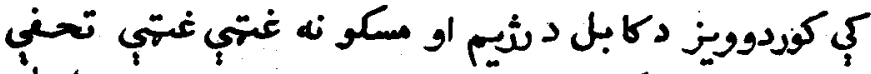

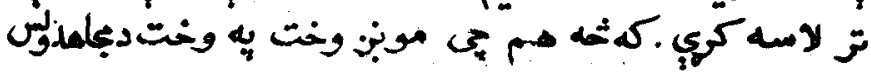

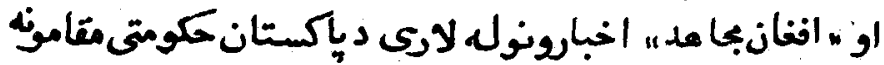

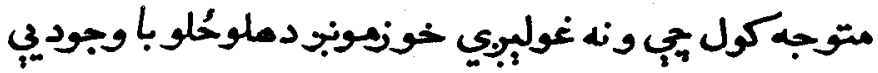

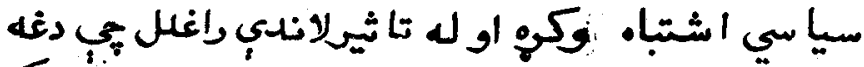

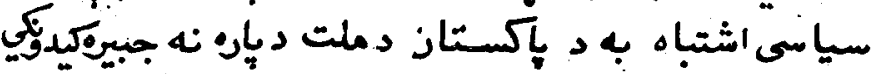

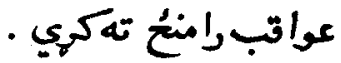

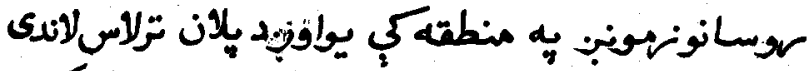

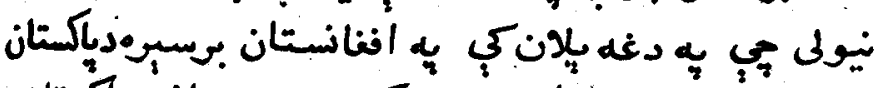

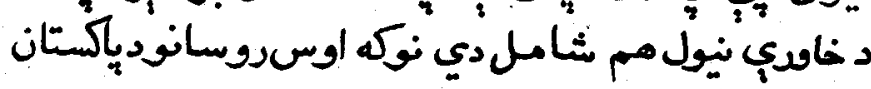

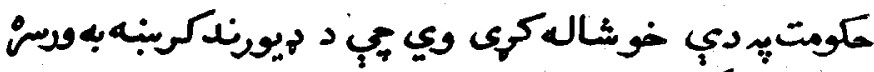

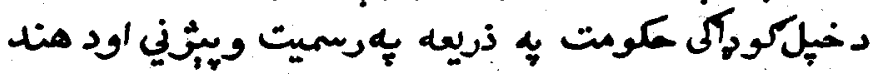

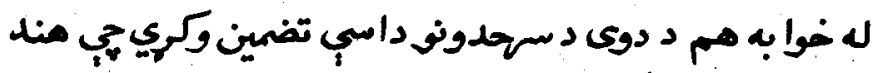

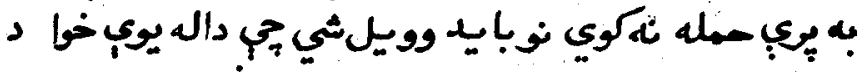

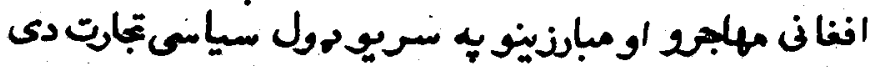

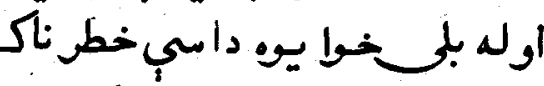

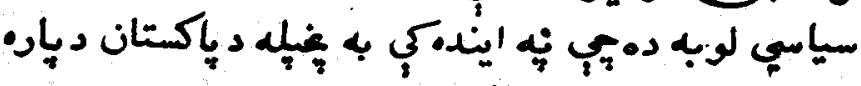

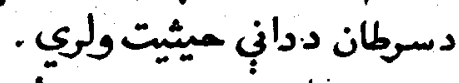

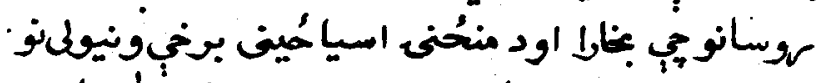

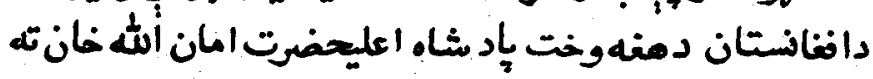




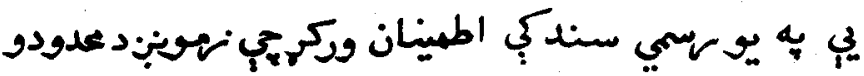

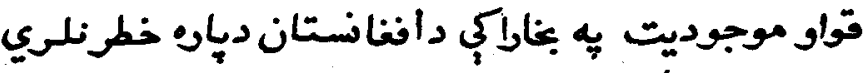

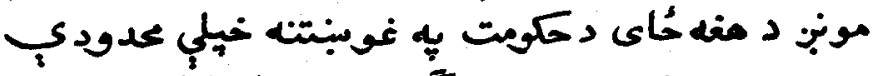

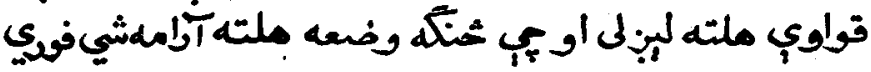

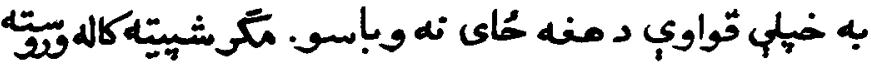

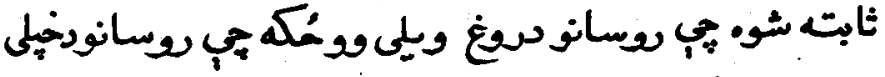

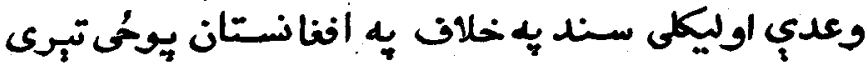

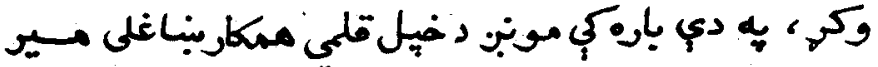

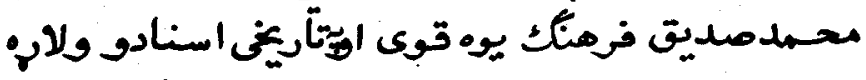

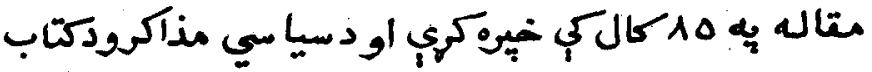

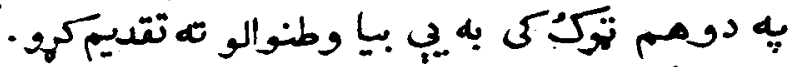

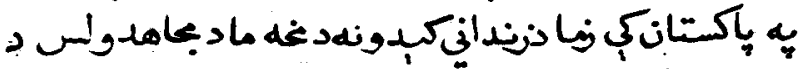

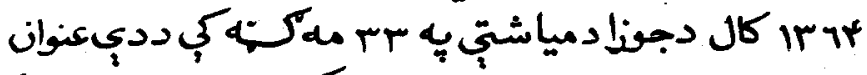

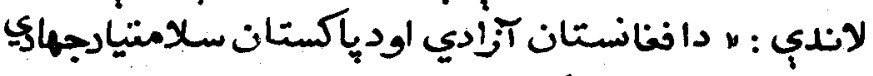

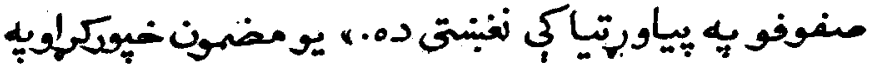

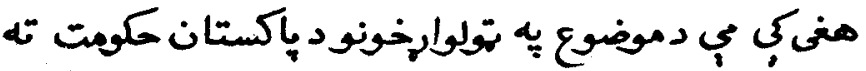

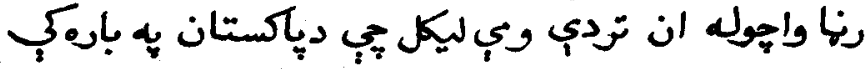

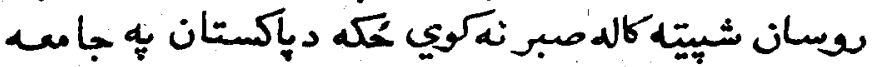

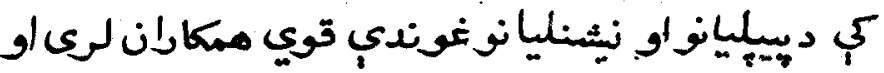

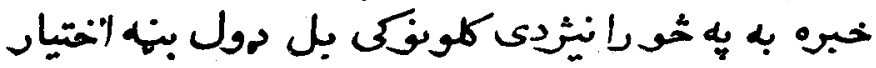

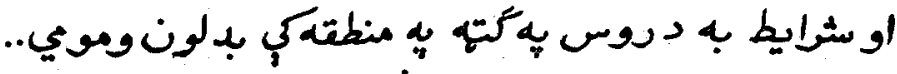




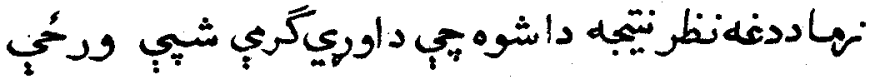

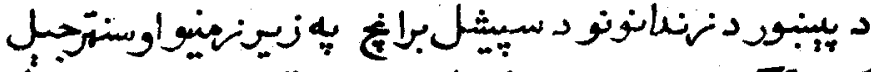

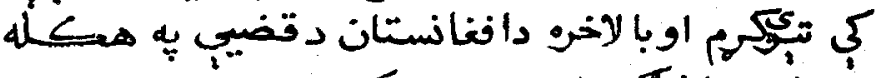

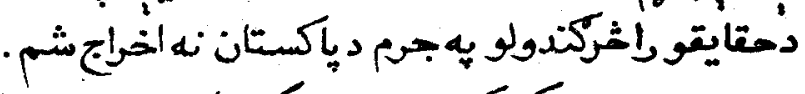

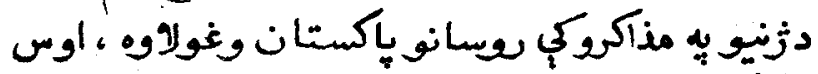

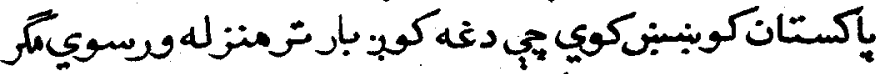

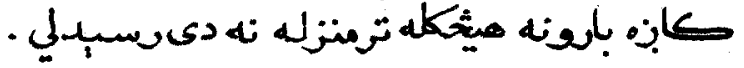

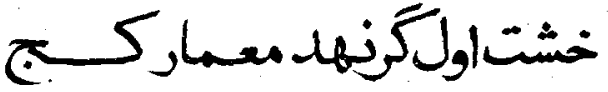

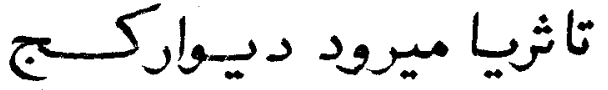

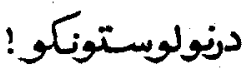

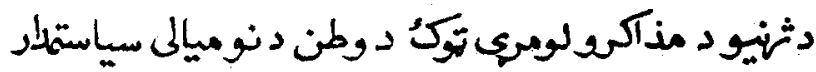

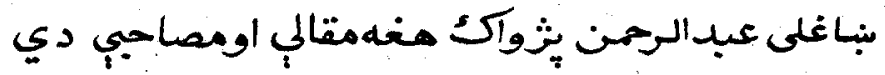

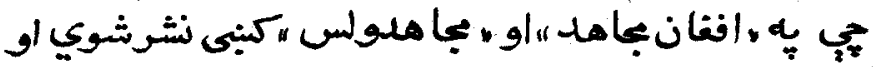

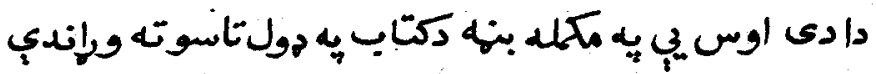

ددني سلسلى دومتم توكُ 2 ا فنا نستان دنظوديخاوندانو

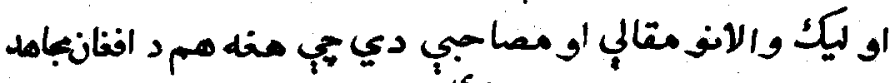

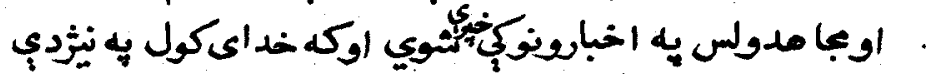

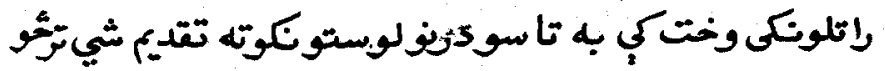




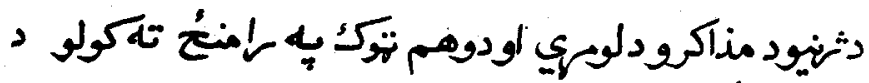

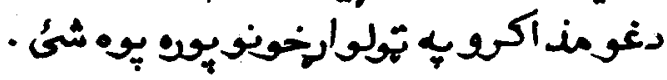

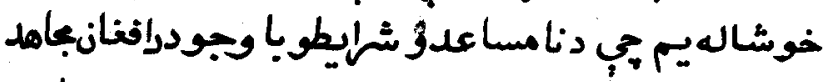

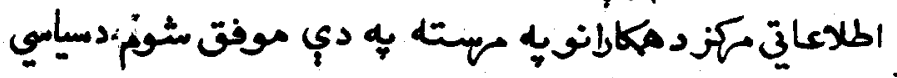

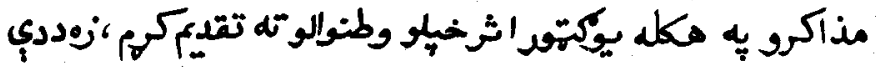

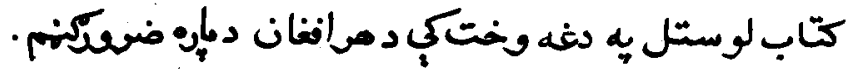

محجحسن ولسمل دافظانبامدا الملاعاتي مكنشث دمايج rاוمه

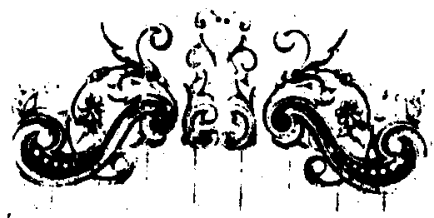




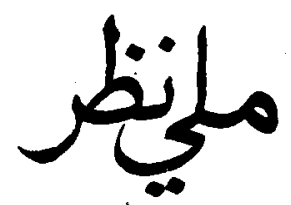

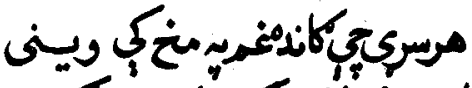

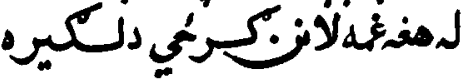

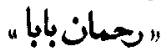

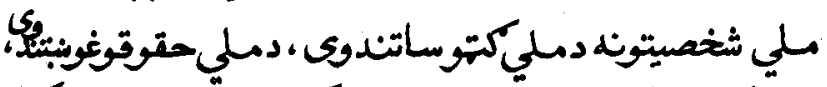

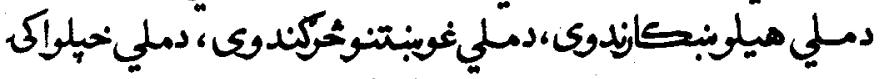

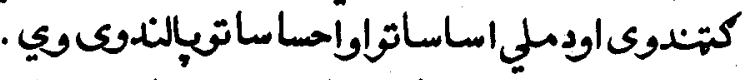

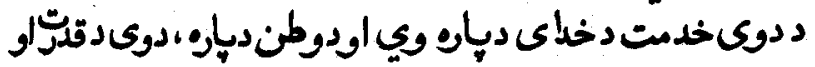

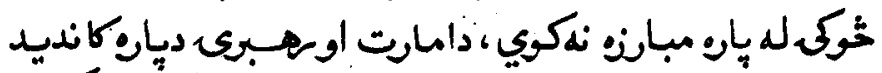

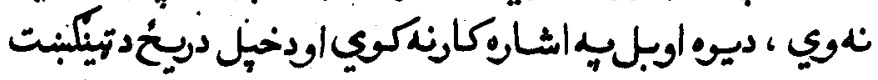

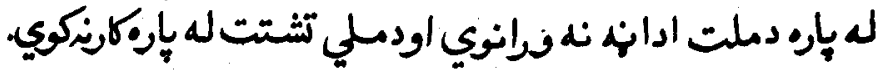

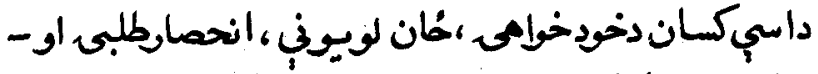

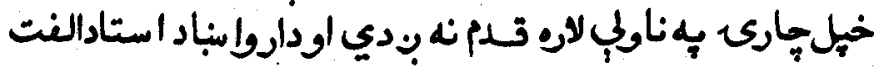

حَبَر: 


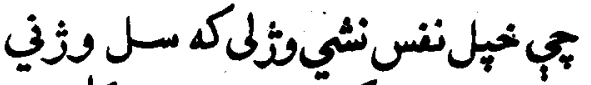

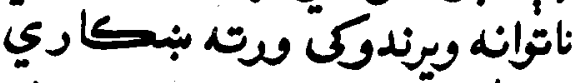

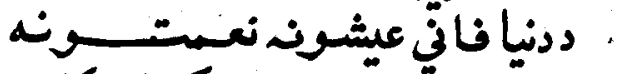

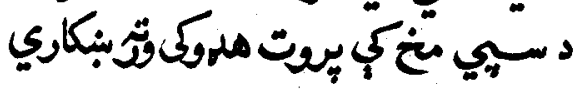

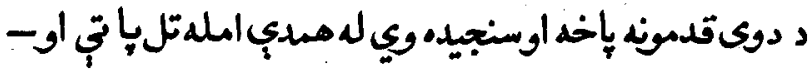

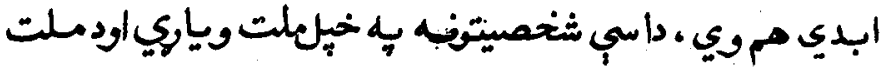

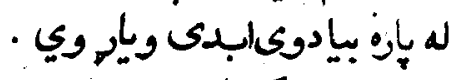

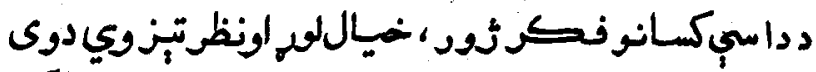

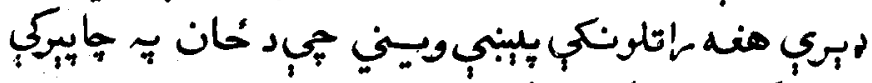

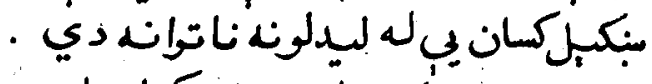

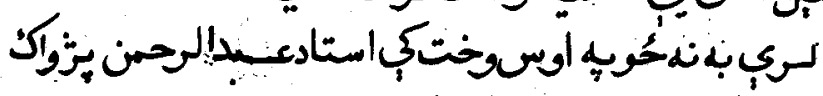

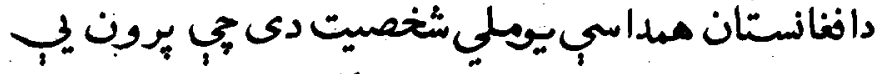

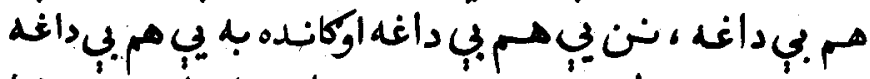

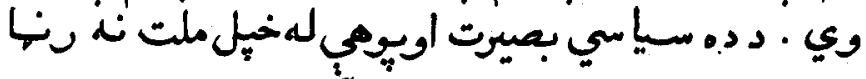

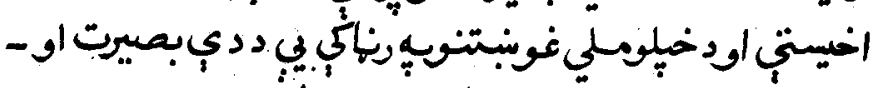

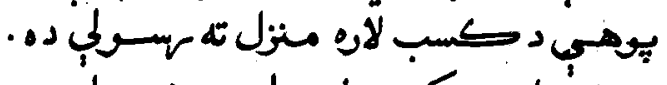

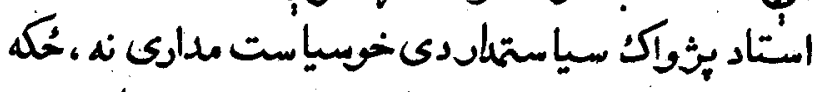

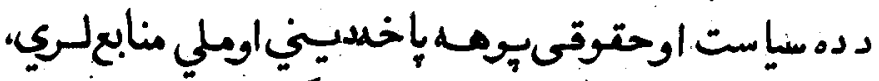

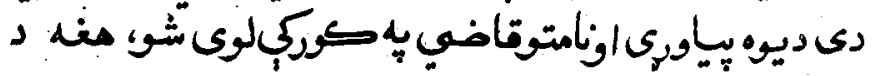




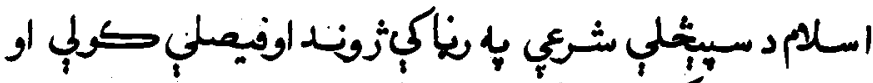

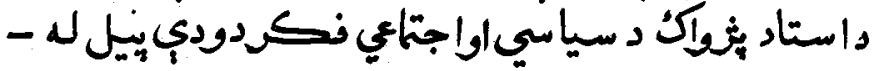

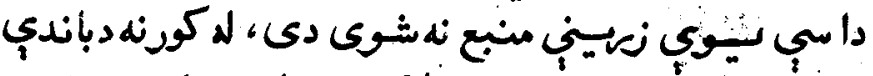

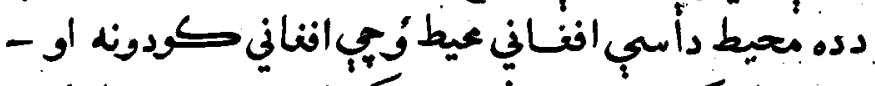

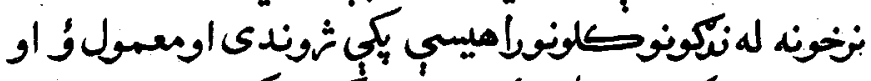

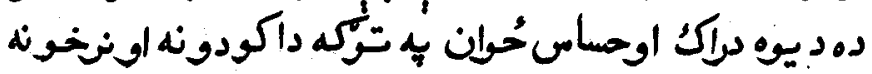

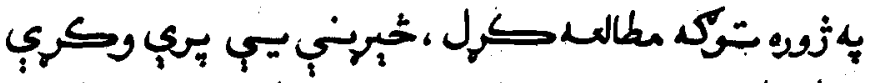

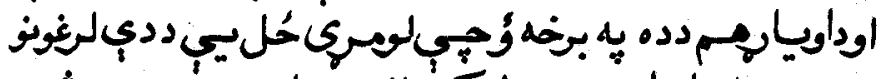

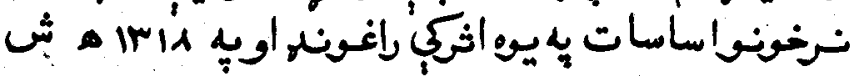

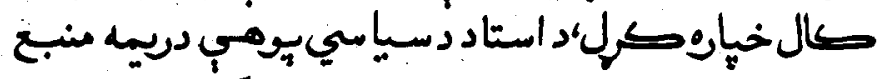

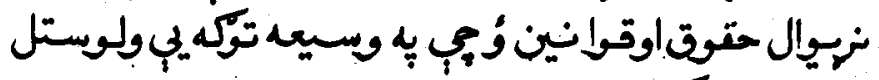

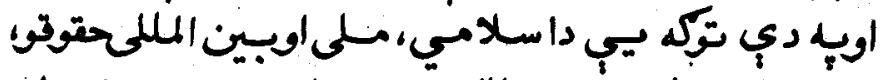

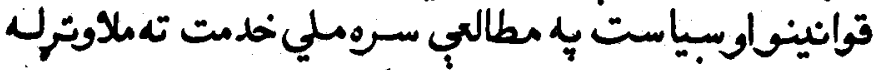

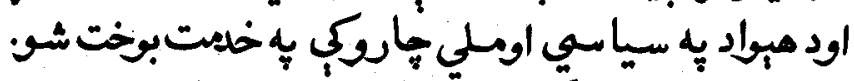

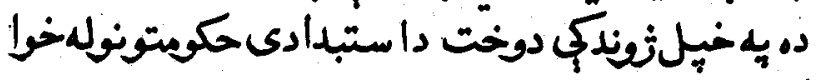

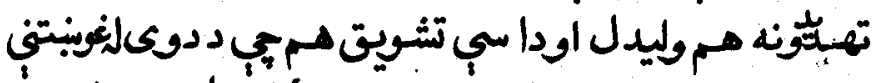

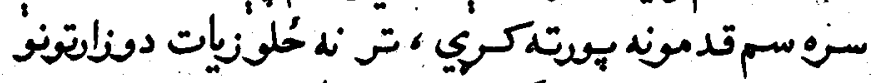

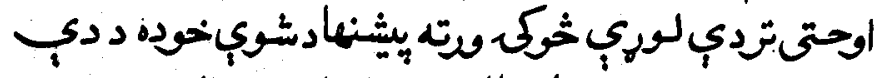

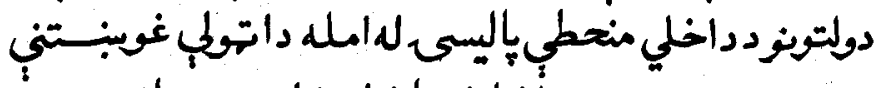

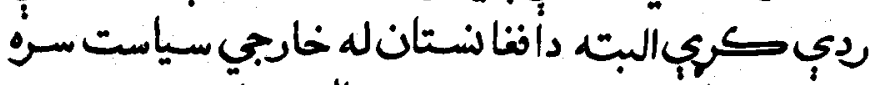

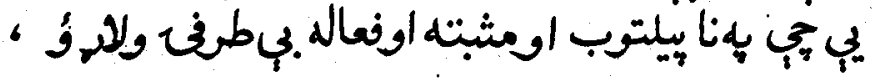


موافتت درلود اوله مسدي كبكبلهي سنارتونه مـم ومنل اويوه

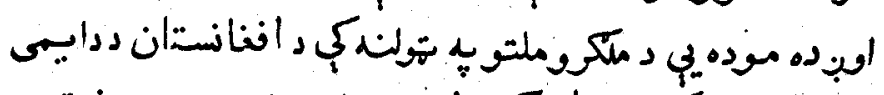

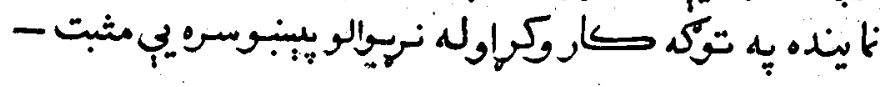
برخود.

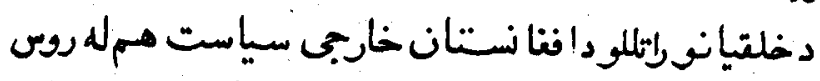

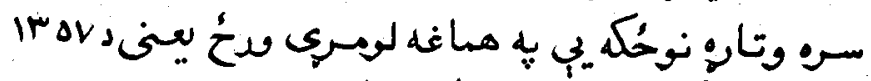

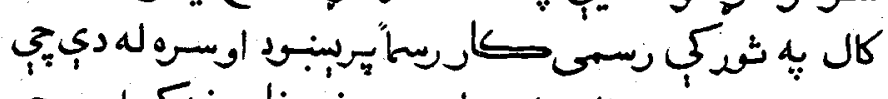

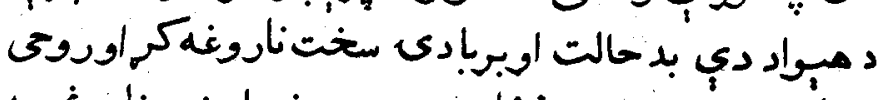

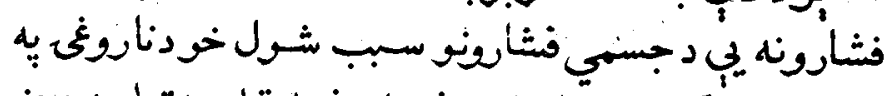

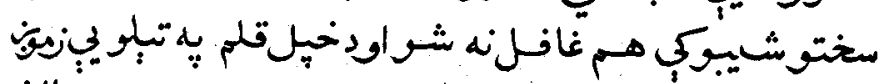

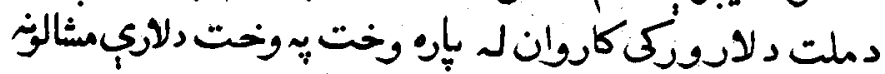

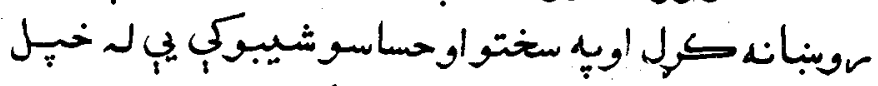

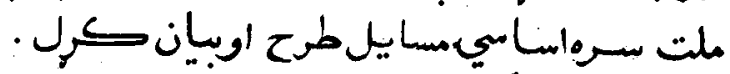

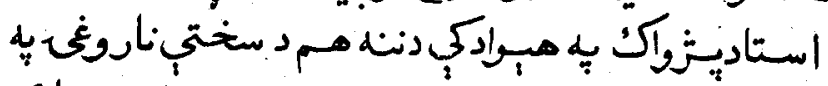

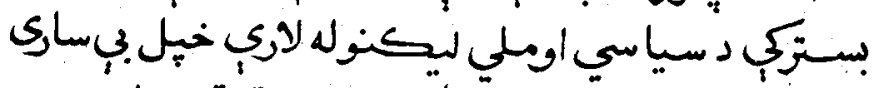

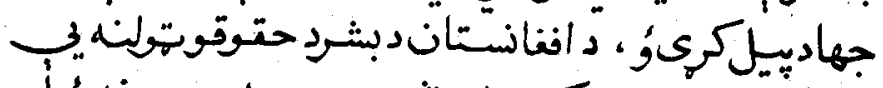

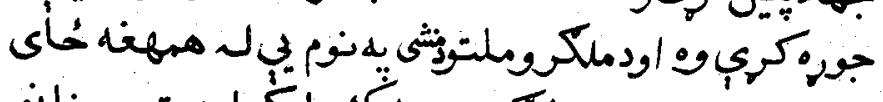

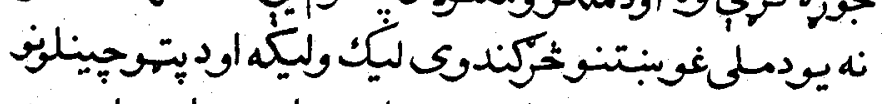

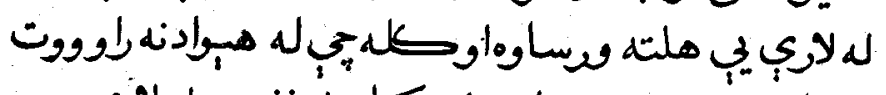

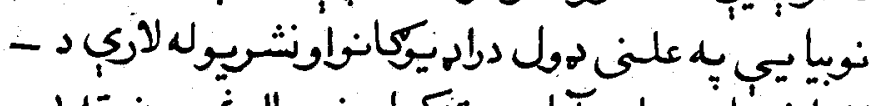

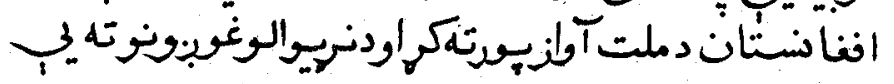




\section{يد}

טوساون.

له هبواد نه د دهل للوتلو سسو سم دافنا شتان دمنلموخومبرني

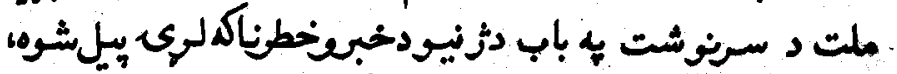

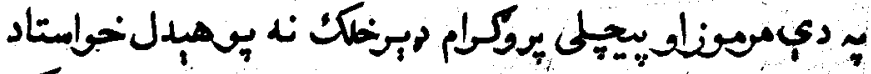

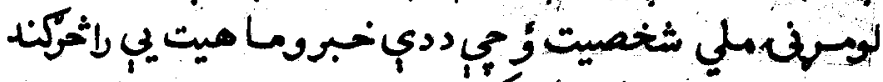

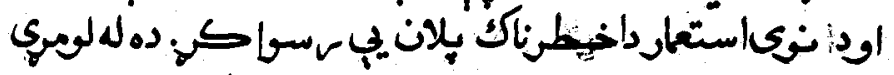

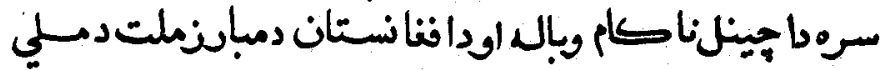

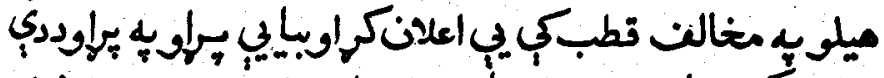

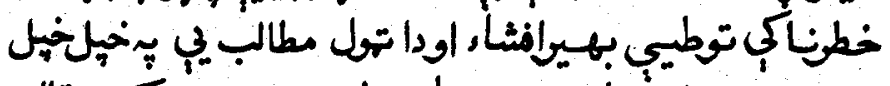

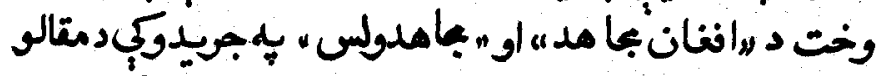

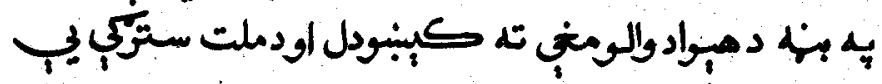

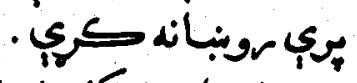

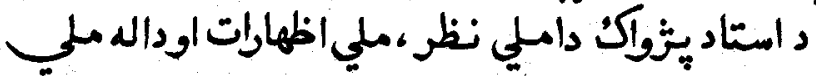

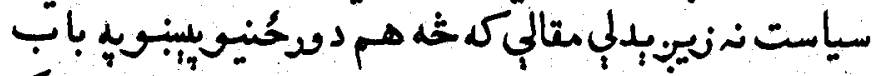

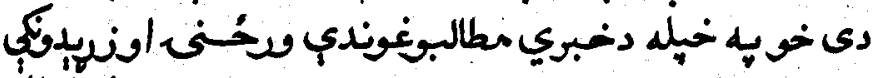

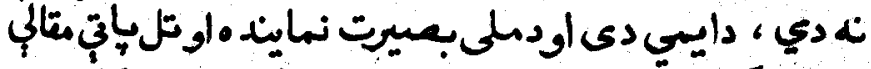

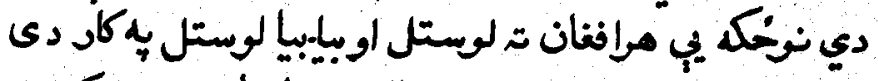

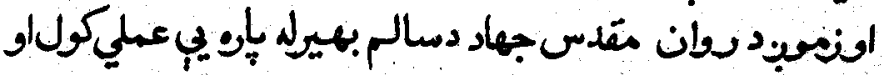

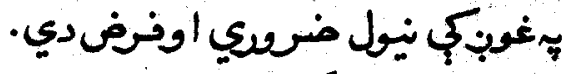

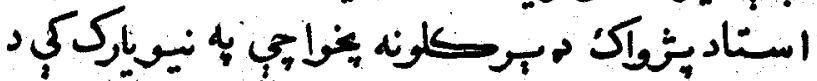

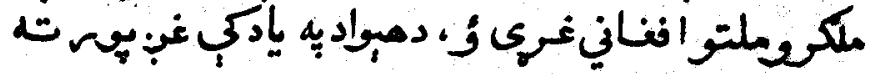


s.
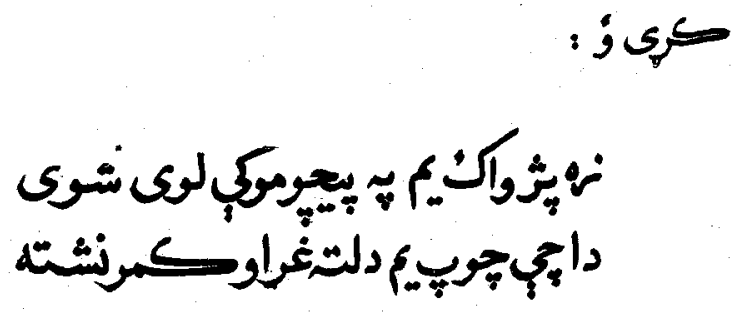

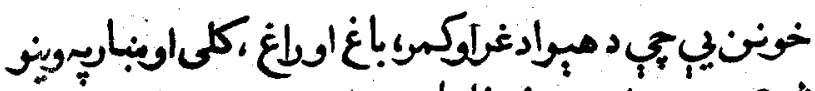

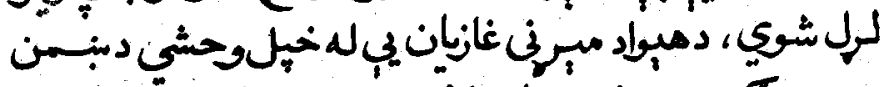

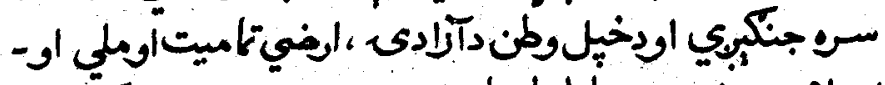

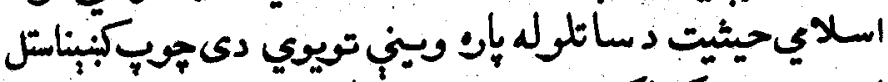

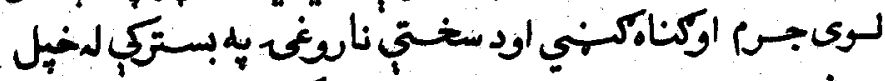

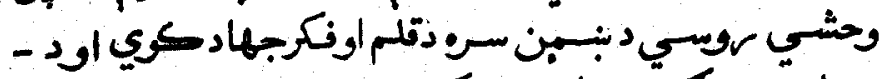

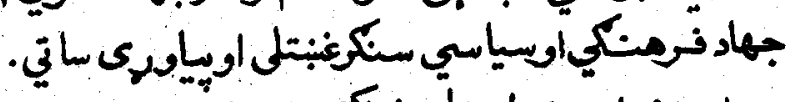

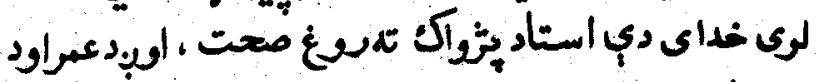

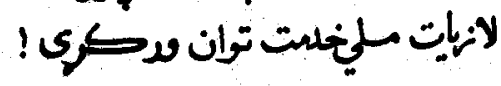

$$
\begin{aligned}
& \text { T'T } \\
& \text { بو } \\
& \text { حبي اللة رنيع } \\
& 1177 / 9 / Y 7
\end{aligned}
$$

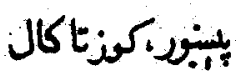




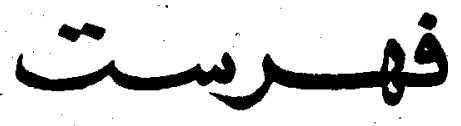

منحd

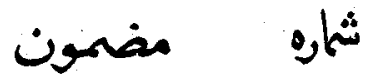

1

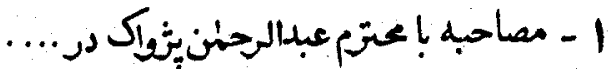

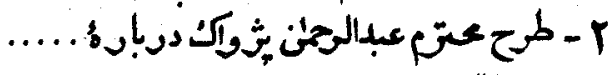

9

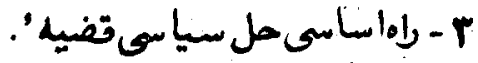

$\pi$

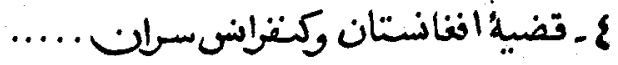

rr

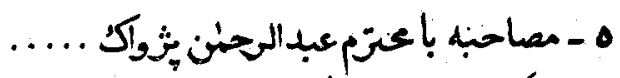

\&.

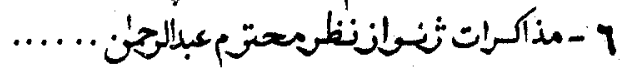

yo

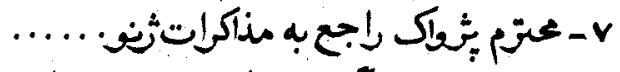

$v 8$

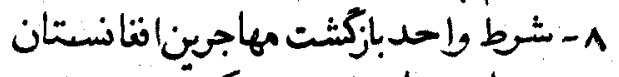

A.

9

9

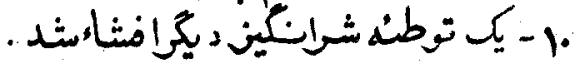

1.r

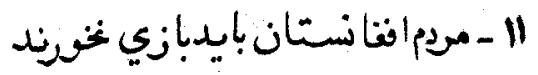




\section{ين}

صنه

شار

I.V

rا

IIT

114

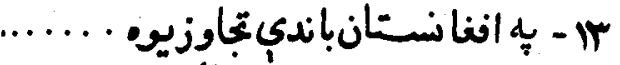

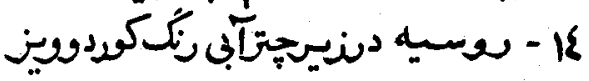

IVV

IrI

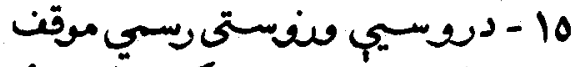

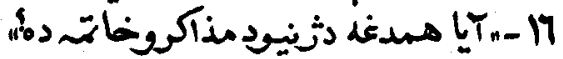

IIr

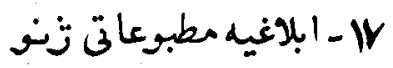

Irg

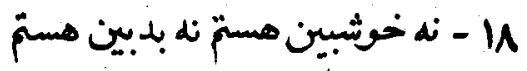

16r

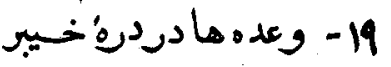

10.

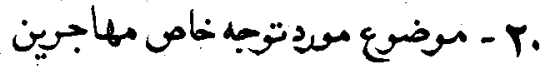

17

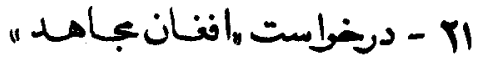

ivr

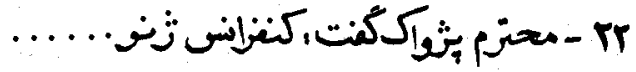

IVV

$$
\text { مo - Tr }
$$

IN.

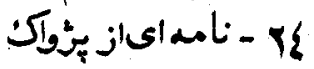

INT

IAN

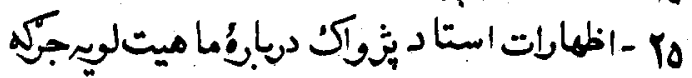

190

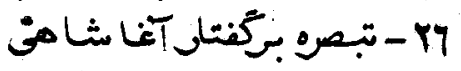

r..

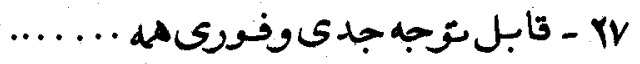

1

Y.O

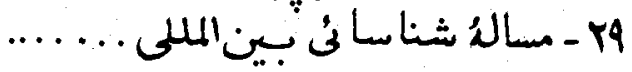

rir

YIT

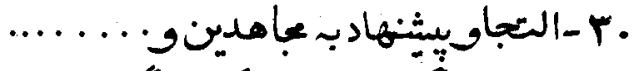

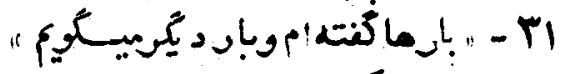

rritir

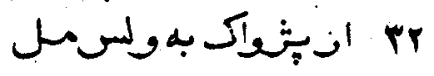


مئ

نras oth

Try

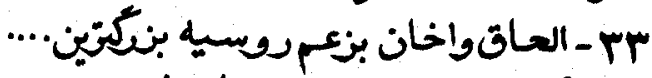

rer

रहq

TOA

r

rus

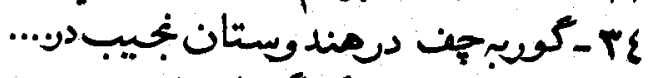

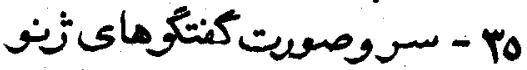

YAI

TM

rar

pqv

4.1

r.4

TrE

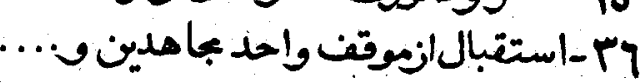

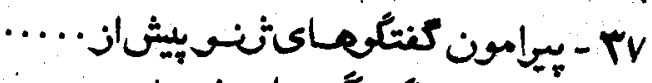

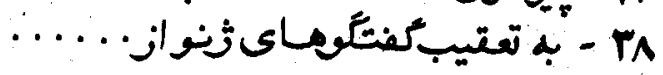

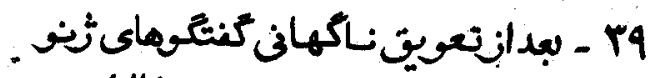

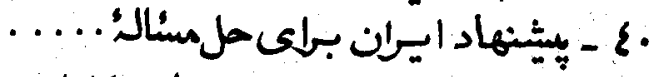

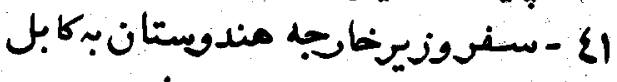

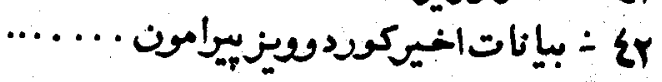

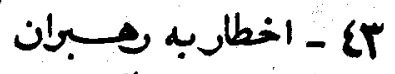

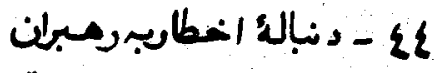

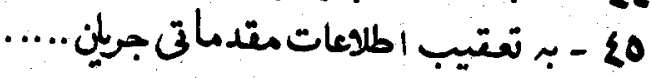

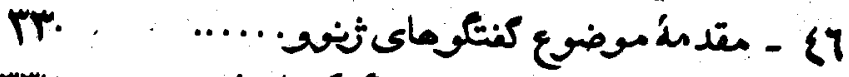

rrr

rór

ZV

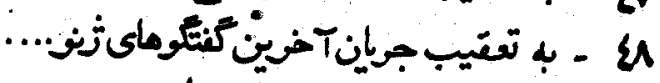

ro.

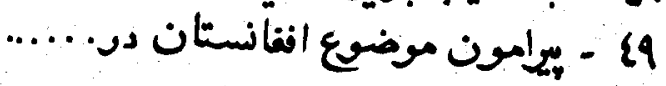




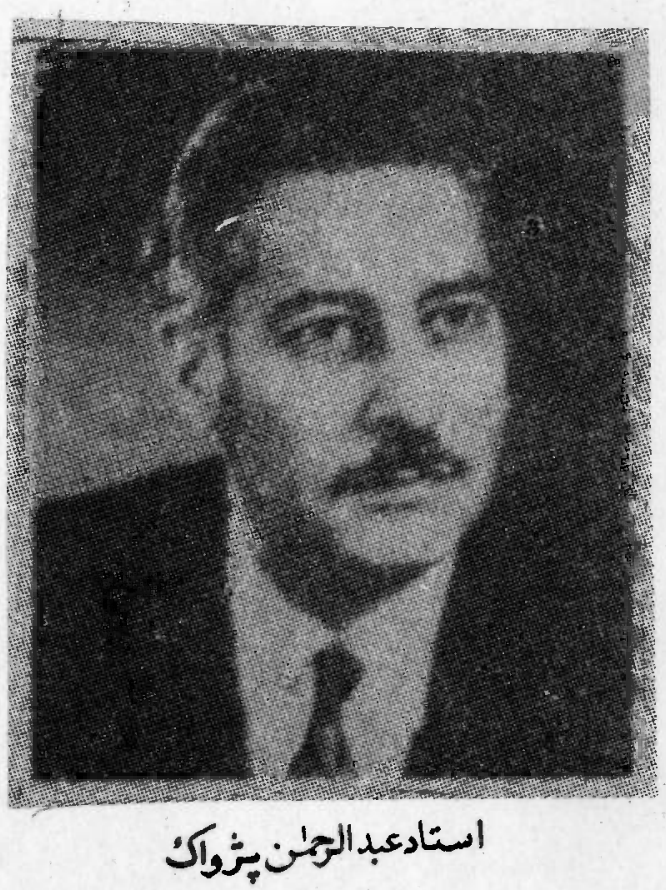




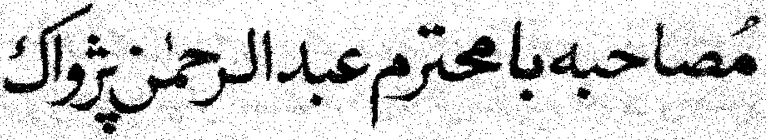

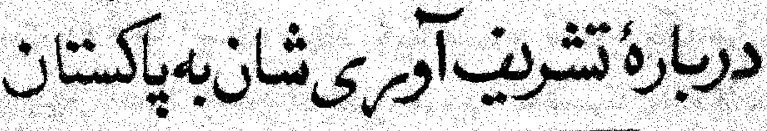

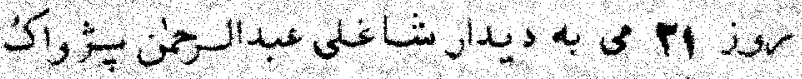

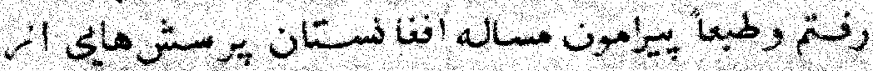

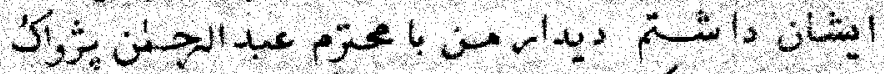

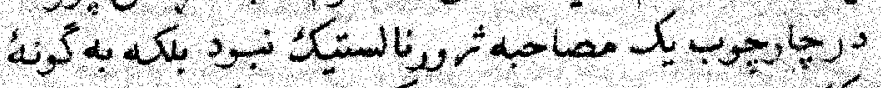
ك

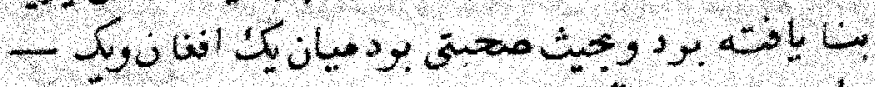

$$
\text { - ن ن is }
$$

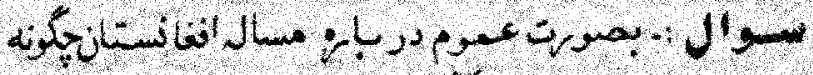
S

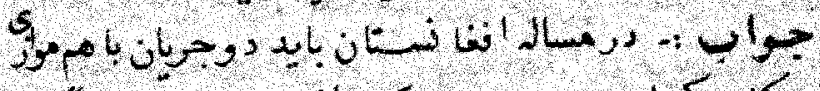

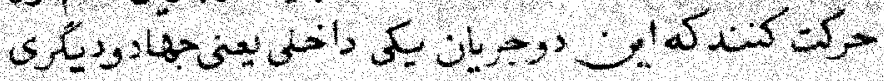




\section{r}

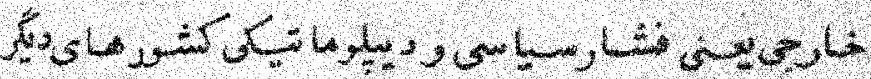

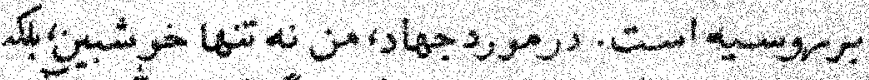

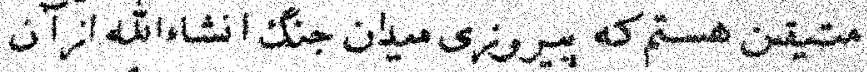

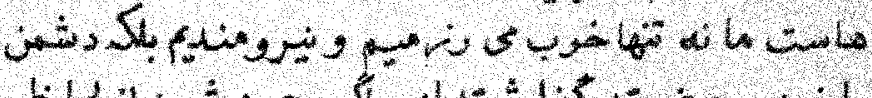

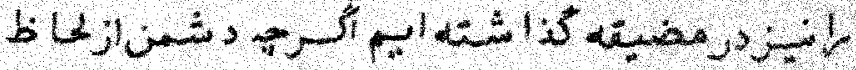

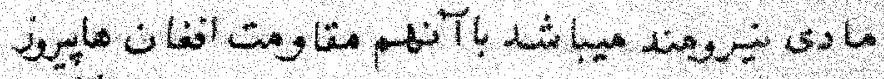

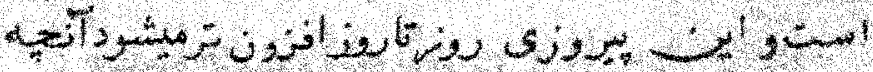

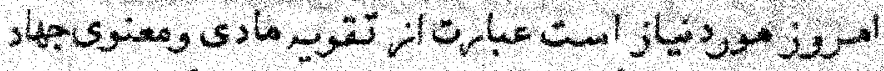

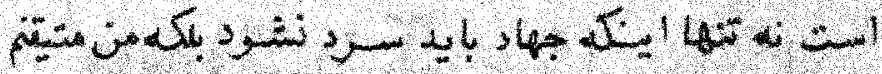

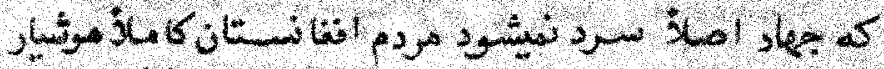

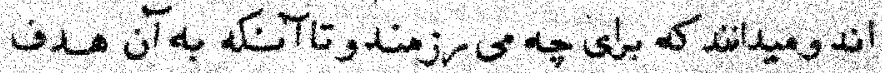
.

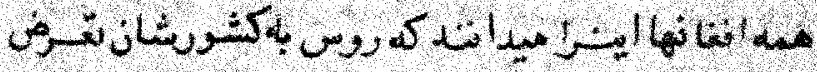

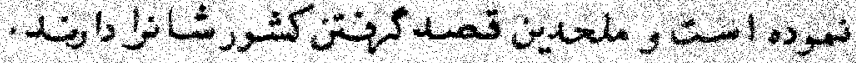

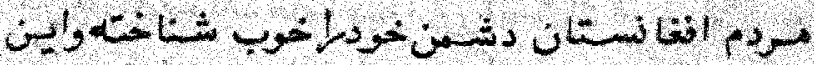

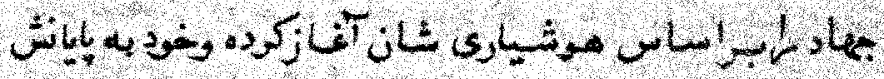
- Lilurs

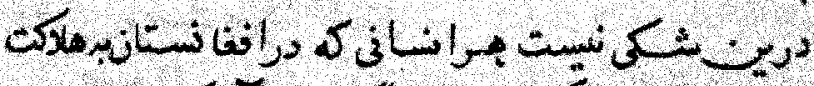

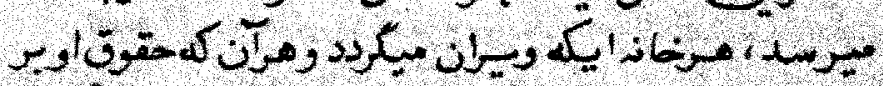

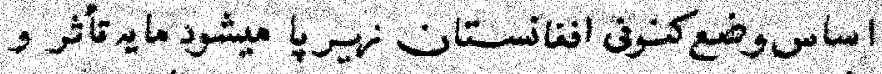

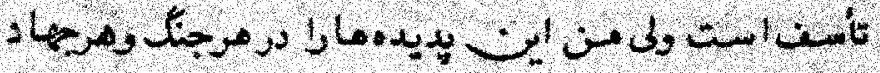




\section{$r$}

ومتاومت طبيى مي يندارم من اميد واريى ويقينكامل داريم

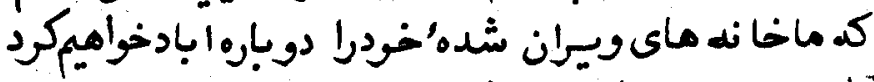

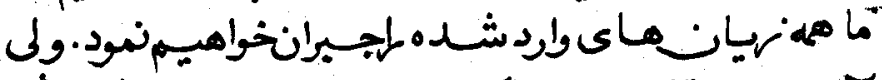

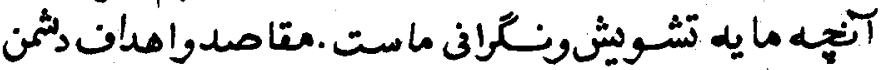

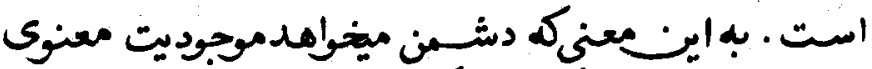

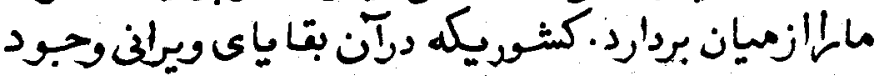

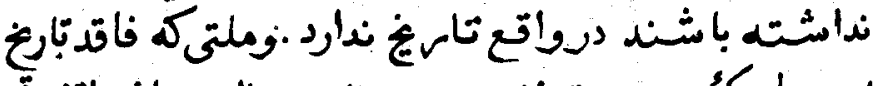

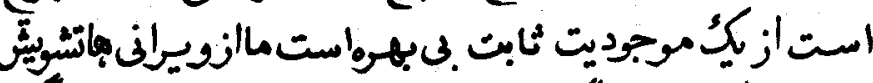

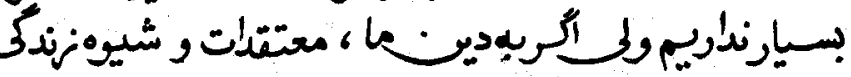

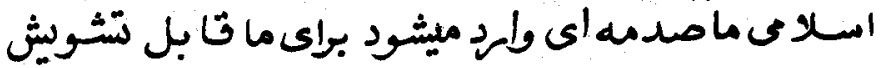

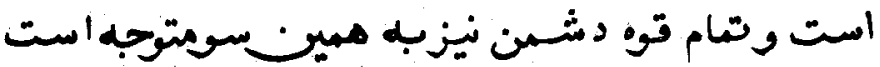

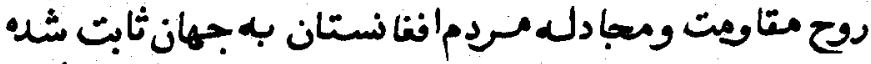

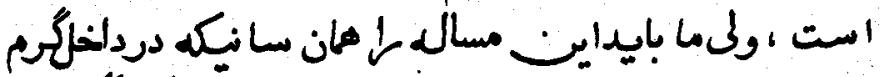

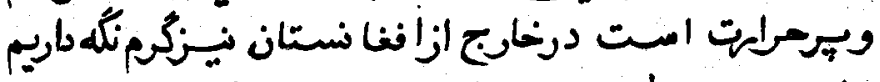

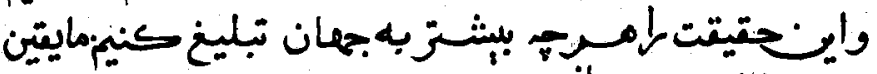

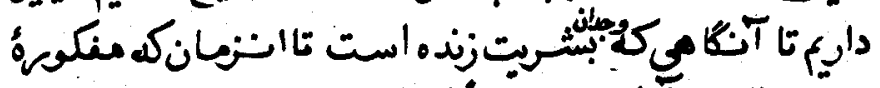

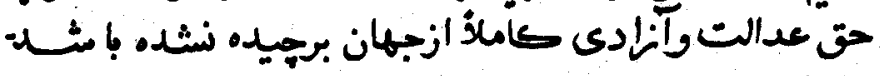

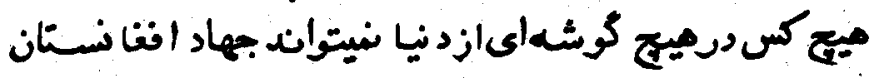

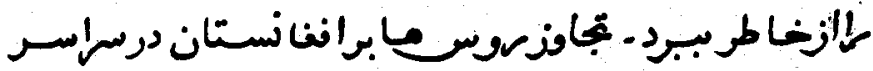

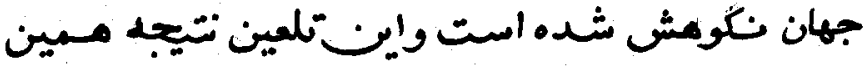

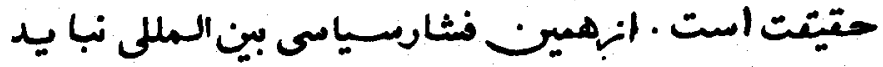




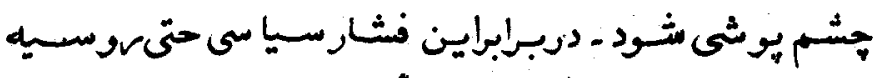

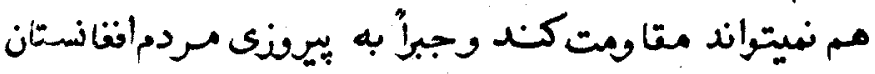

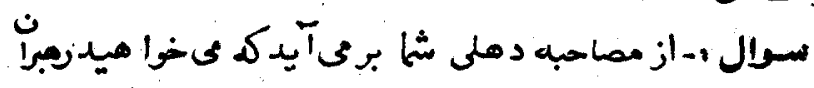

$$
\text { اعتراف نى كند. }
$$

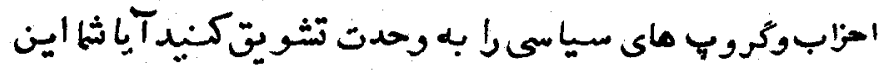

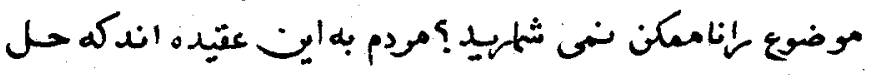

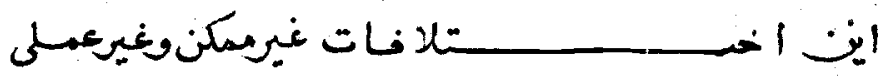

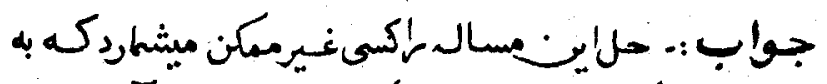

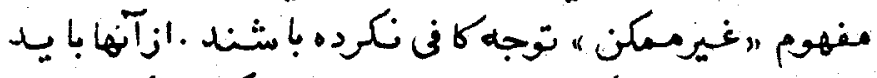

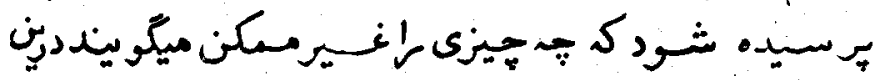

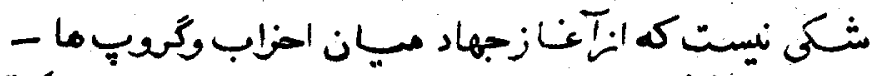

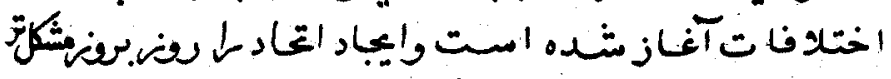

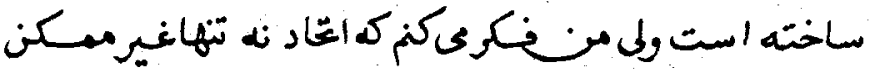

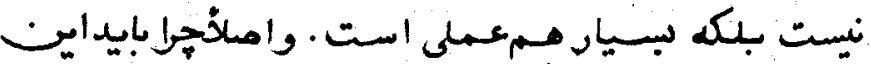

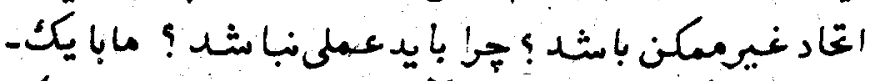

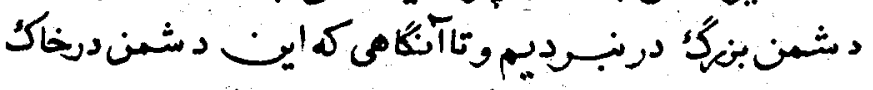

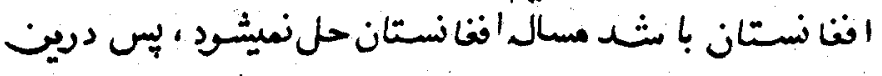

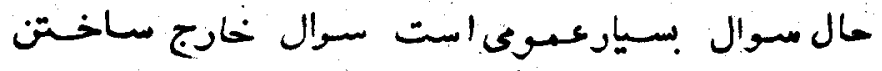

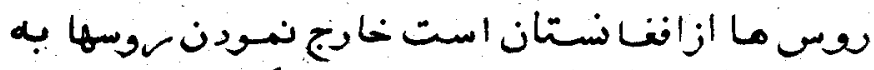

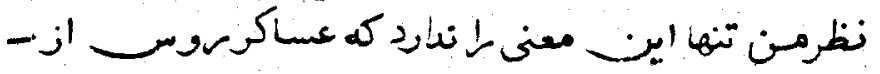

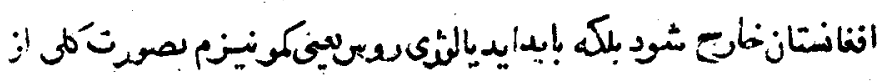




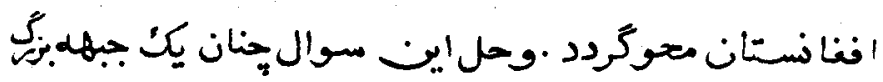

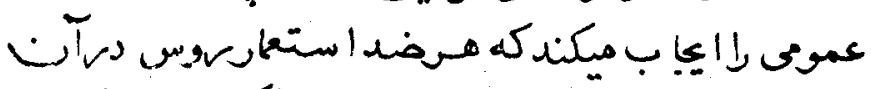

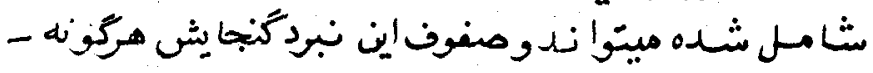

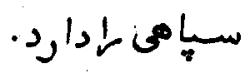

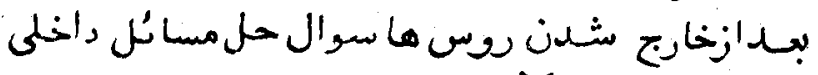

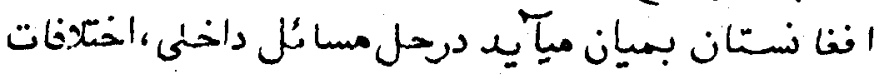

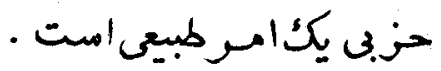

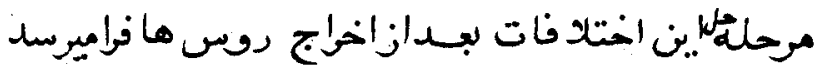

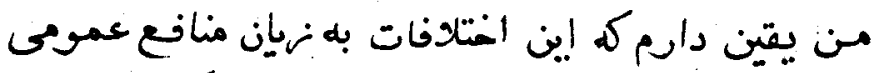

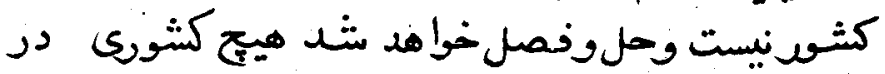

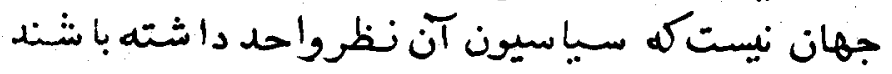

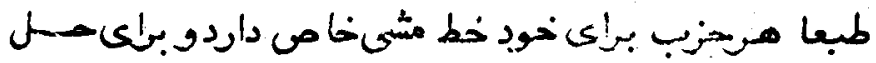

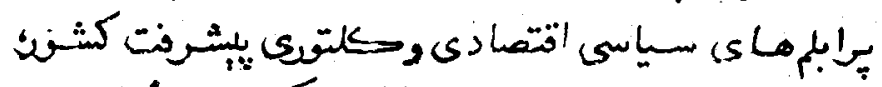

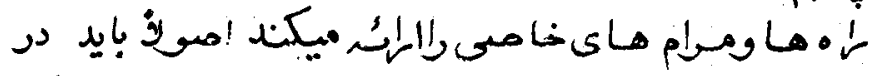

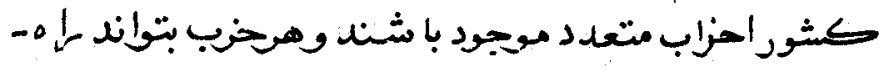

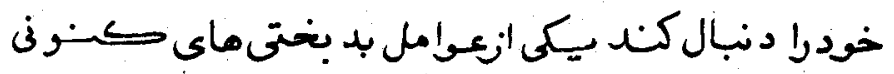

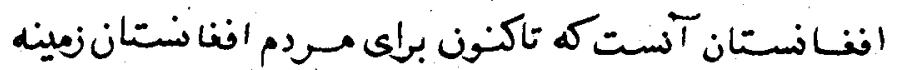

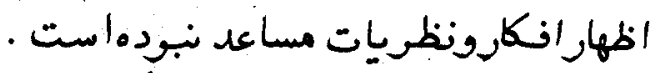

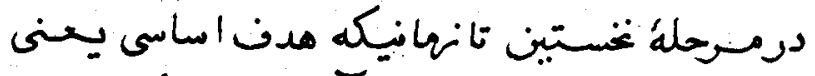

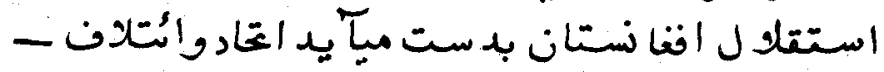

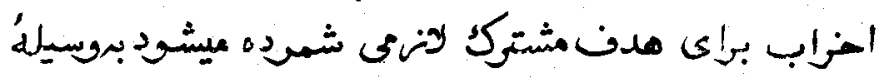




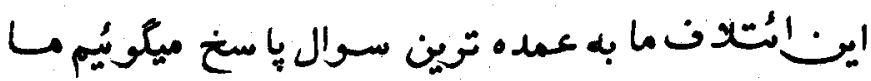

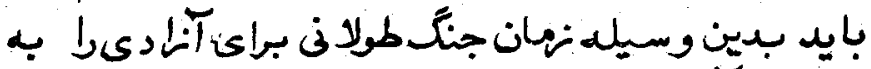

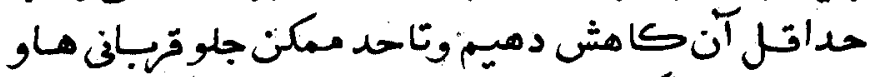

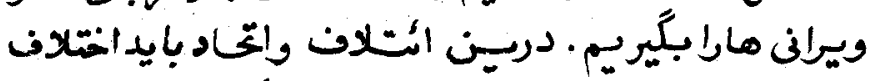

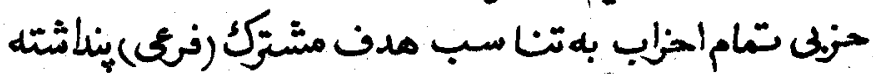

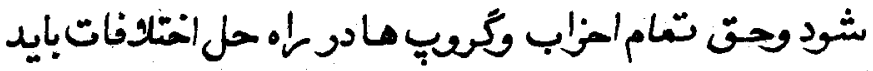

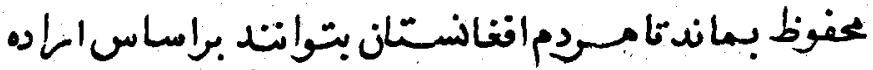

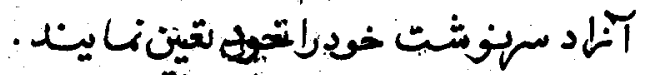

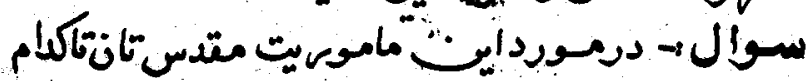

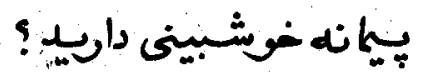

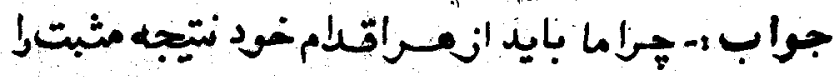

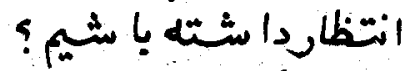

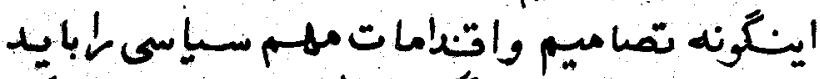

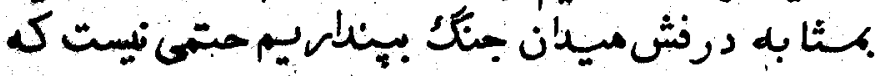

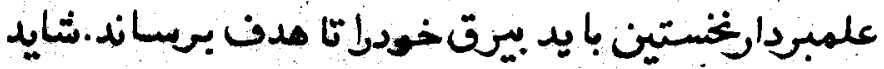

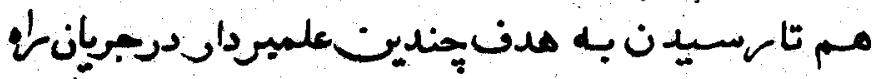

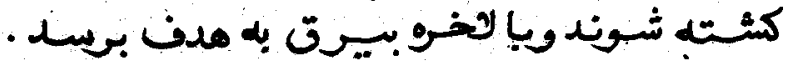

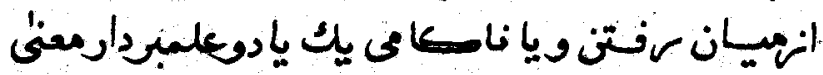

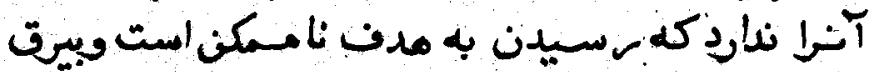
درنيه راه بهما شئودي.

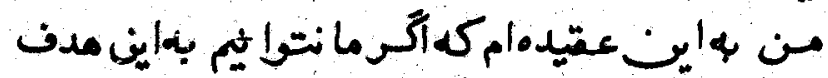




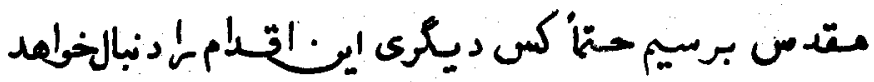

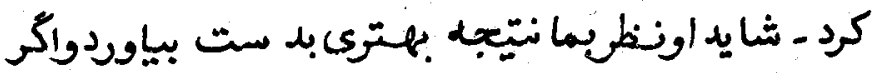

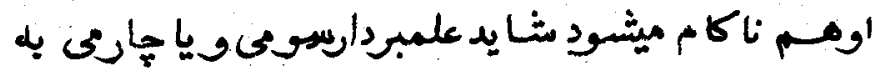

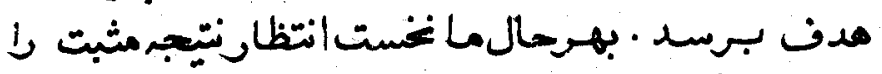

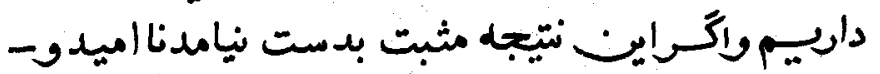

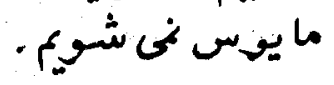

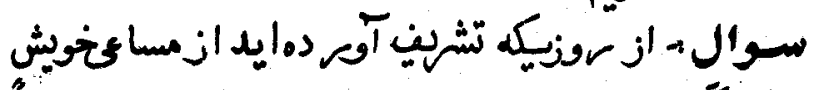

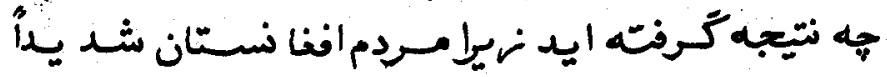

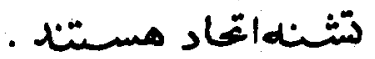

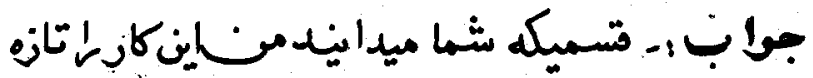

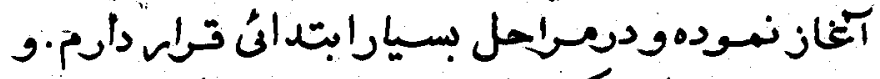

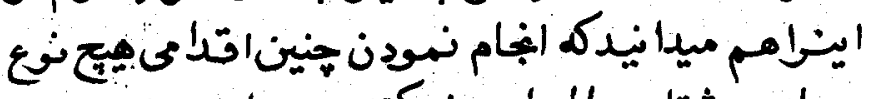

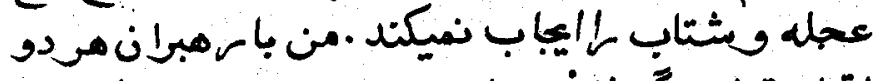

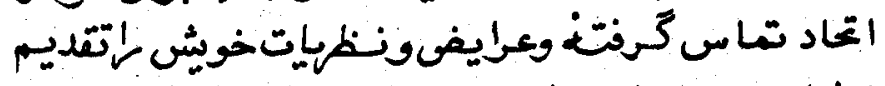

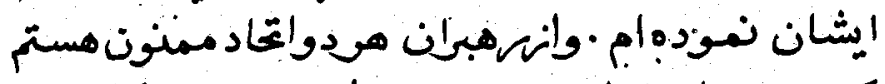

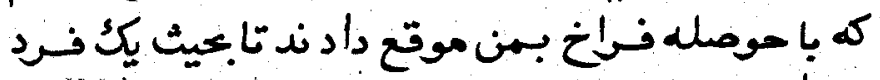

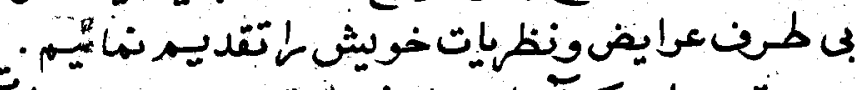

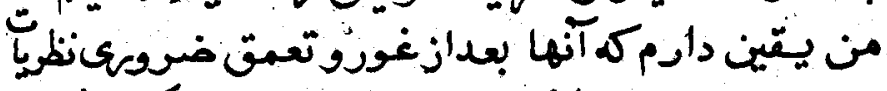

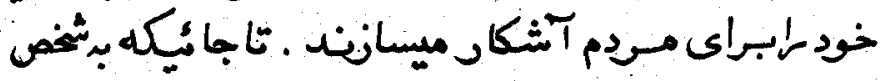

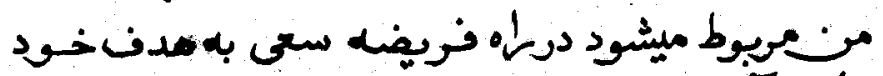

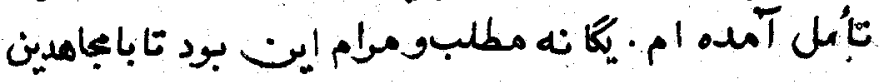


$\wedge$

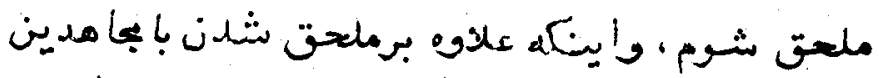

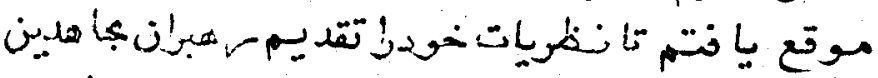

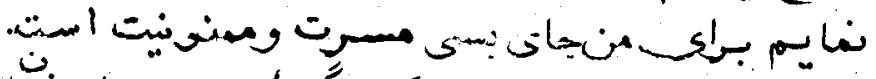

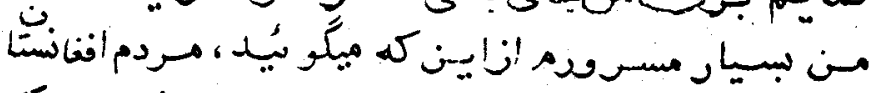

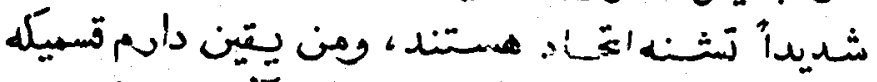

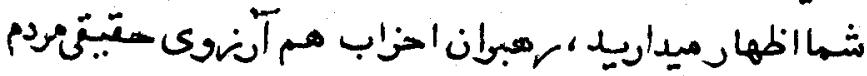

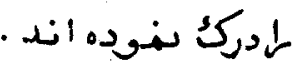

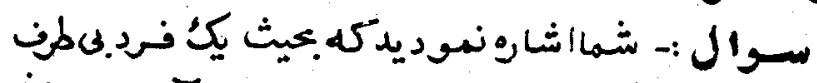

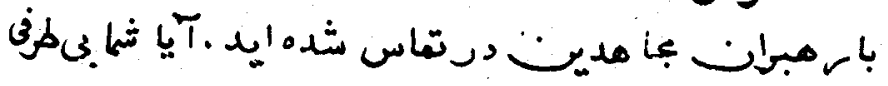

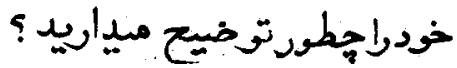

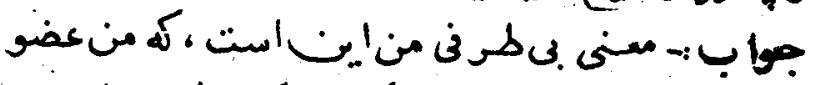

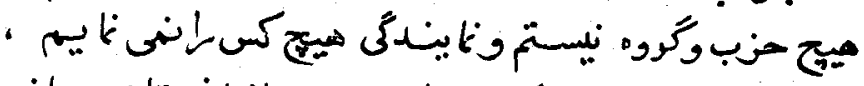

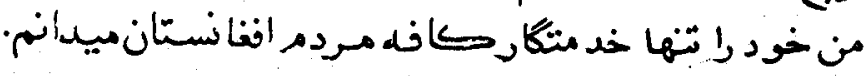

شُرهُرَ، اننان مبجاهـ \& / 


\section{طرحعتم عبدالرمنن يُّروك دربارؤمذاكراتثنيو}

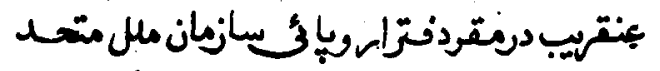

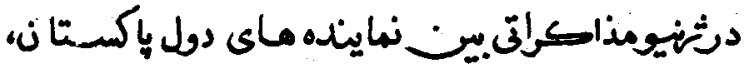

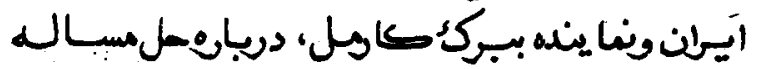

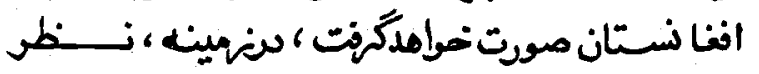

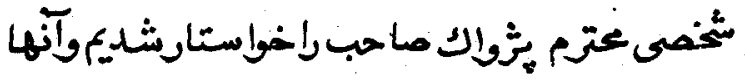

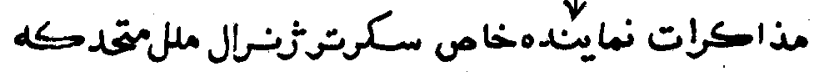

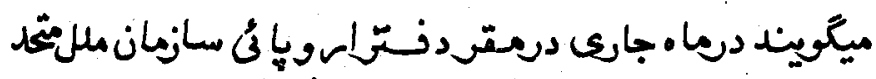

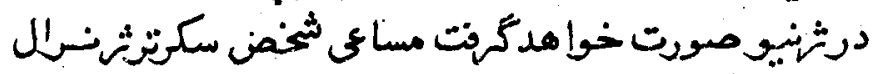




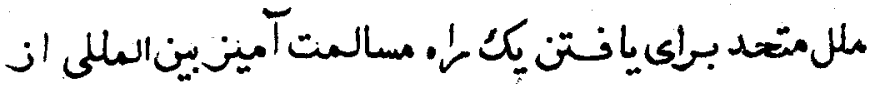

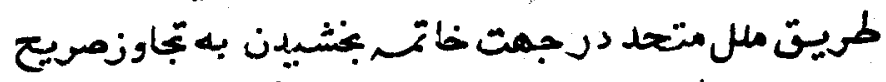

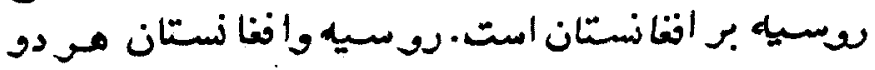

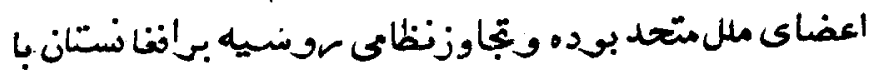

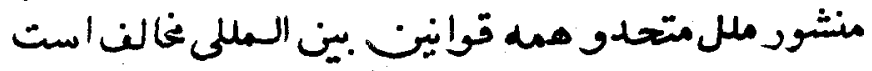

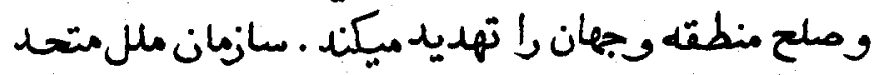

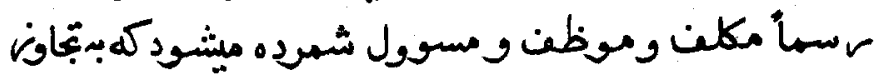

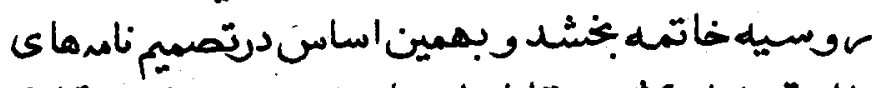

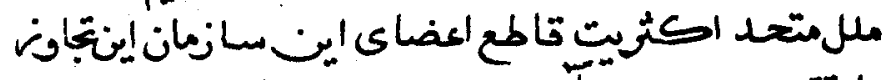

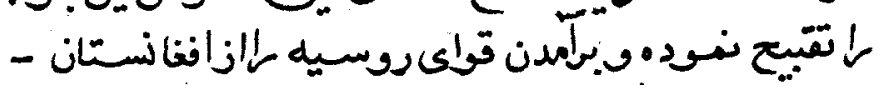
مطالب نموده أند.

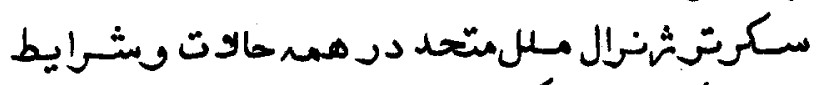

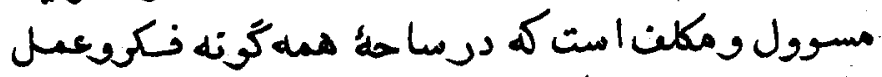

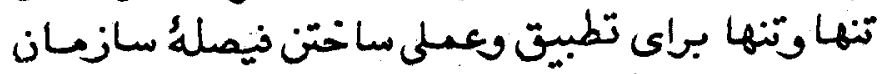

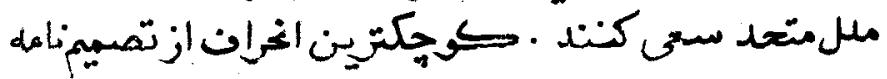

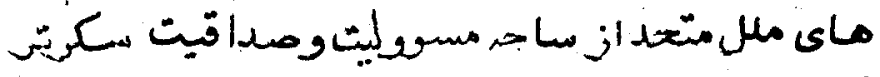

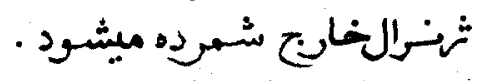

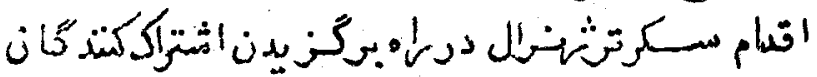

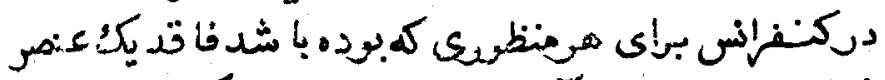

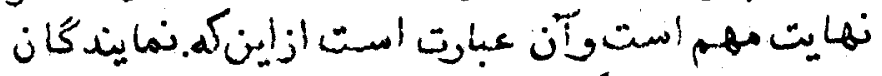

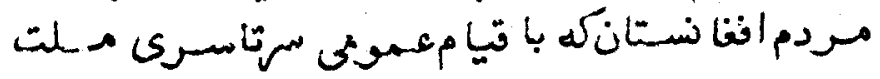




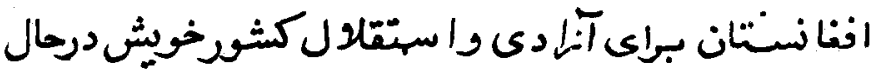

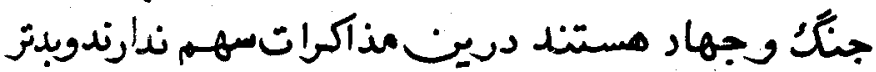

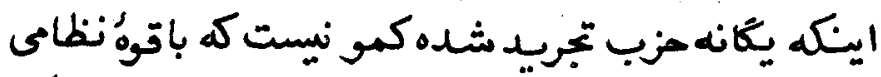

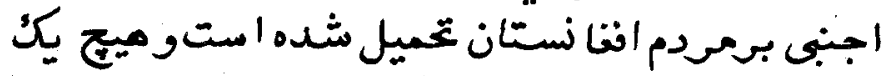

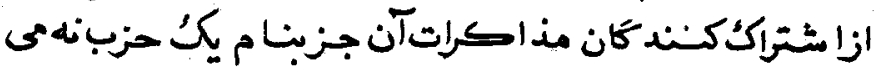

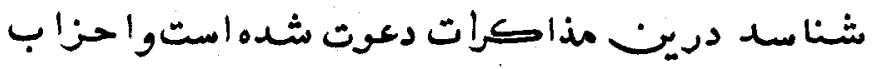

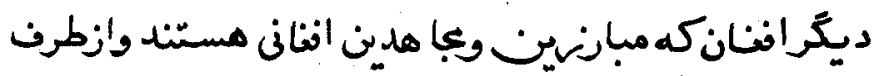

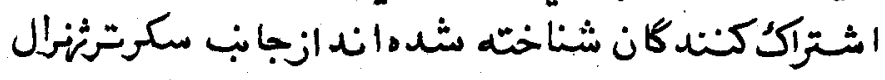

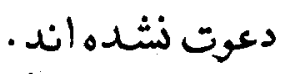

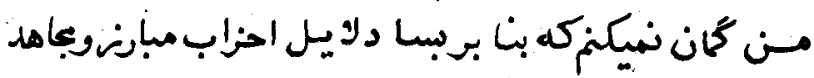

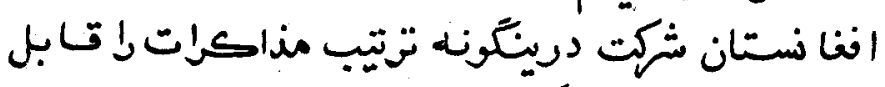

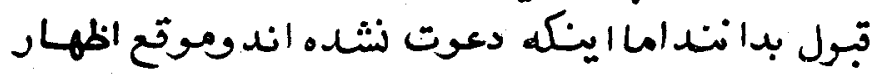

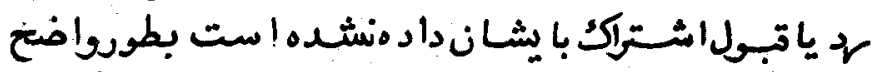

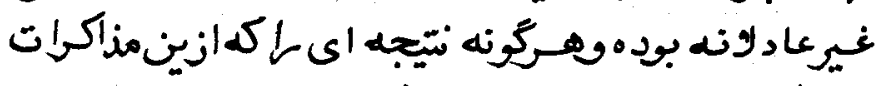

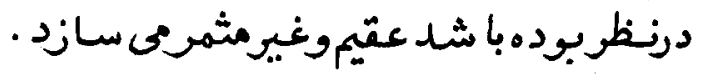

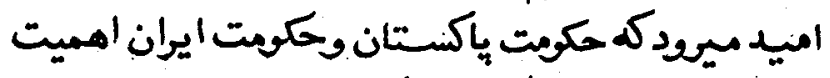

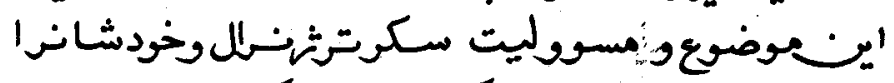

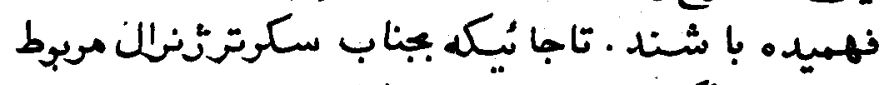

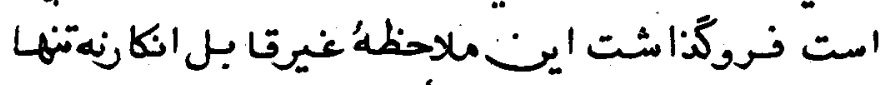

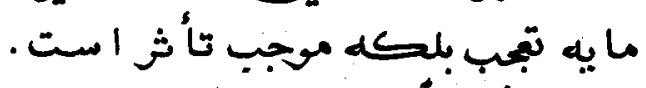

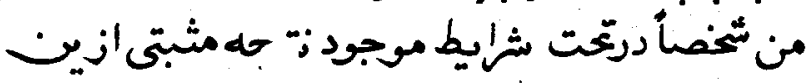




\section{ir}

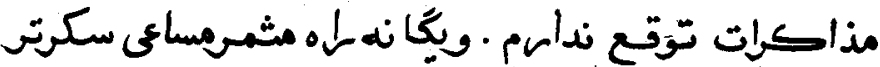

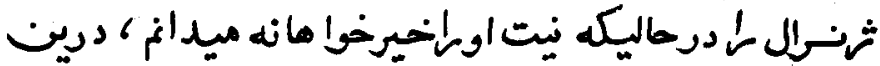

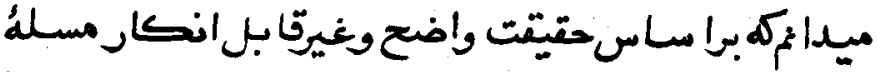

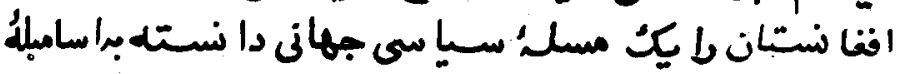

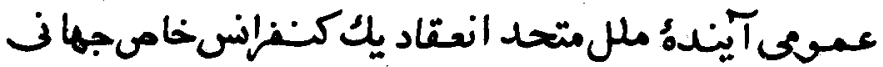

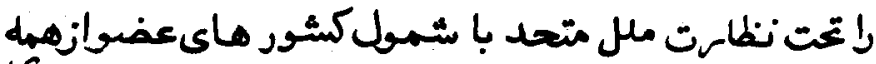

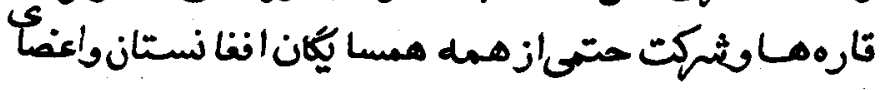

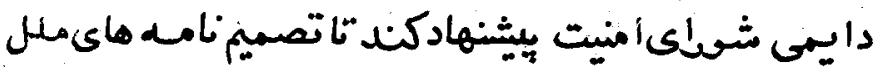

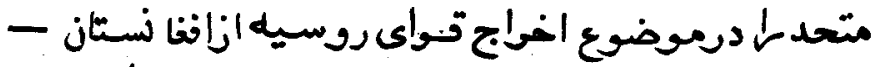

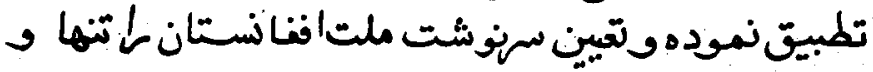

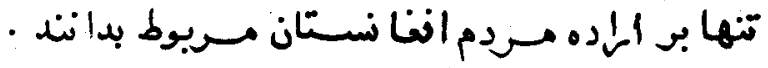

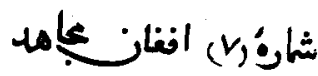

Ir 


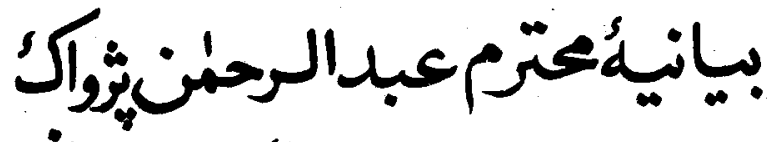

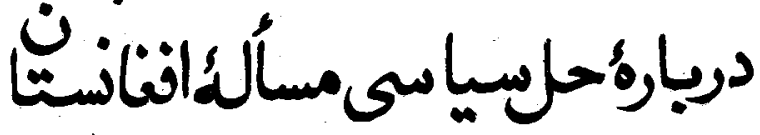

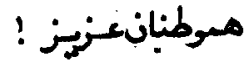

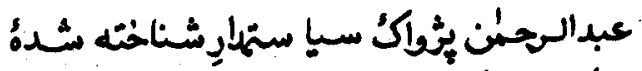

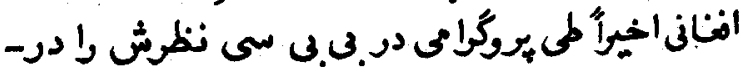

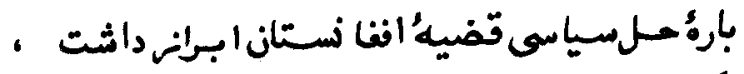

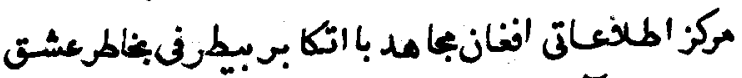

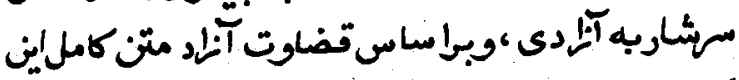

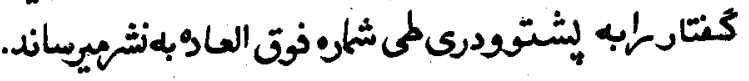

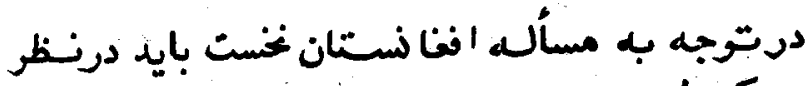

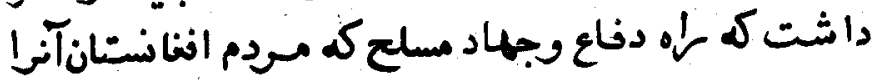




\section{$1 \varepsilon$}

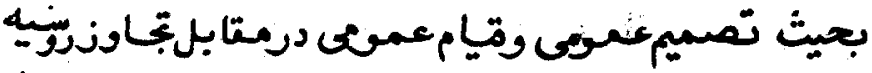

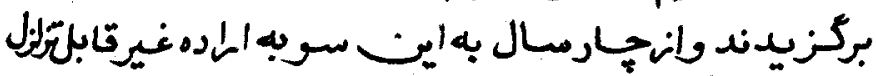

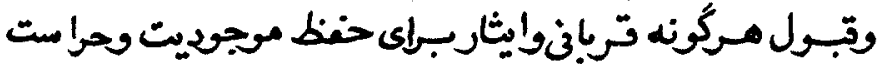

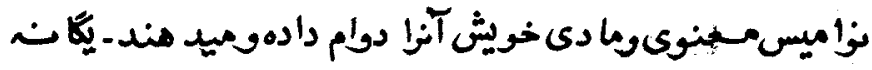

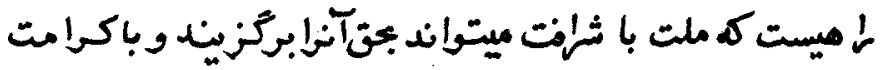

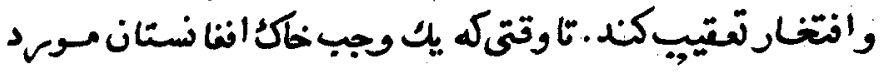

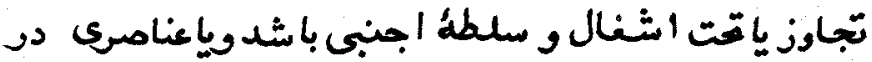

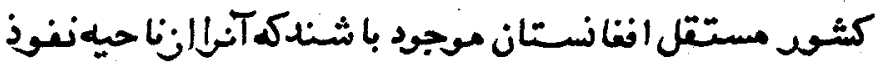

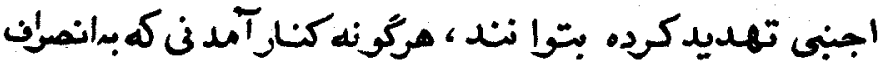

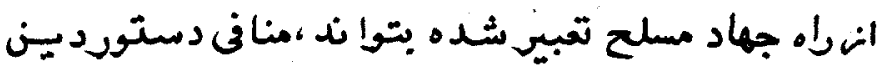

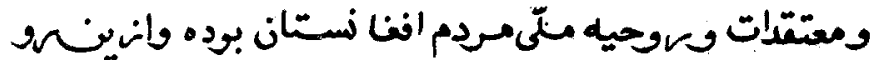

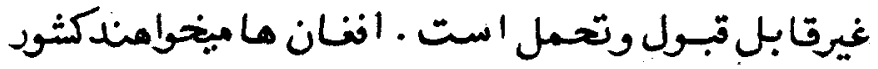

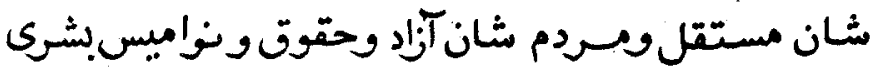

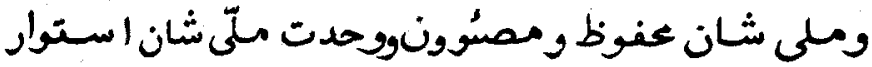

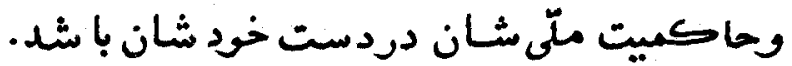

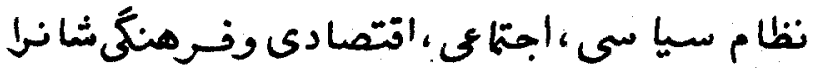

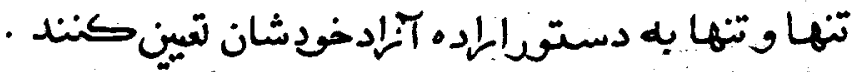

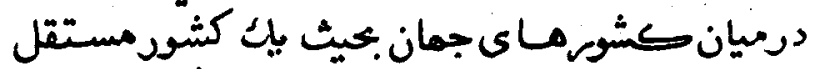

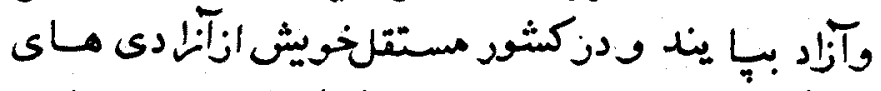

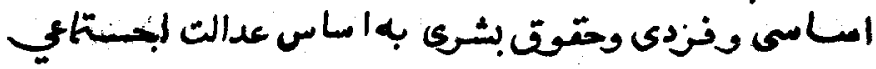

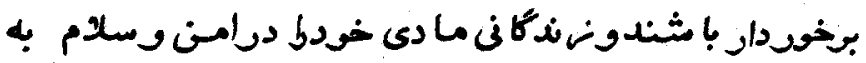


وجه احسن تأمين كنتل .

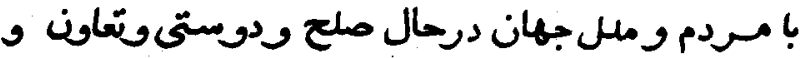

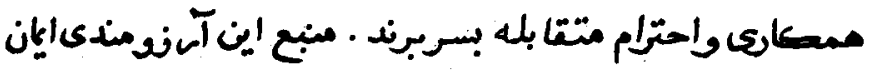

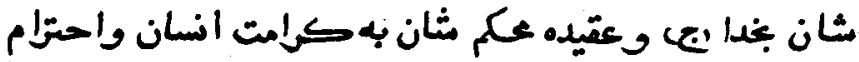

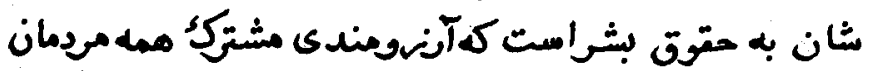

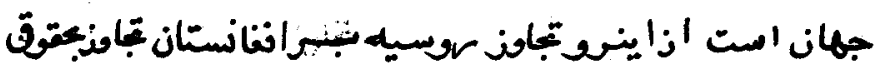

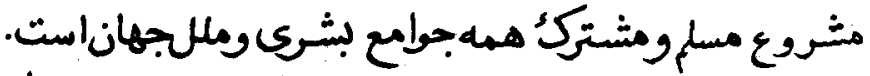

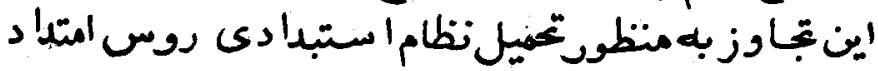

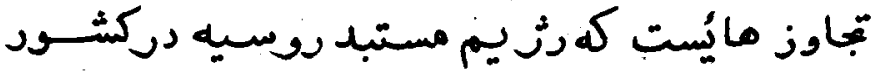

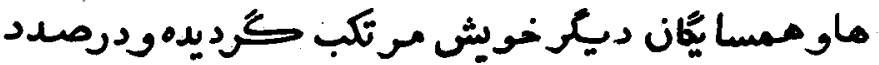

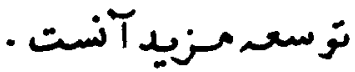

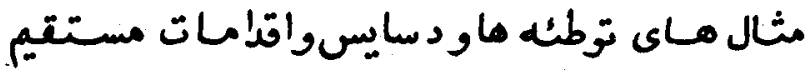

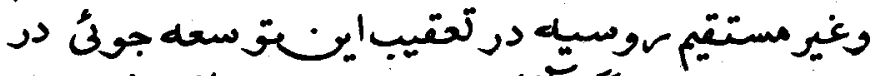

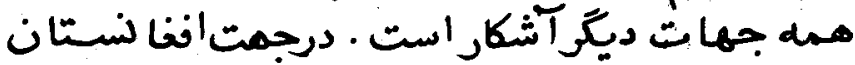

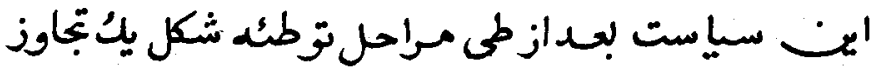

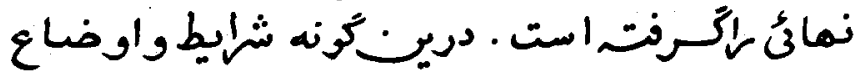

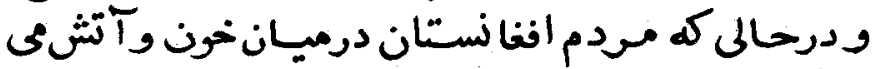

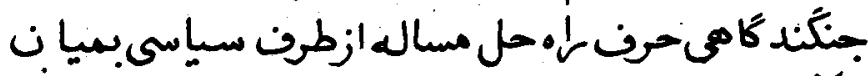

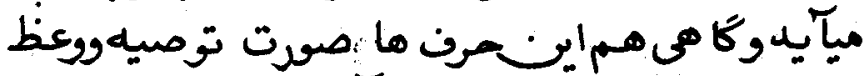

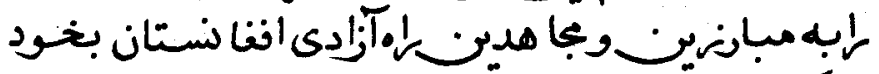
متكرد. 


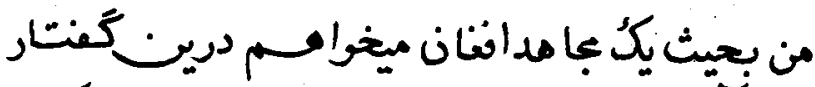

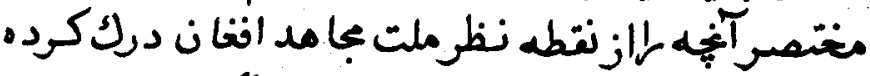

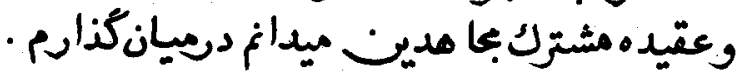

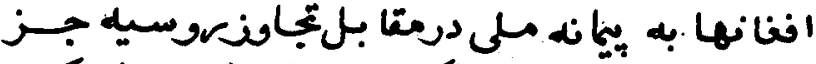

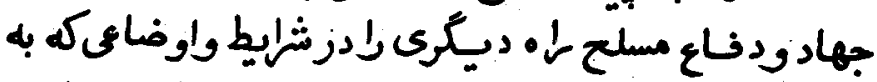

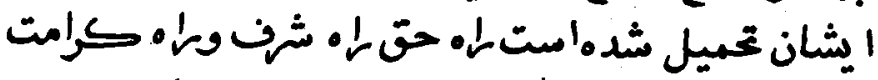

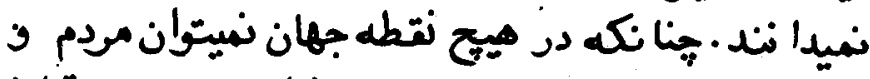

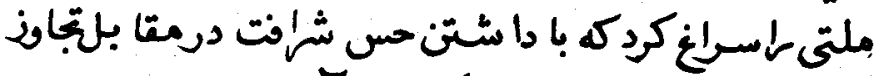

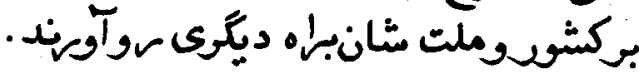

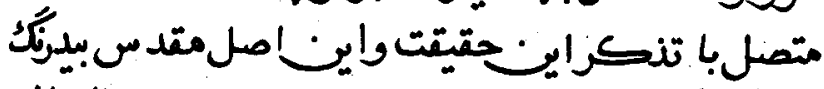

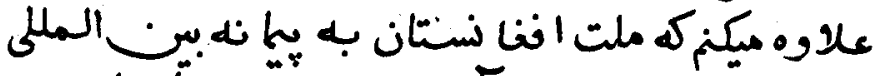

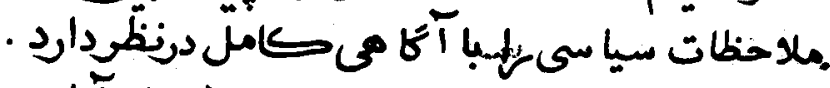

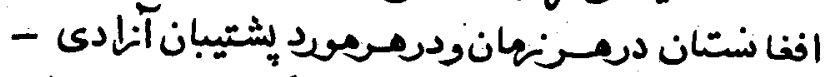

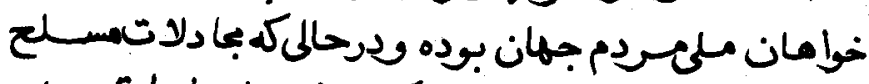

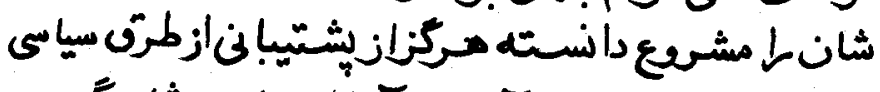

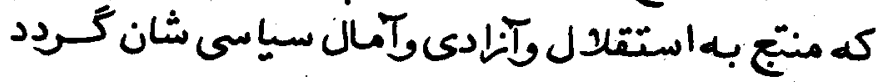
بالفت نتموده است.

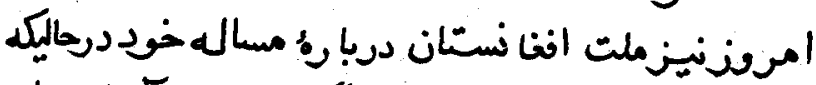

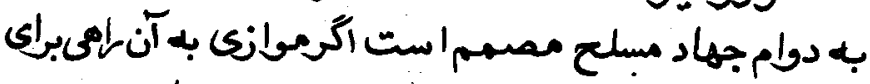

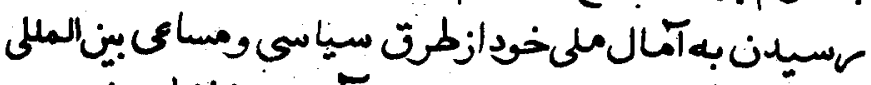

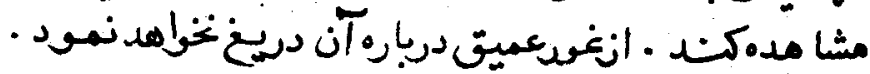




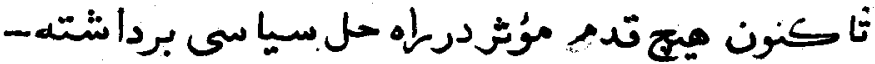

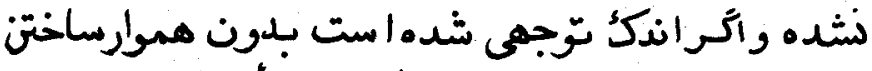

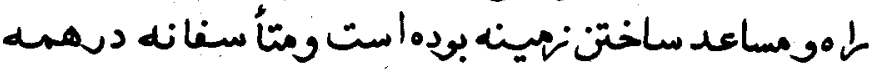

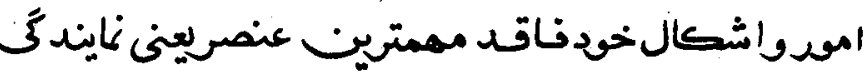

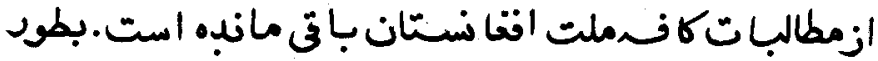

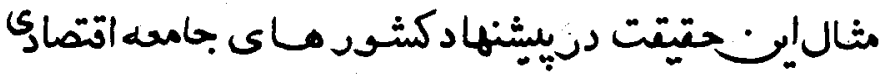

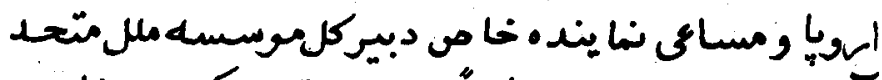

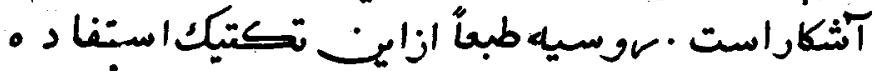

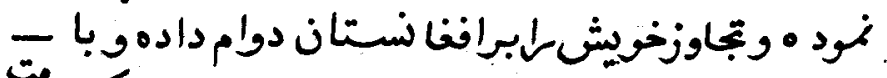

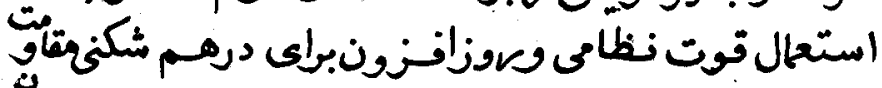

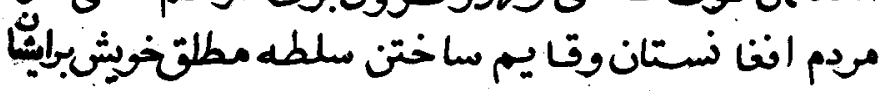

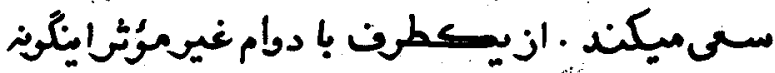

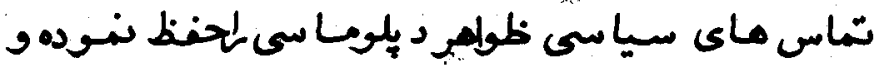

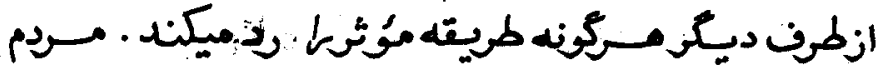

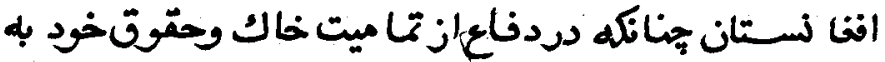

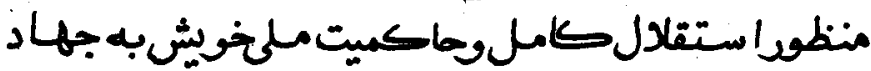

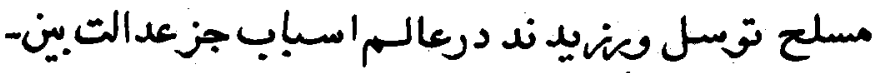

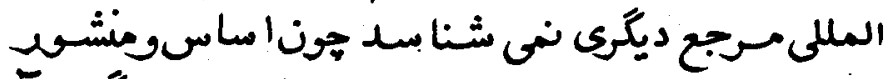

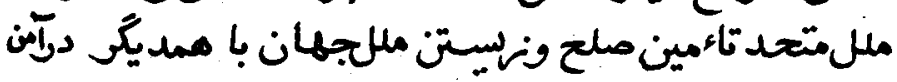

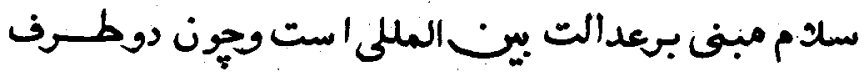

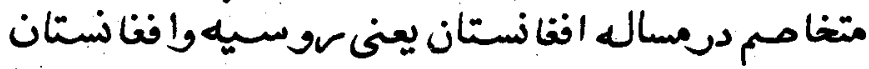


iv.

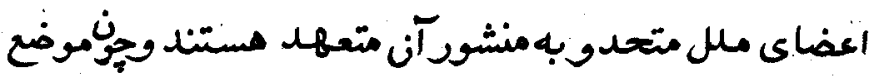

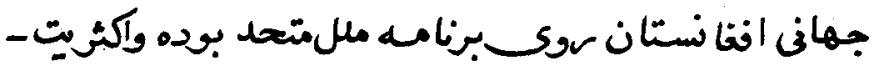

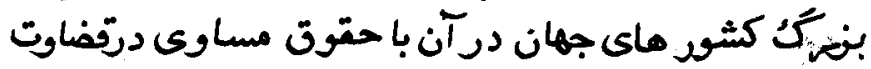

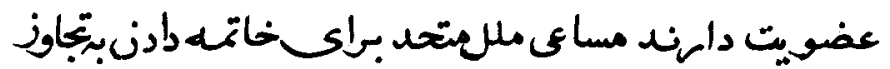

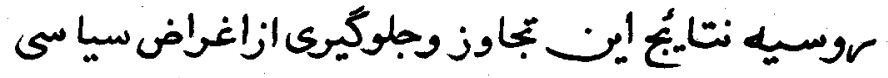

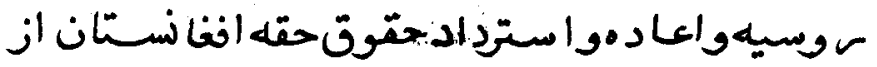

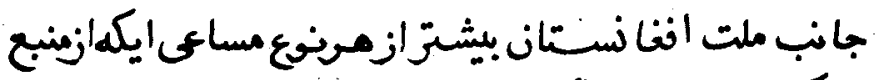

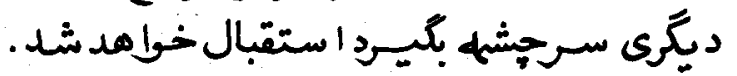

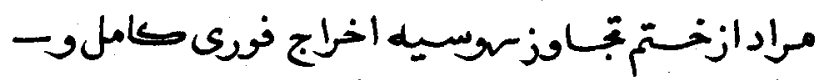

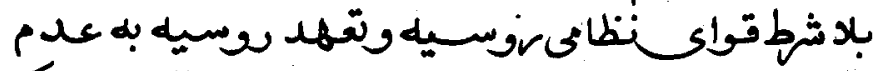

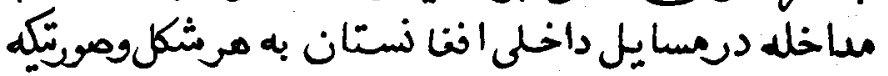

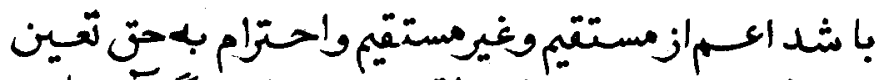

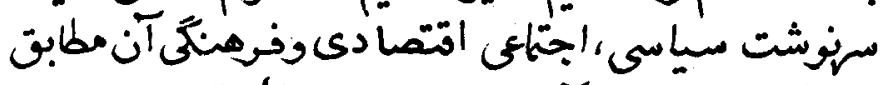

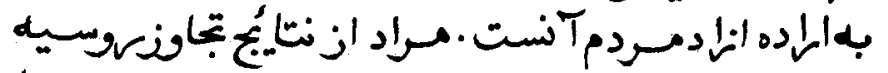

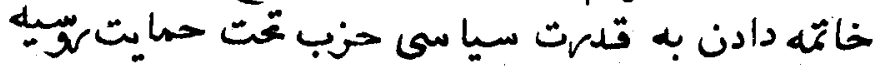

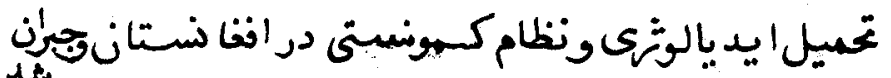

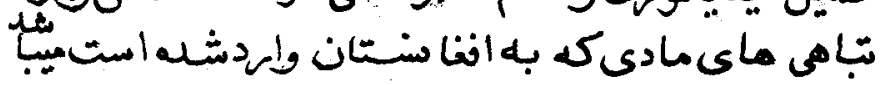

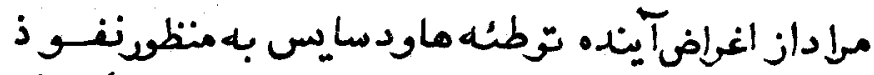

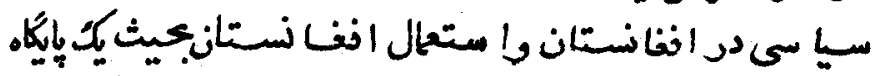

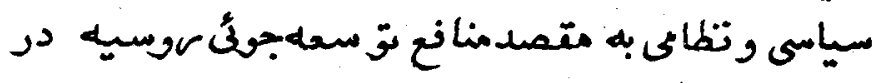
خارج مسرحلات انتا نستان أست . 
بتا برملحوظلا تيكم نتيه آنرا به ميجيج صورت نميتوان

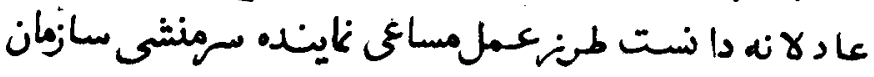

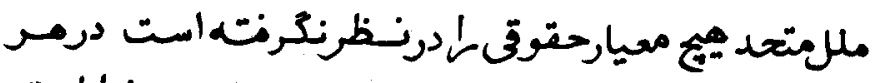

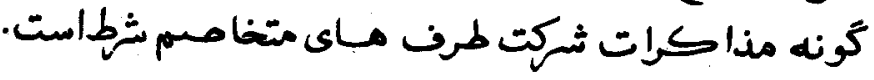

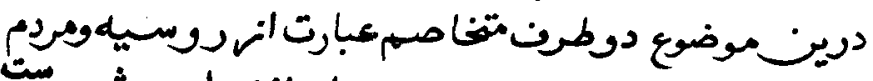

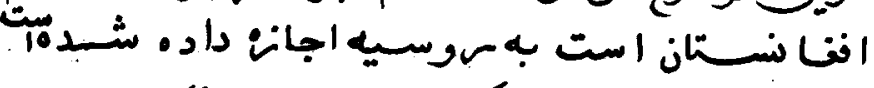

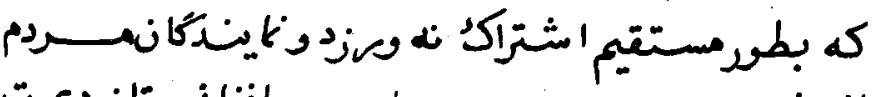

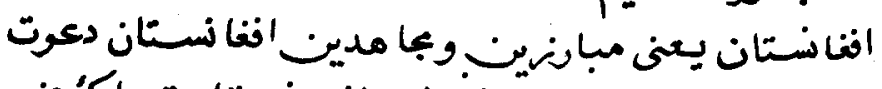

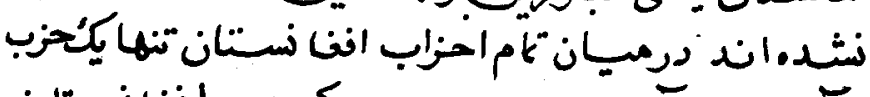

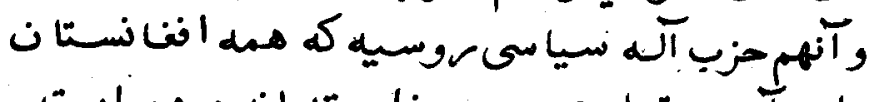

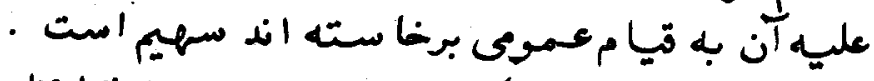

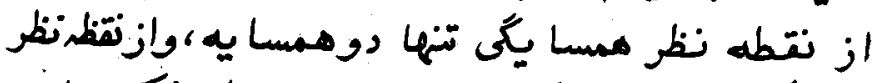

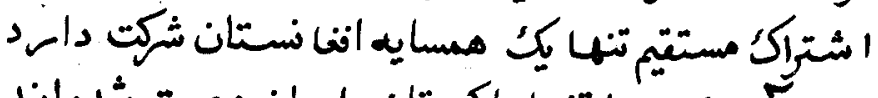

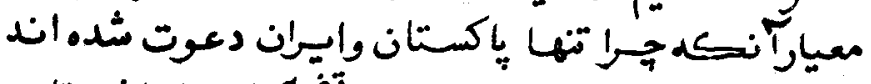

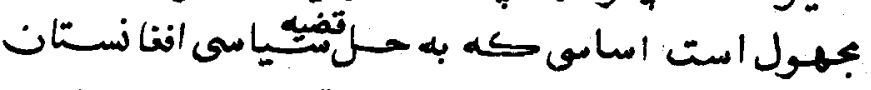

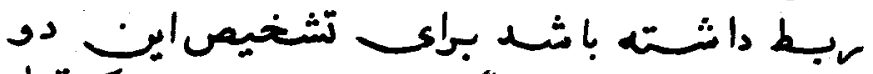

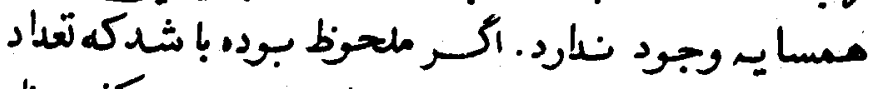

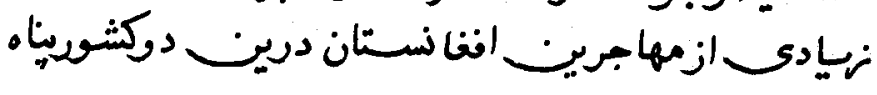

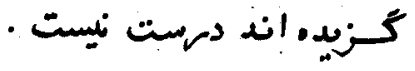

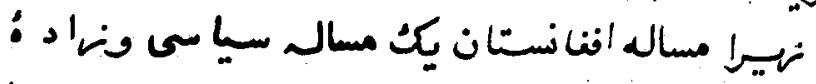

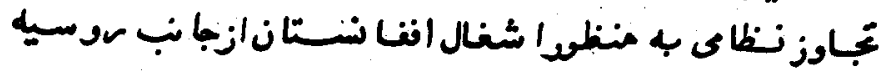




\section{$r$.}

است ـ ومسوضوق مهاجسرين نادهايت تباوزويكيازمسايل

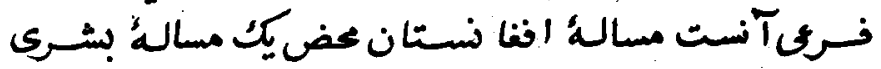

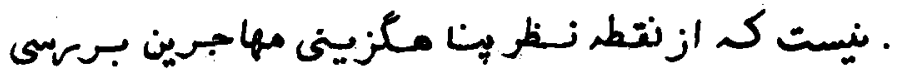

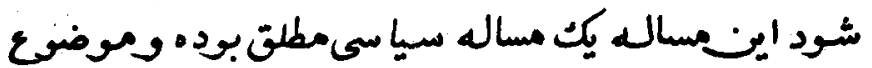

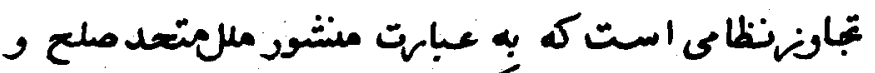

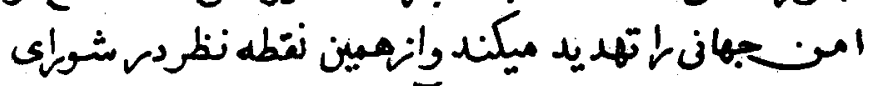

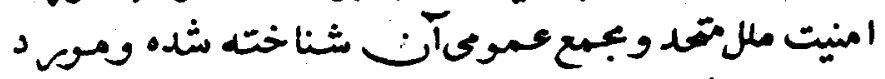

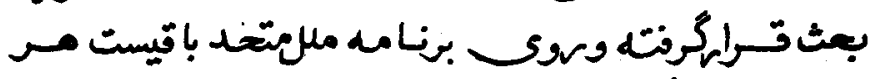

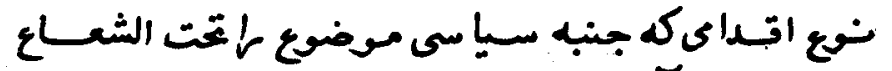

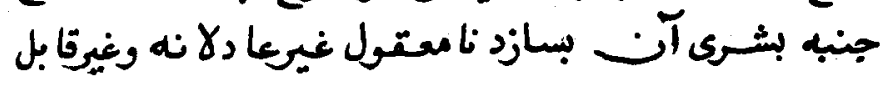

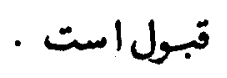

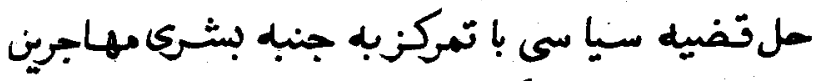

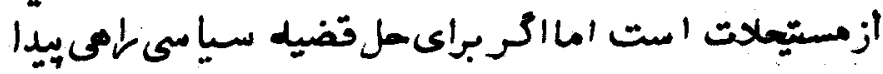
شهود موضوع مهاجرين خوف بخود ململ ميشود.

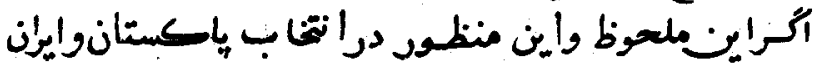

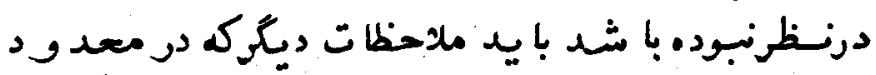

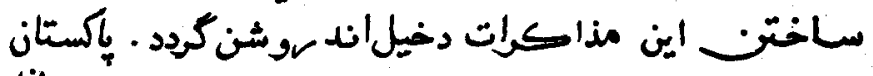

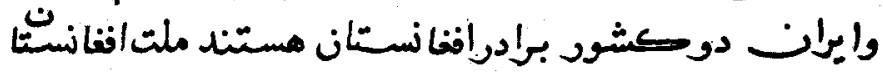

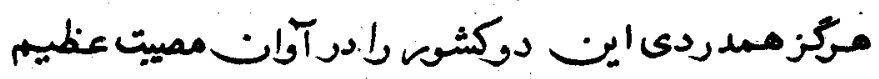

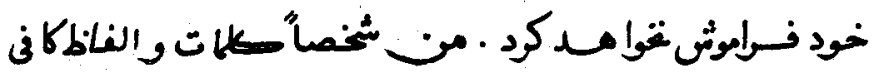

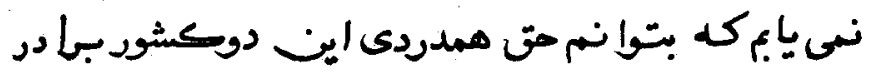




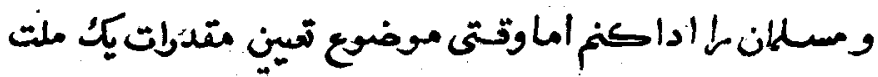

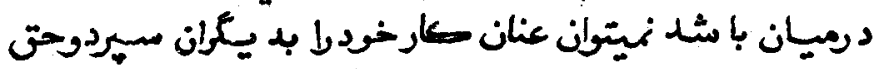

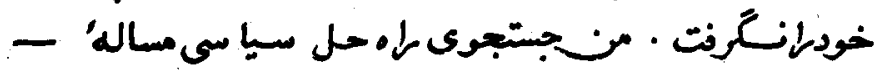

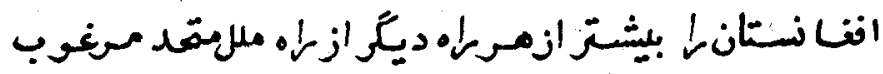

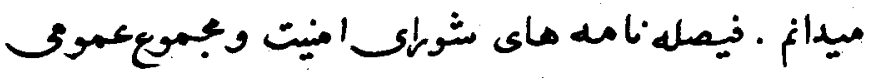

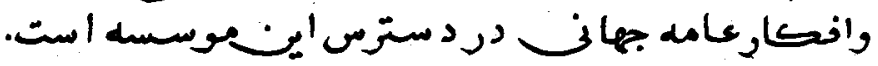

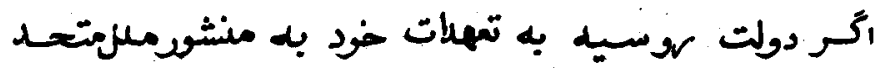

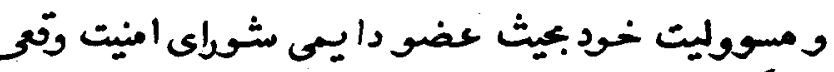

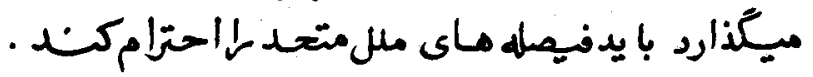

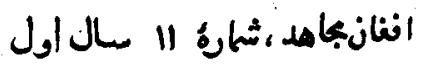

$$
\text { r }
$$




\section{rr}

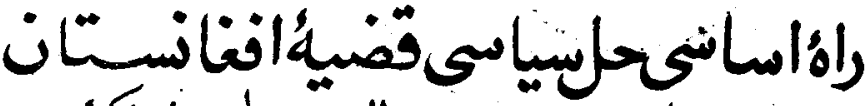

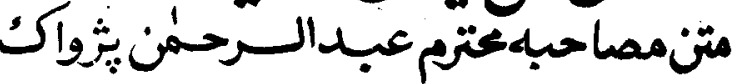

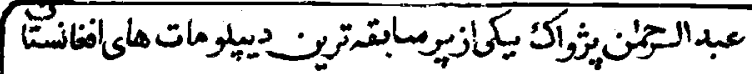

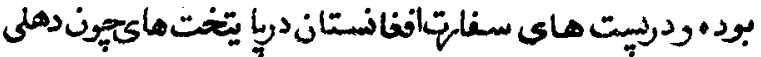

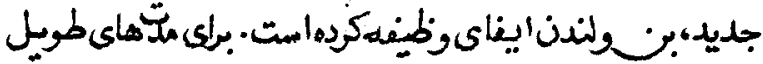

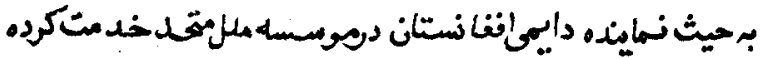

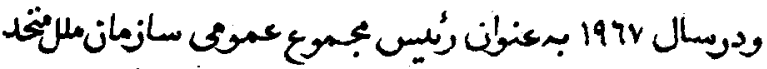

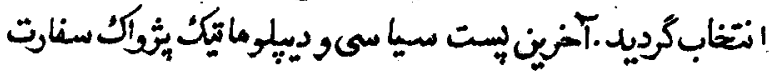

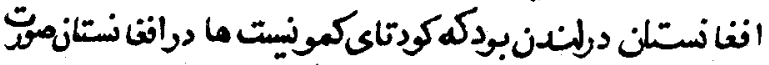

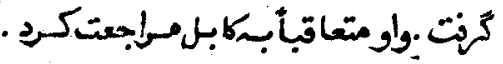

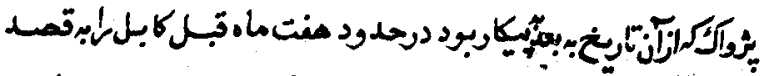

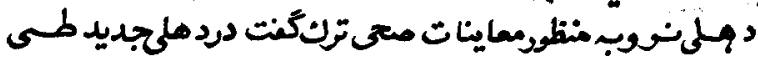

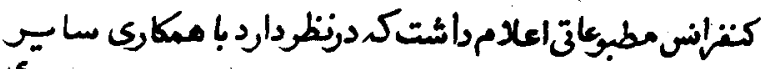

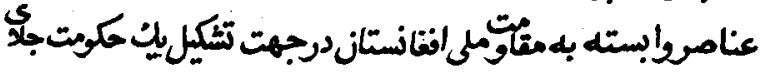

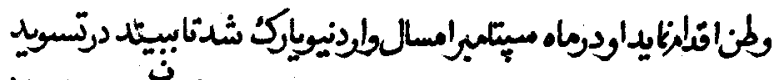

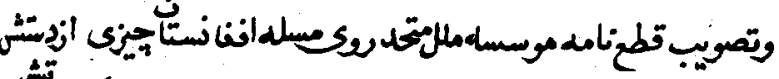

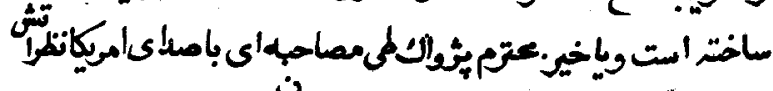

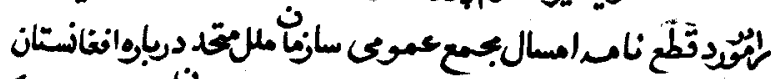

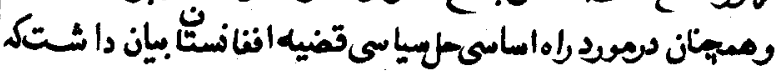

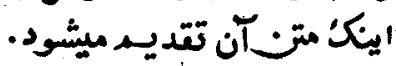




\section{$\left(\begin{array}{c}0^{E R T} \\ a^{2} A C K U \\ 2043\end{array}\right)^{2}$}

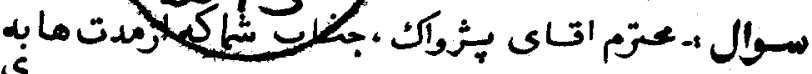

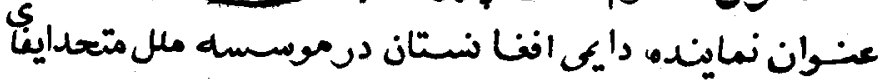

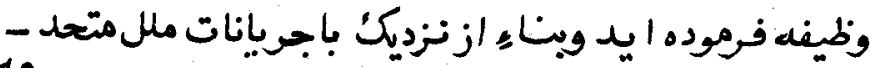

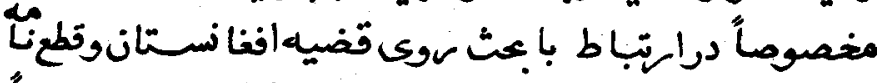

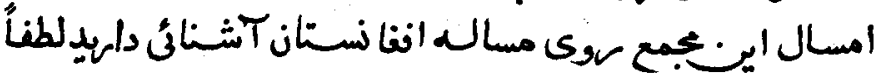

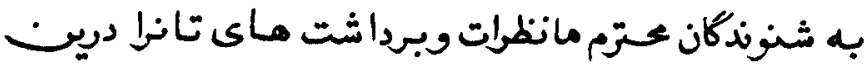

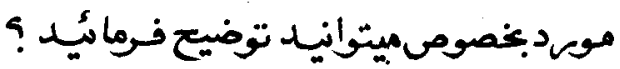

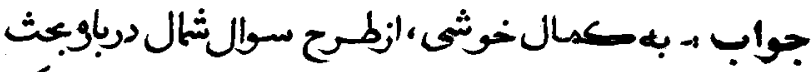

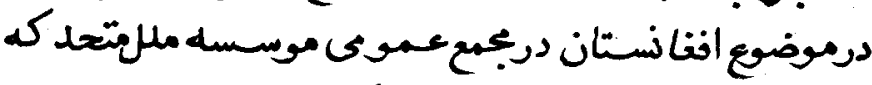

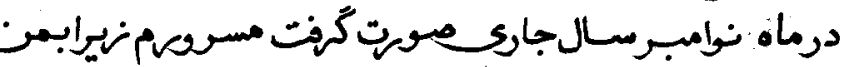

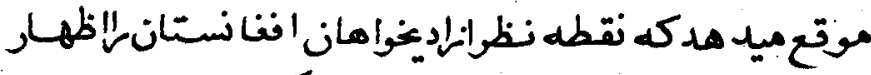

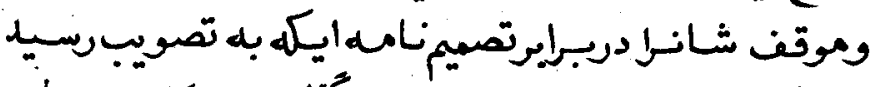

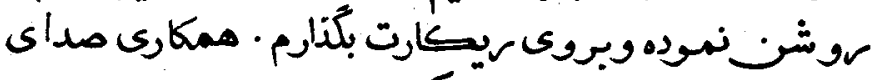

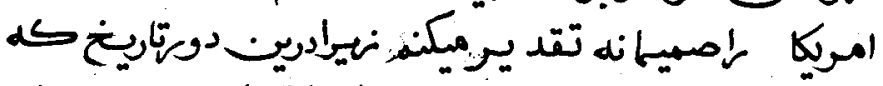

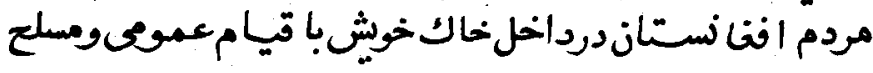

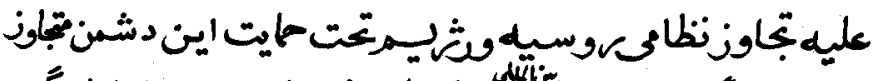

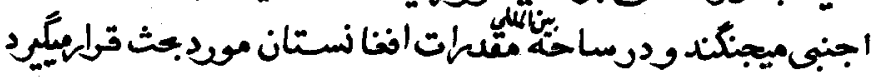

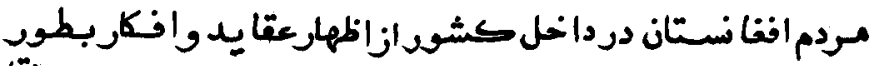

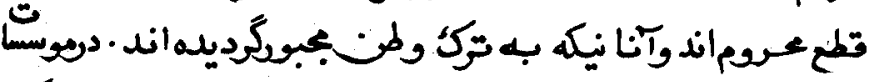

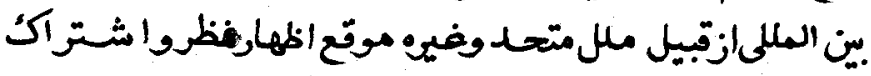

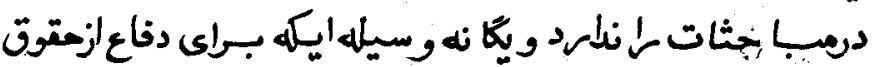




$$
\text { re }: 3,
$$

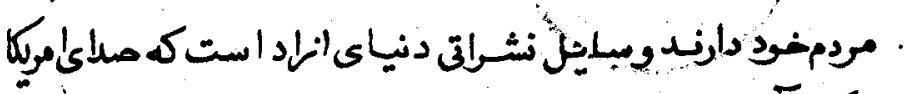

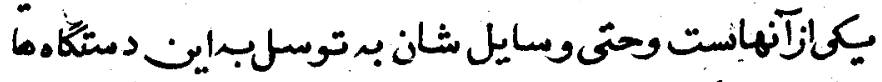

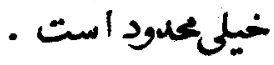

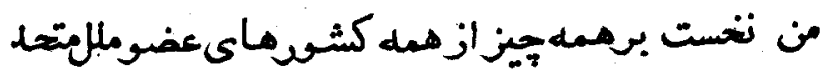

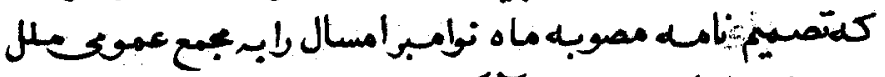

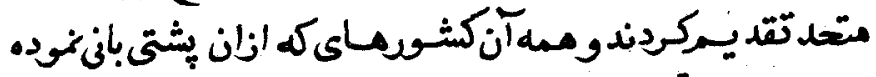

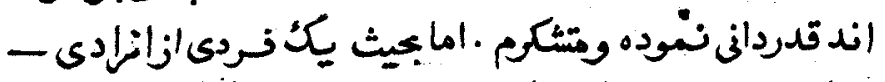

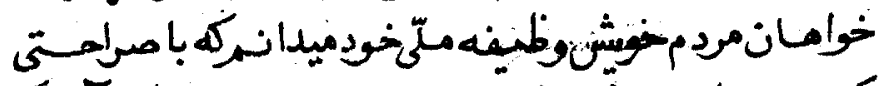

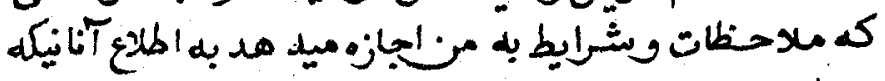

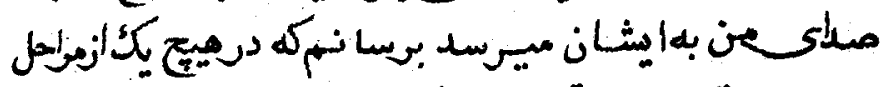

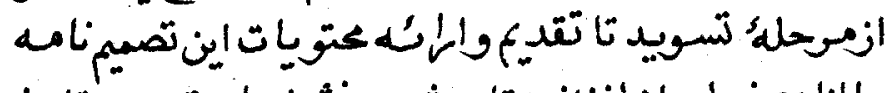

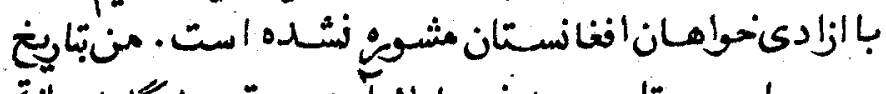

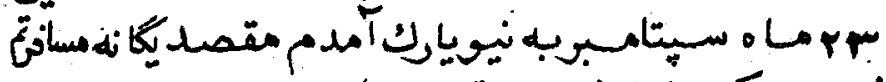

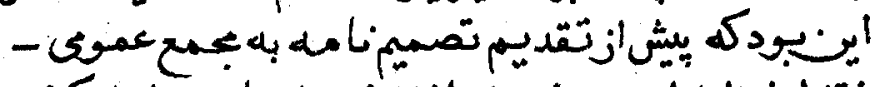

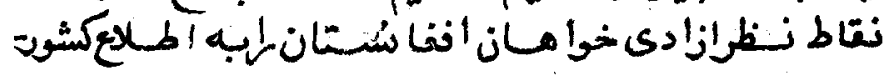

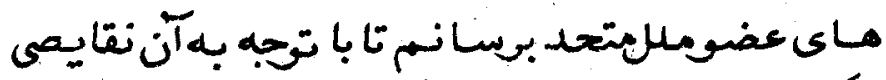

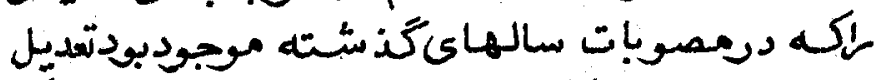

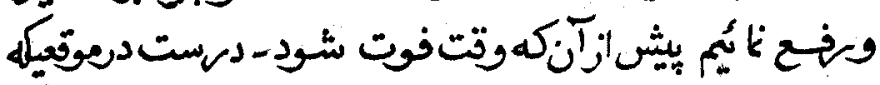

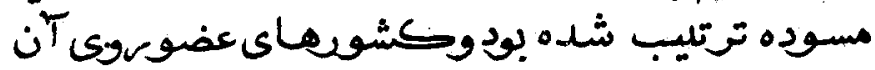

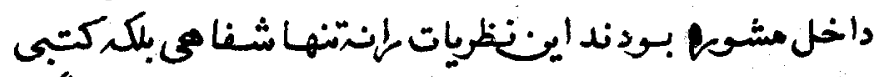

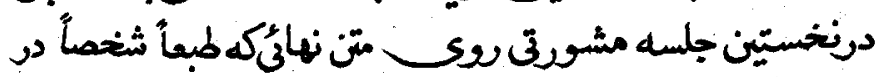




\section{ro}

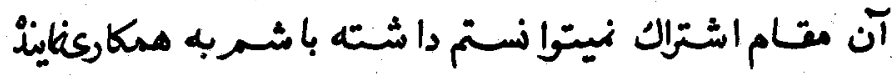

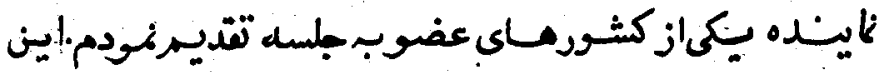

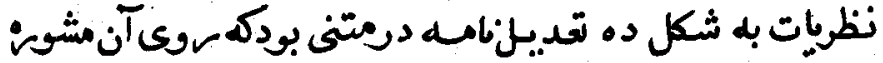

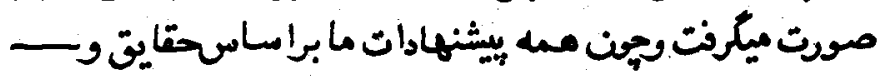

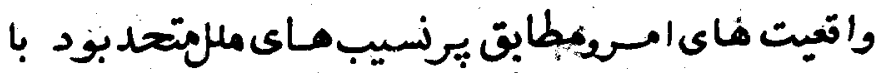

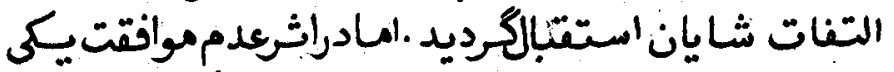

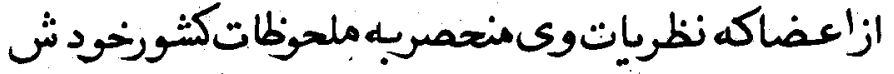

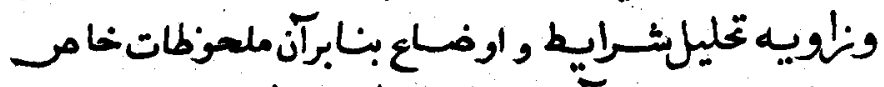

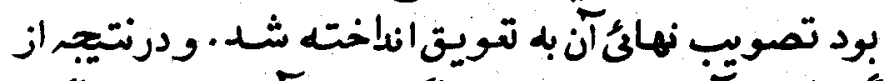

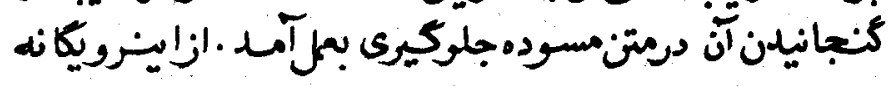

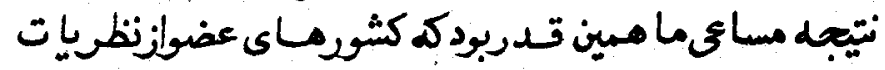

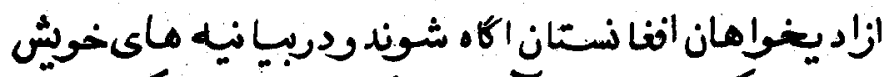

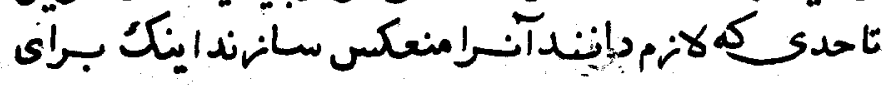

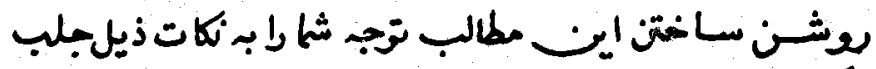

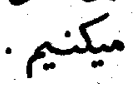

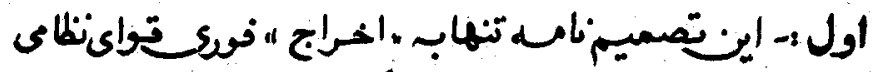

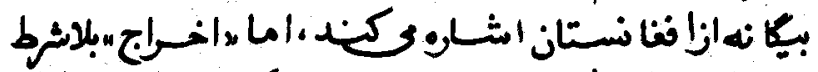

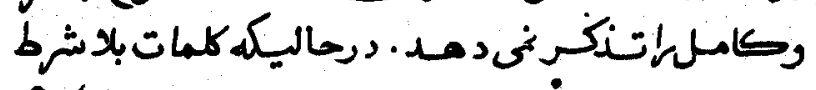

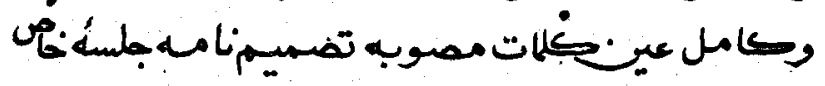

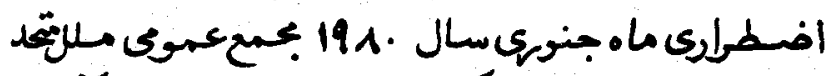

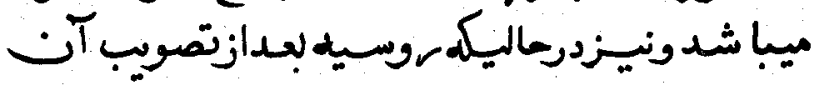


พา

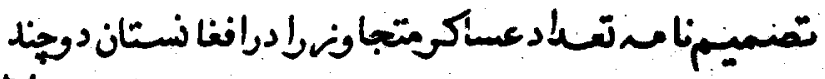

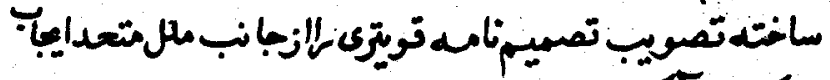

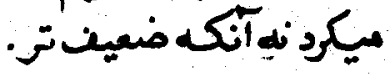

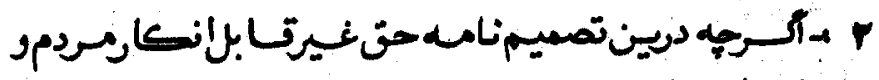

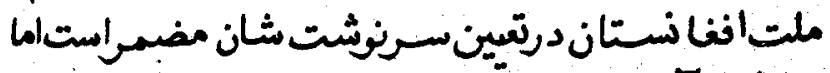

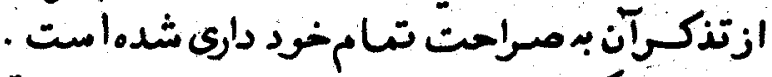

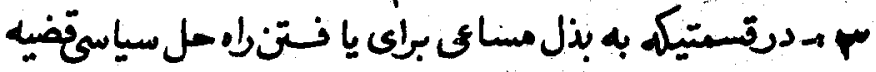

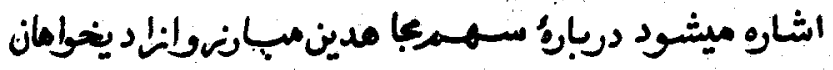

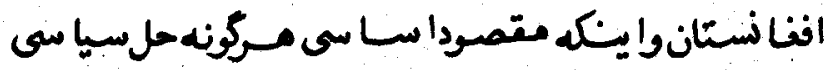

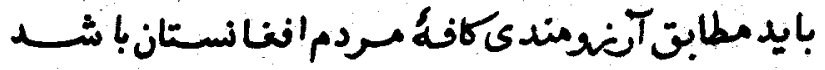

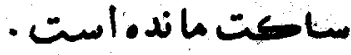

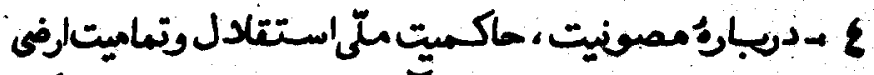

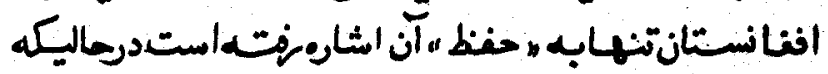

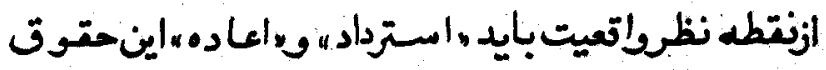

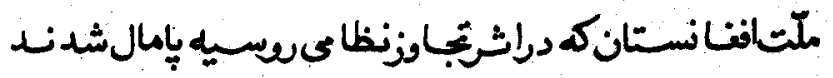

مطالبر ميشد.

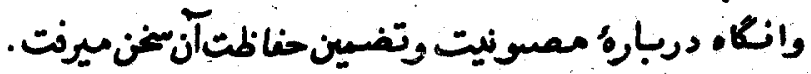

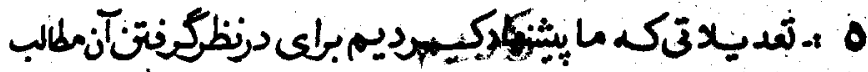

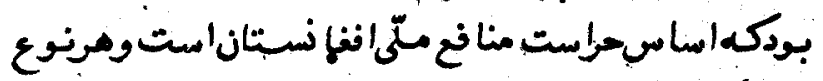

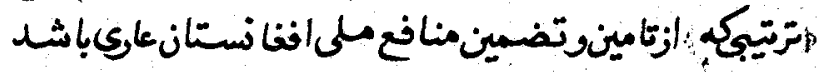

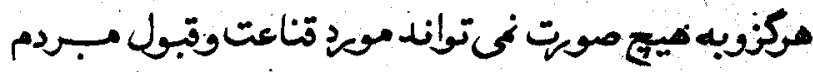




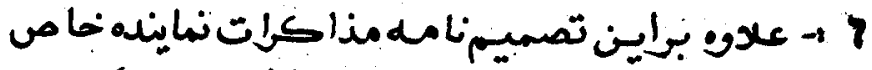

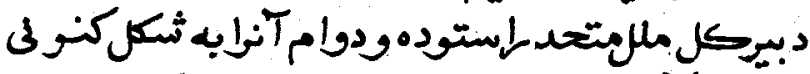

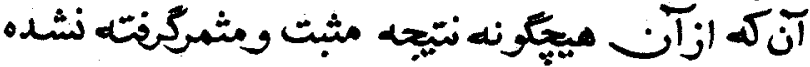

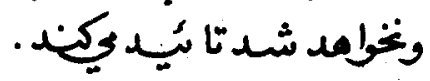

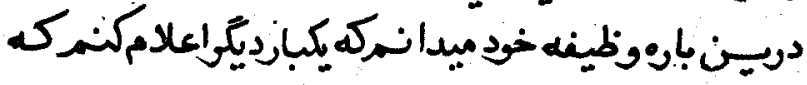

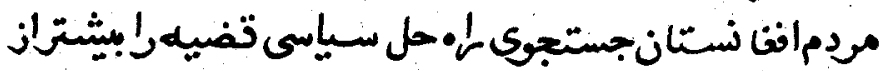

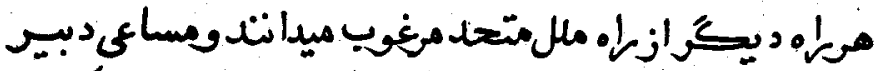

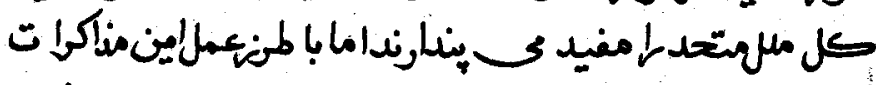

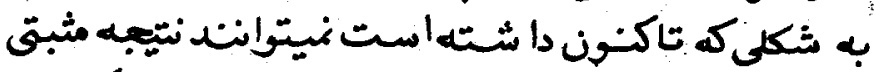

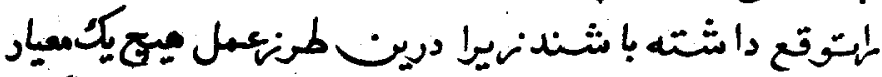

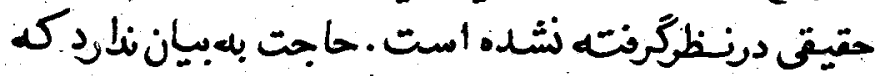

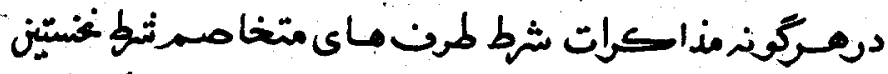

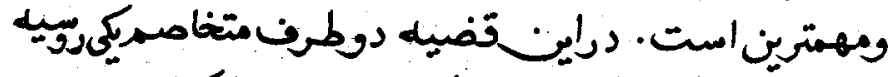

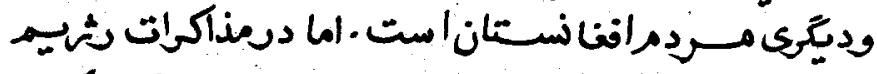

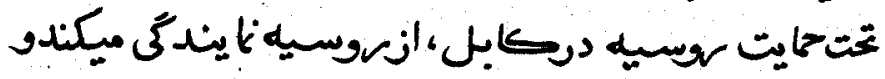

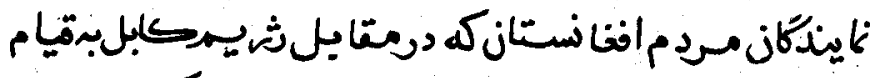

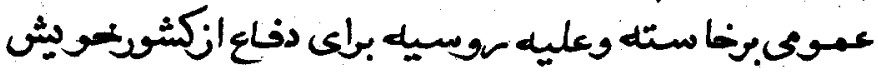

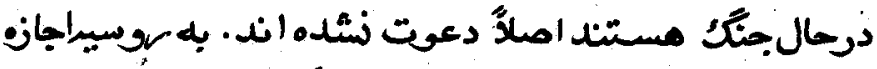

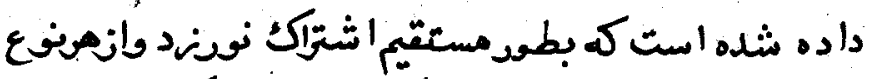

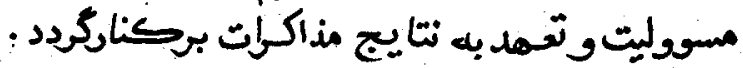




\section{$\mathbf{r}$}

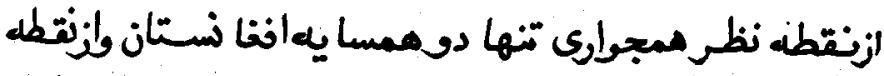

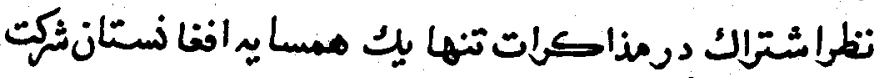

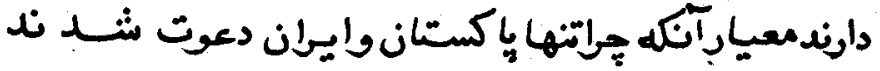

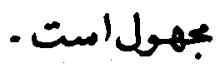

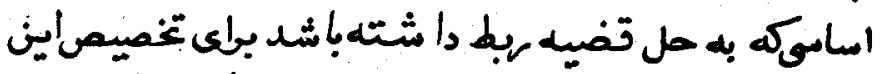

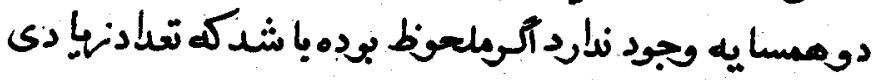

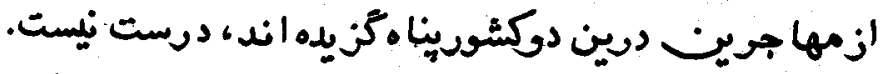

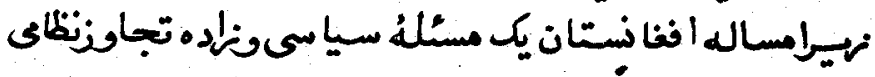

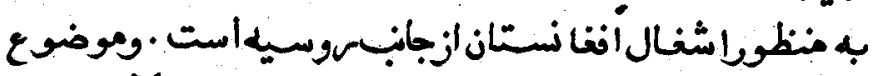

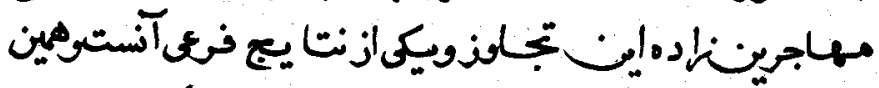

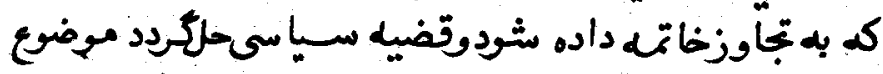

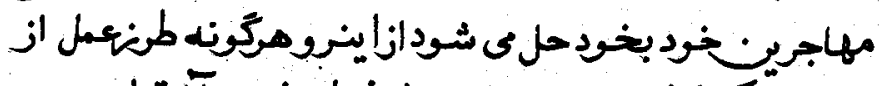

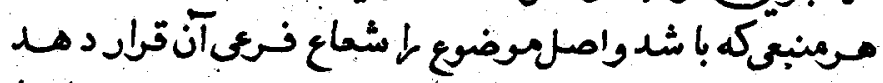

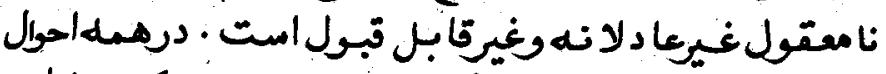

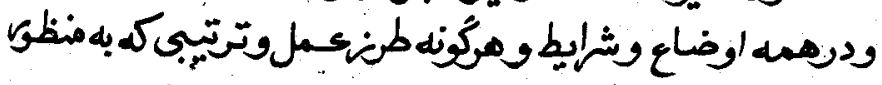

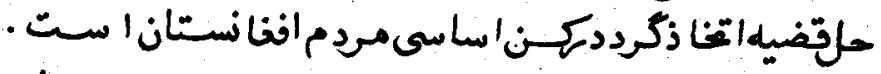

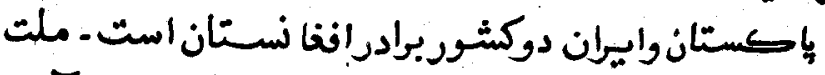

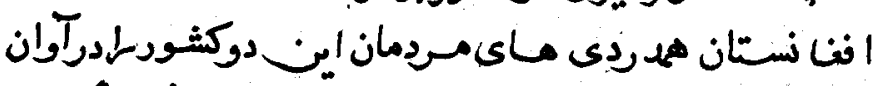

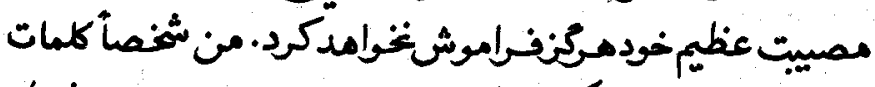

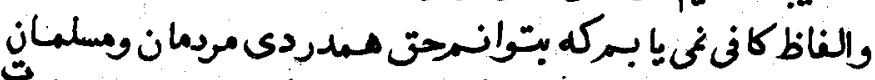

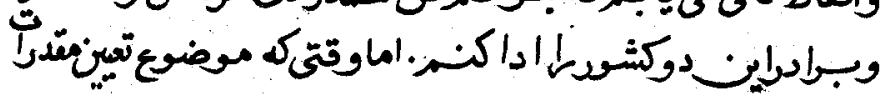




\section{ri}

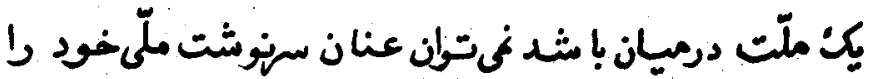

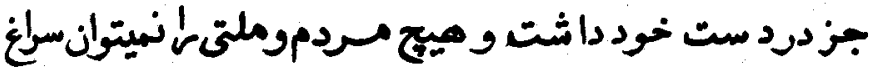

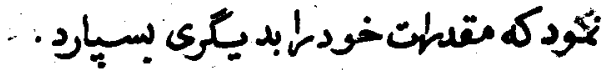

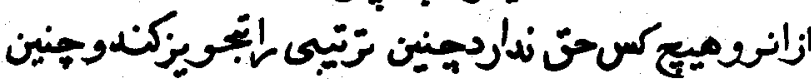

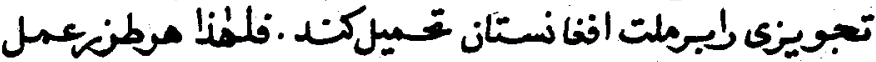

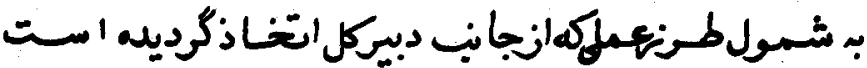

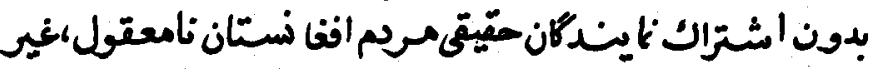

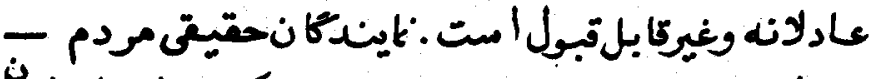

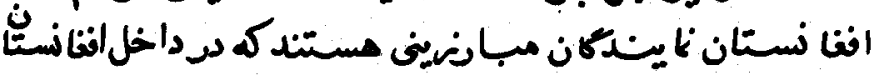

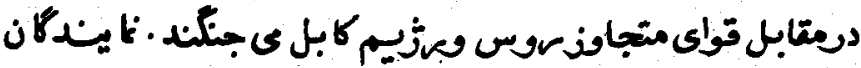

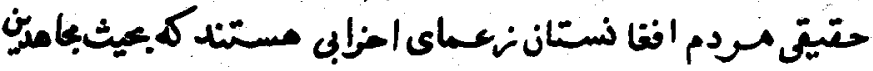

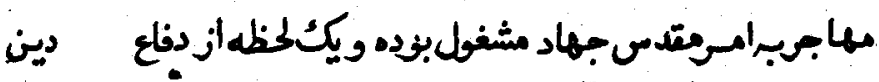

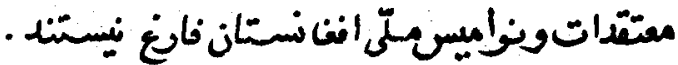

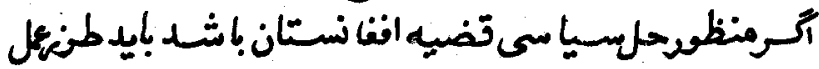

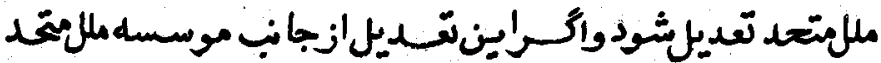

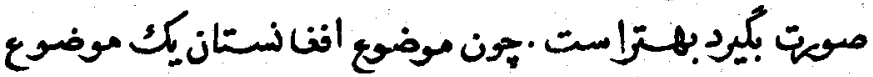

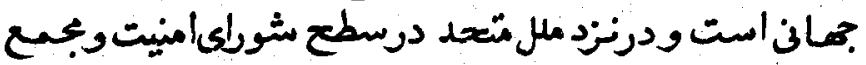

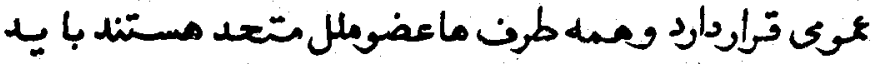

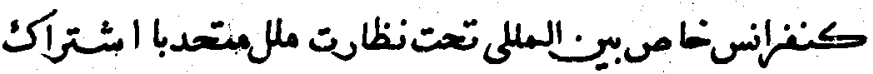

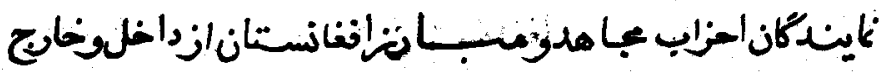

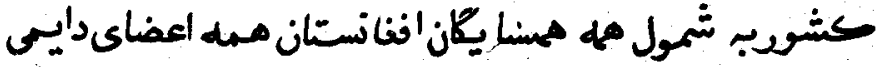




\section{$r$}

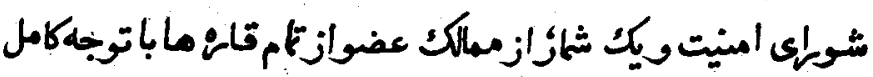

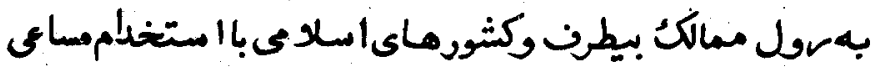

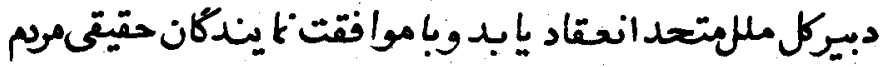

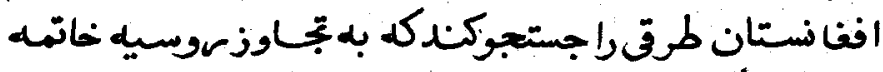

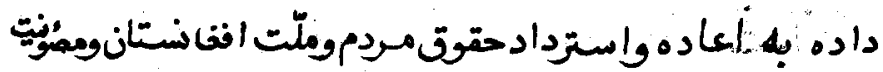

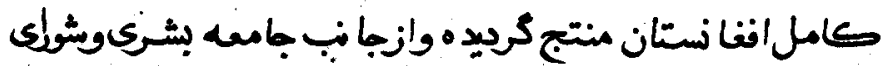

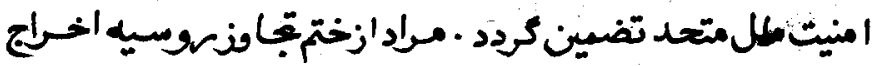

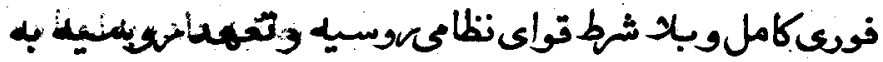

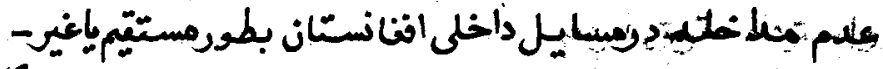

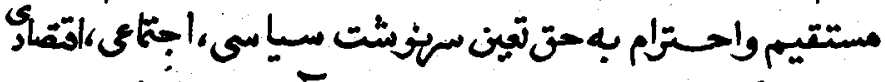

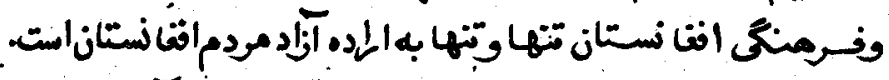

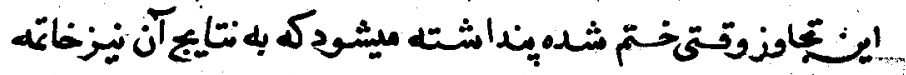

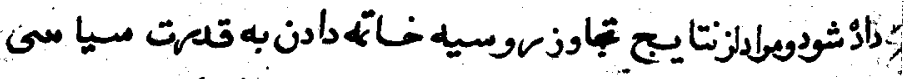

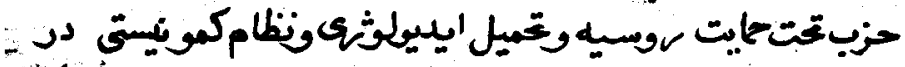

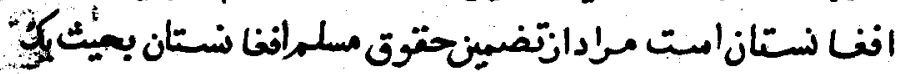

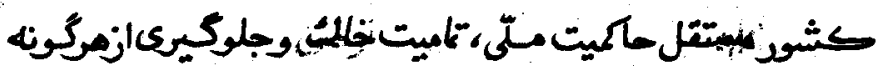

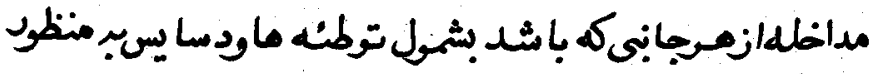

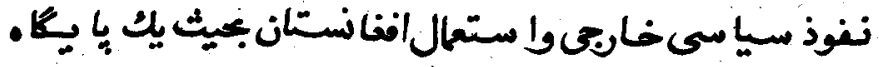
تنظأى ميبا شده. مودم افنا نستان ميغوأهندكئوريثان مستتل ،مردمريثان

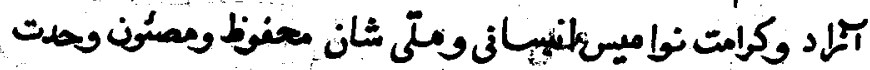




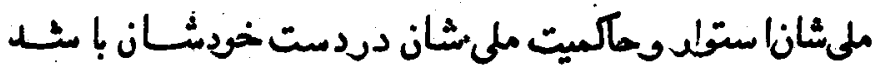

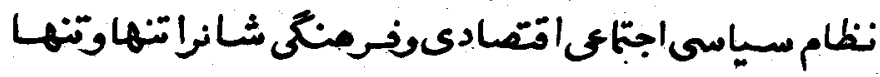

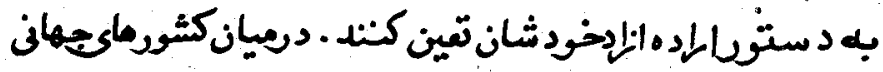

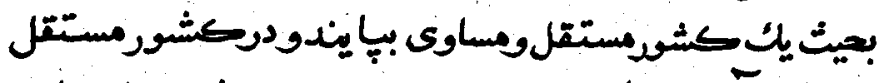

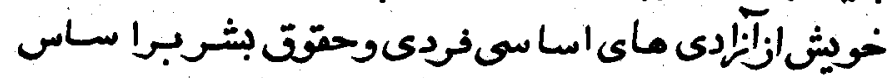

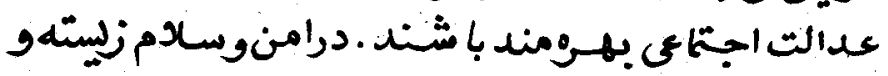

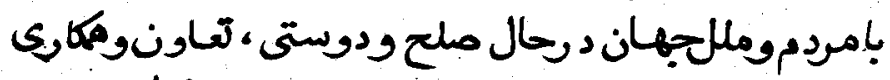

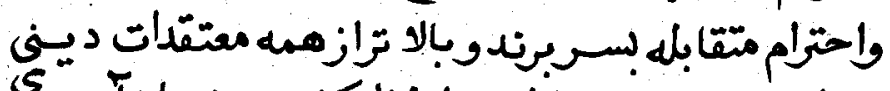

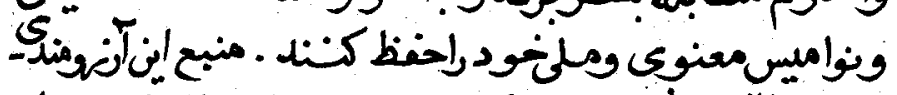

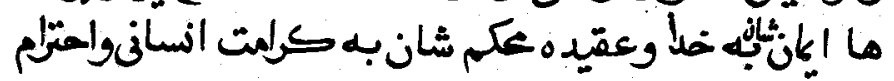

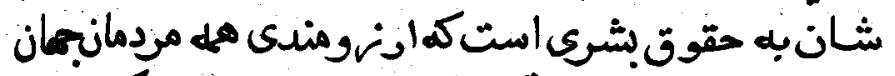

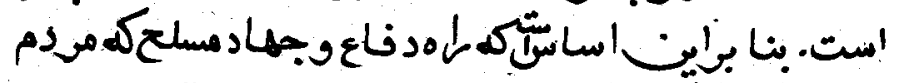

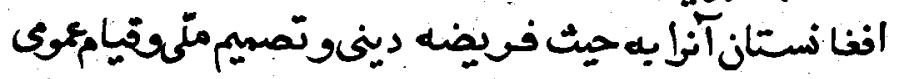

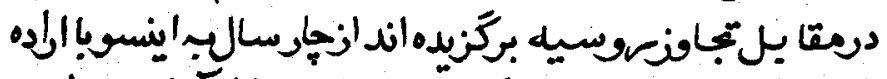

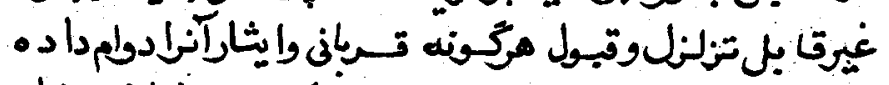

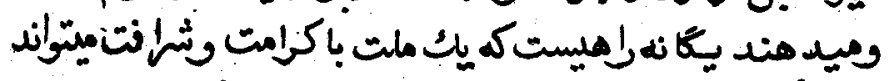

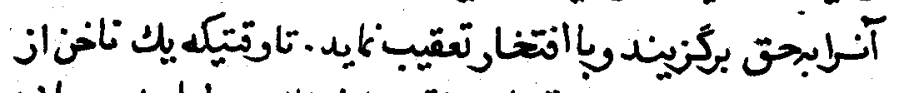

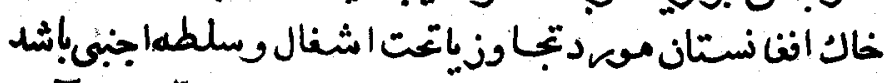

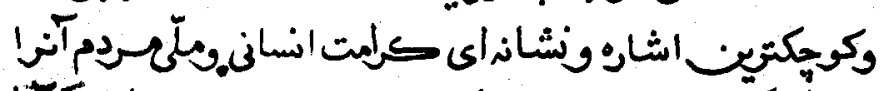

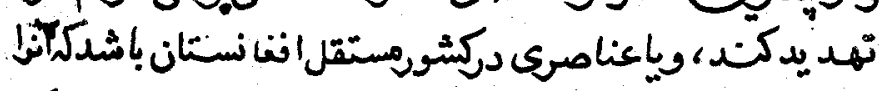

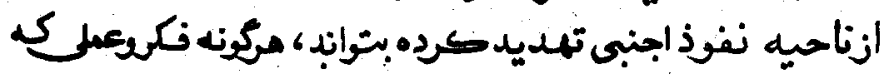

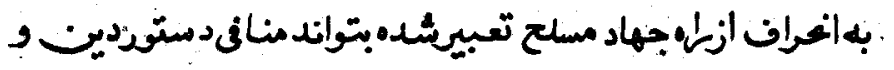




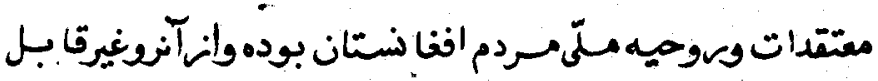

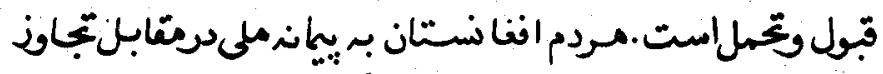

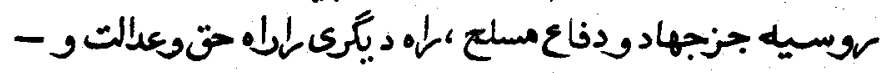

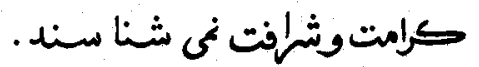

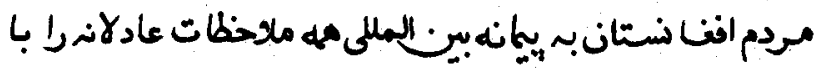

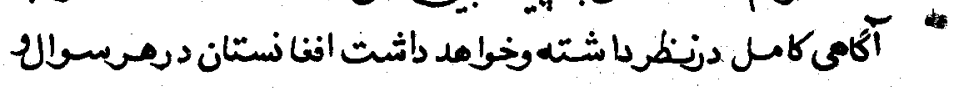

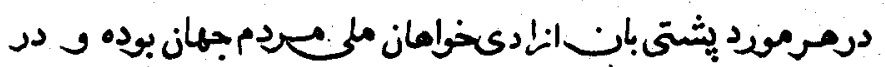

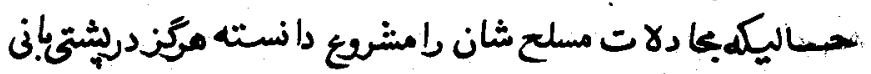

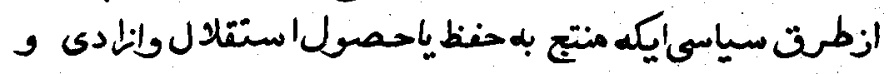

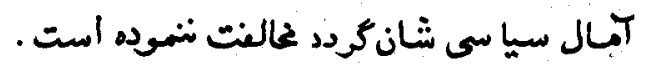

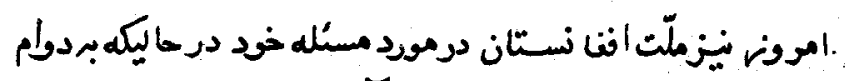

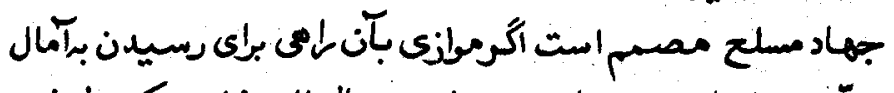

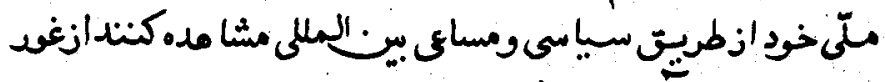
عميت درباره آن دريغ غخامند سكرد .

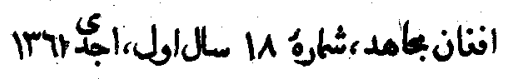




\section{قضئأفنانتان}

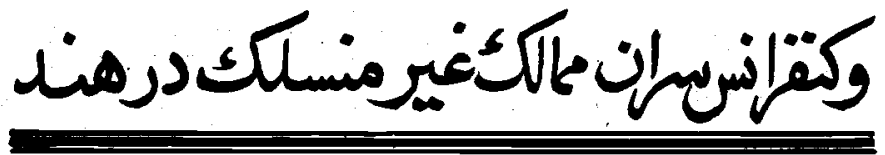

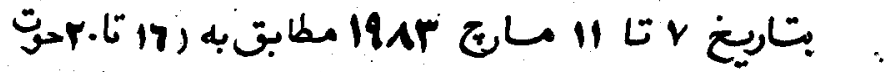

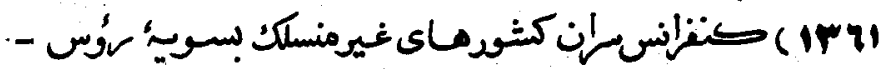

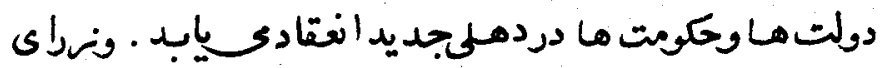

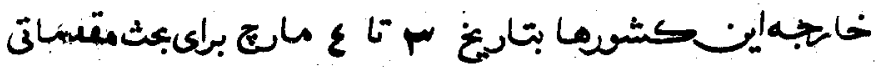

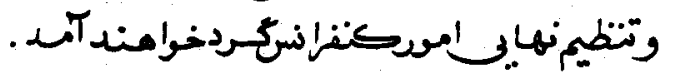

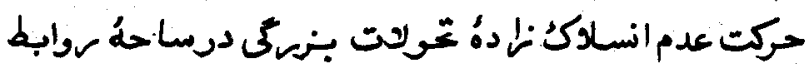

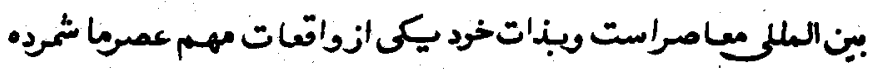

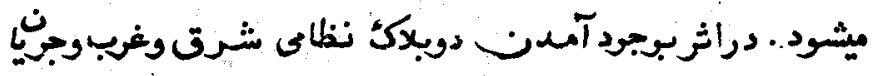

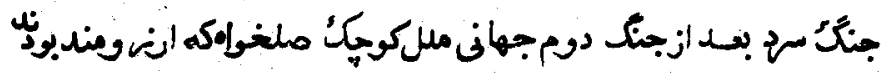

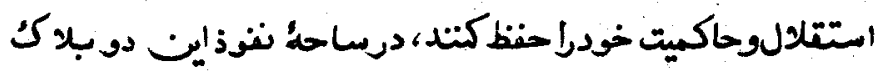

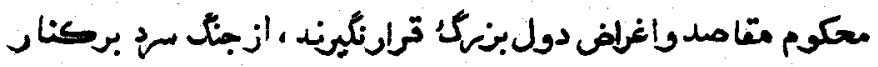


rq

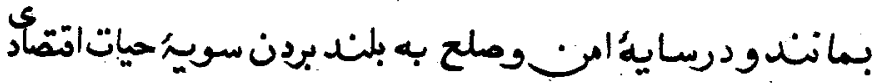

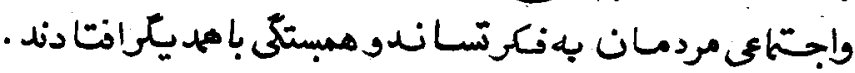

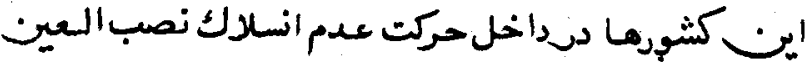

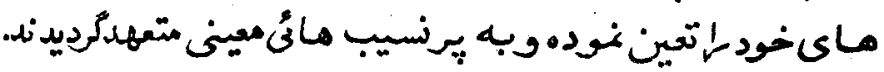

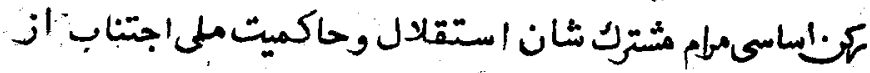

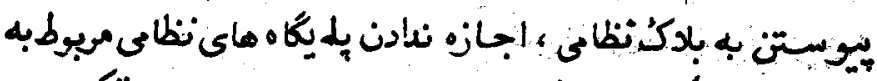

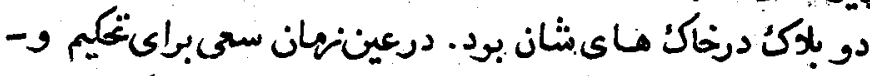

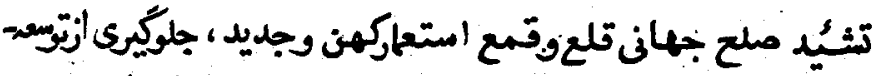

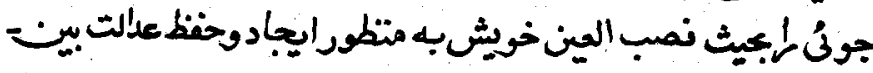
المللى بركزيسيدند.

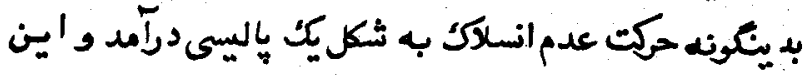

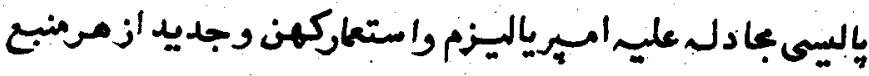

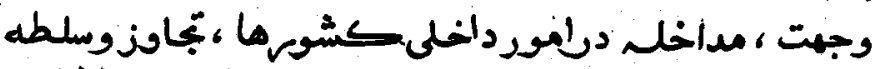

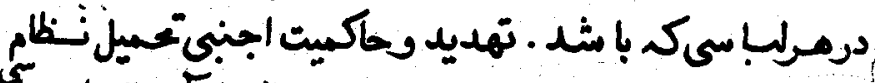

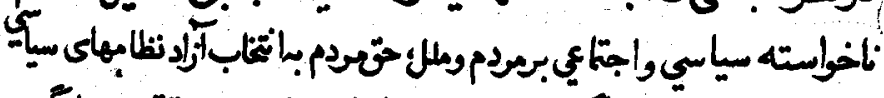

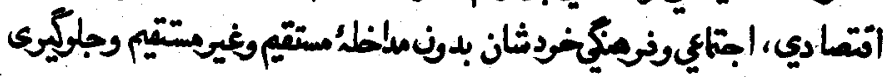

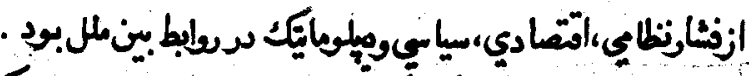

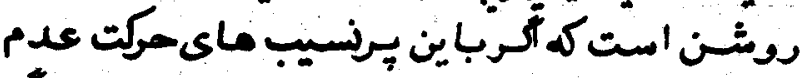

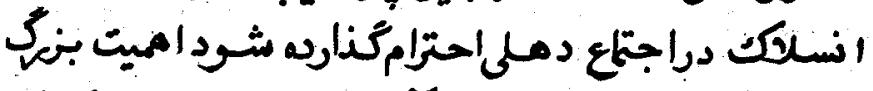

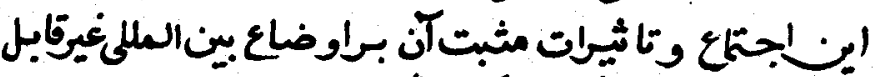

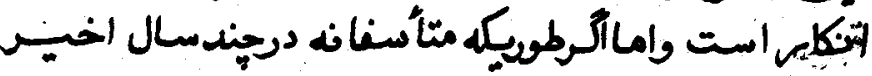




\section{ri}

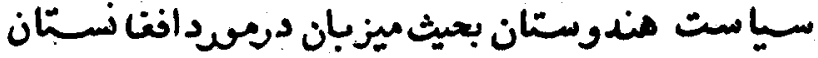

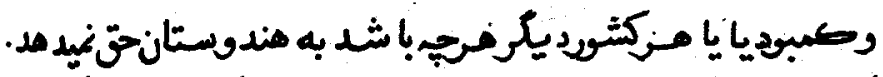

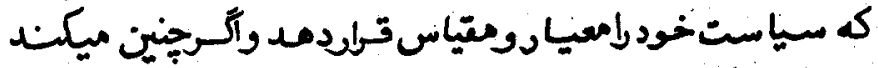

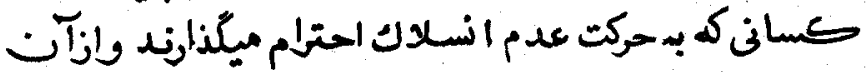

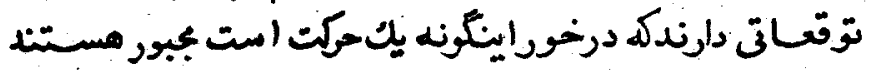

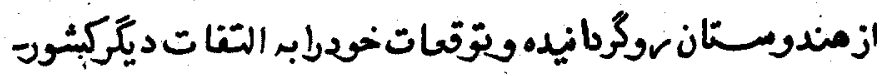

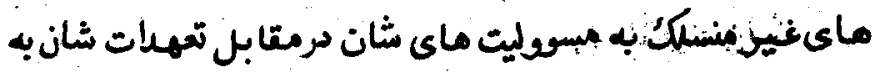

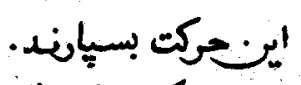

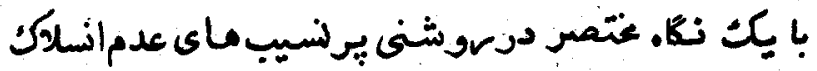

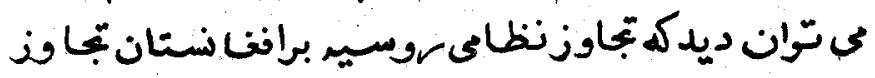

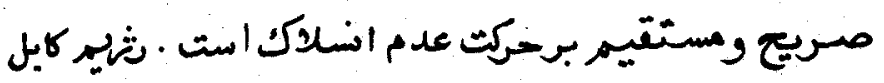

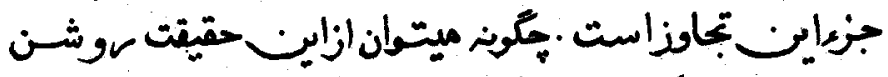

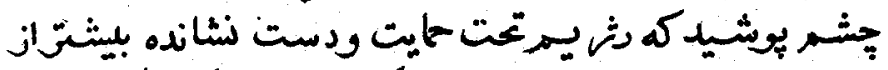

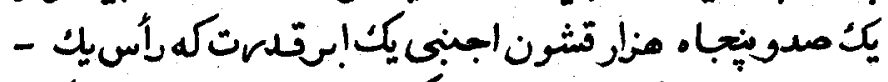

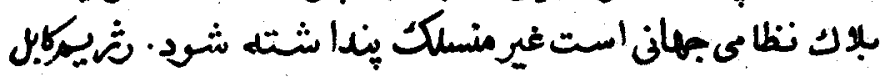

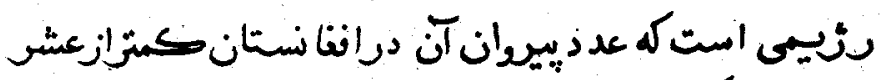

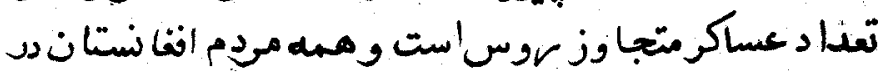

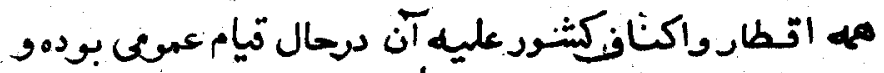

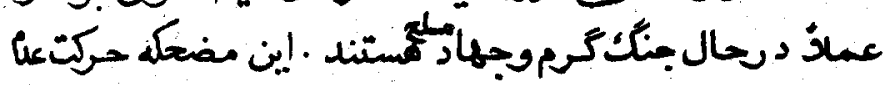

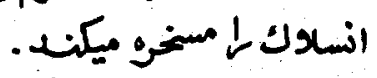

حتايت اوفطع درافنا سنتان بهمه جهان آشكابودو 


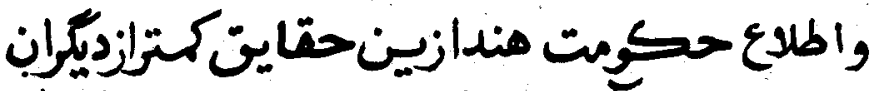

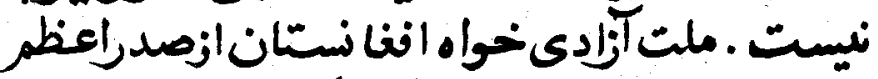

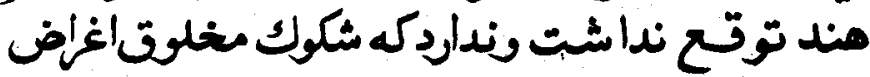

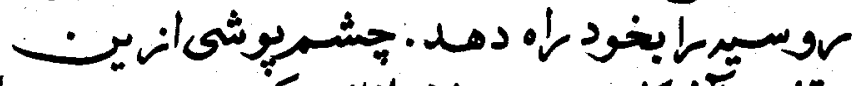

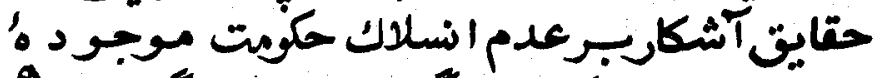

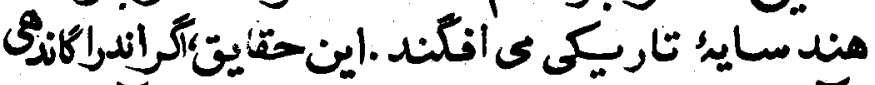

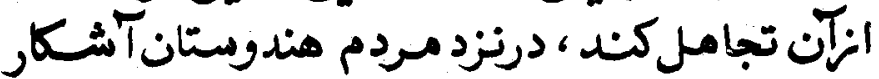

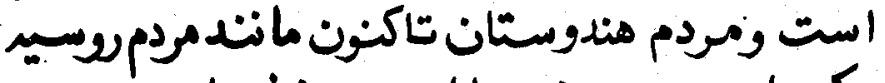

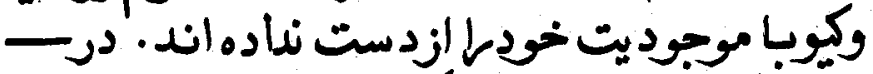

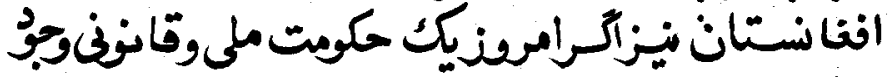

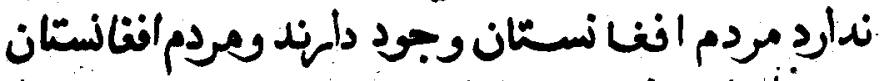

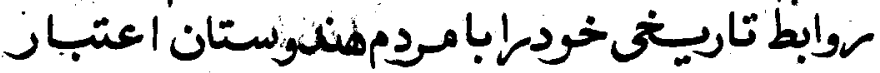

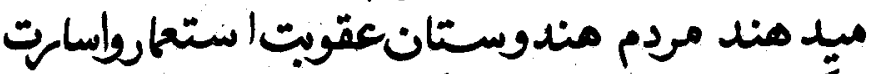

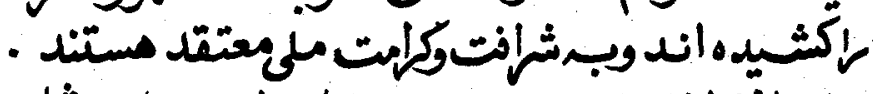

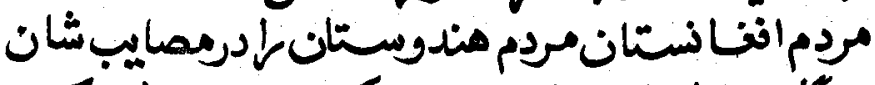

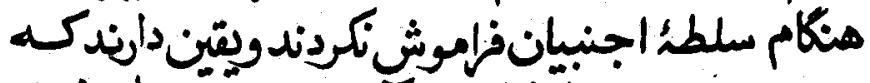

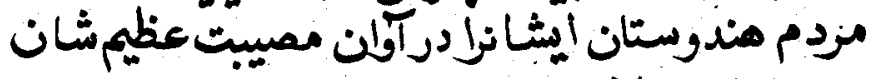

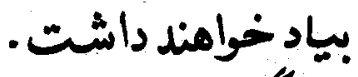

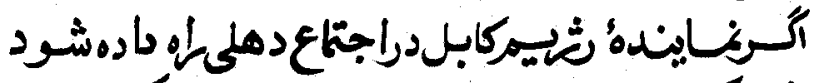

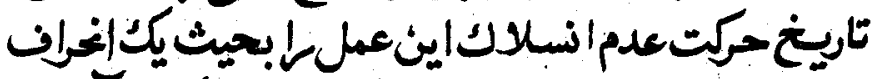
صريح از الصول عدم اسلاكتثبت خوامدكردوآنانى 


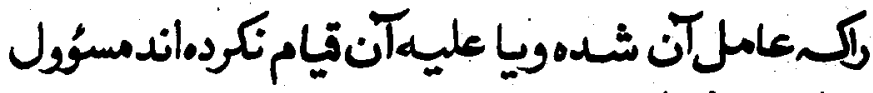
خوامند شُنَاخت .

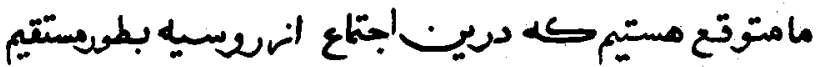

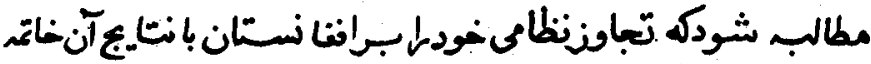

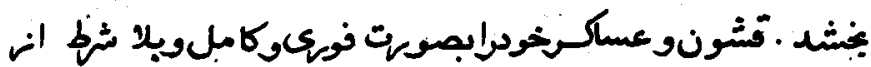

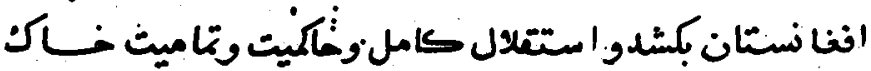

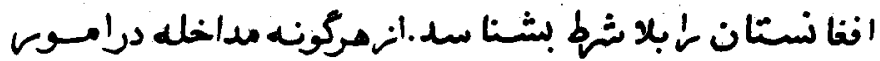

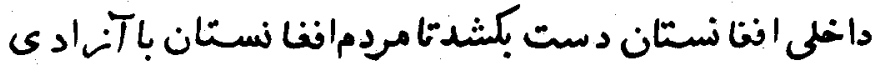

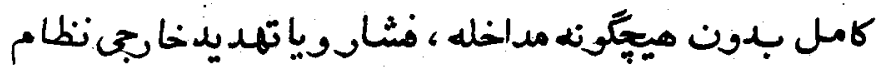

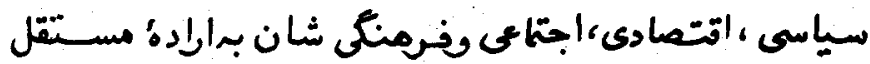

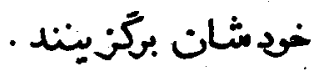

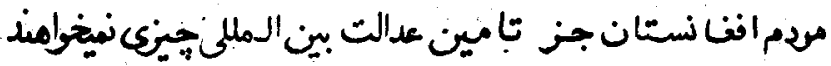

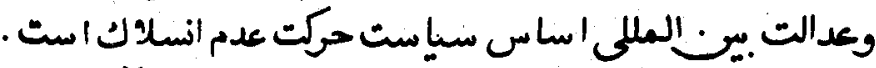

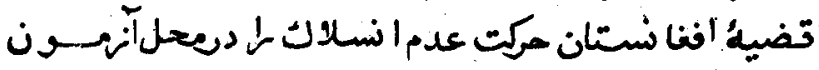

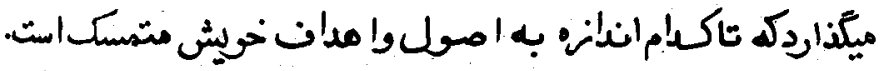

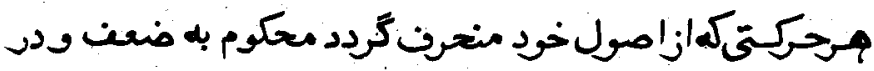

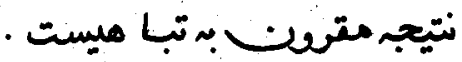

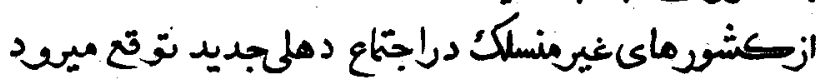

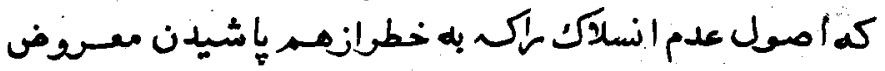

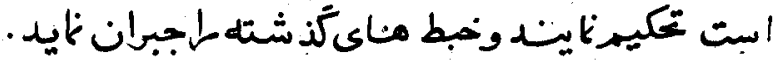

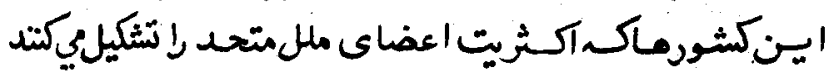




\section{$r q$}

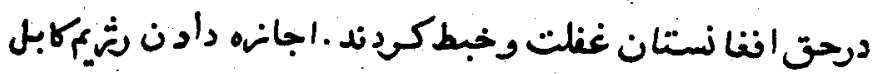

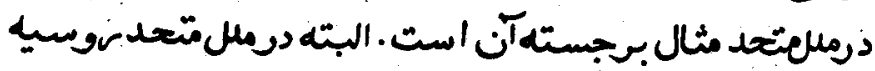

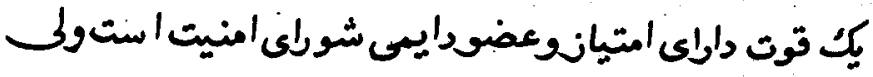

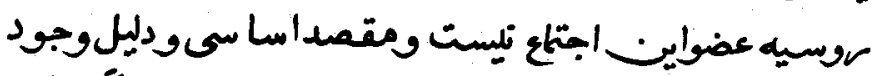

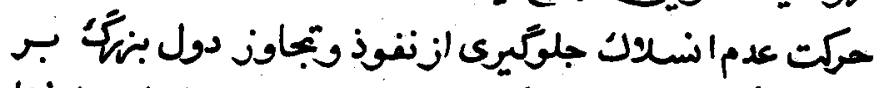

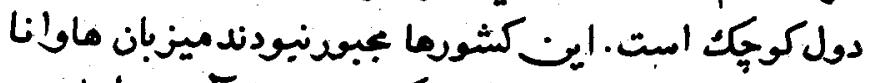

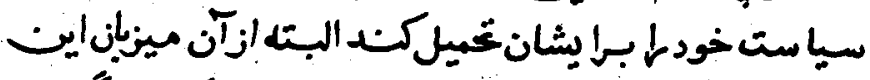

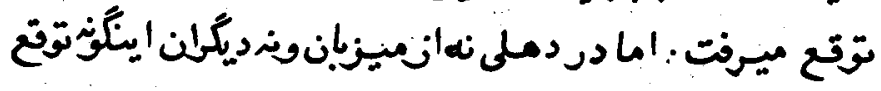

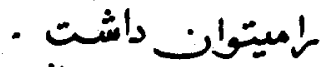

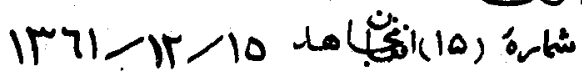




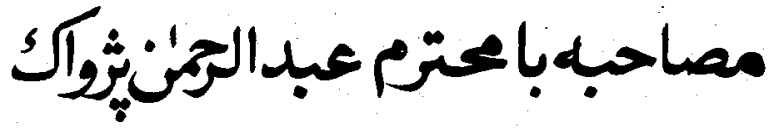
سياستمارونيدة افنانستـان

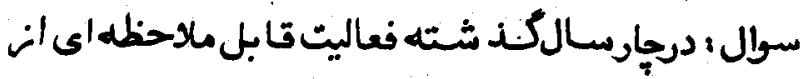

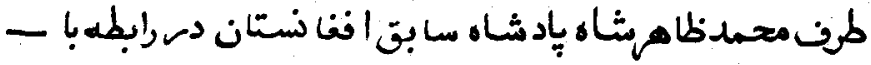

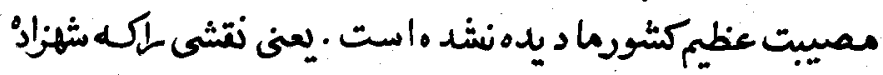

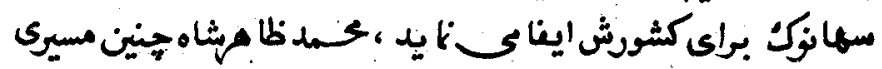

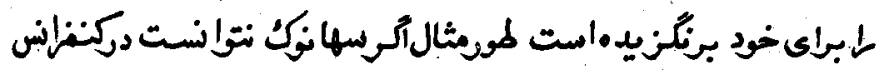

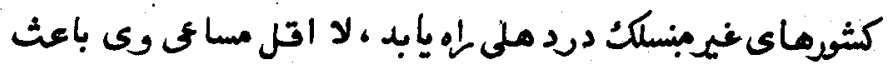

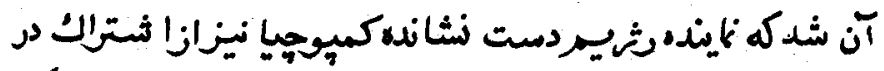

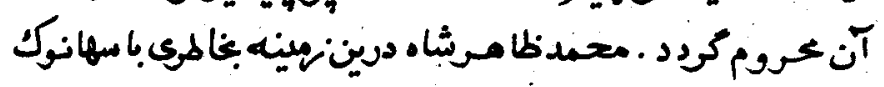

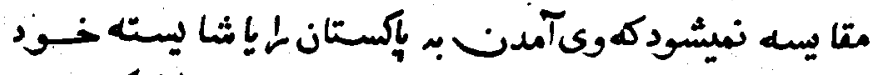

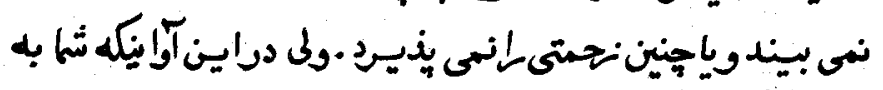

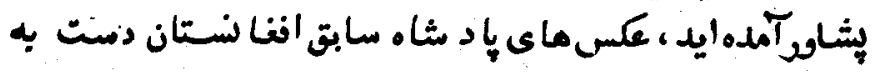




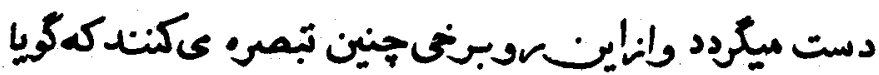

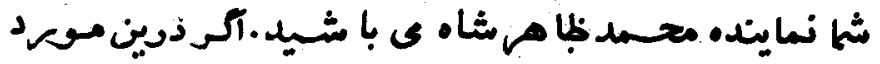

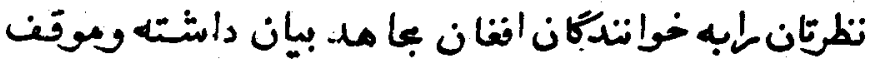

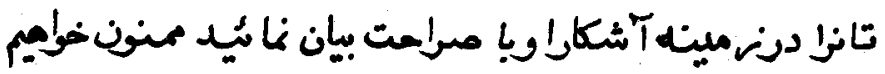

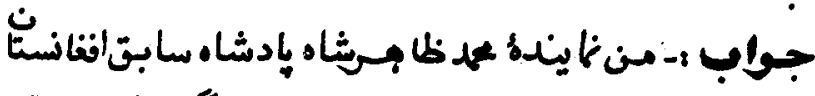

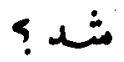

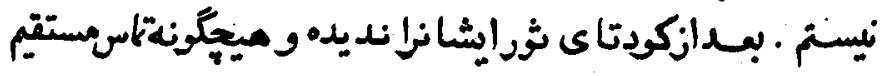

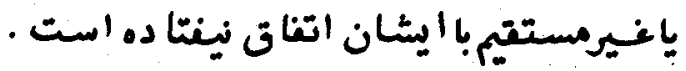

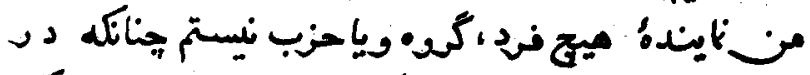

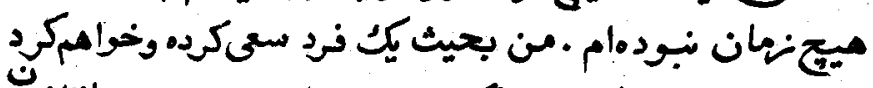

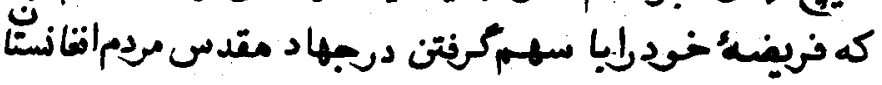

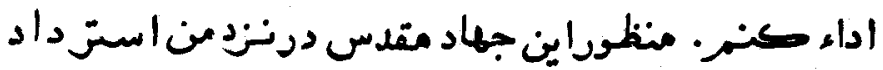

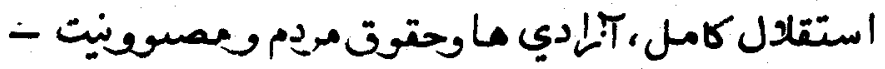

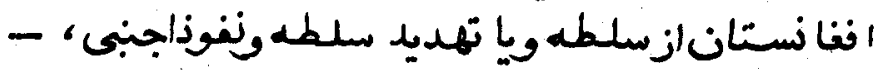

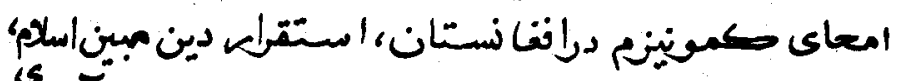

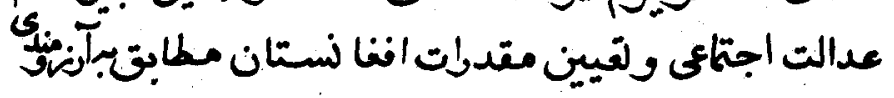

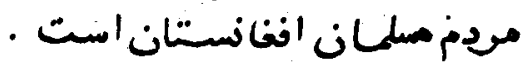

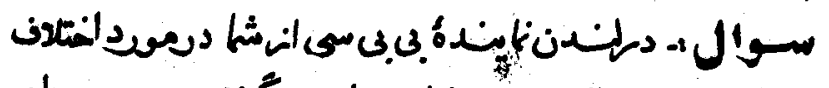

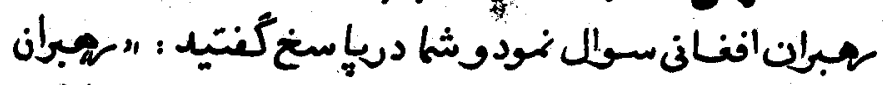

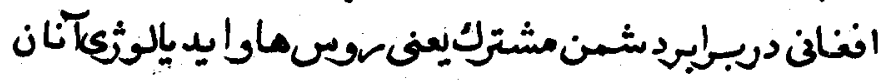

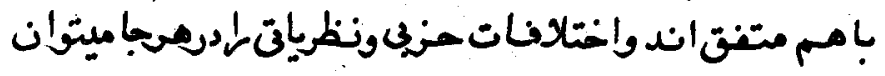




$$
\text { " مسرأن خوبك }
$$

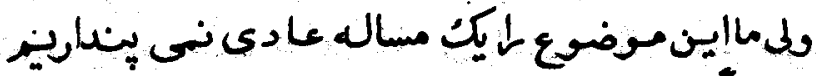

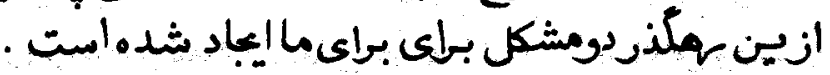

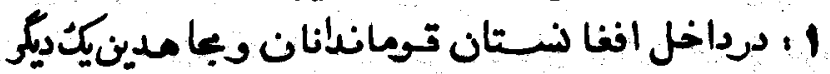

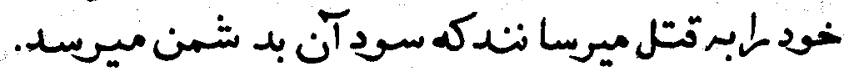

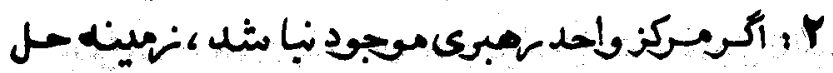

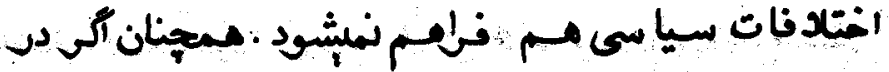

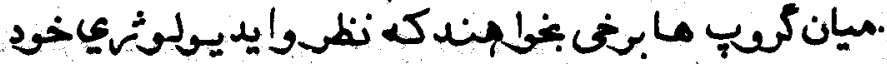

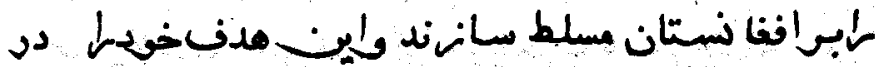

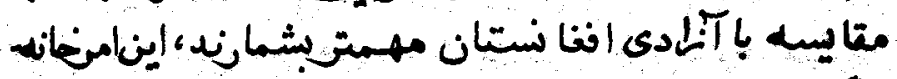

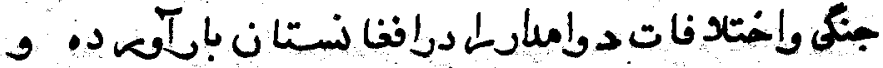

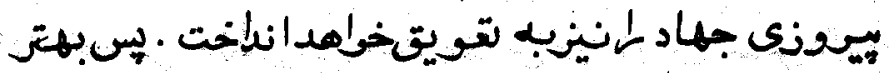

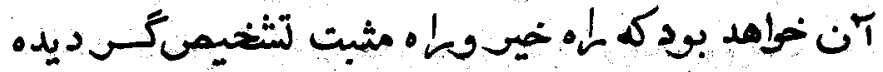

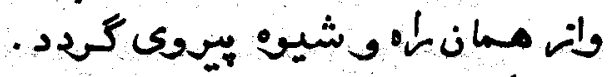

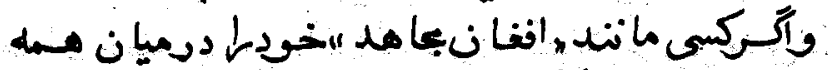

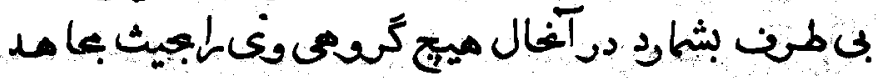

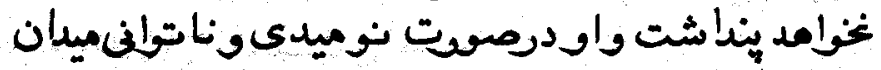

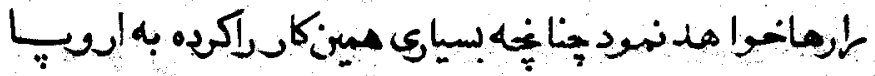

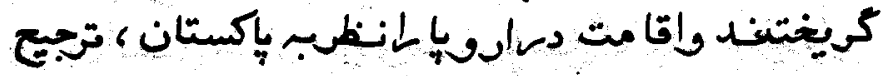
داد

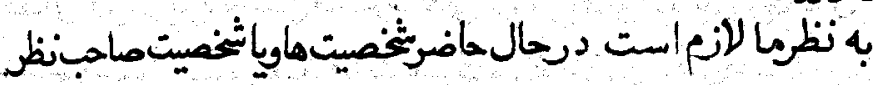




\section{\&r}

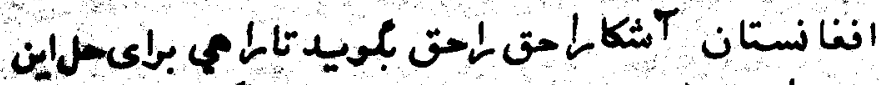

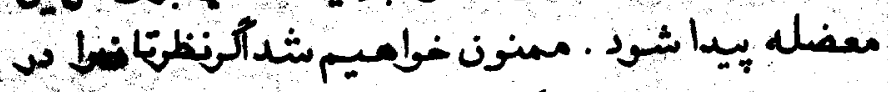

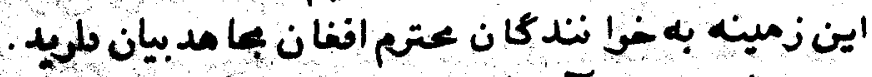

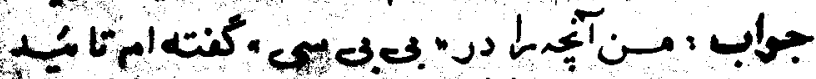

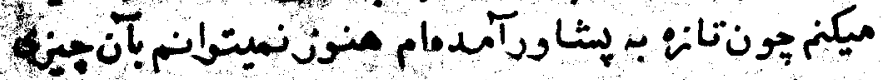

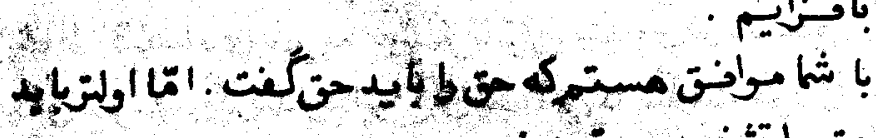

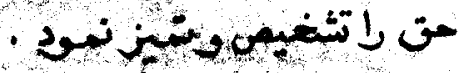

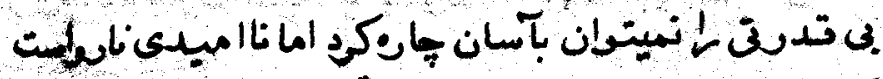

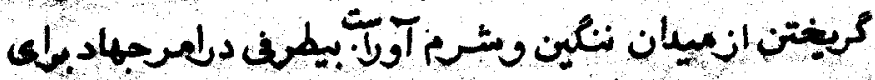

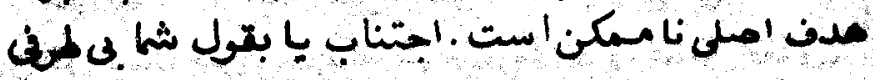

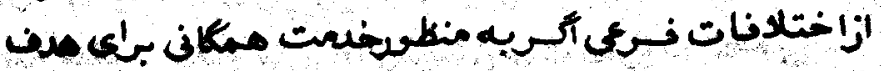

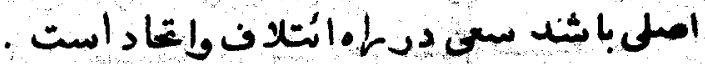

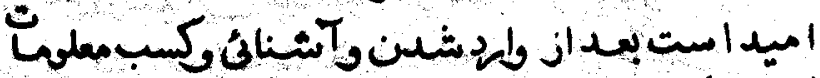

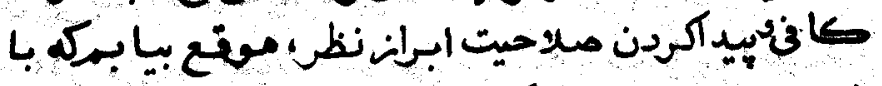

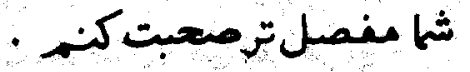

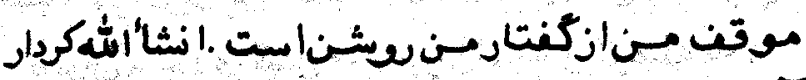

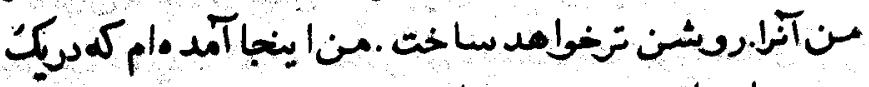

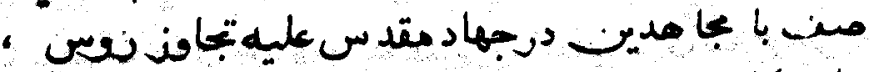

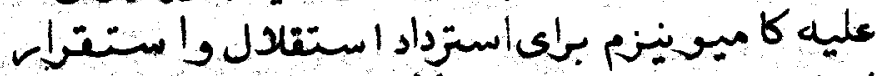

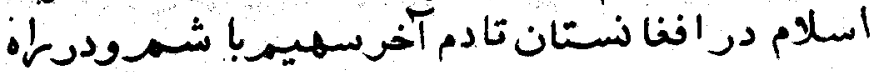




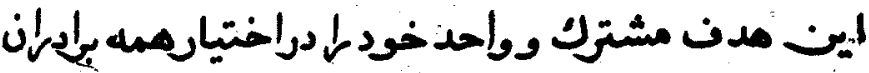

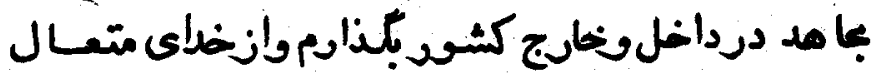

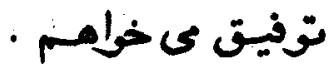

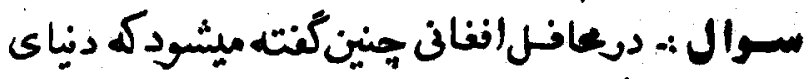

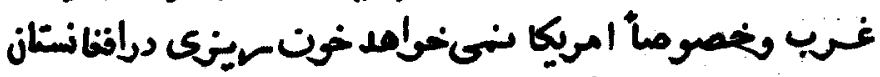

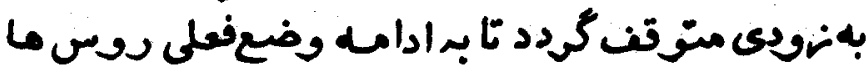

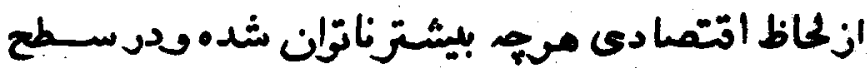

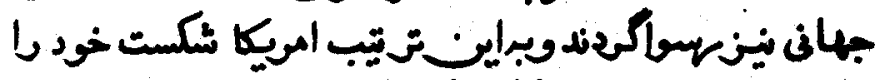

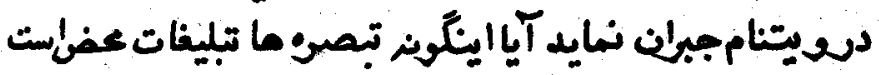

\section{ويإستيتت داند}

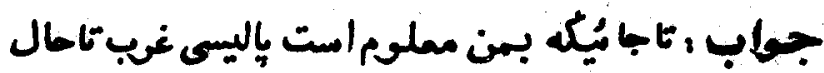

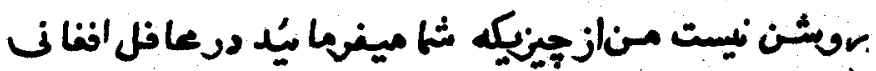

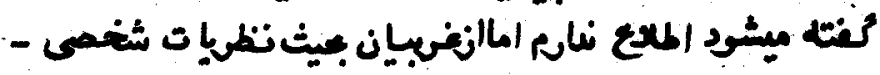

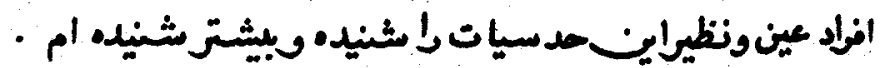

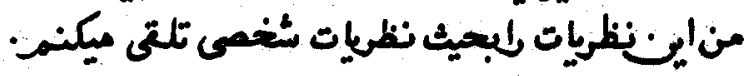

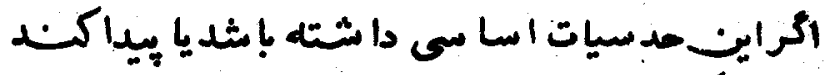

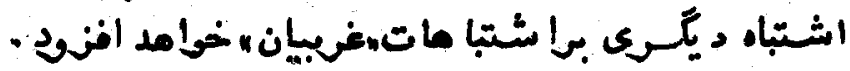

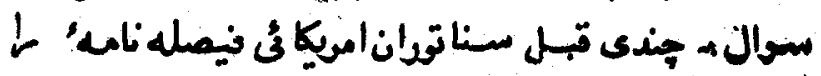

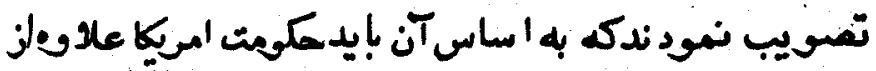

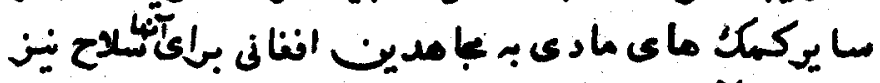

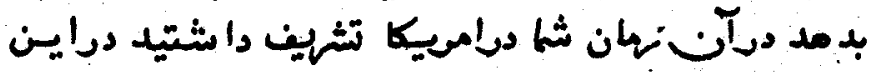




$$
\text { لابطه ما دو سوال داريم: }
$$

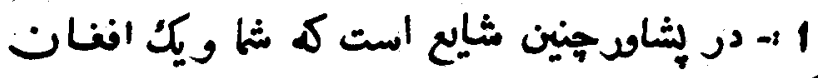

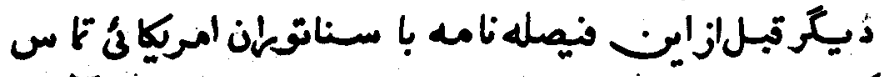

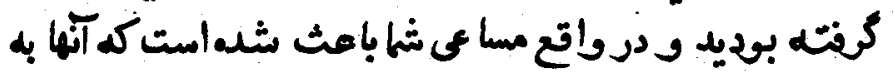

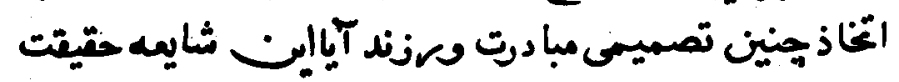
دارد ؟

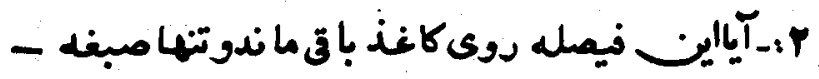

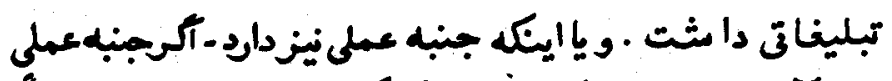

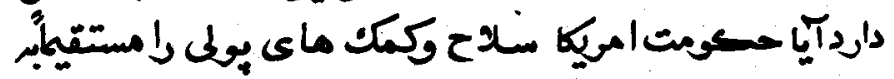

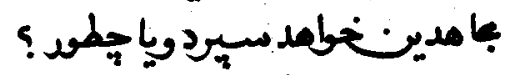

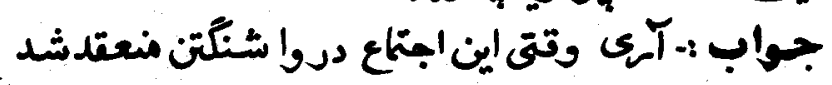

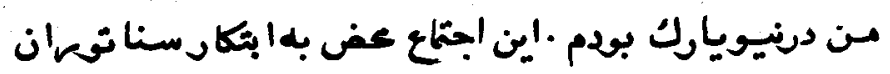

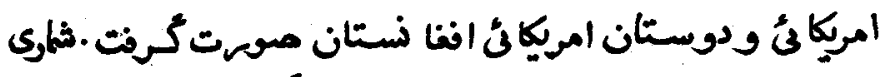

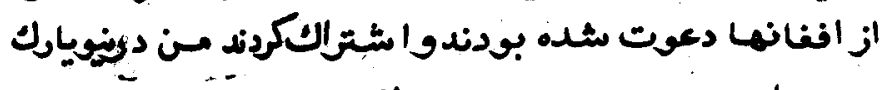

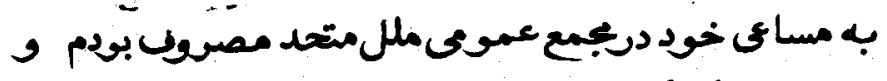

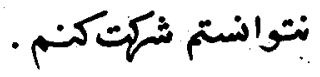

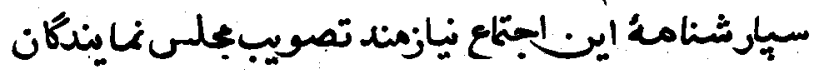

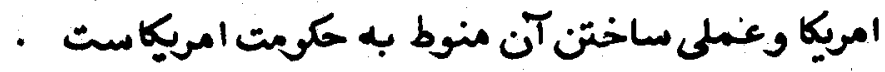

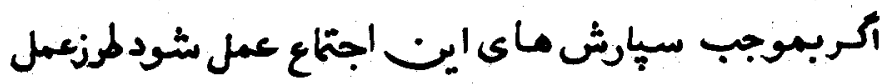

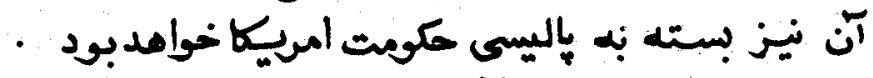
إيد منتظرنتايج عملى آن يود. 


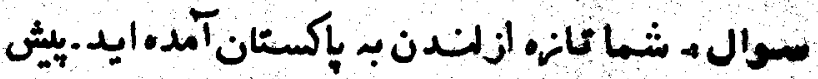

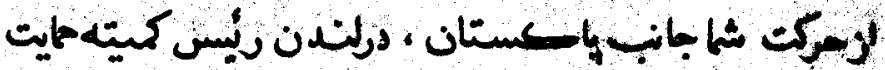

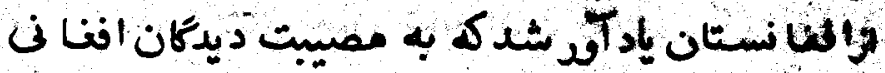

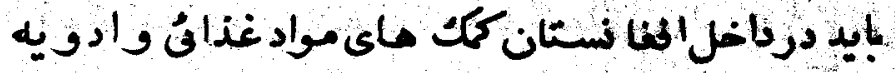

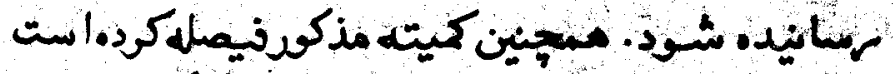

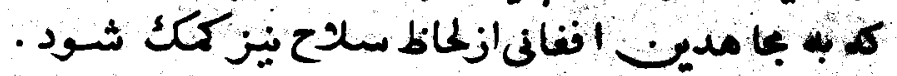

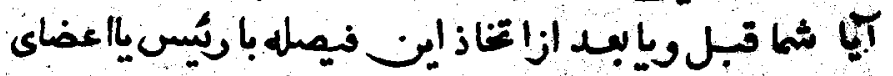

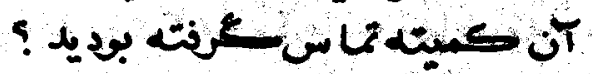

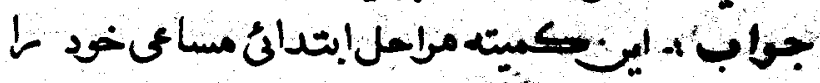

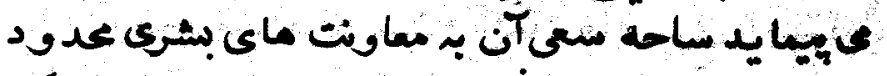

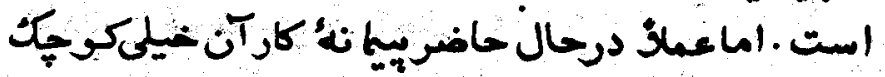

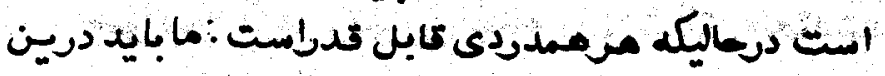

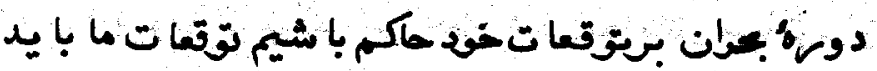

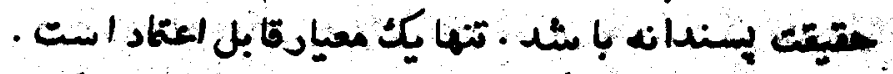

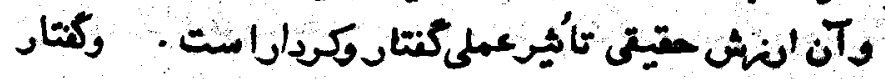

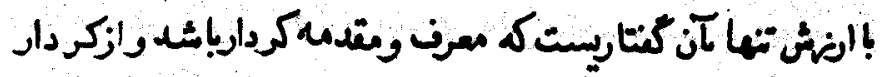

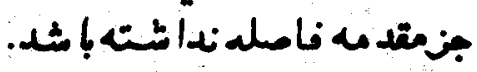

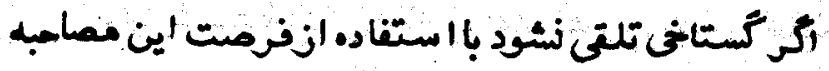

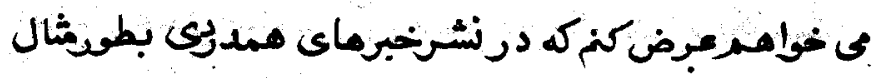

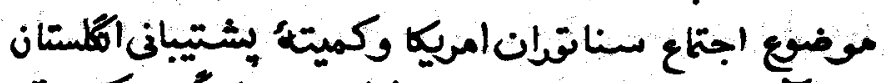

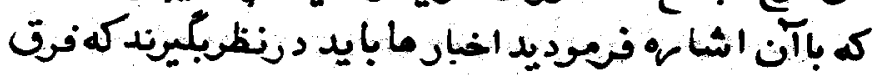




\section{\&V}

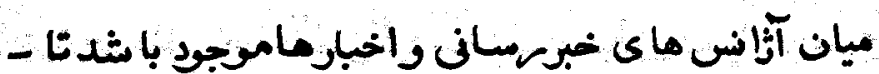

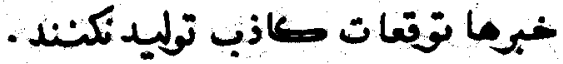

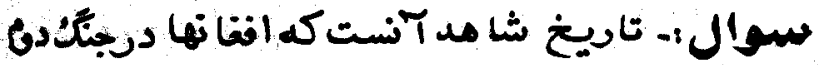

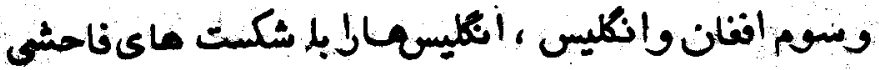

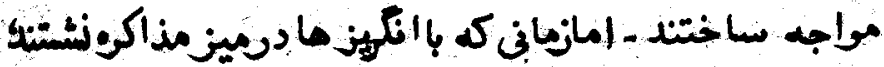

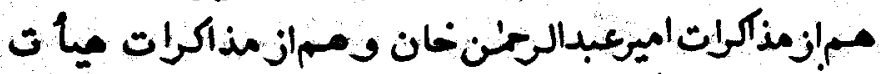

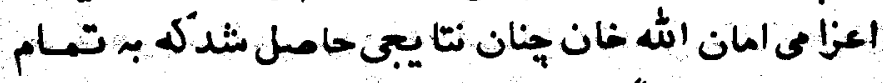

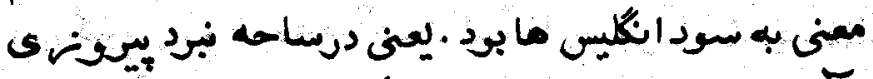

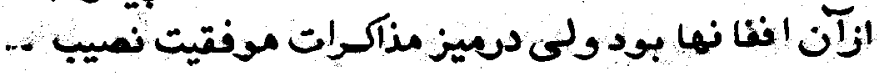

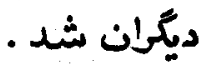

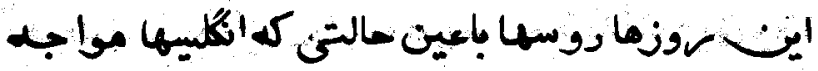

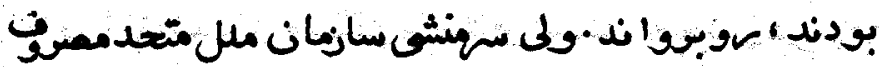

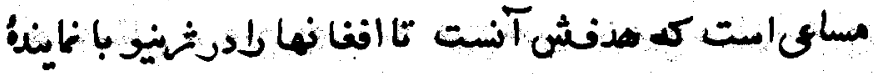

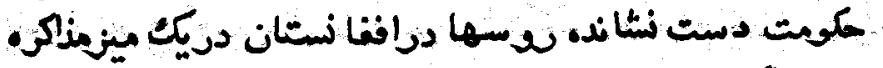

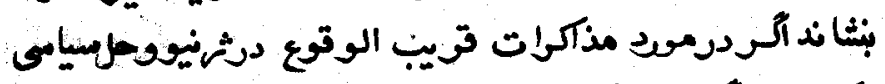

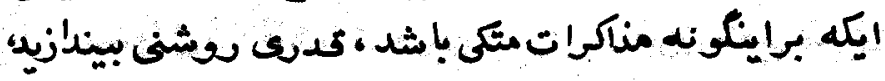

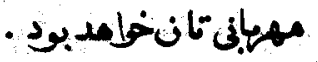

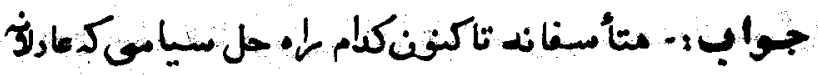

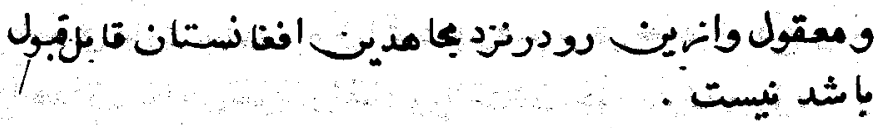

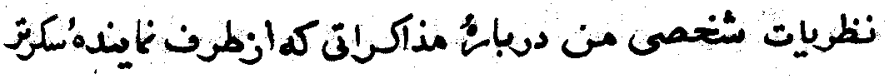




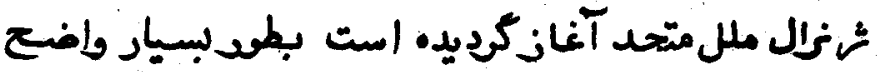

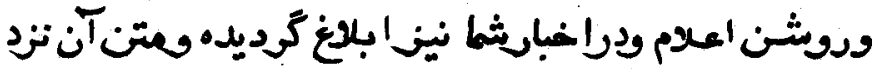

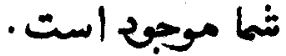

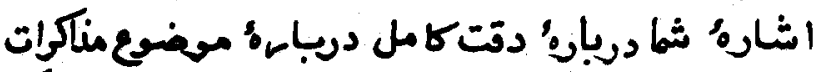

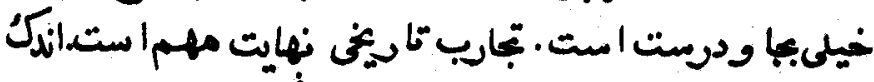

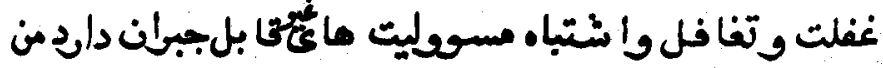

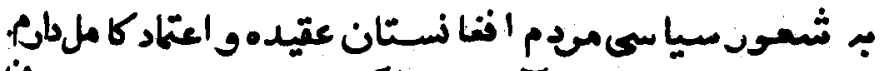

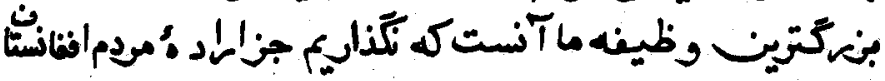

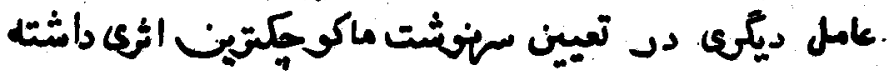

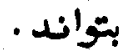

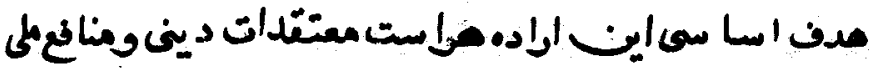

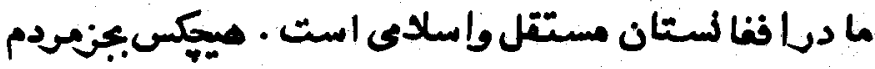

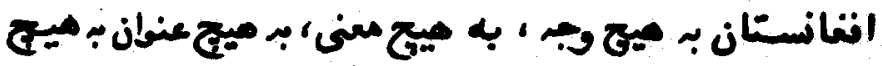

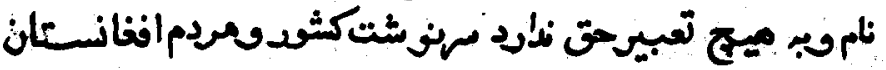

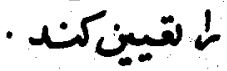

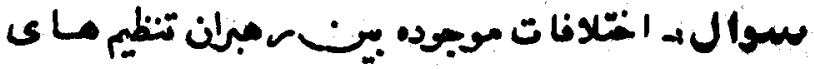

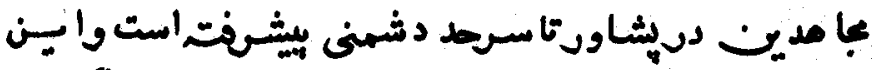

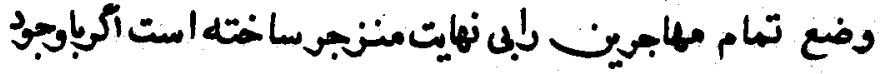

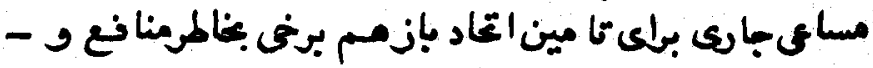

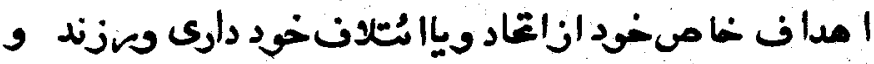

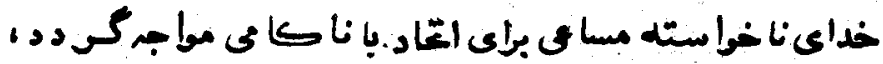




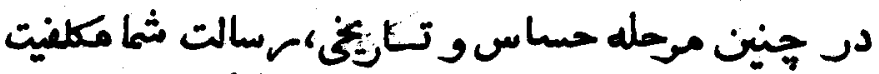

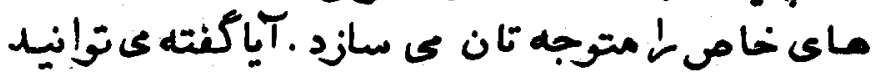

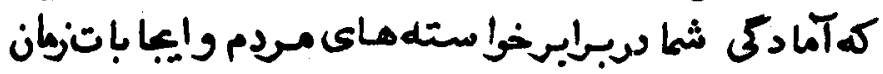

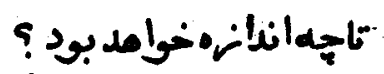

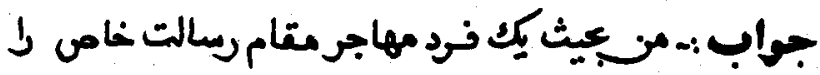

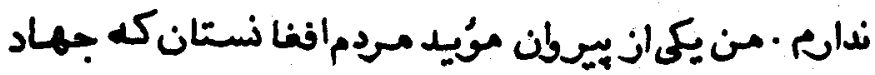

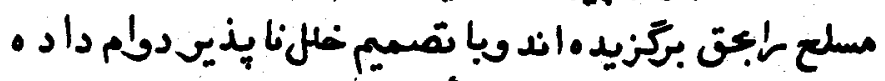

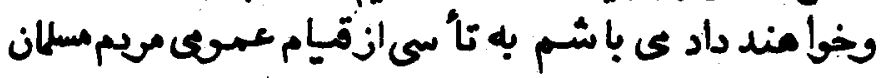

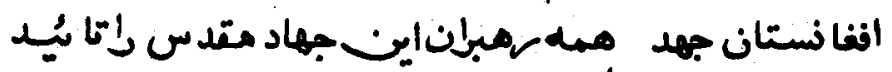

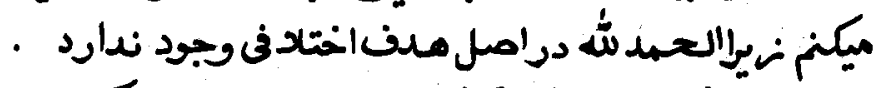

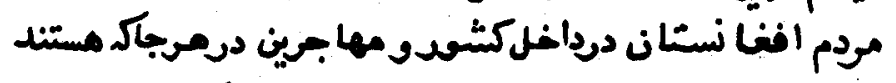

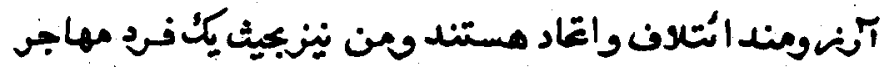

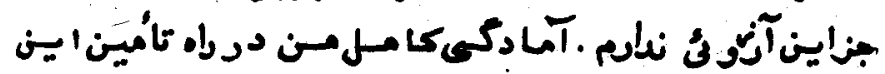

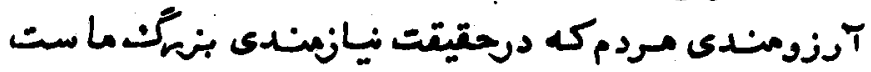

$$
\text { مد واندازه نداري }
$$

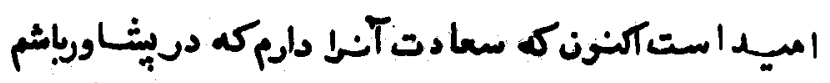

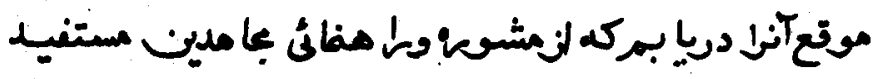

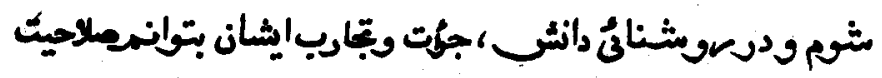

$$
\text { ابرانهنظى إييداكنمر. }
$$

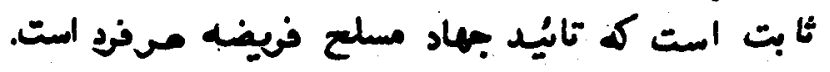

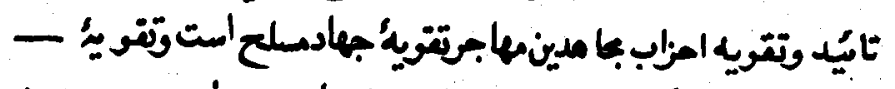

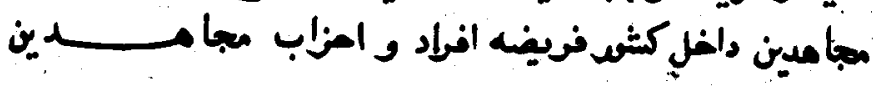




\section{$\Delta$}

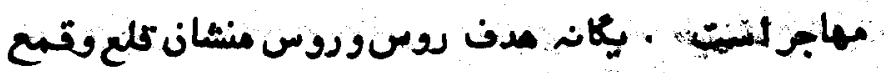

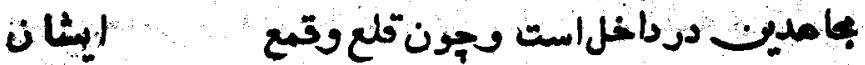

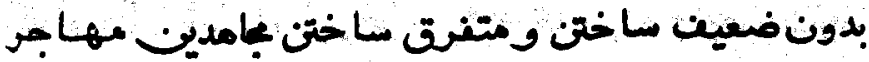

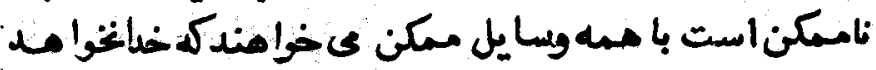

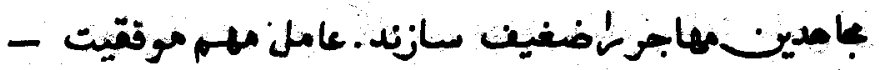

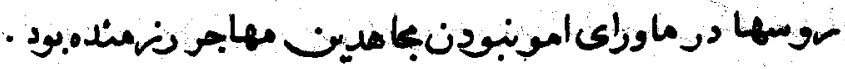

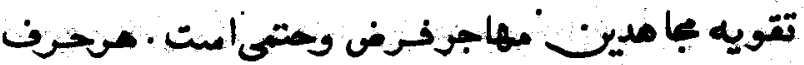

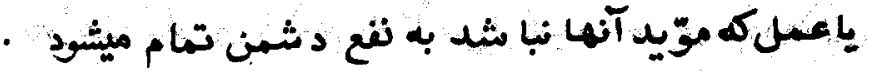

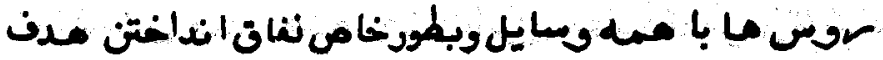

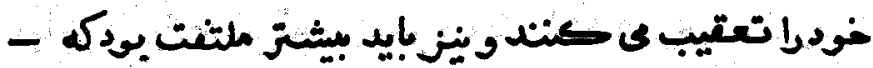

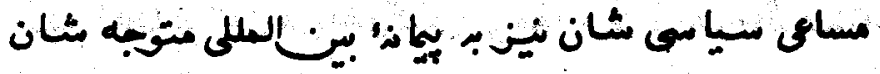

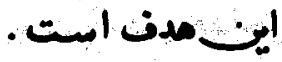

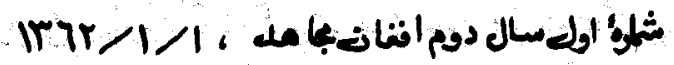

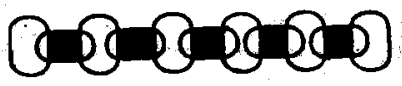




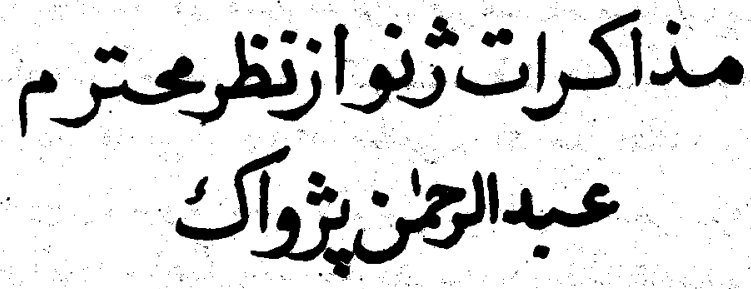

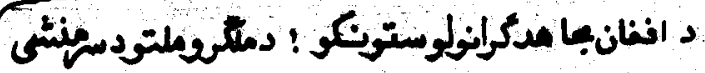

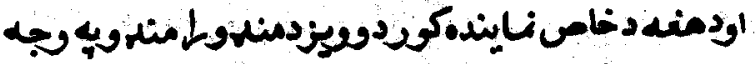

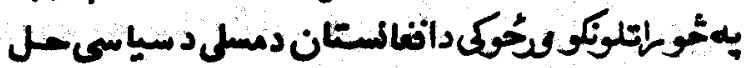

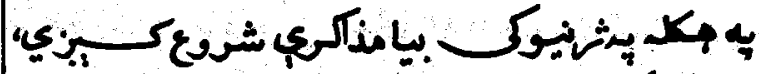

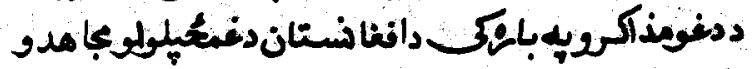

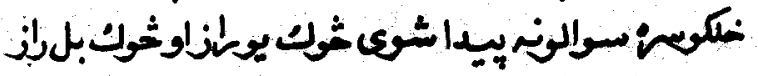

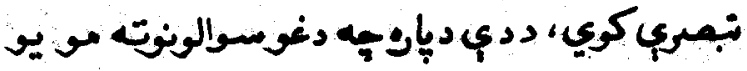

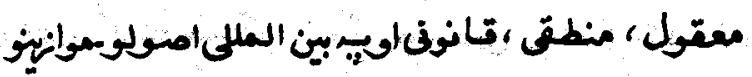

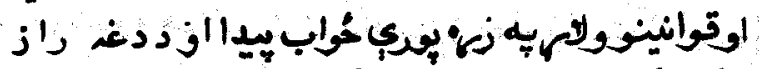

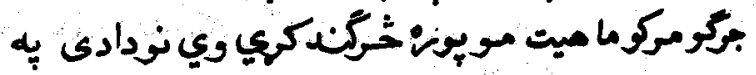

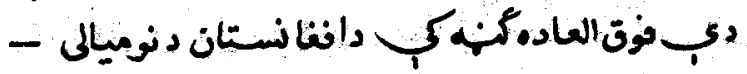

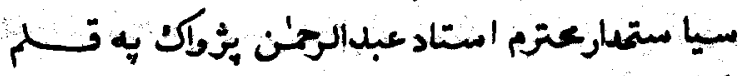
يكلمضمون تا سسوته تتضيمون.

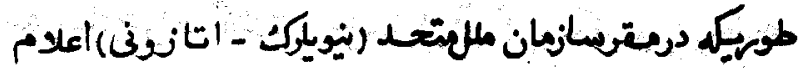




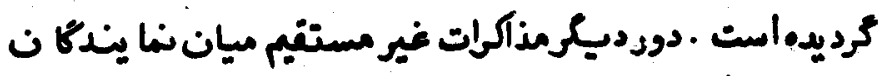

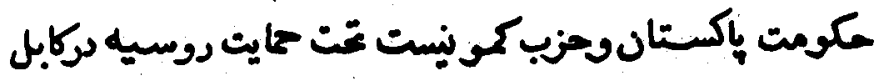

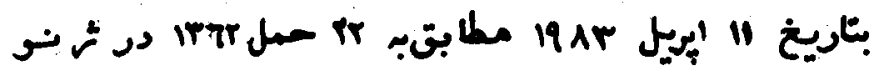

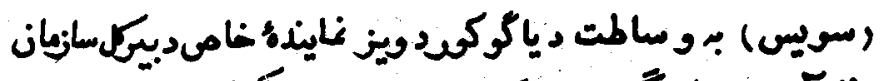

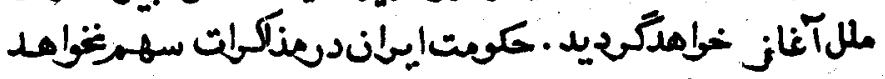

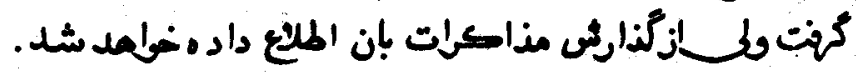

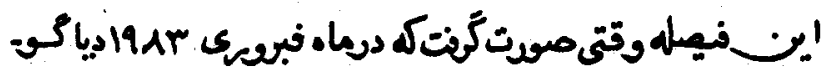

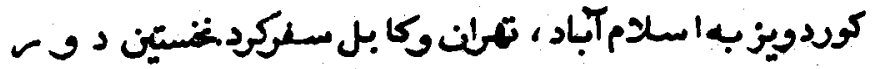

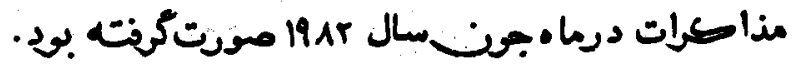

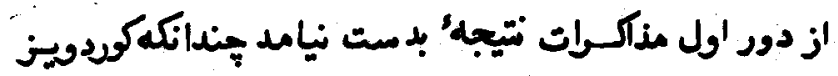

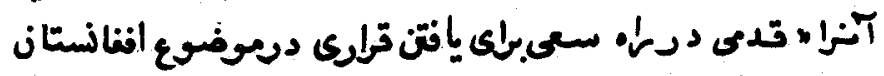

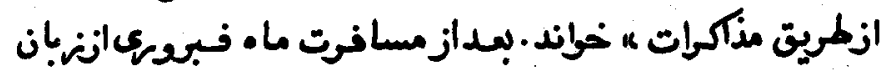

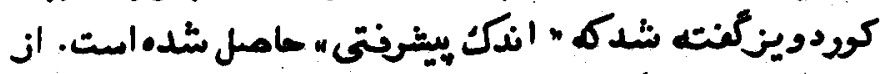

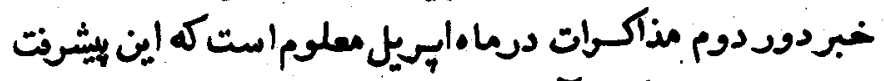

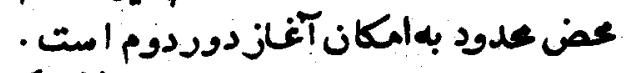

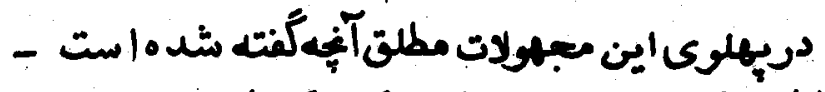

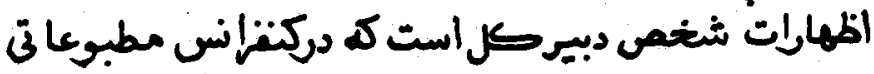

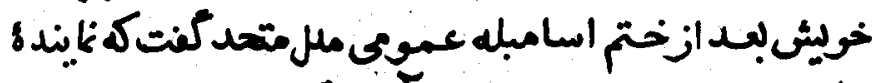

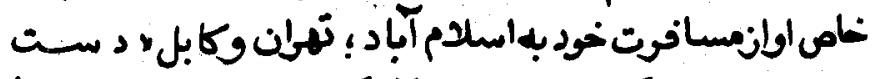

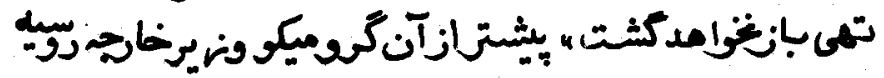

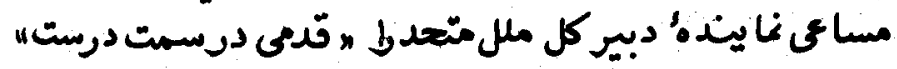




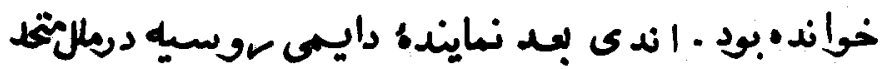

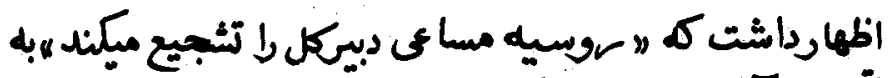

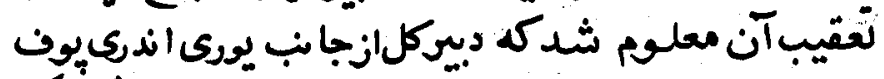

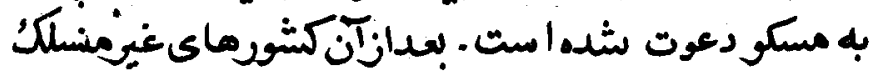

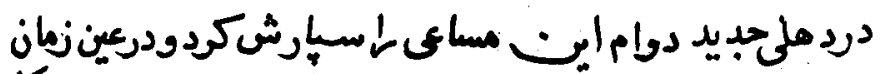

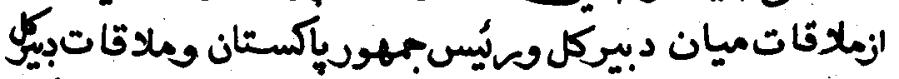

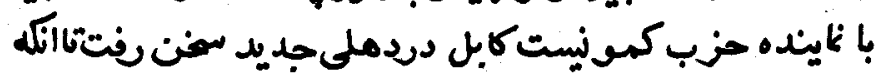

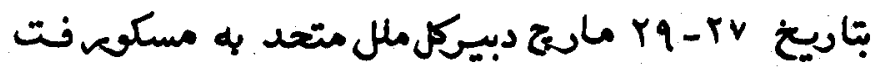

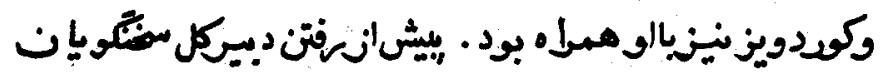

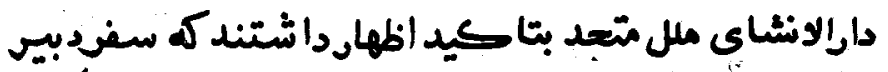

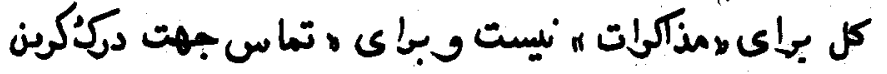

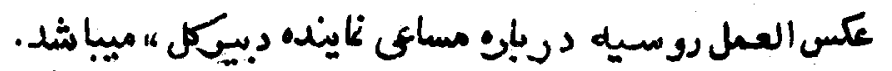

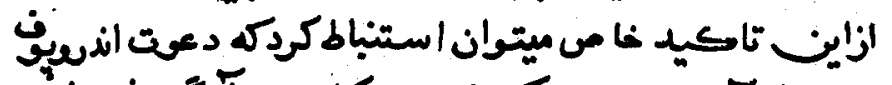

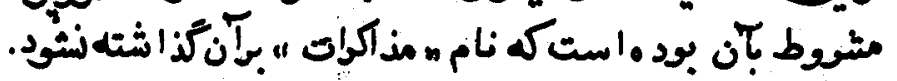

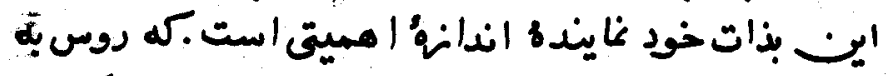

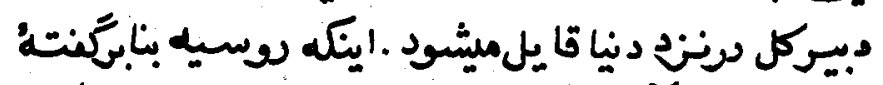

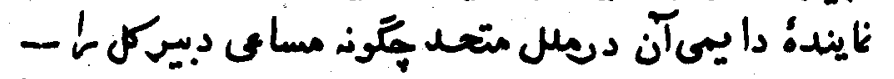

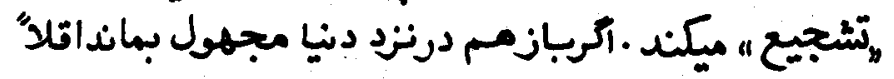

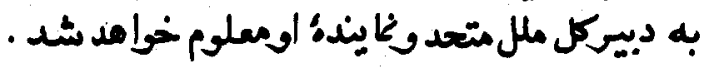

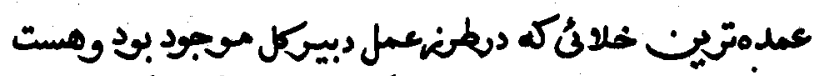

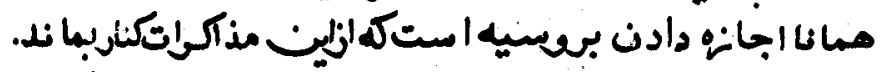




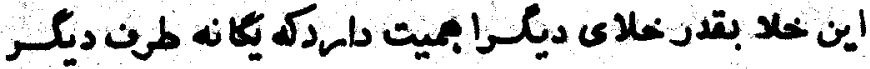

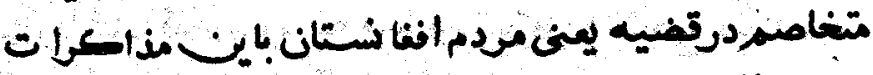

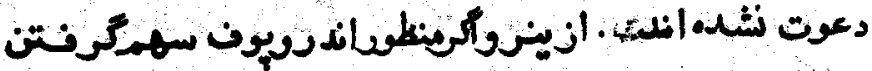

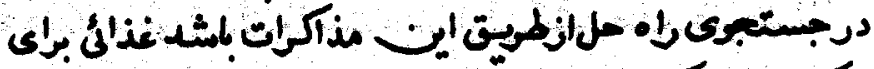

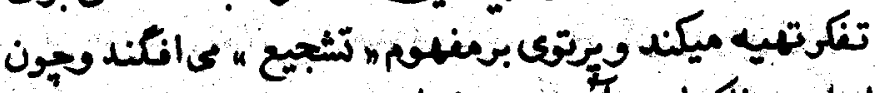

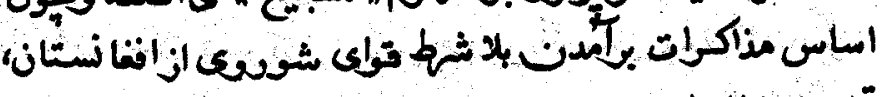

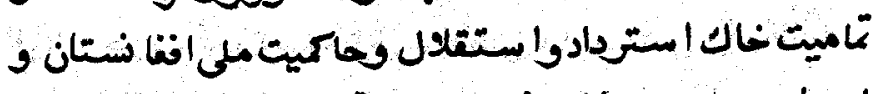

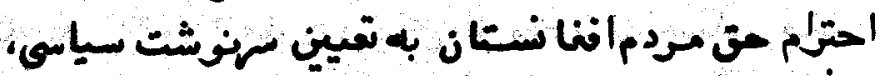

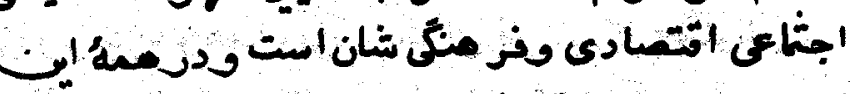

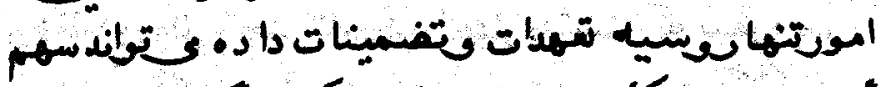

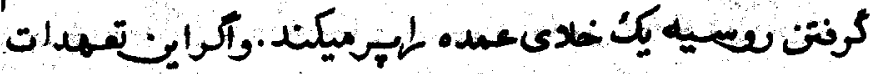

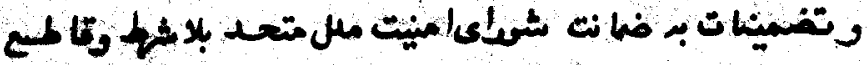

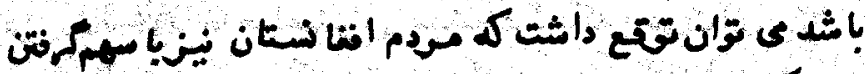

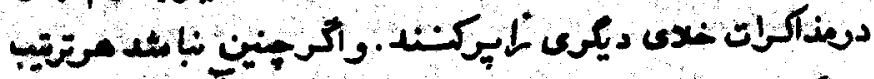

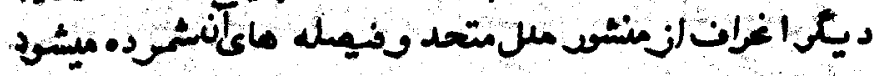

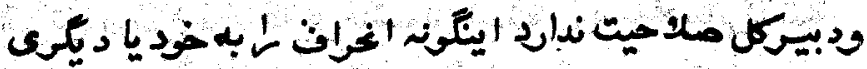

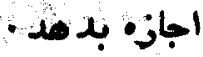

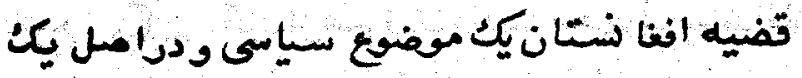

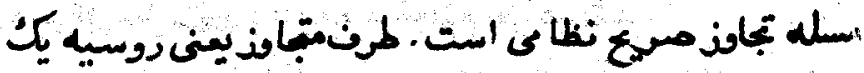

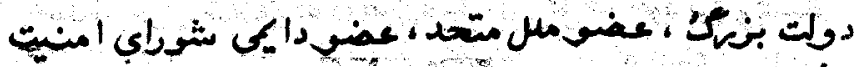

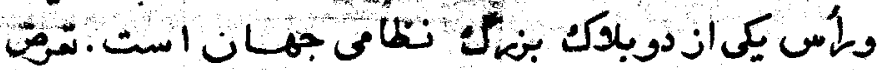




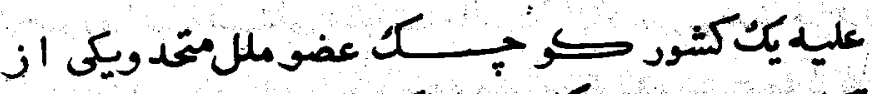

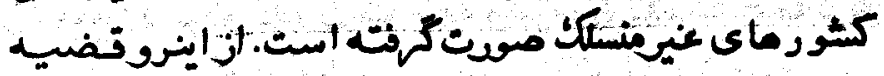

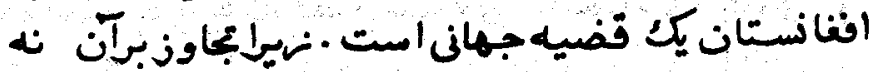

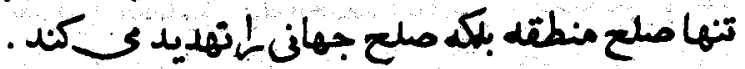

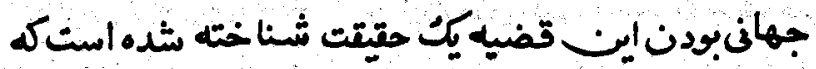

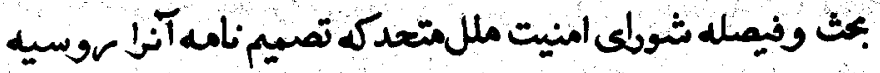

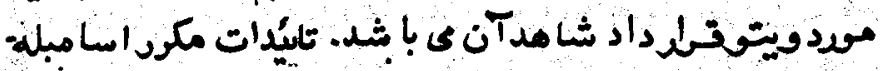

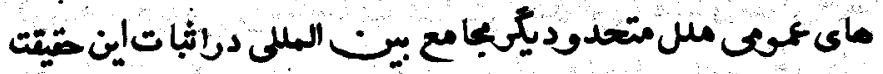

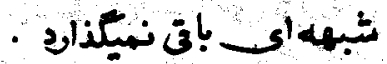

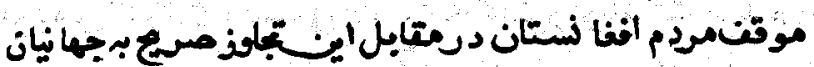

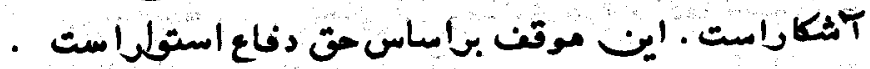

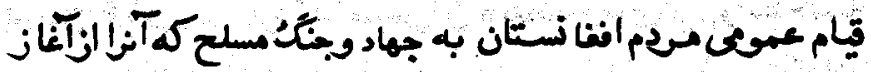

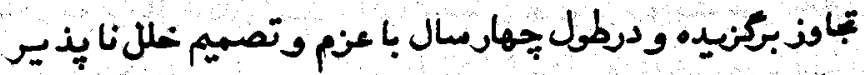

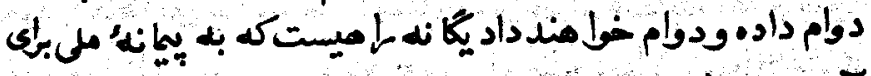

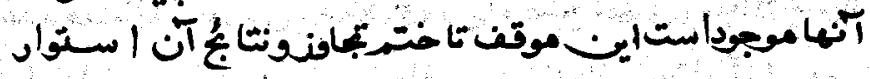
خوامدماند

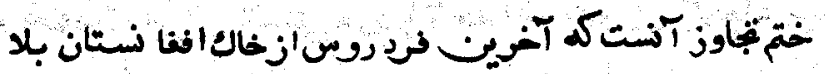

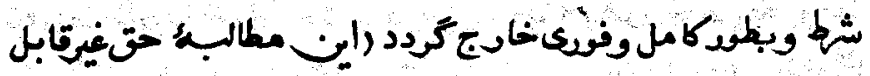

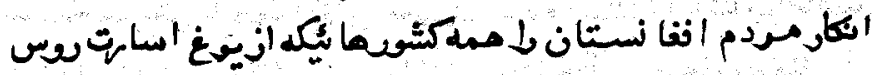

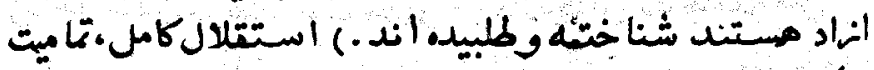

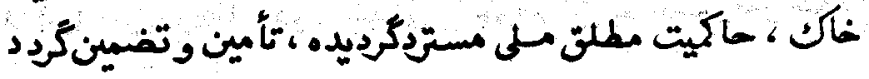




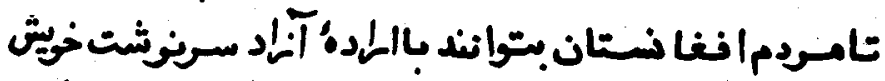

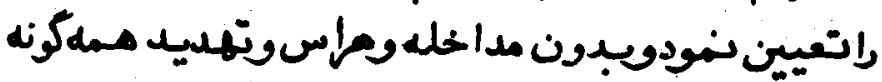

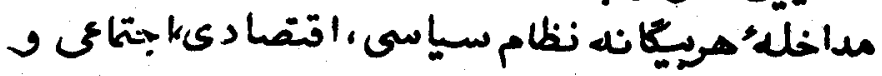

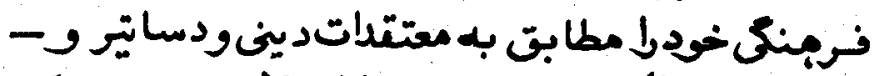

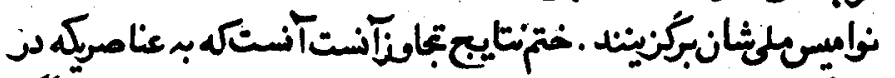

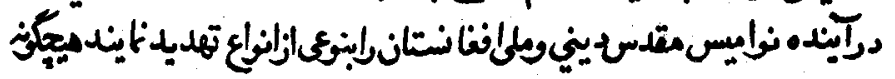

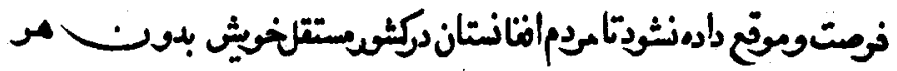

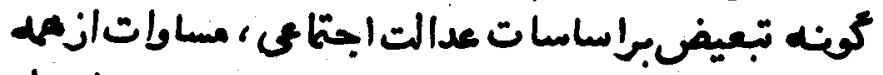

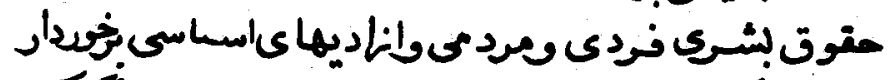

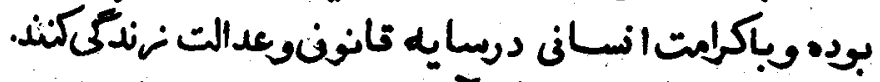

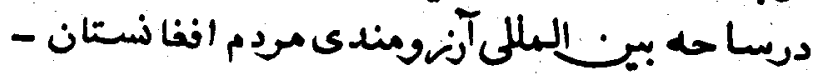

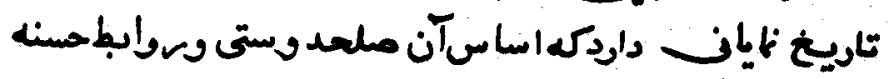

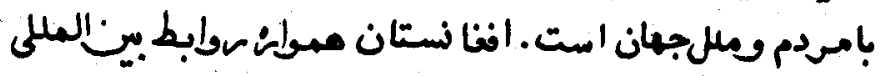

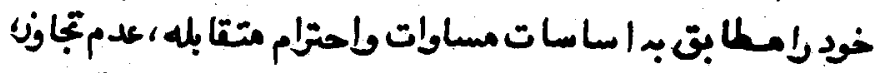

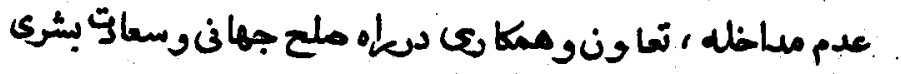

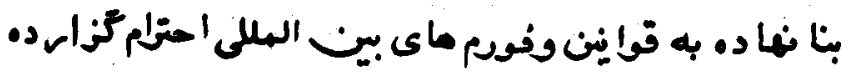

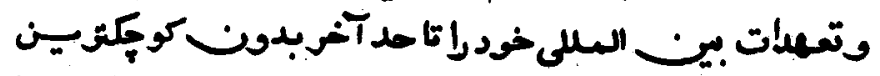

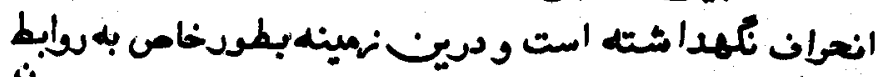

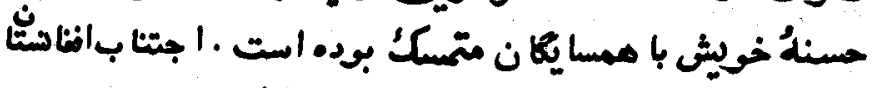

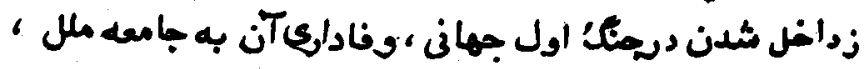

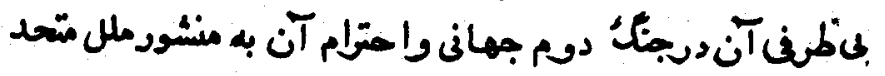




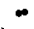

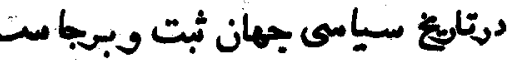

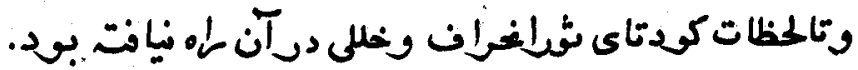

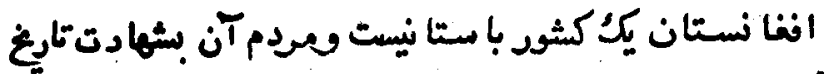

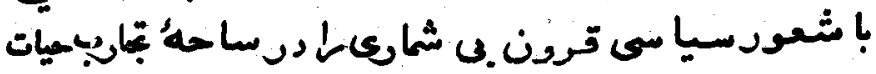

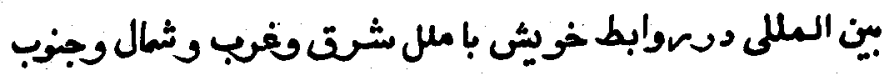

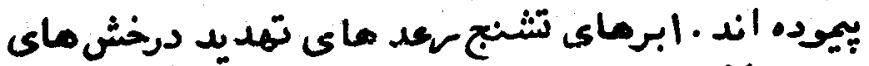

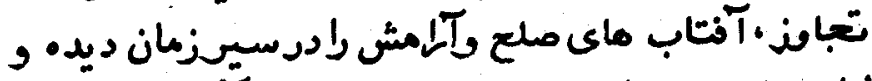

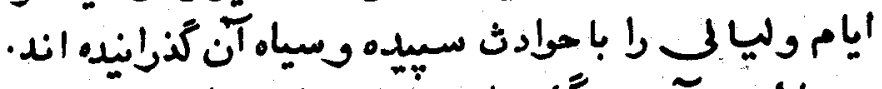

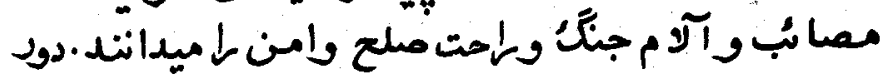

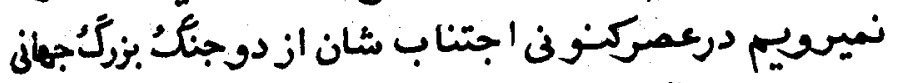

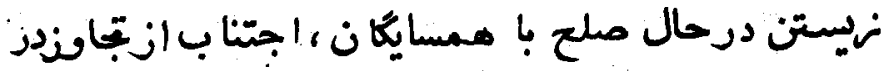

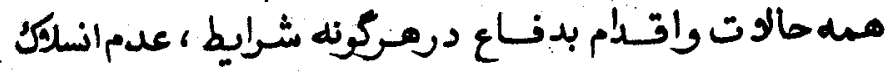

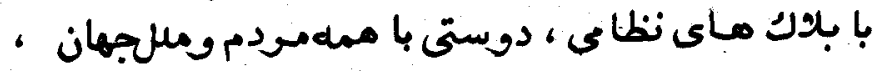

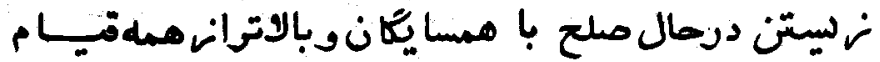

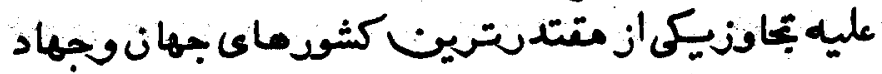

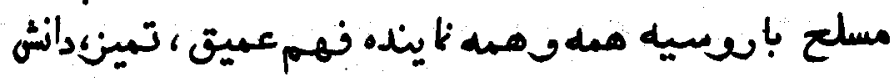

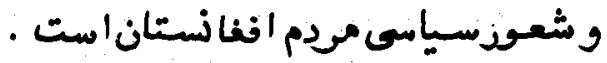

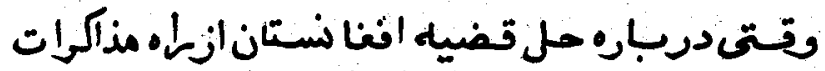

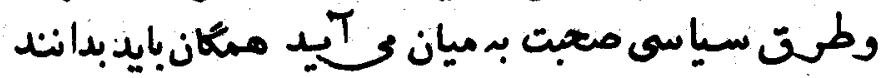

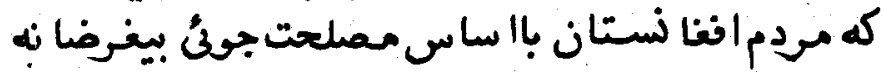

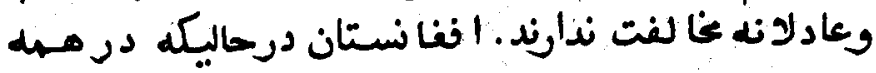


تاره ها مبا دله مشـروع آزاديغوا مان رادرمعابل استعار

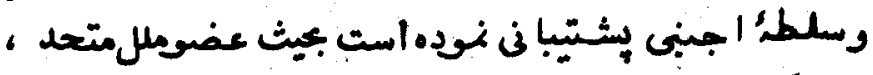

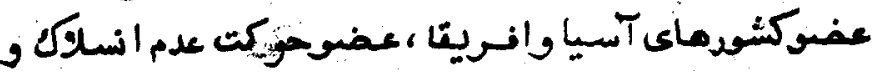

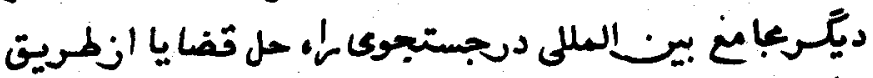

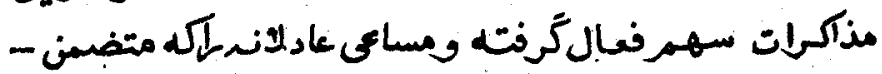

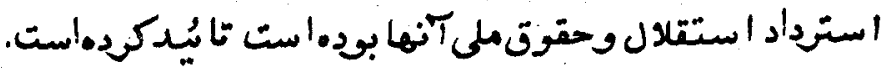

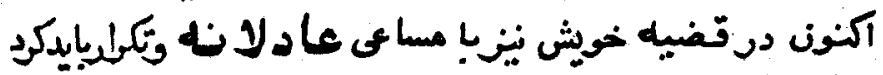

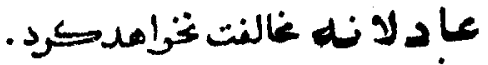

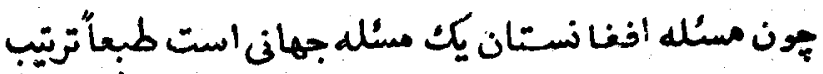

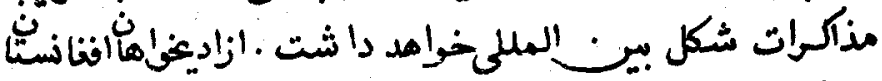

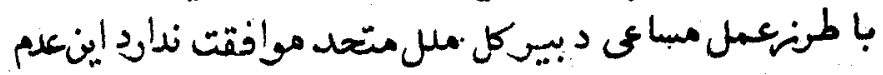

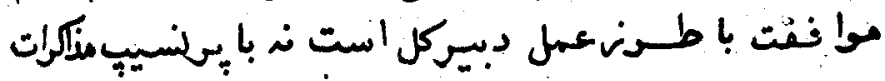

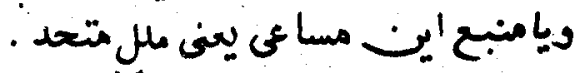

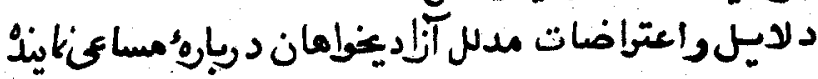

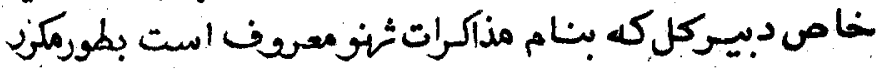

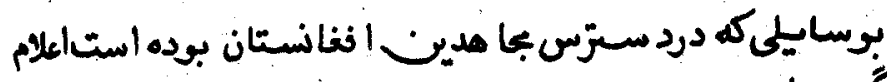

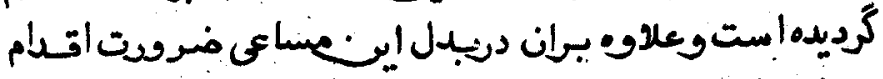

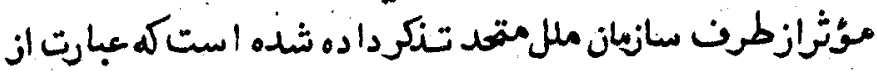

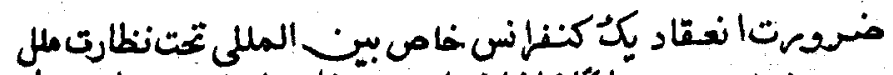

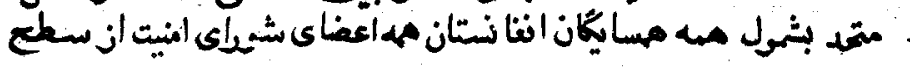

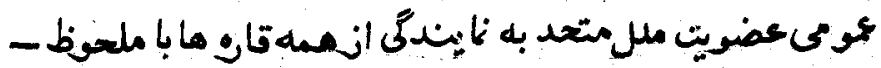




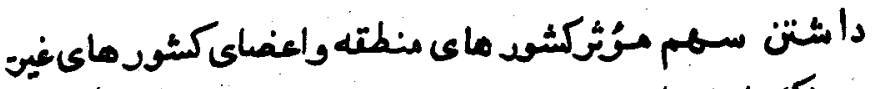

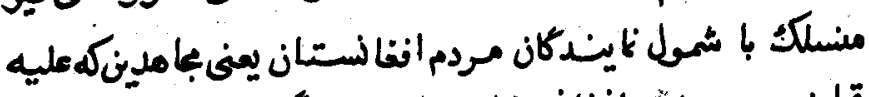

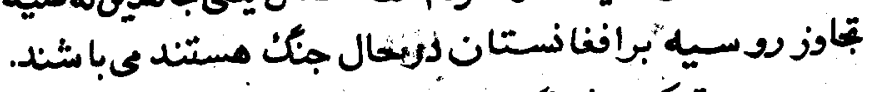

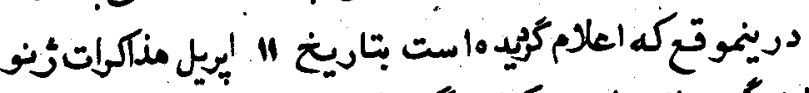

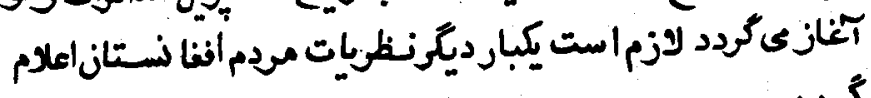

$$
\text { . . }
$$

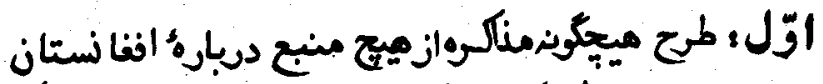

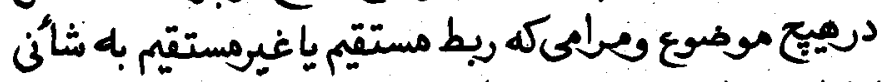

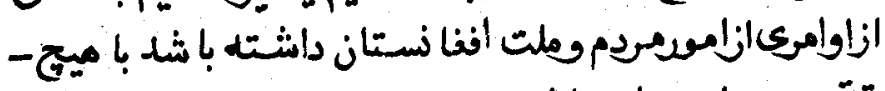

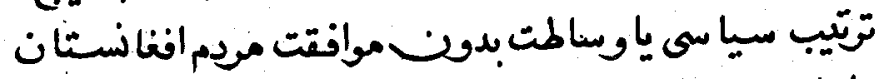

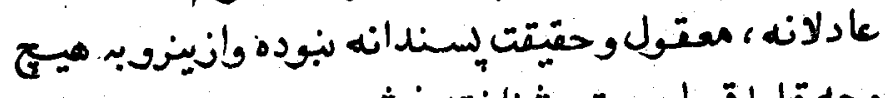

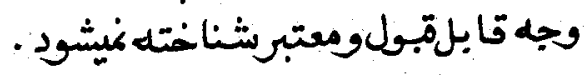

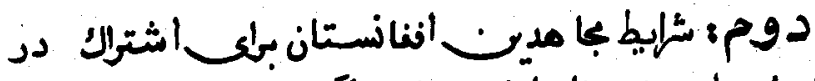

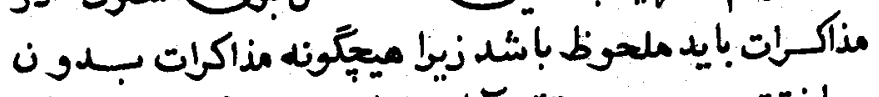

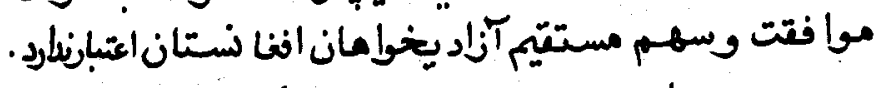

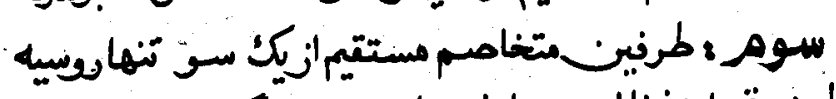

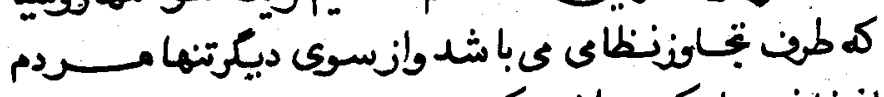

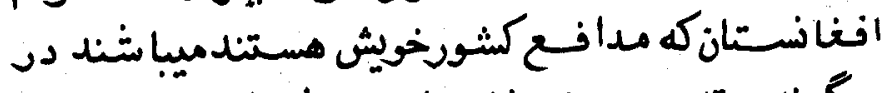

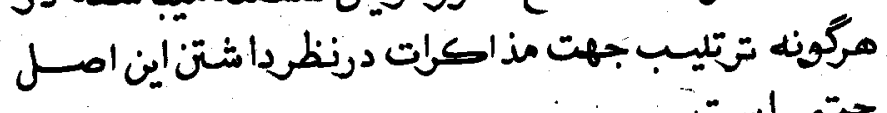

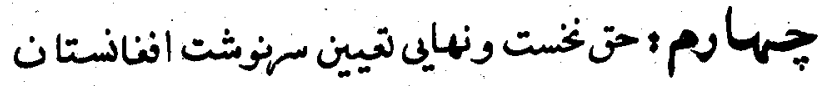




\section{7 . \\ تهاوتنهاحت نابت مردم افنانستان است .}

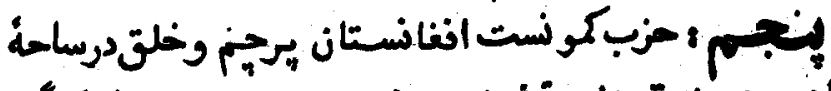

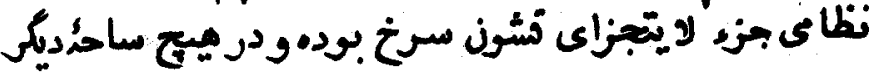

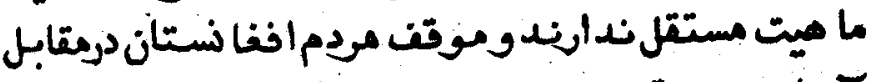

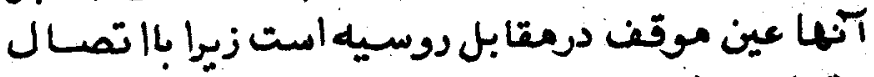

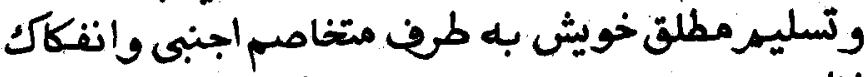

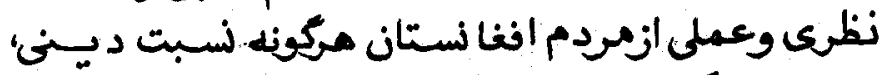

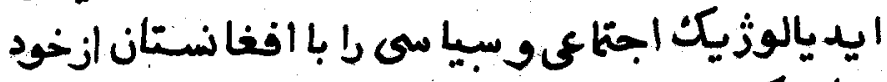

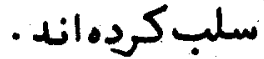

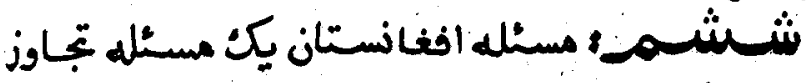

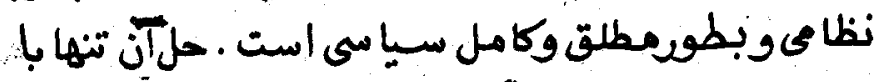

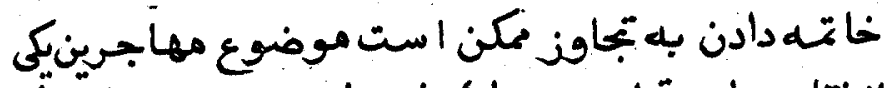

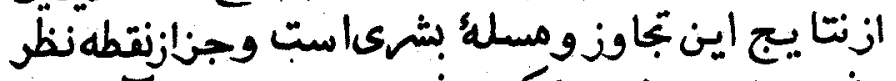

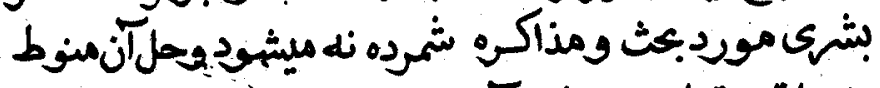

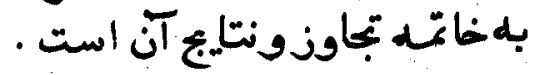

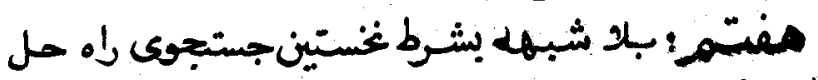

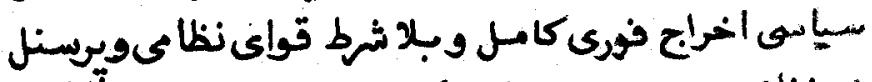

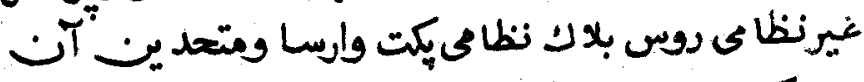

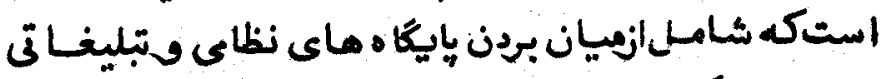

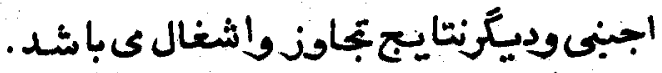
كر:استرداداستقلالكامل، حاكميت ملىوحتى - 


\section{1}

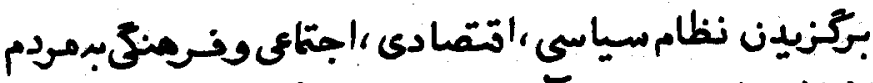

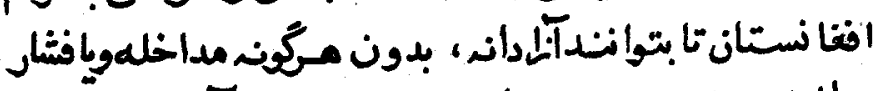

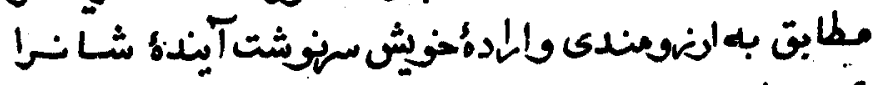

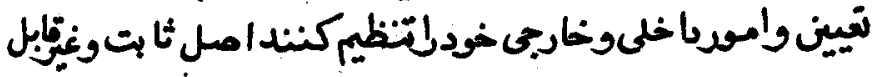
انحكارامت . ليسين

إين اساسا ت واصول ممكان مطابق به قوإبنبين المبلى.

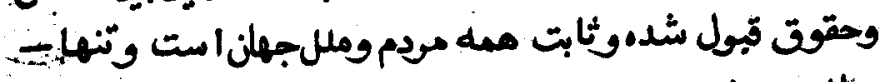

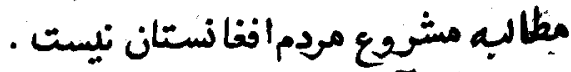

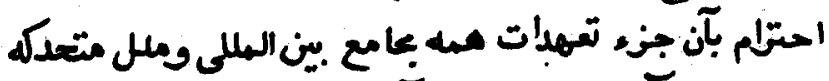

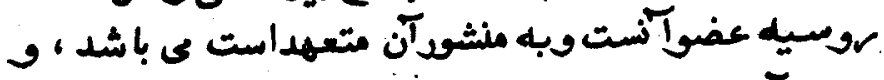

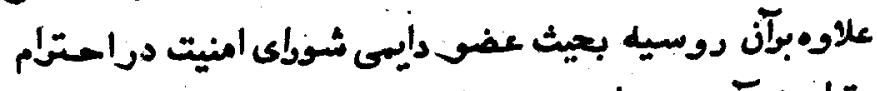

$$
\text { وتمبيق آن مسووليت خامس دارد. }
$$

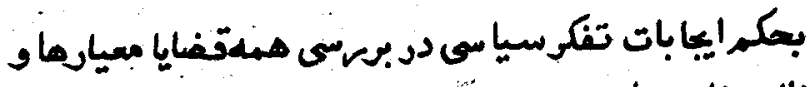

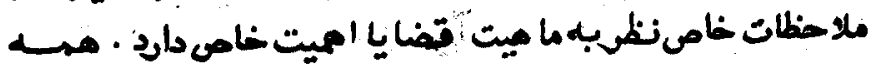

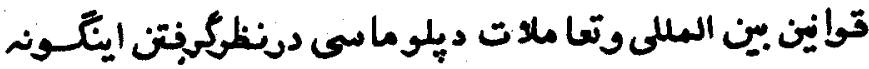

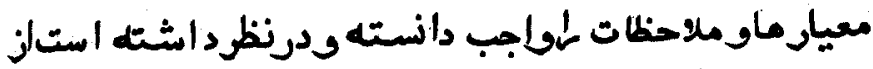

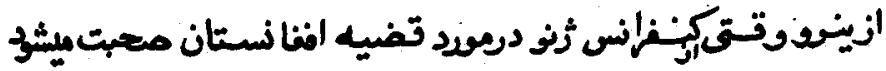

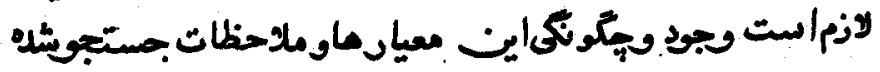

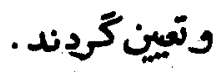

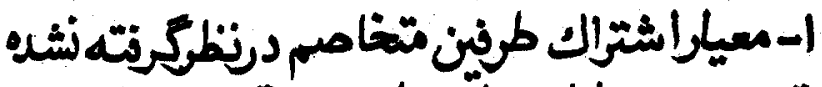

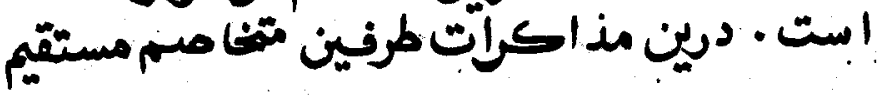




\section{Tr}

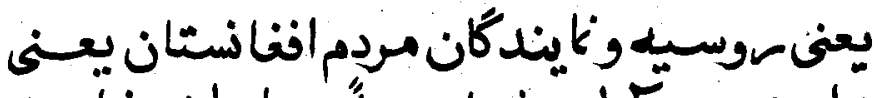

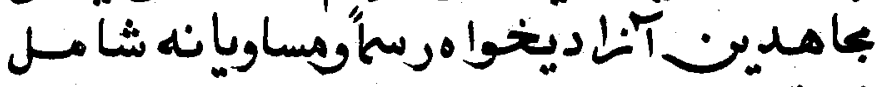
- نسمتنا

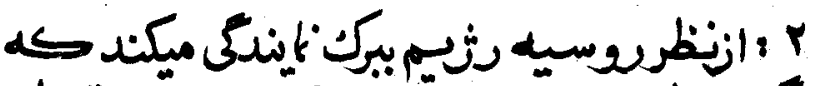

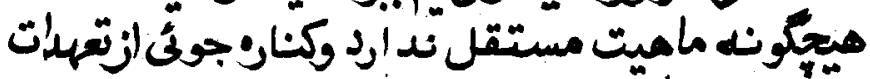

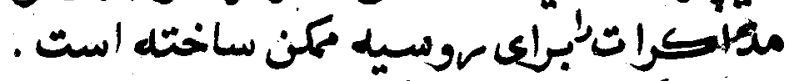

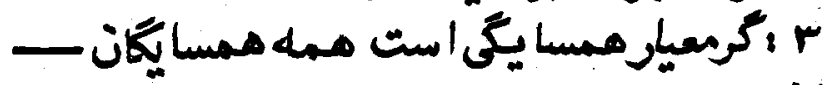

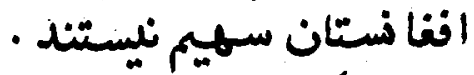

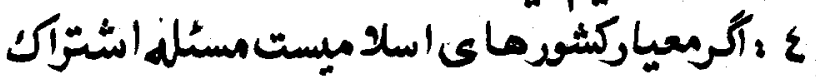

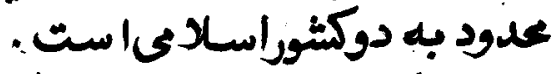

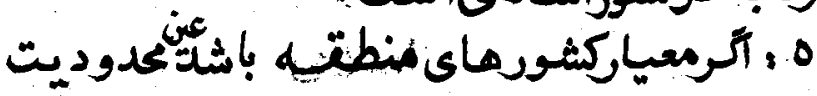
وجود دارد ن

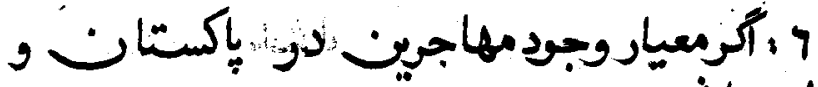

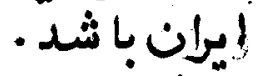

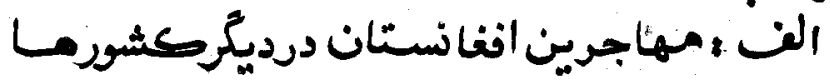

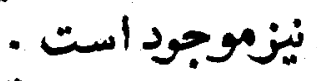

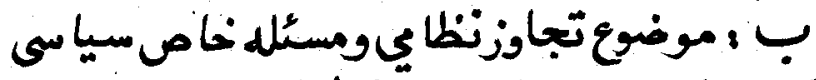

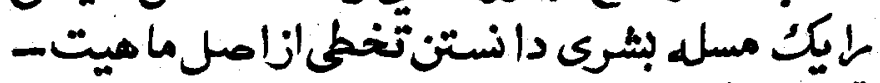

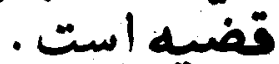

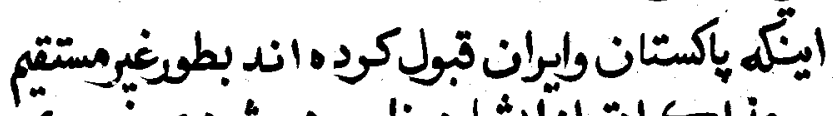

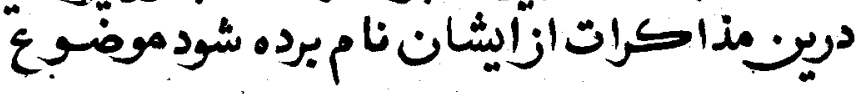




\section{Tr}

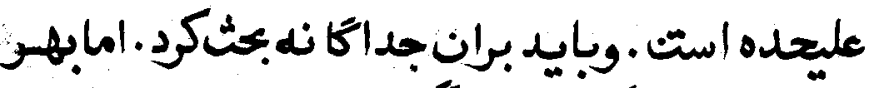

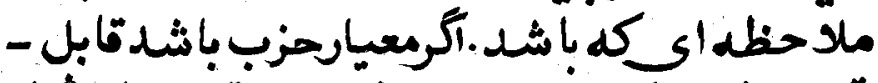

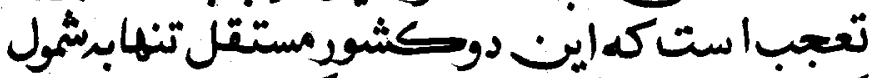

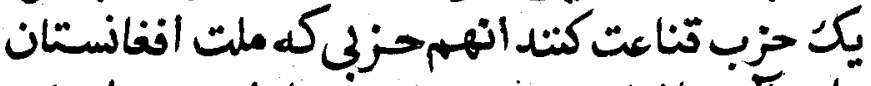

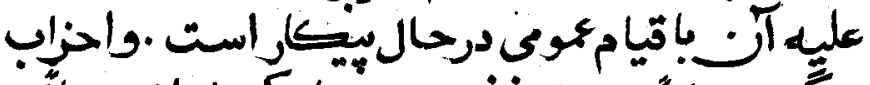

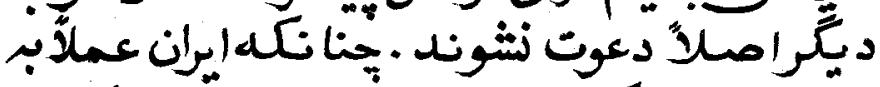

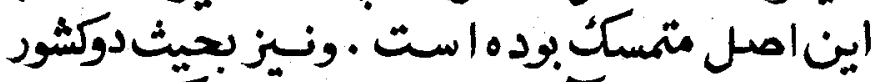

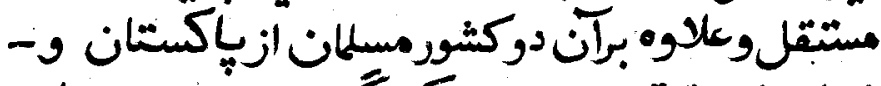

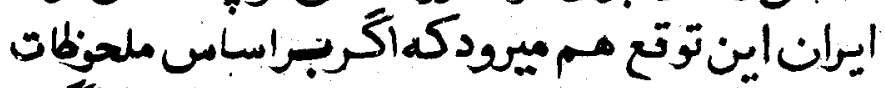

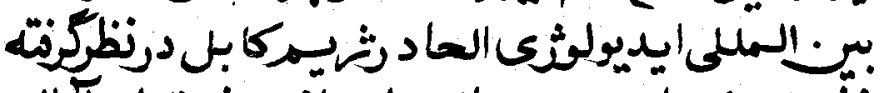

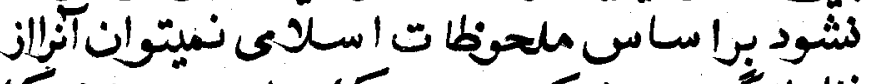

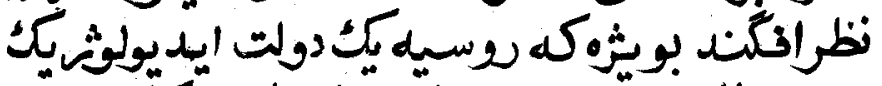

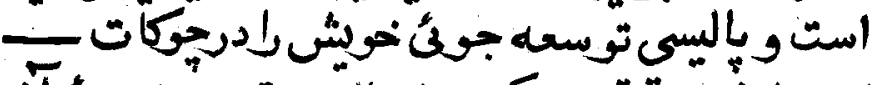

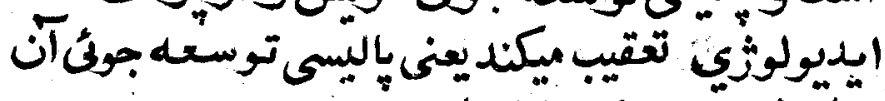

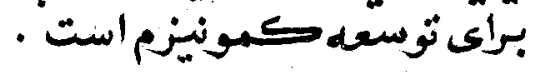

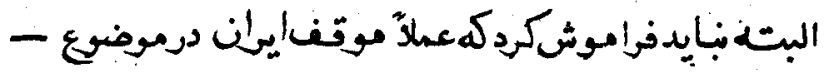

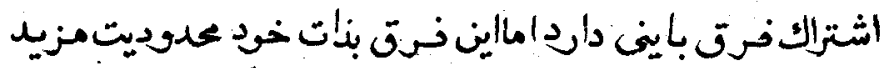

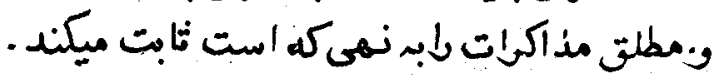

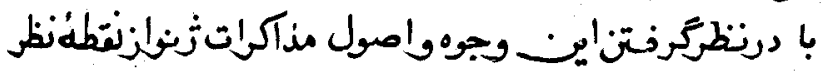

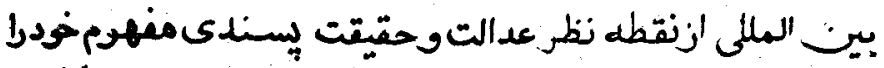

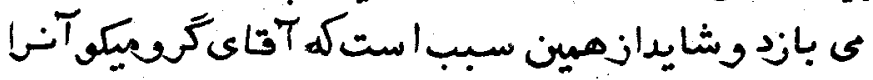




\section{2}

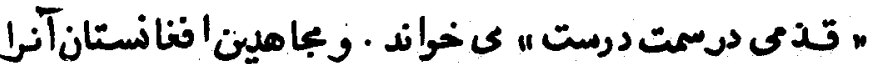

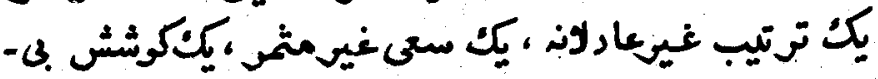

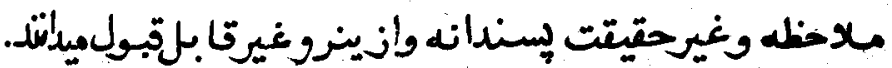

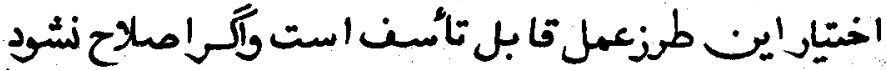

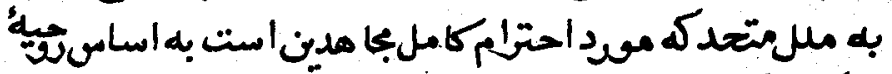

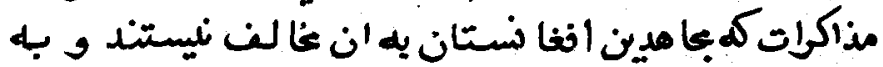

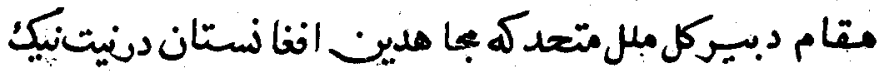

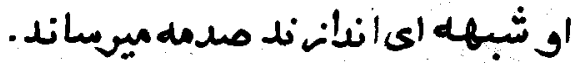

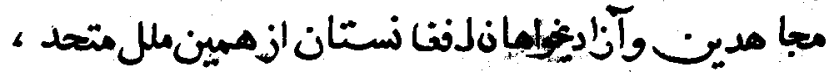

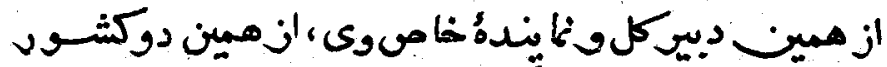

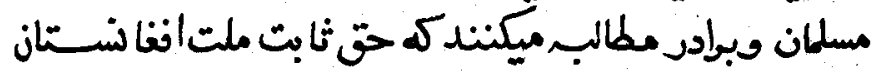

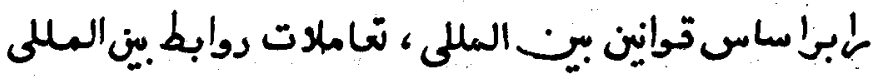

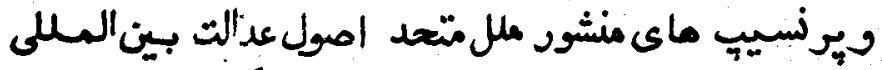

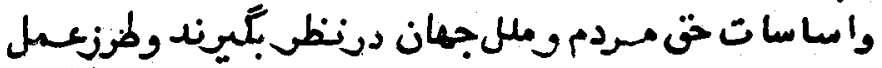

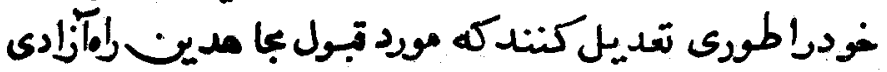

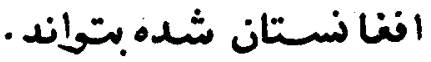

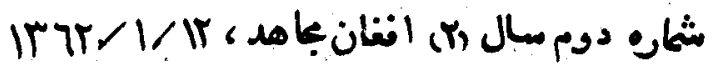

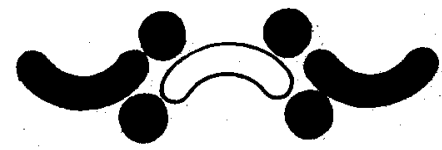




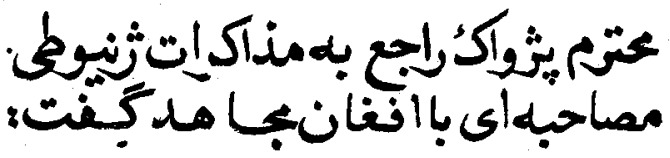

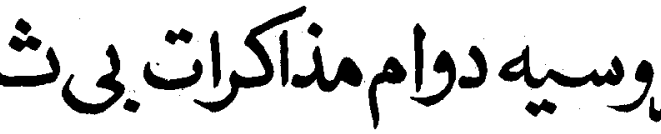
رابه نفعخوداستعالىكنت

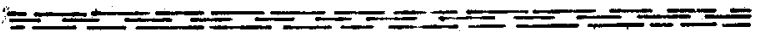

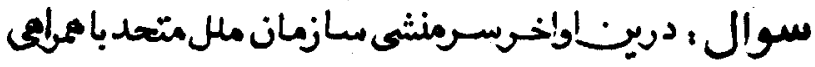

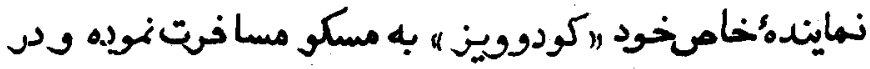

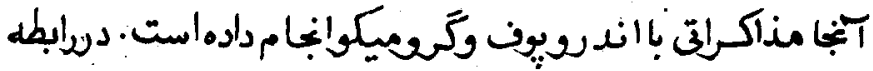

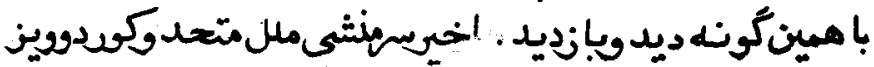

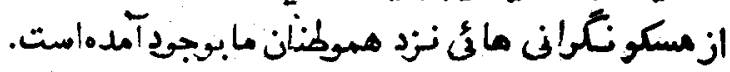

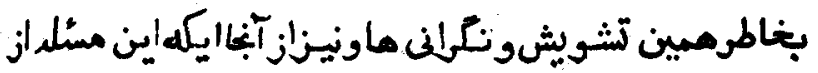

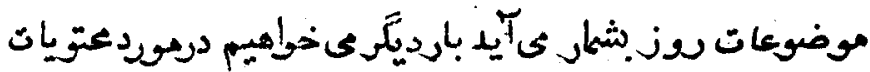

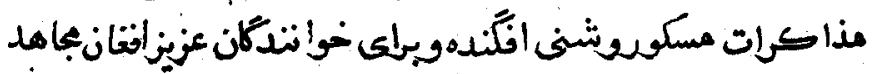


اين نحته لـا روشتن سانهيدكة آيا منأكرات مسكوبرمذاكرات

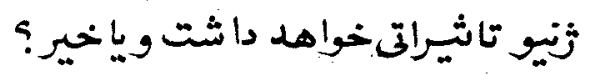

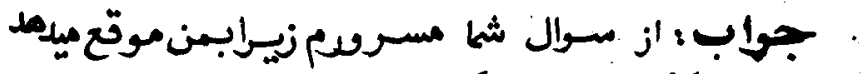

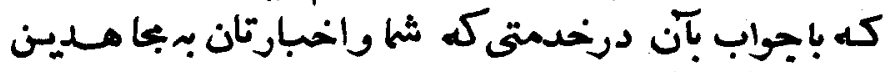

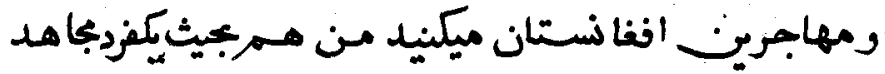
مهاجرسهنى داشئته با شئمر.

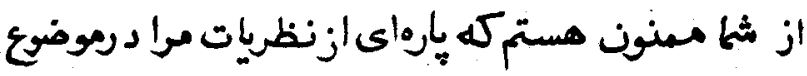

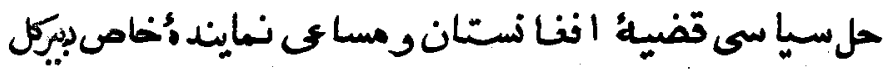

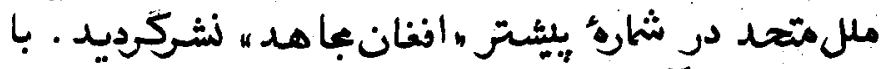

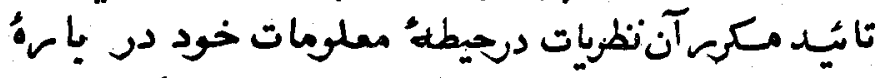

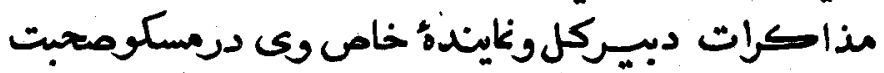

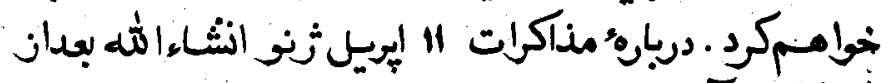

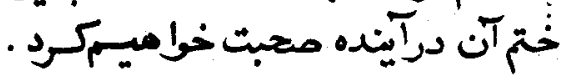

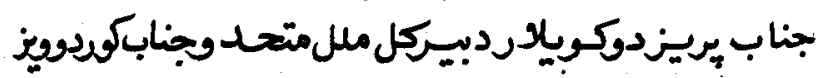

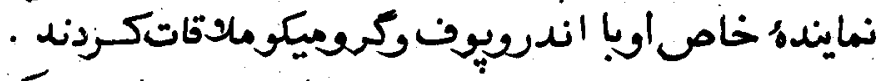

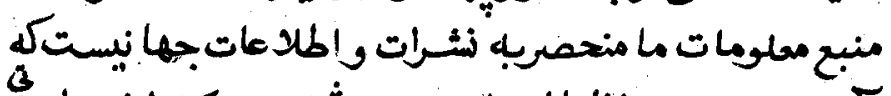

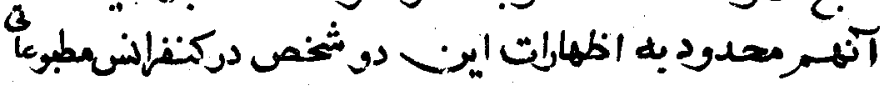

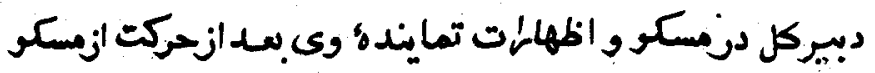

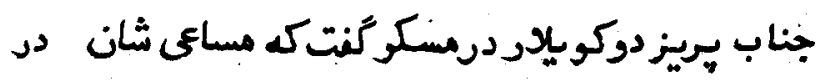

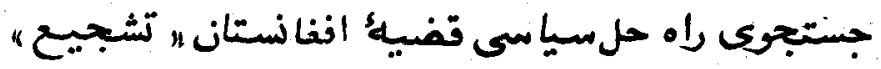


شد ه است وعلاوركرد :

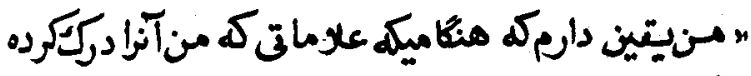

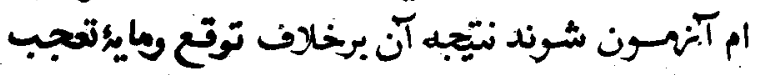

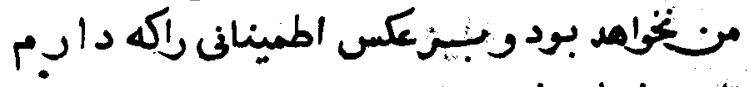

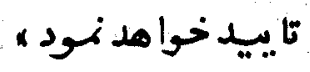

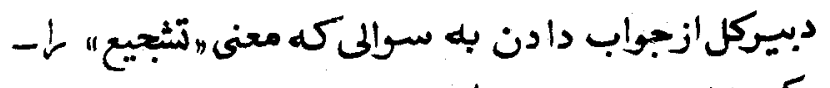

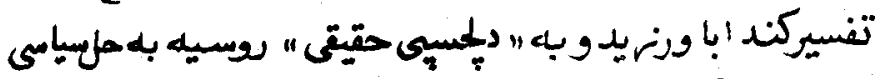

$$
\begin{aligned}
& \text { اشاركرد وكفت : لشيركن }
\end{aligned}
$$

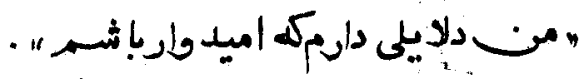

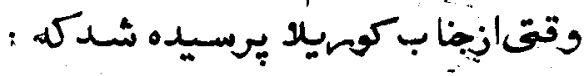

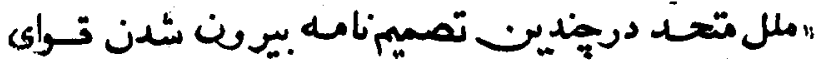

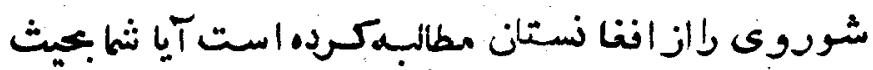

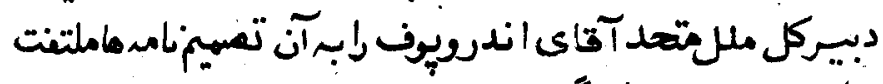

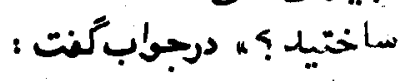

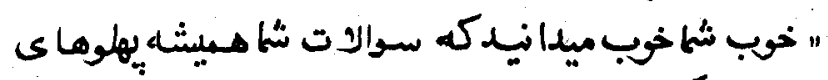

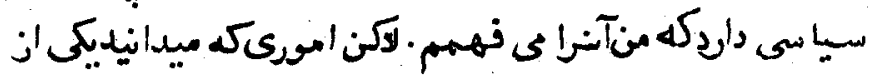

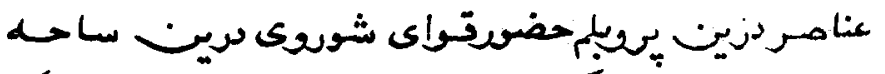

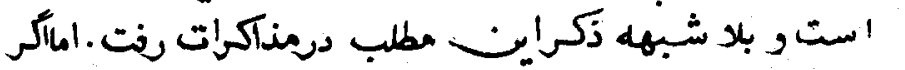

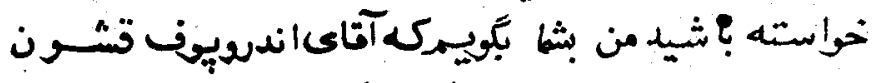

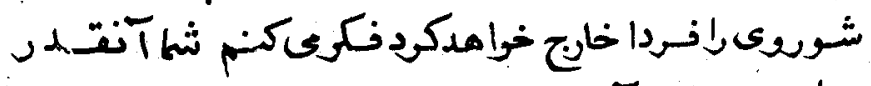

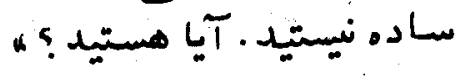


واضح ابت نغواست بـ سولمكه متوبه مسوليّي

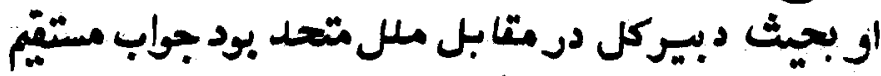

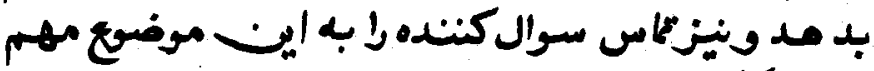

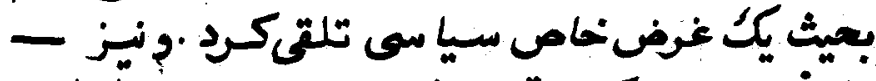

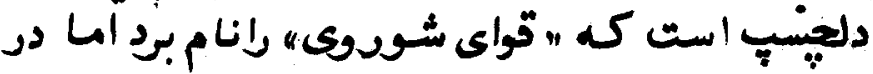

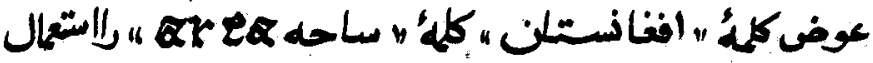

$$
\begin{aligned}
& \text { كري }
\end{aligned}
$$

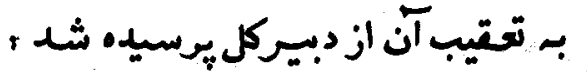

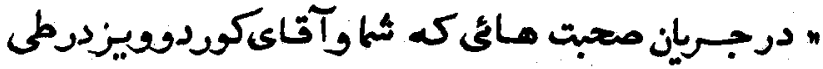

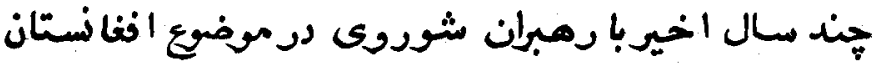

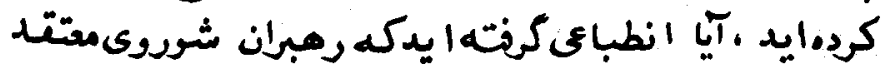

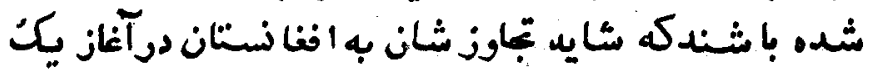

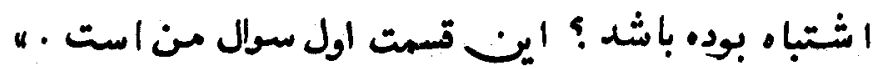

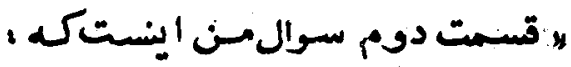

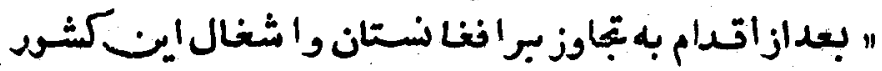

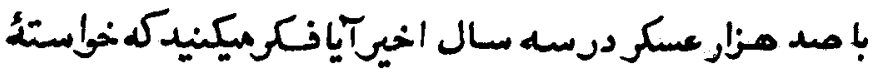

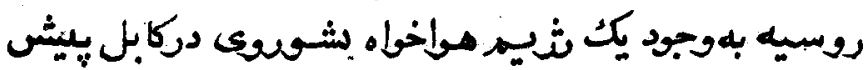

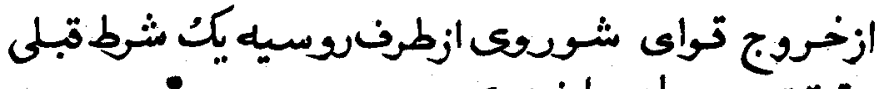

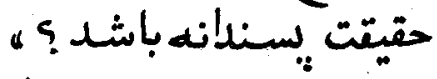

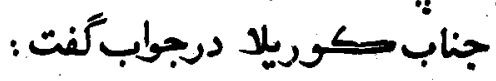

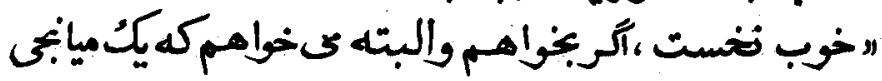




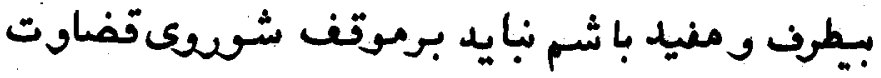

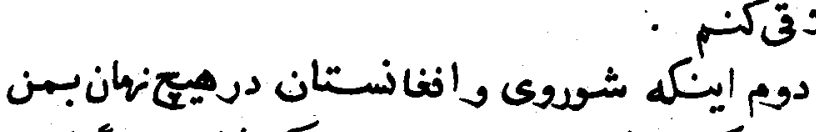

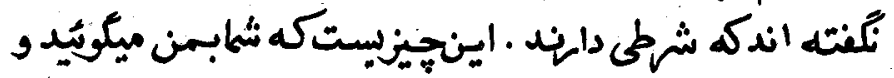

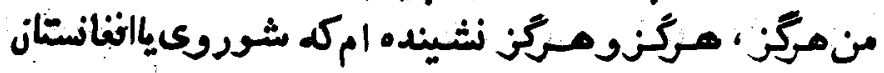

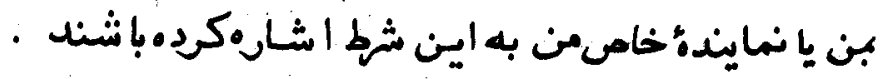

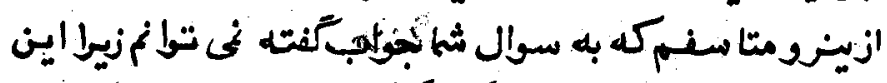

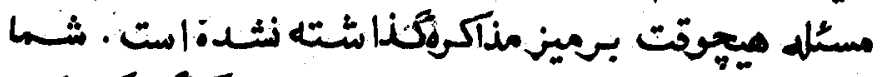

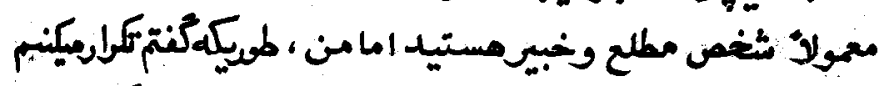

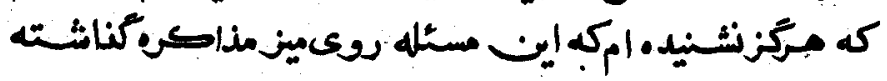

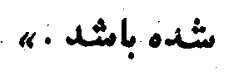

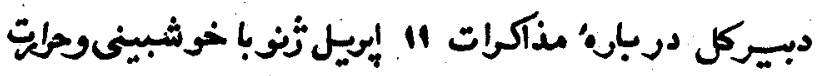

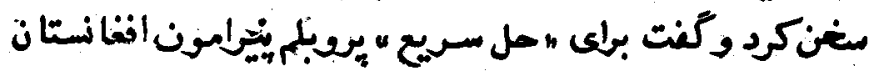

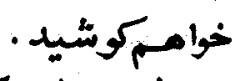

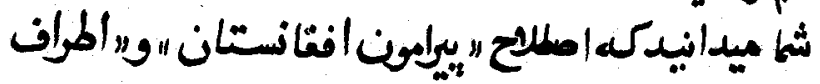

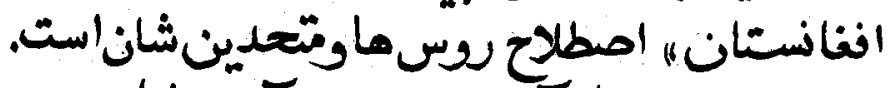

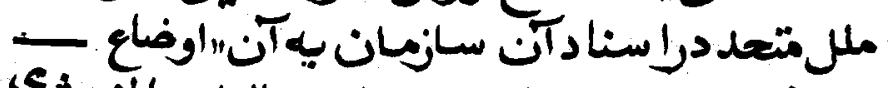

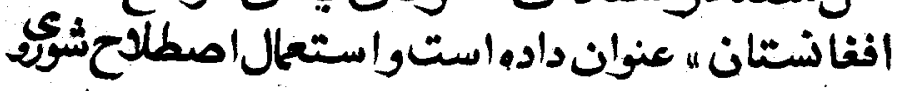

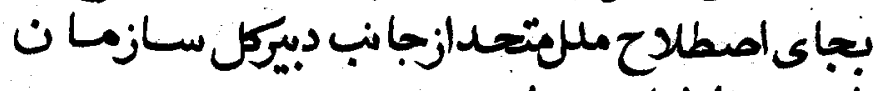

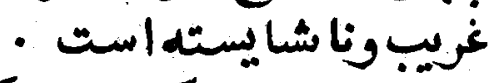

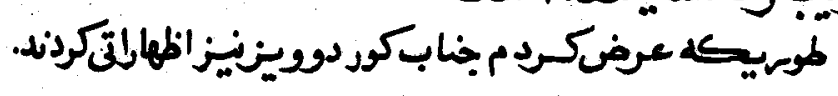


v.

جنابكوردوريزكّت :

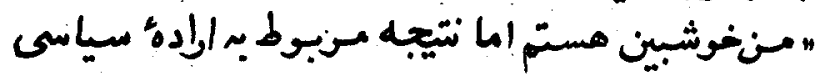

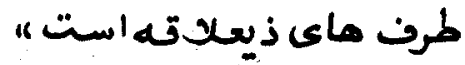

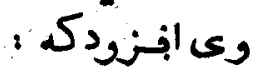

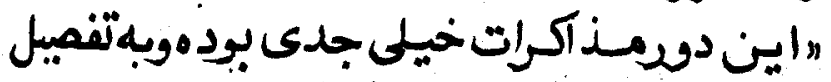

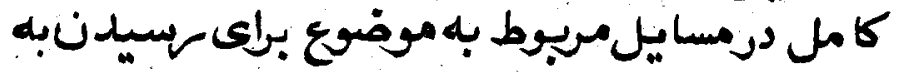

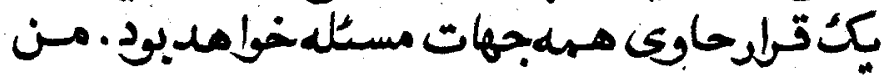

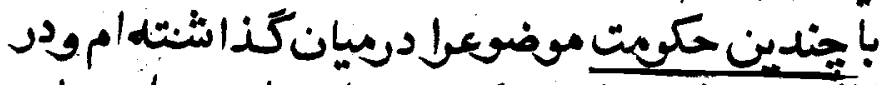

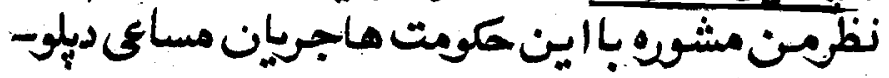

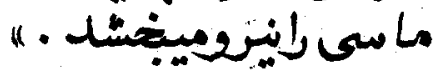

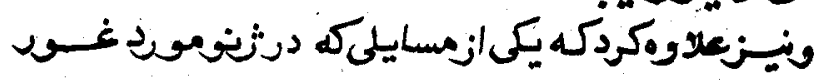
قرارخماهدخرنت .

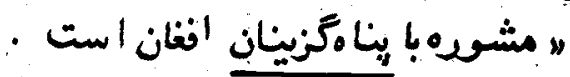

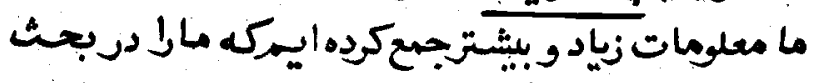

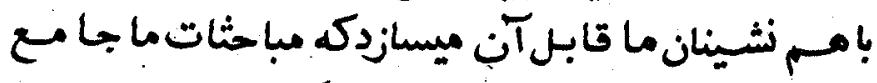

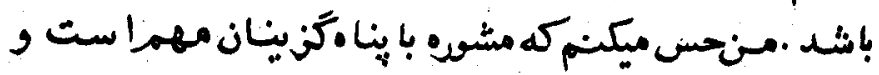

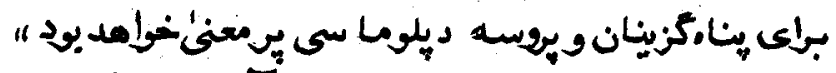

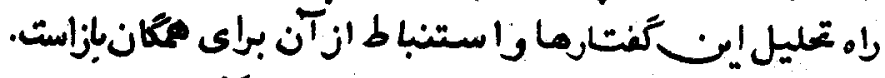

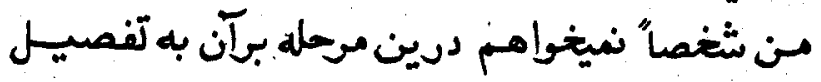

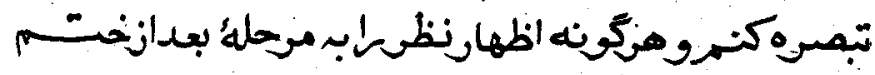

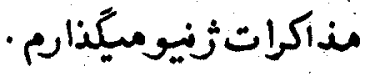




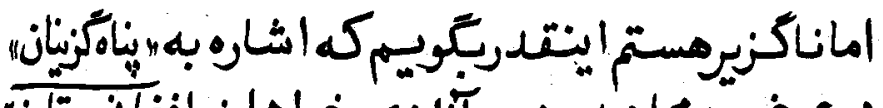

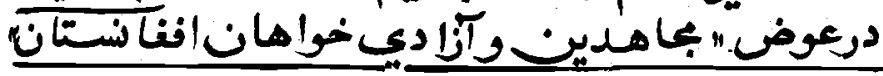

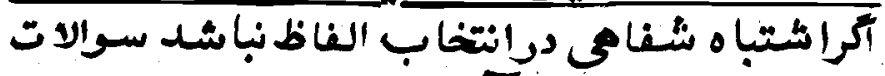
غامضى إبه ميان ميآورد .

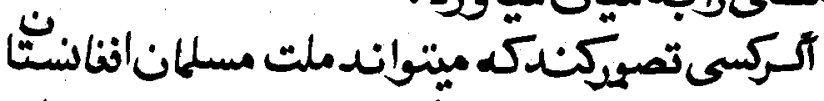

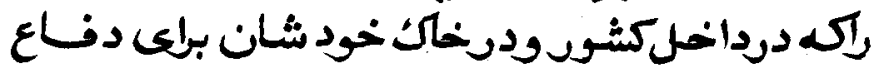

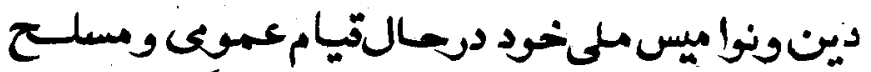

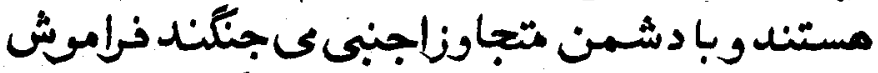

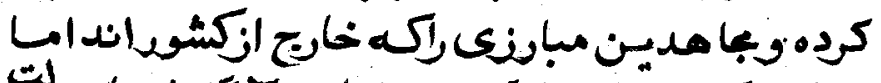

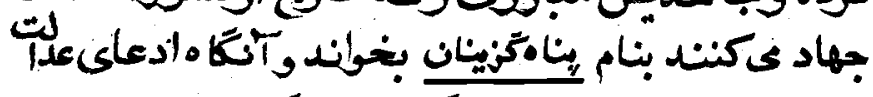

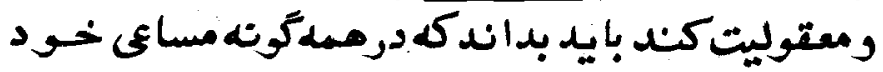

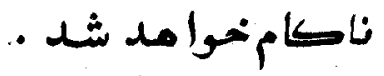

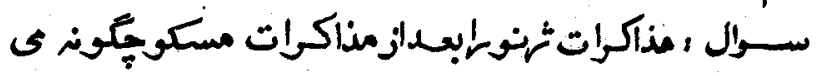
بينيد?

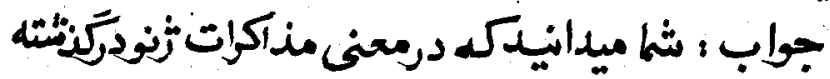

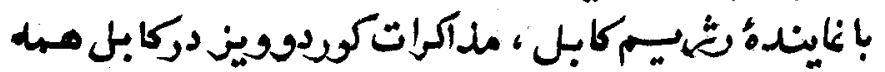

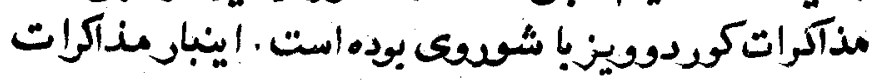

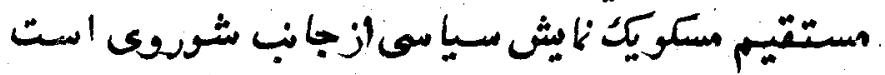

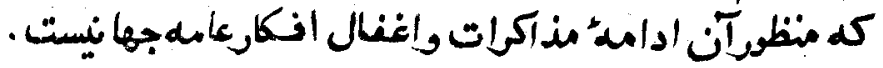

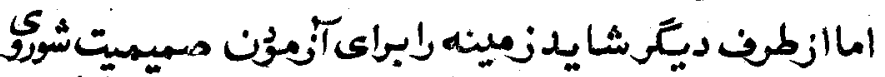

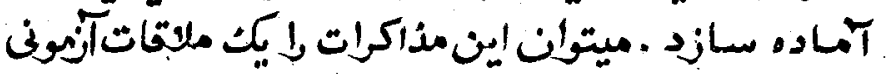




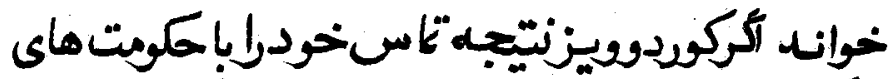

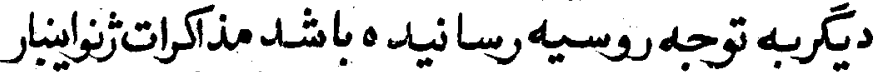

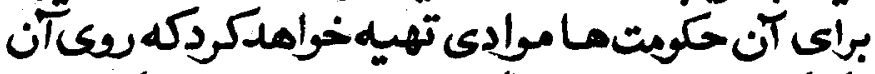

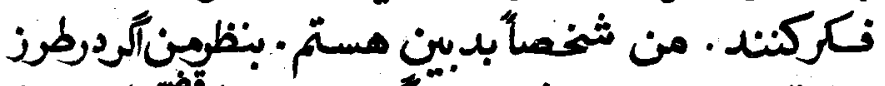

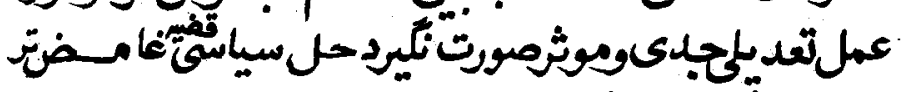

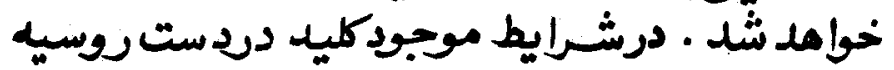

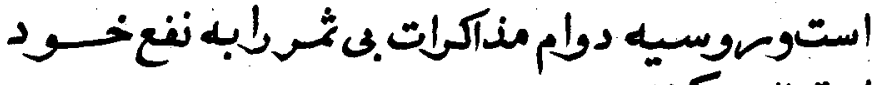
استعالىكند.

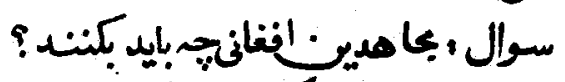

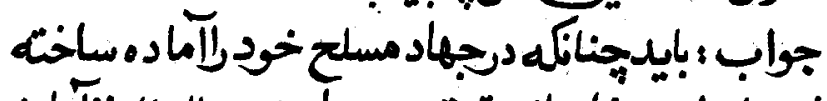

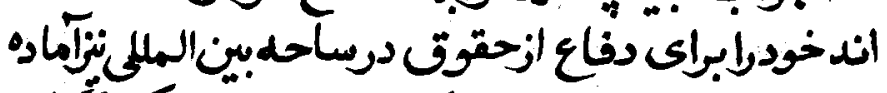

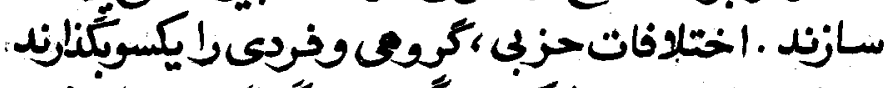

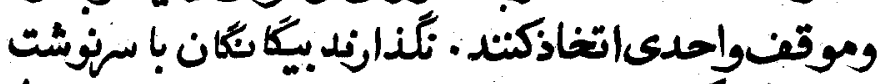

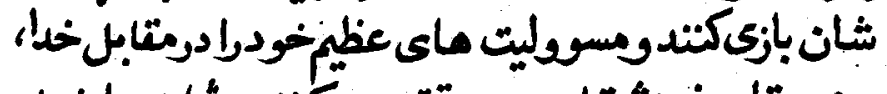

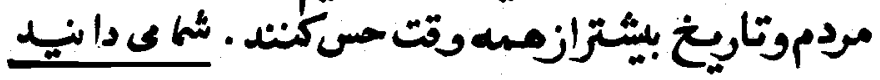

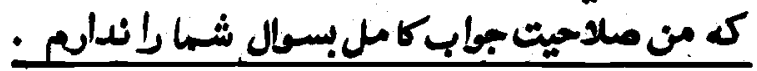

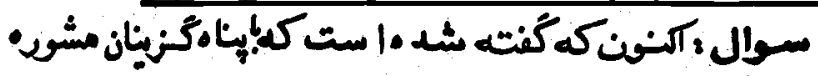

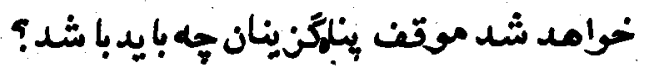

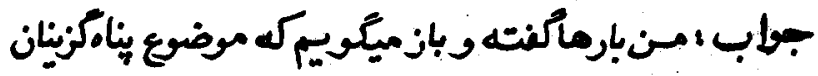

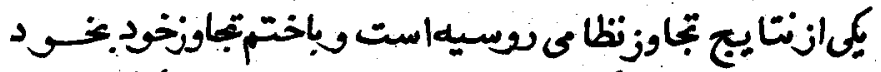

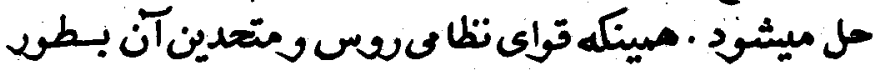




\section{vr}

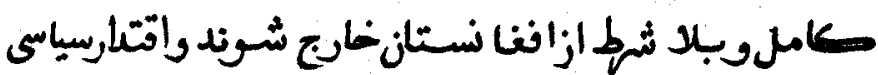

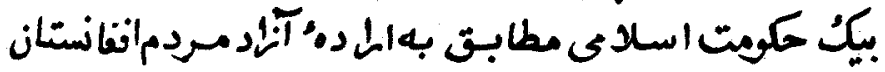

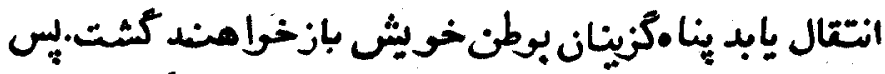

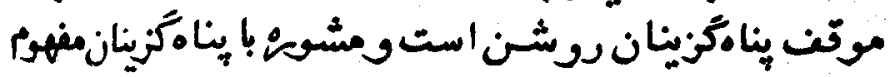
ندارد.

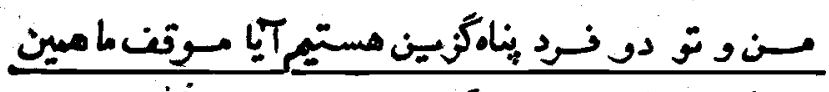

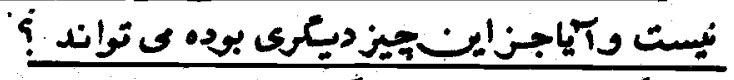

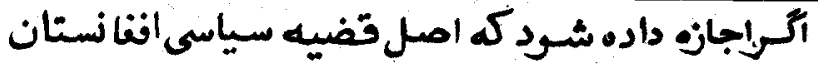

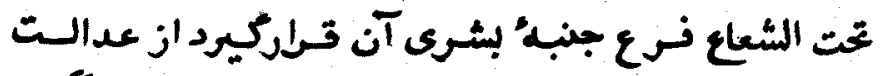

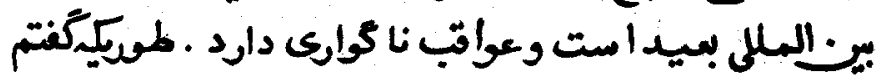

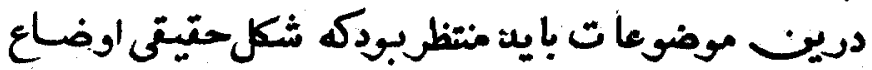

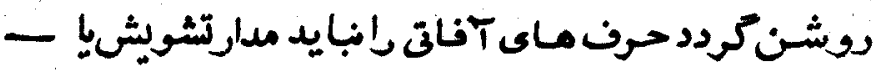
اطمينان تــئرداد.

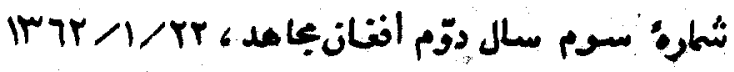

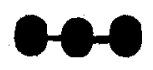




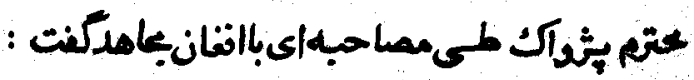

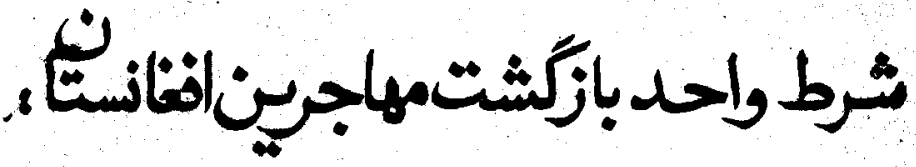

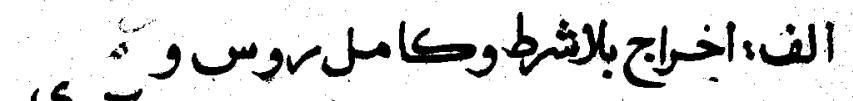

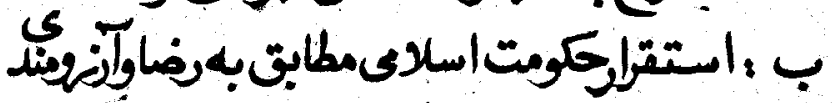
مسردماست

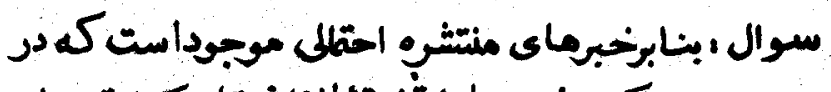

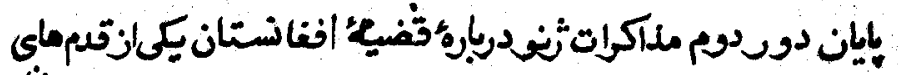

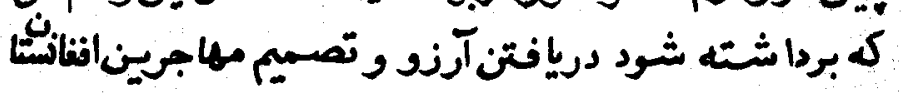

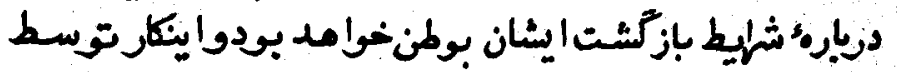

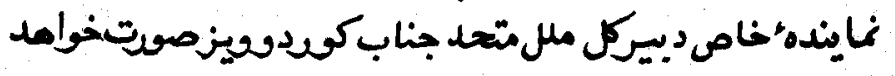
كرنت نظوئمايجيست

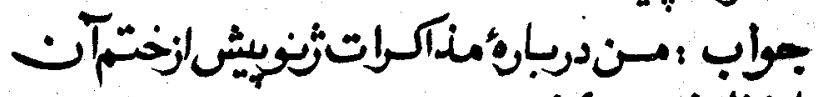

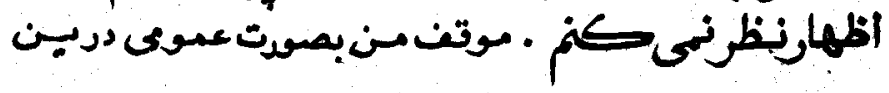




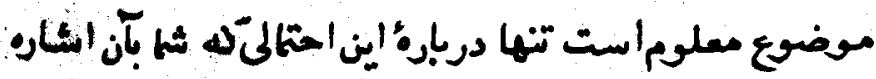

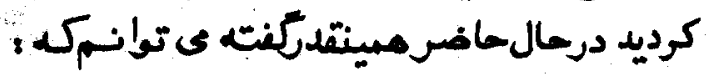

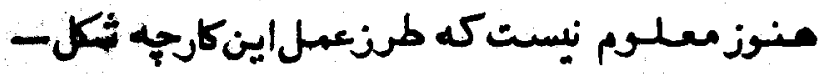

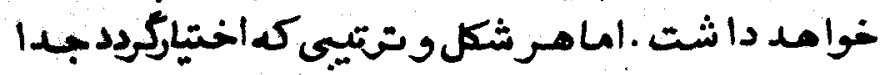

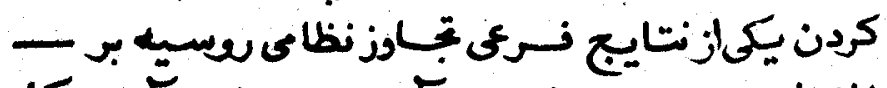

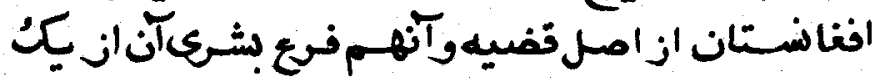

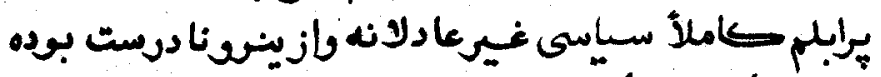

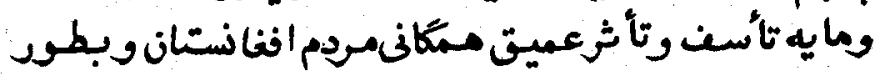

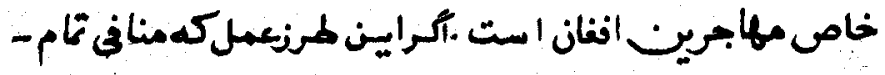

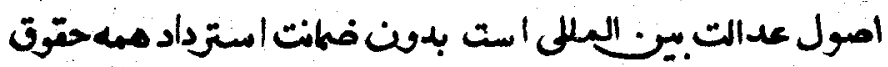

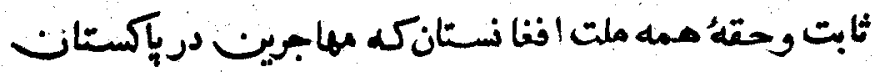

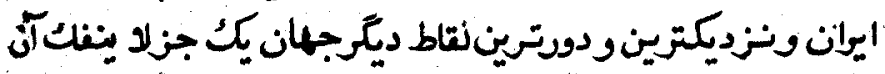

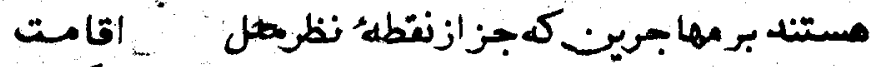

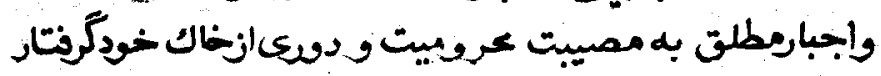

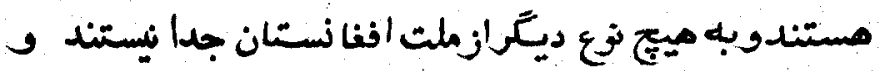

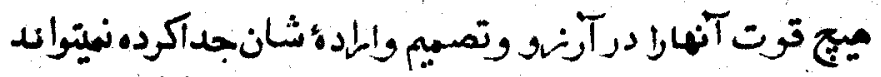

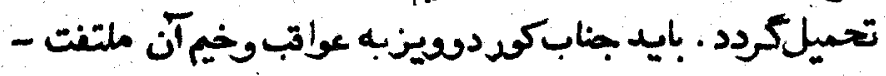

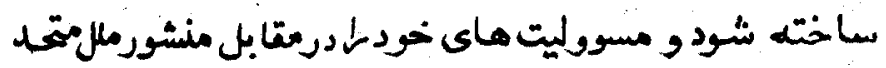

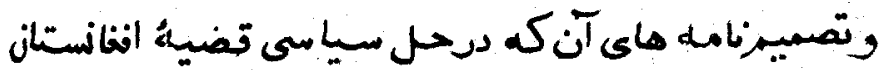

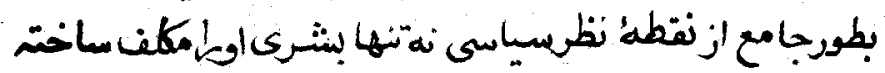

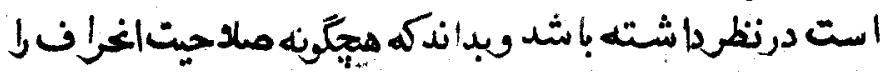




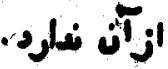

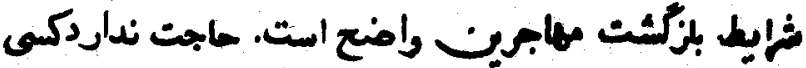

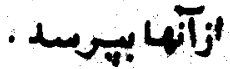

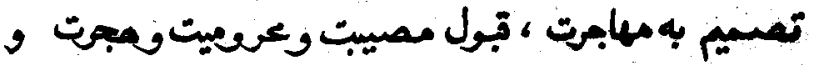

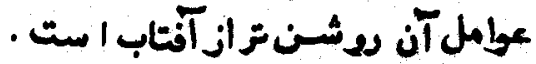

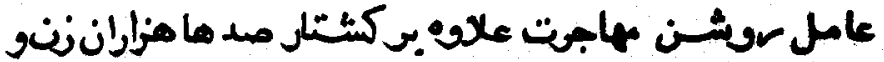

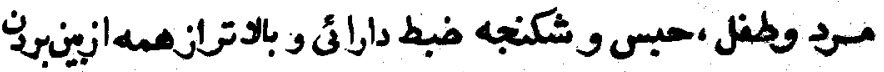

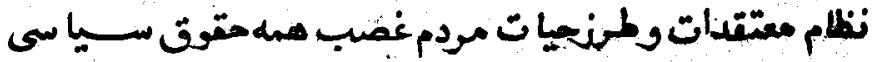

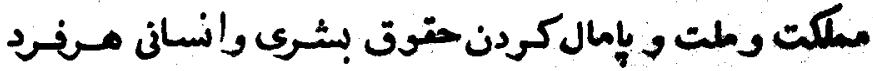

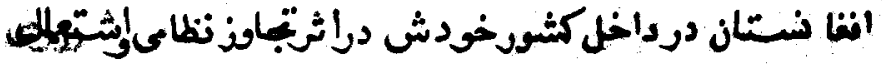

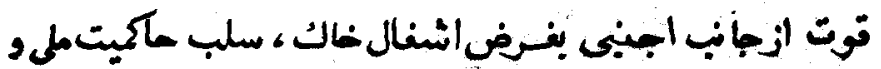

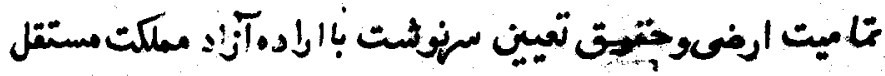

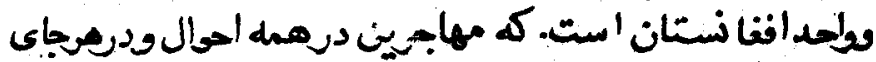

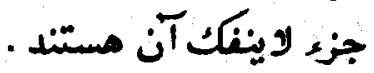

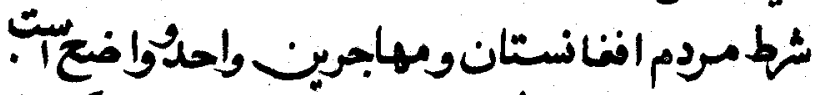

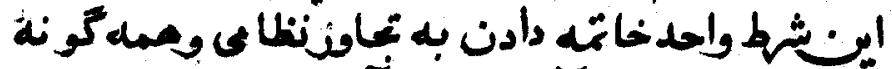

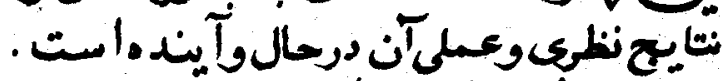

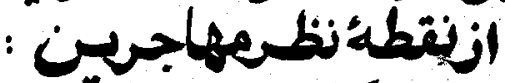

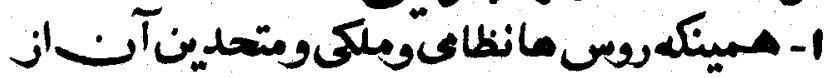

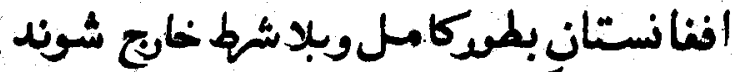

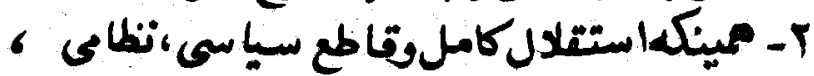




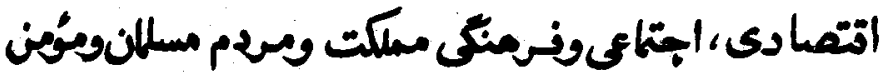

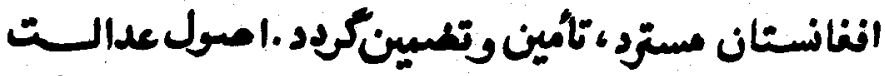

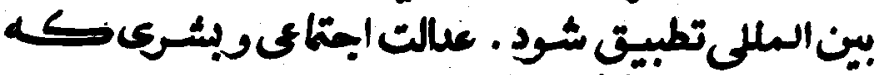

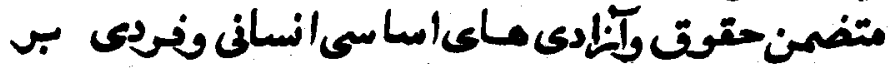

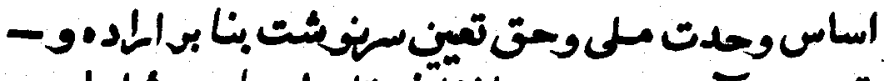

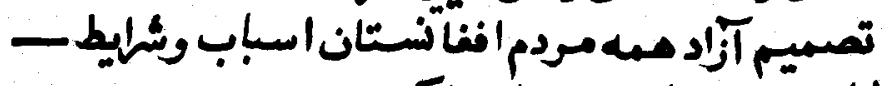

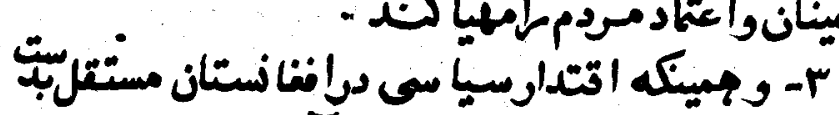

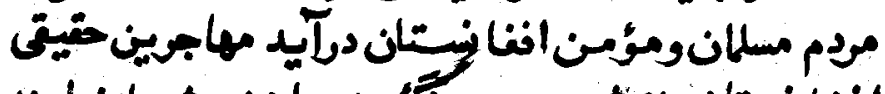

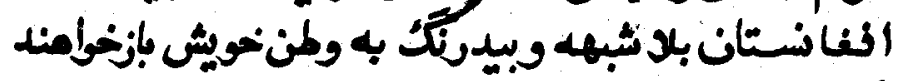

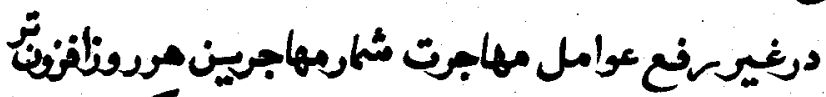

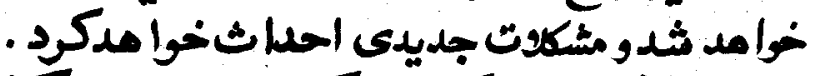

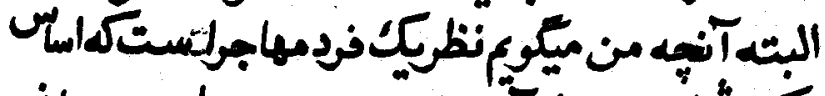

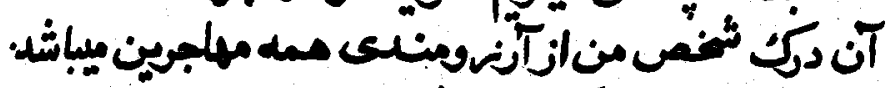

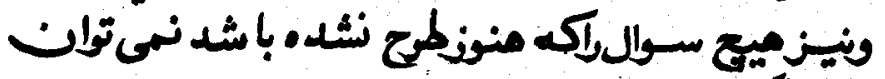
مواب منه

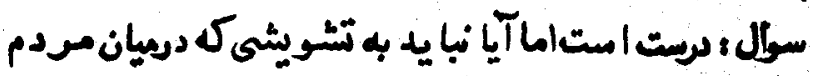

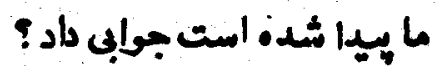

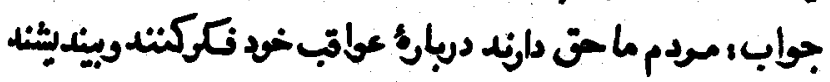

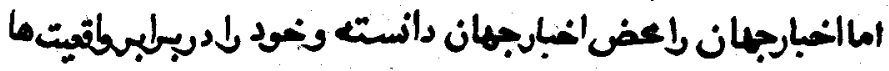




\section{VA}

الماده مغالزوندوالشياء الله آماده هستند .

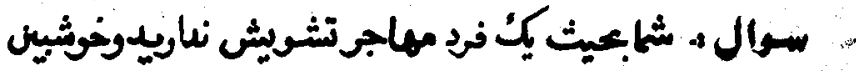
?

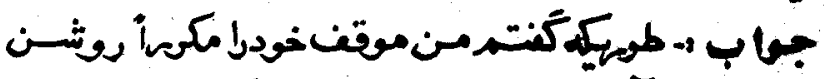

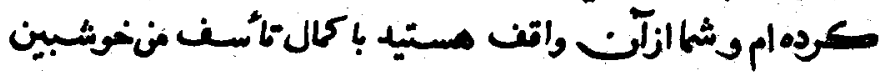

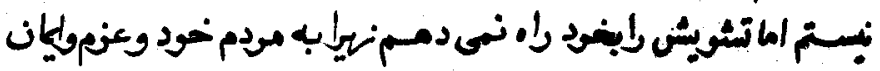

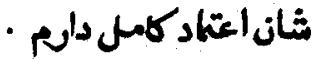

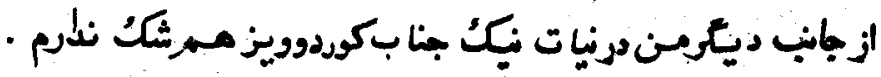

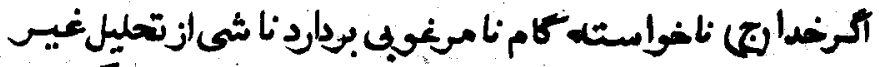

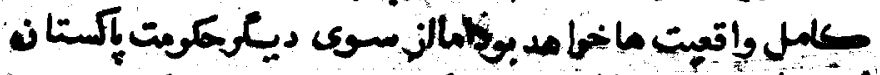

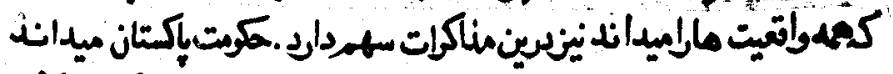

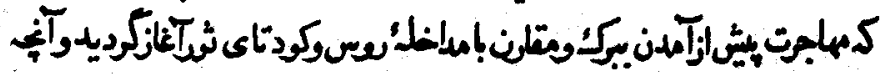

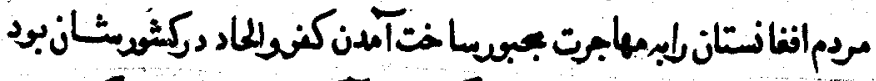

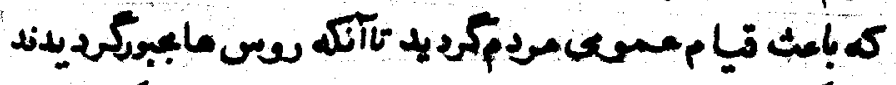

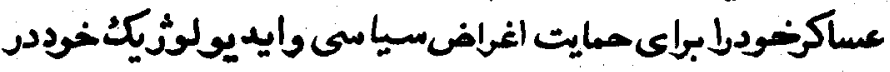

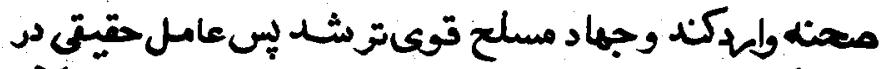

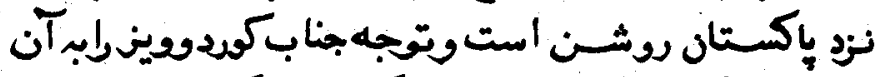

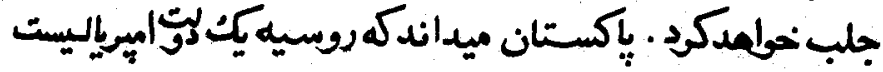

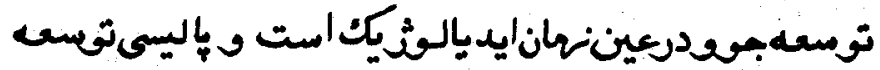

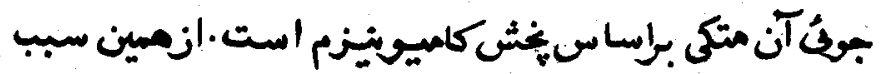

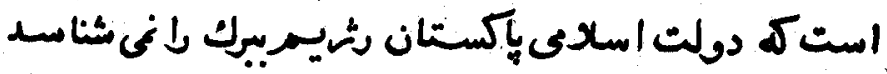




\section{vq}

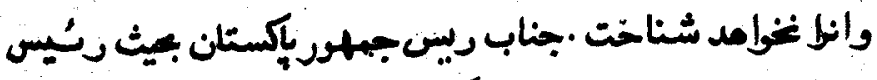

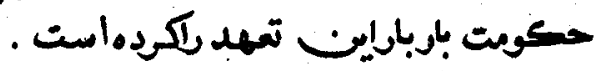

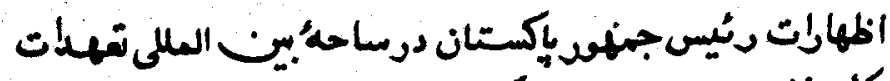

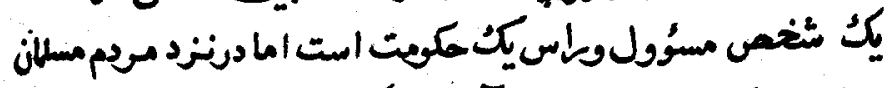

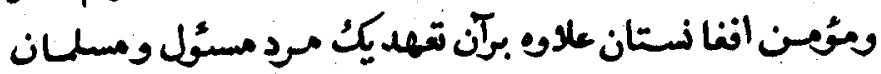

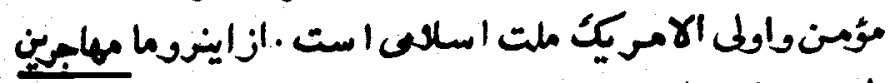

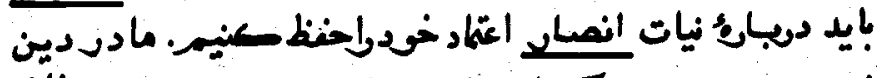

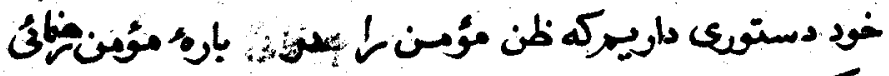

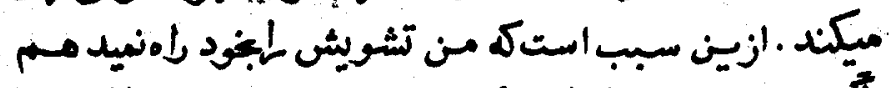

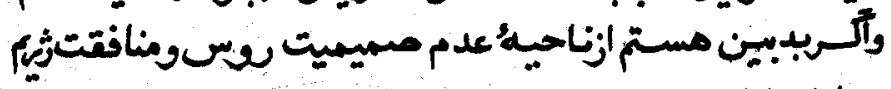

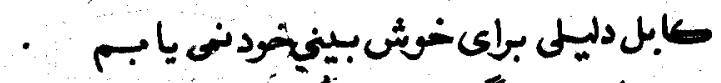

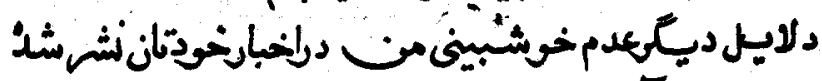

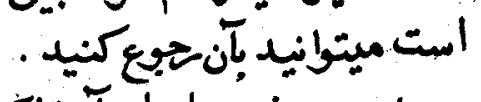

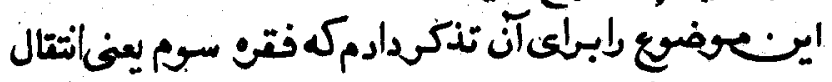

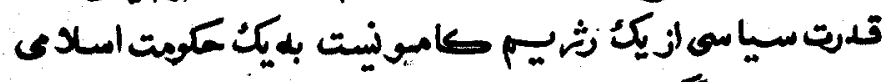

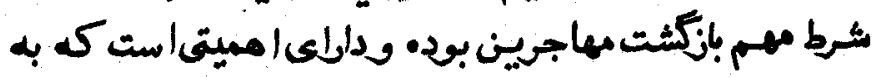

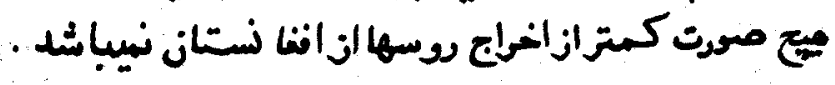

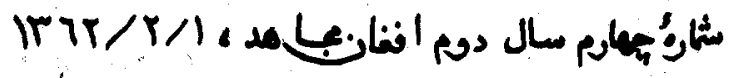




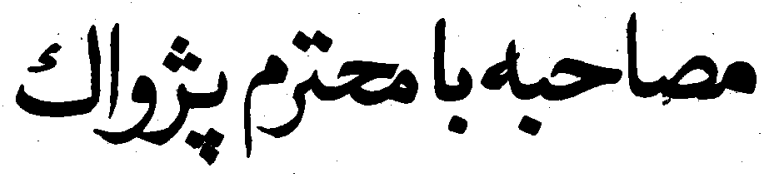

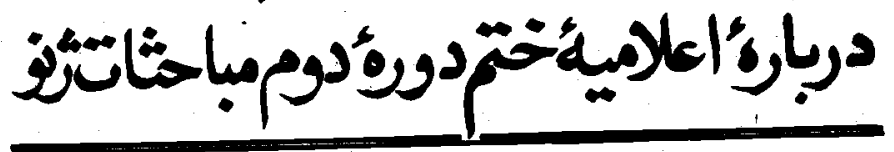

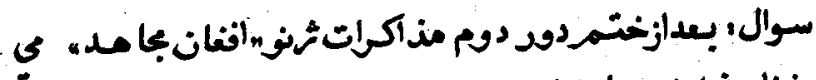

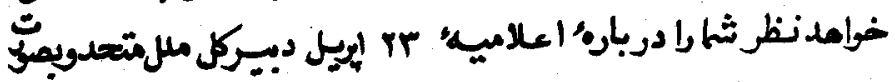

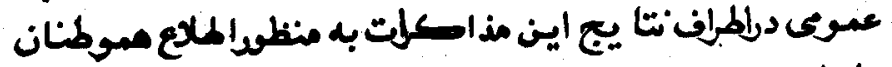
مابدانك.

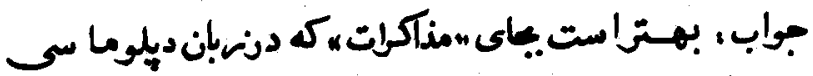

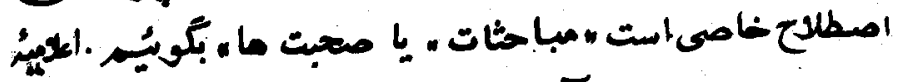

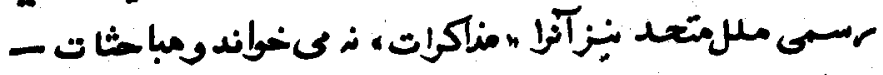
مينامد.

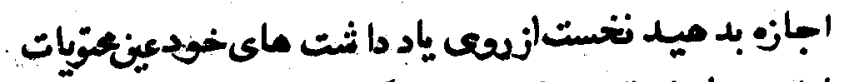

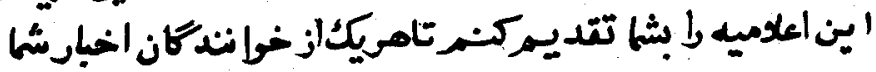




\section{A)}

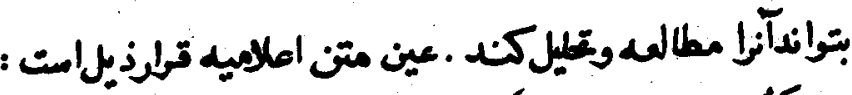

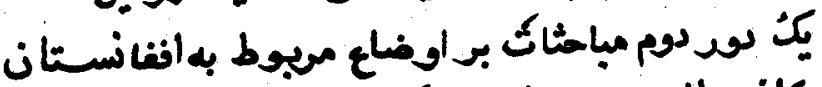

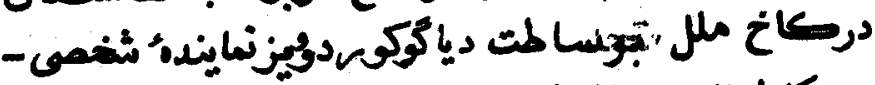
دمركلازئريخ

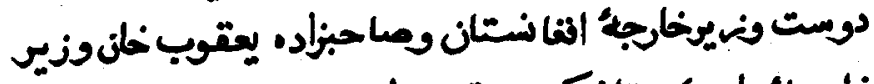

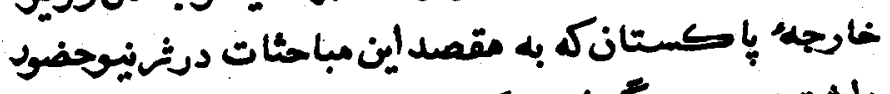

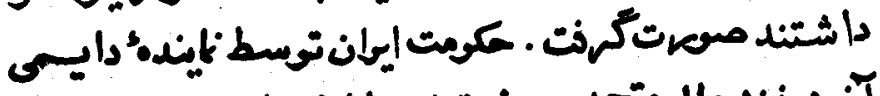

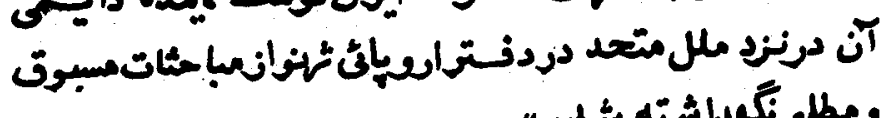

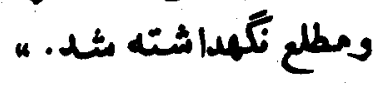

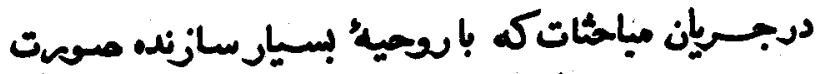

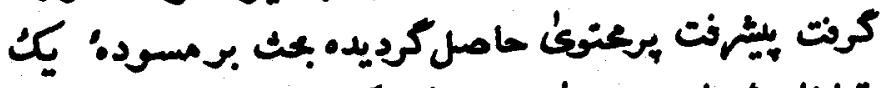

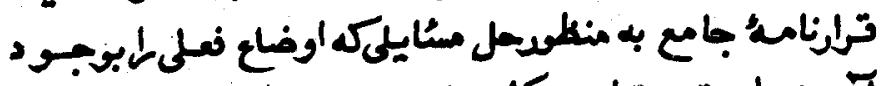

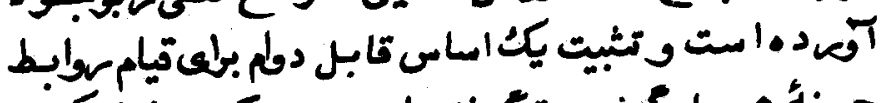

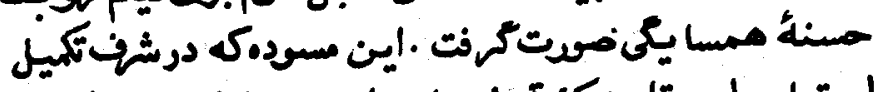

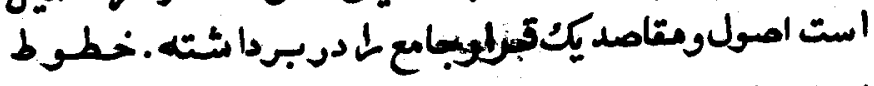

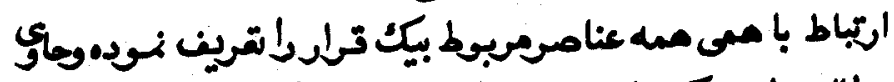

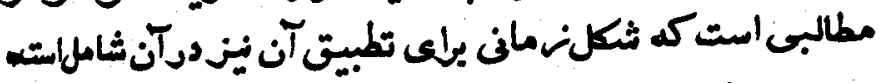

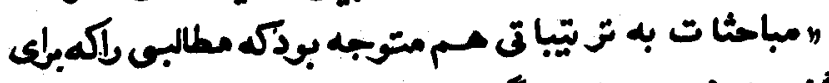

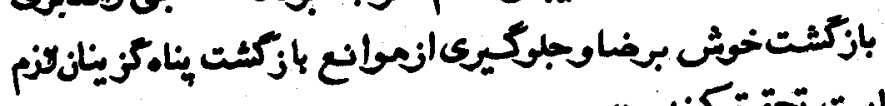

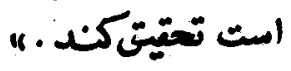

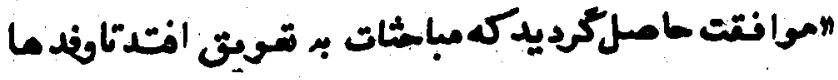




\section{Ar}

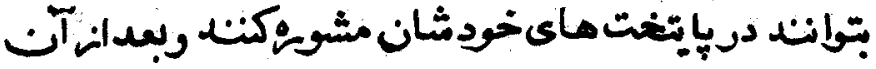

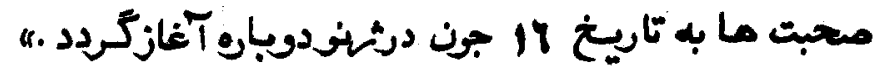

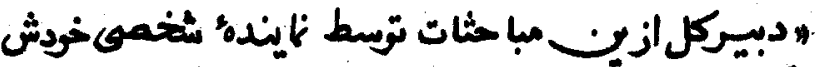

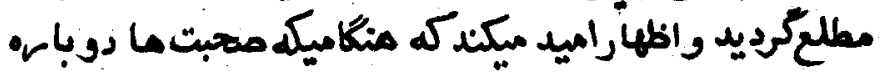

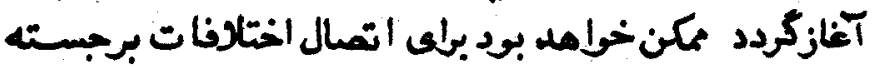

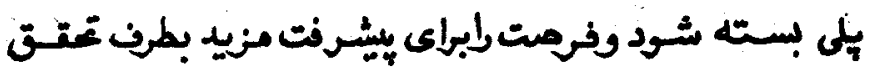

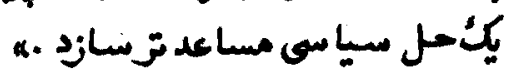

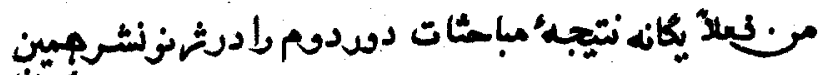

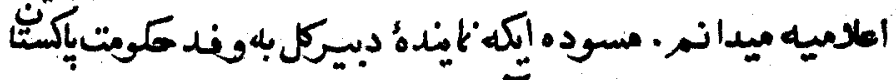

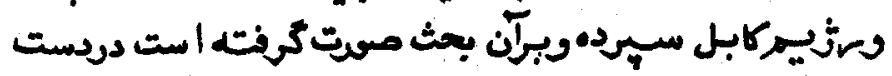

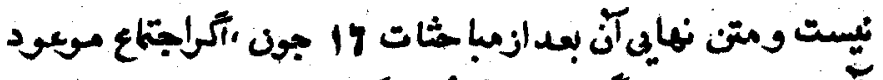

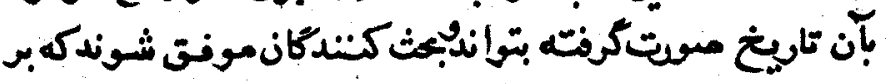

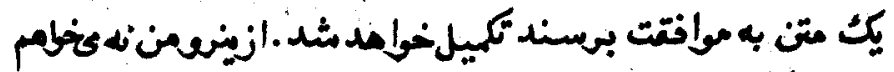

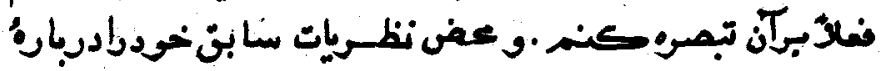

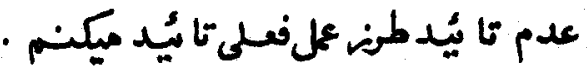

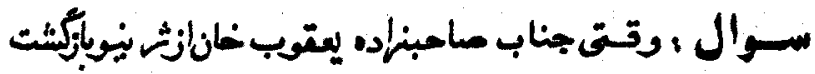

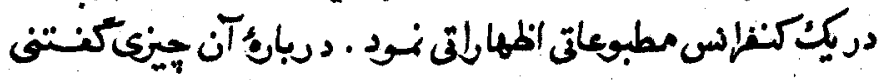

$$
\text { دارئ }
$$

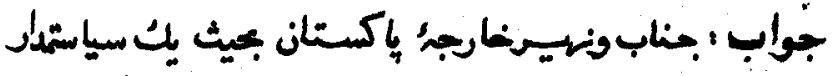

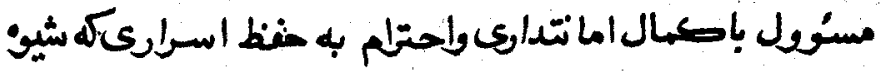

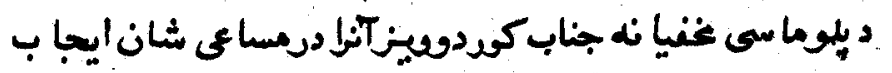




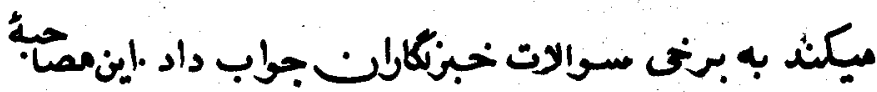

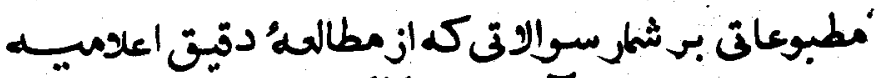

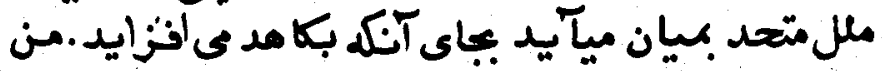

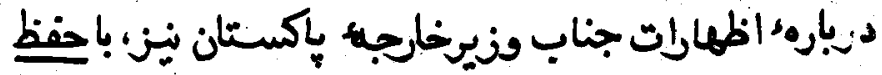

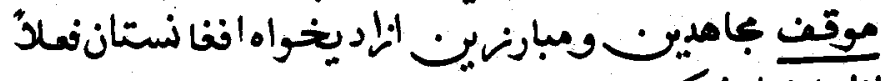

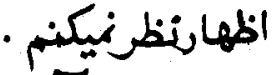

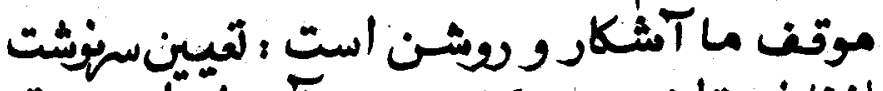

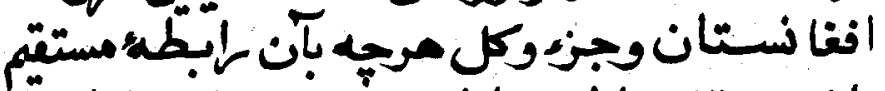

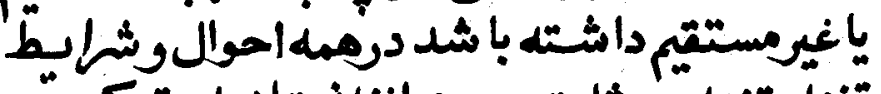

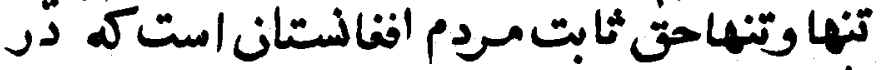

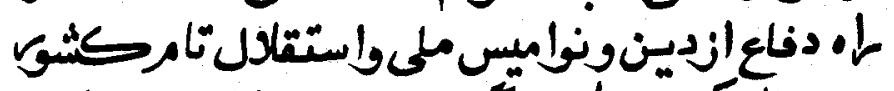

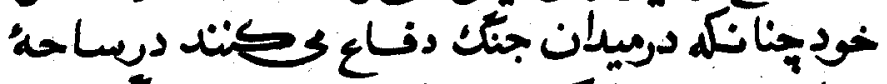

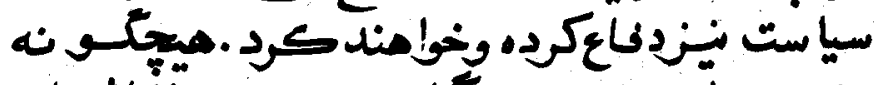

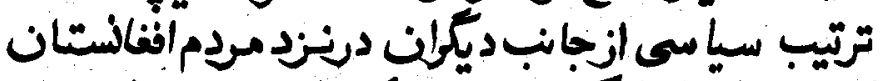

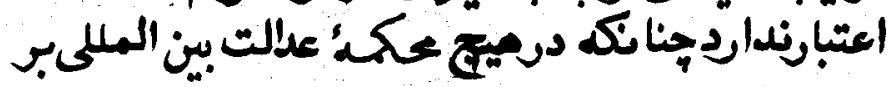

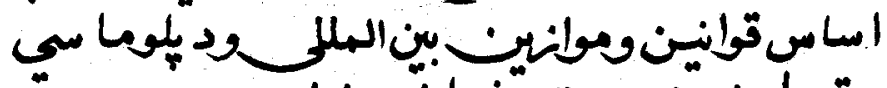

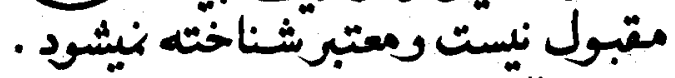

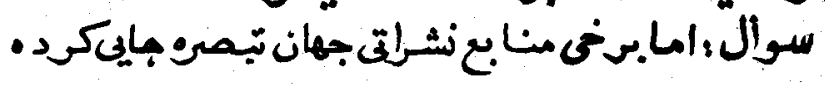
اند.

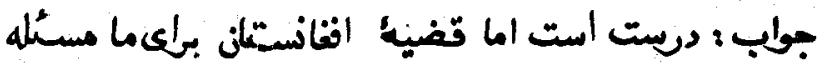

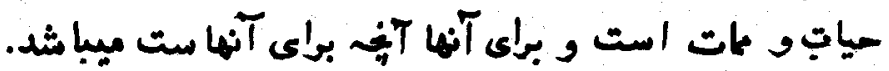




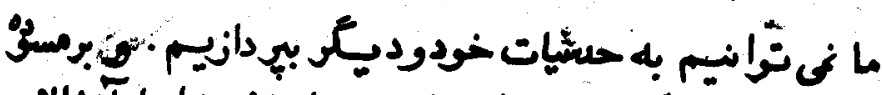

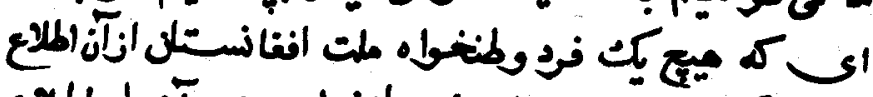

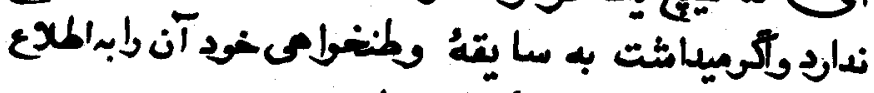

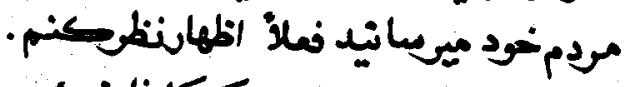

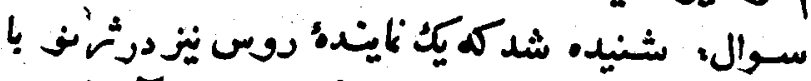

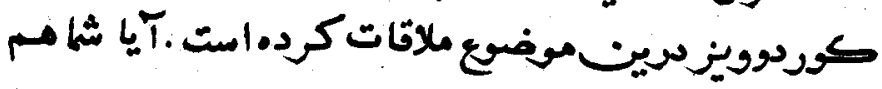

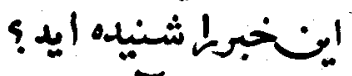

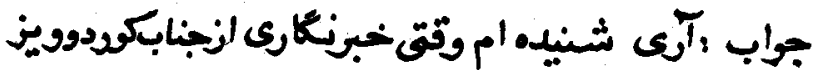

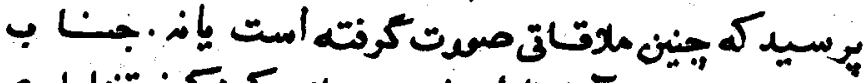

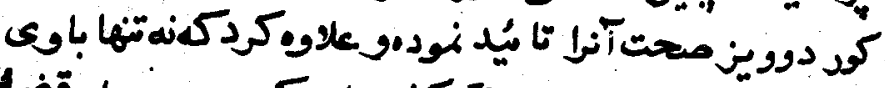

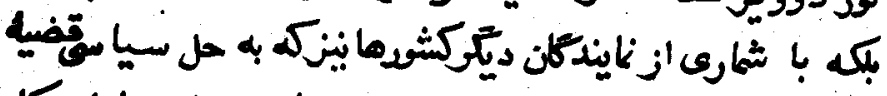

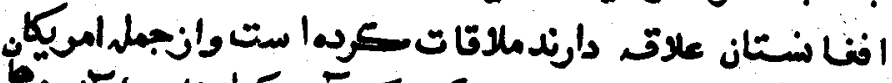

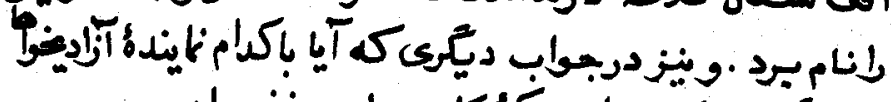

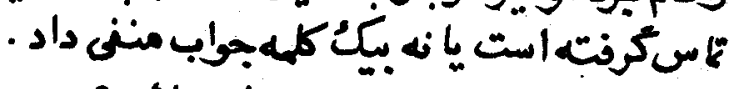

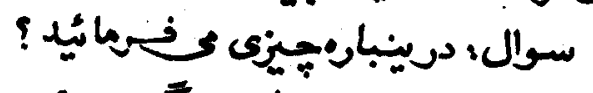

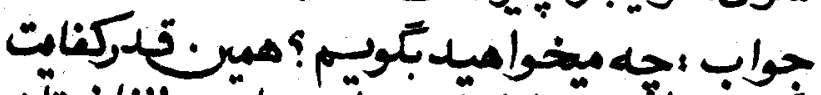

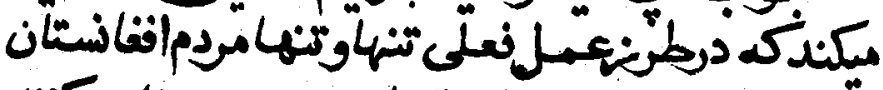

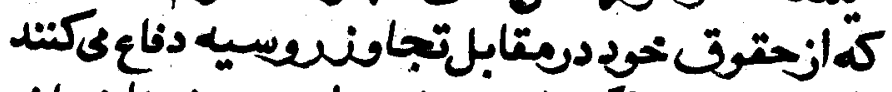

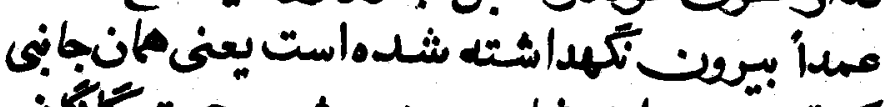

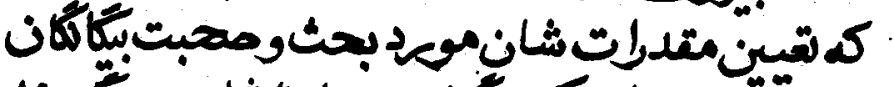

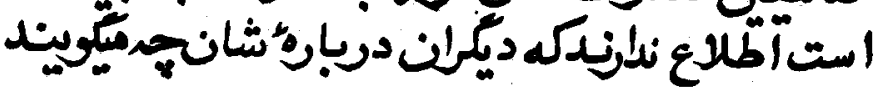




\section{وجه در نظطر داريند .}

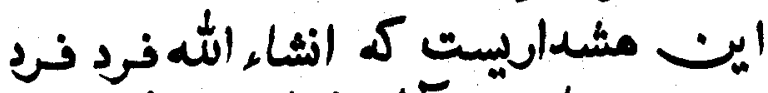

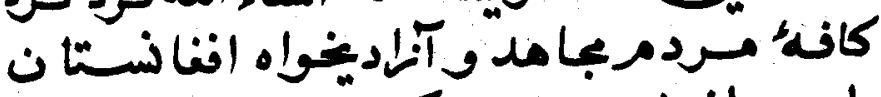

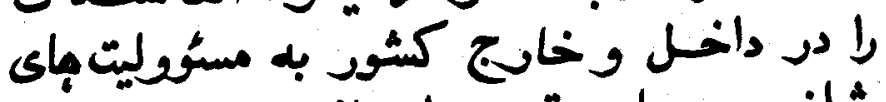

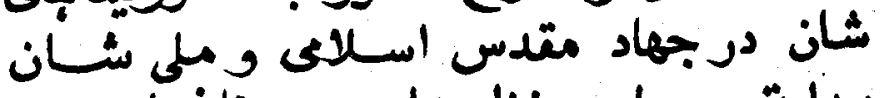

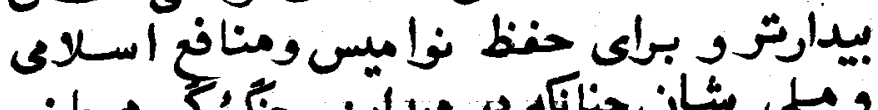

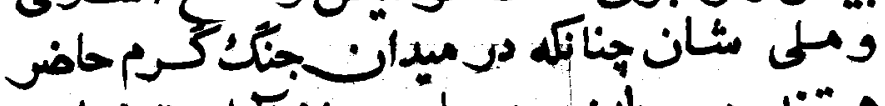

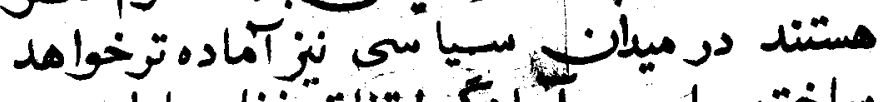

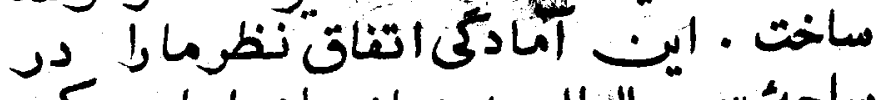

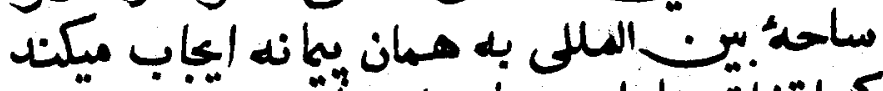

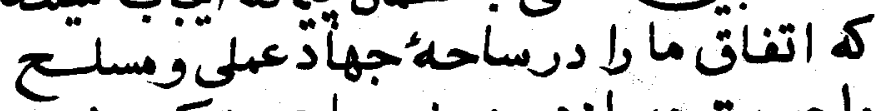

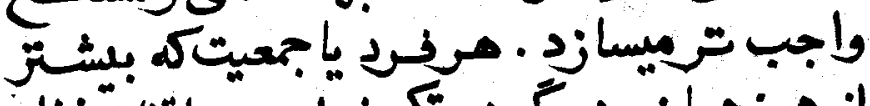

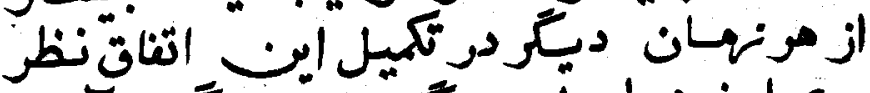

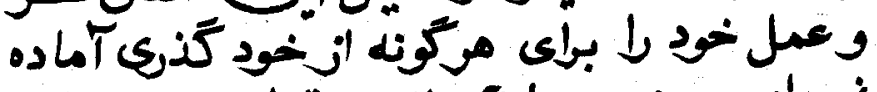

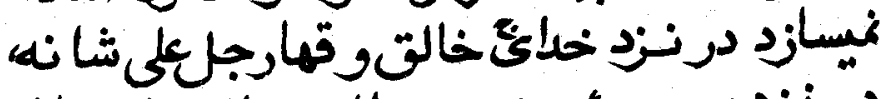

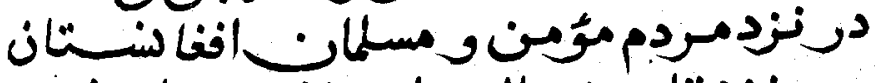

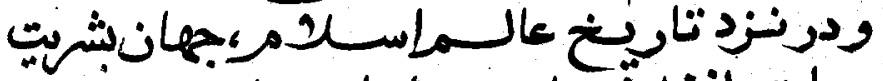

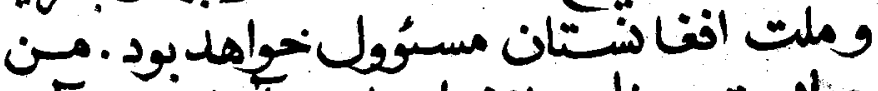

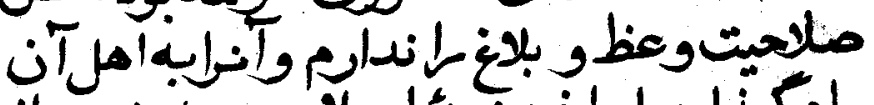

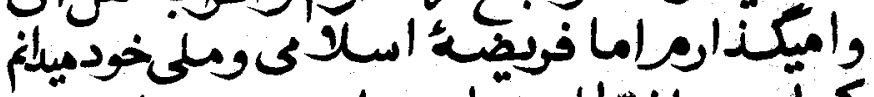

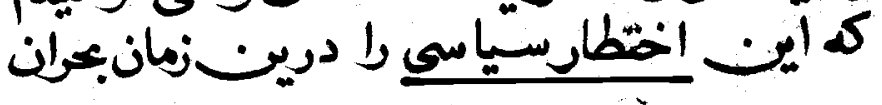




\section{A7}

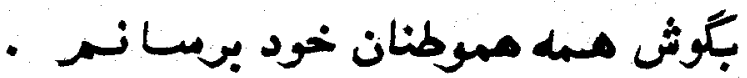

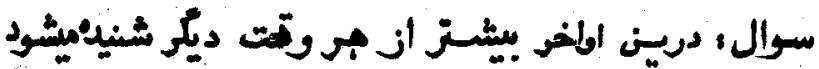

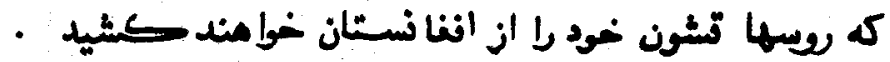

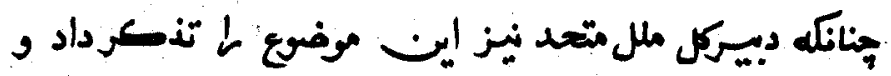

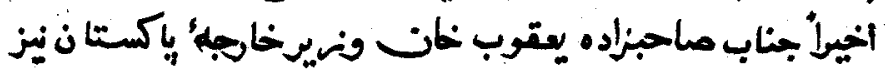

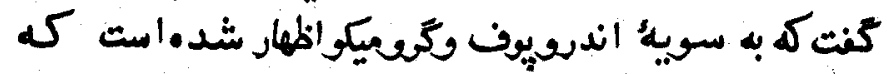

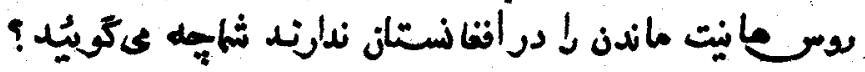

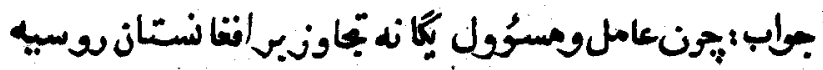

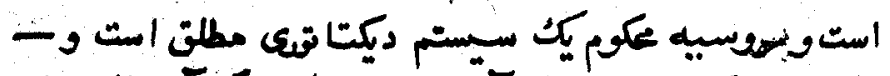

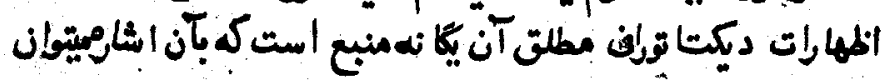

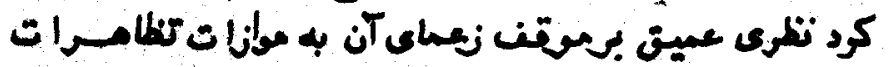

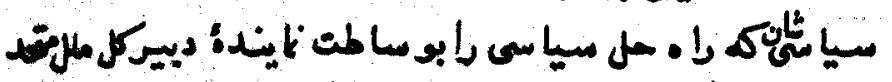

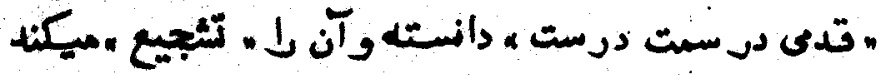

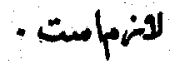

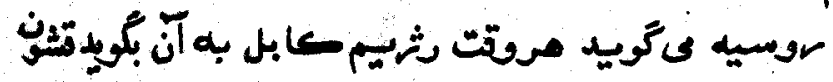

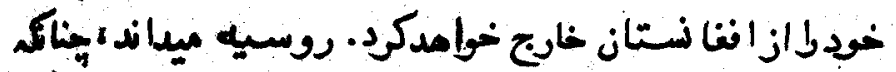

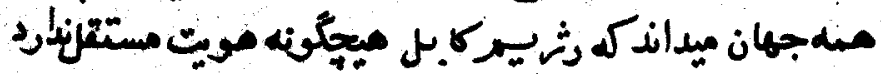

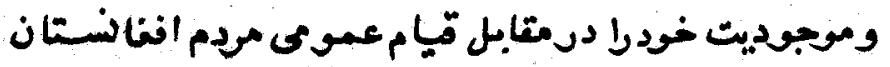

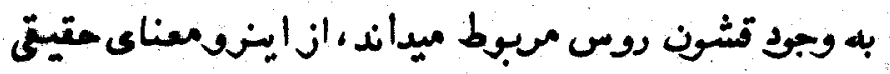

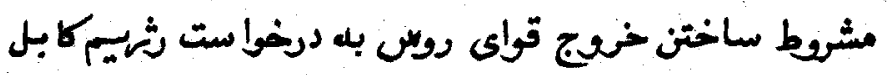

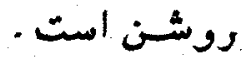




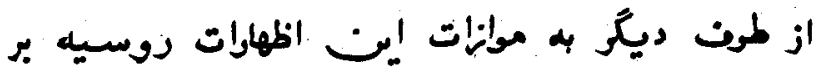

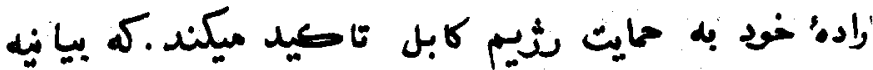

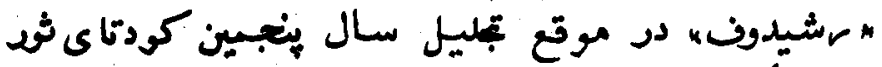

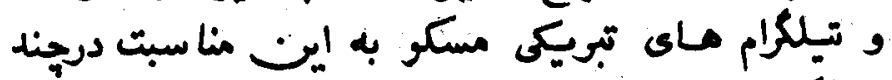

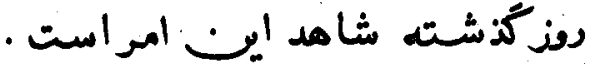

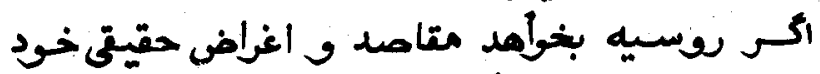

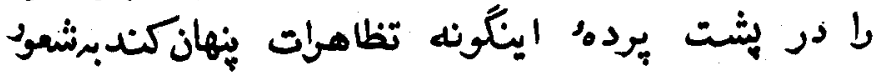
وذكاى سياسى جهان امانت ميكند.

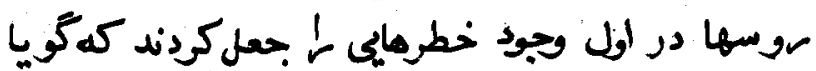

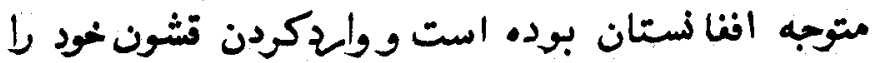

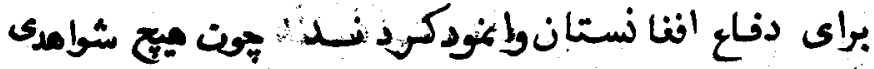

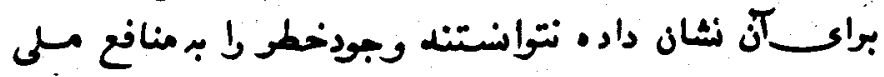

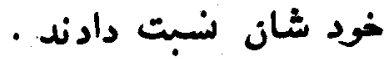

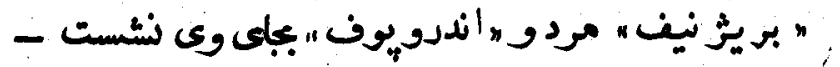

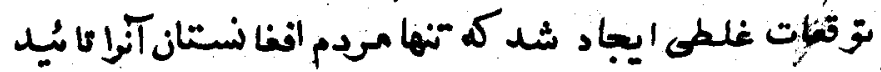

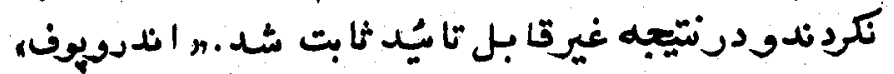

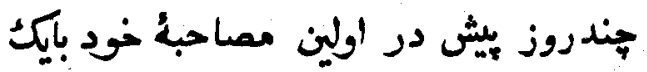

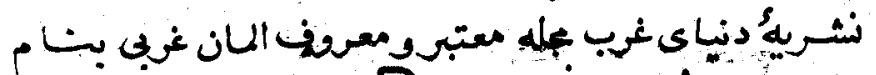

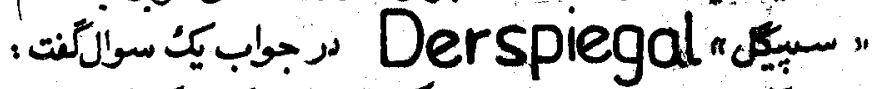

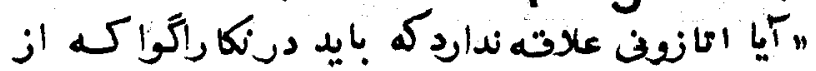

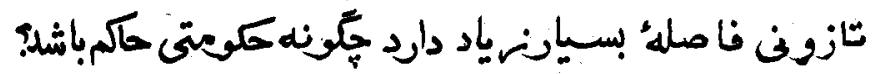




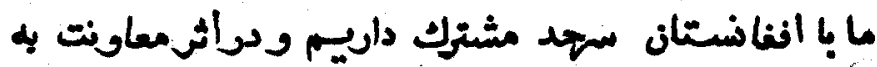

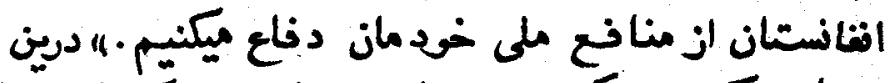

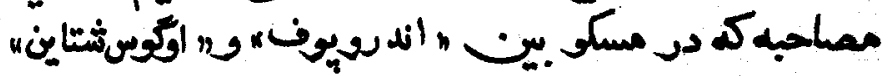

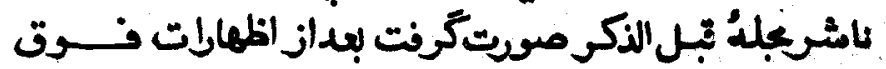

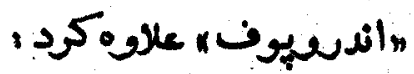

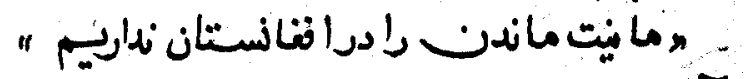

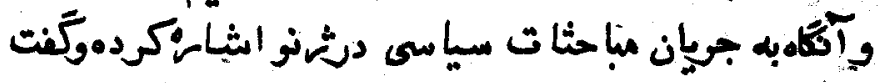

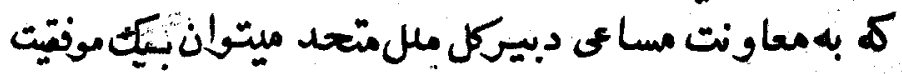

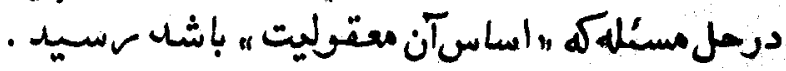

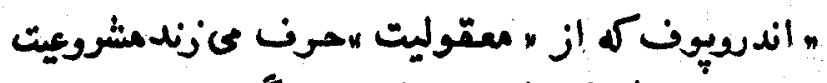

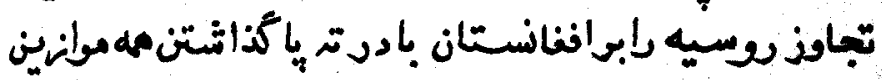

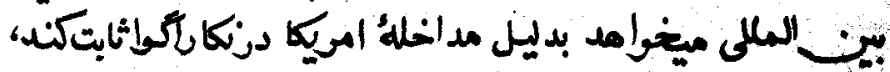

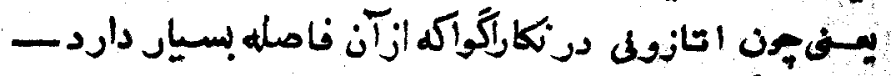

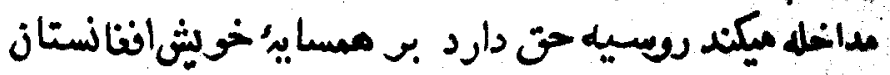

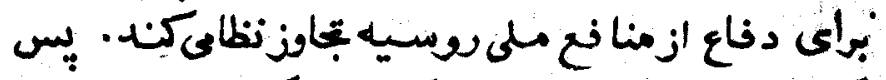

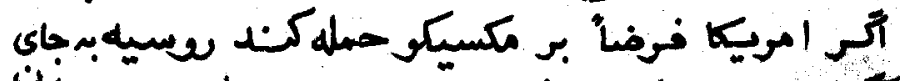

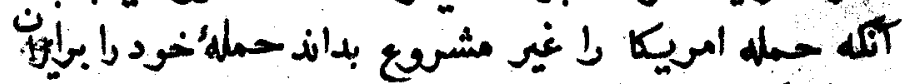

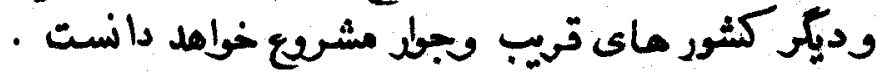

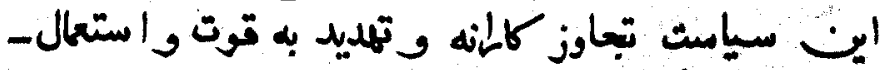

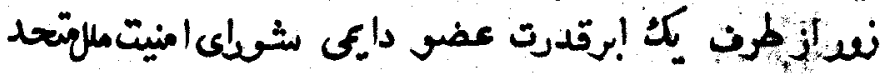

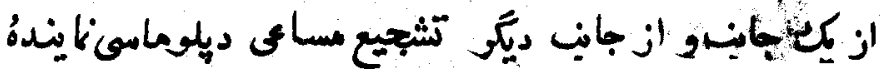




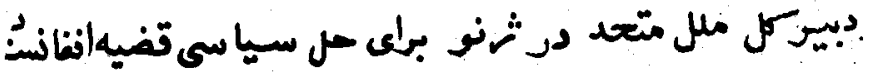

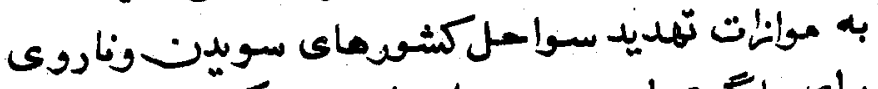

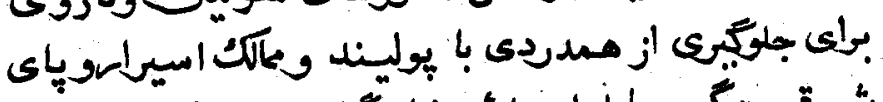

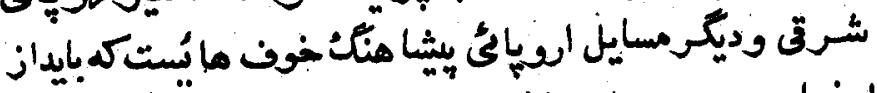

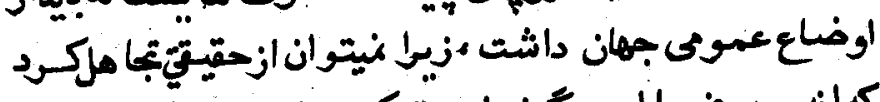

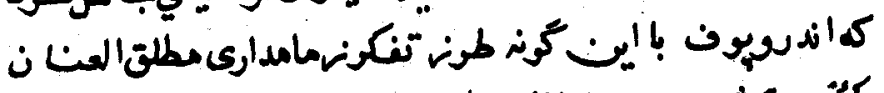

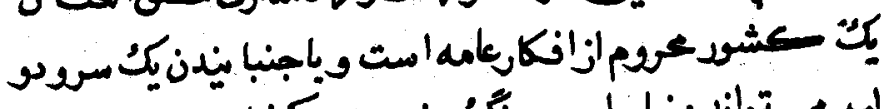

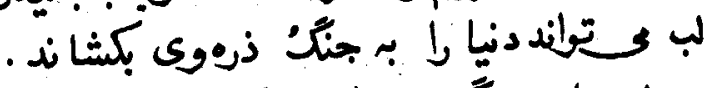

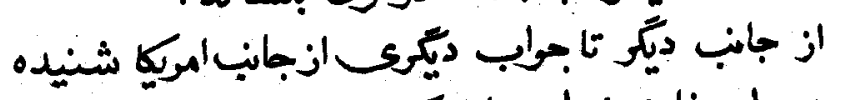

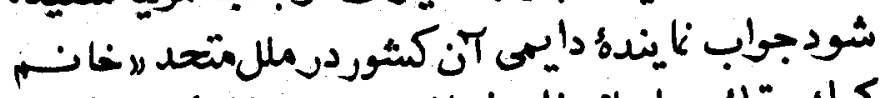

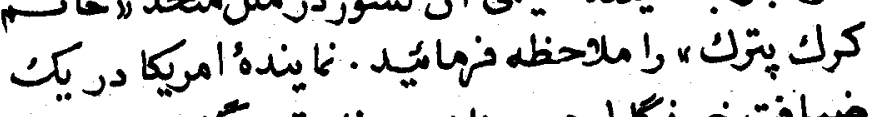

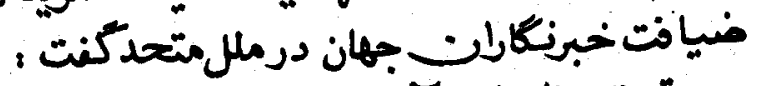

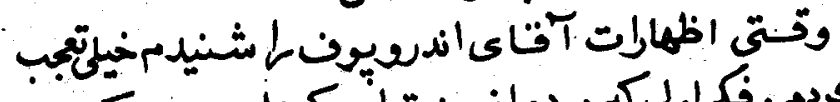

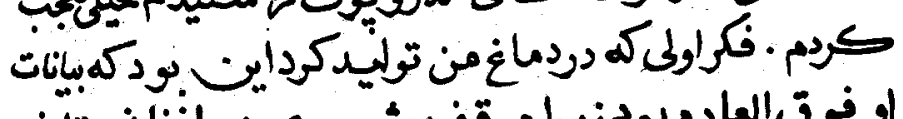

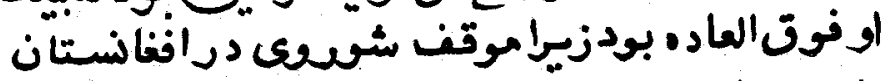

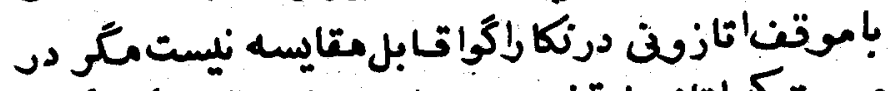

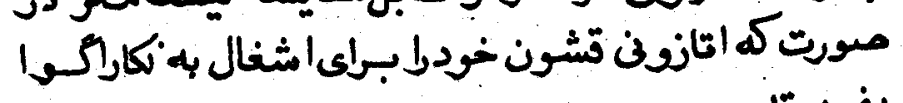
ن بفرستّا

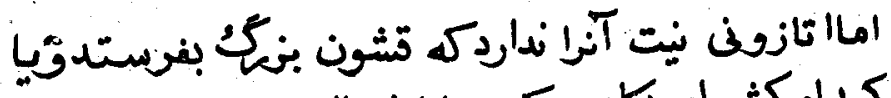

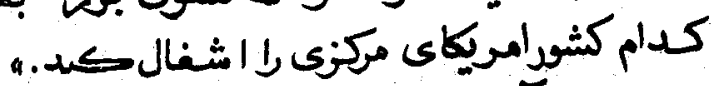

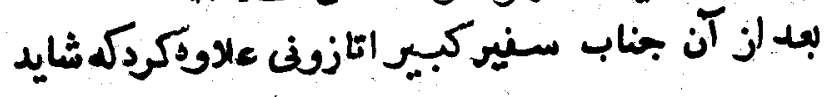




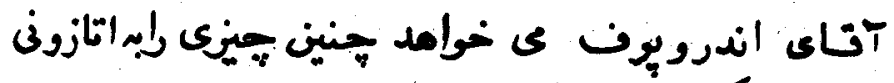

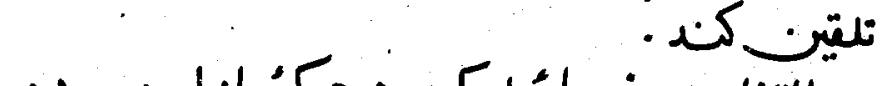

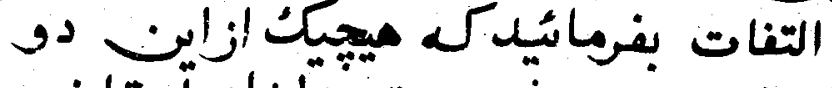

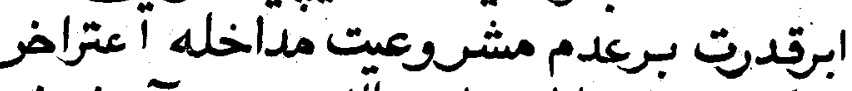

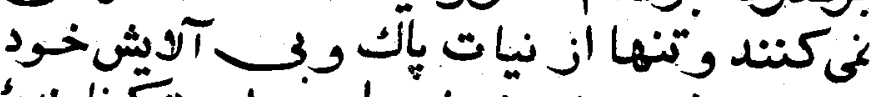

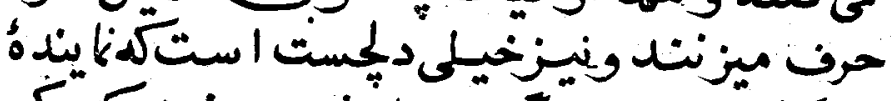

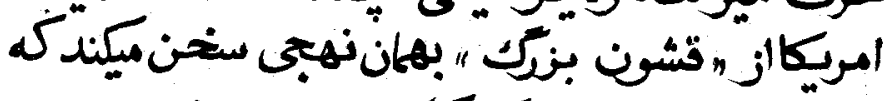

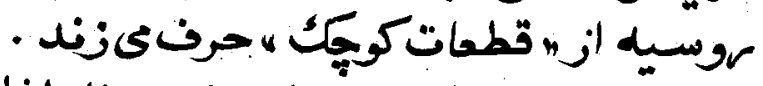

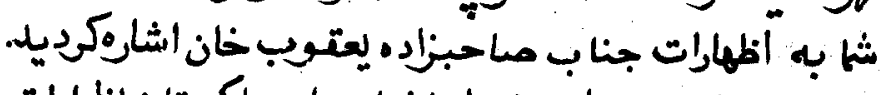

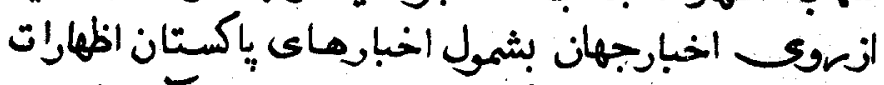

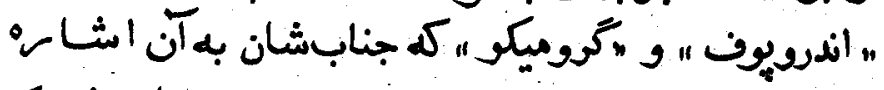

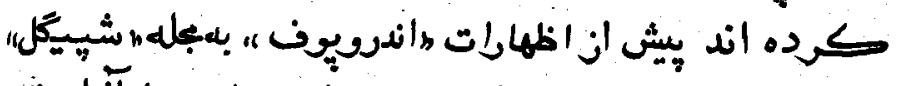

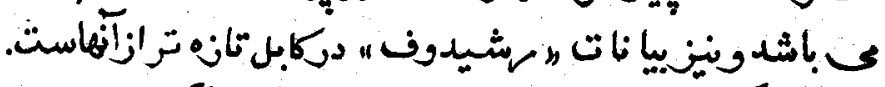

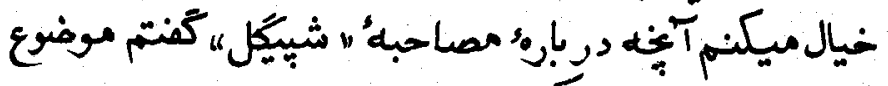

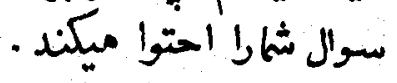

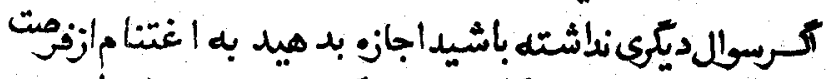

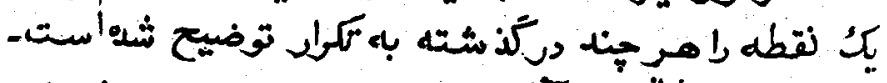

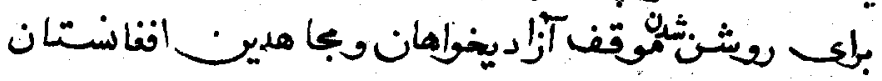

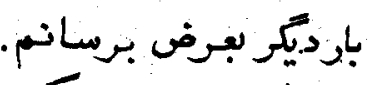

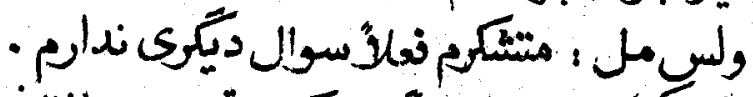

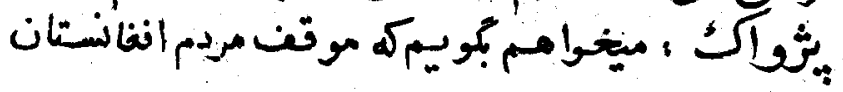


براساس متون ومورحيه" تصاويب بمامع بيت المللىبه

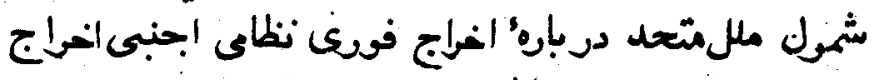

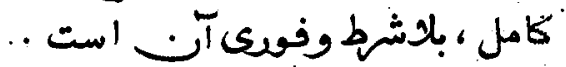

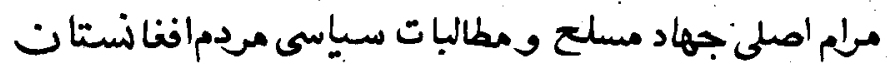

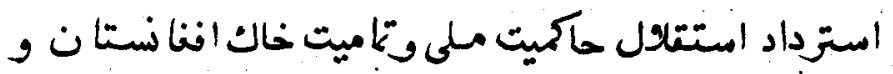

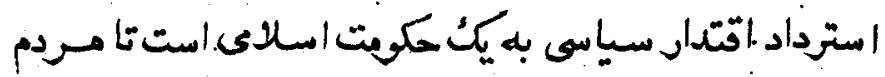

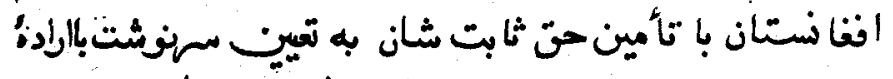

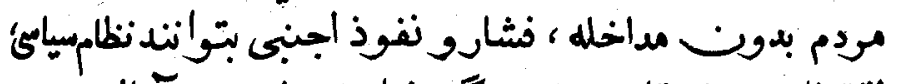

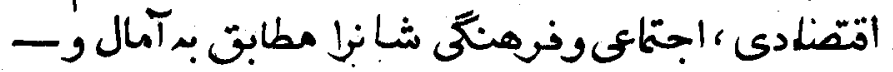

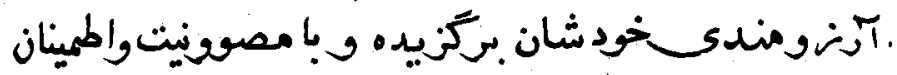

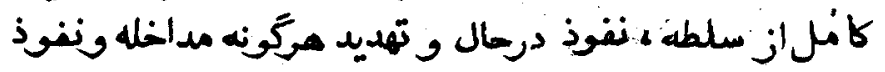

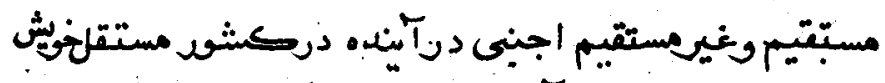

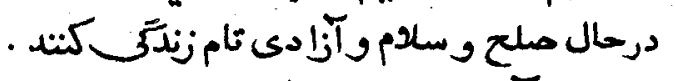

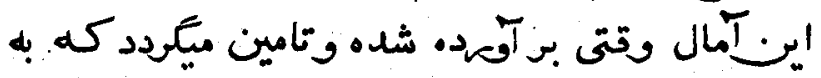

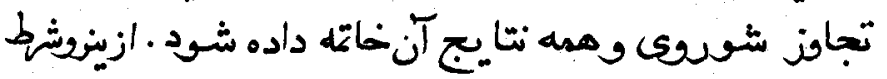

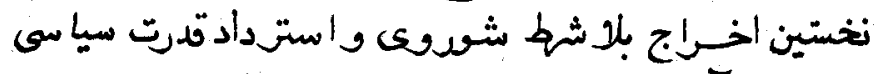

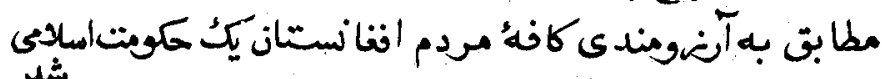

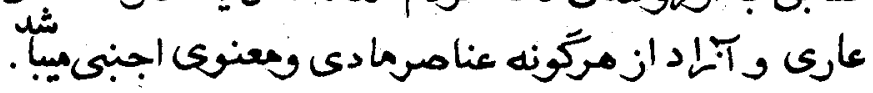

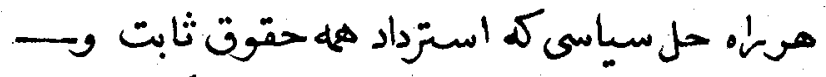

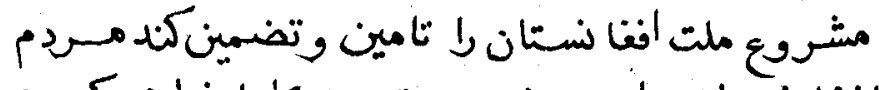

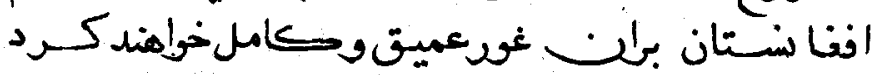




\section{qr}

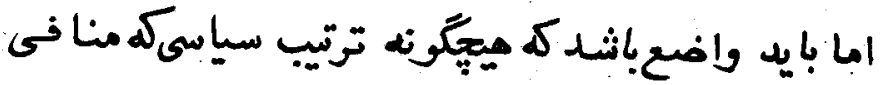

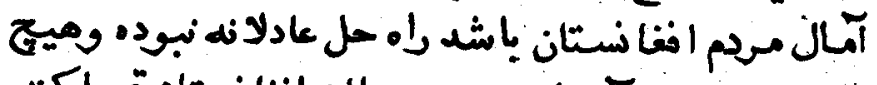

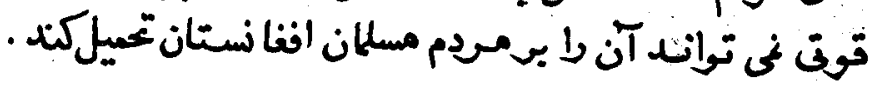

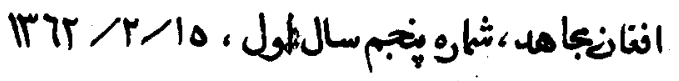




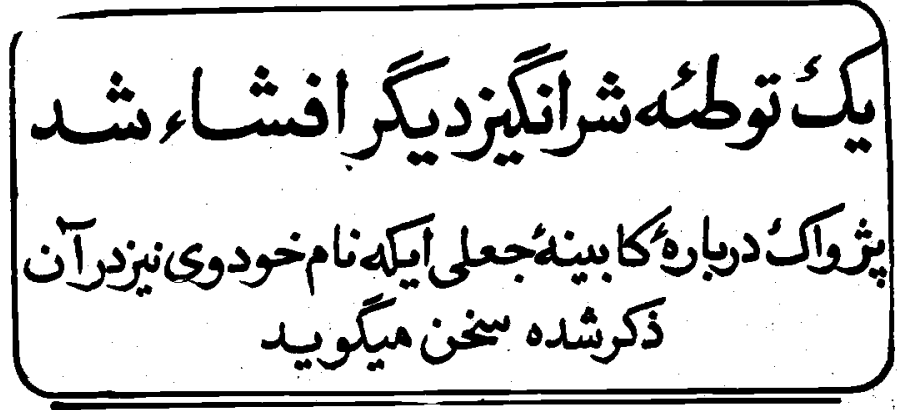

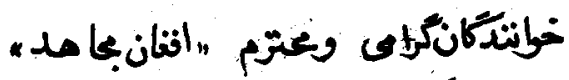

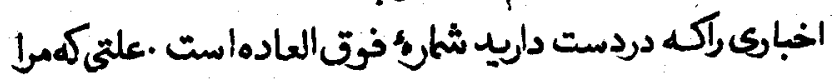

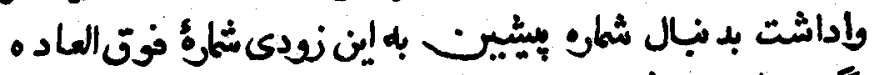

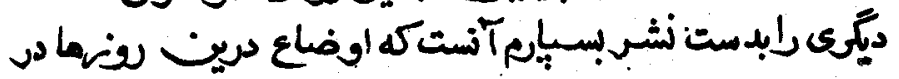

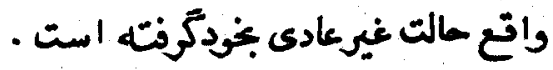

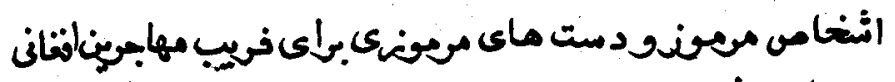

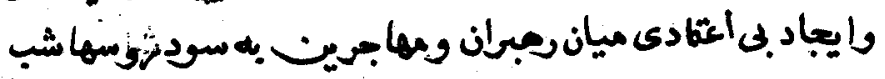

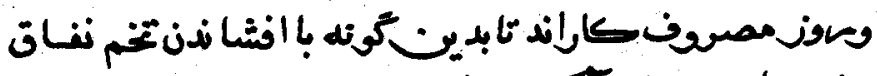

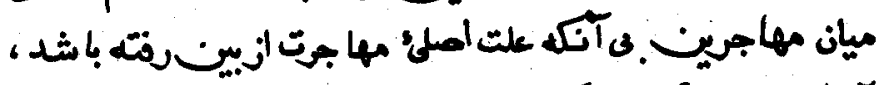

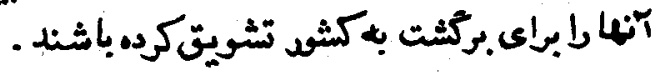




\section{2}

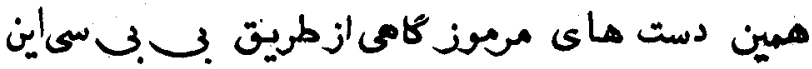

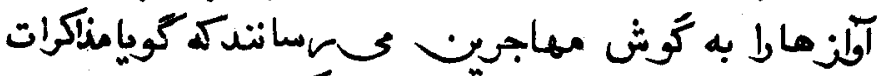

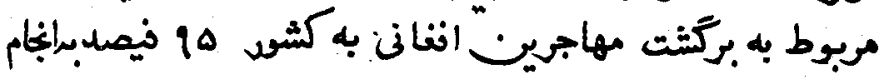

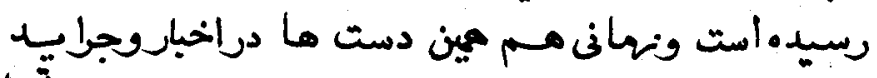

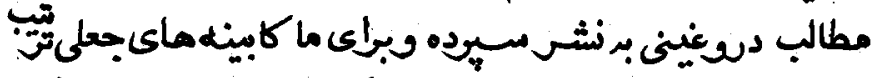

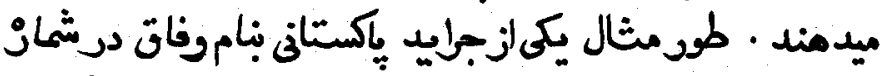

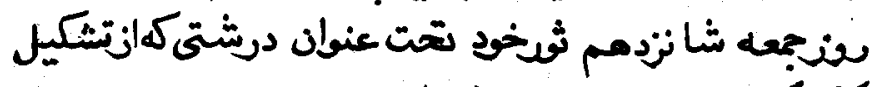

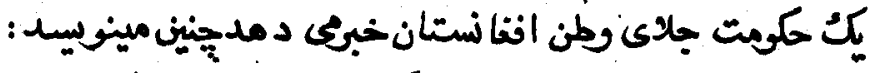

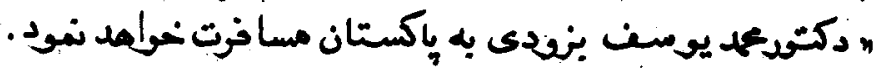

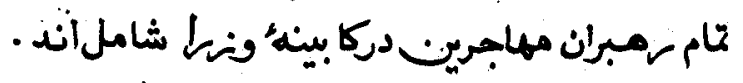

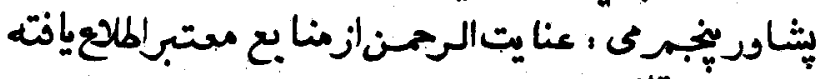

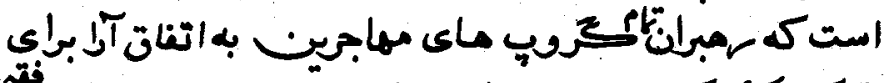

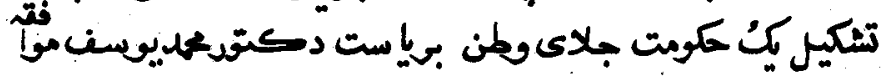

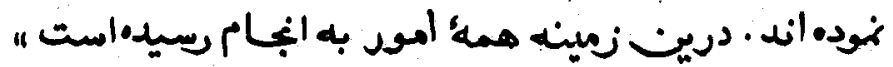

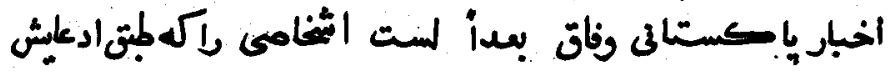

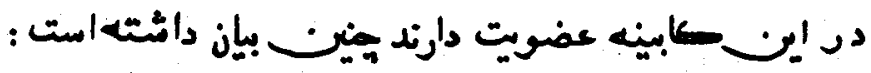

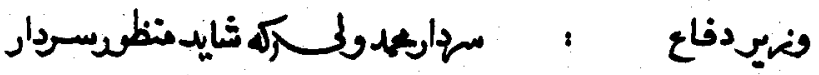

$$
\begin{aligned}
& \text { عبدالولى باشده }
\end{aligned}
$$

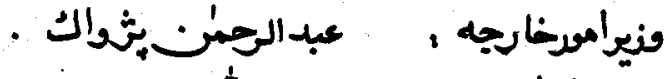

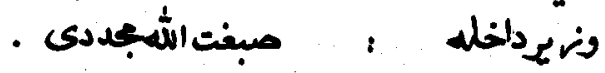

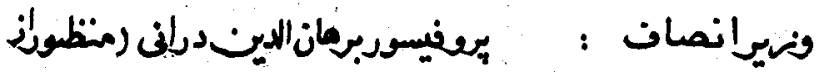


90

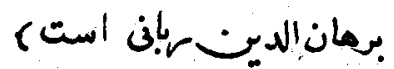

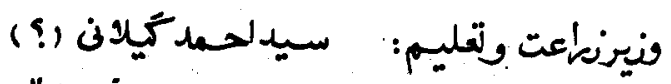

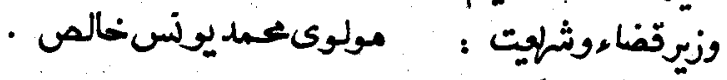

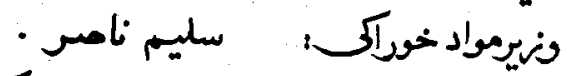

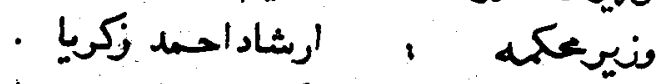

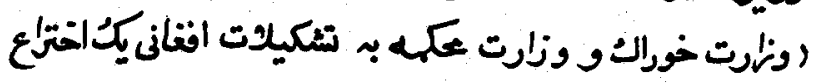

نوملمي ميشّود )

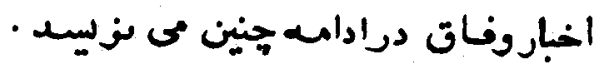

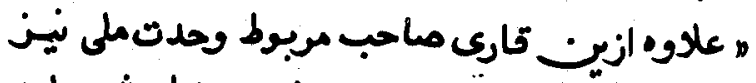

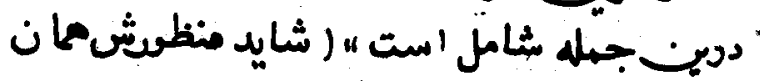

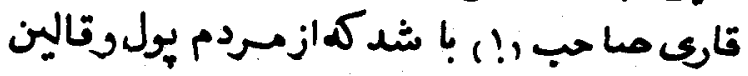

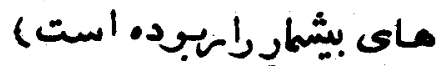

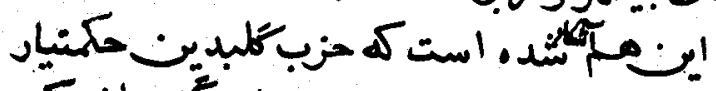

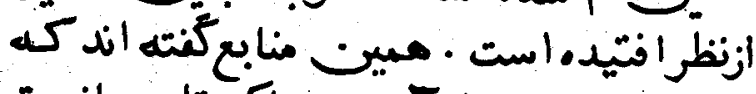

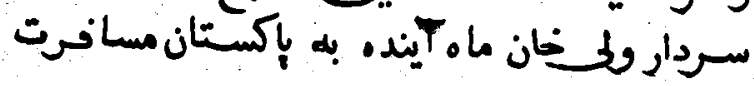

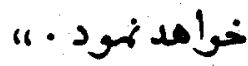

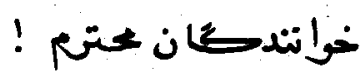

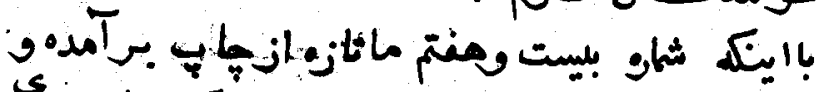

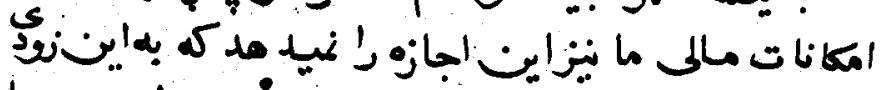

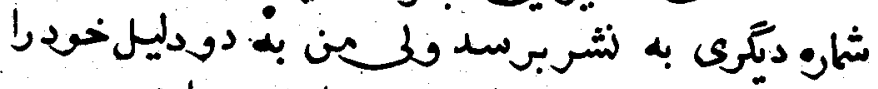

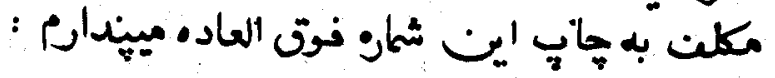




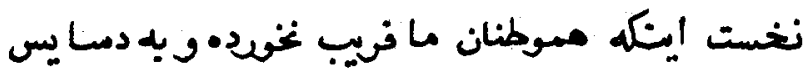

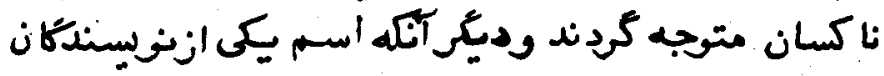

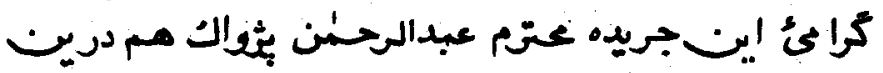

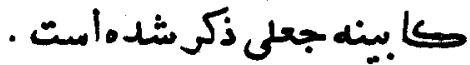

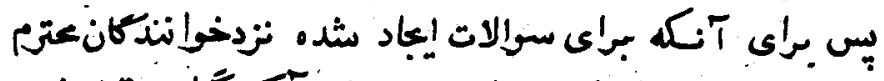

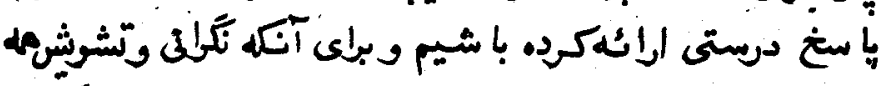

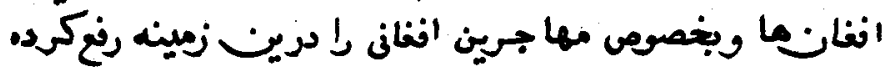

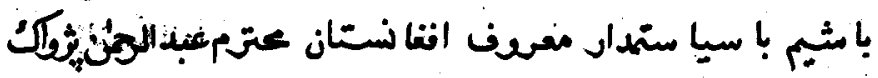

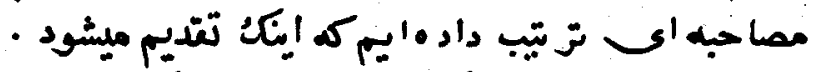

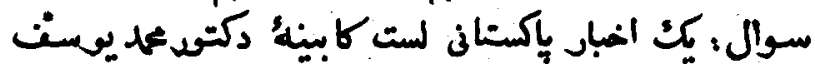

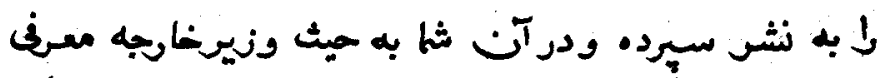

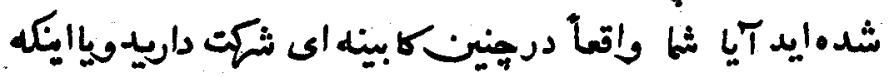

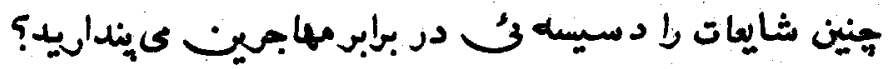

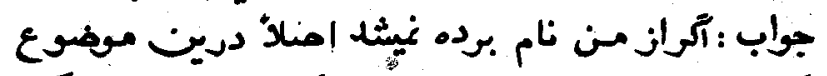

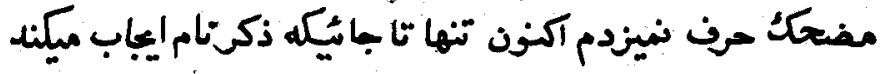

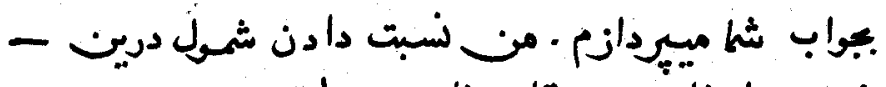

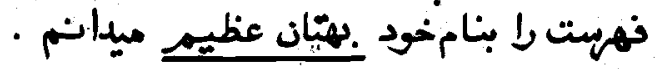

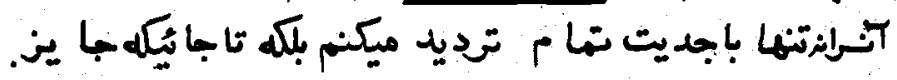

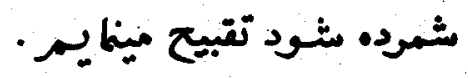

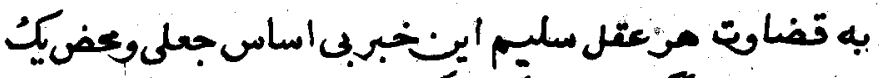

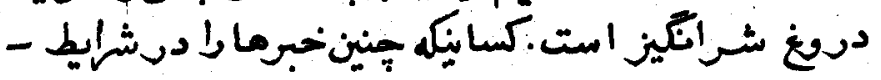




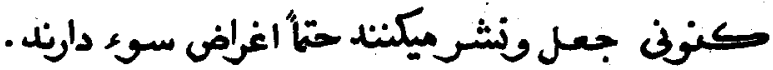

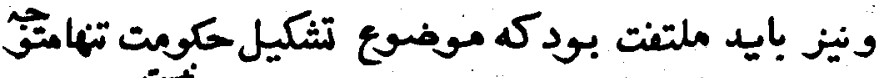

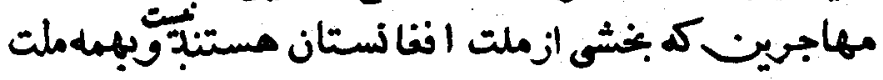

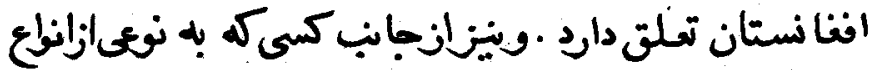

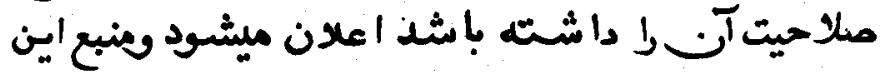

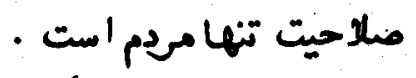

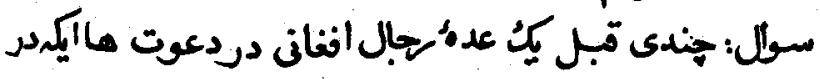

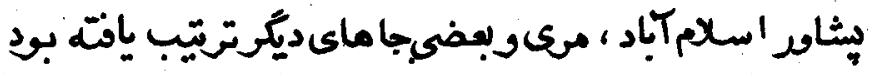

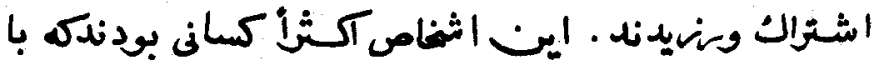

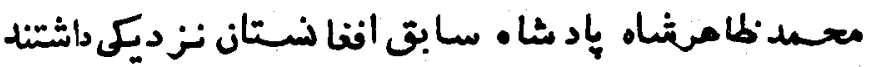

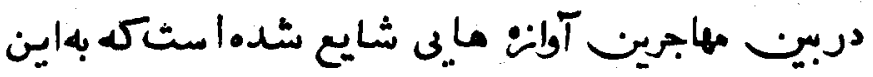

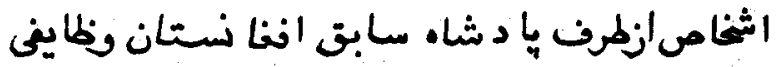

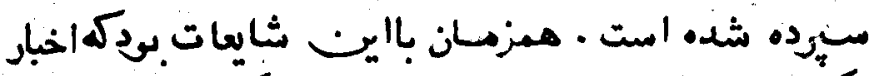

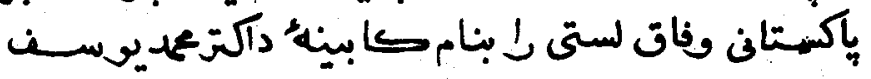

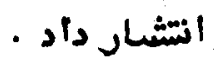

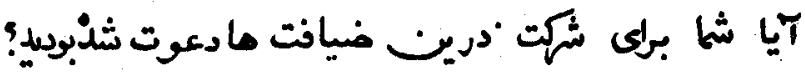

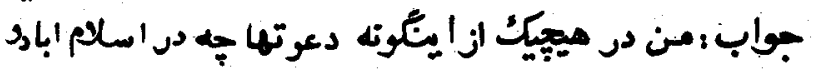

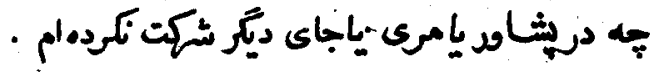

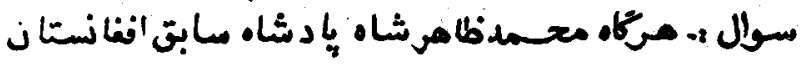

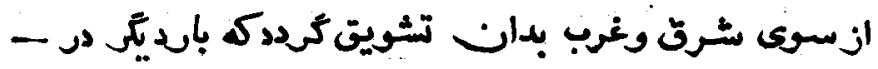

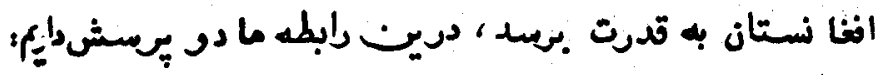


M

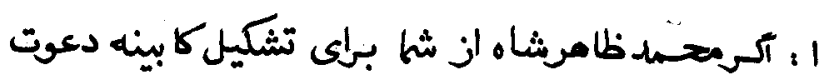

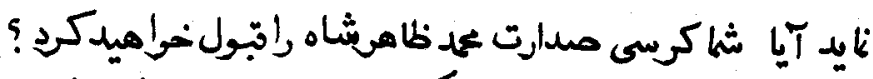

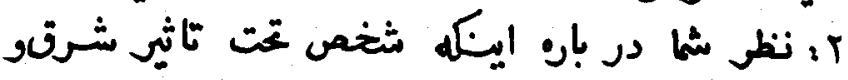

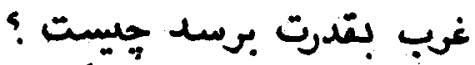

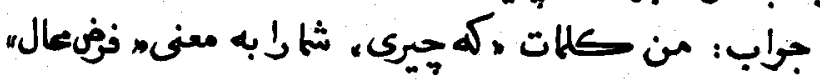

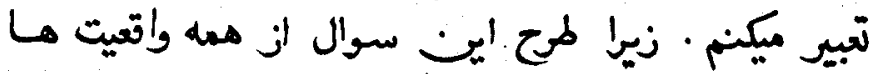

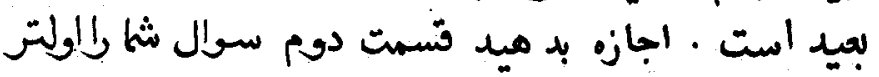

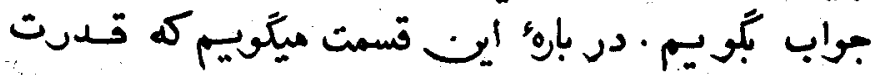

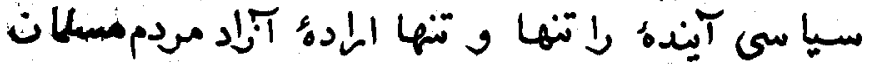

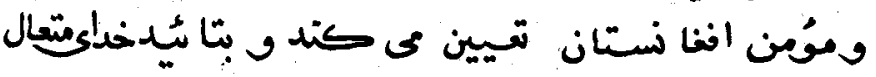

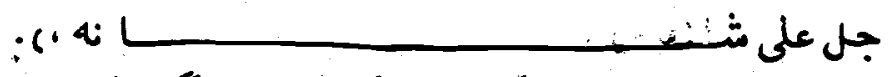

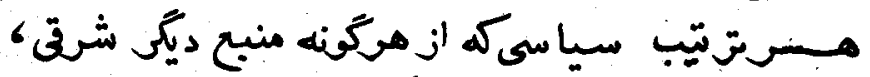

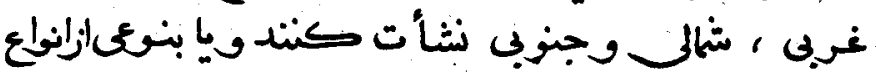

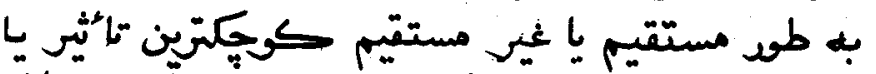

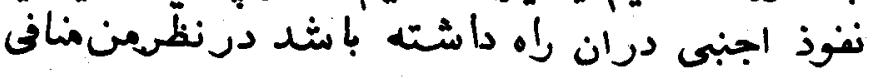

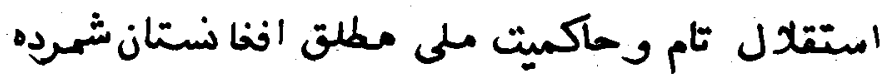

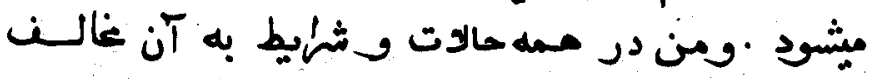

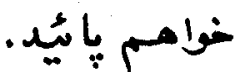

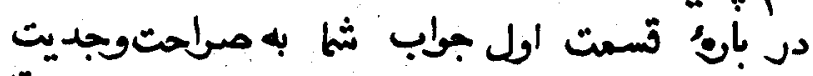

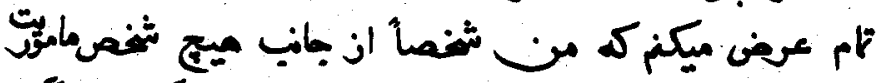

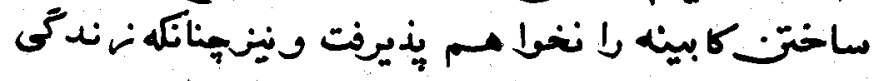




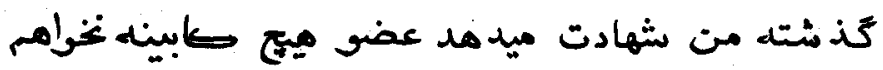

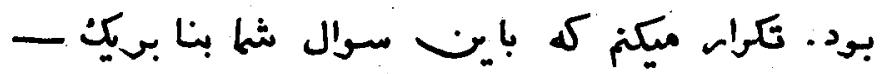

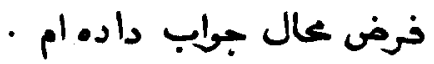

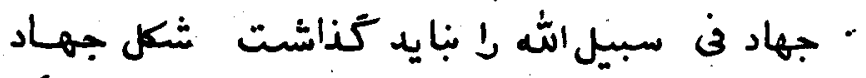

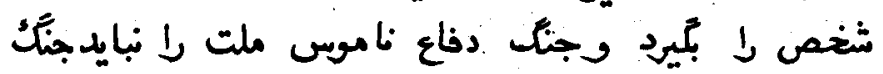

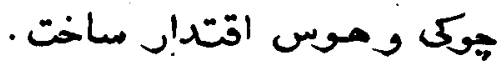

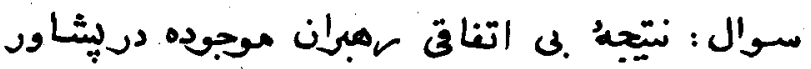

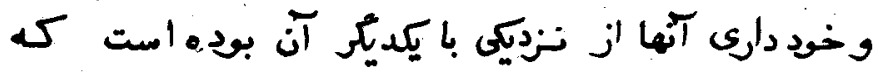

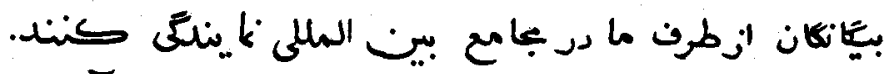

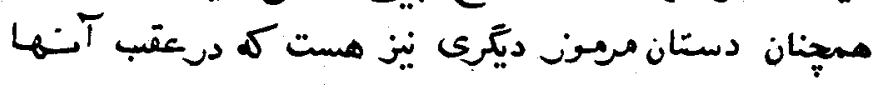

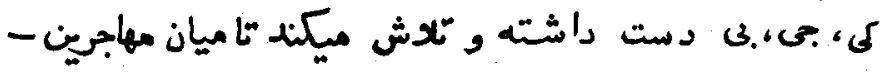

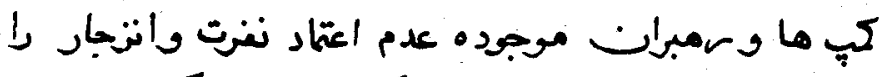

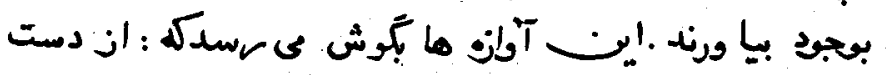

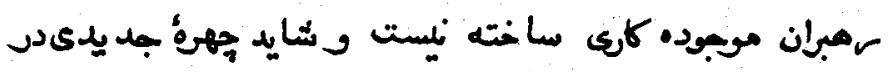

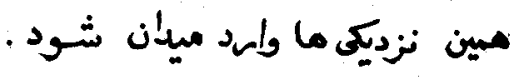

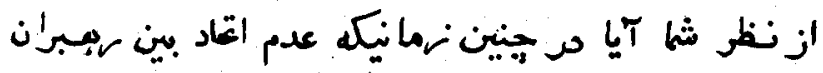

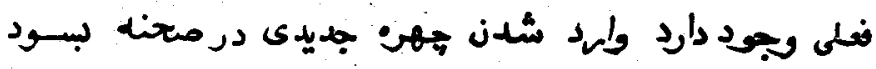

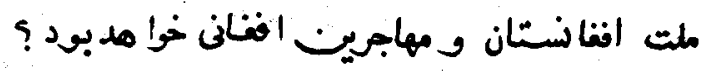

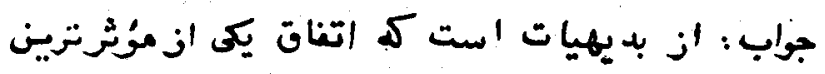

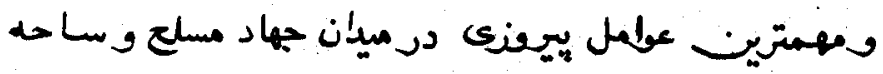

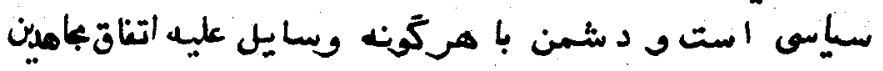

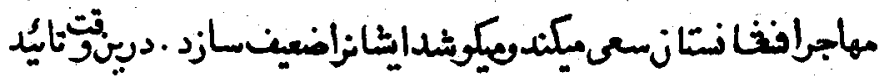




\section{$1 .$.}

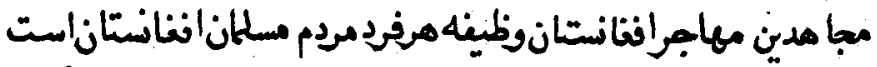

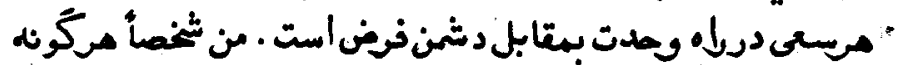

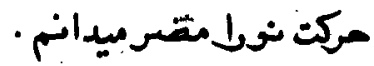

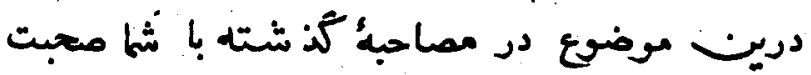
كرده ام

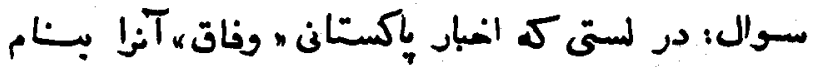

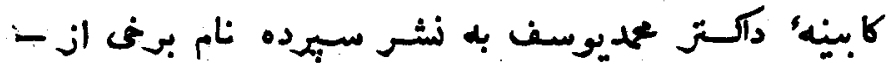

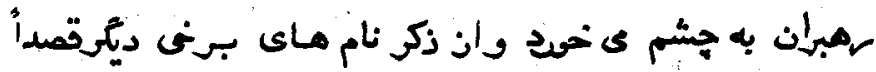

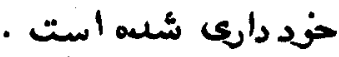

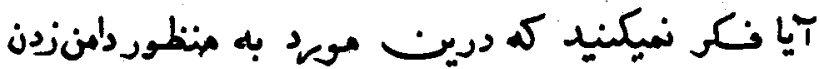

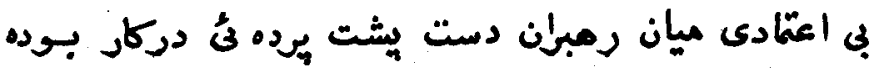
باشد ب

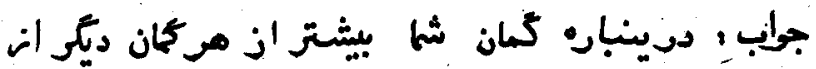

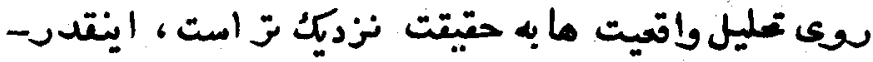

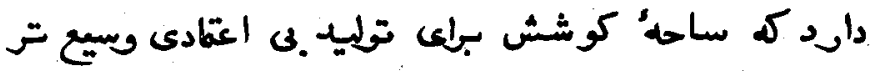

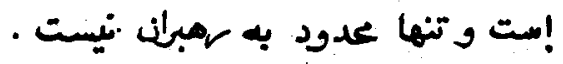

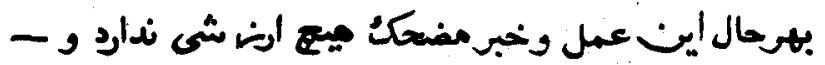

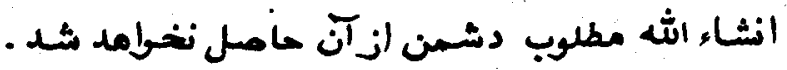

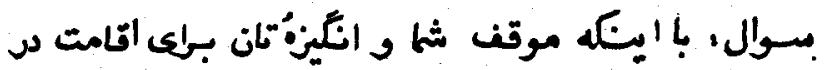

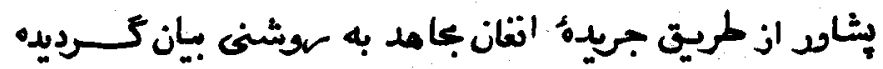

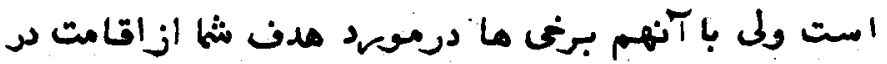




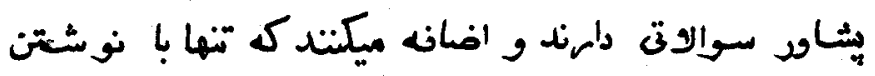

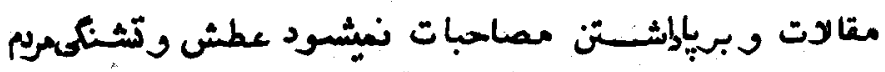

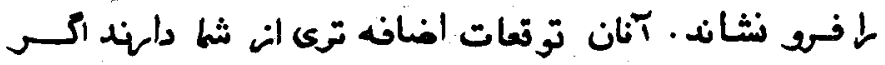

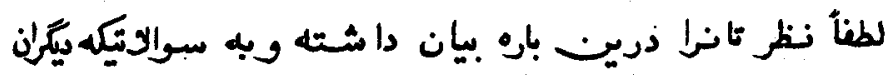

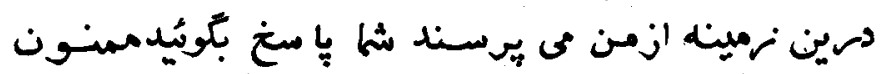

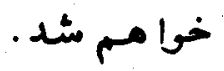

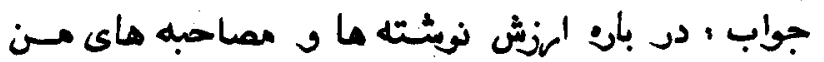
نظرشان مانب است من دعىى تكرده و نميكنم كم بتوانت

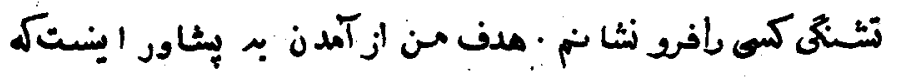

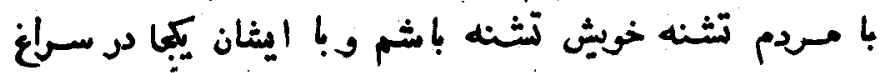

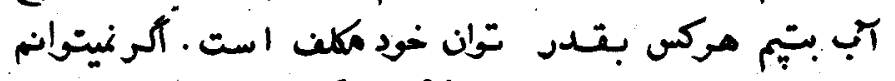

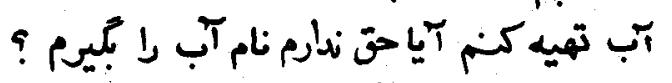

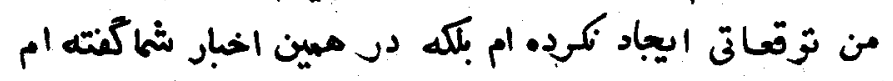

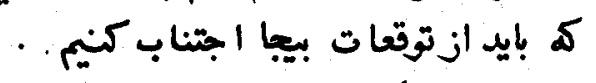

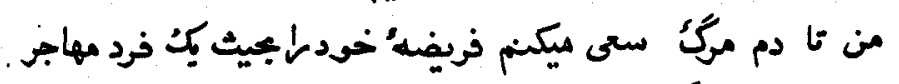

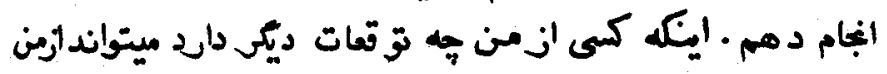

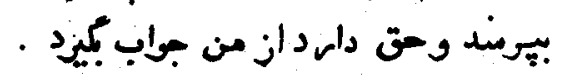

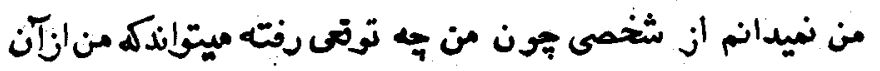

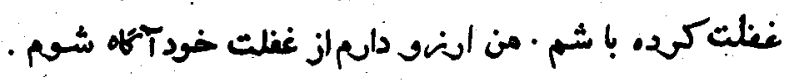
i

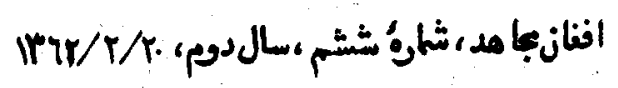


مردمافنانسان بايد بانهي نخونيد
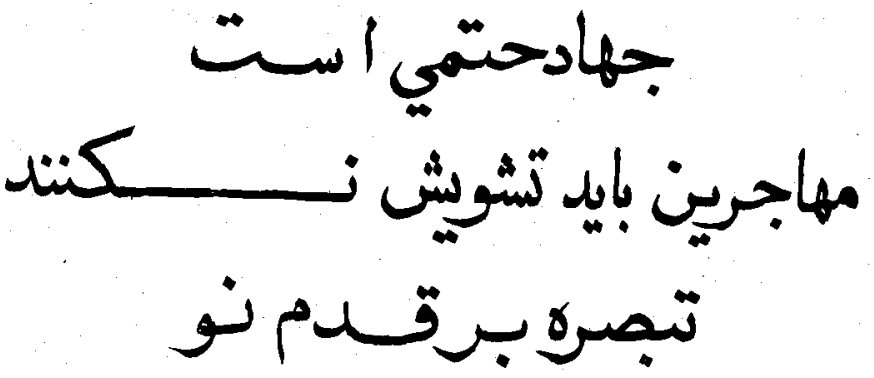

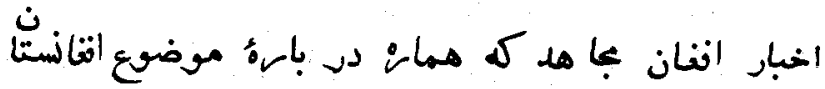

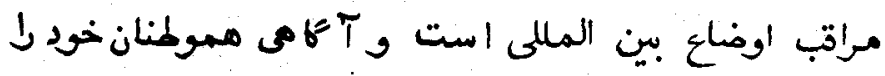

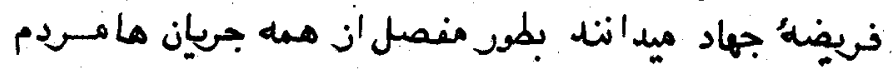

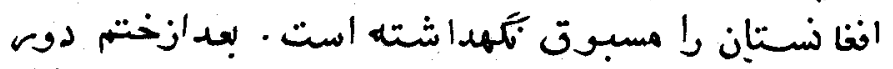
دوم مباختات ورحبت ماى ثزنو كم هيجكونه نيصله اي درآن

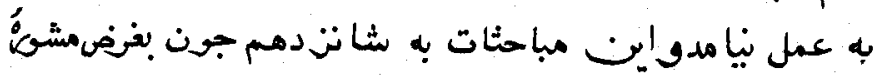

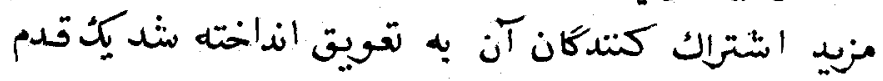


مهم جديد از طرت حكومت باكستان برداشته شـند

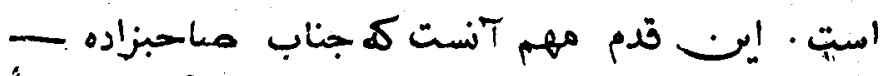

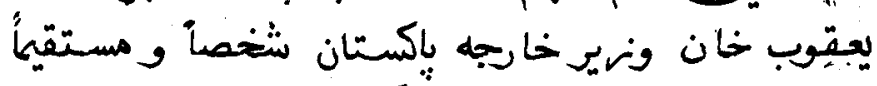

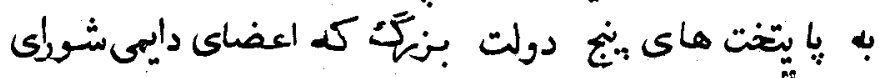

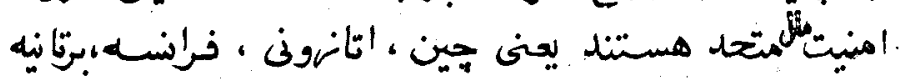

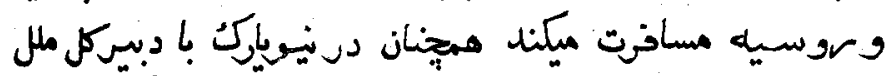

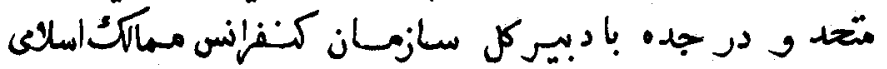

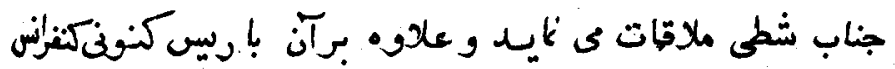

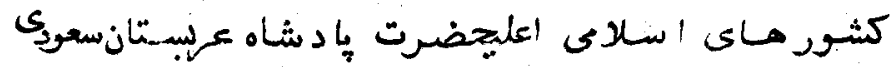

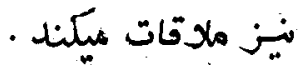

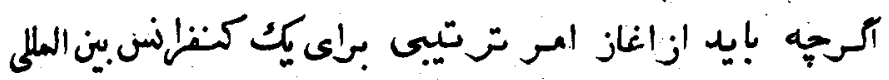

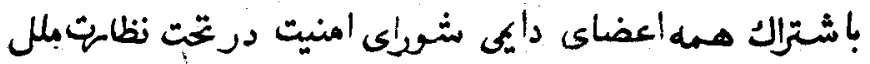

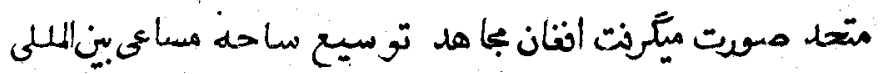

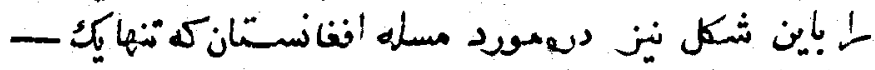

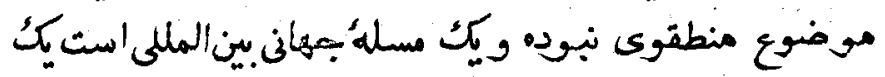

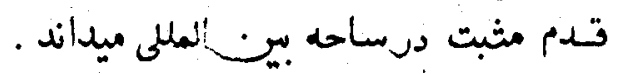

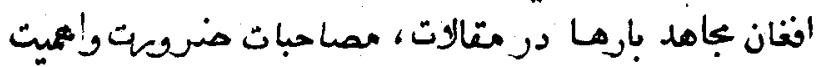

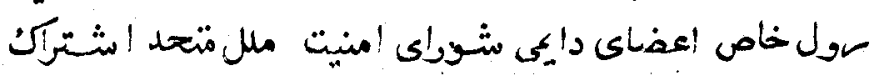

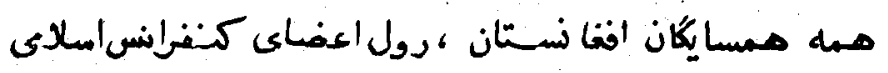

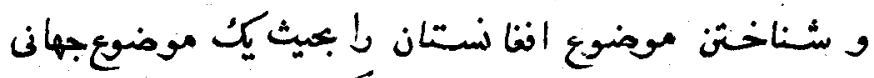

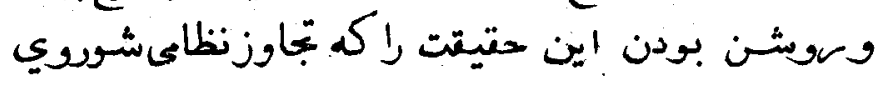




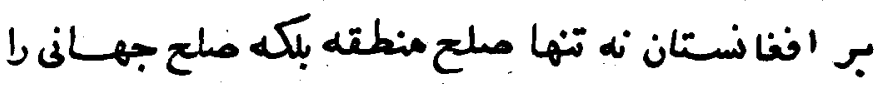

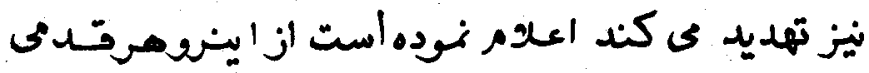

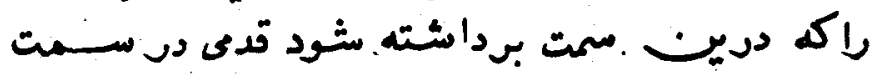

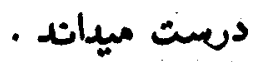

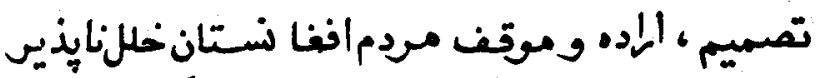

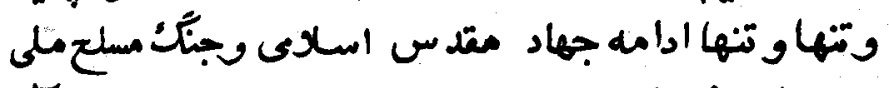

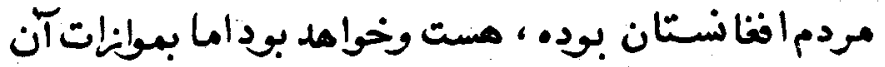

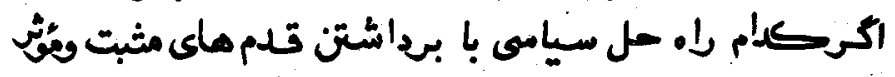

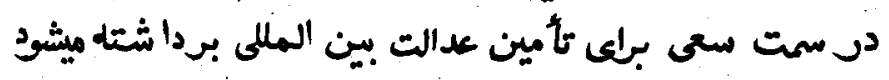

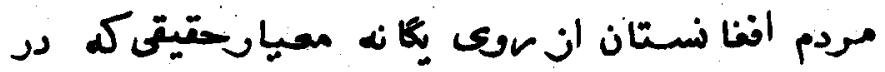

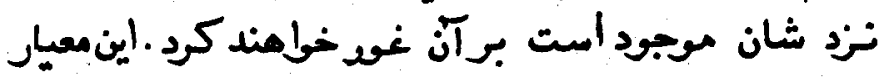

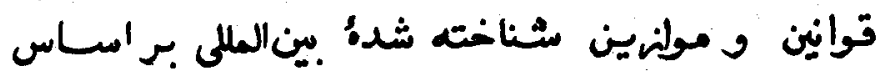

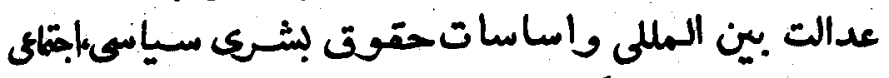

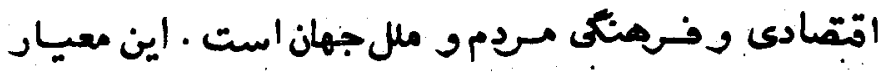

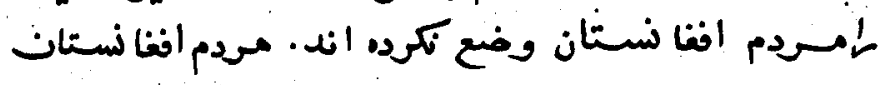

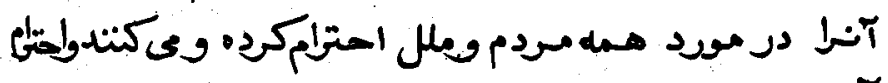

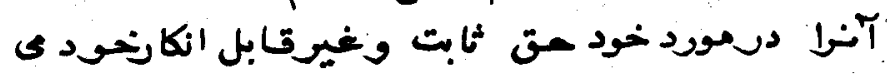
دانتد .

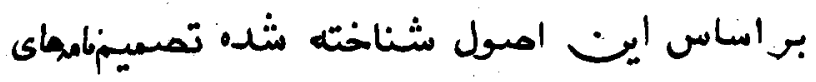

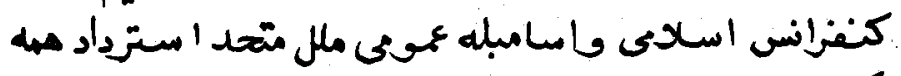

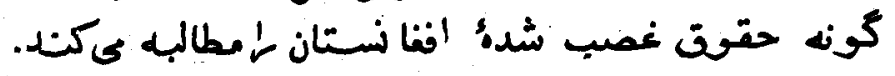




\section{0}

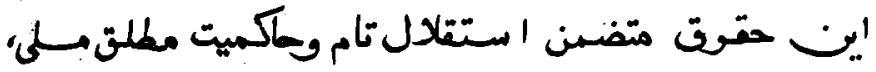

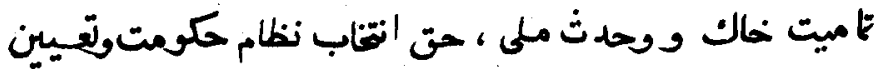

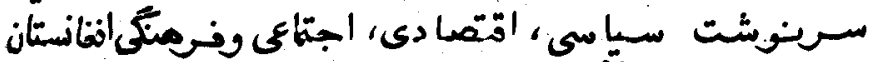

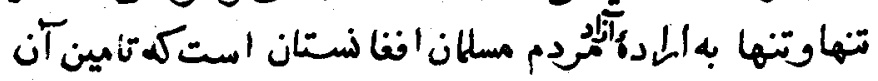

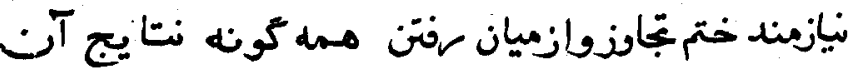

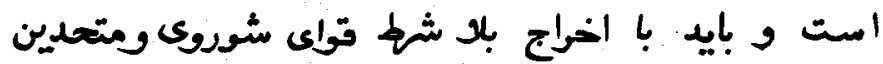

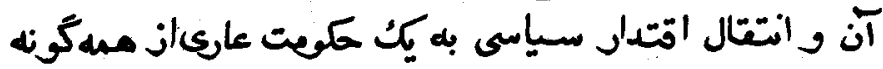

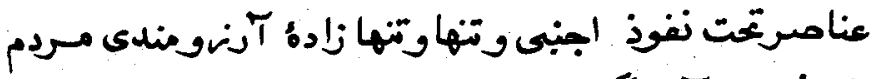

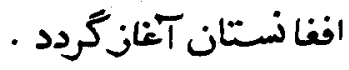

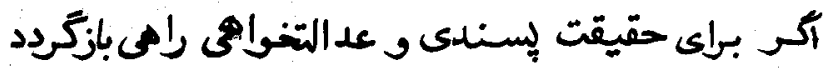

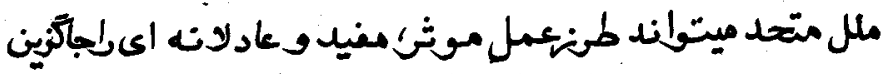

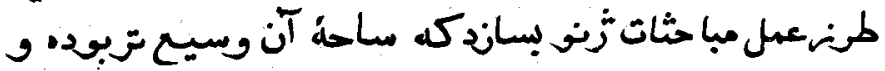

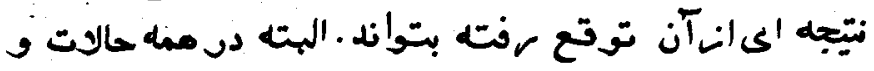

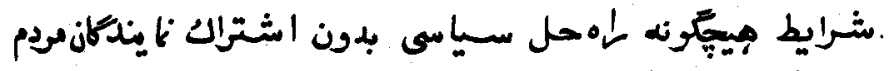

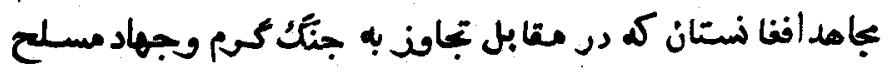

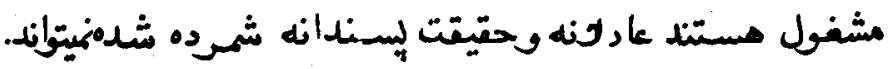

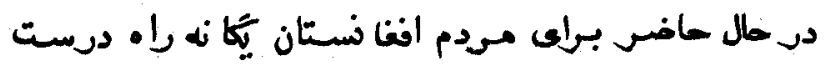

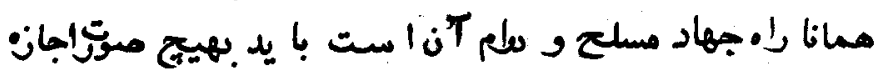

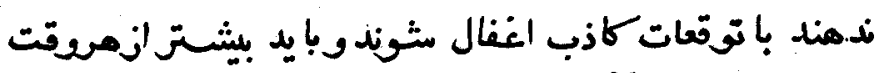

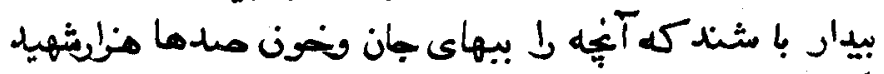

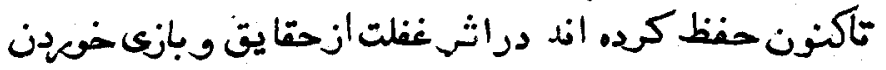




$$
1.7
$$

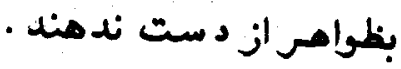

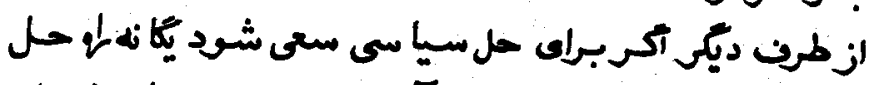

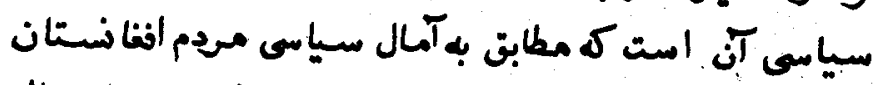

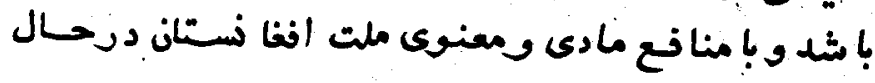

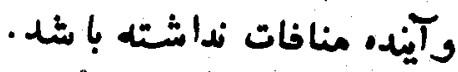

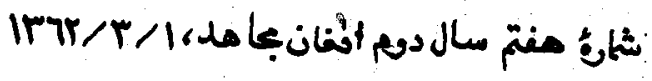

acedore 


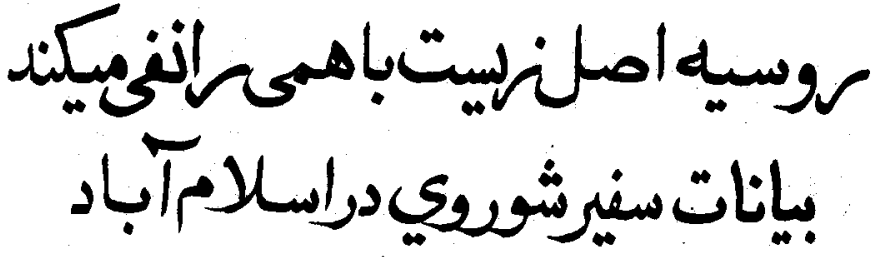

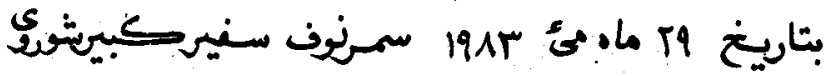

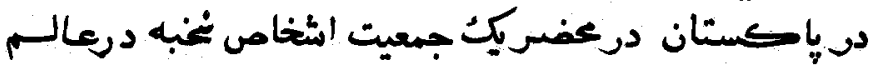

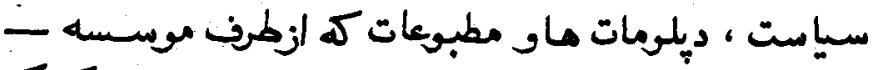

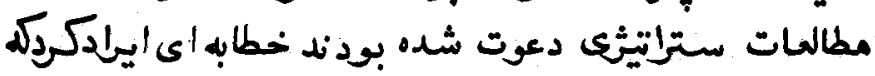

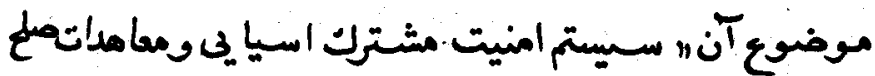

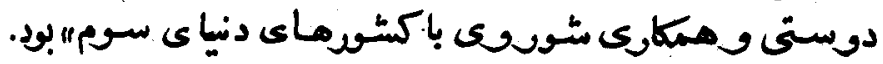

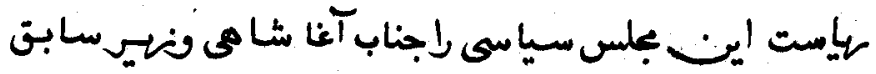

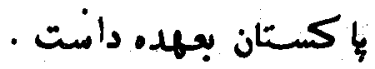

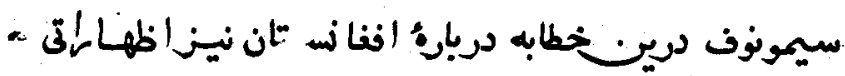

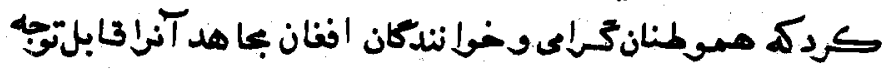
خوا هند يانت . 


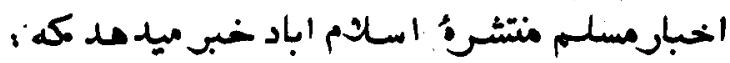

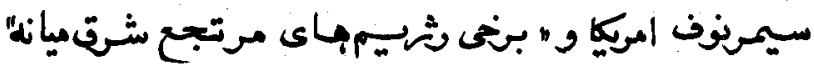

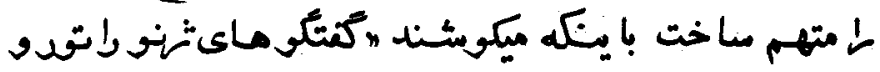

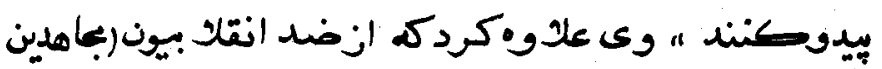

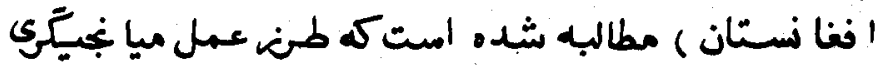

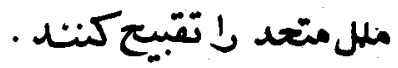

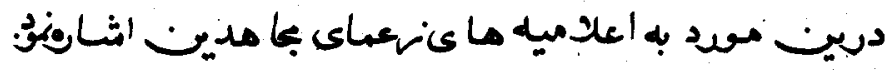

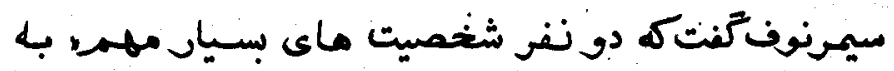

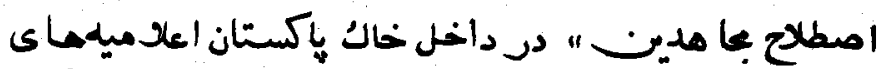

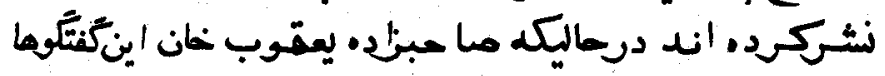

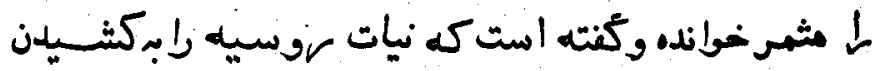

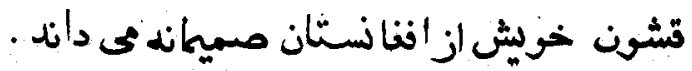

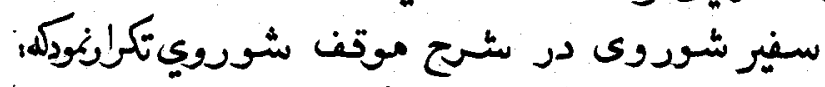

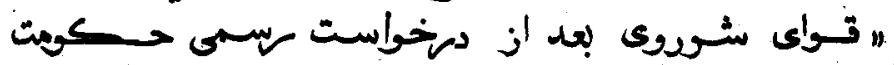

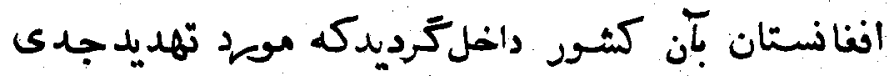

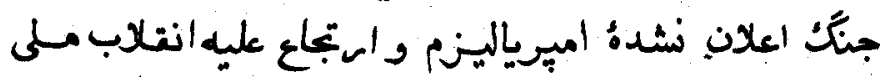

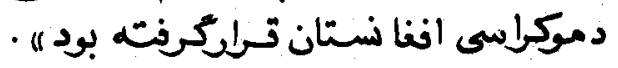

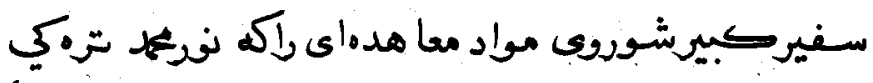

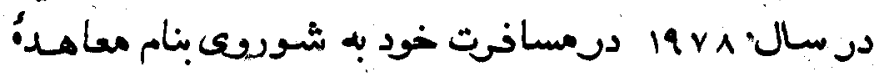
ملح و دوستي وممكاري با مشوروى امضا كرده بودبتائل ادعاى خوشئ فرائت نهيد . 


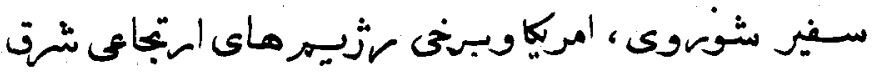

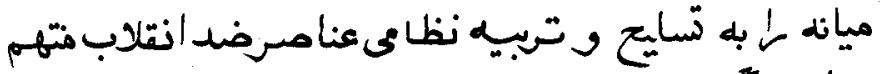

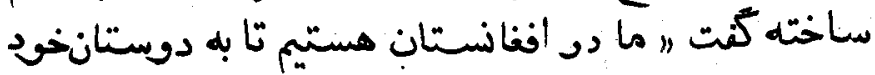

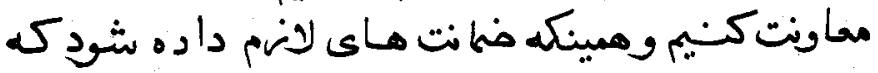

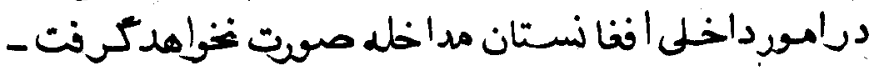

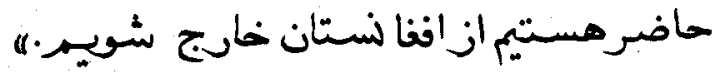

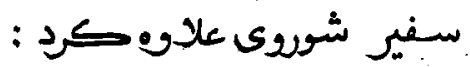

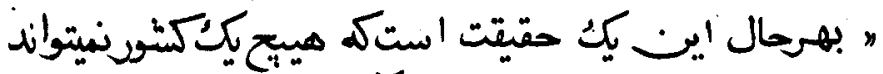

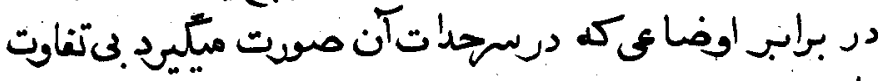

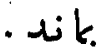

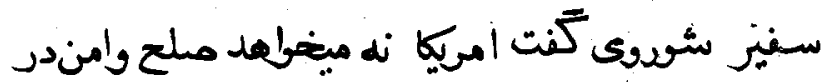

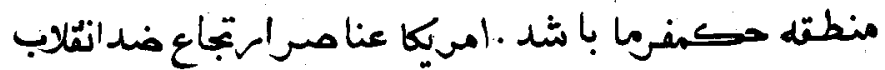

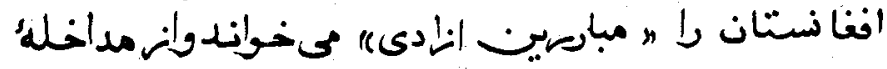

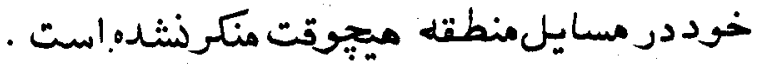

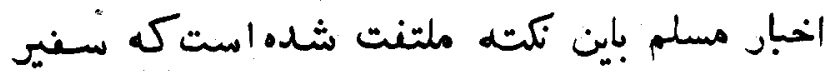

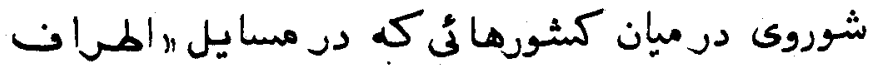

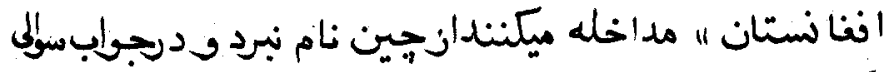

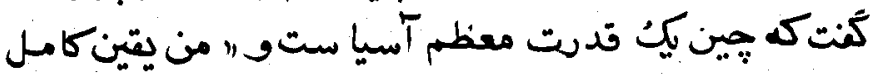

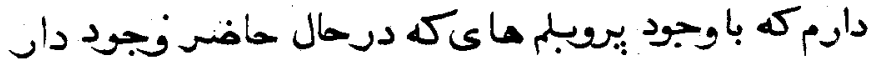

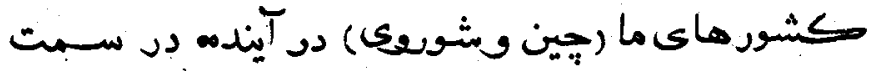

$$
\text { "احدى سيرخواهندكرد - " }
$$




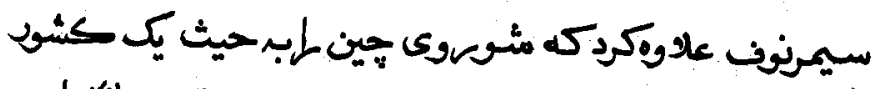

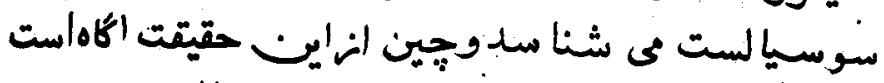

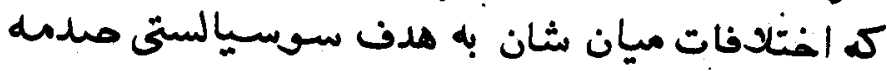

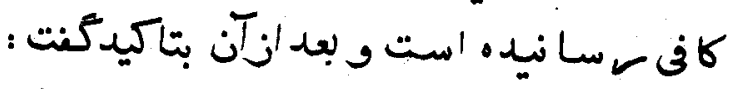

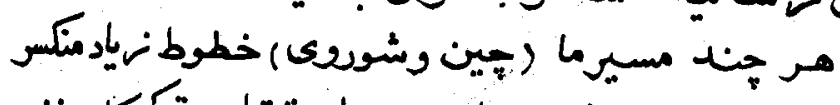

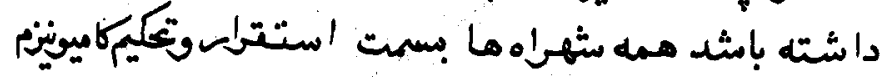

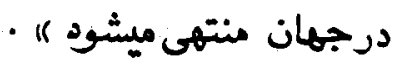

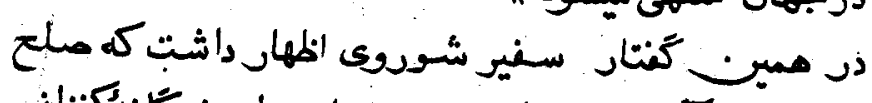

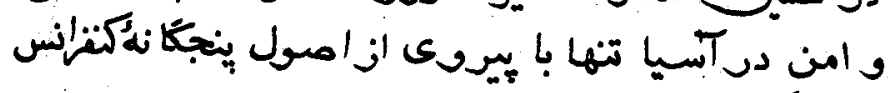

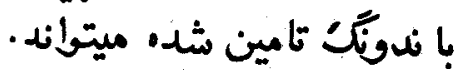

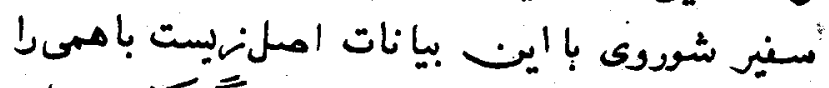

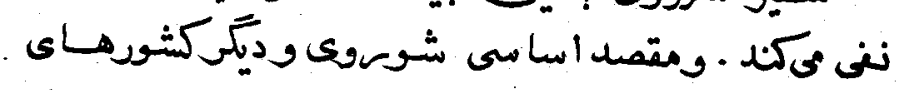

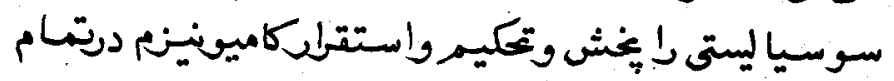

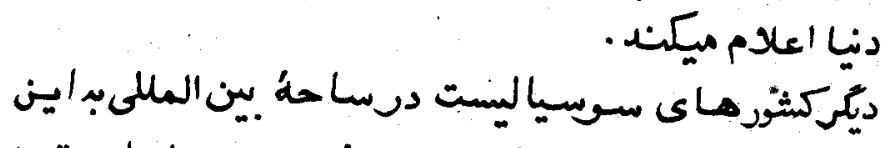

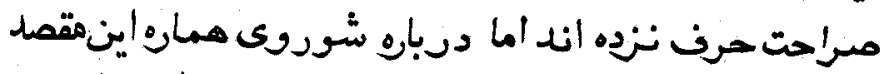

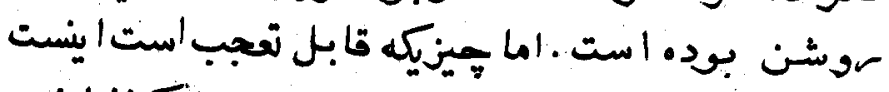

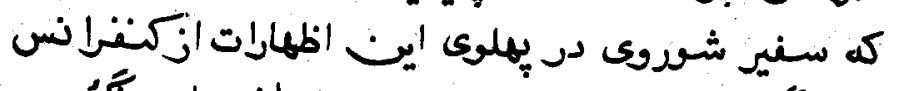

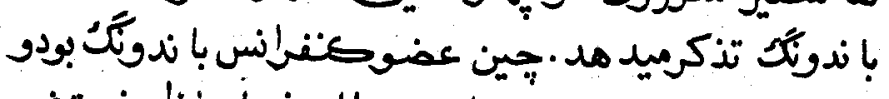

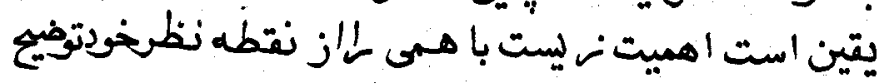
خوامدكرد . 


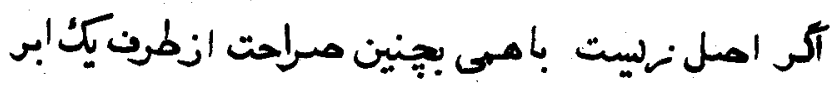

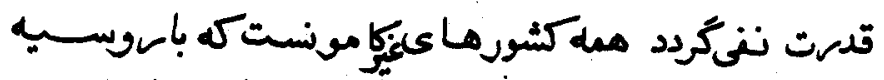

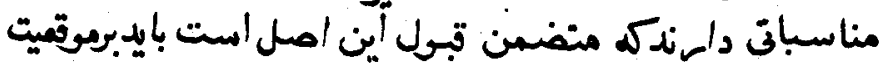

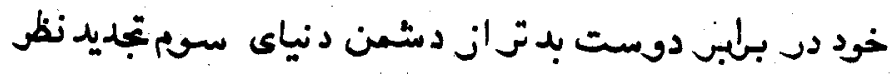
كتند .

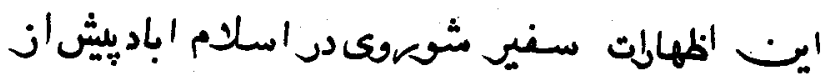

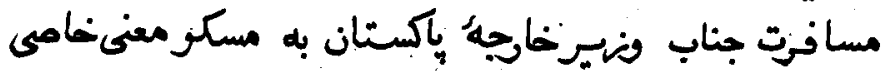

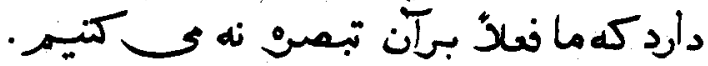

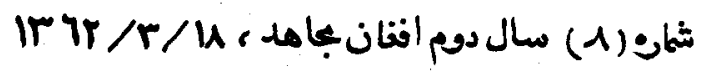


يهافتانسان بانديتباوزيوه سينهائه

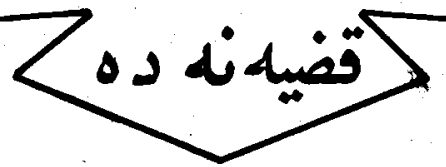

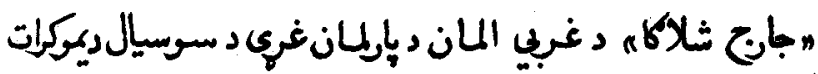

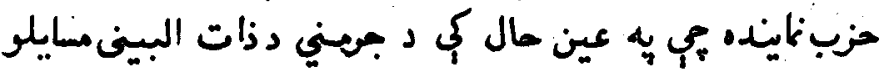

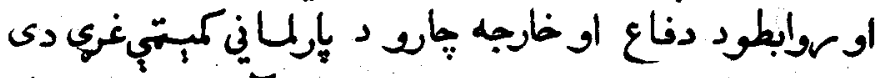

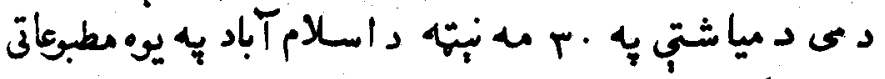

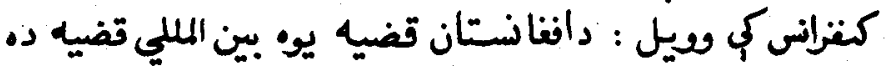

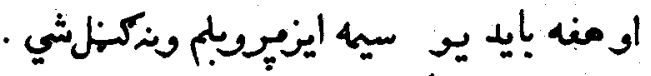

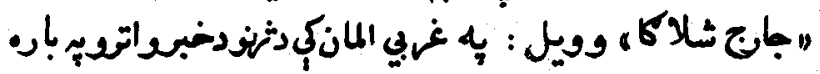

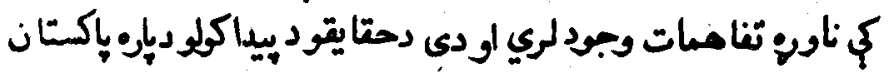

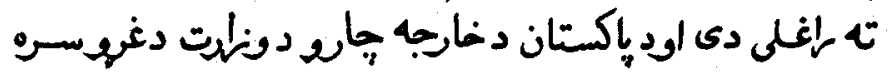

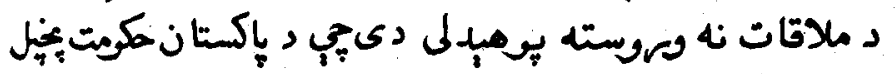




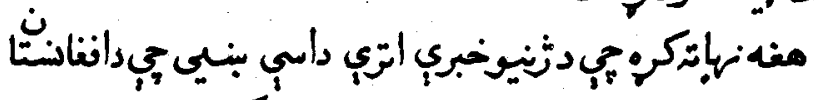
موقف تينك ولاردى .

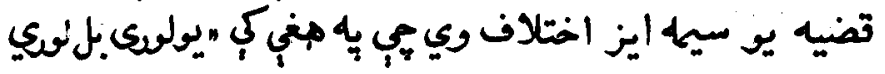

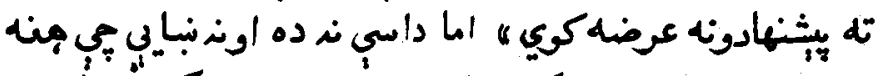

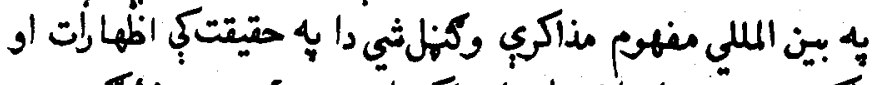

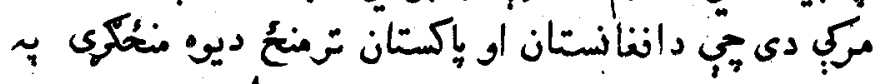

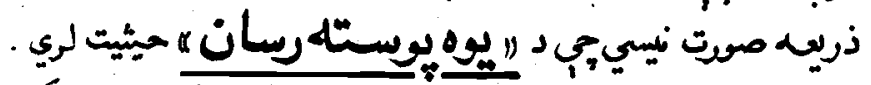

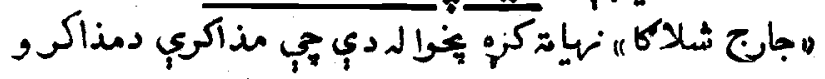

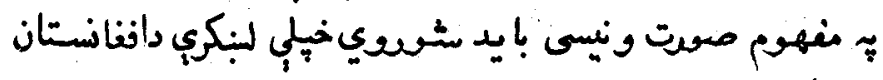

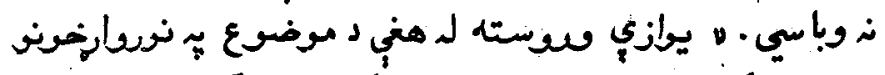

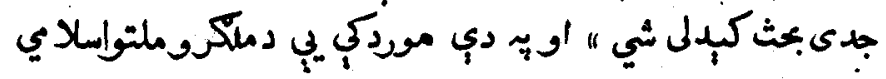

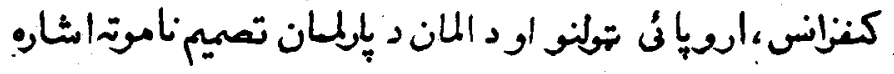

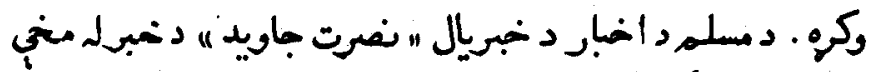

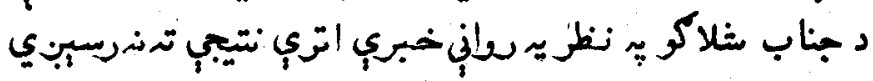

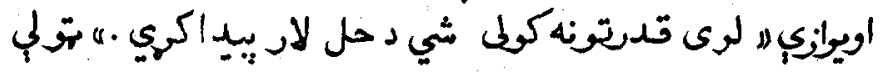

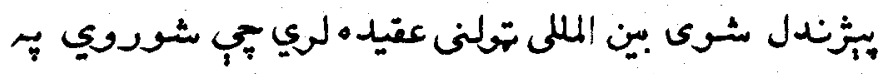

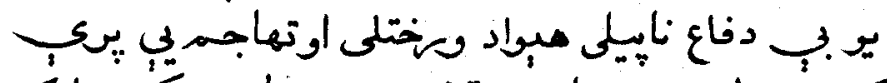

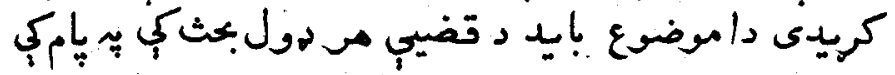

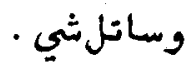

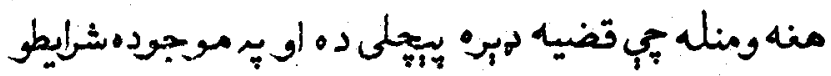

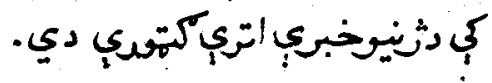




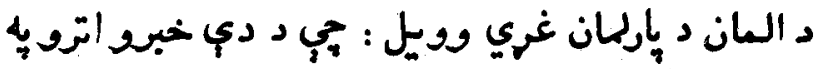

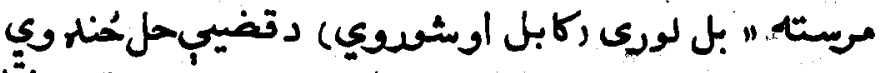

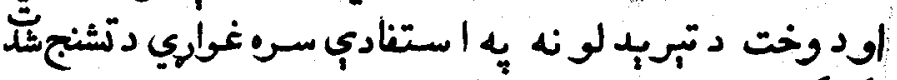

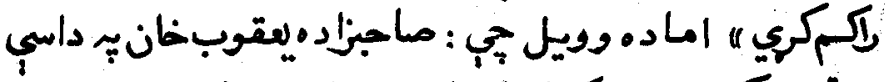

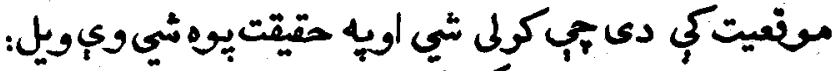

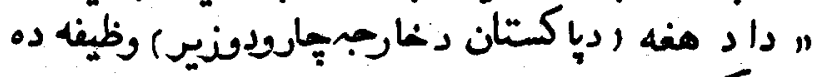

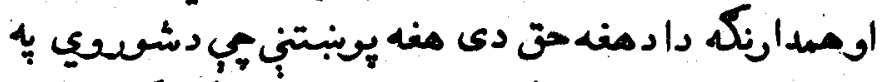

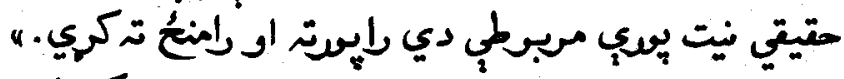

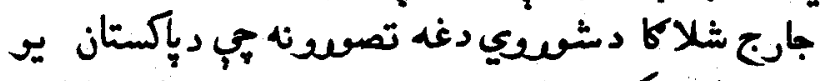

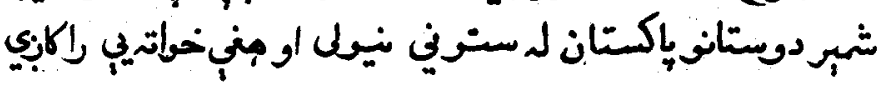

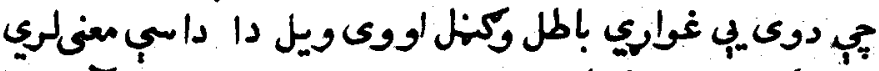

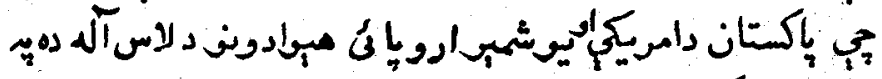

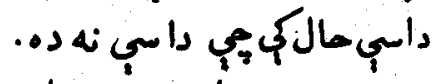

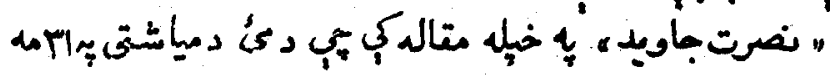

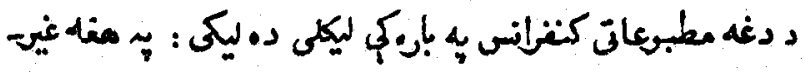

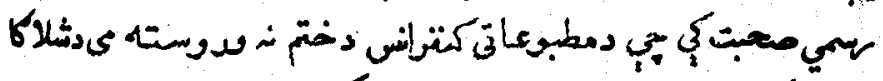

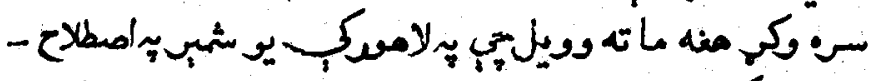

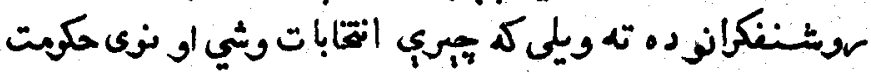

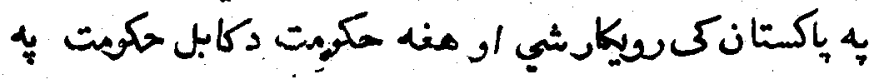

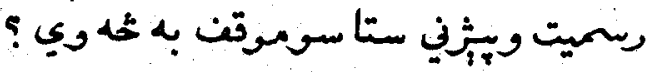

$$
\begin{aligned}
& \text { شلاكاوريل : }
\end{aligned}
$$




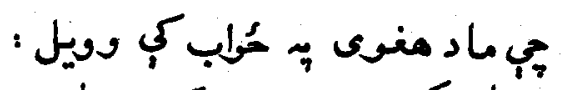

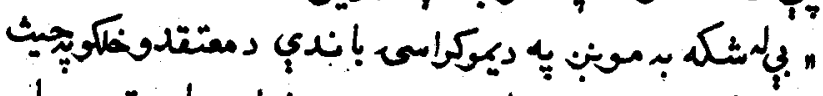

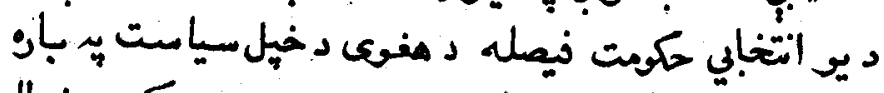

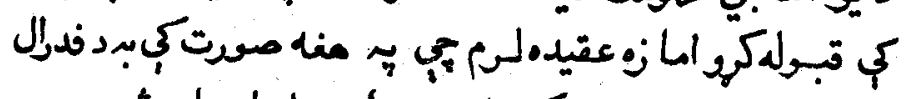

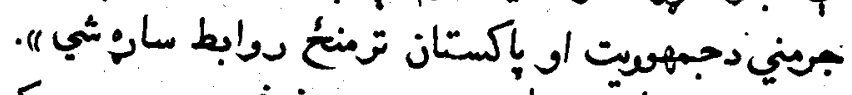

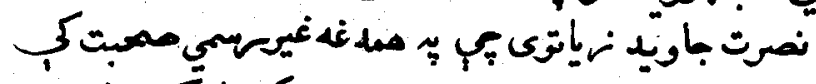

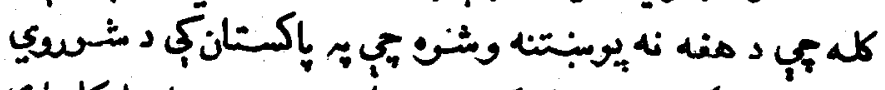

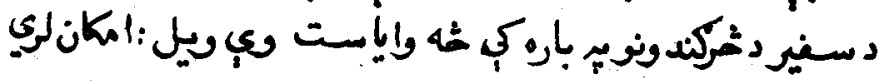

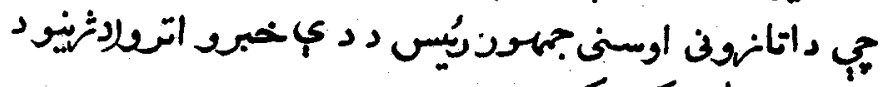

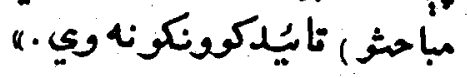

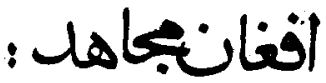

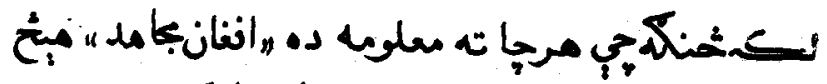

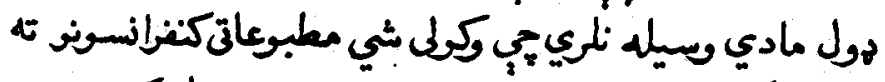

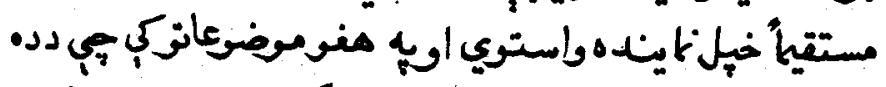

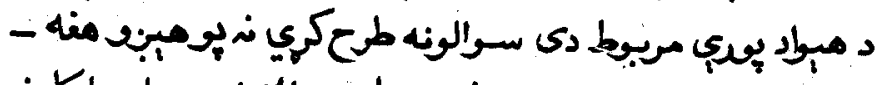

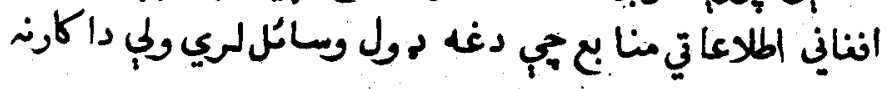

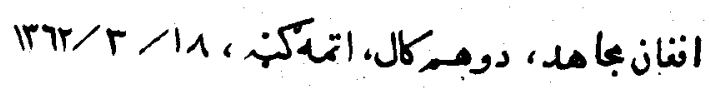

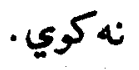




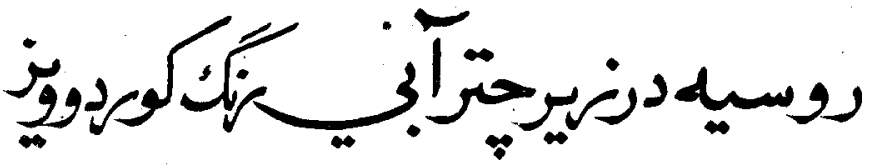

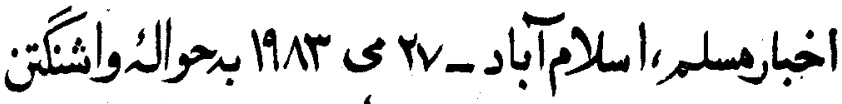

$$
\text { צr كئ: }
$$

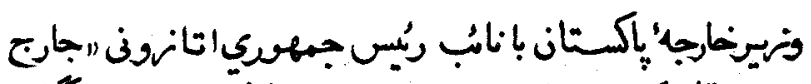

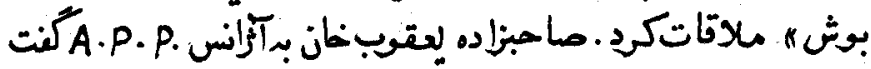

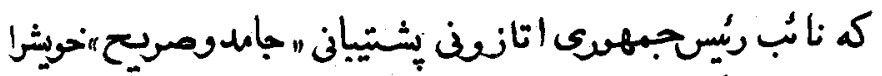

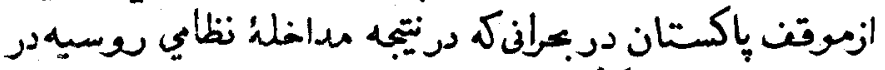

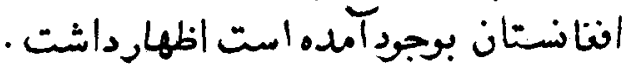

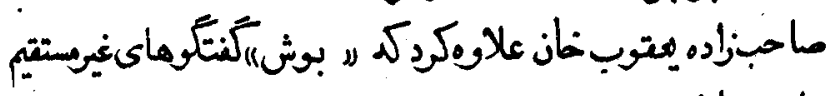

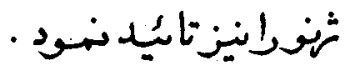

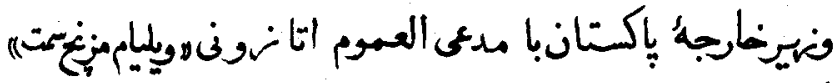

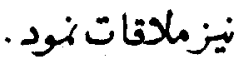




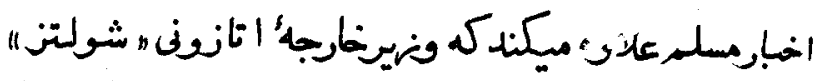

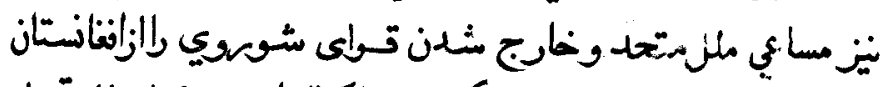

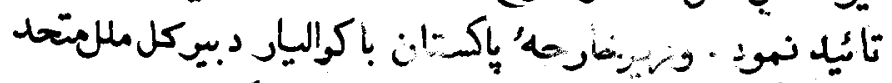

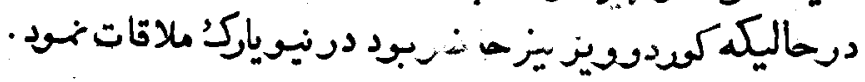

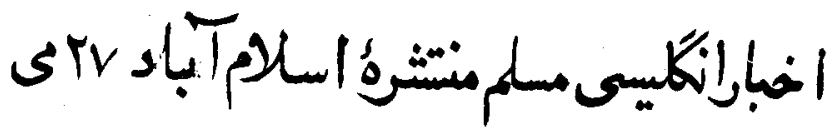

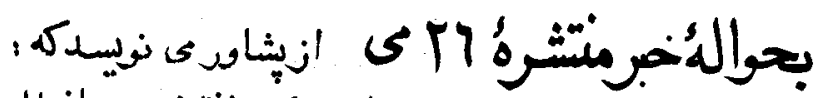

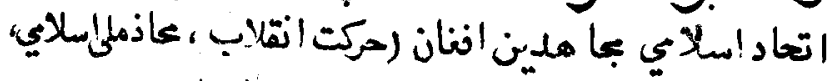

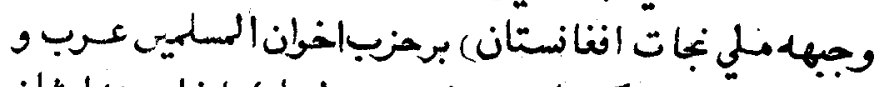

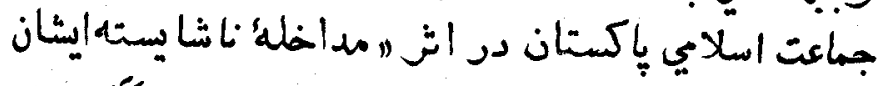

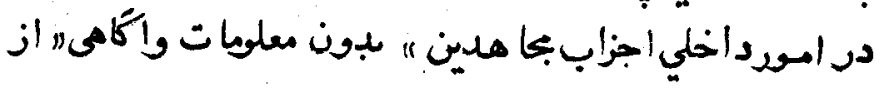

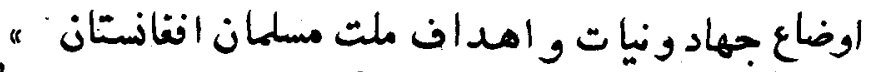

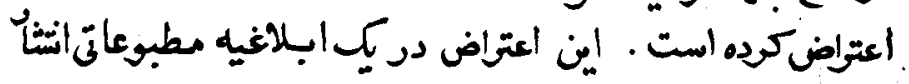

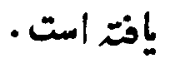

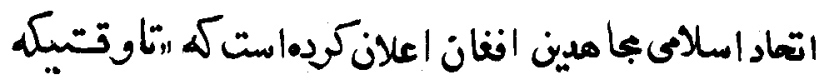

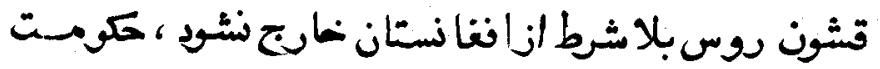

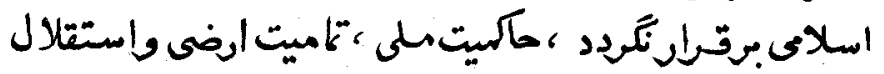

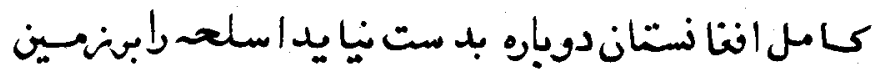
نغرا هندكذاشتشم. 


\section{III}

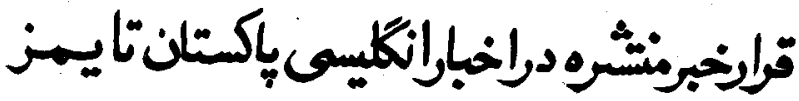

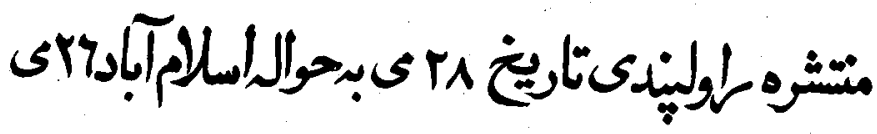

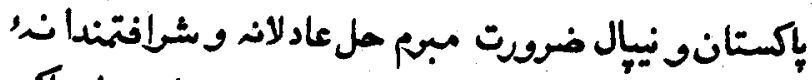

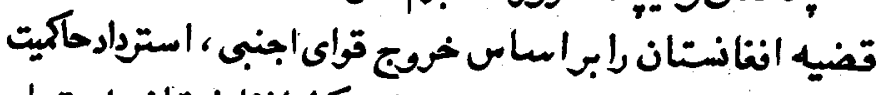

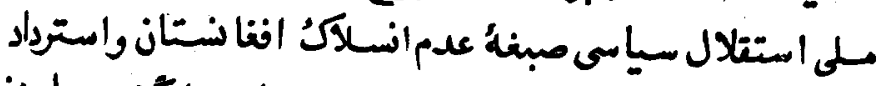

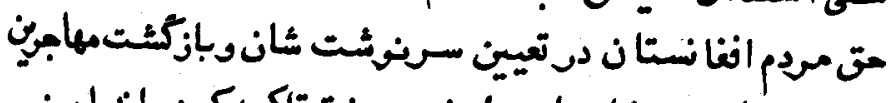

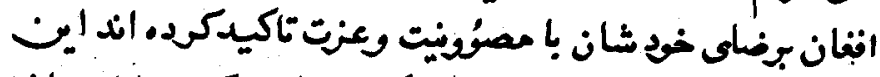

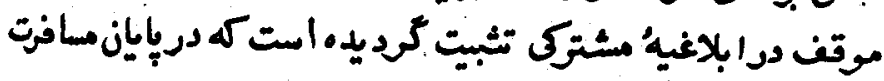

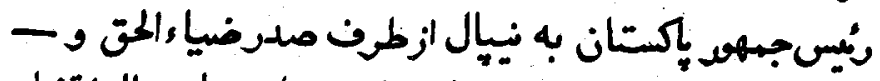

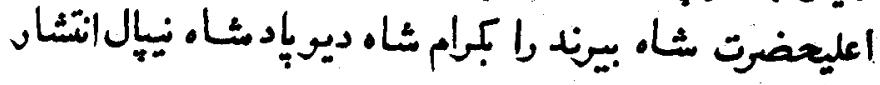

$$
\text { إفتهاست. افتباهد : }
$$

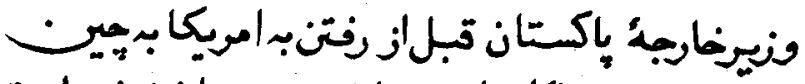

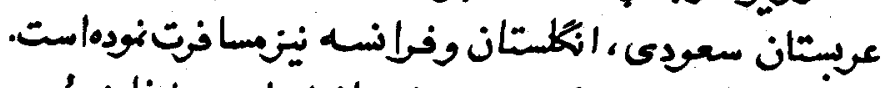

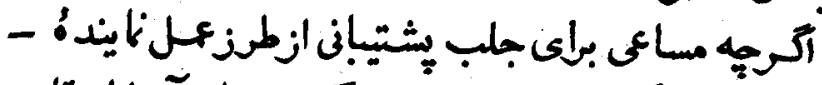

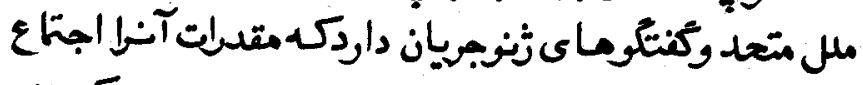

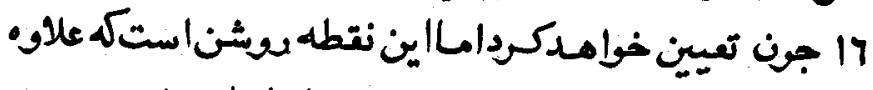

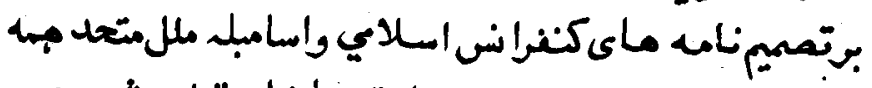

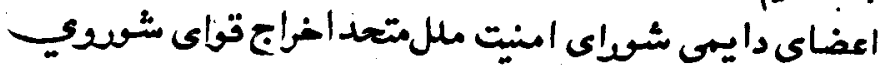




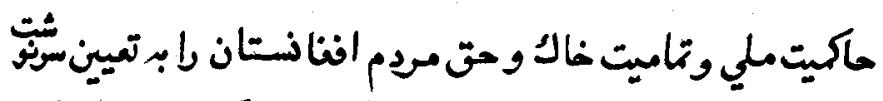

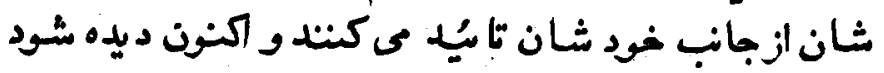

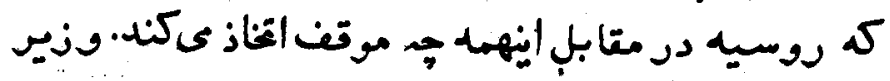

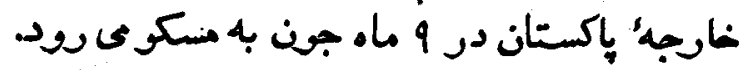

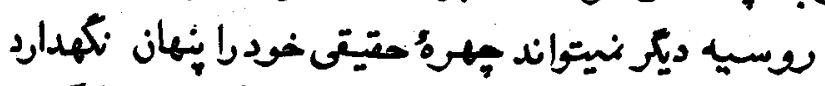

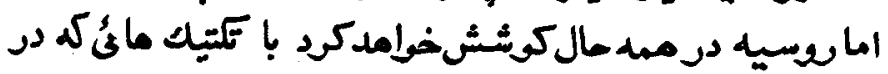

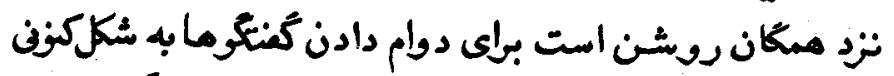

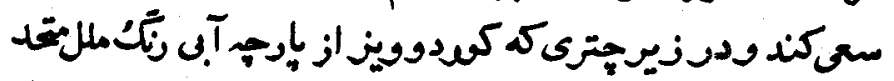

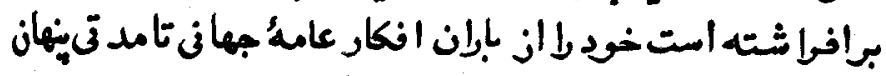
كند.

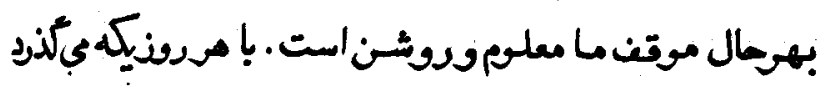

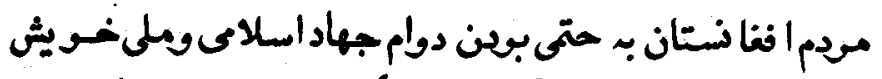

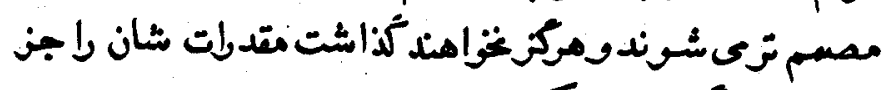

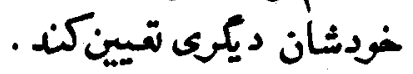

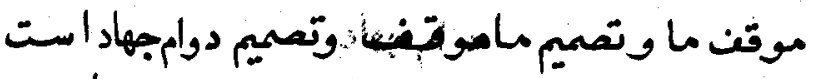

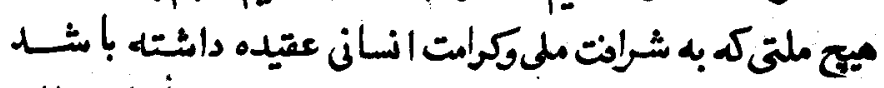

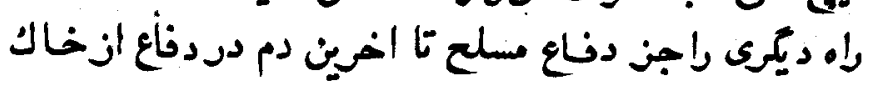

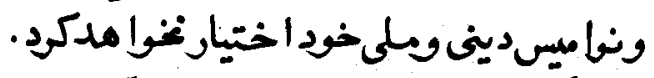

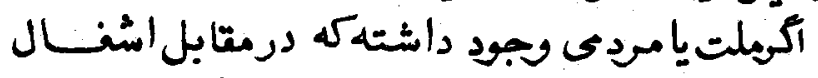

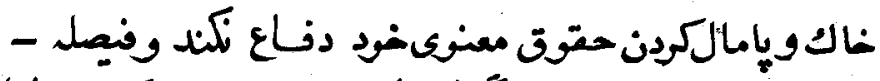

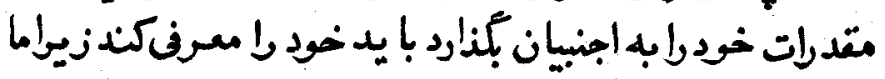


$\pi$.

جنين مردم وملقق أسواغ نداريم وتصورآن ازيغيلُِما بيرون

است.

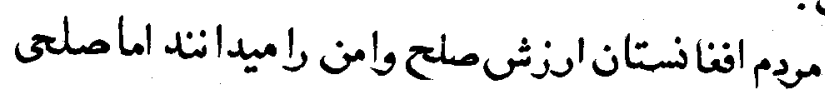

كم عارلاند نباشد هلح نيست.

شمارةُ 1 سال دوم افنانغبامد

$1 \pi \pi / r / \Lambda$ 


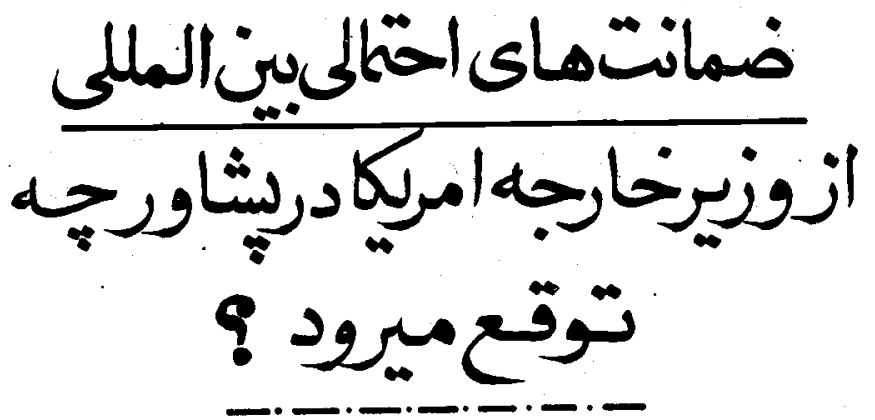

آتسرجه از نتطه نظس مبارنهين آناديغواه افنا نستان

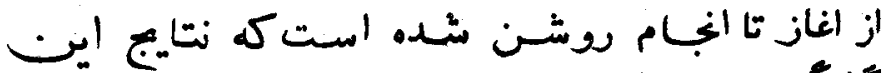

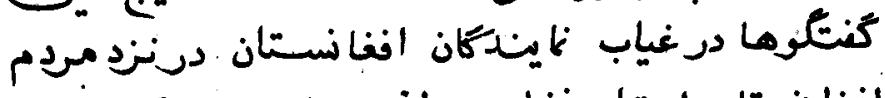

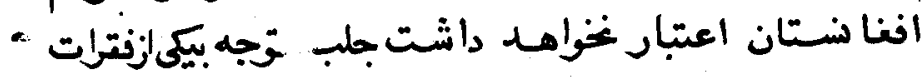

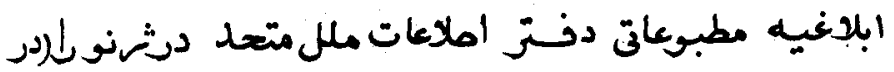

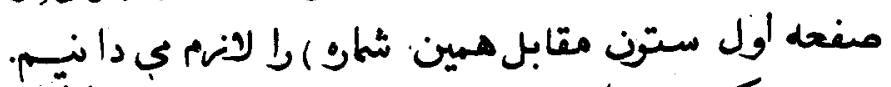

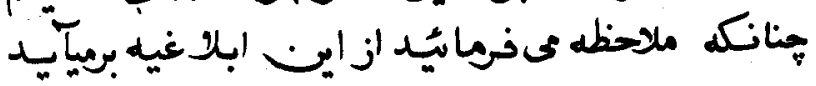




\section{IrT}

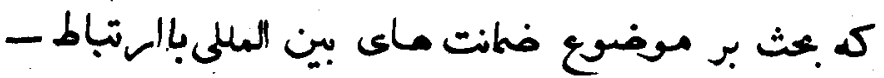

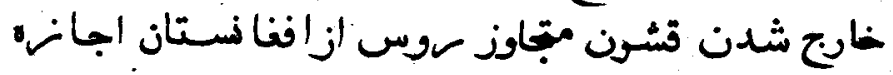

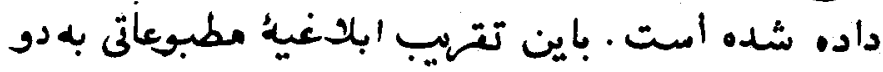

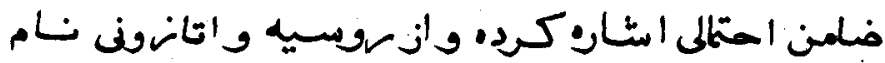

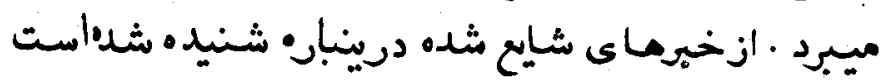

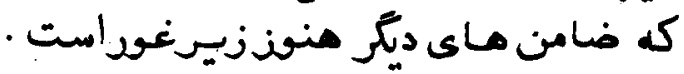

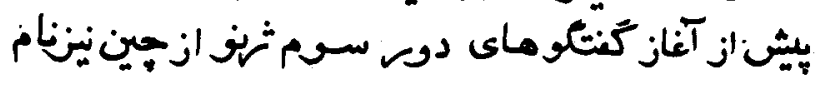

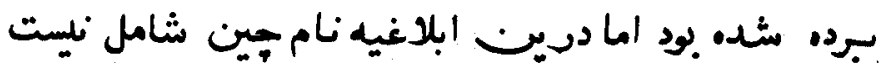

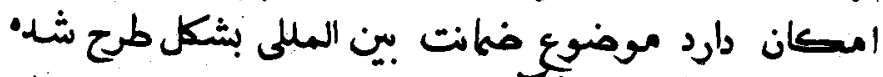

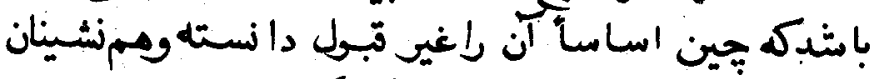

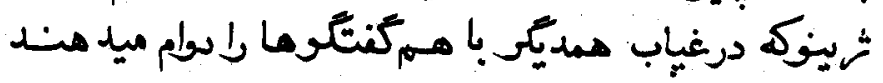

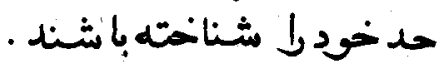

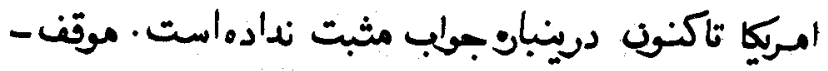

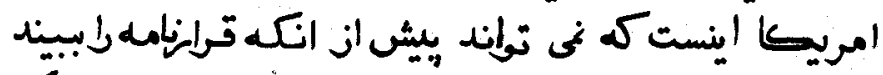

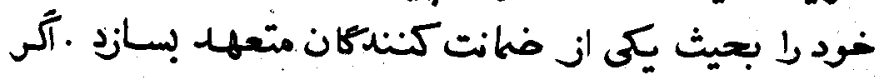

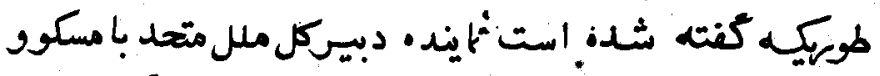

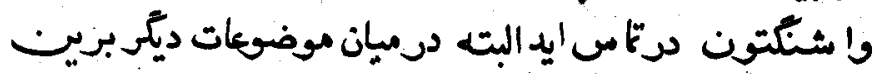

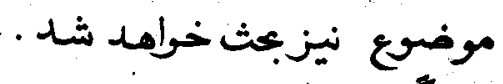

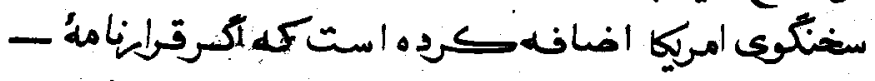

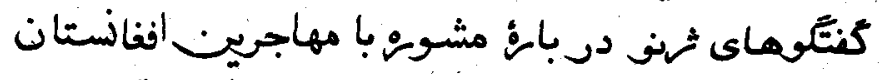

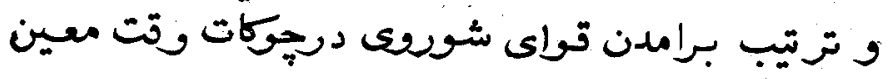




\section{Irr}

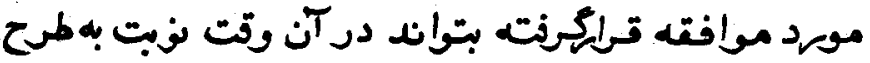

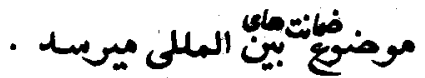

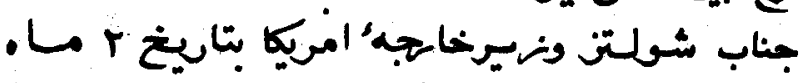

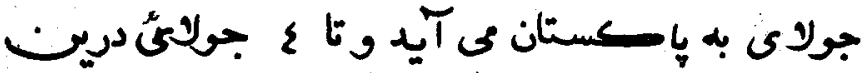

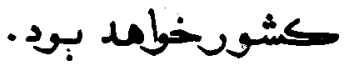

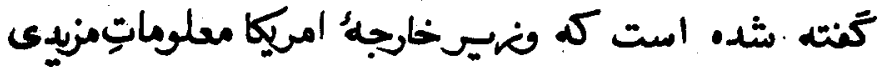

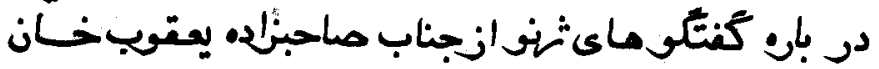

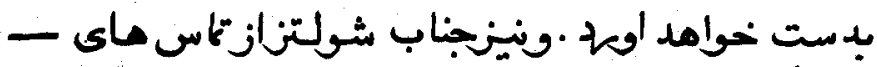

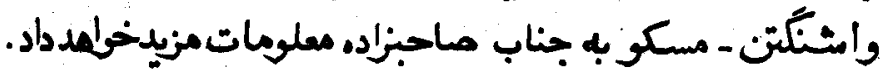

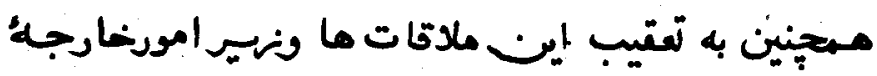

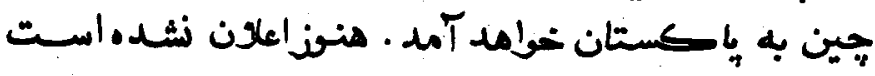

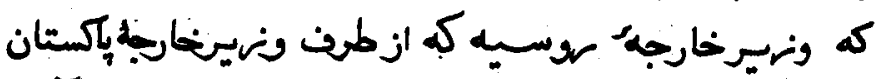

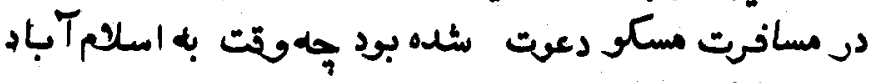
خوإمد آمد.

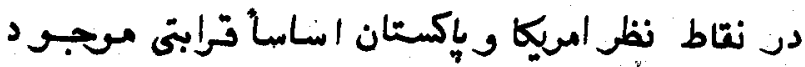

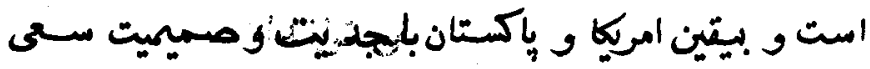

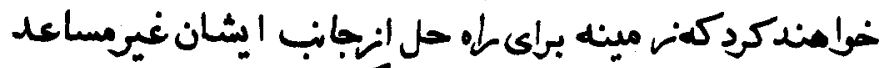

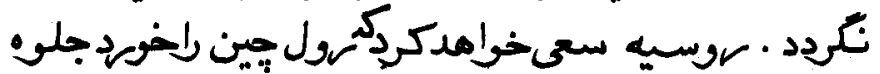

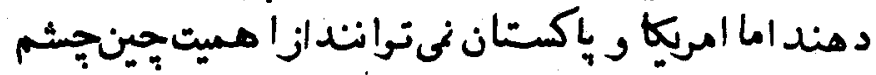

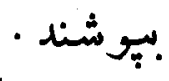

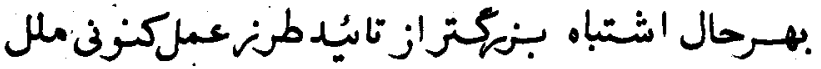




\section{Irz}

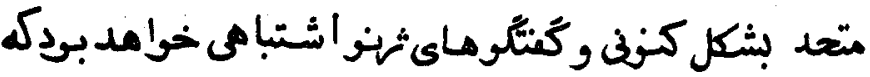

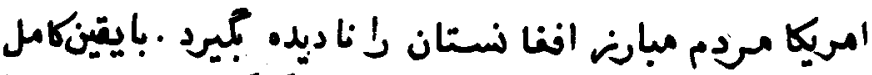

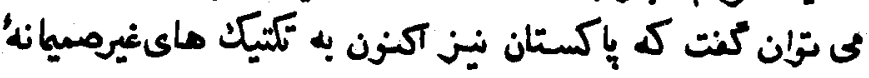

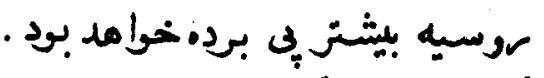

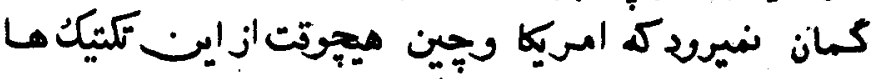

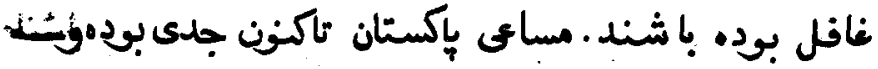

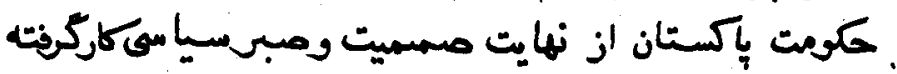

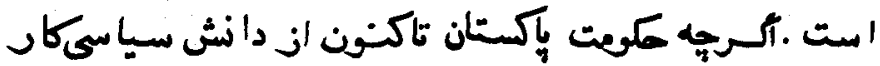

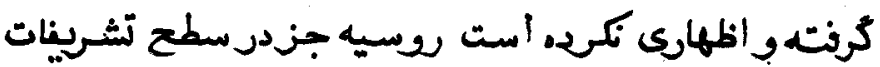

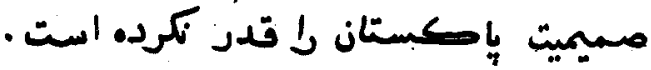

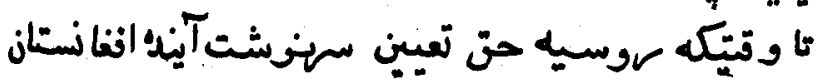

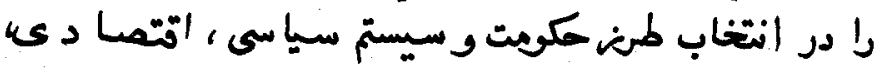

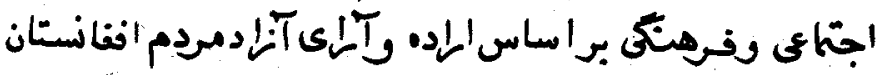

$$
\text { نشنا سل. }
$$

تاوتيكه ماكميتملى و استقلال ثام سيا بعى وتما ميت ارضى انفاذنتان تضهين وتامين نكردد.

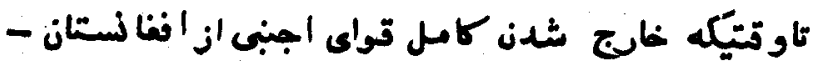

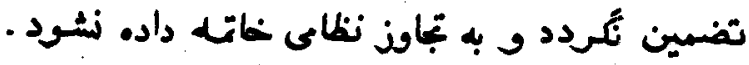

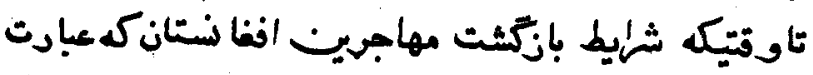

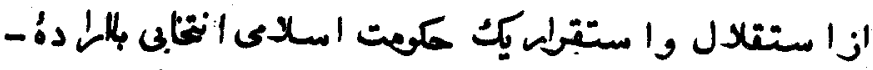

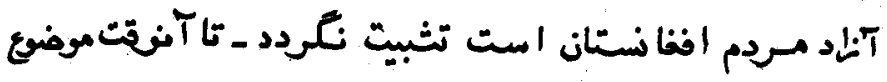


Irs

ضانت بين السلى لا نمبتوان قابل بحث ندا نست.وحتى در

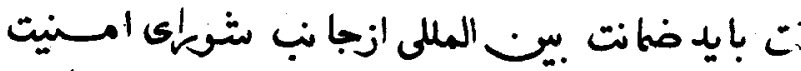

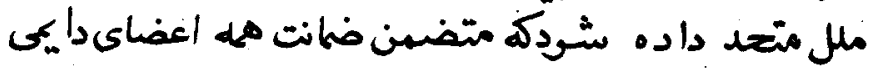

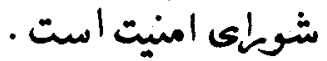

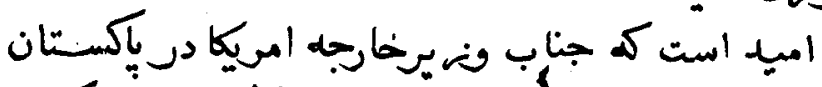

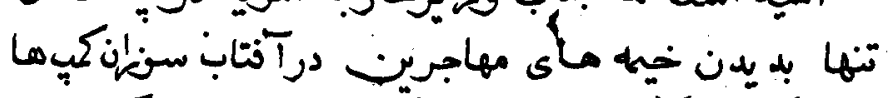

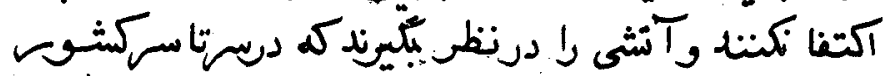

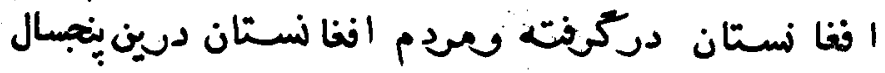

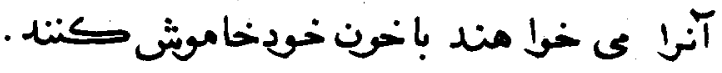

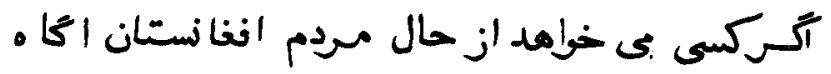

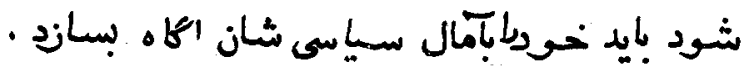

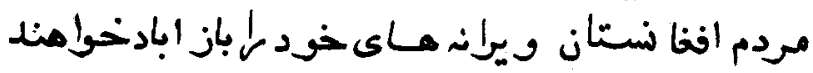

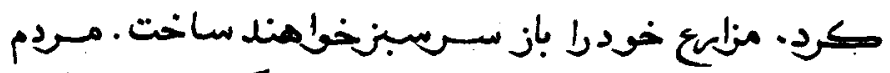

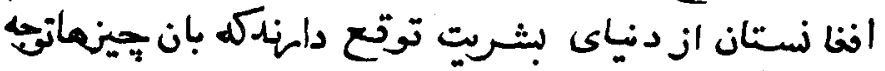

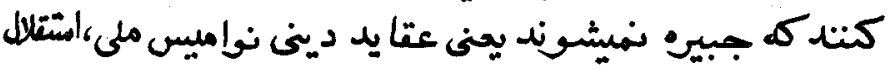

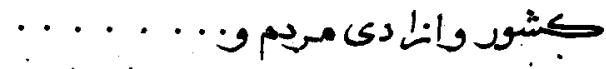

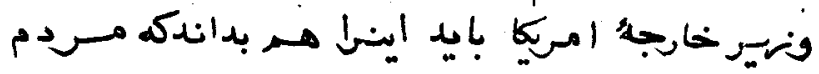

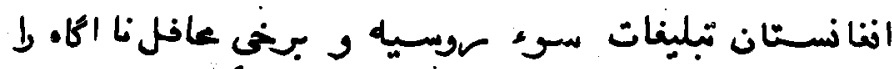

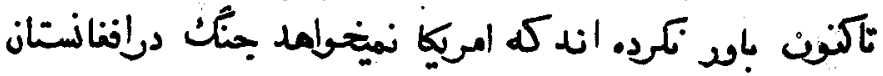

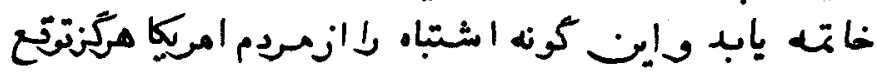

ندارد . 
IrT

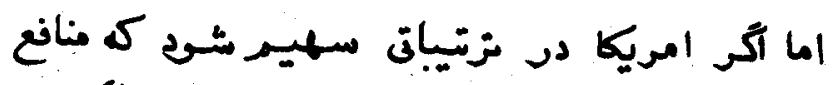

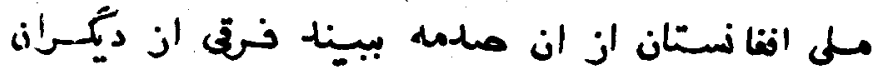
نغواهـ داثتيت.

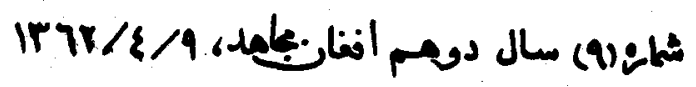




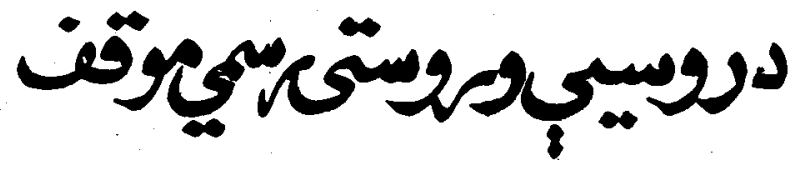

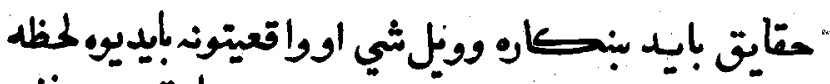

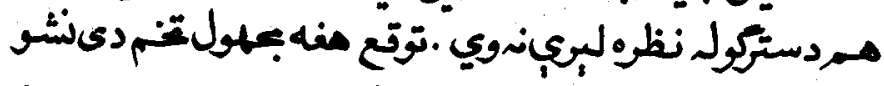

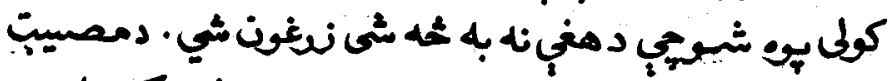

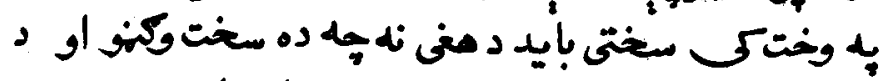

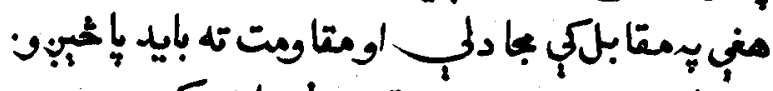

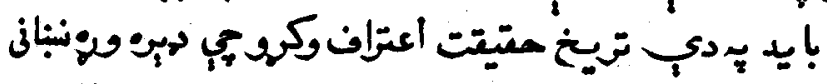

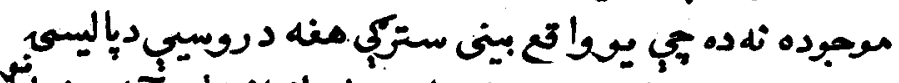

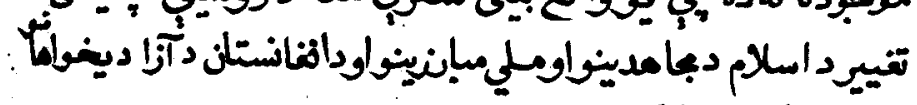
يه مثا بلكي تبول كري.

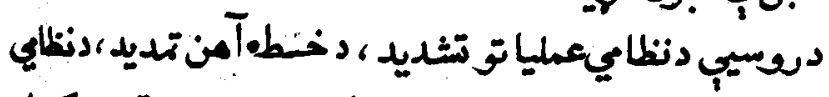

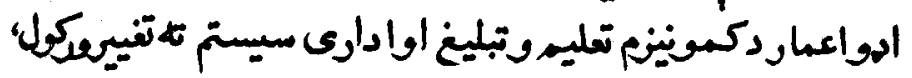

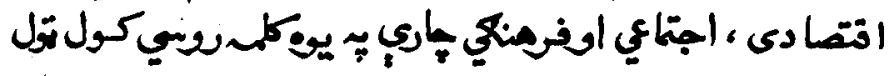




\section{ITA}

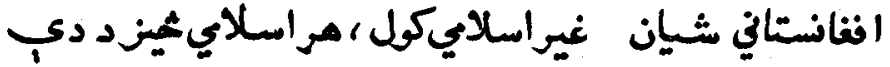

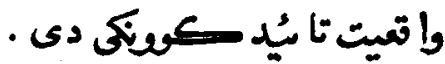

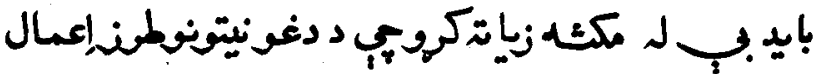

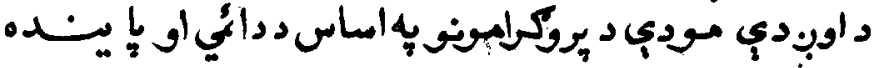

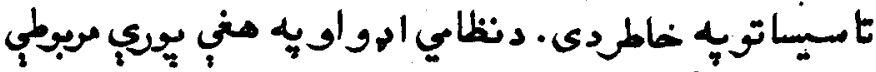

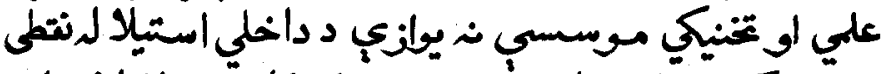

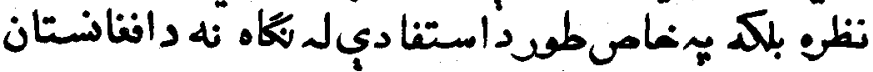

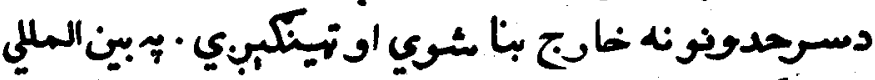

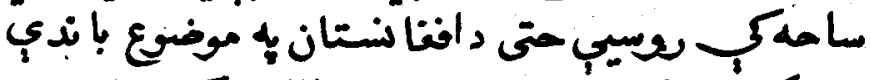

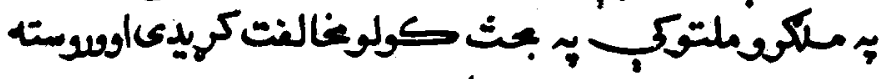

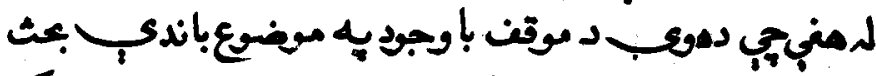

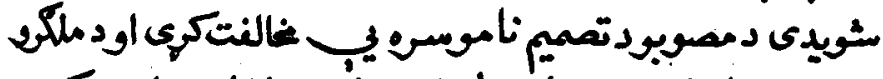

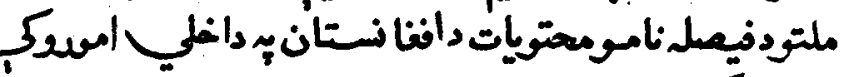

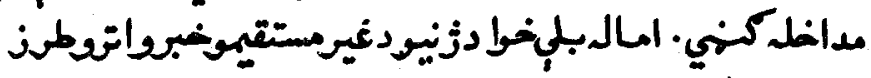

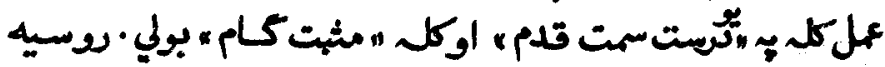

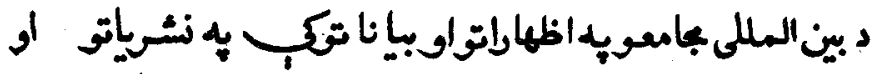

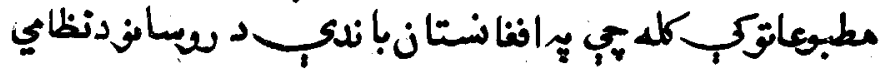

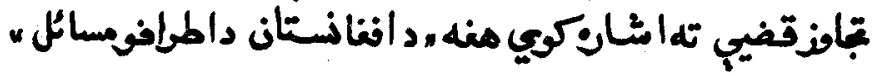
بولي . بوإن

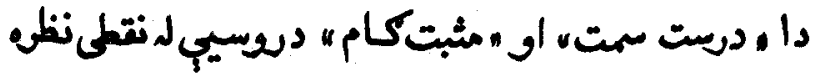

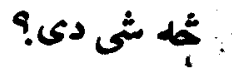




\section{9}

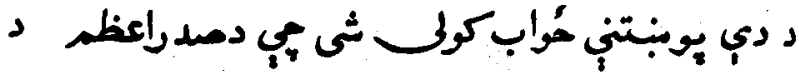

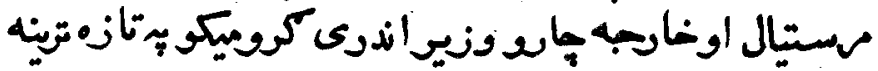

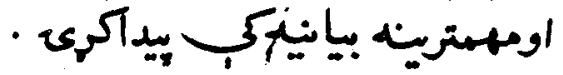

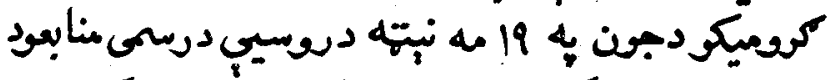

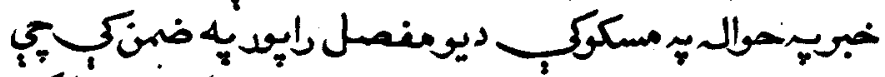

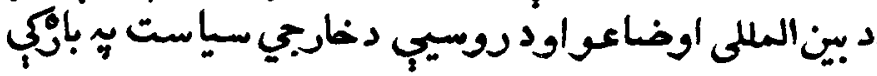

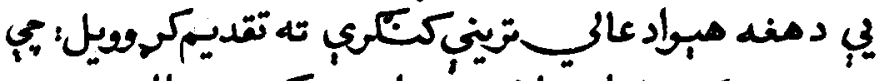

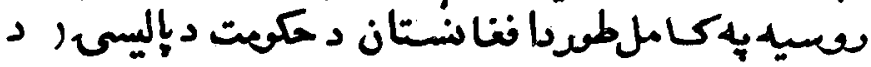

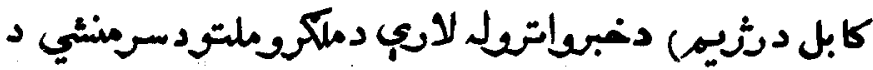

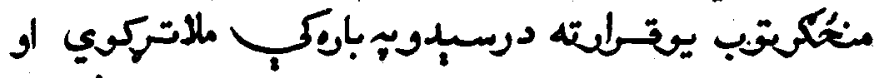

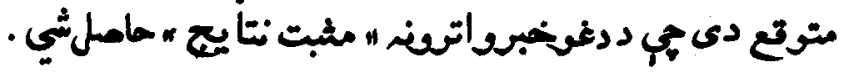

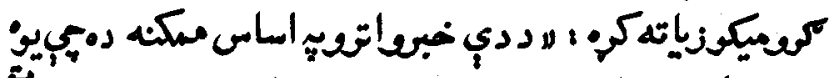

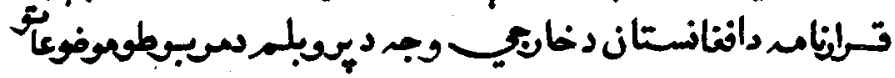

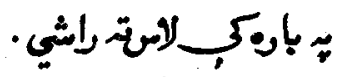

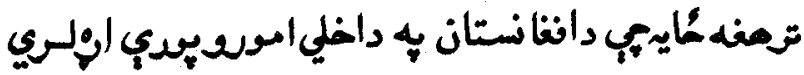

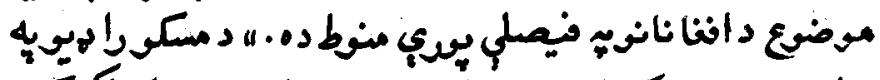

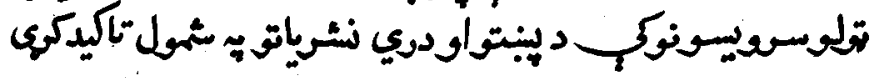

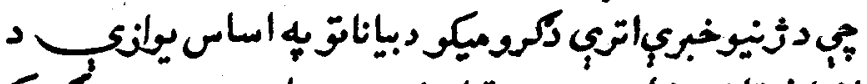

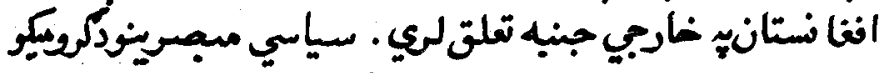

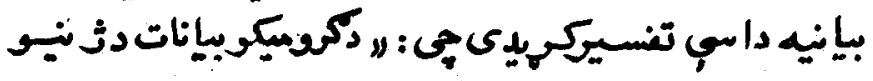

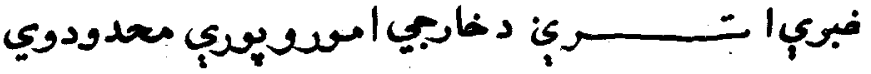




\section{ir.}

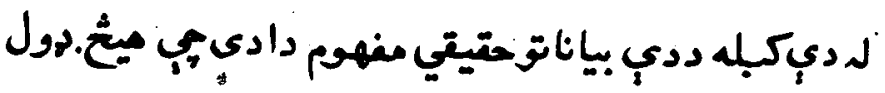

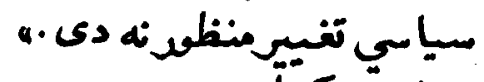

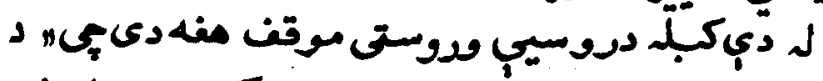

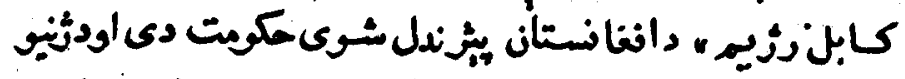

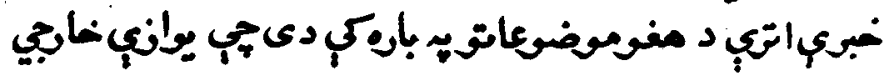

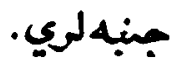

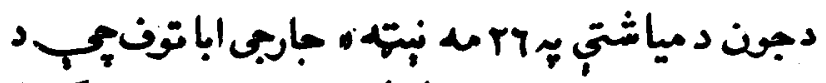

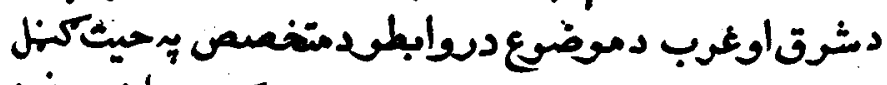

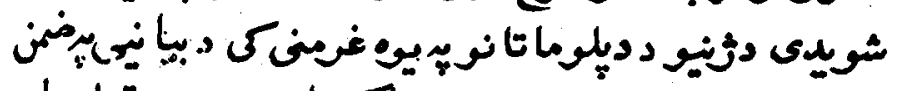

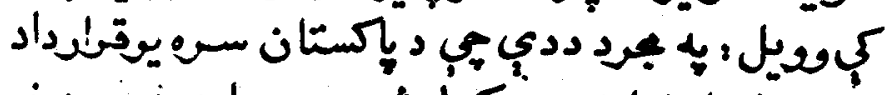

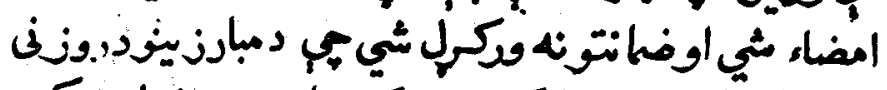

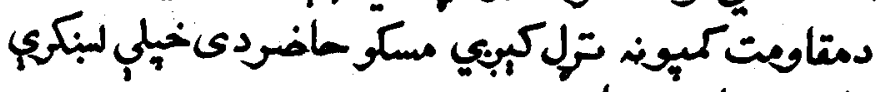

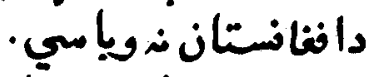

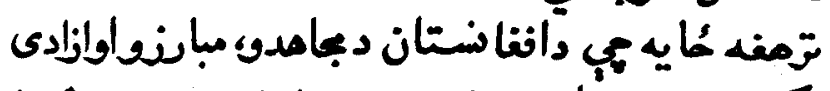

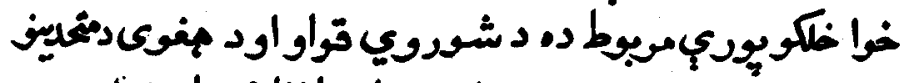

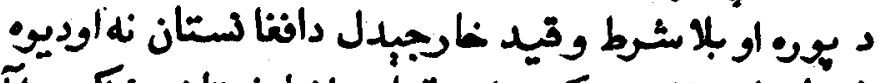

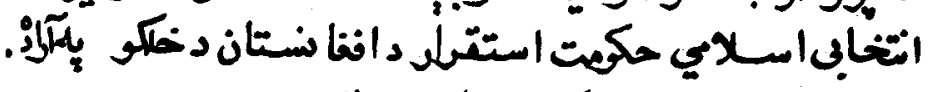

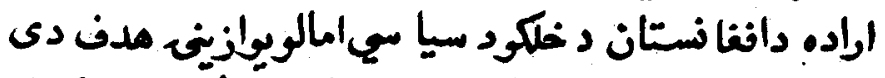

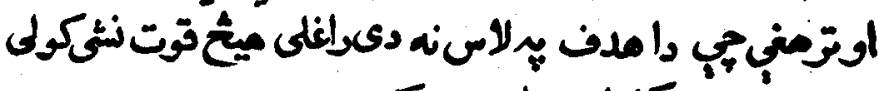

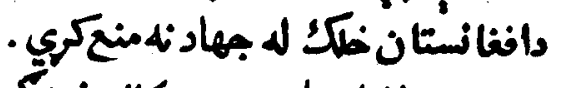

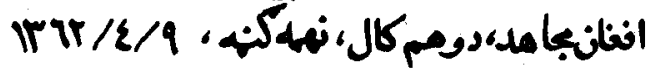




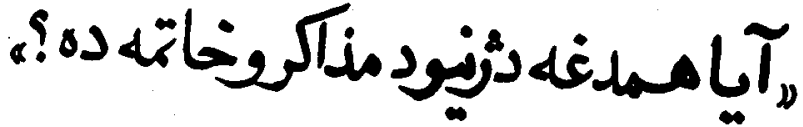 •ابلى!}

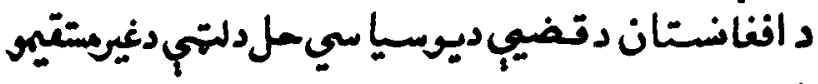

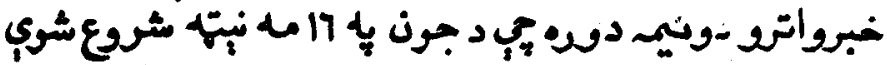
و. د و

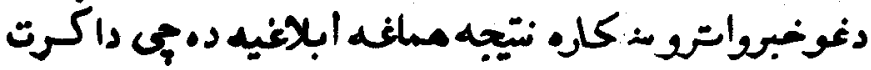

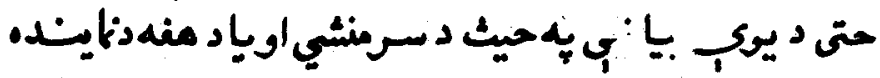

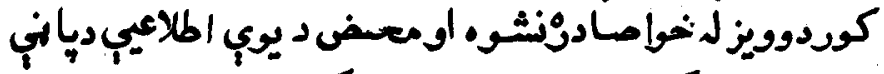

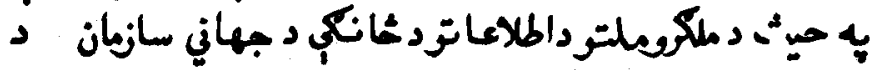

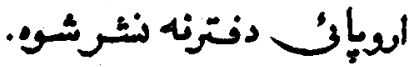

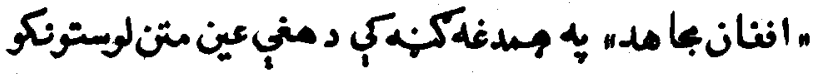

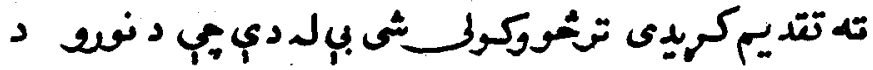

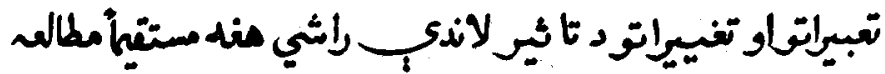

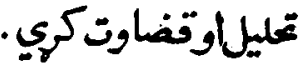




\section{IrT}

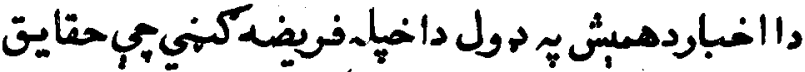

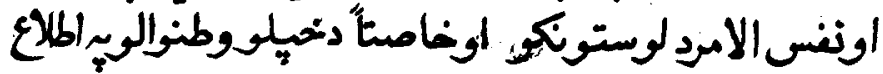

ومهيوي:

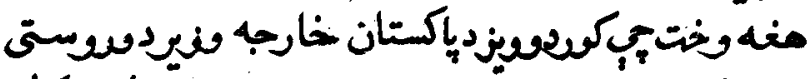

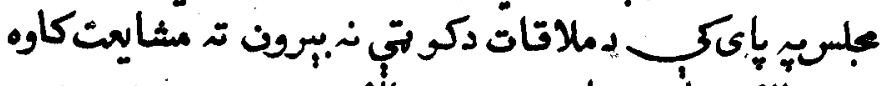

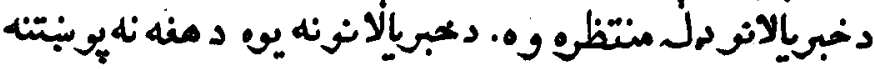
ك5:

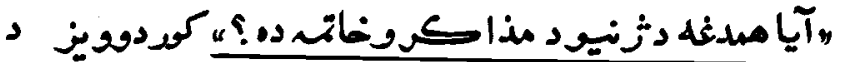

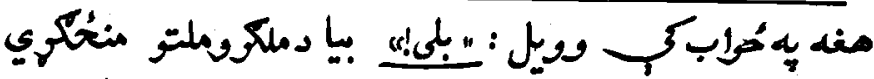

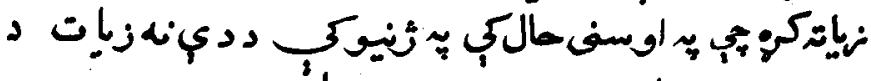

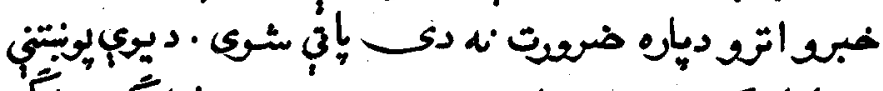

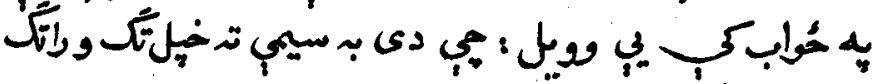

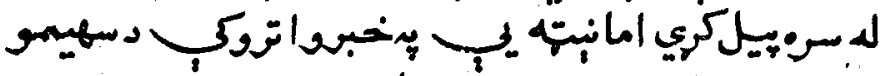

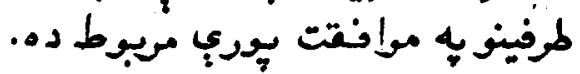

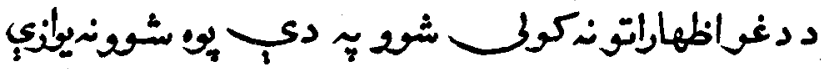

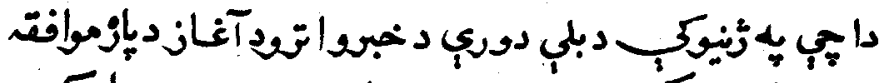

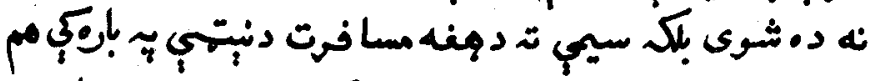

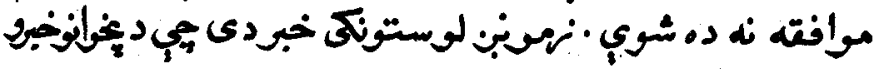

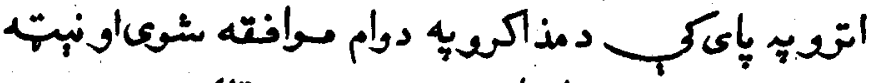

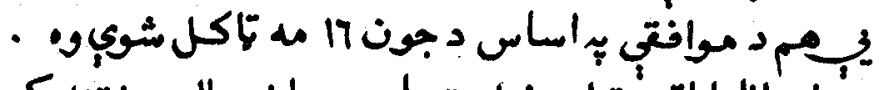

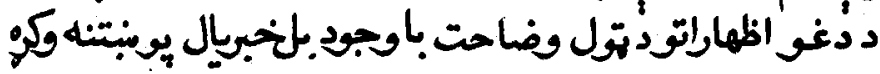




\section{irr}

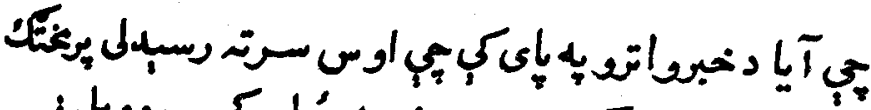

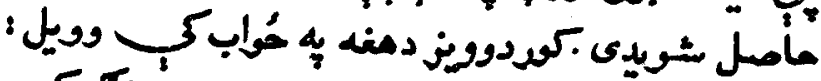

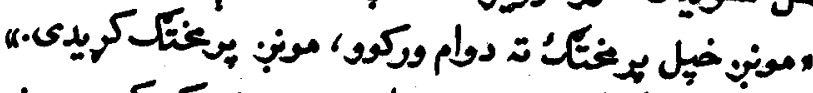

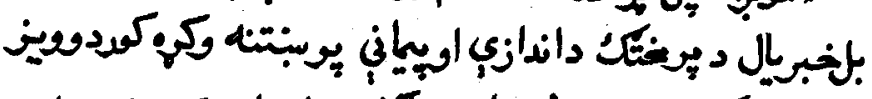

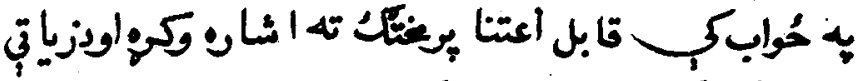

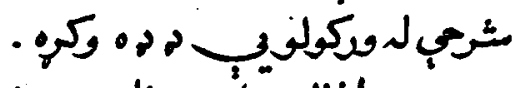

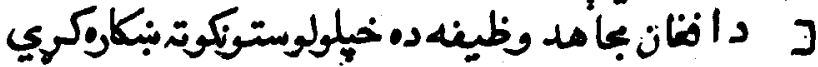

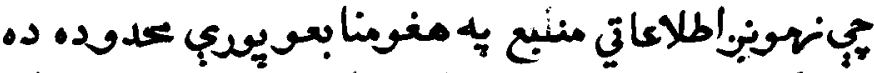

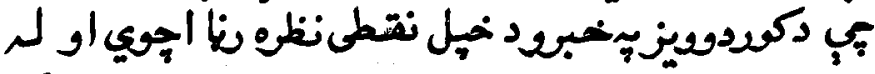

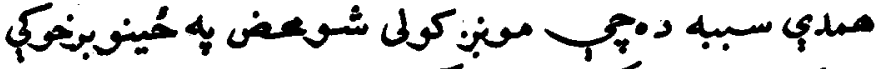

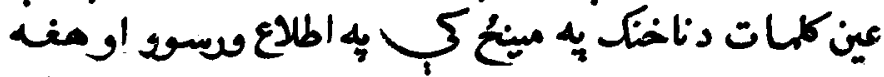

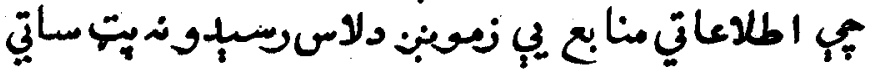

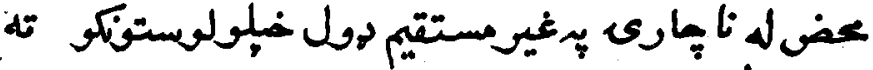

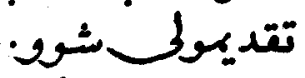

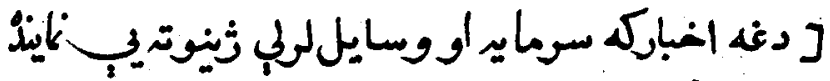

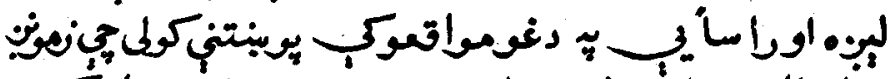

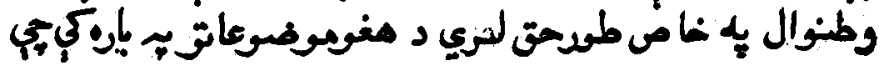

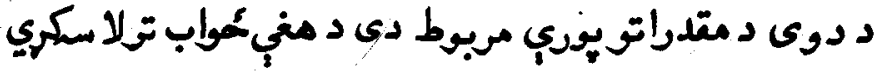

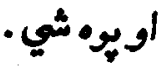

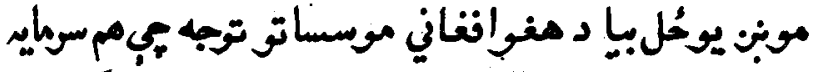

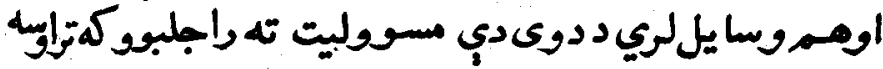




\section{2}

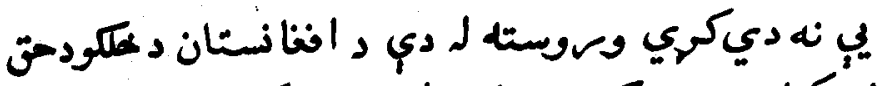

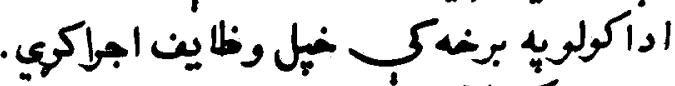

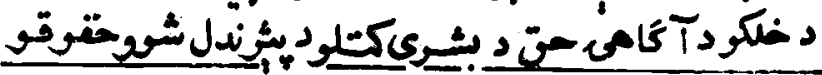

هُخهدئ.

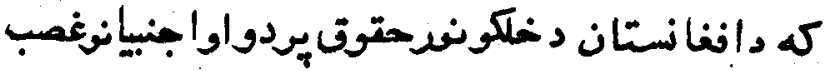

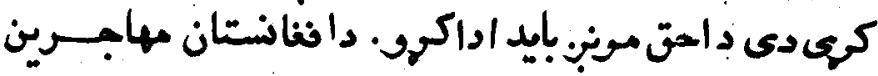

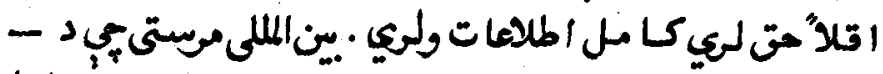

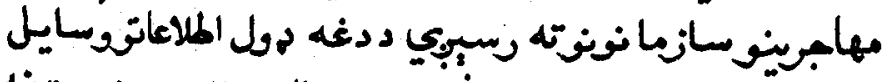

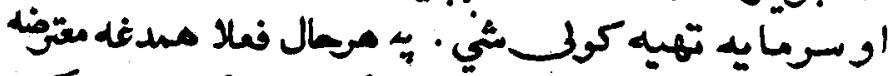

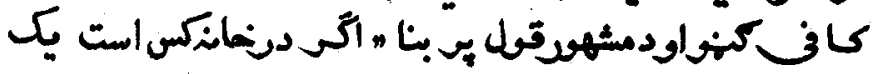

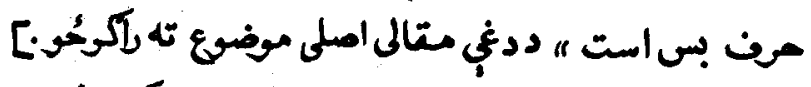

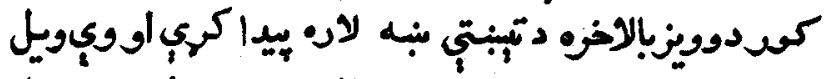

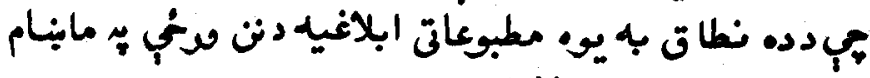

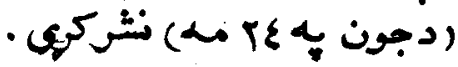

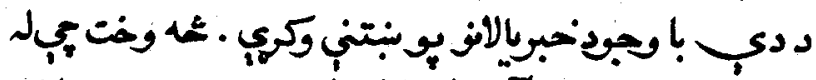

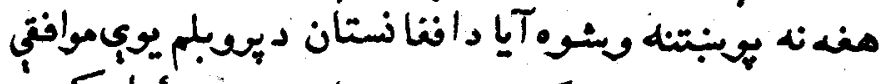

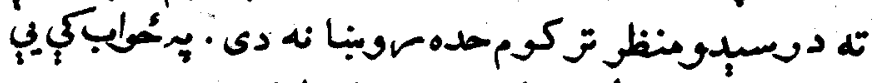

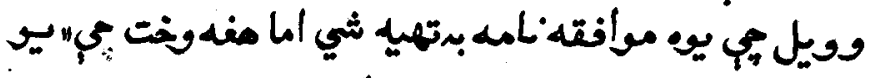

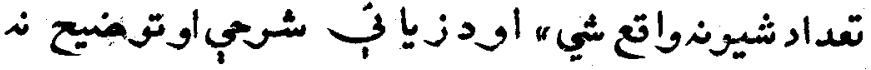

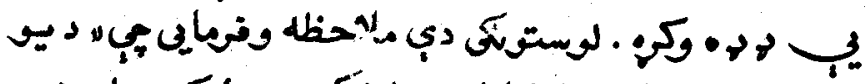

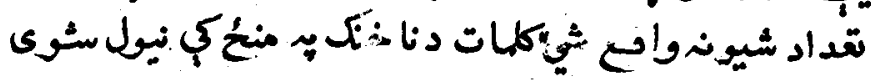




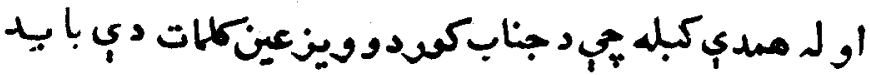

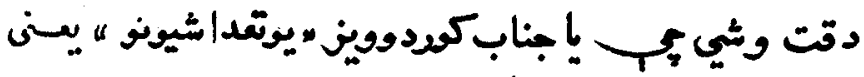

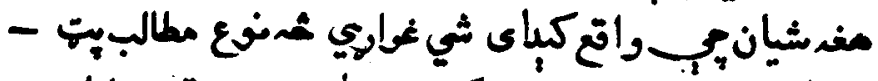

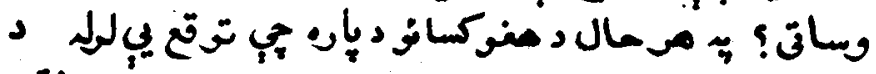

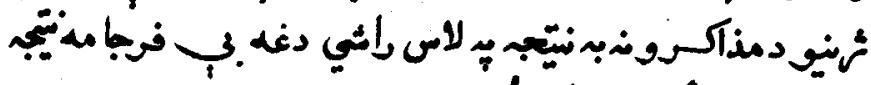

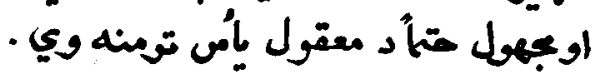

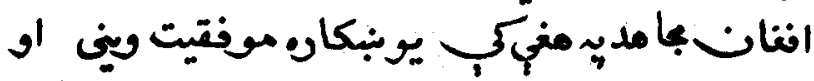

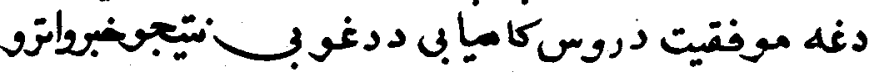

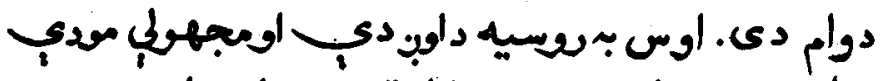

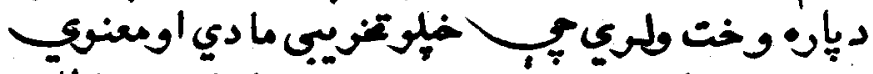

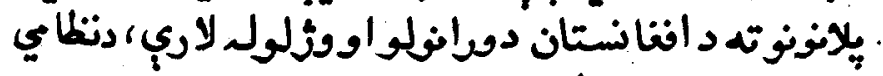

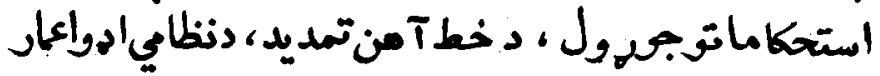

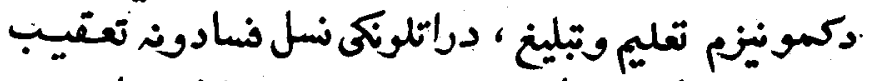

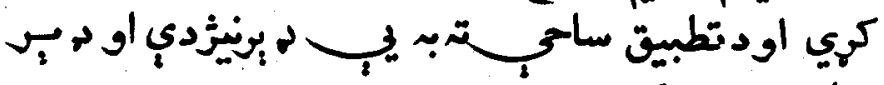

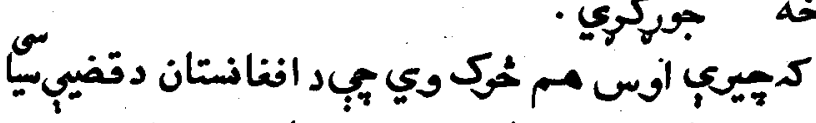

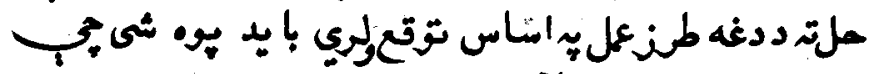

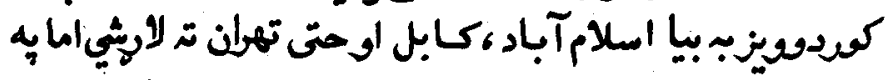

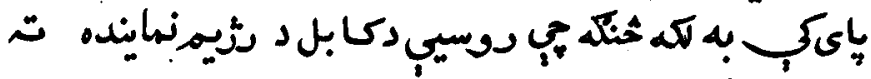

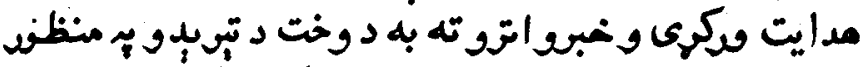

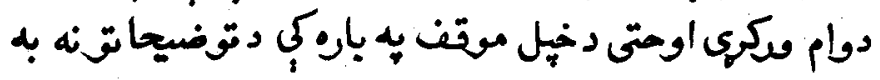




\section{Iry}

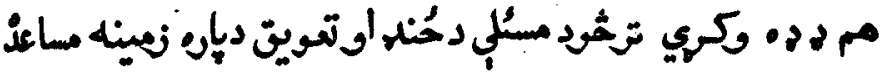

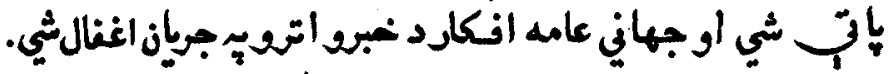

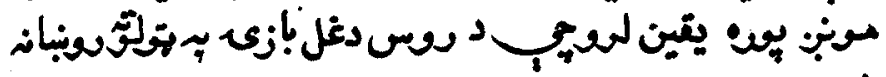

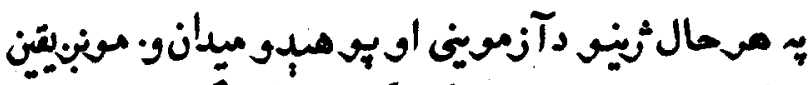

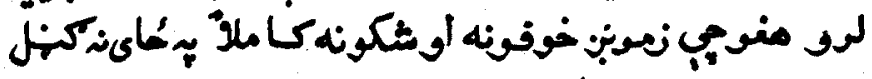

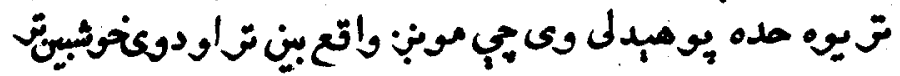
פو

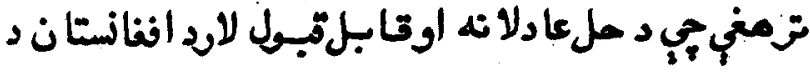

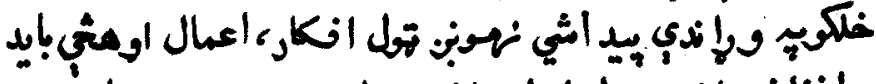

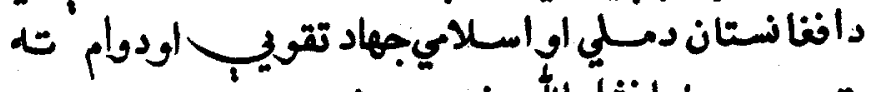

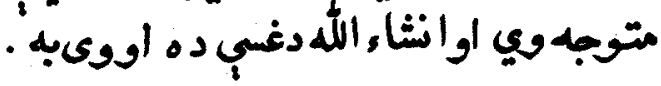

افتانبجامد، دومركال، نهلكئنه

$$
\text { Iritr- } \varepsilon-1
$$




\section{ابلاغيلُمطبوعاتثثنو}

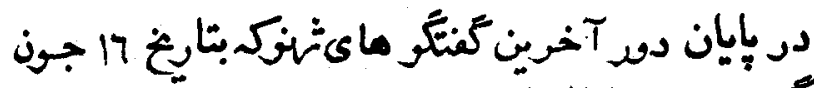

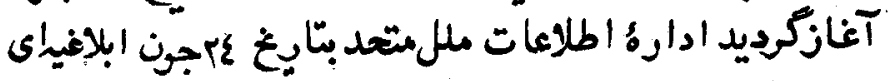

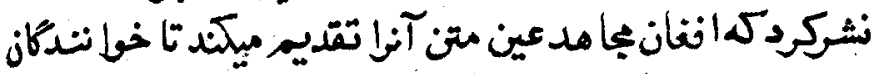

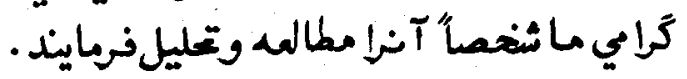

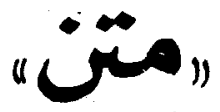

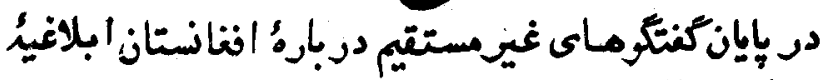

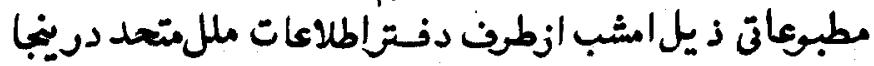
أزّنو ) نشيكريد.

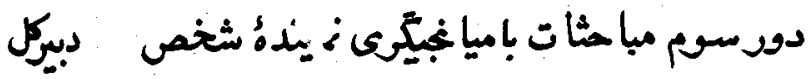

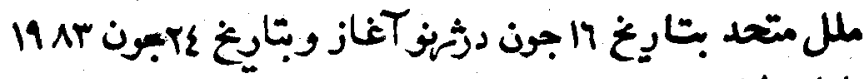

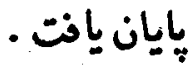




\section{ITA}

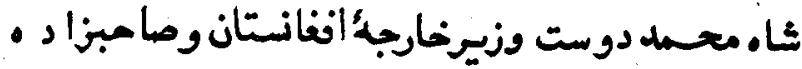

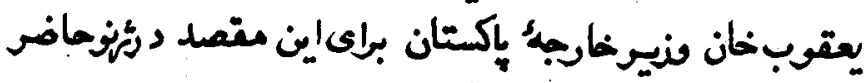
بوند - ميك

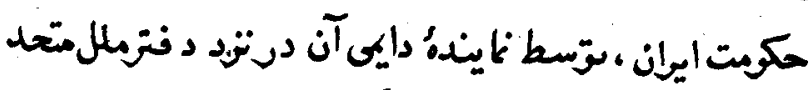

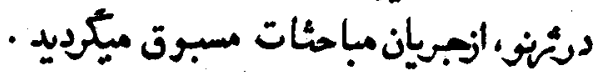

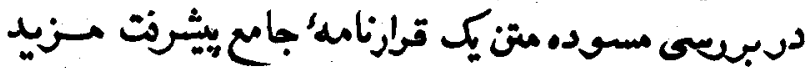

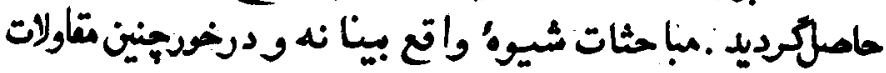
صوتكفت.

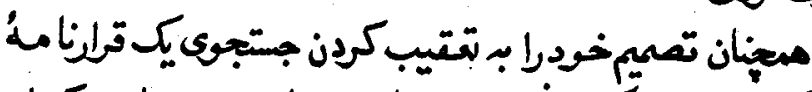

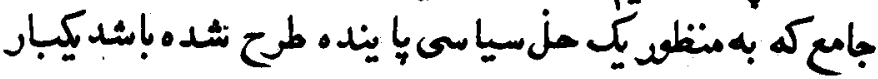

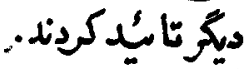

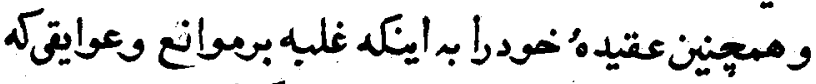

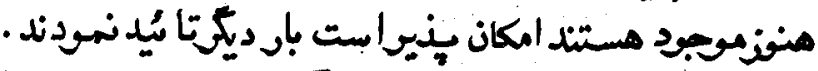

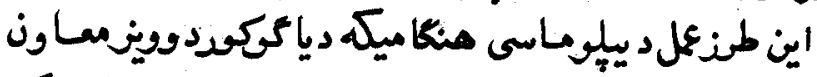

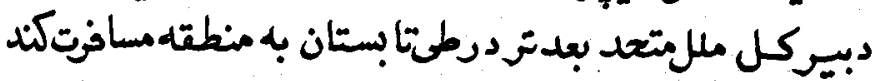

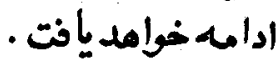

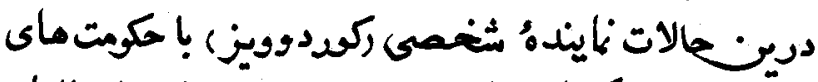

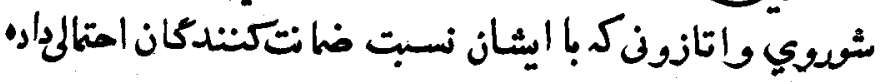

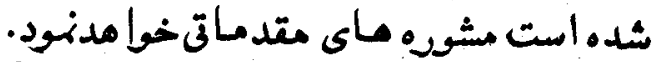

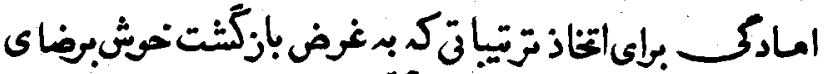

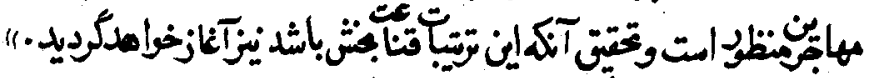

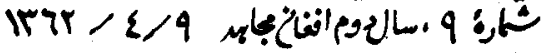




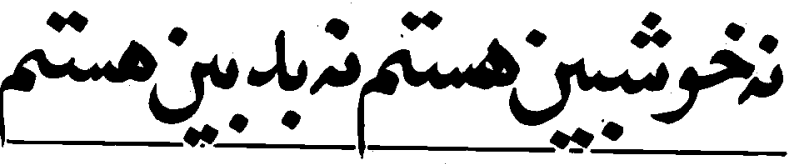

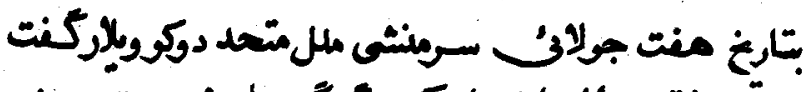

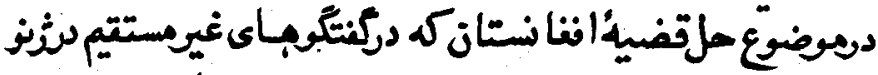

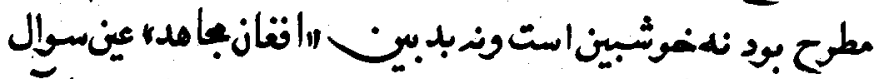

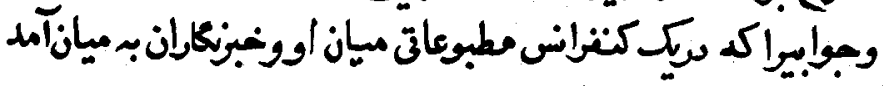

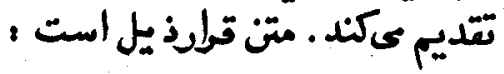

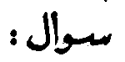

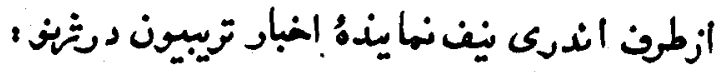

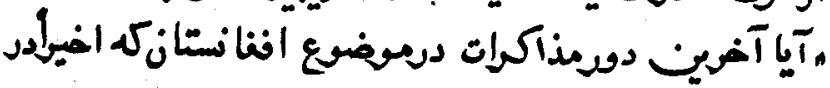

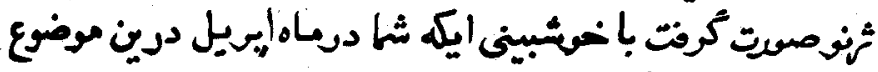

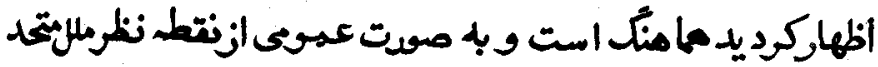

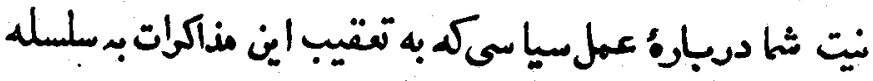

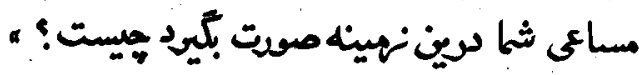




\section{جواب:}

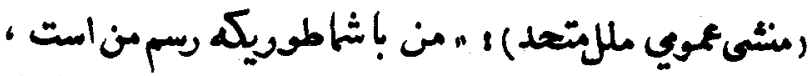

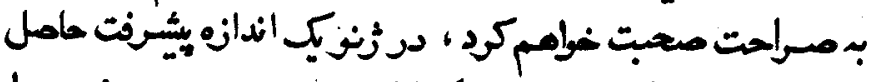

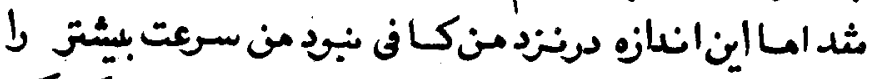

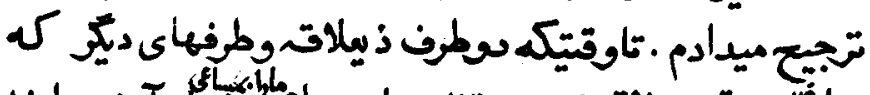

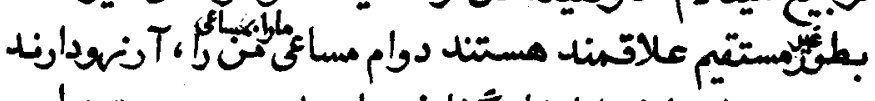

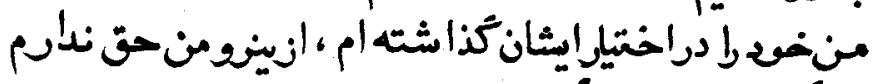

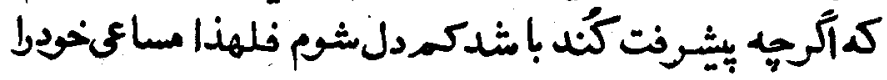

$$
\text { دوام خواميم داد. }
$$

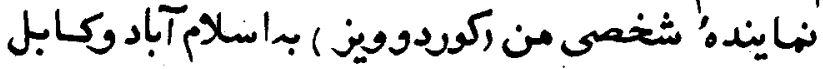

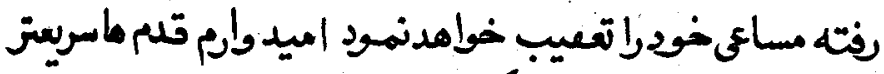

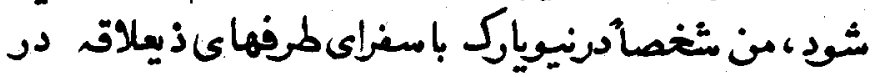

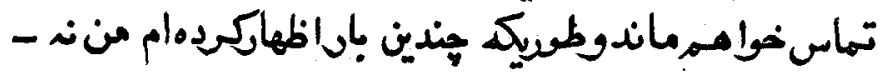

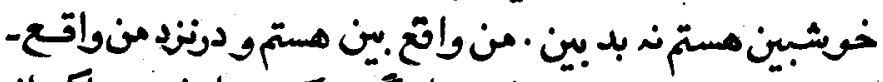

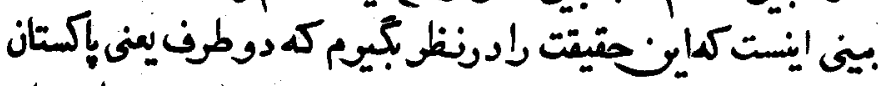

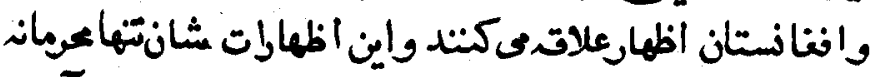

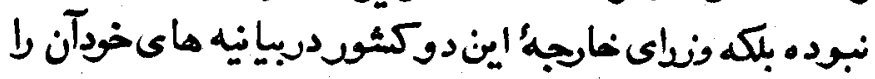

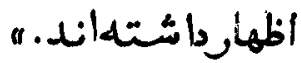

$$
\begin{aligned}
& \text { مسوال : }
\end{aligned}
$$

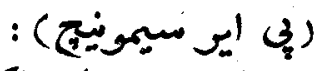

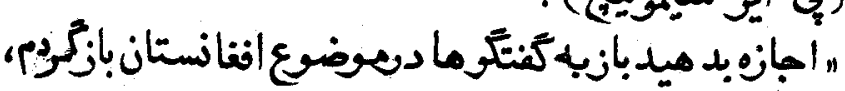




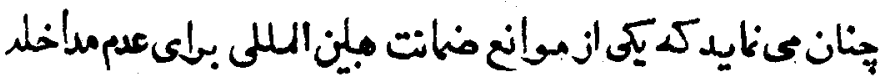

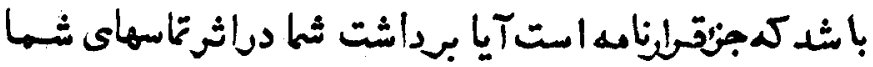

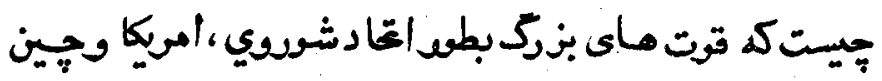

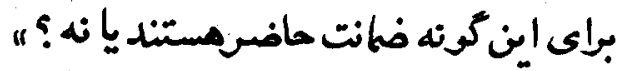

$$
\text { بواب }
$$

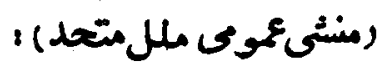

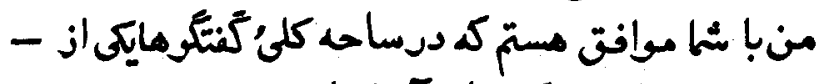

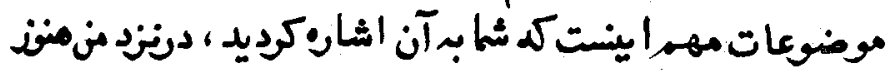

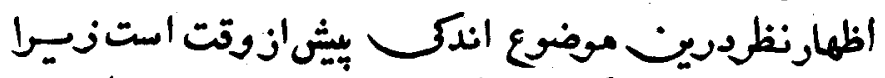

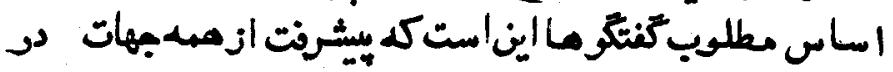

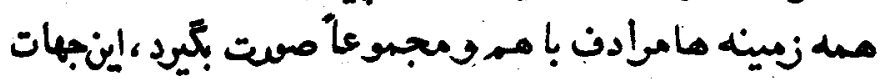

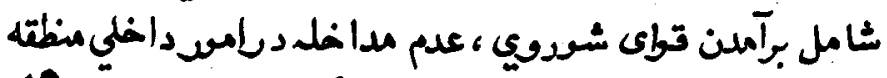

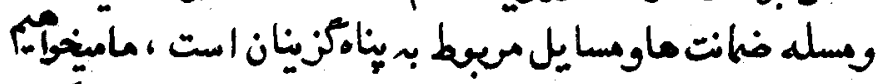

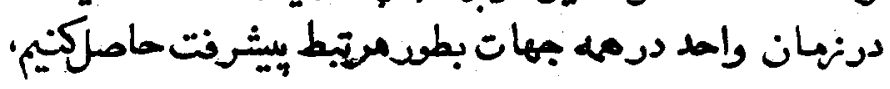

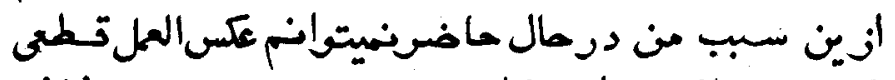

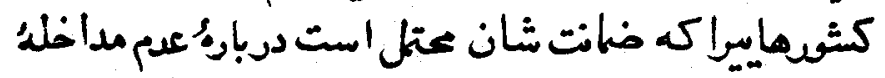

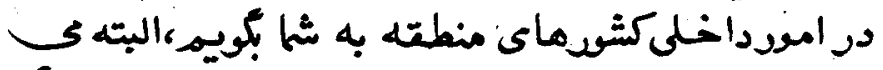

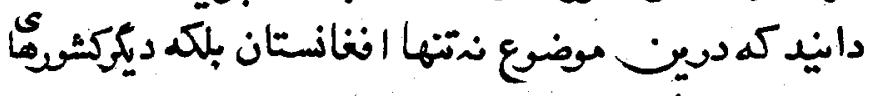

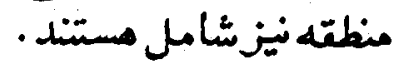

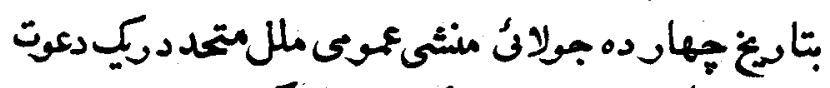

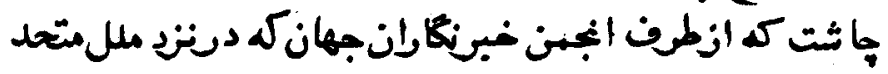




\section{IEr}

مقيم مستند ترتيّ داده شُمده بود نسبت بر سرعت جريات

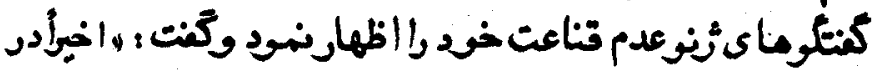

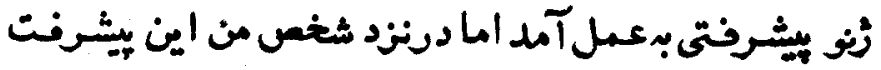

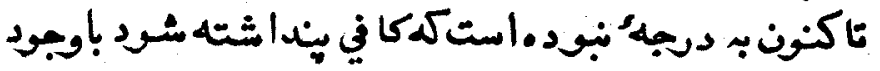

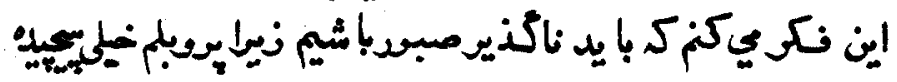

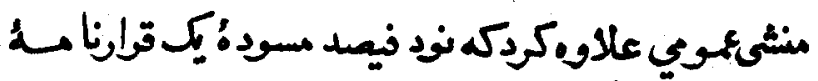

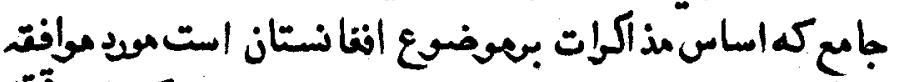

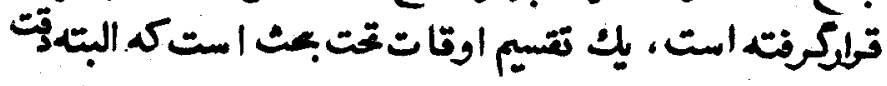

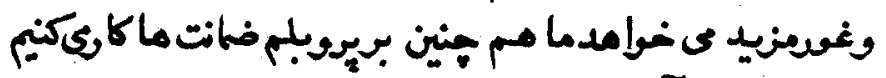

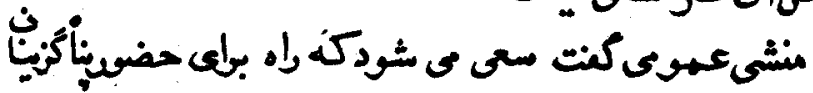
كدمل آنكارآمانى نيت فيت.

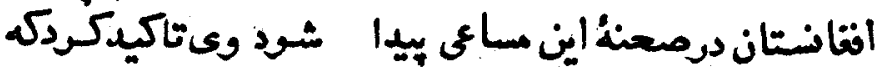

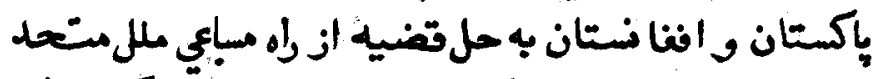

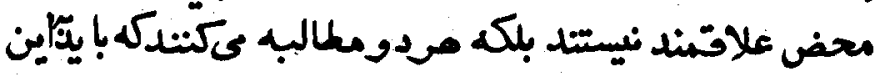

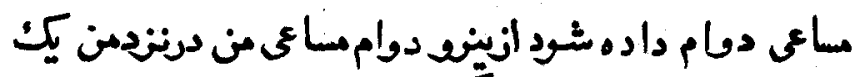

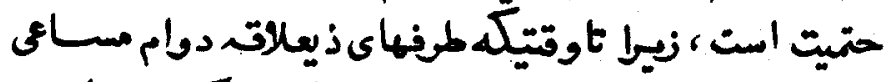

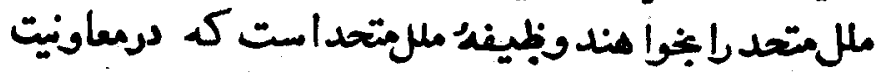

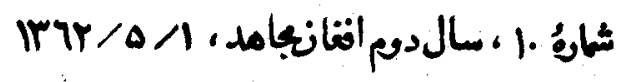

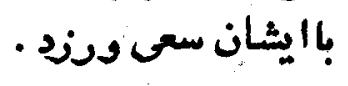




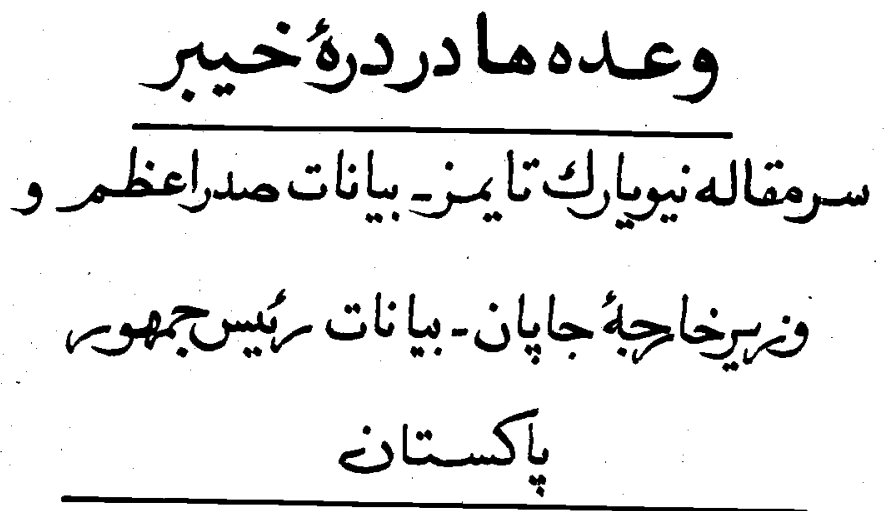

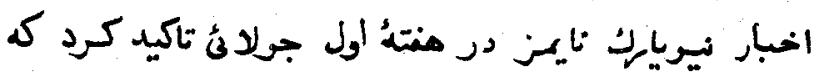

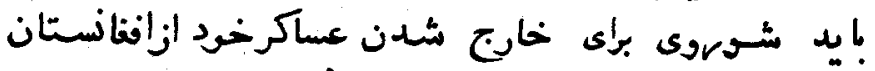

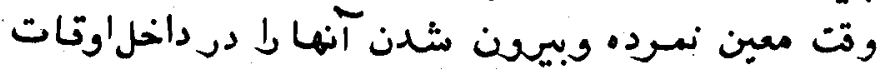

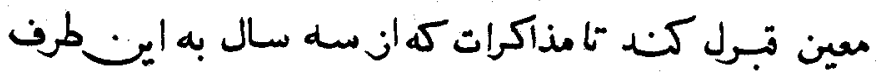

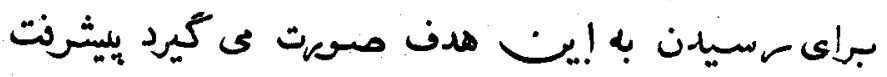
كرده بـتراند . 


\section{2}

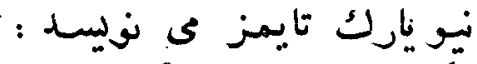

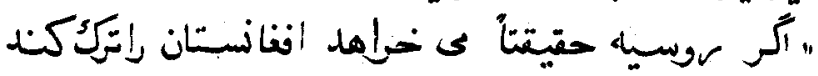

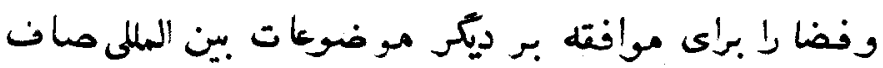

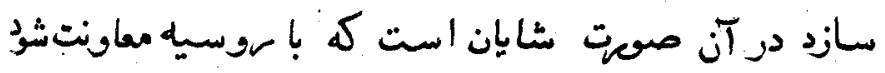

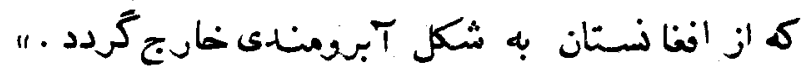

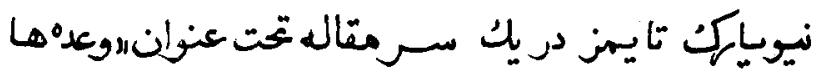

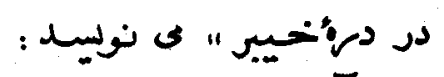

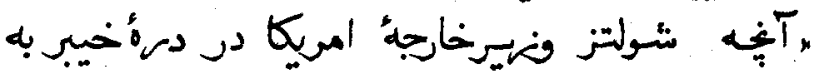

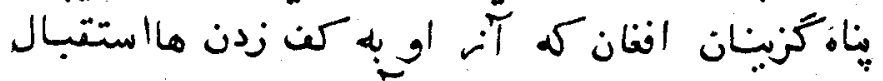

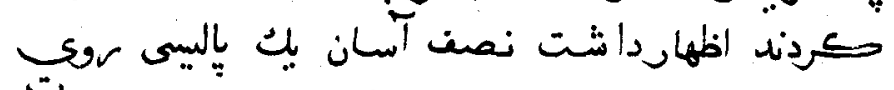

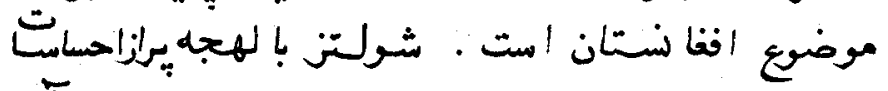

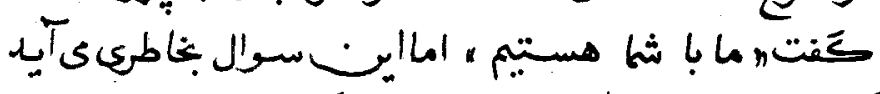

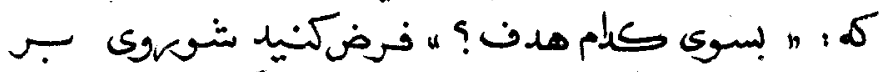

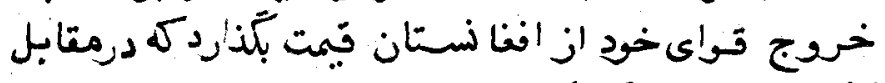

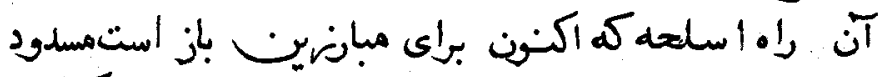

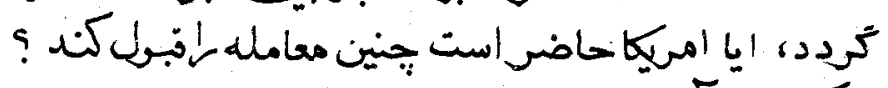

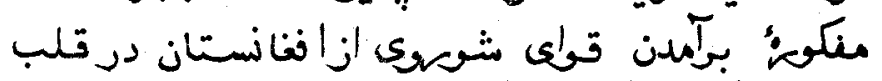

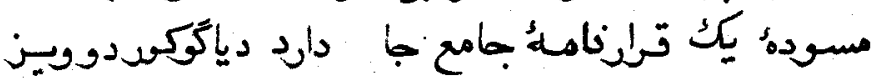

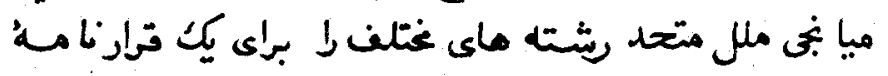

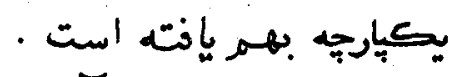

مطلوي ايت تراريه بهم يامه آنست كه كئ اتش بس ( (ورنبند) 


\section{0}

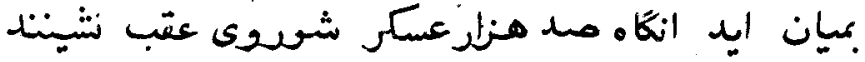

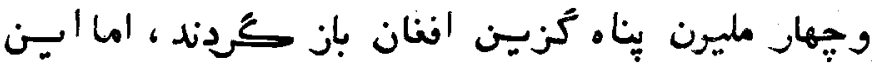

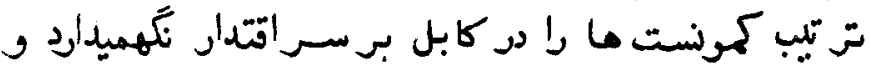

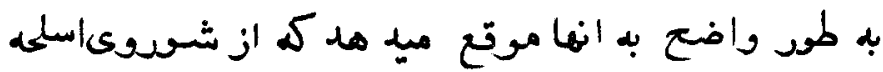

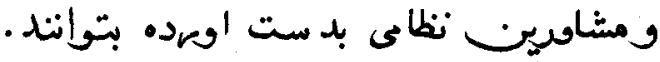

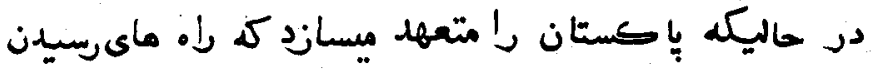

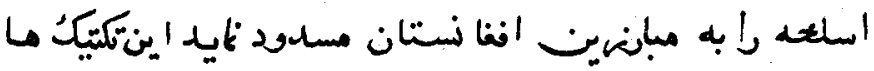

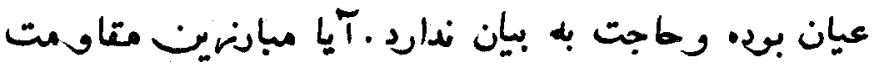

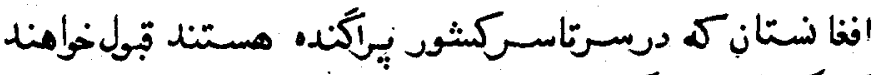

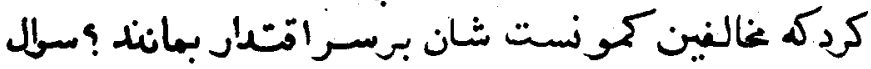

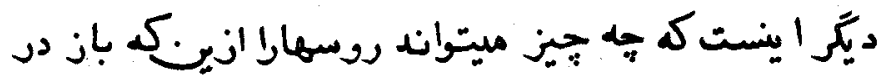

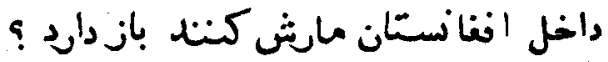

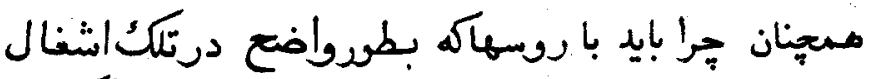

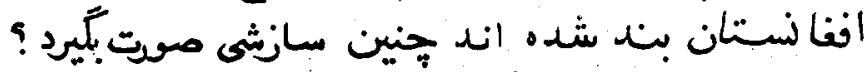

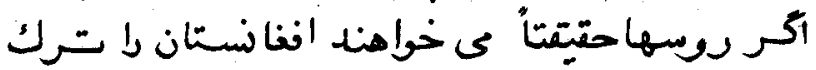

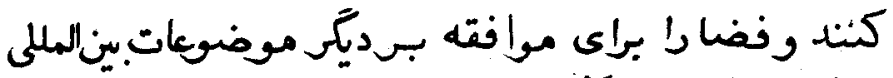

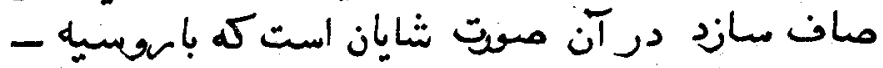

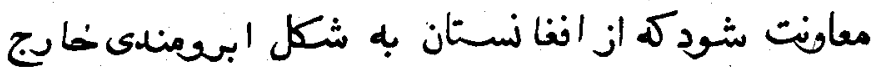

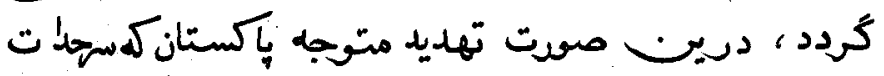

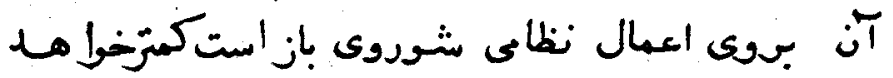

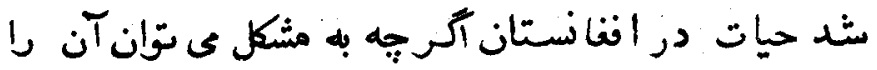


127

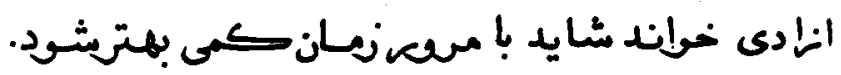

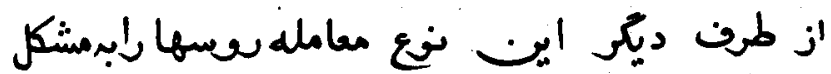

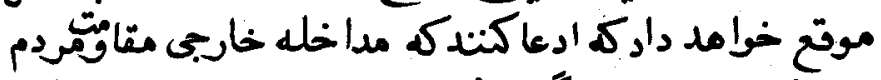

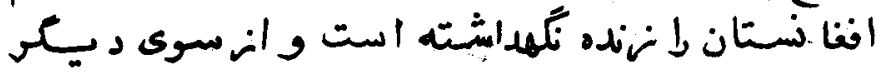

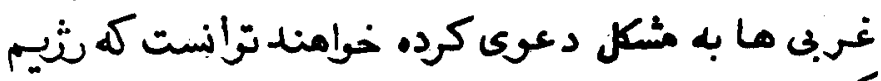

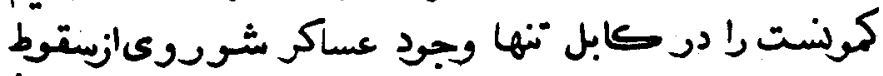

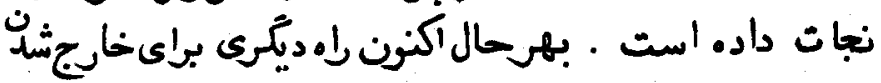

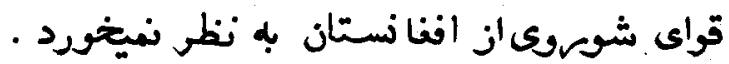

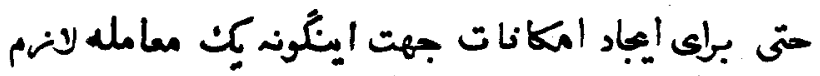

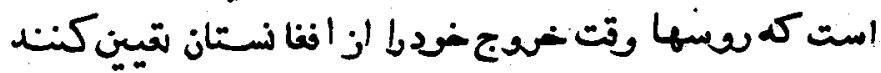

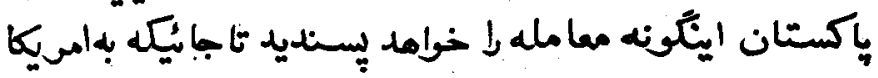

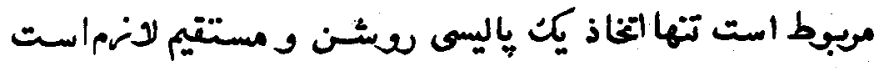

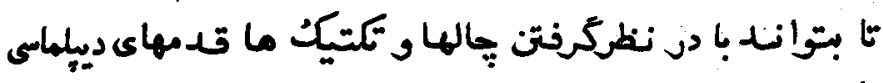

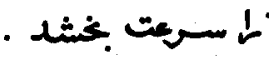

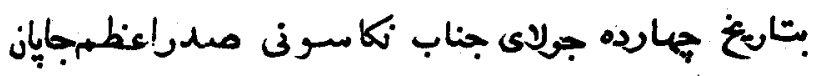

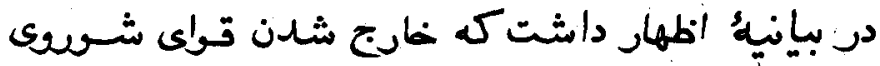

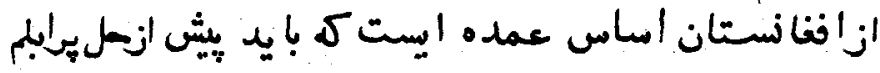

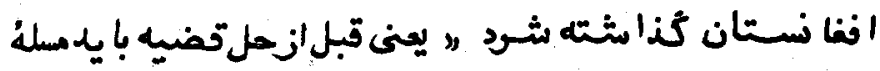

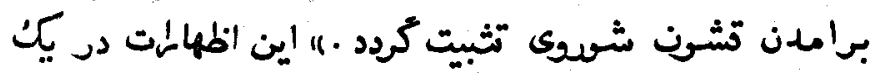

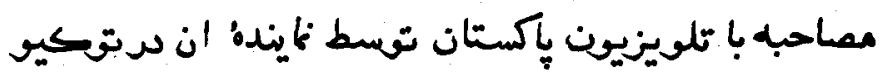

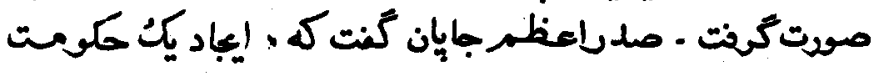


بر اسلس حت تهين مسريفشت مردما فنا نستان أساس

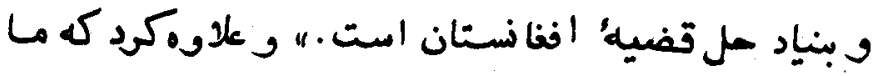

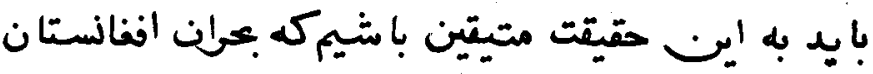

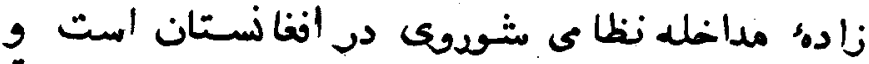

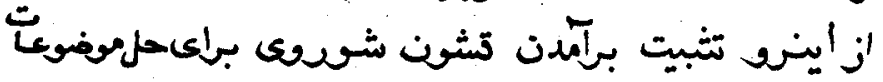

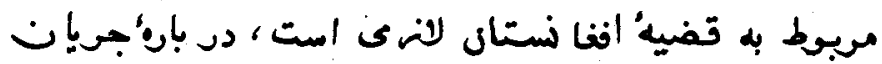

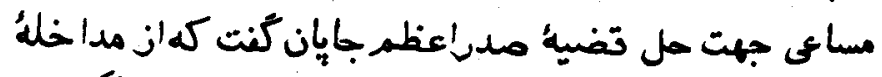

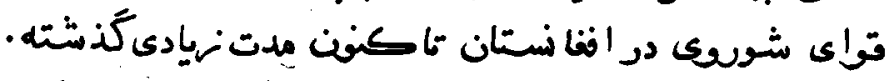

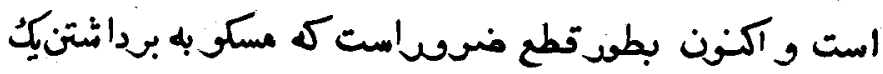

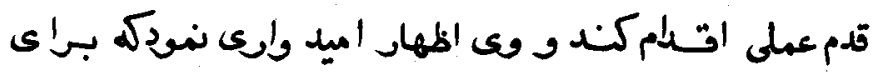

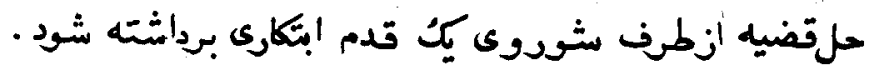

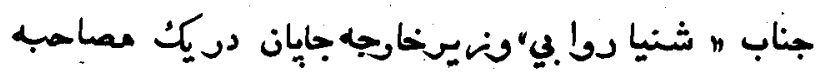

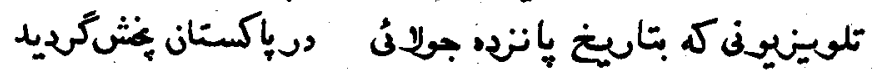

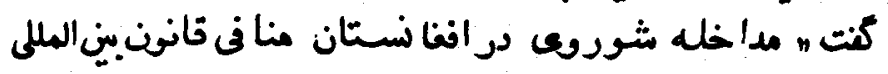

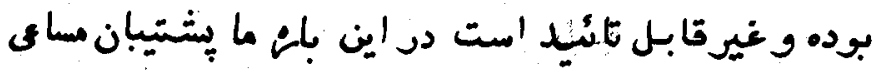

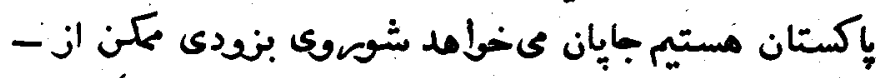

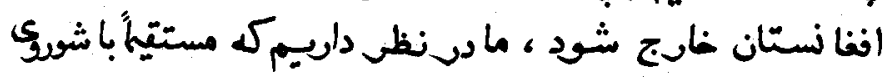

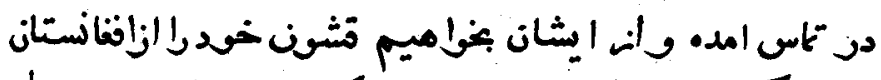

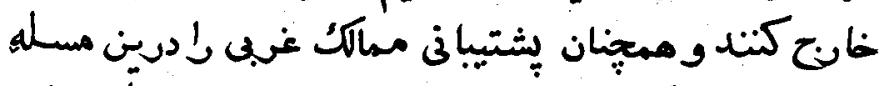

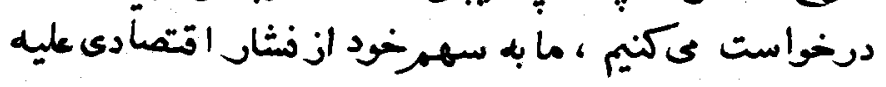

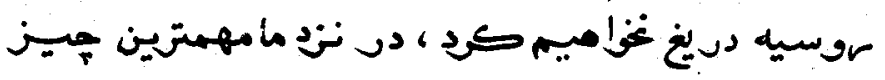


121

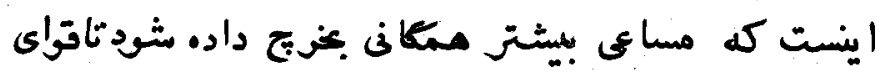

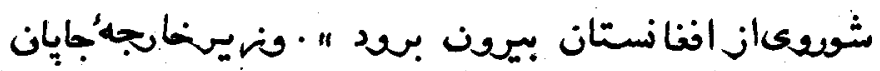

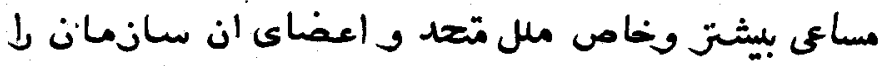

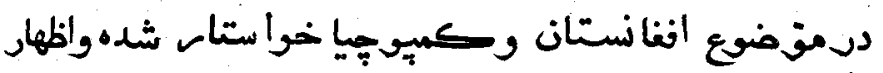

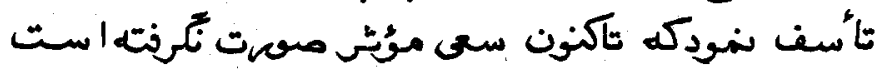

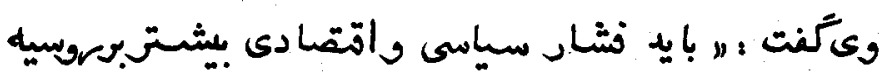

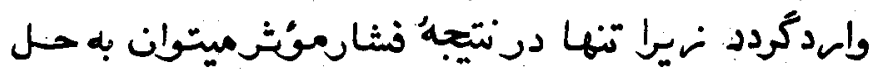

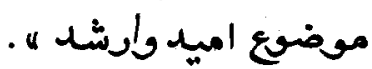

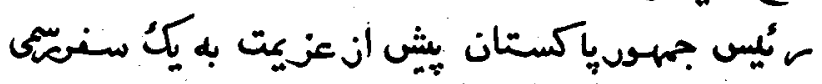

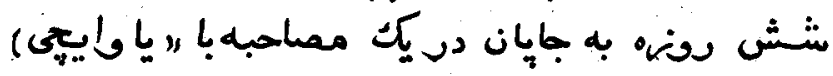

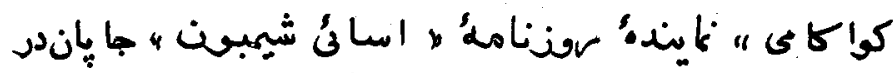

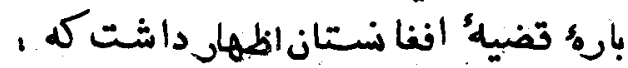

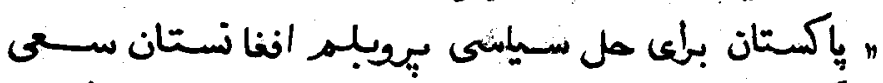

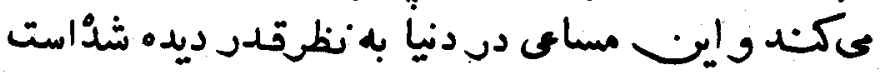

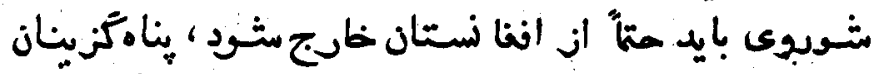

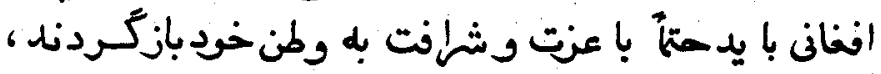

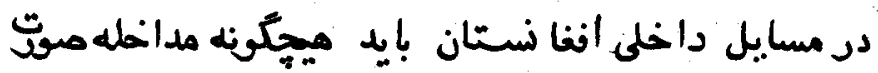

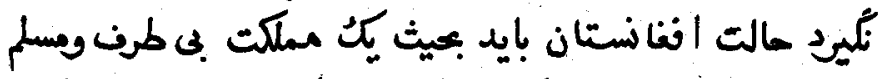

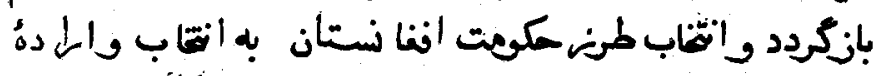

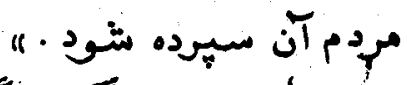

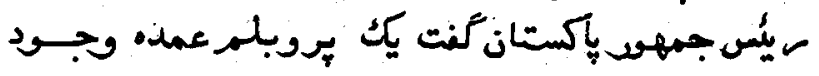




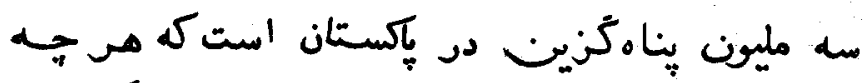

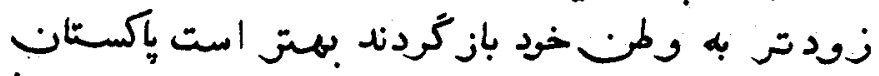

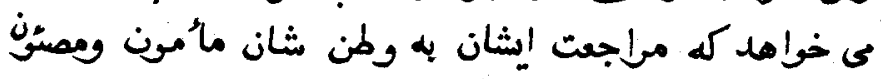

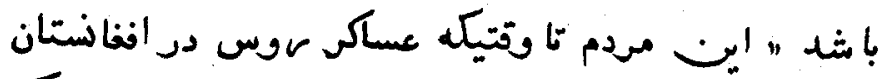

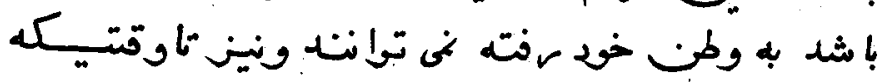

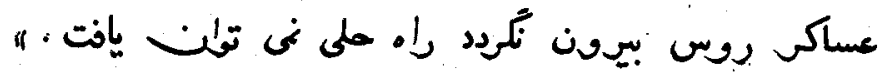

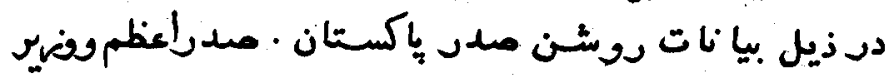

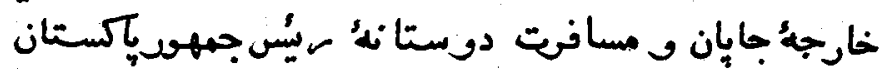

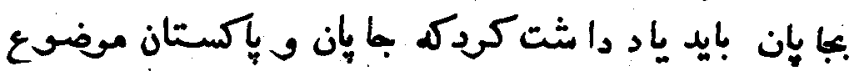

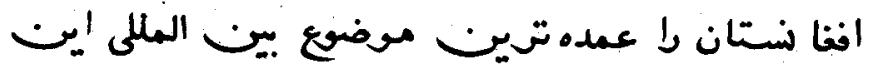

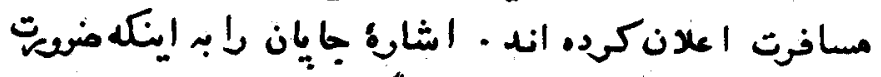

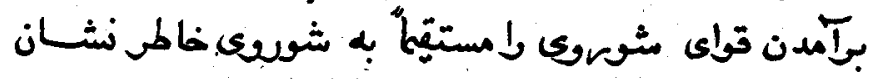

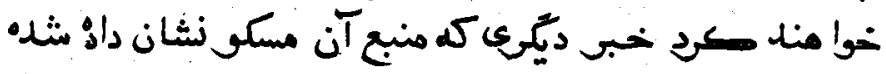

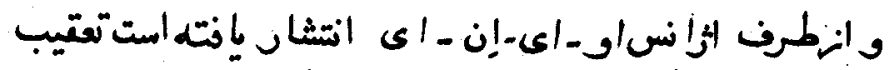
مكند.

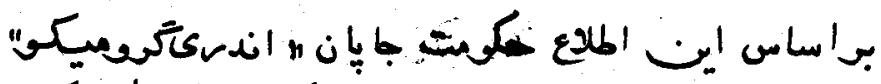

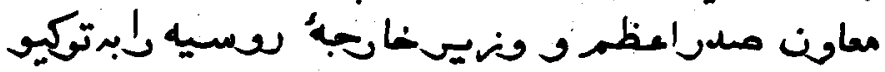
دعوت كيد. است .

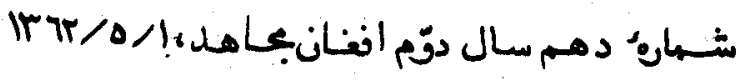




\section{موضوعمورد توجهاصممهاجرين مرحلة قككرعميق}

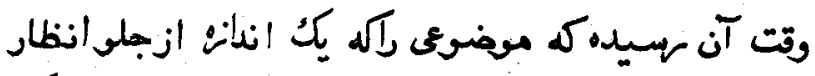

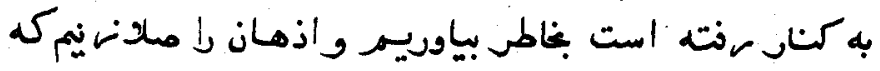

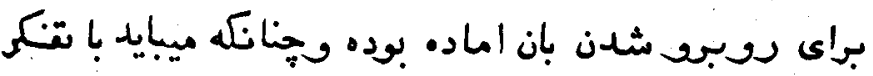

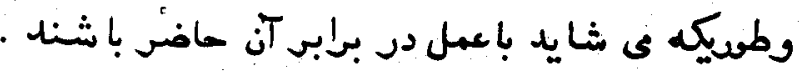

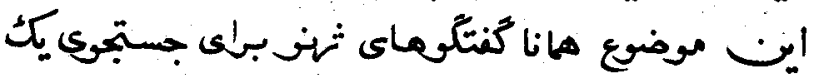

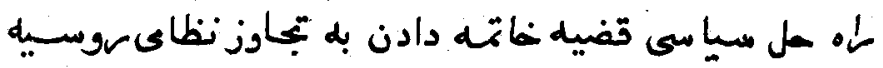

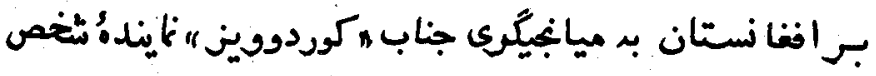

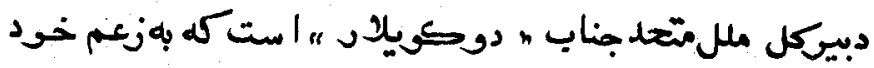

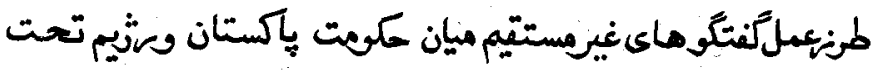




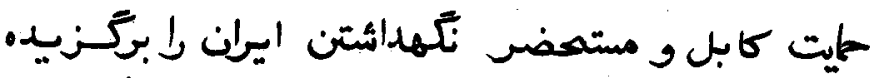

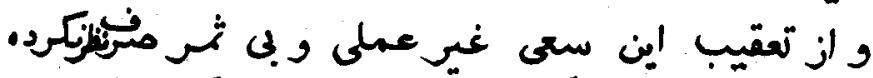

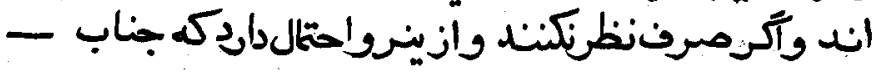

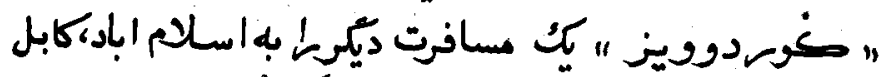

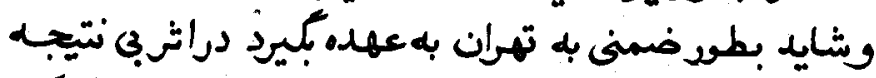

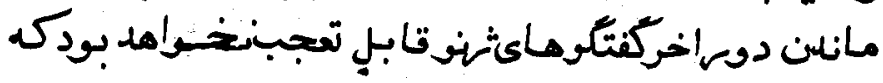

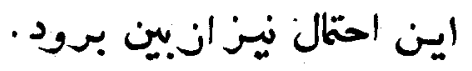

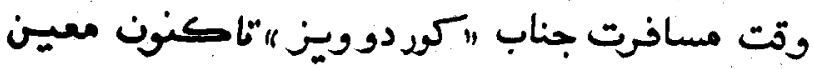

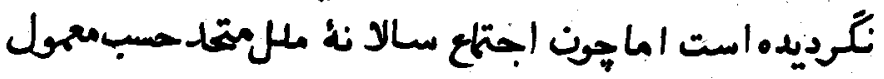

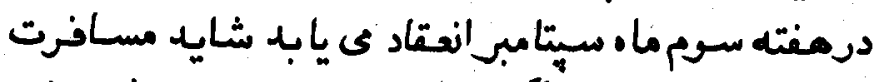

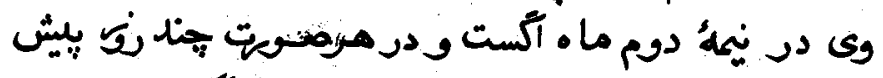

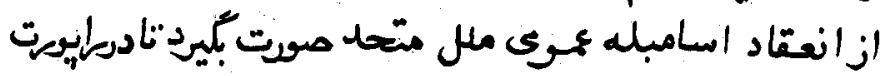

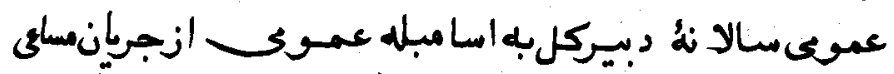

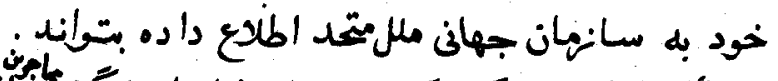

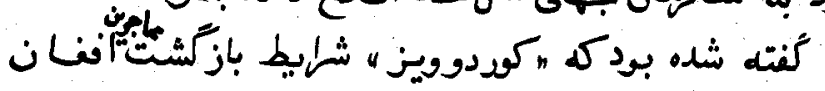

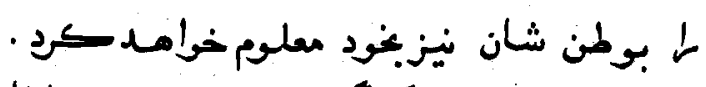

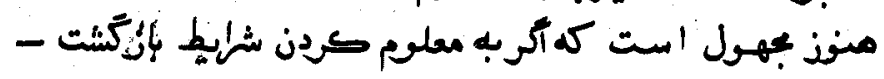

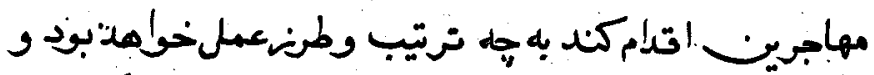

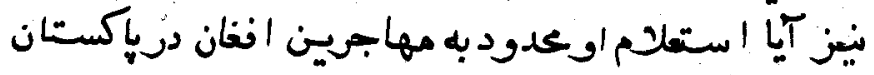

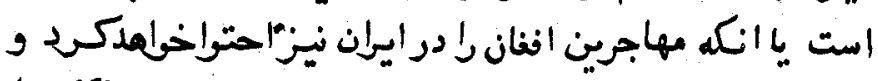

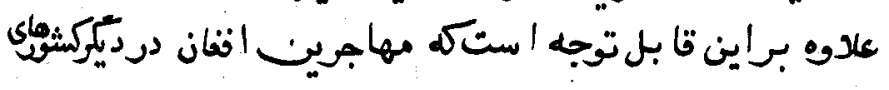




\section{Ior}

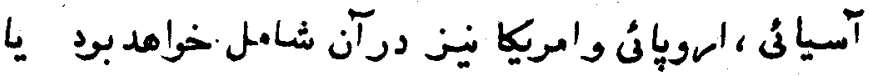

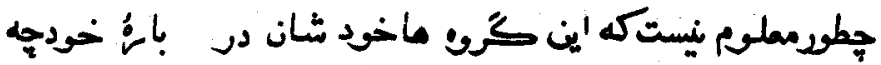
نكريكرده اند.

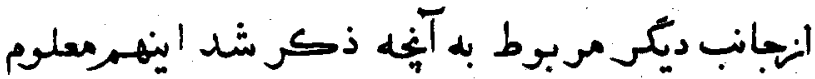

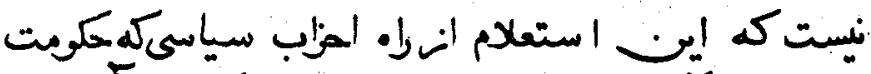

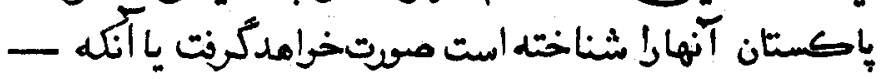

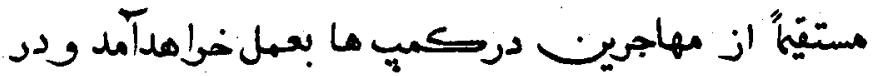

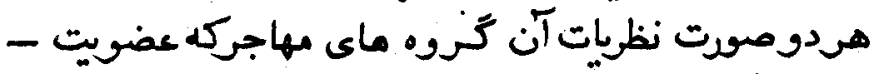

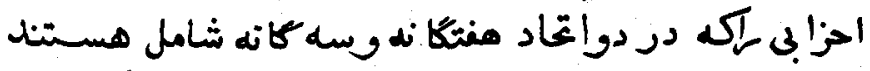

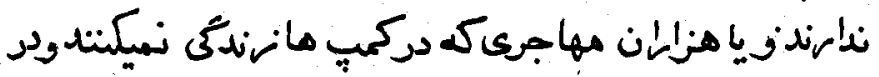

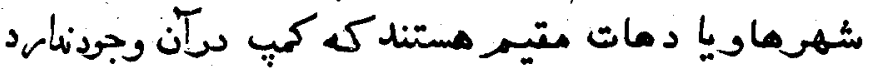

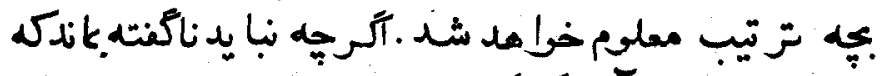

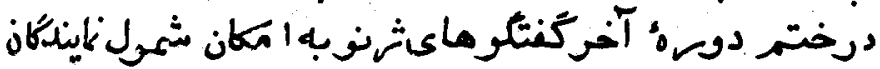

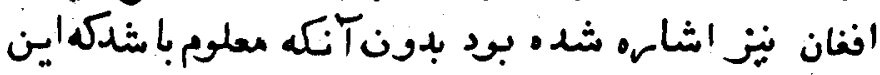

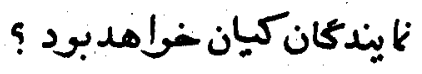

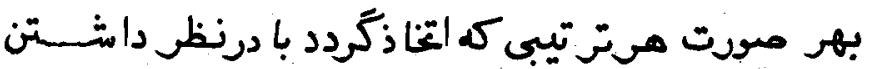

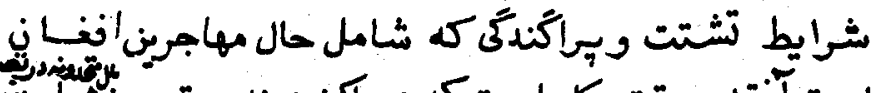

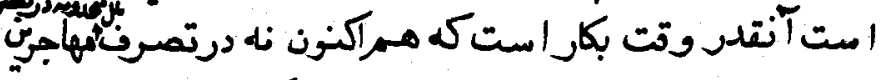

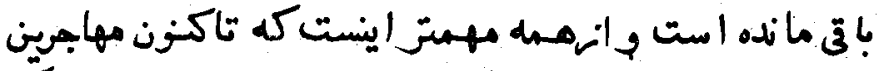

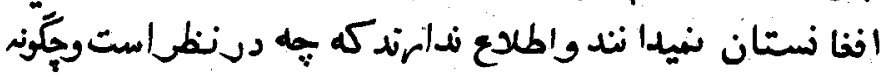
عمل :مالهد شعل: 


\section{lor}

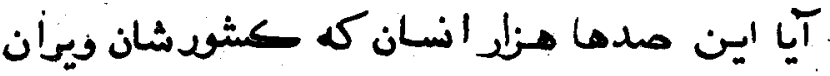

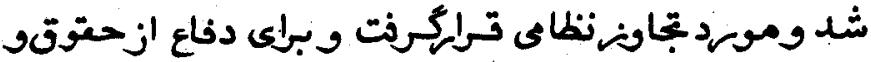

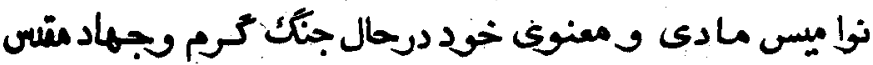

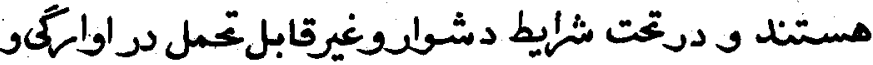

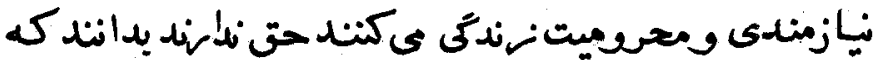

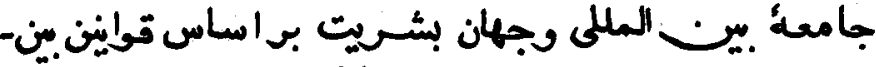

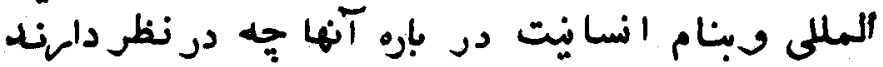

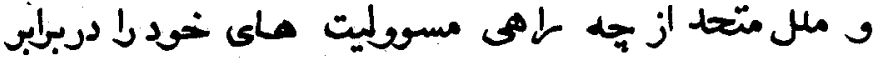

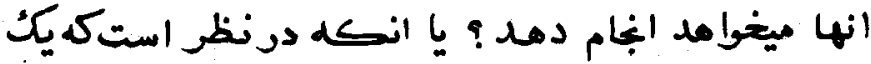

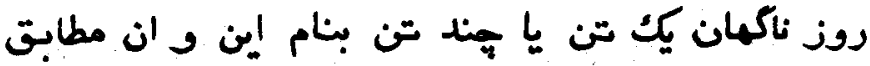

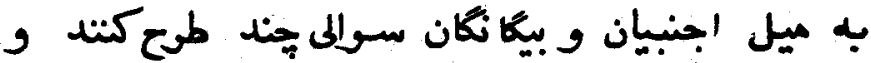

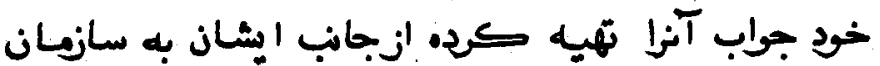

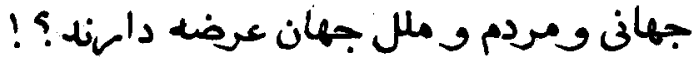

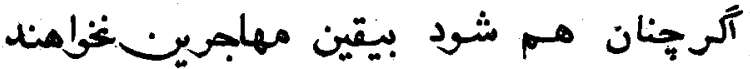

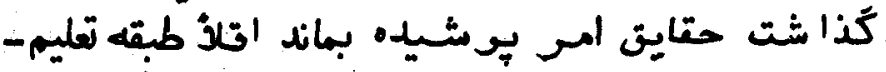

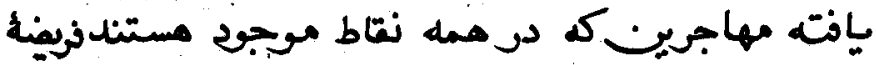

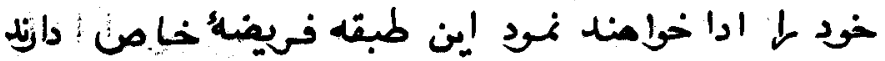

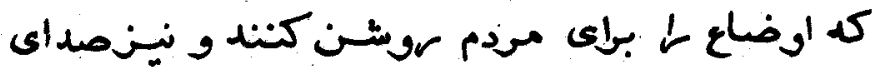

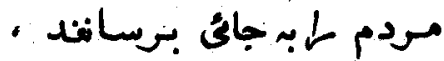

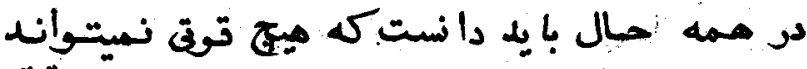

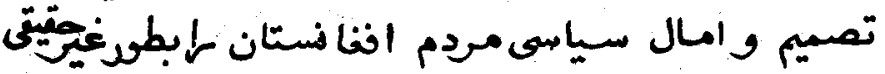




\section{2}

و نا دهست در انظان جهانيان جلو. دمدوانعبواتب

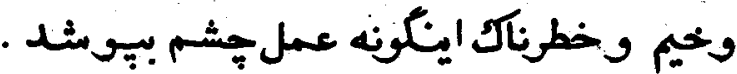

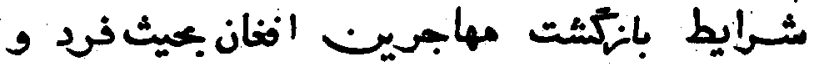

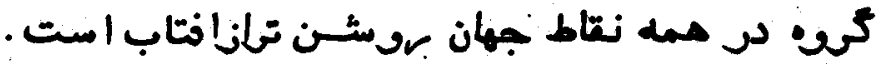

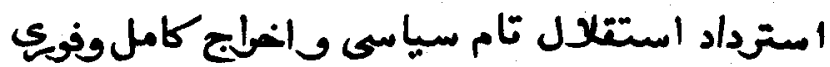

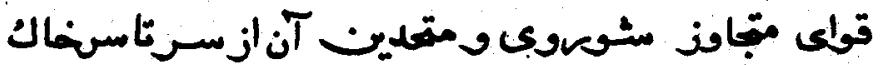

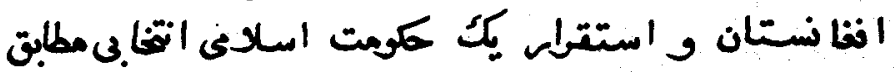

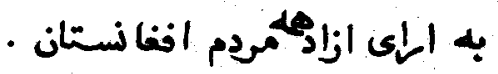

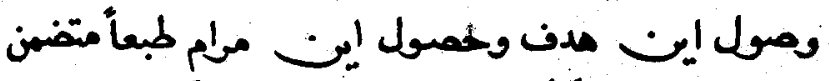

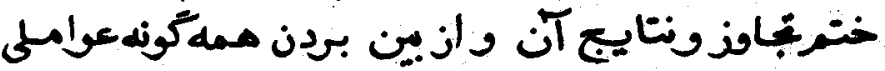

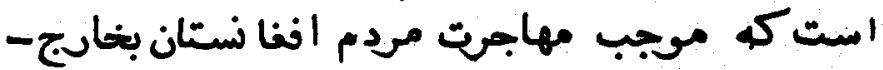

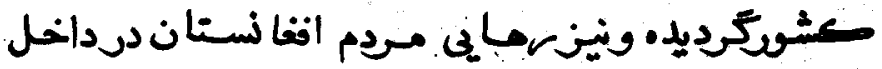

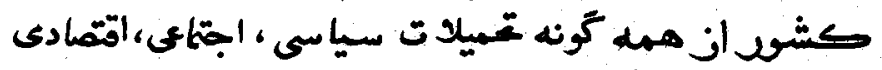

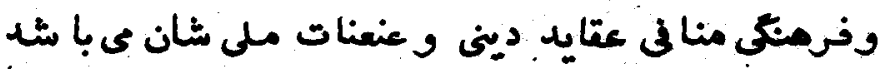

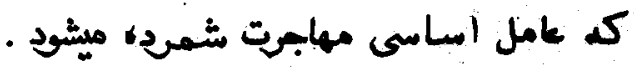

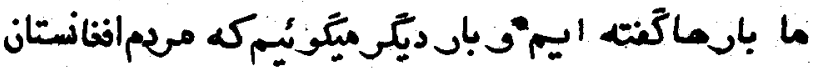

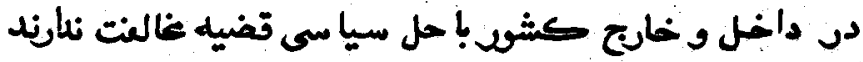

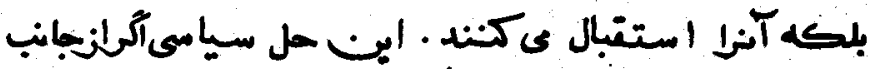

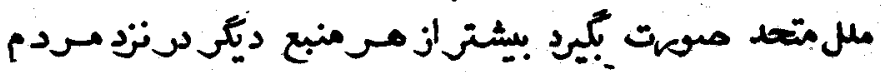

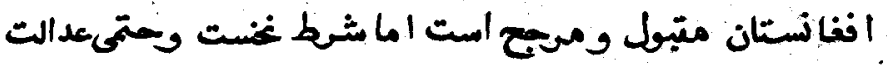

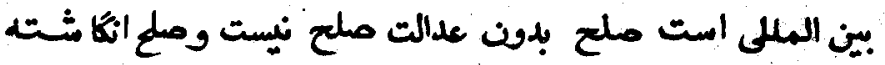




\section{0}

شده هن توإند زيسا امن و مشلام بايدار بلدف عدالتمكن

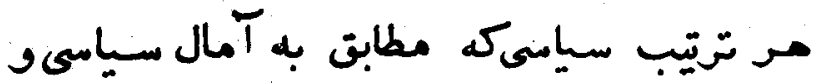

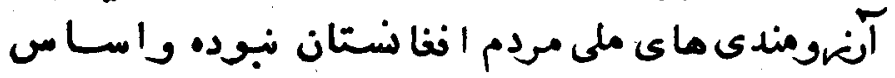

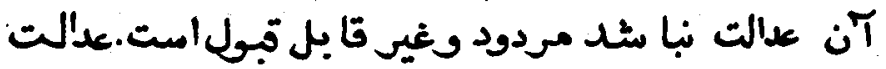

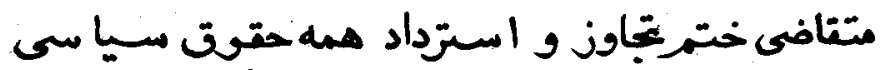

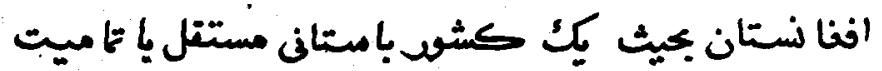

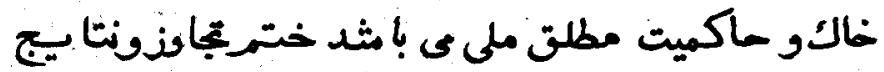

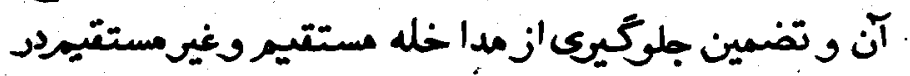

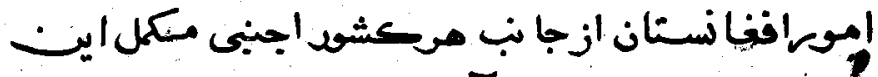

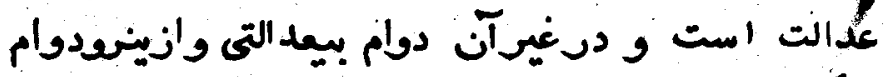

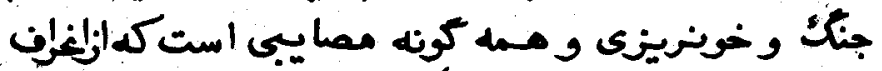

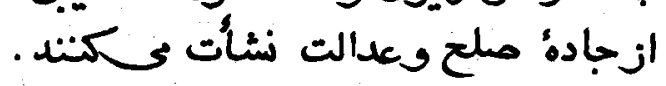

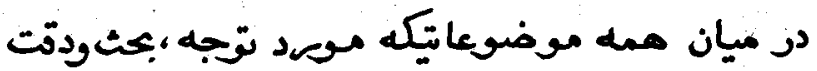

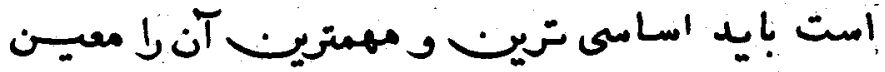

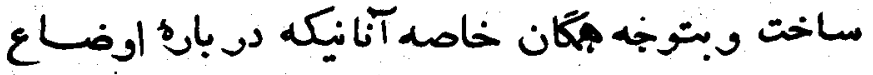

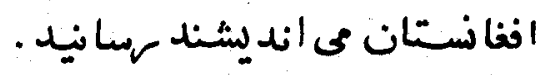

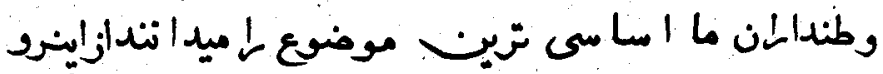

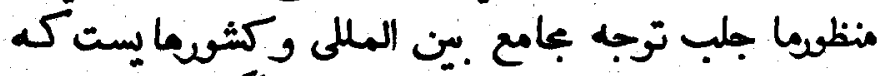

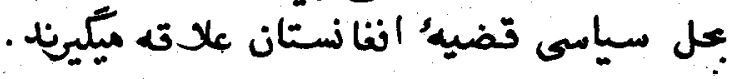

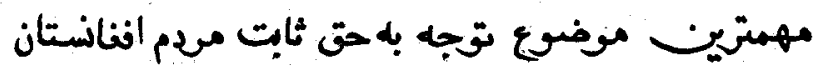


107

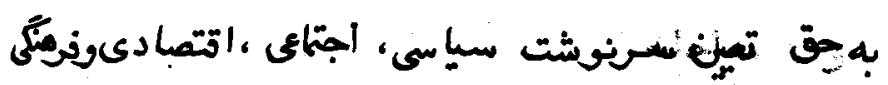

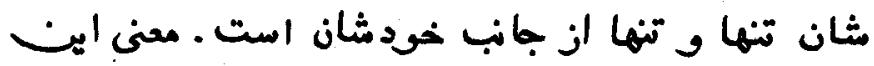

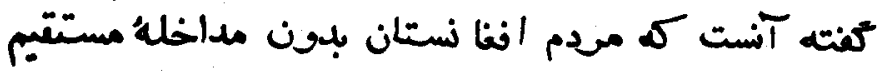

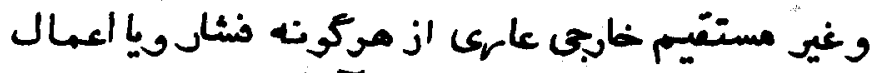

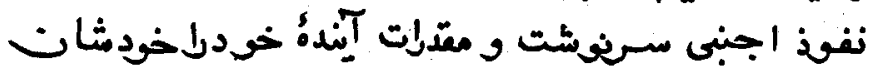

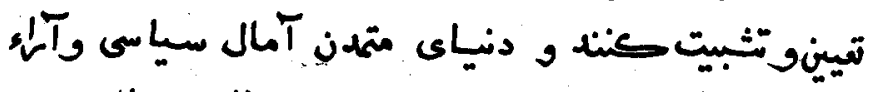

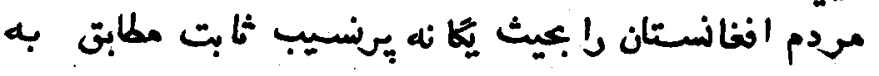

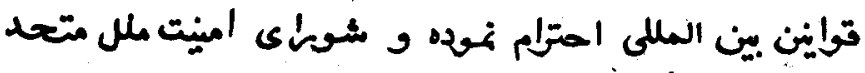

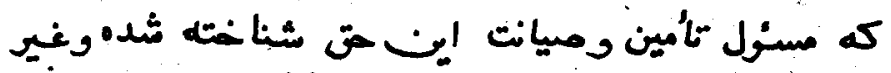

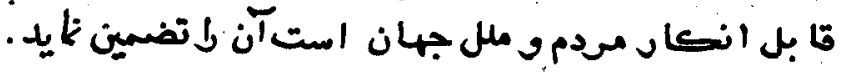

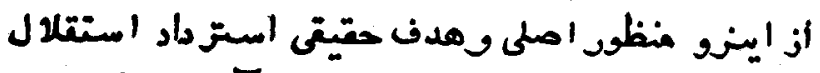

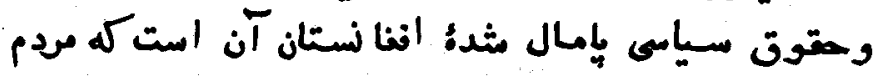

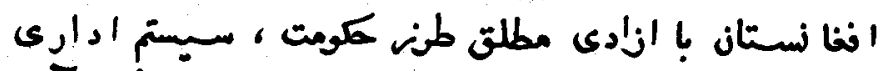

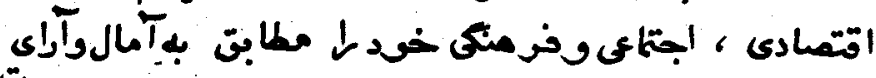

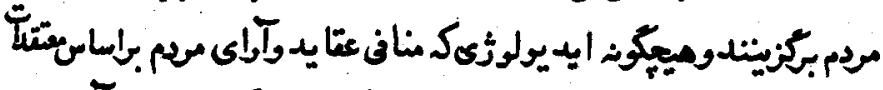

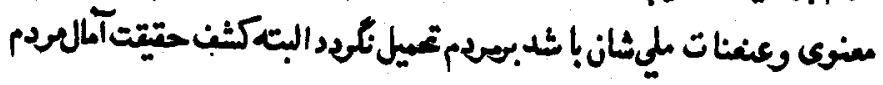

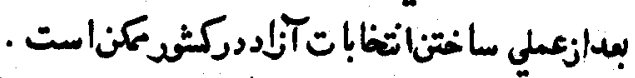

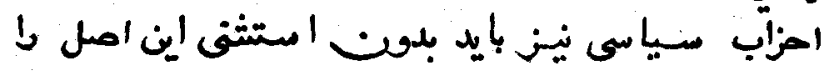

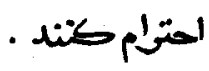

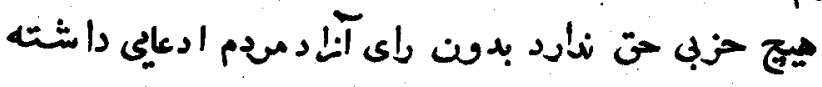

با شد. 


\section{lav}

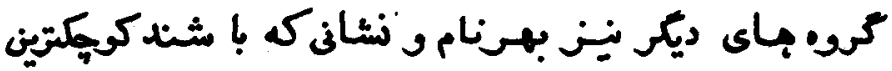

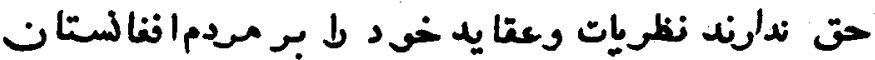

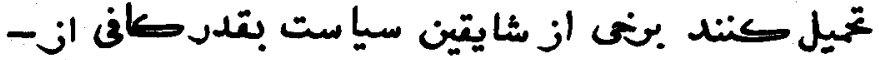

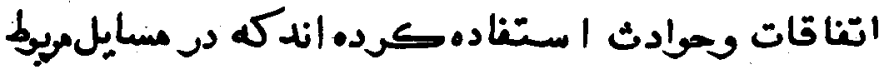

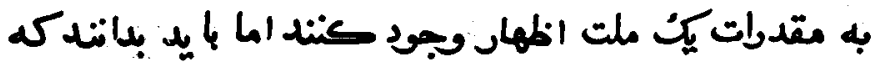

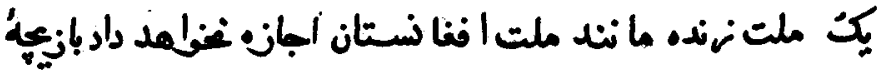

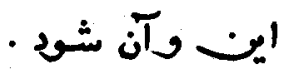

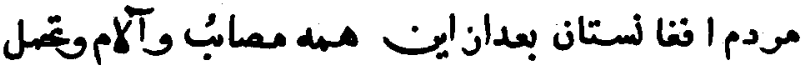

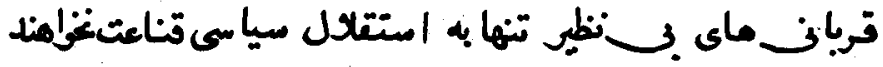

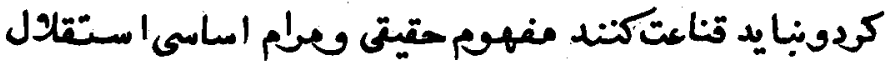

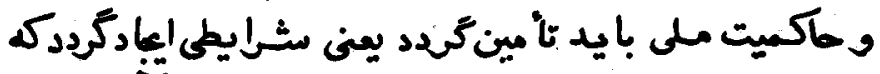

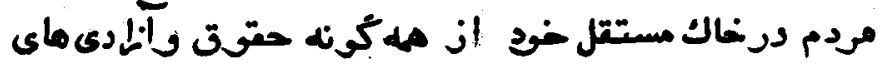

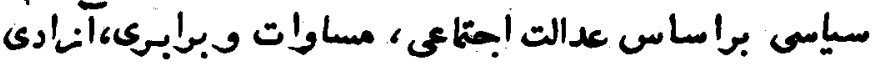

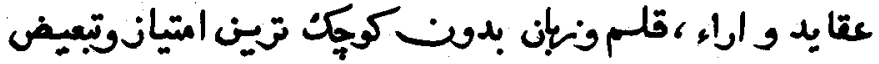

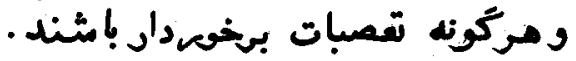

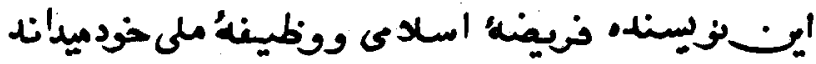

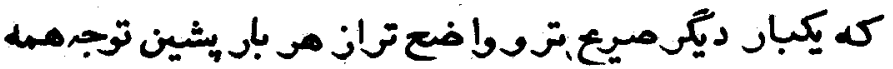

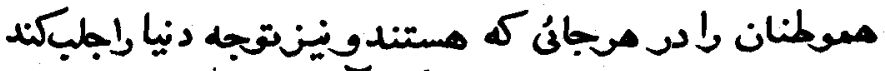

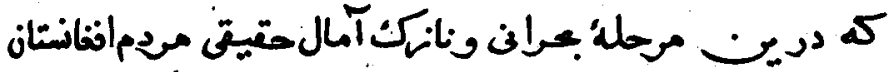

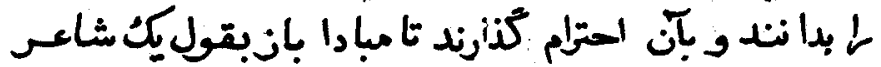

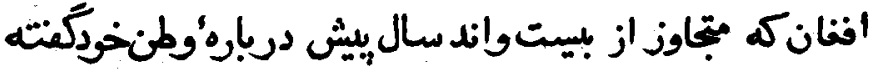




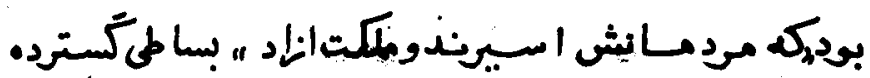

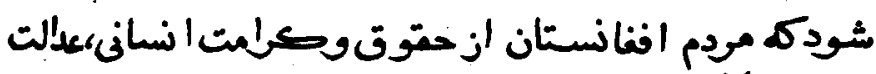

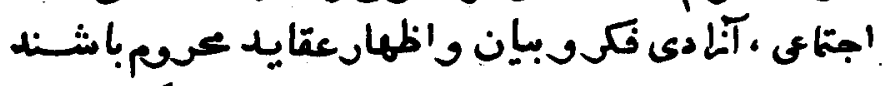

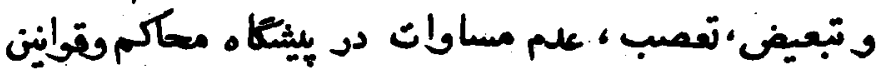

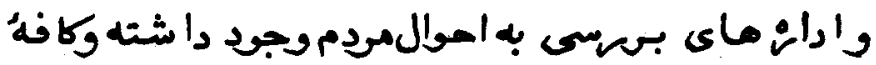

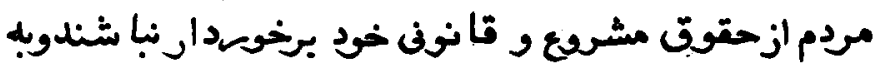

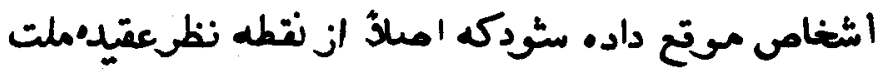

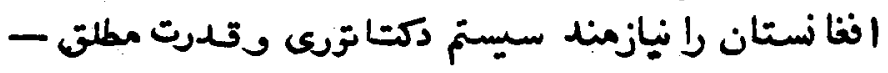

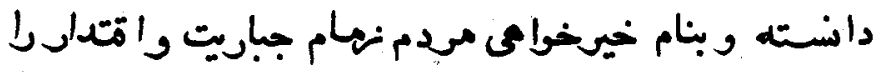

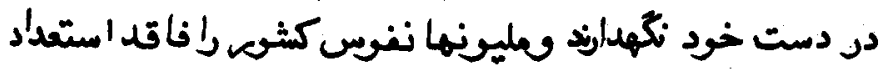

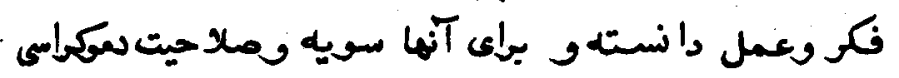

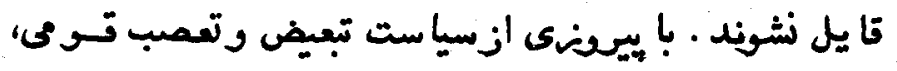

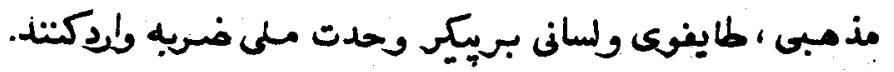

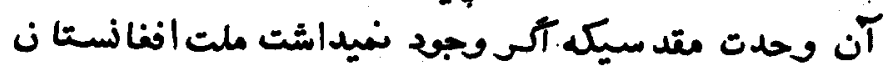

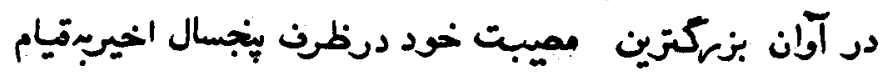

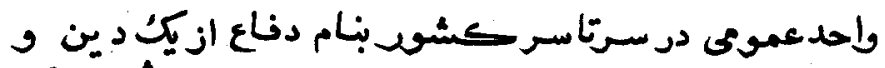

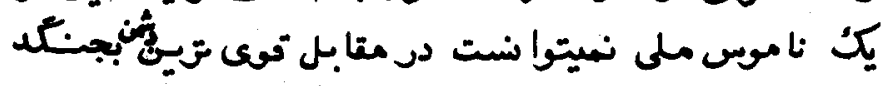

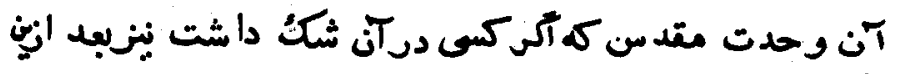

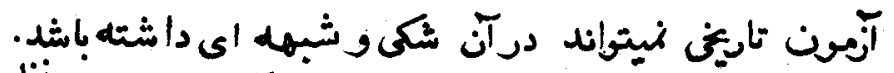

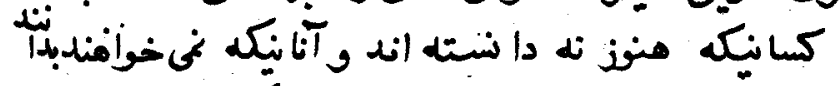

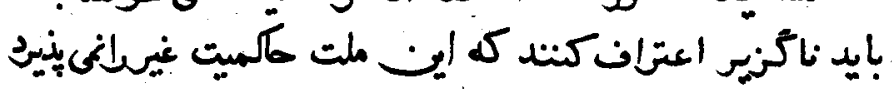




\section{9}

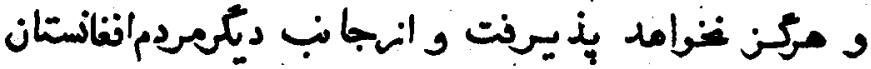

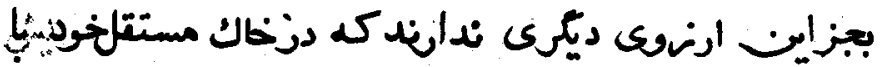

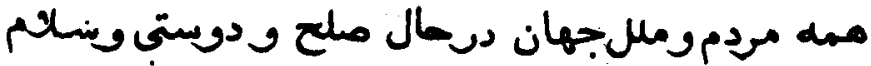

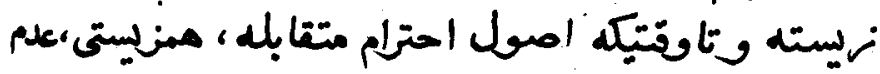

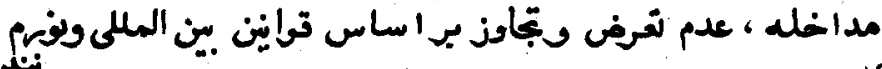

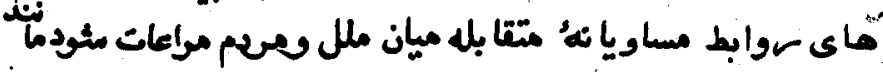

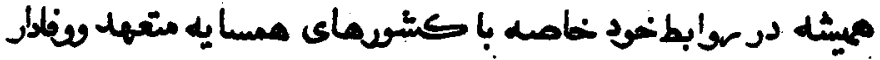

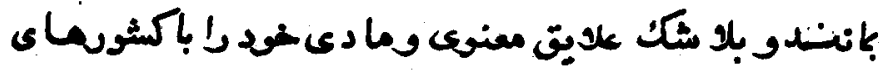

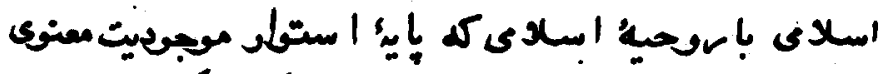

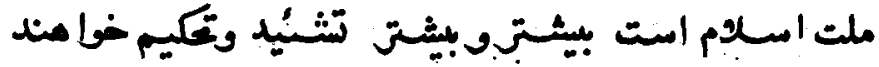

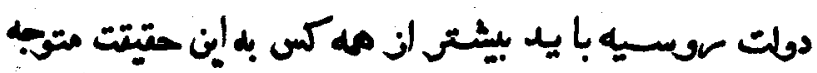

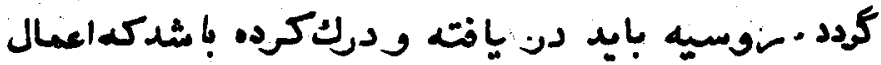

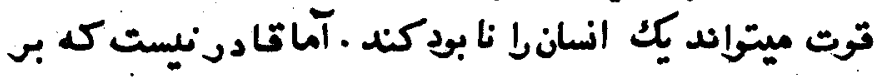

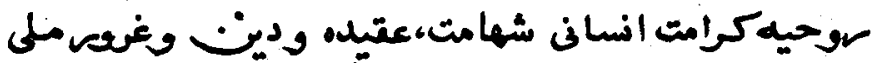

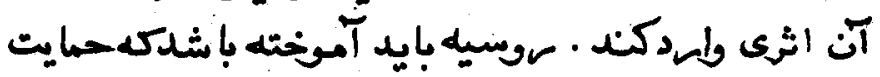

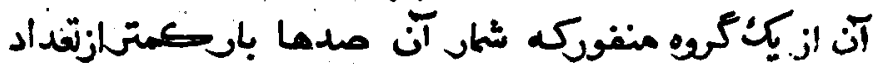

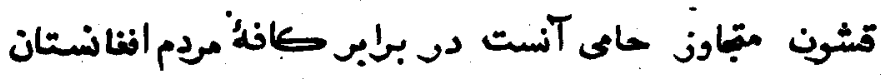

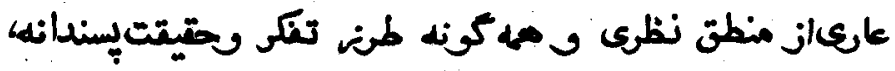

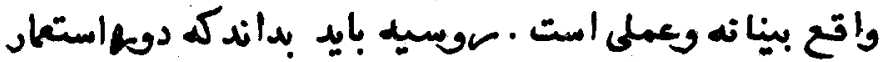

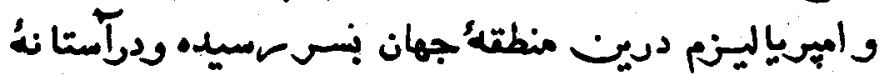


قهن الr بركنيدن كشيوع كم نخستين تيامكتد. درمتابل

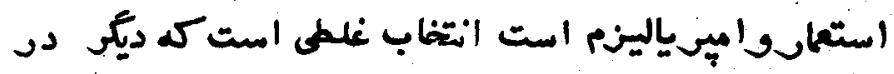

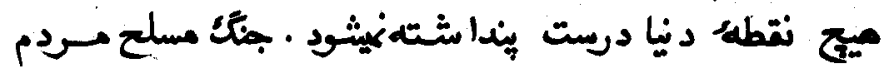

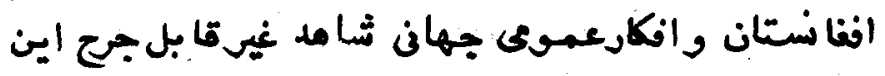
دعرى است .

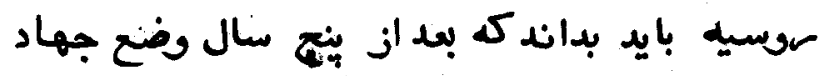

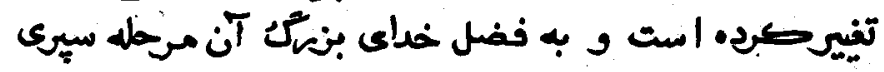

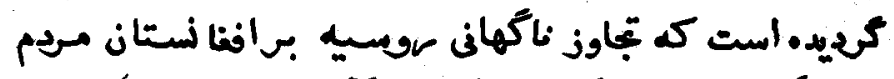

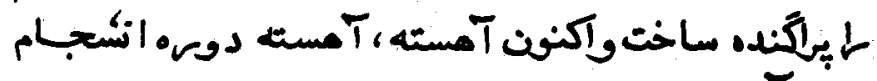

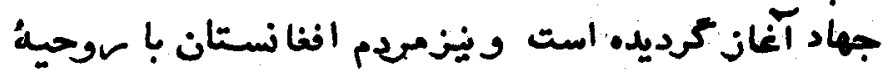

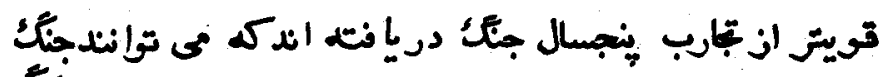

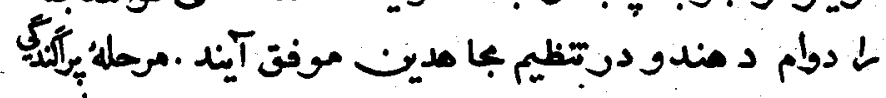

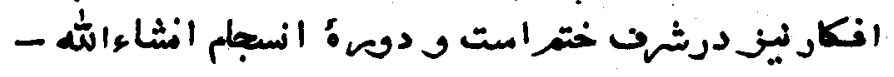

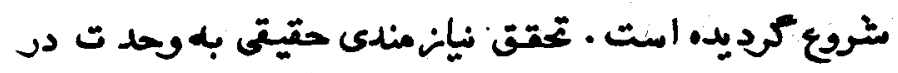

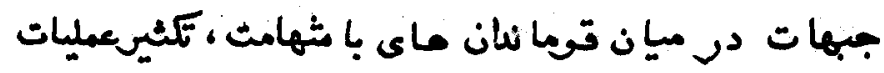

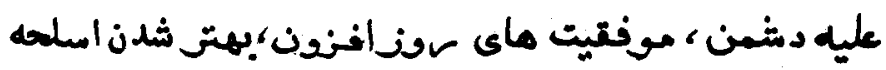

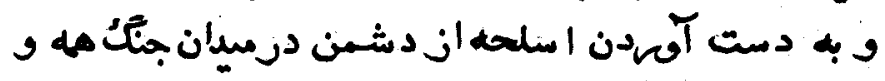

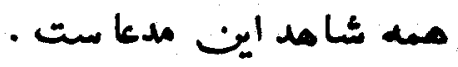

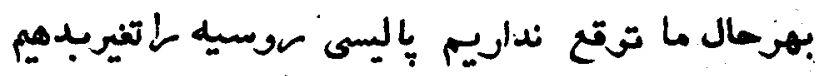

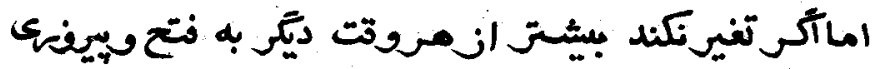

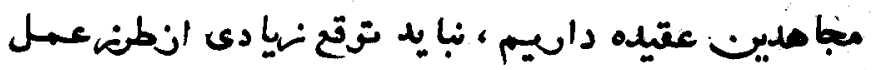


171

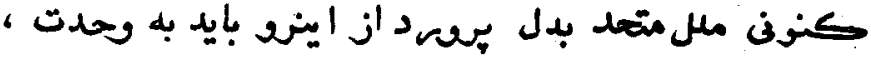

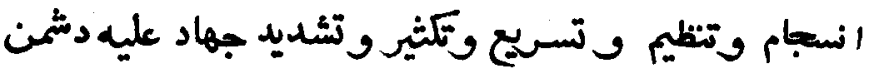

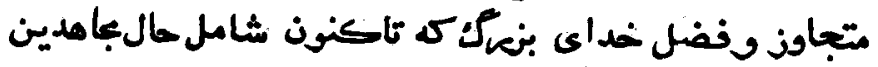

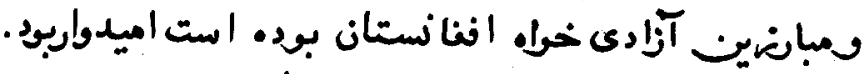

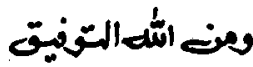

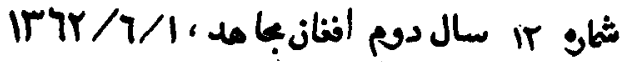


درخواسترافقانبامده

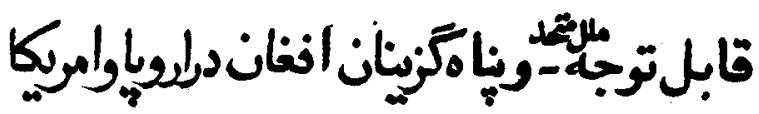

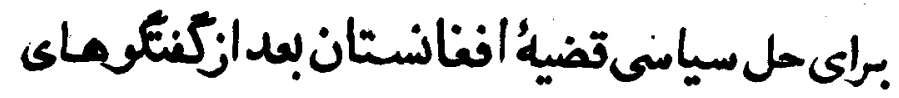

$$
\text { ثهنوجه بايدكرد ؟ }
$$

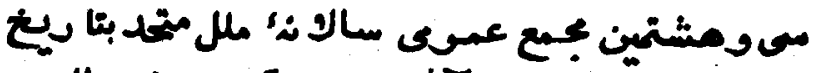

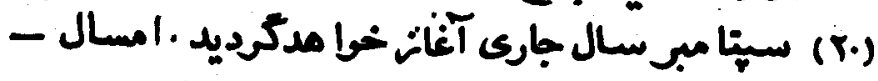

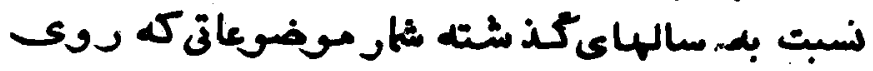

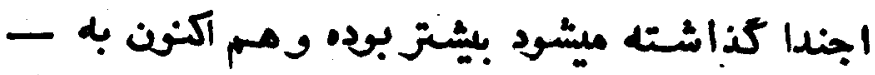

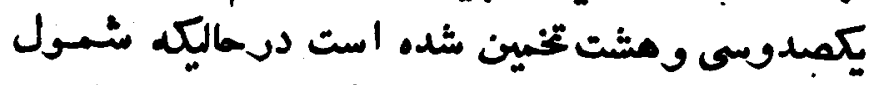

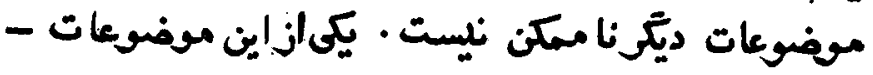




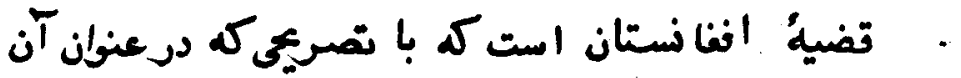

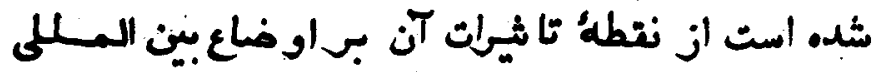

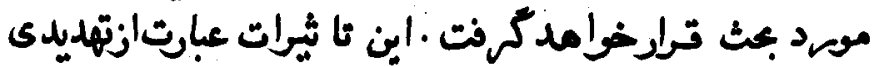

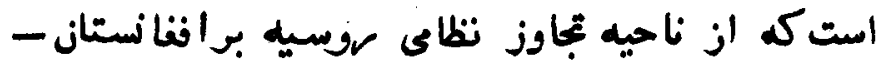

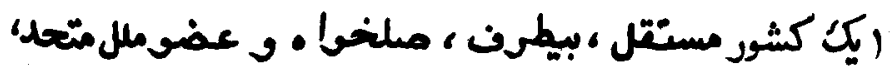

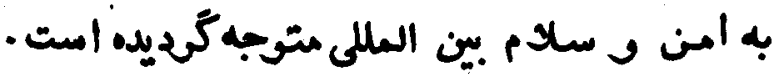

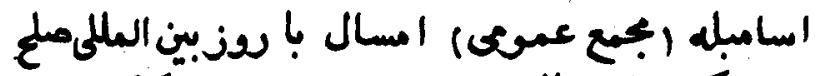

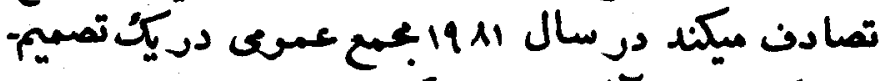

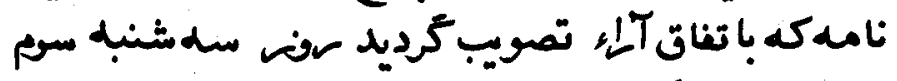

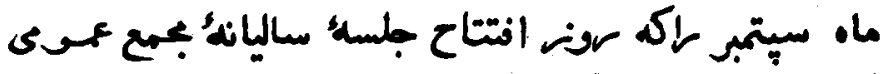

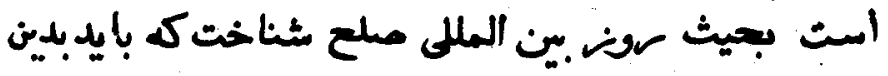

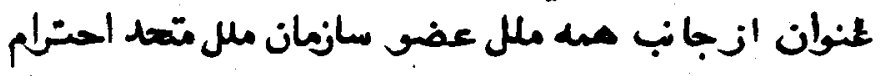

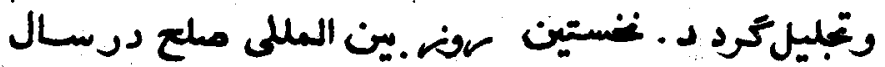


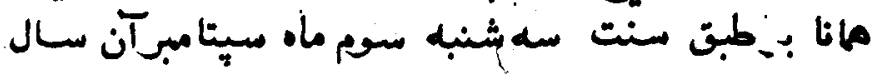

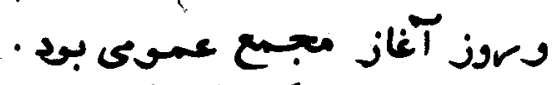

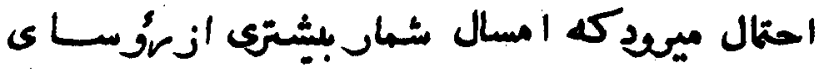

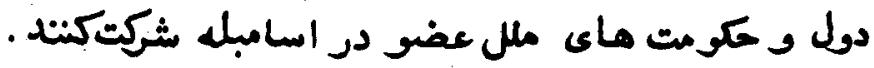

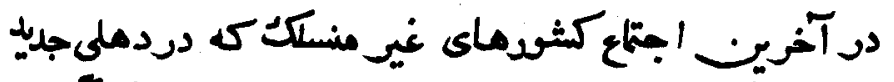

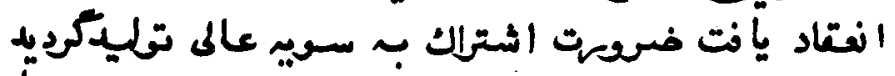

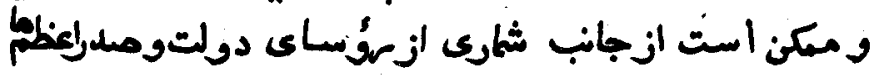




$$
\text { استتبال }
$$

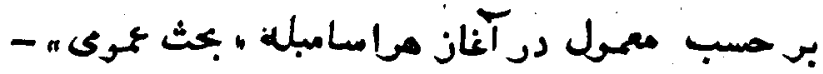

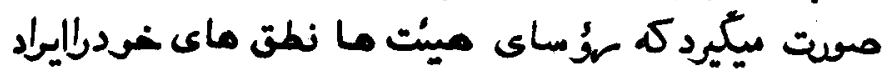

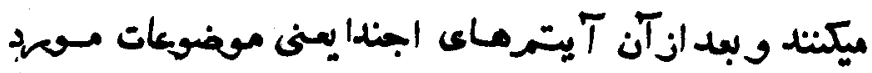

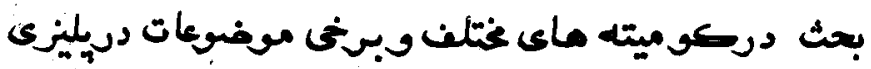

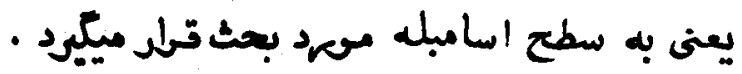

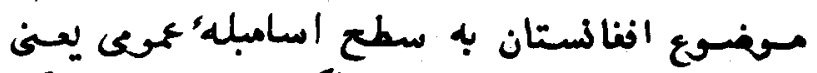

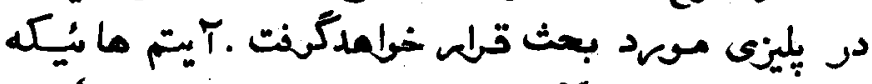

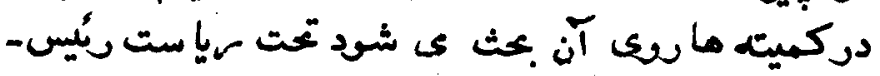

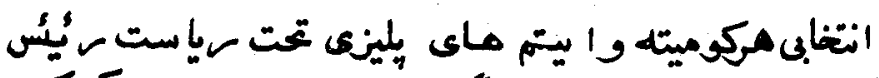

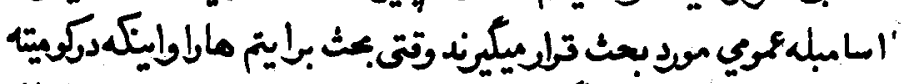

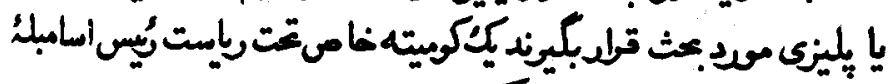

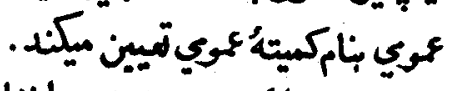

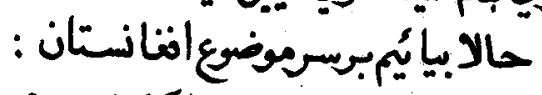

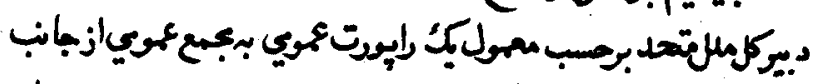

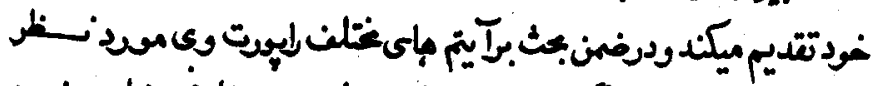

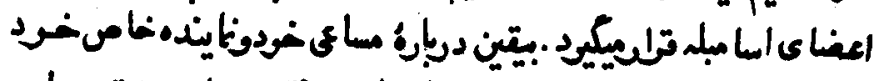

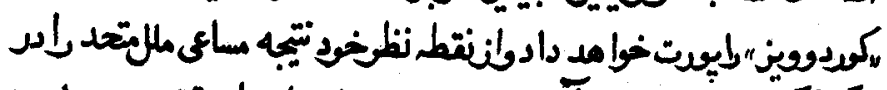

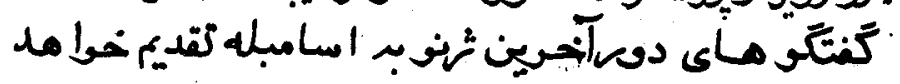

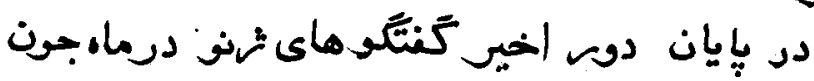




\section{0}

اعلام شدكى "كومهدوفيز" مساخرتى به اسلكم آبادكابل

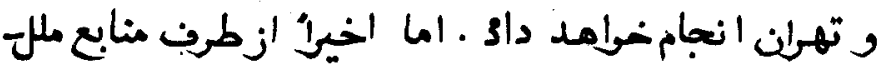

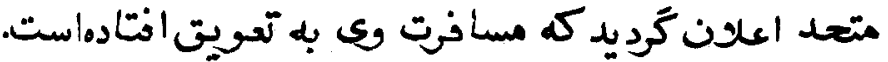

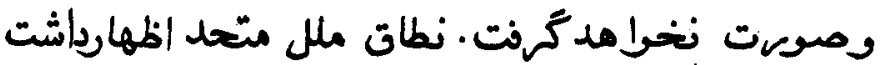

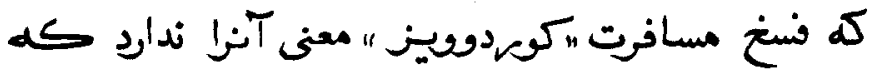

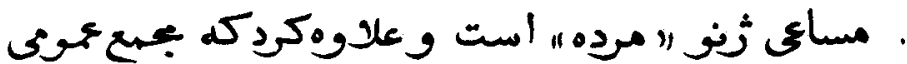

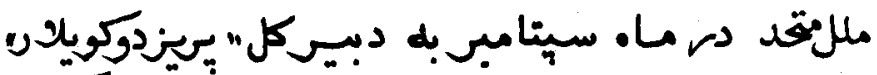

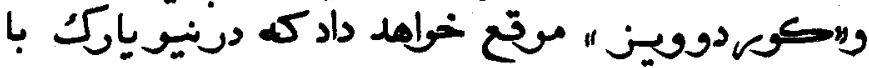

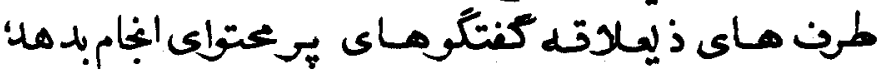

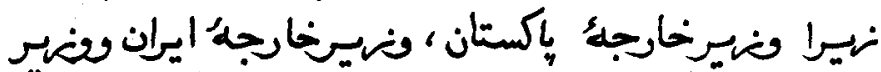

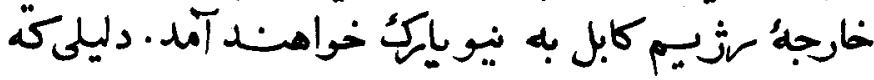

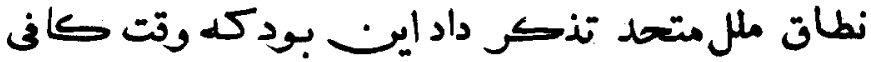

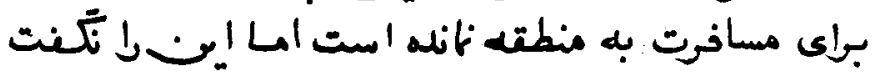

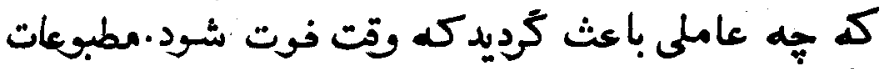

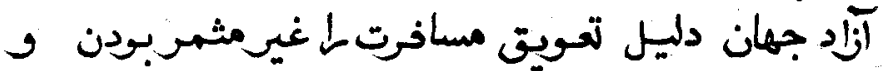

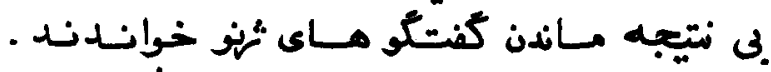

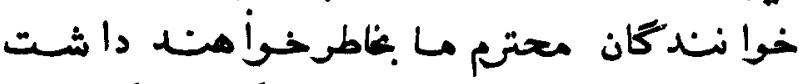

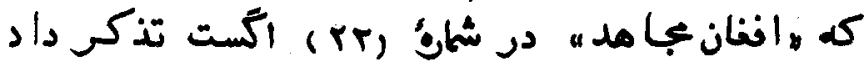

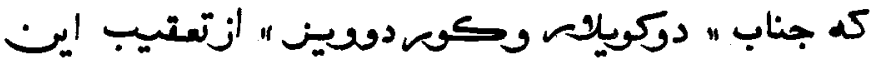

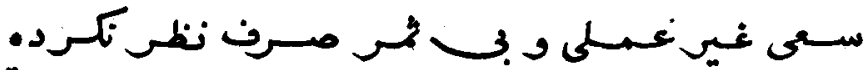

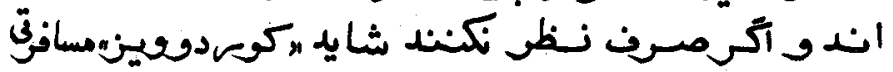




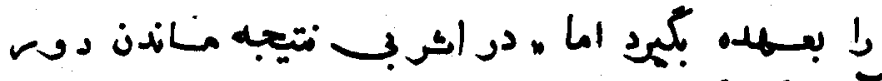

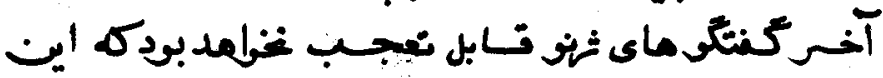

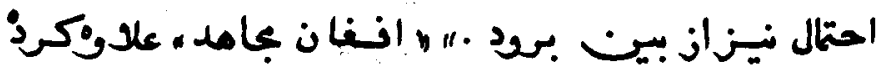

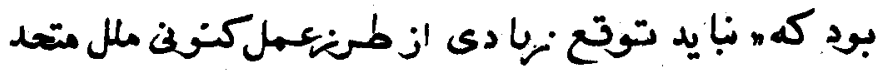

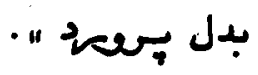

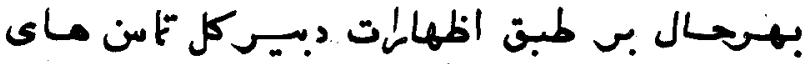

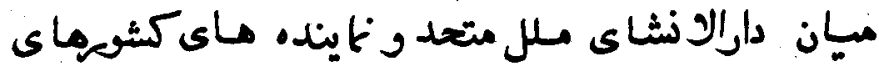

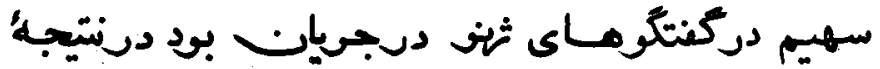

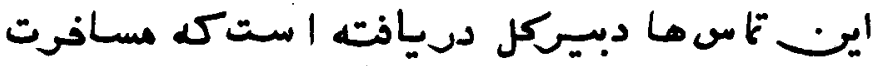

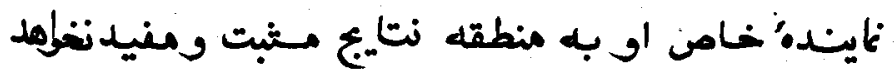

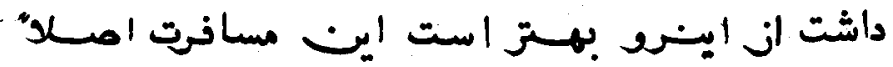

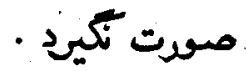

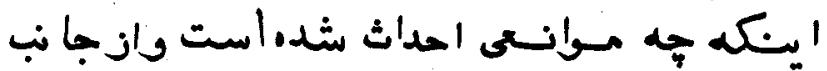

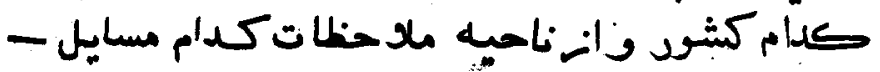

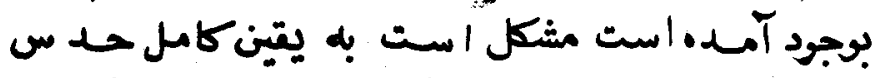

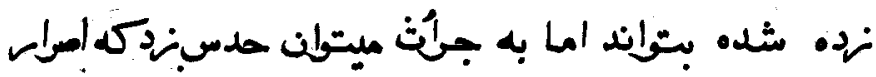

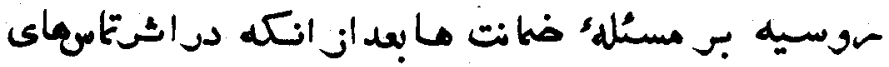

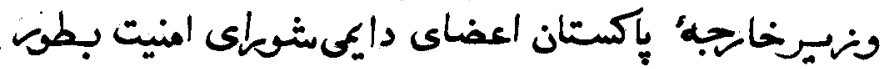

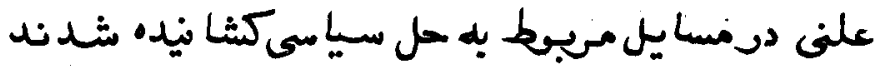

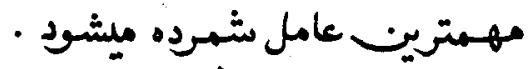

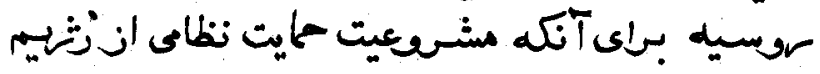




\section{$17 V$}

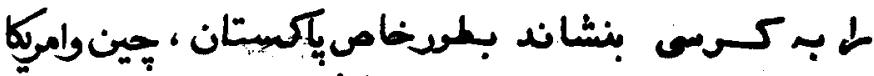

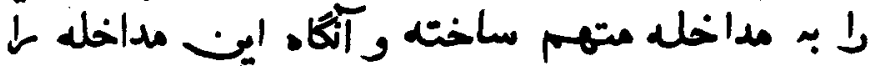

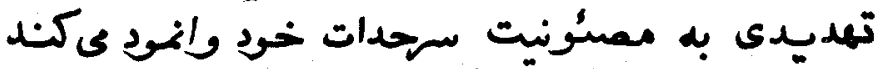

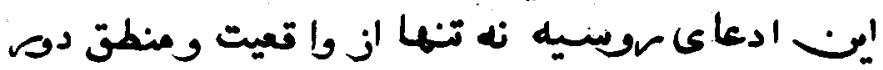

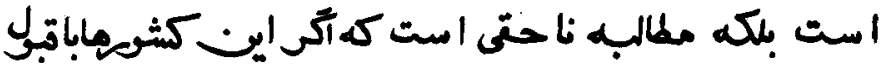

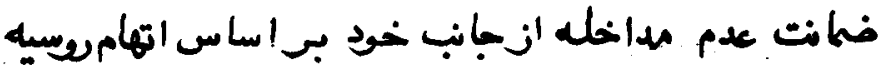

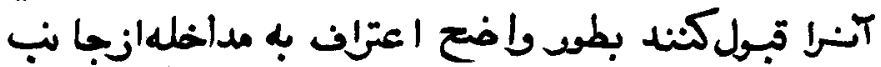

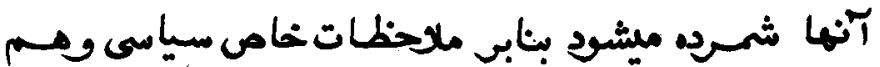

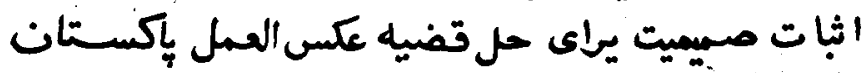

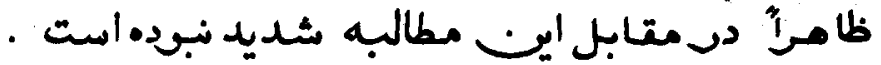

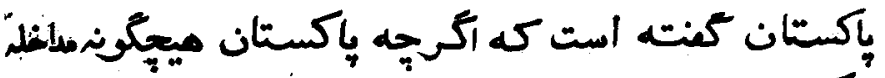

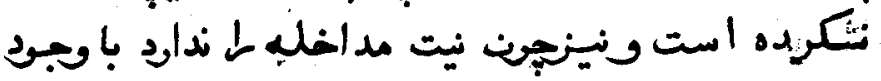

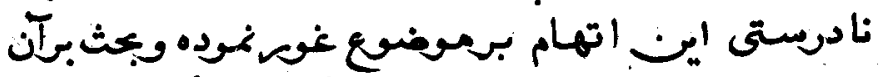

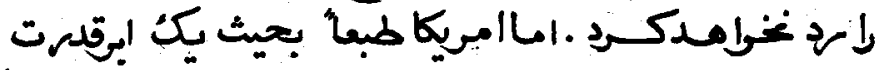

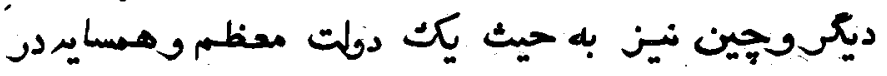

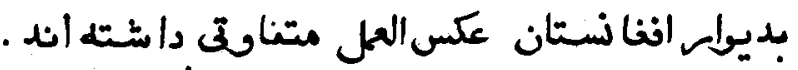

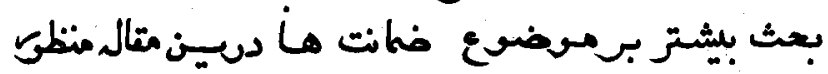

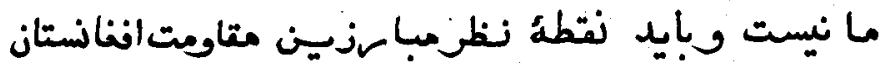

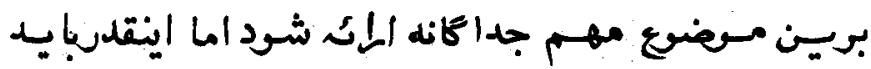

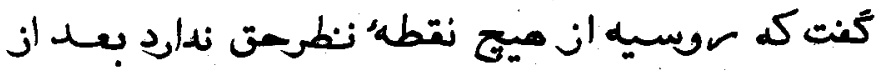

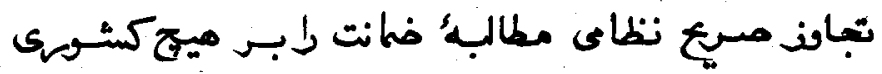


(5)

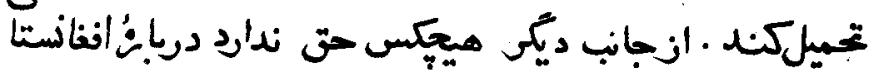

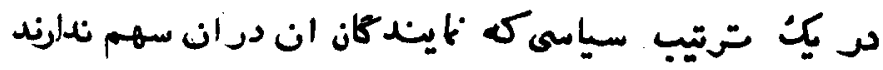

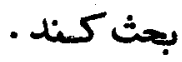

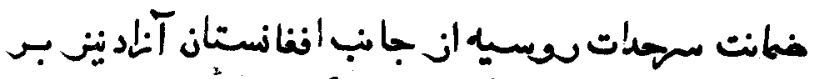

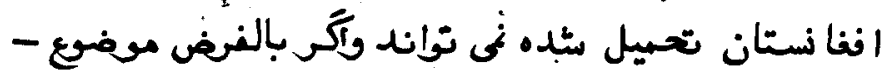

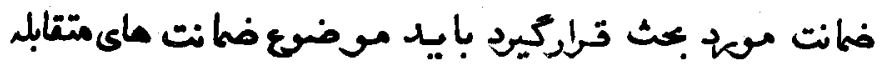
ازجا بب مومسيه كه بطور كامل متكى بـمساوات مطلتي

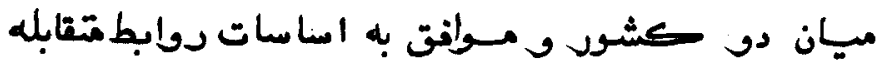

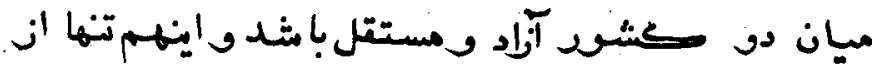

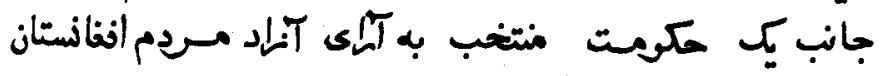

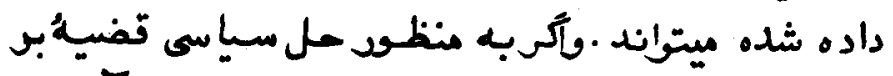

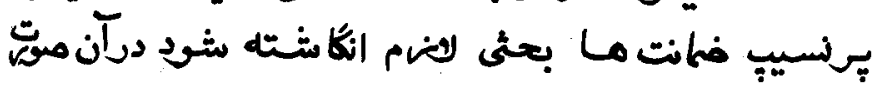

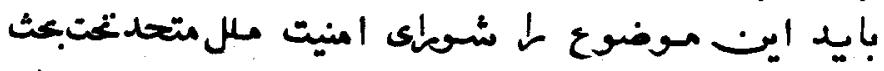

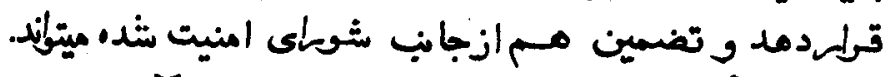

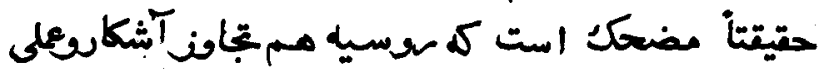

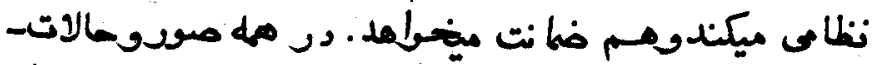

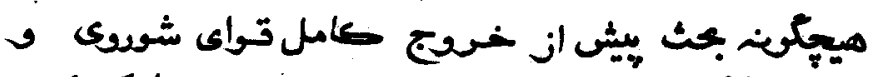

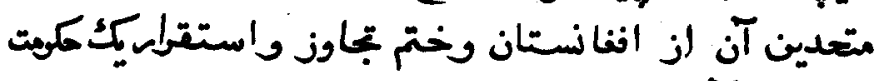

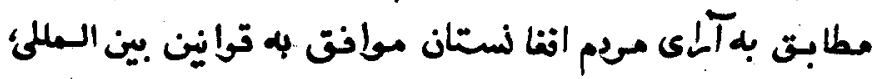

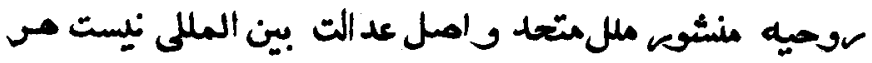

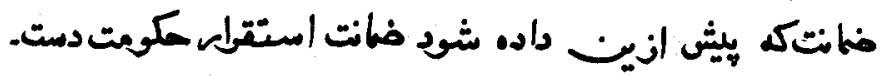




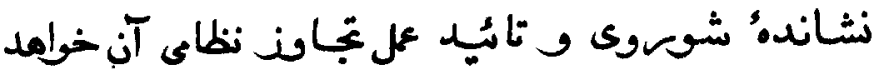

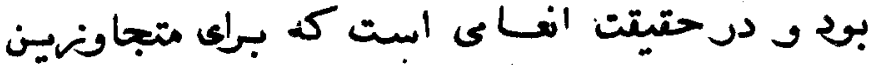

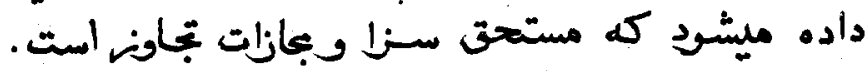

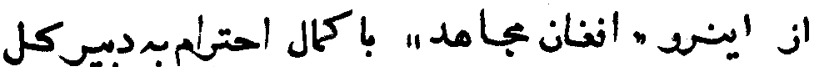

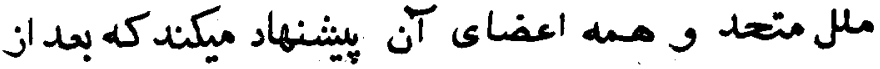

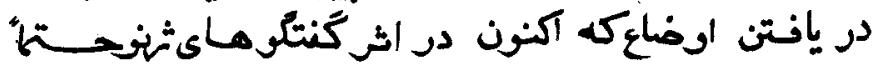

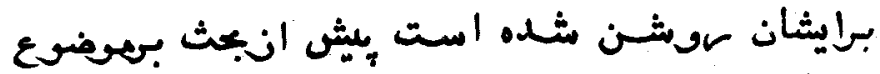

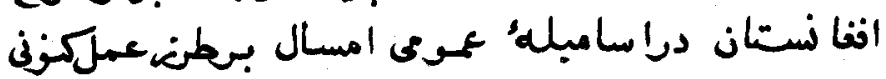

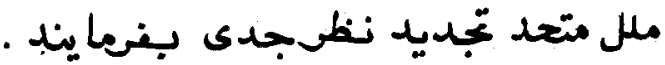

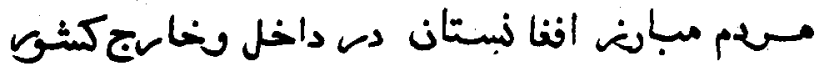

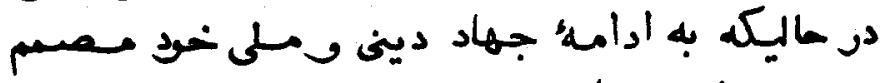

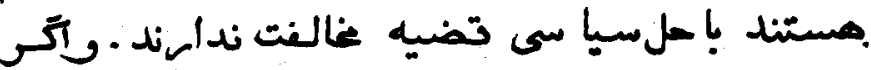

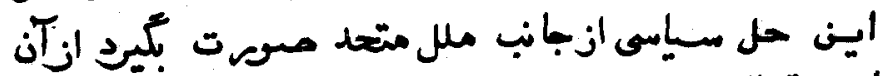

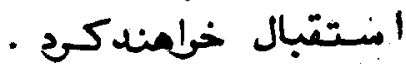

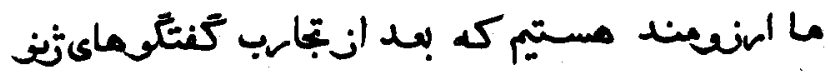

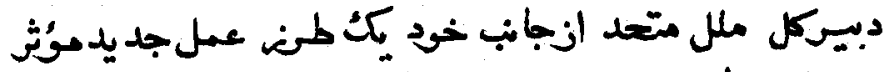

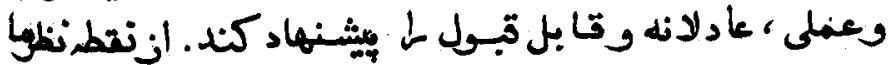

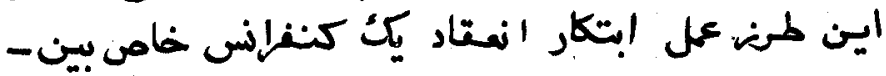

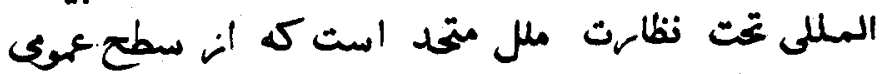

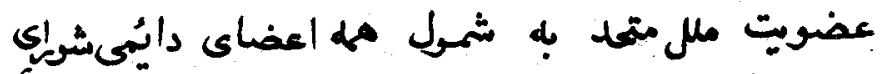

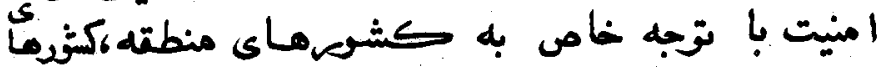


IV.

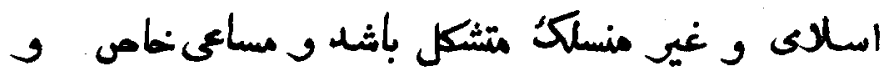

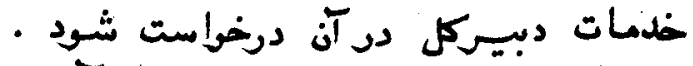

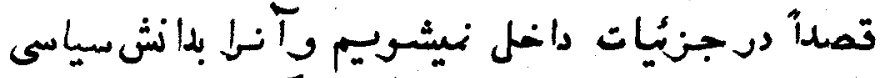

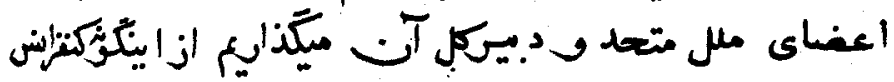

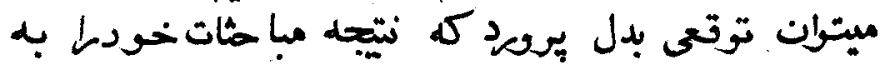

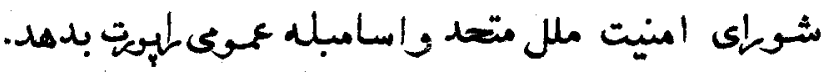

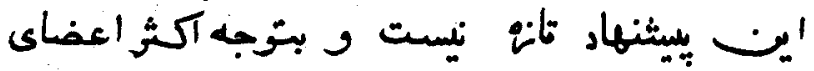

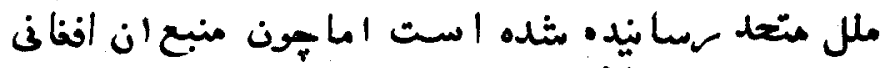

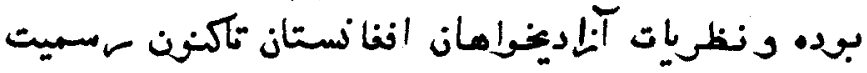

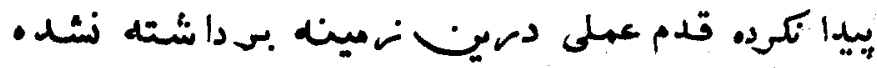

امت .

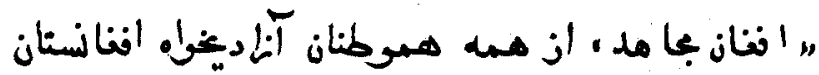

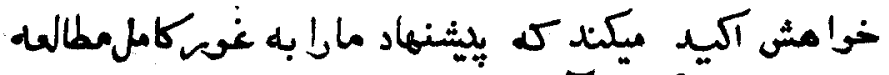

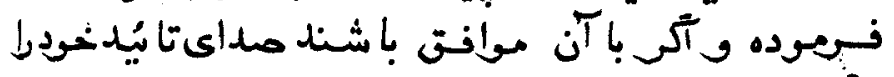

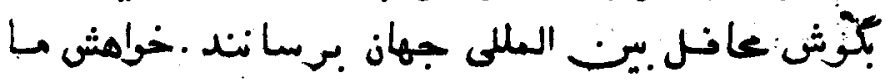

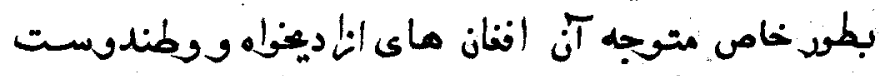

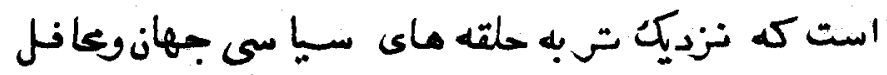

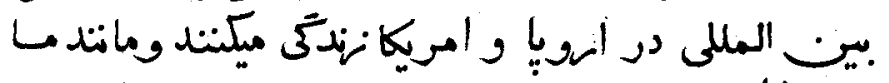

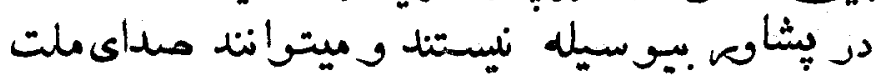

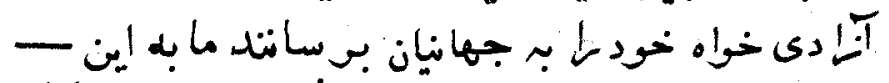

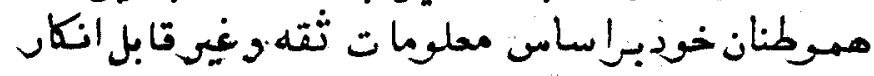




\section{$|V|$}

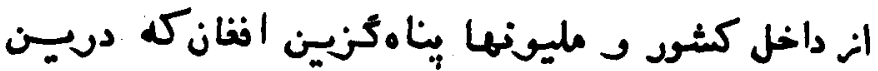

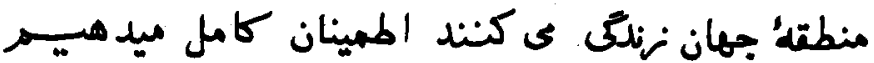

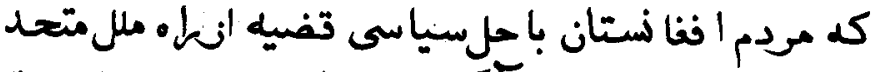

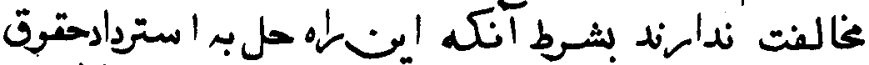

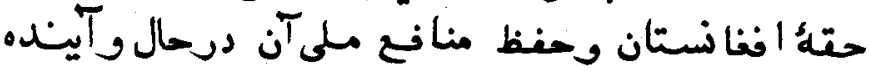

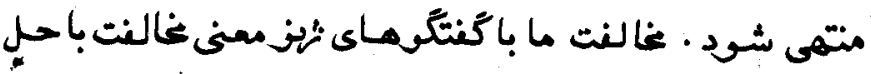

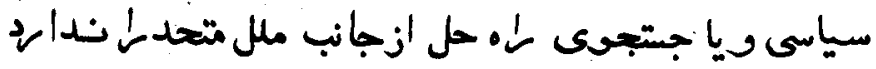

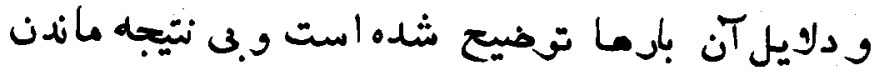

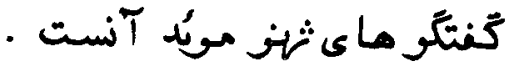

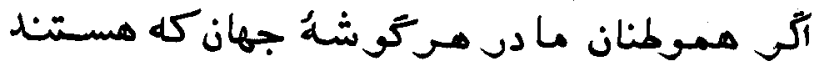

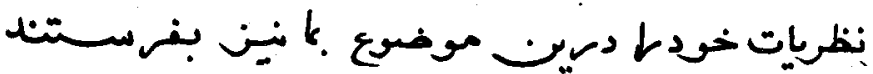

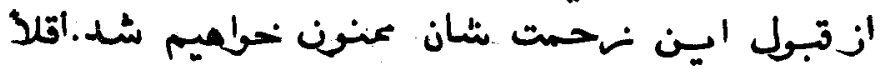

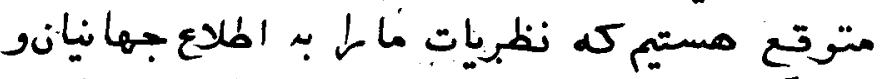

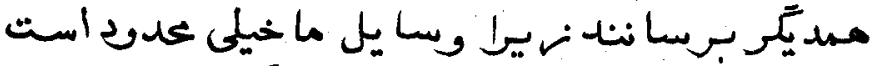

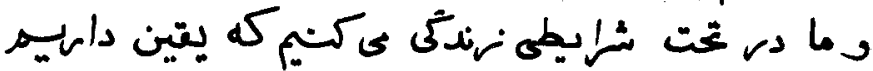

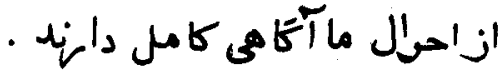

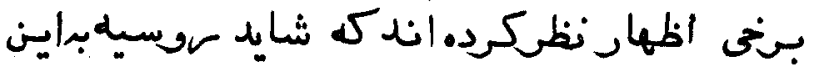

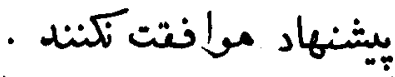

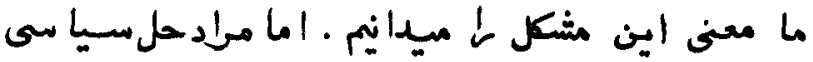

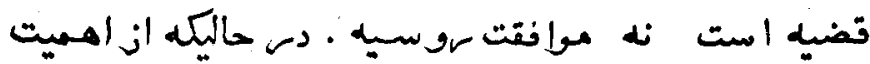

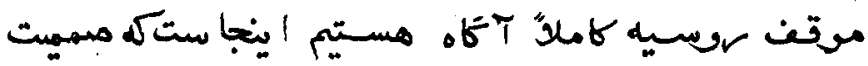




\section{IVr}

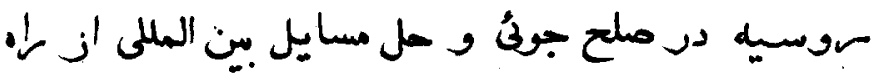

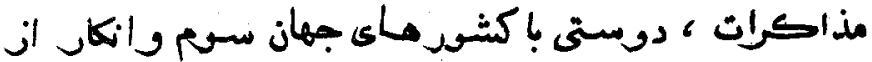

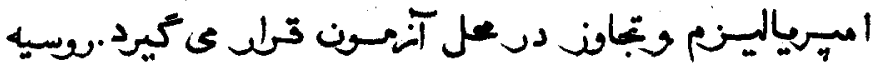

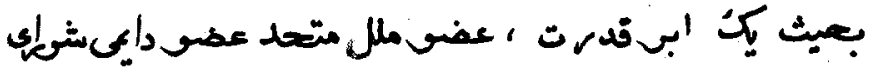

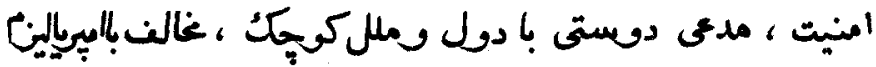

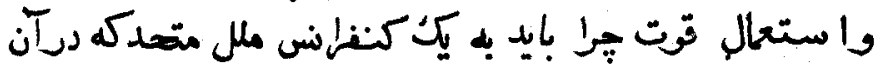

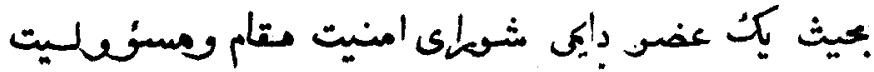

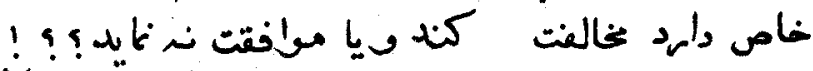

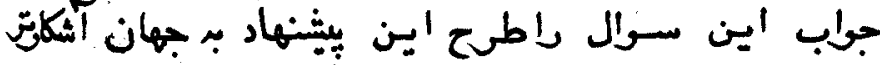

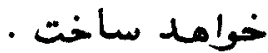

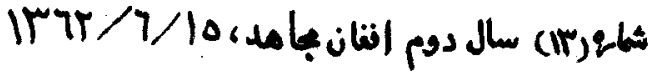




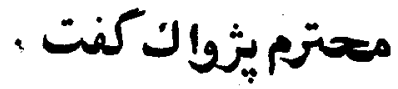

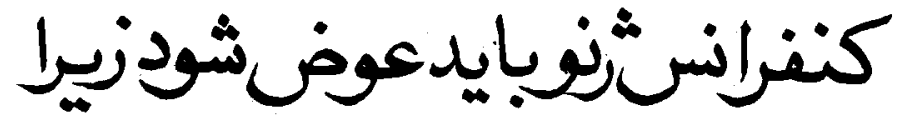

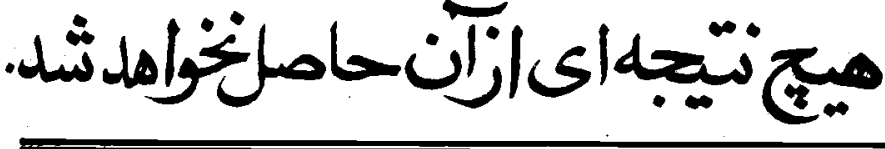

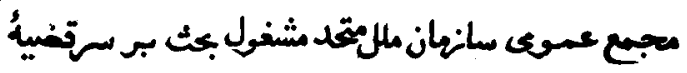

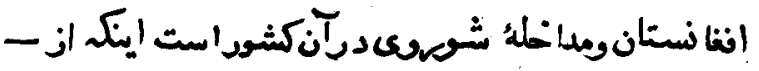

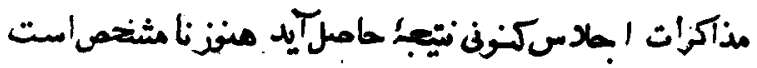

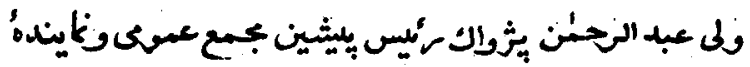

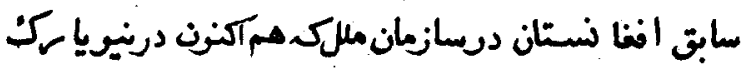

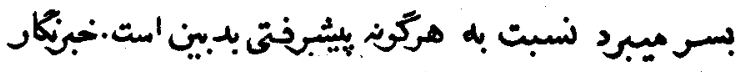

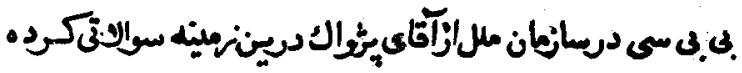

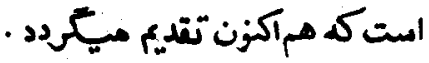




\section{IV}

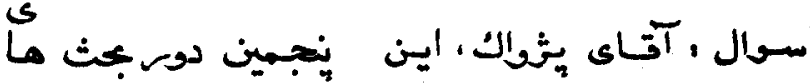

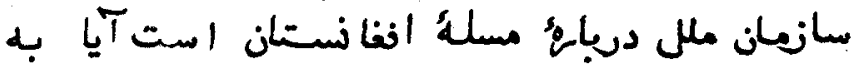

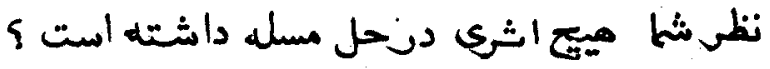

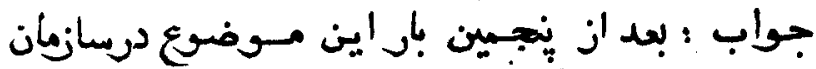

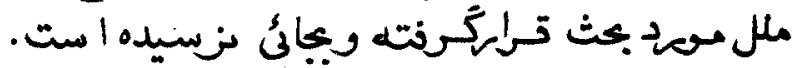

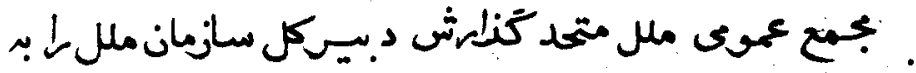

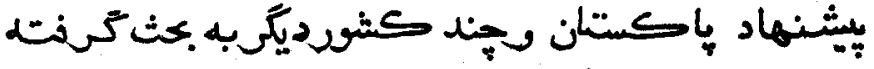

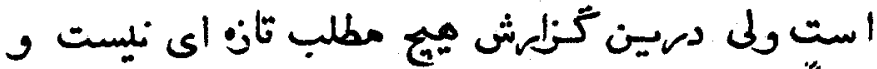

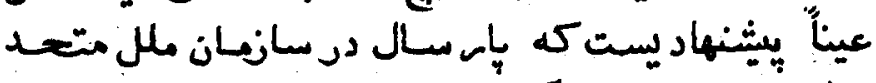

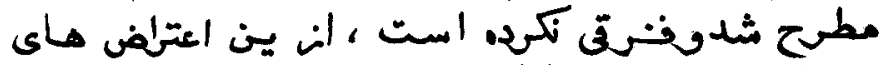

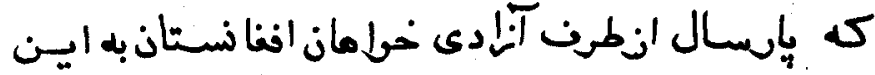

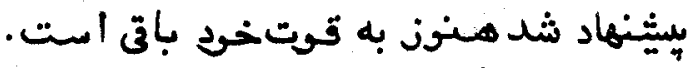

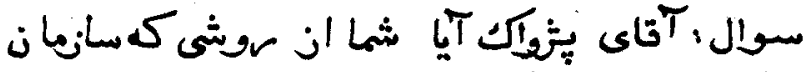

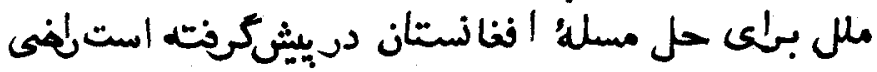

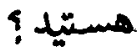

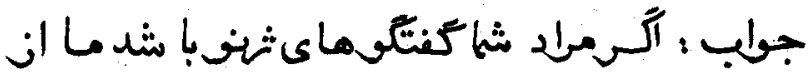

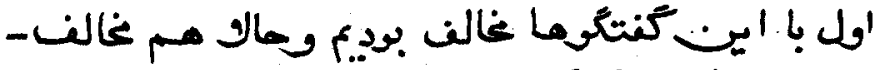

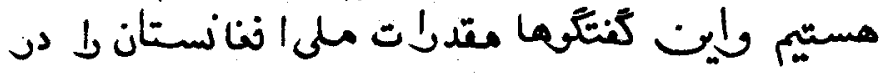

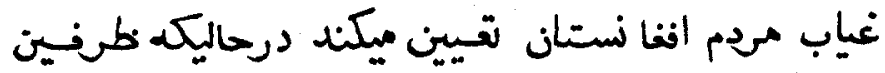

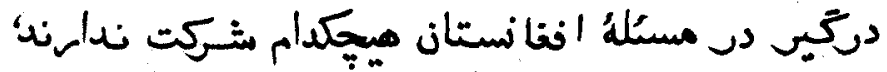

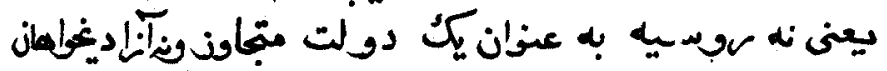




\section{IVo}

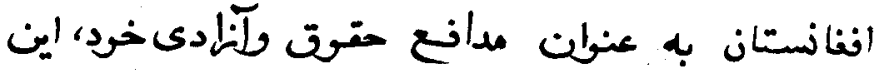

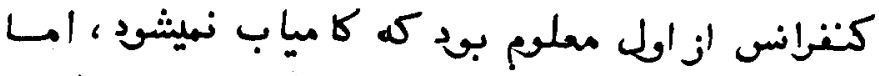

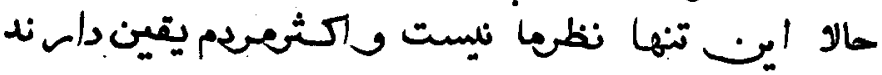

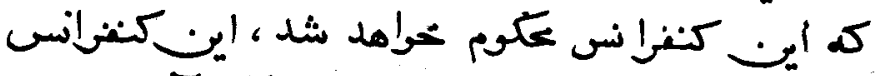

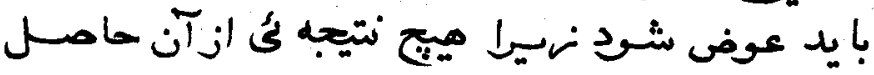
غخرامد شد .

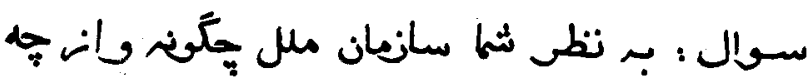

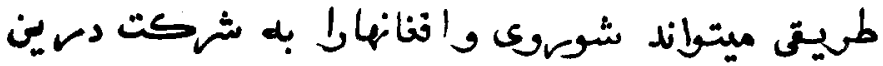
كنفرا نس بكتياند

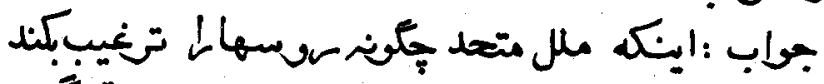

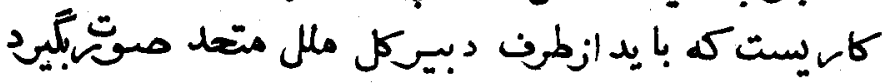

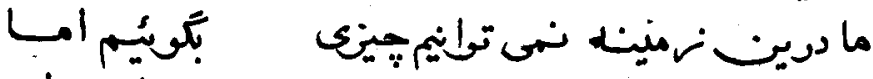

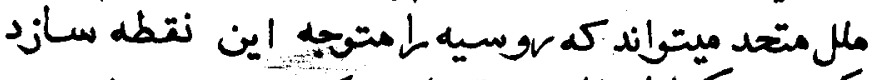

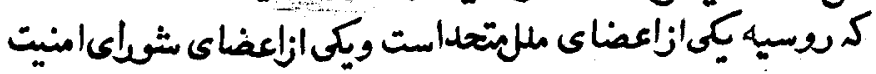

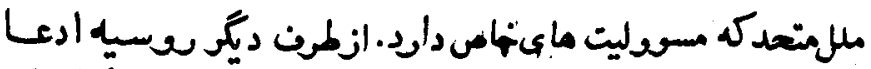

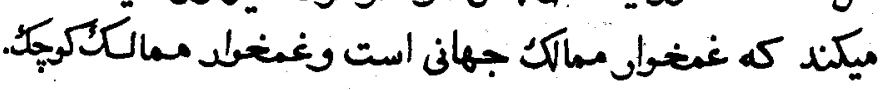

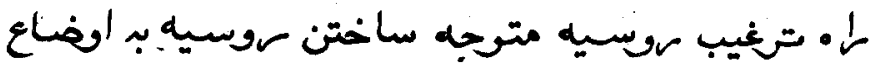

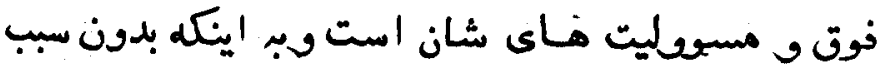

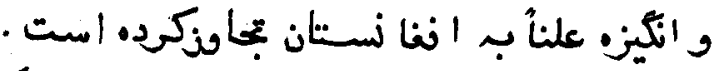

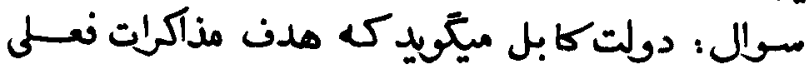

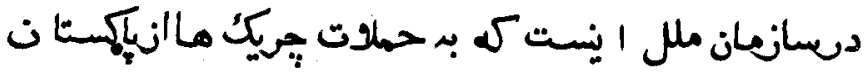


IV7

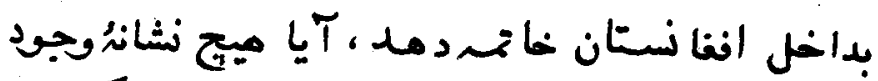

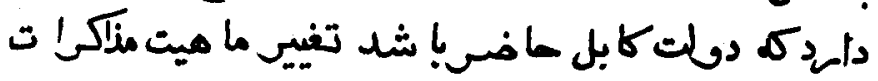

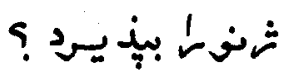

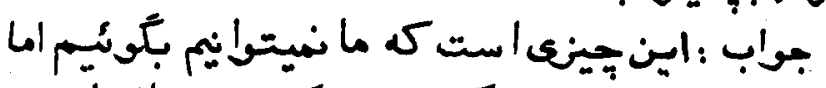

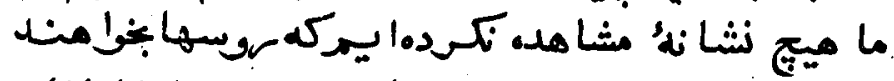

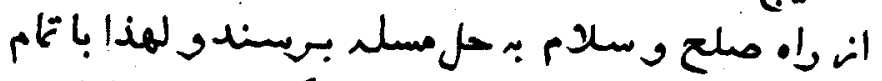

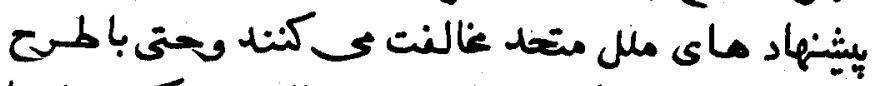

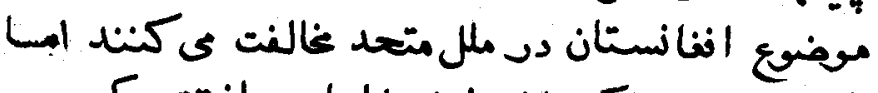

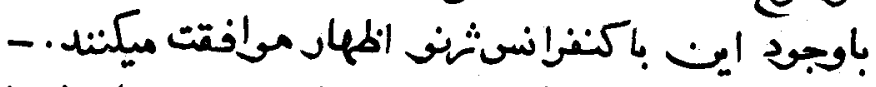

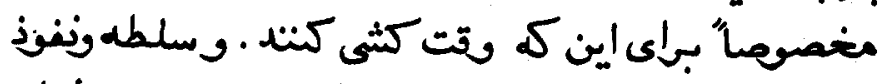

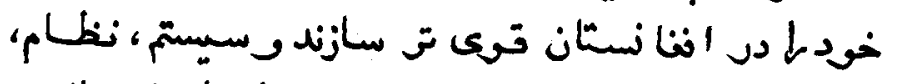

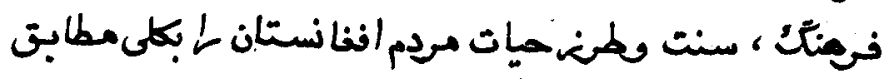

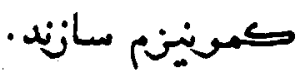

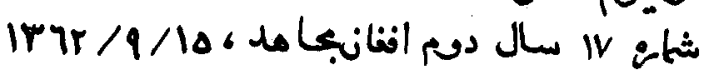


يَيْنهاد مهــم

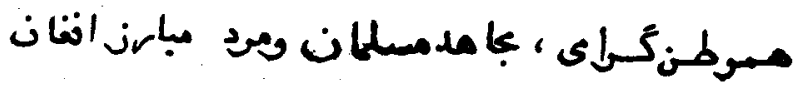

ولسمل !

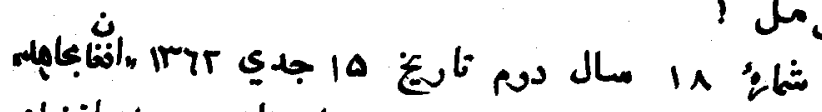

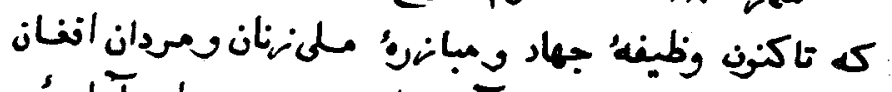

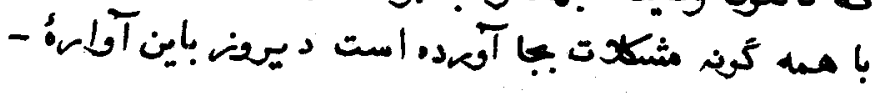

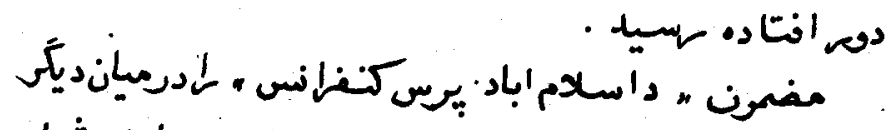

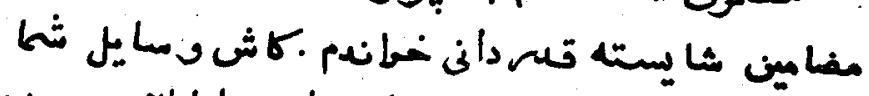

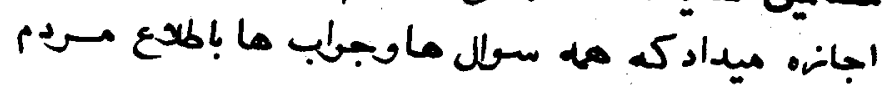

ميرسيد .

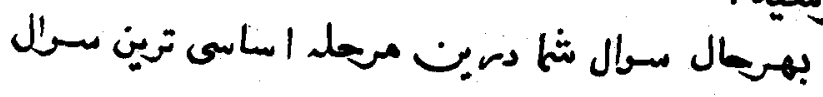


IVA

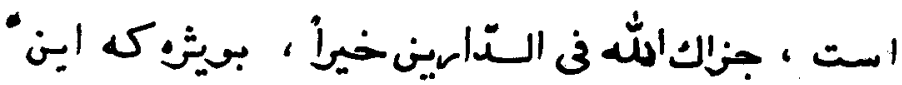

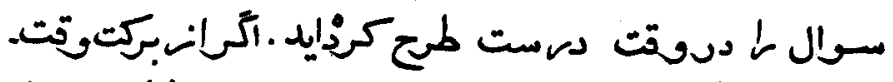

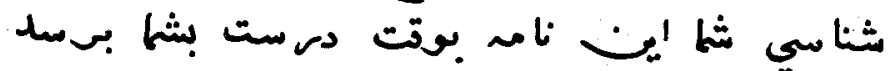

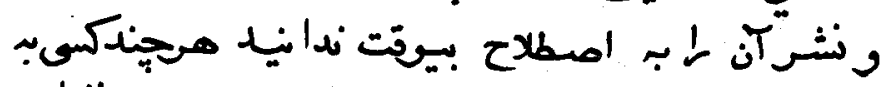

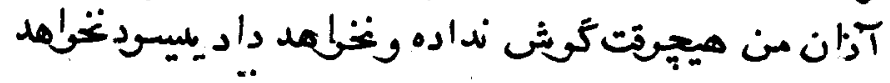

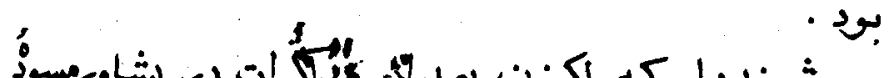

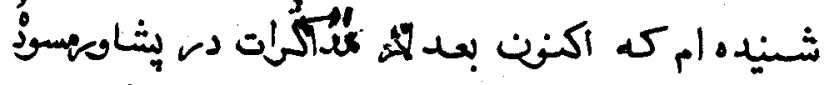

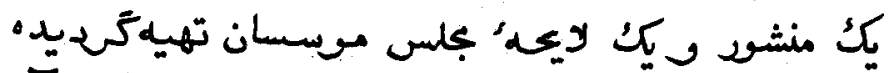

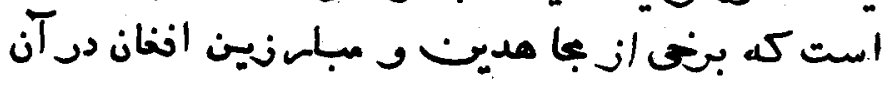

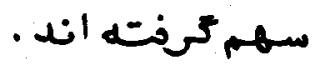

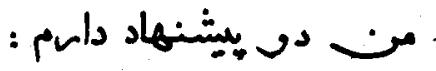

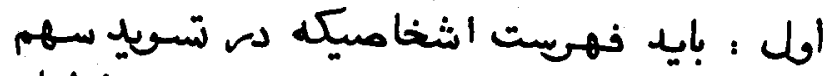

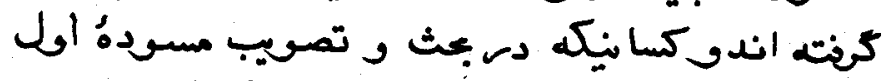

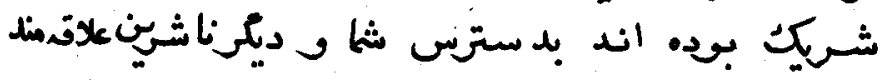

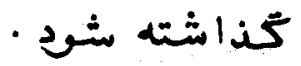

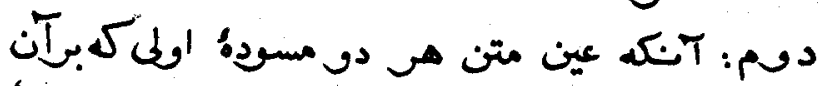

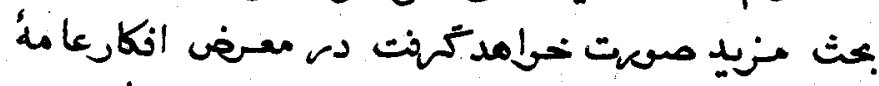

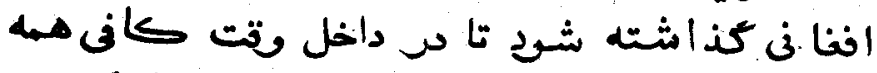

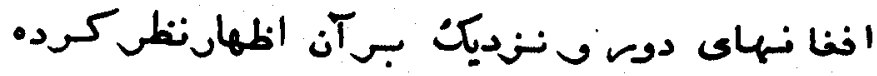

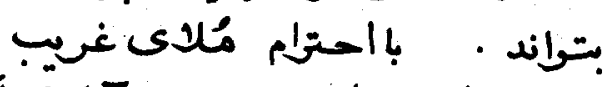

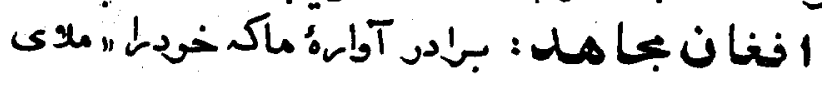


IV9

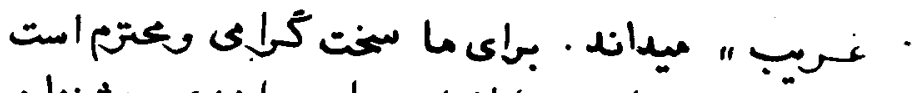

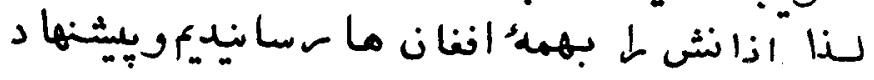

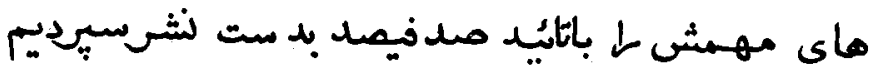

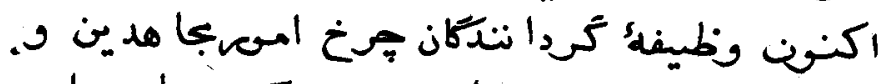

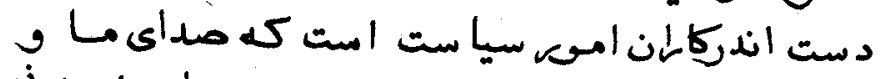

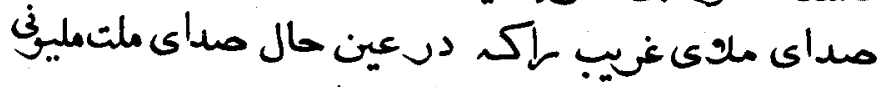

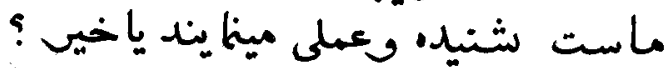

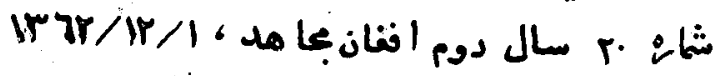

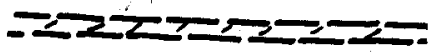




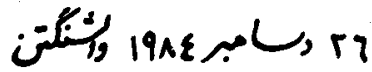

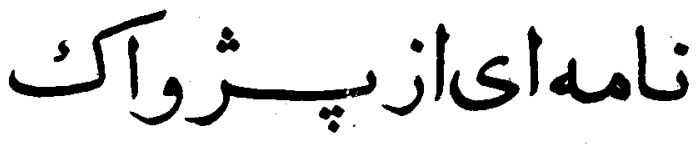

\section{ياحقى!}

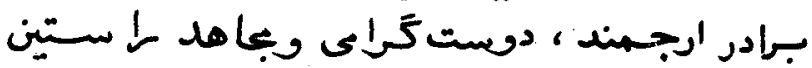

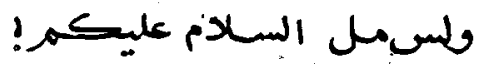

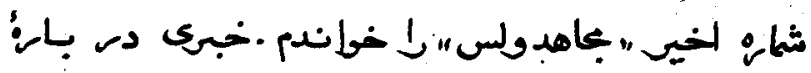

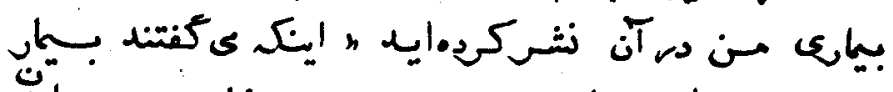

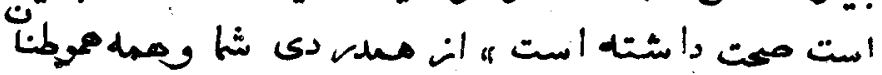

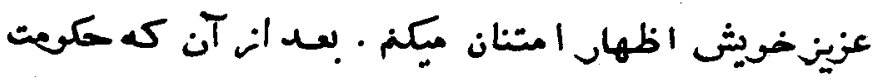

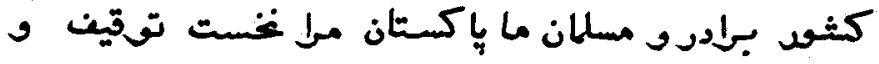

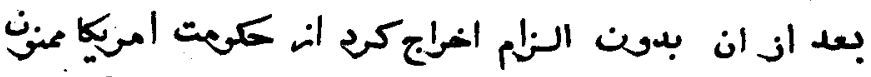

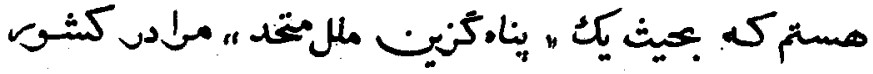

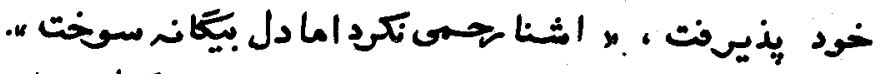

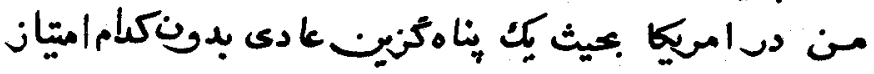


|N|

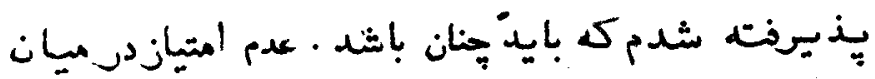

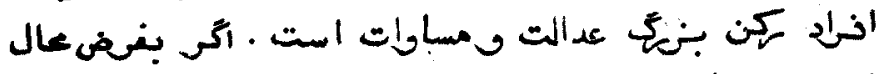

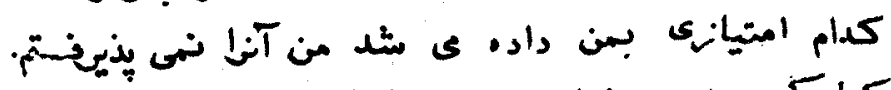

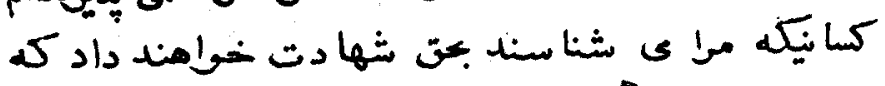

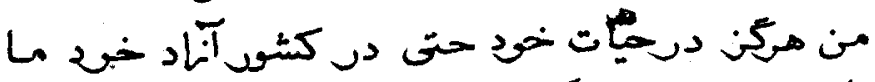

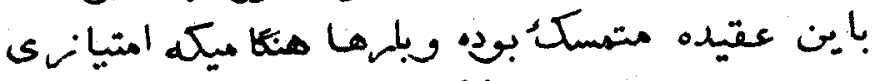

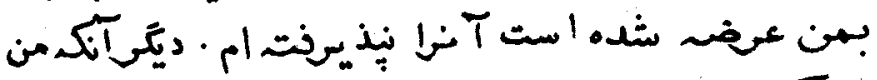

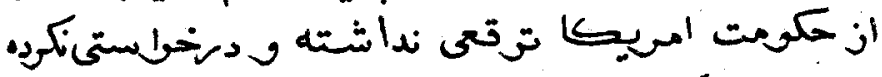

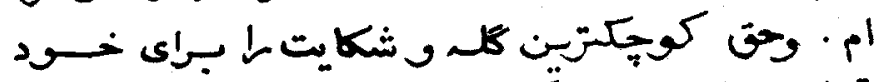

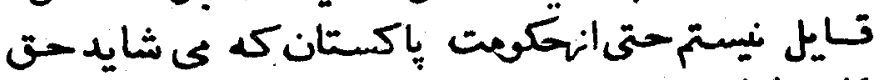

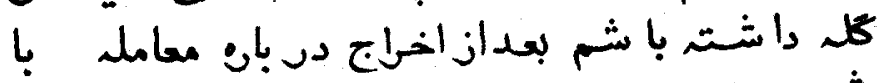

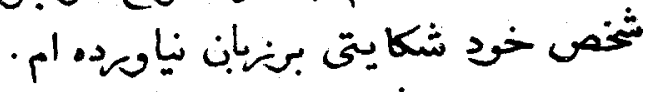

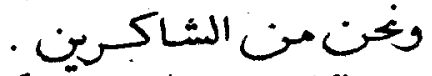

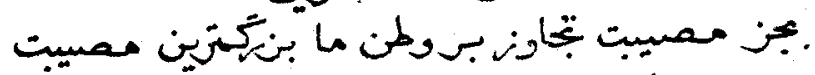

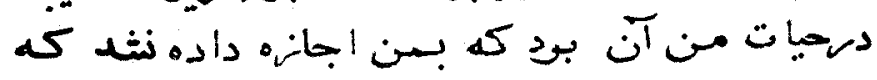

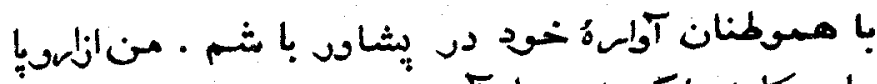

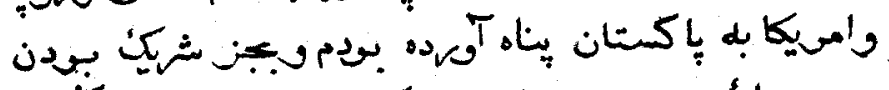

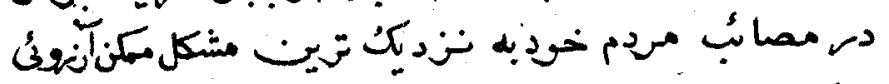

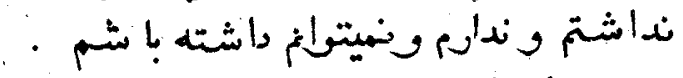

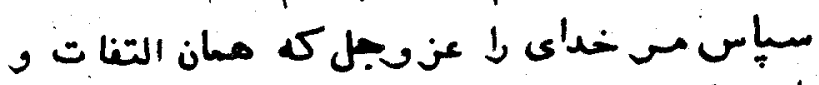

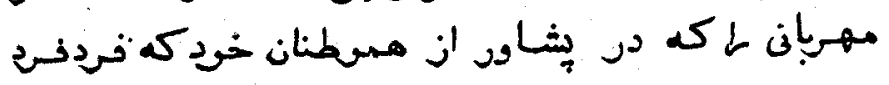




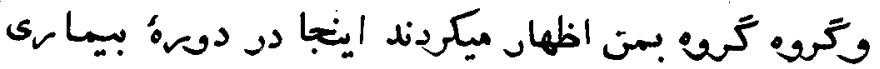

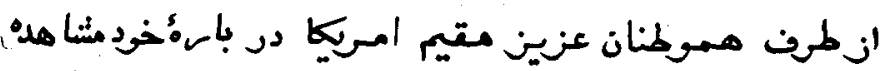

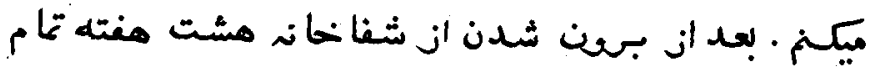

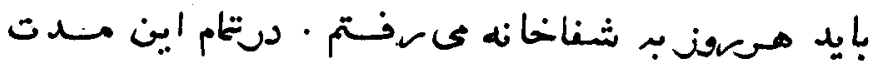

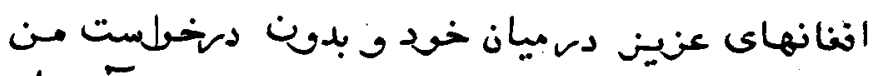

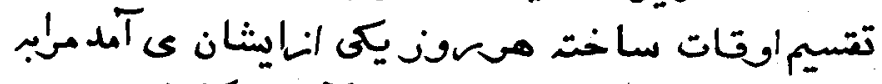

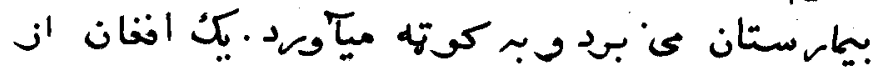

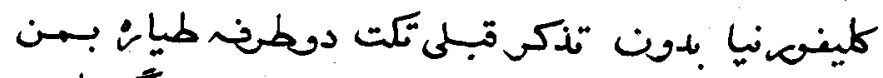

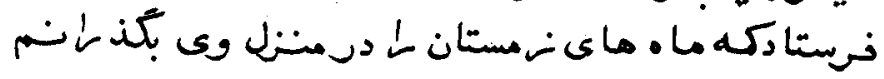

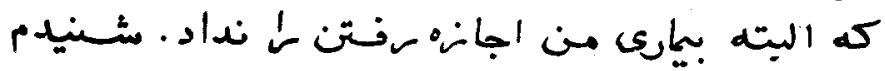

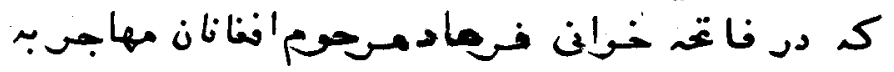

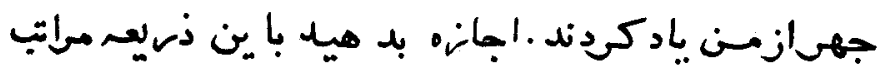

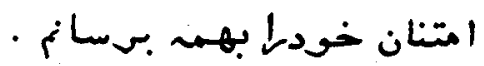

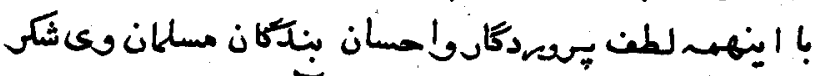

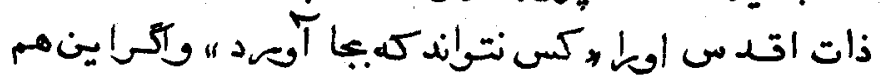

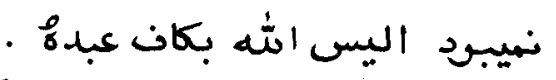

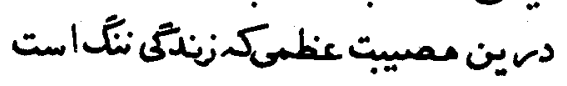

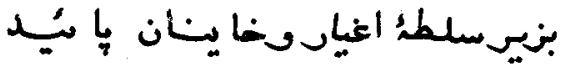

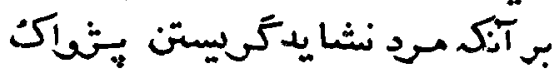

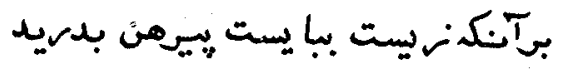

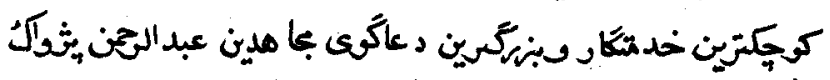

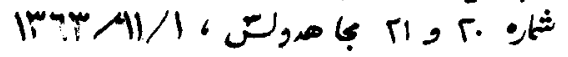




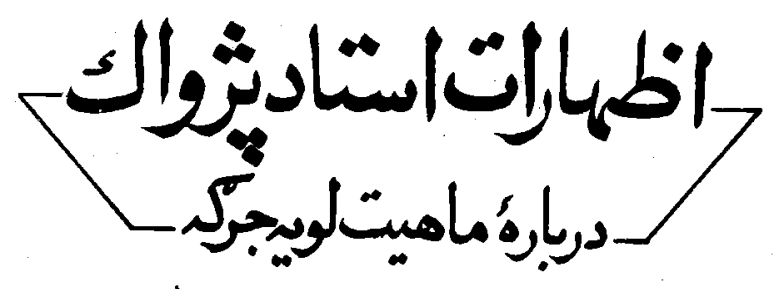

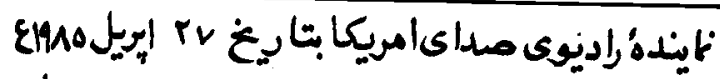

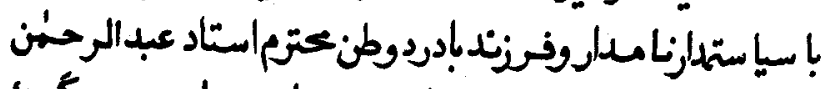

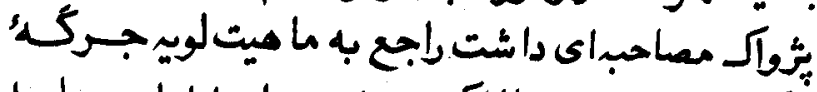

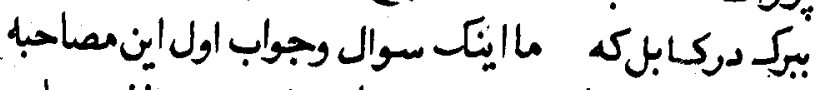

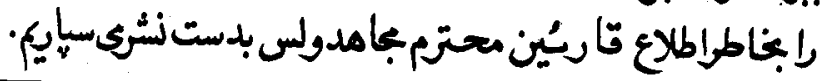

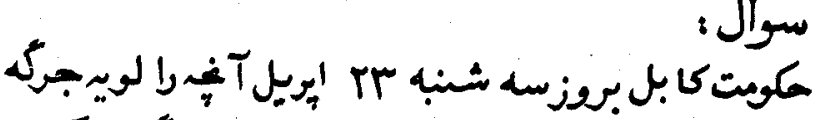

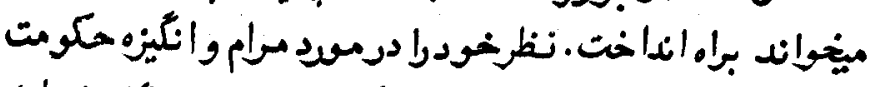

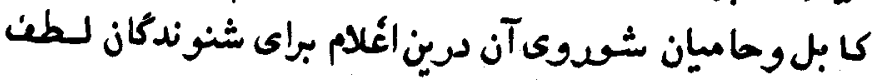

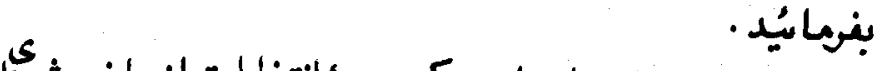

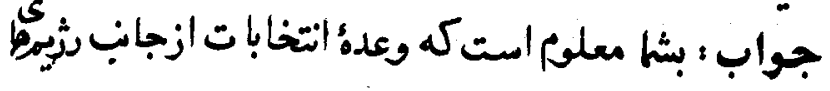




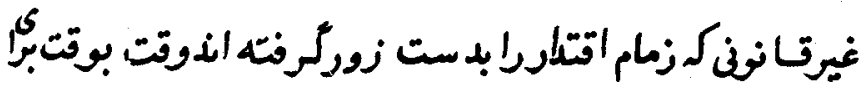

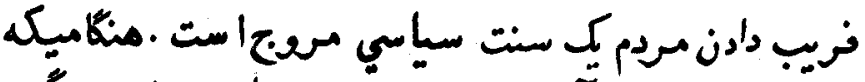

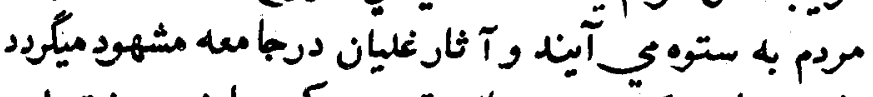

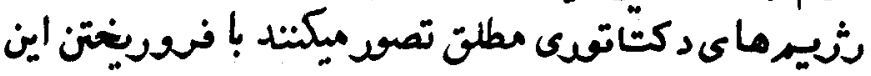

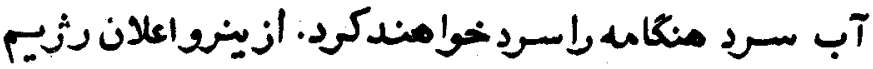

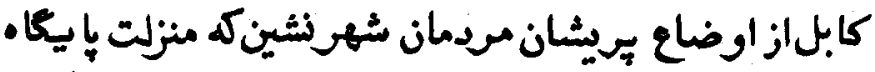

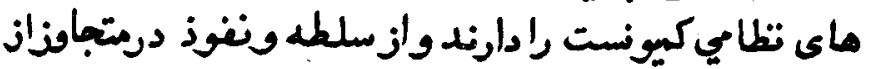

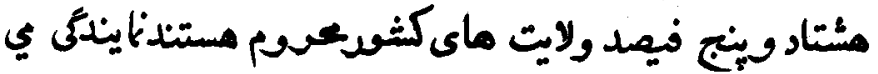
كند.

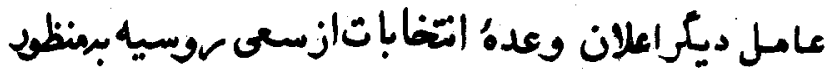

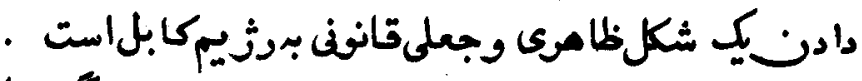

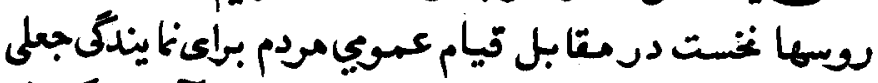

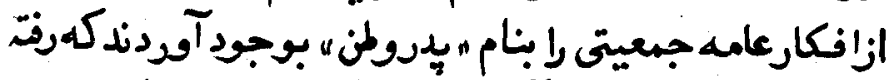

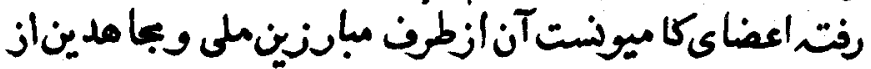

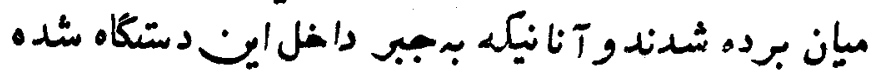

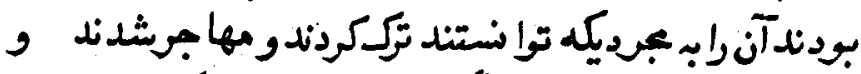

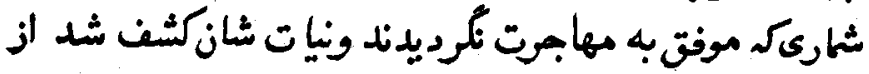

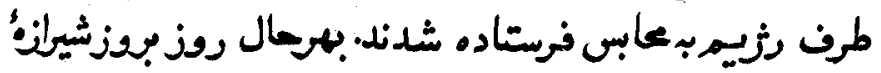

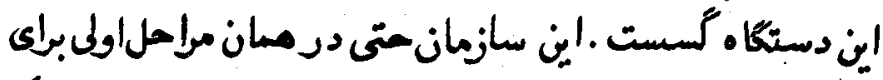

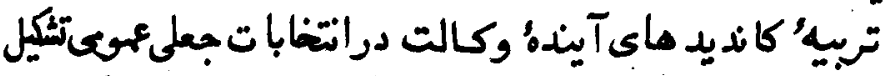

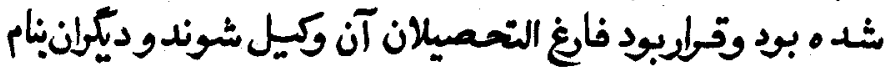




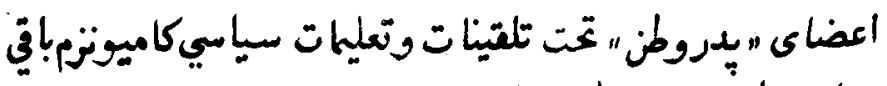

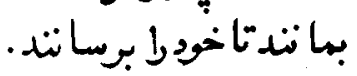

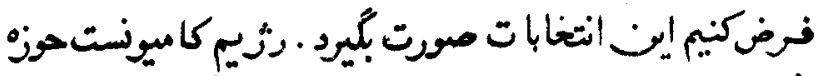

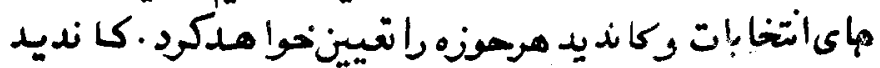

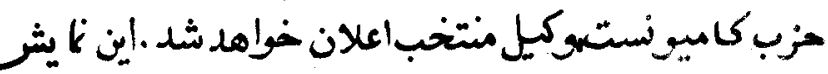

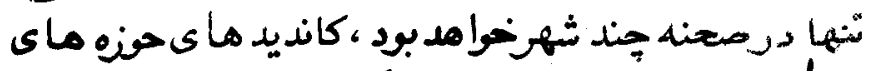

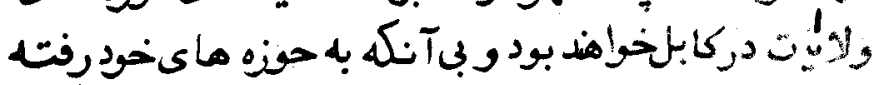

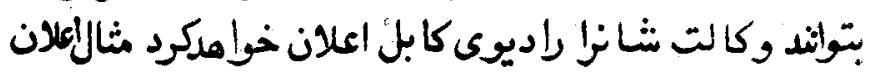

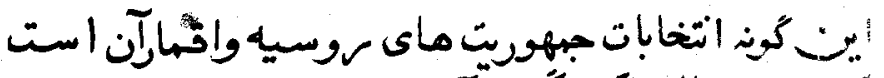

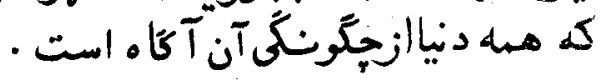

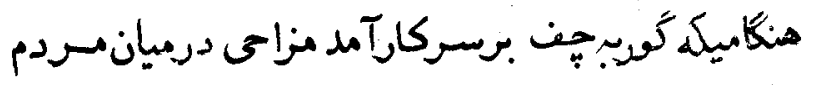

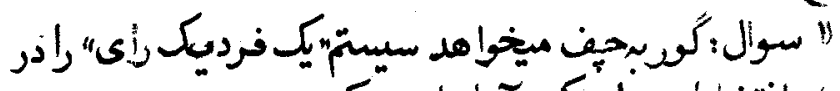

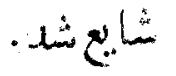

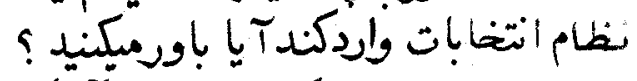

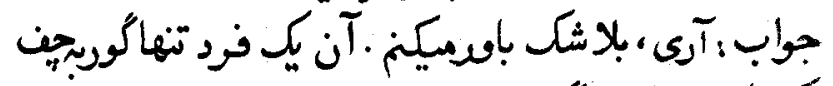

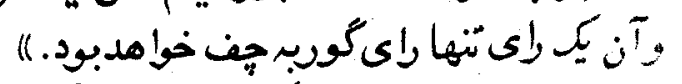

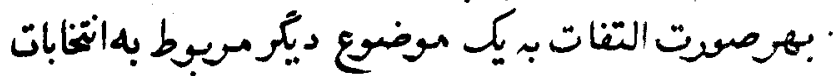

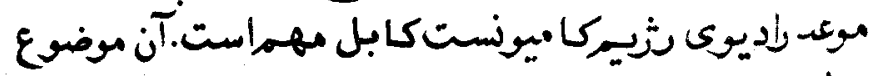

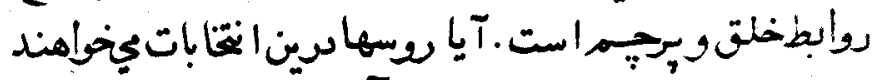

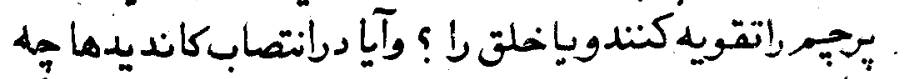

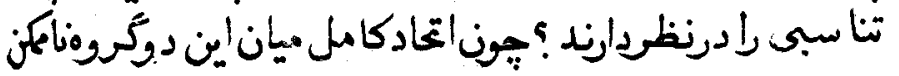




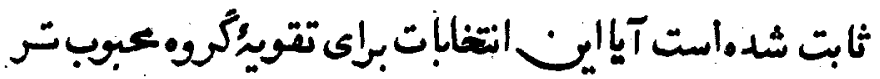

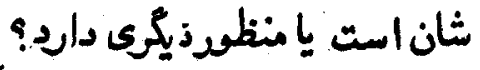

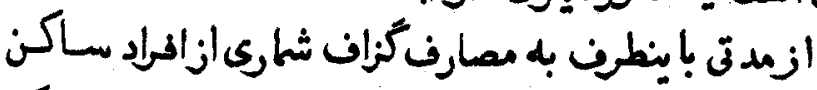

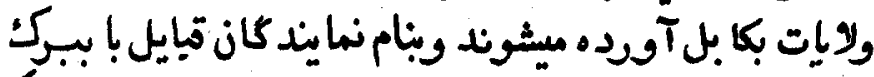

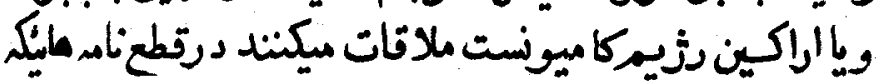

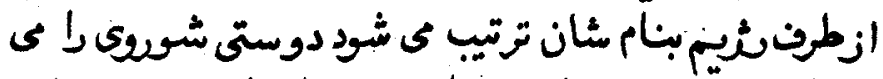

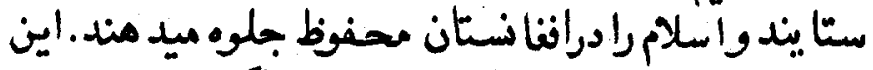

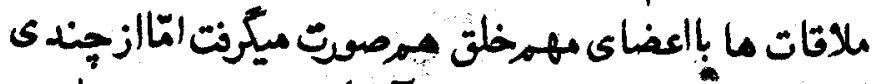

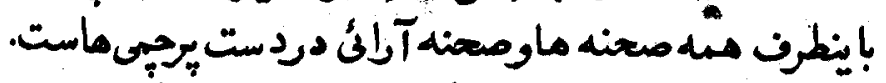

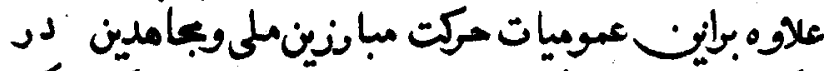

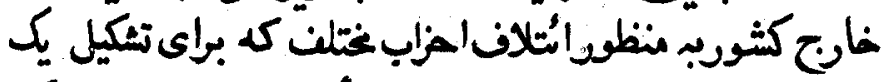

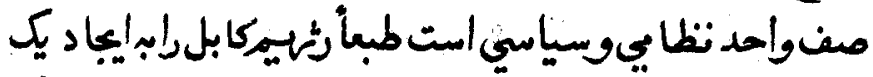

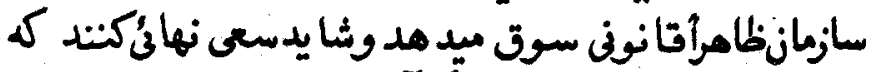

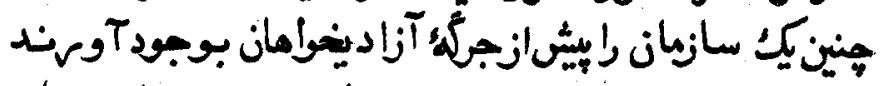

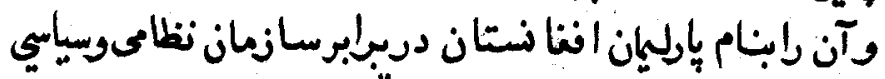

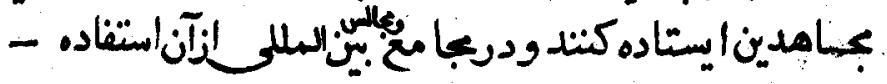

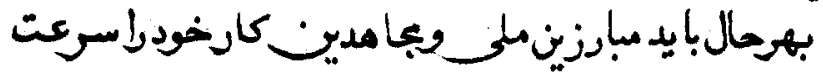
بيجيند.

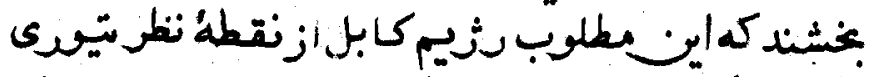

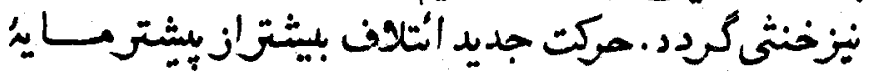

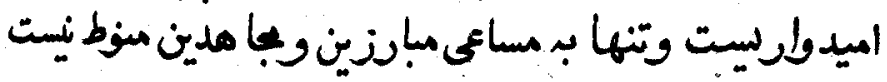


IXY

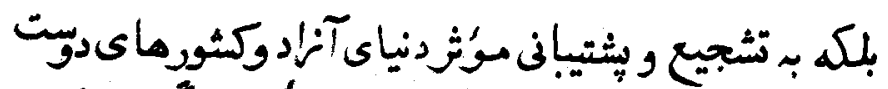

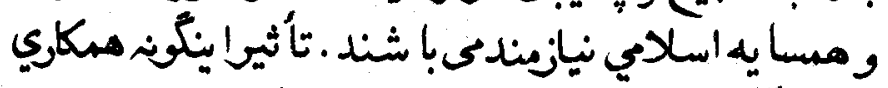

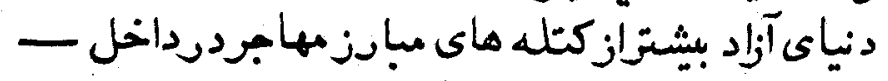

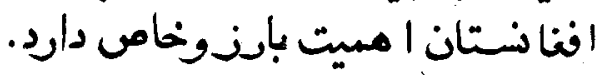

شاره 9 و.ا سال دوم بجاهدولى Ir 


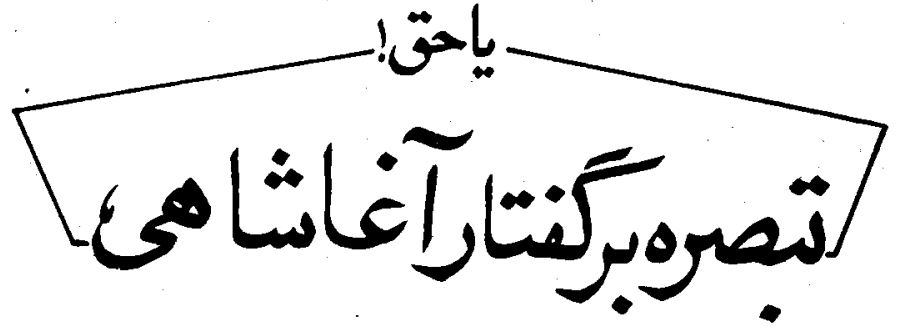

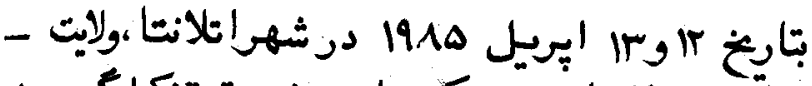

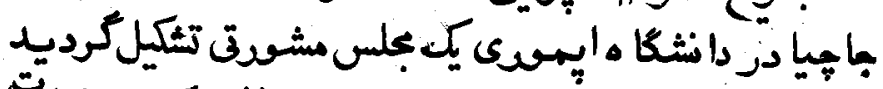

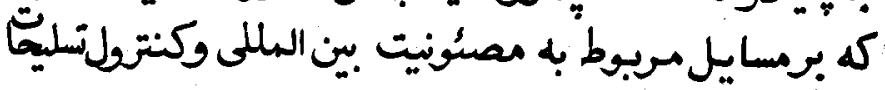

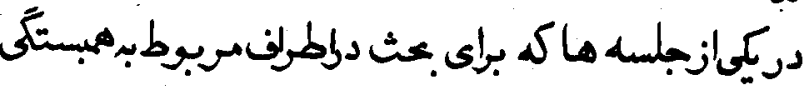

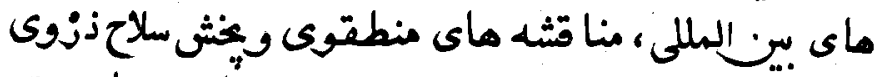

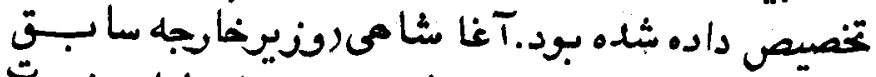

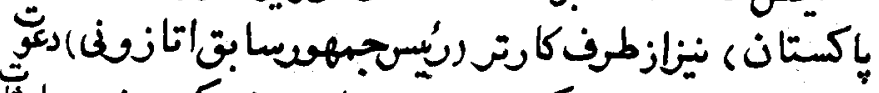

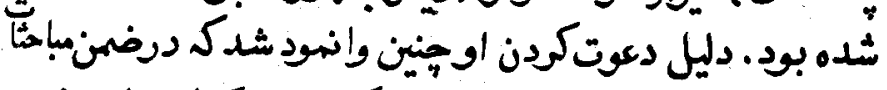

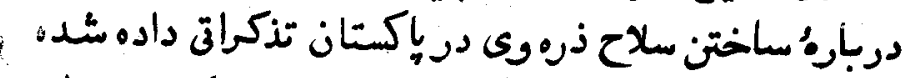

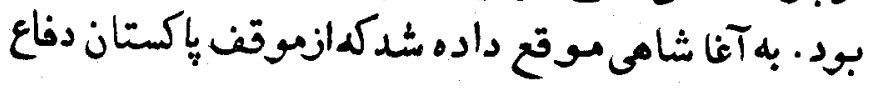




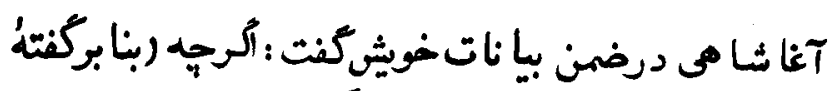

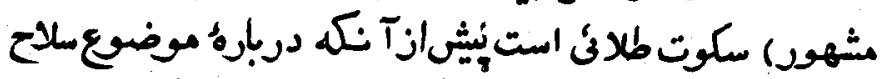

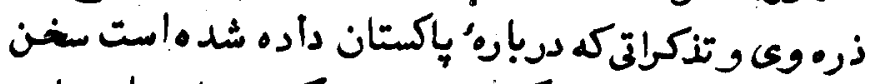

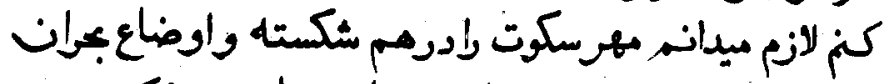

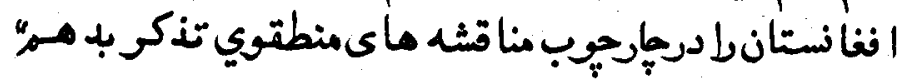

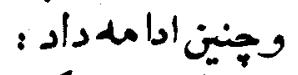

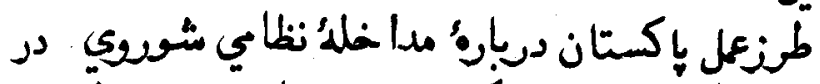

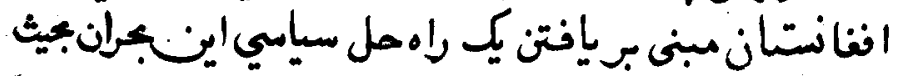

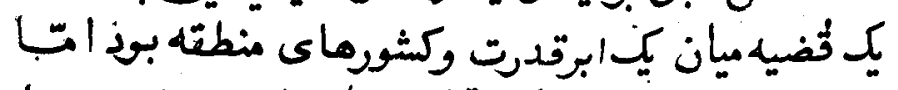

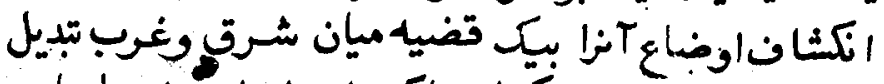

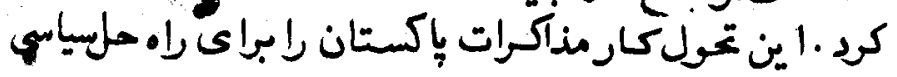

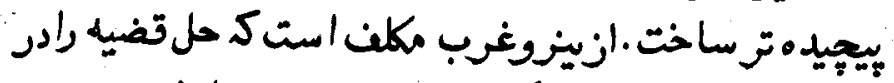

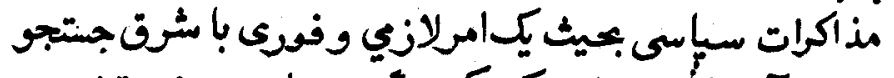

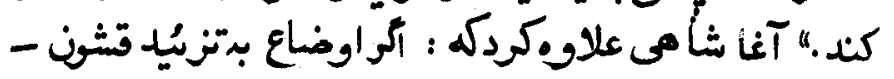

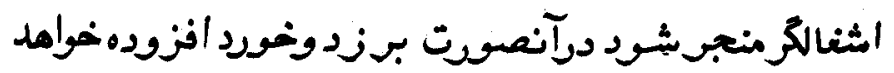

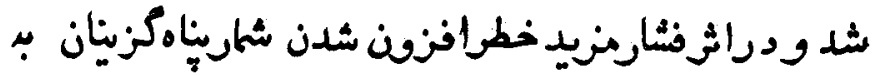

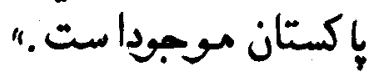

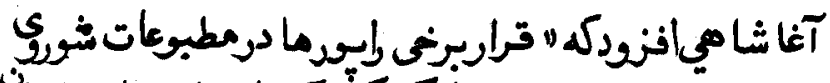

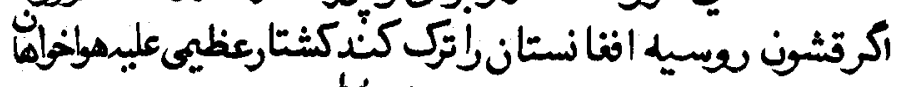

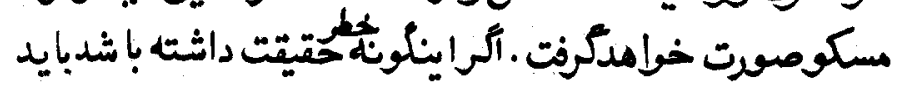

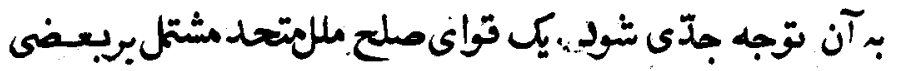




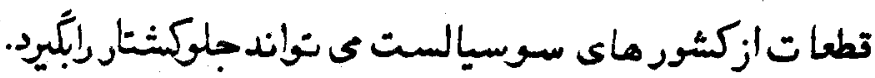

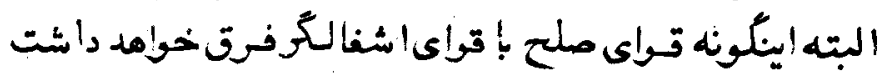

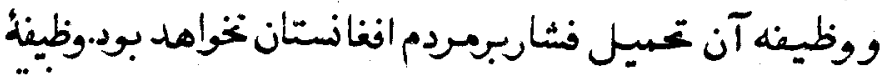

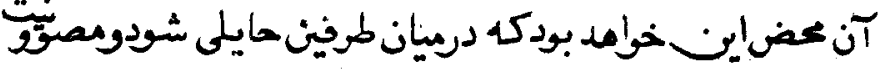

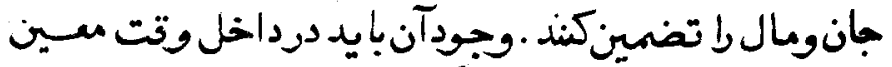

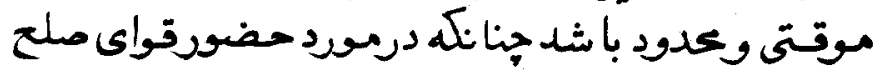

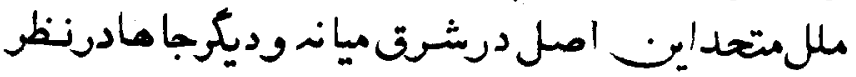

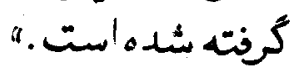

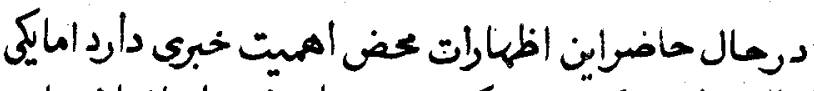

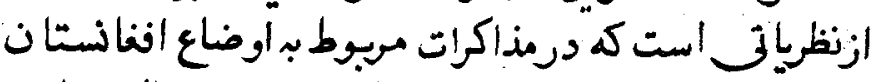

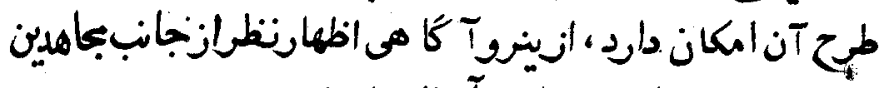

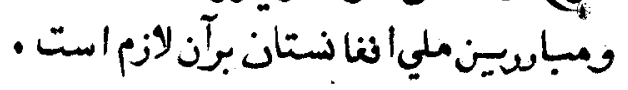

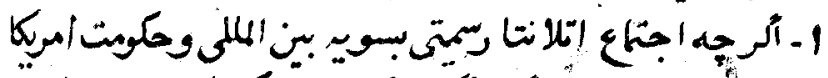

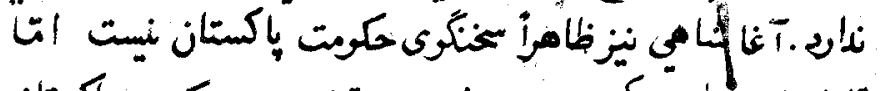

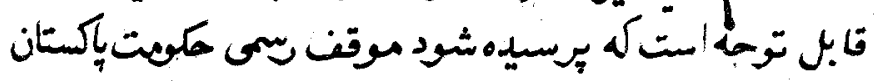

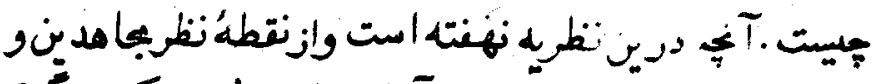

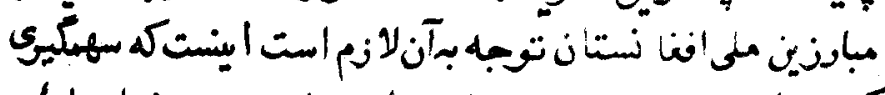

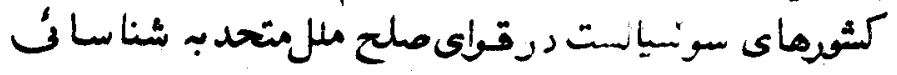

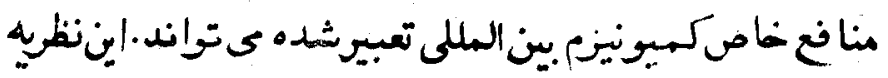

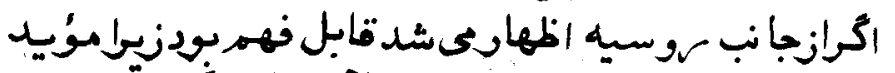

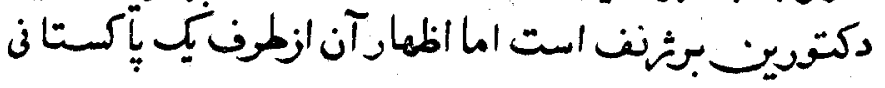




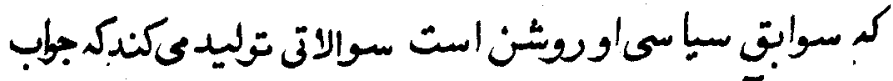

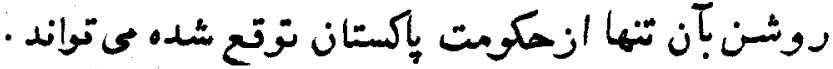

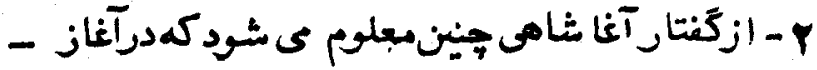

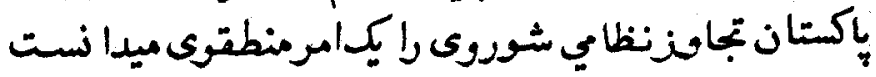

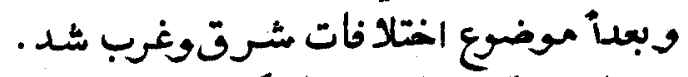

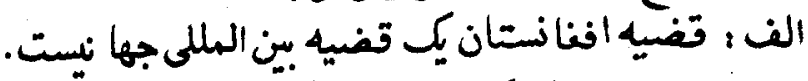

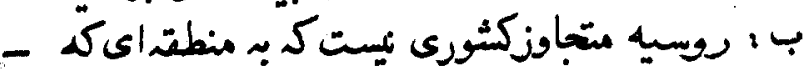

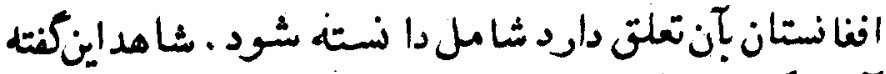

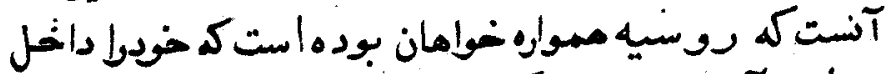

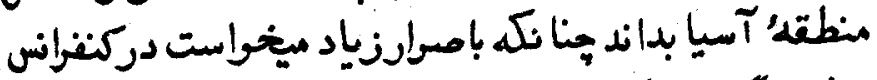

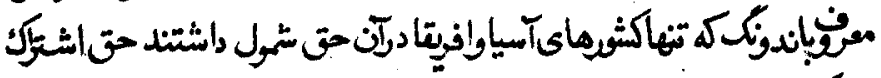

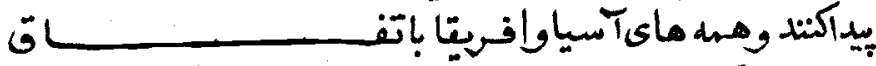

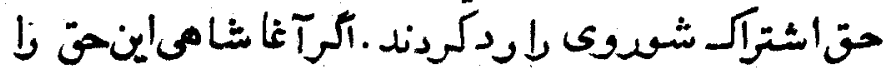

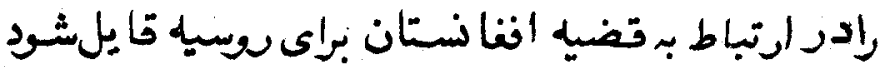

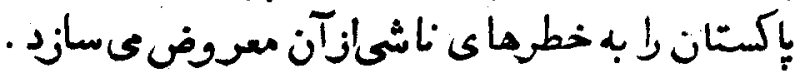

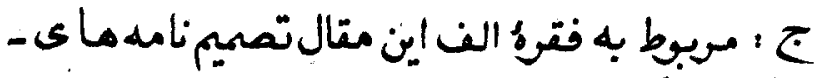

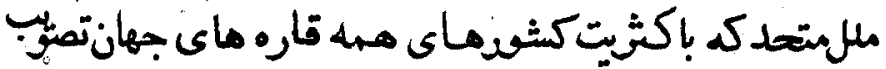

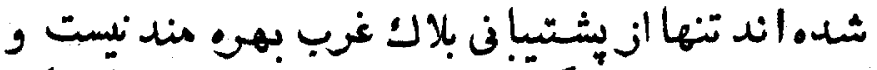

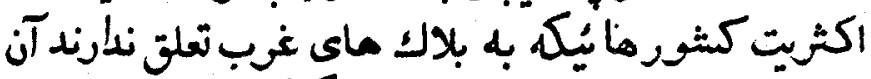

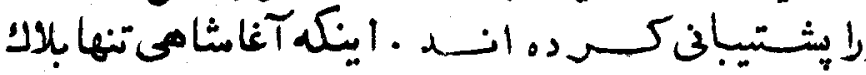

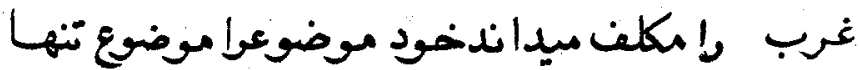
بلاك ماي شقتوغيب ميسازدكم نبايست ميكرد. 


\section{7}

盟

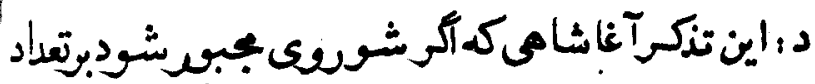

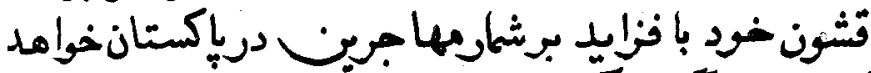

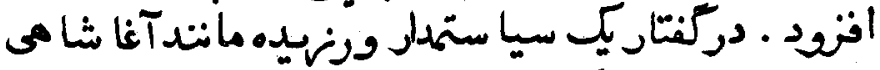

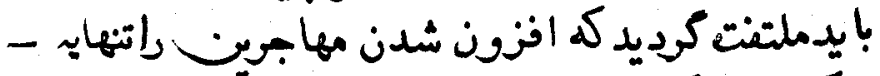
:

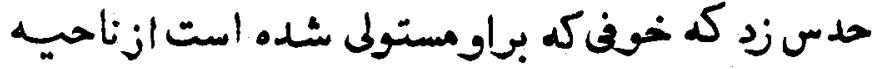

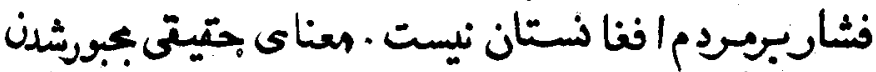
ك

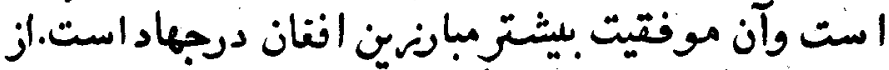

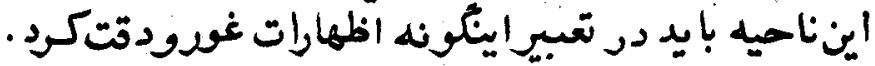

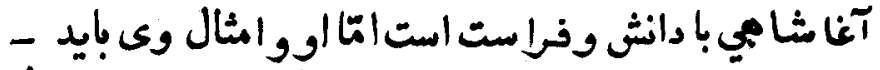

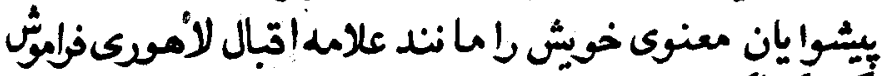

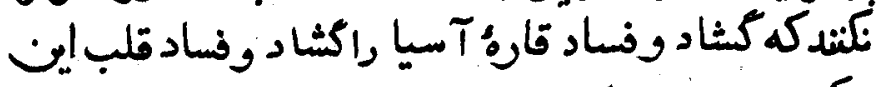

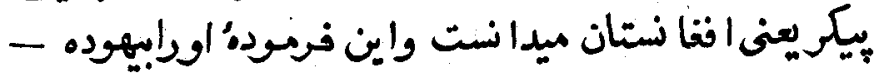
نشارند :

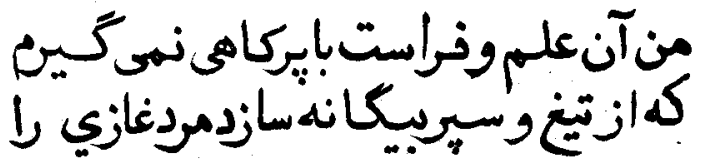

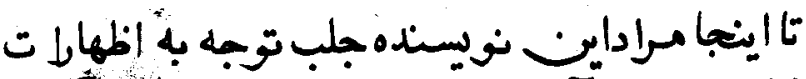

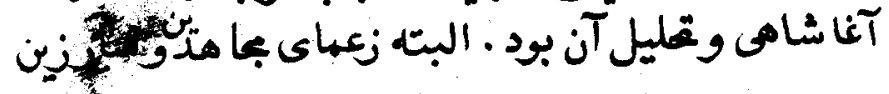




\section{4}

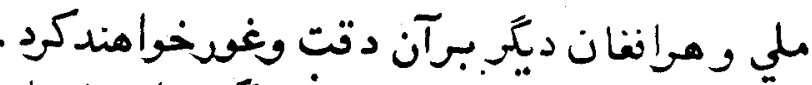

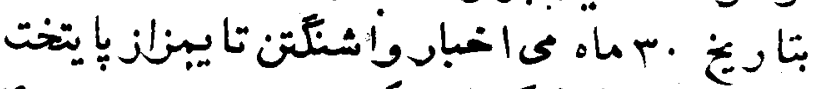

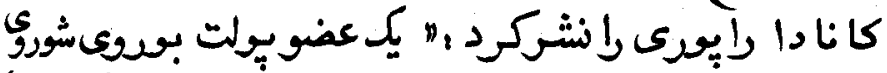

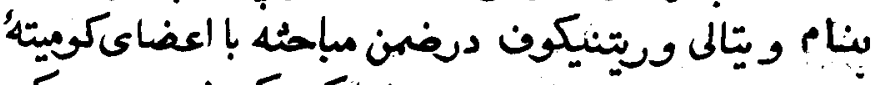

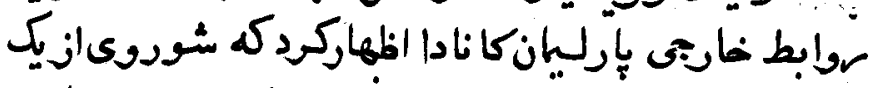

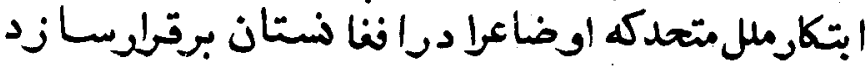

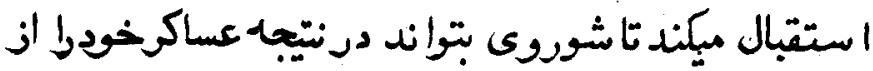

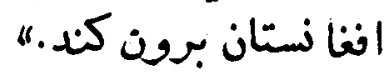

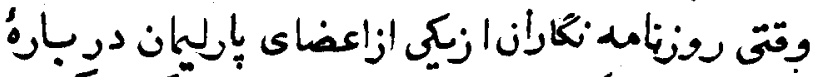

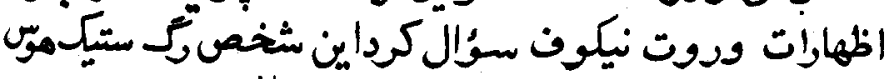
Reg Stack house

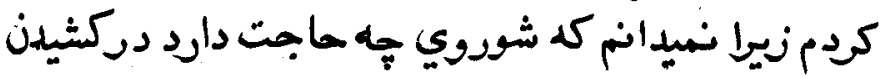

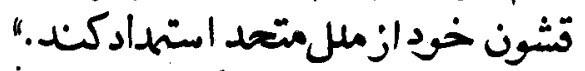

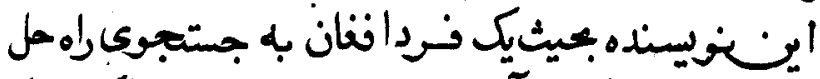

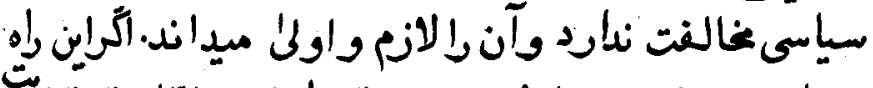

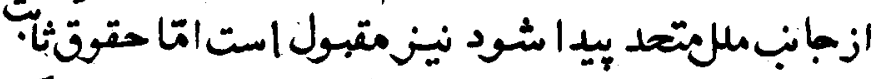

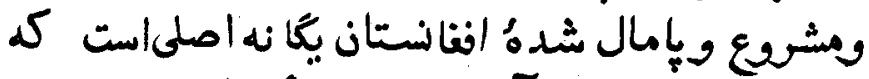

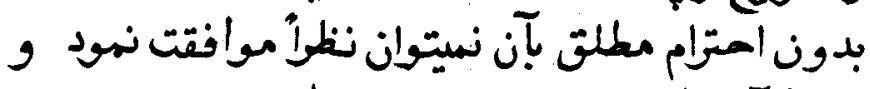

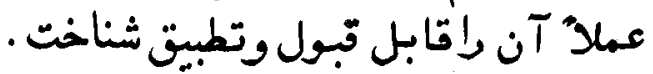

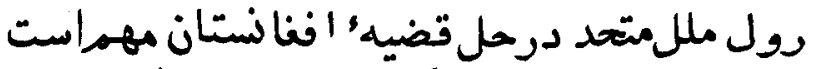

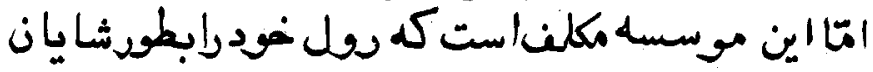




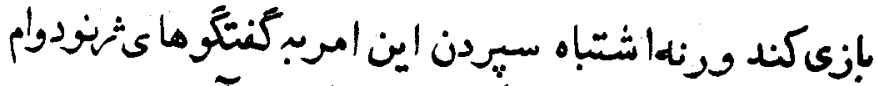

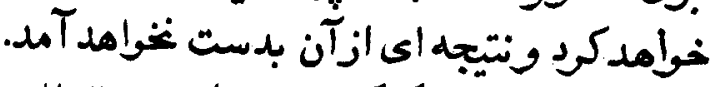

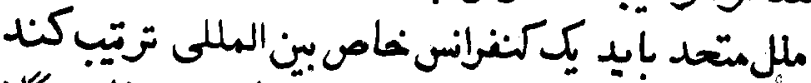

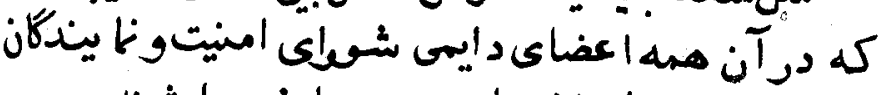

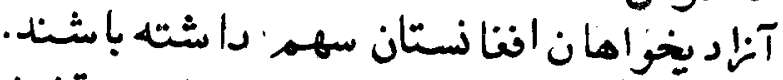

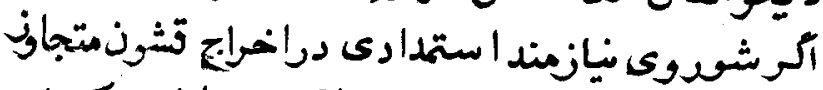

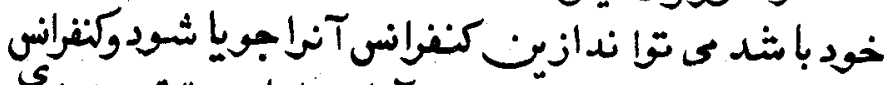

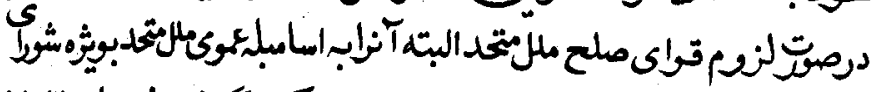

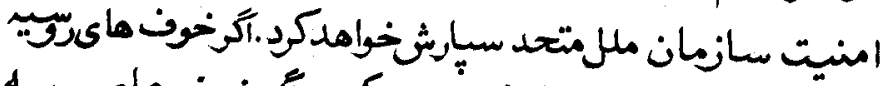

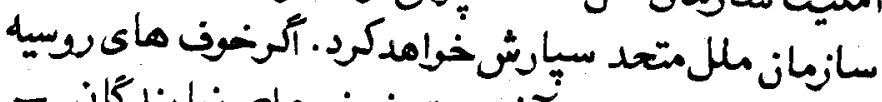

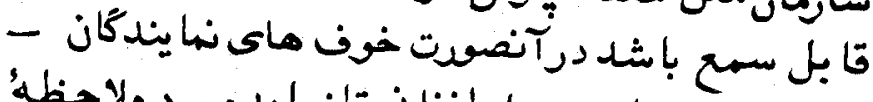

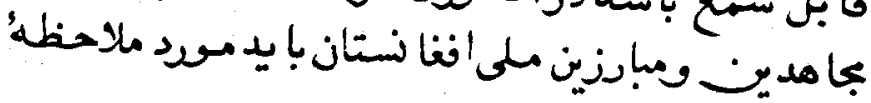

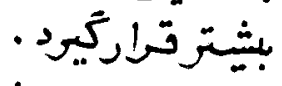

شار رُ ماوعا سال دومبكاهدولس

$\mid \Gamma \tau / \varepsilon / 10$

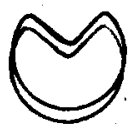




\section{قابلتوجه جدّي وفوري هه|فنانها .}

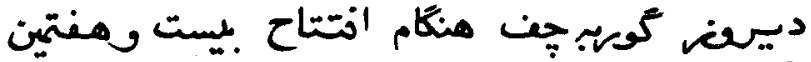

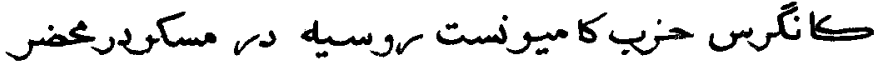

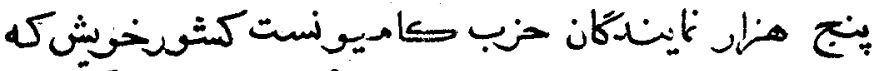

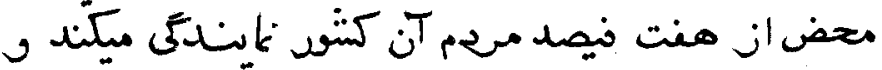

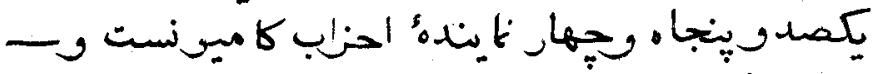

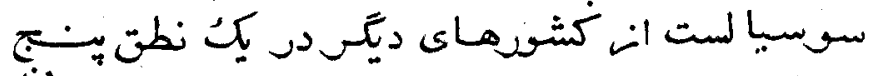

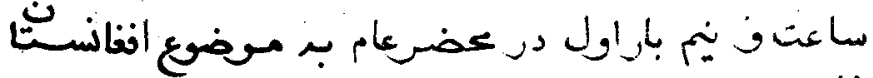

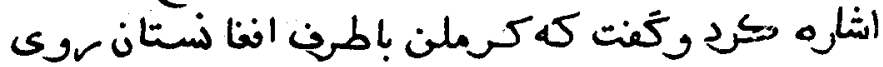

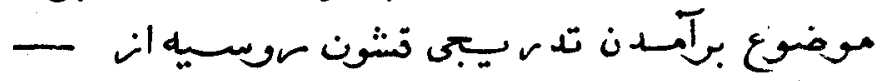

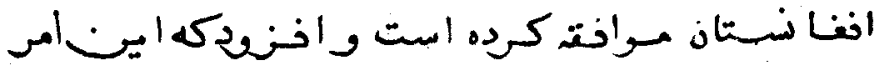

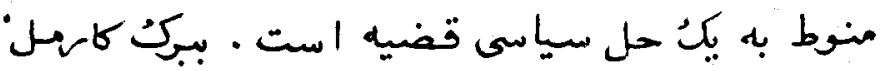

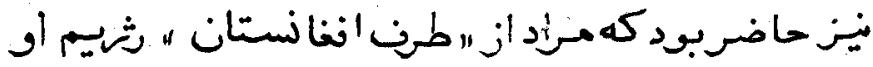


د

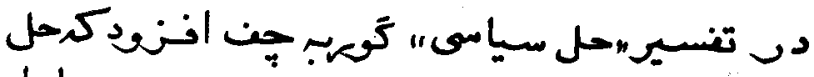

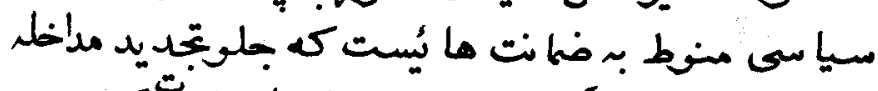

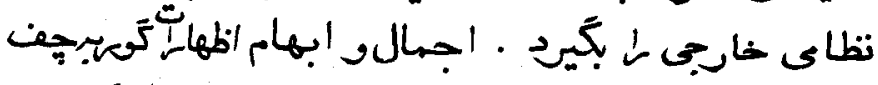

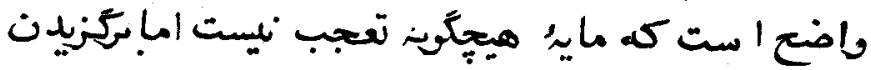

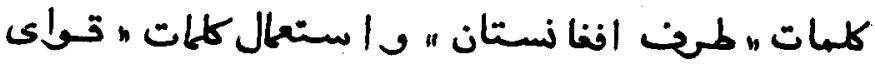

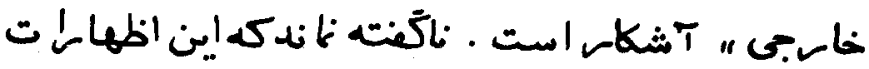

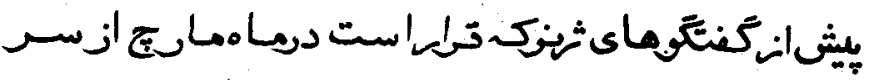

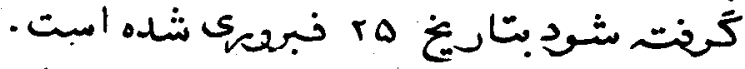

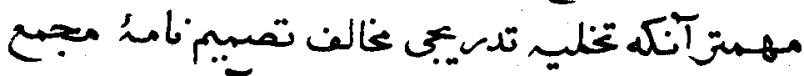

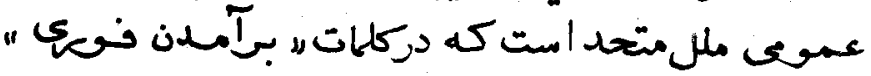

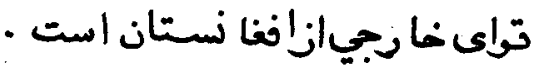

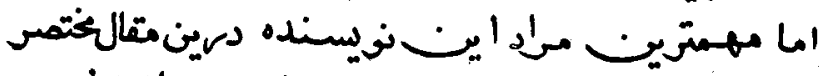

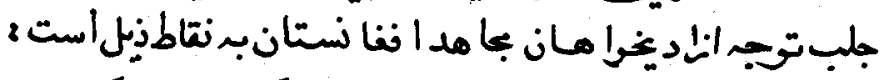

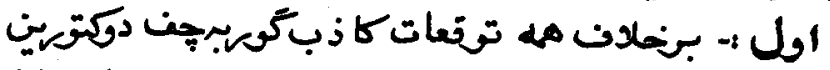

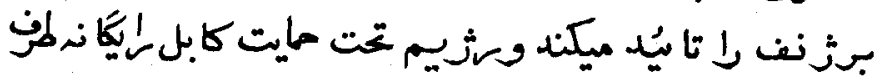

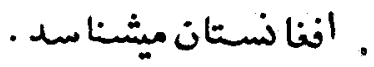

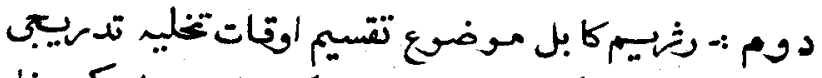

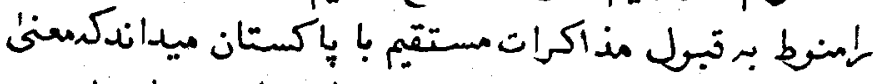

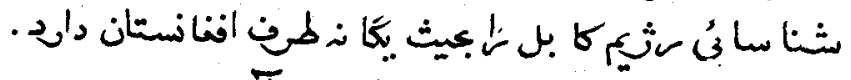

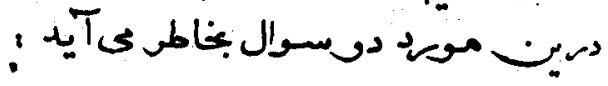




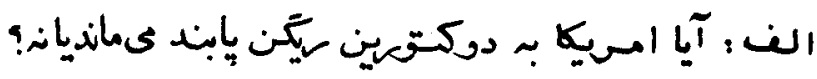

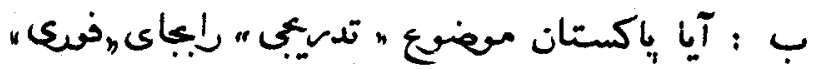

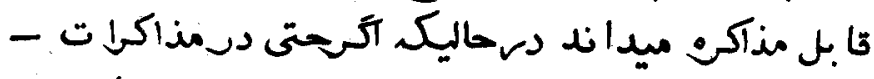

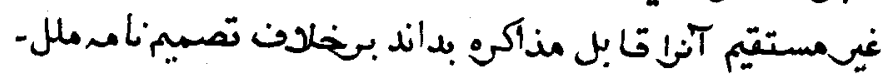

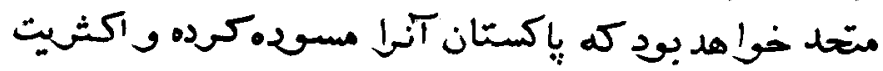

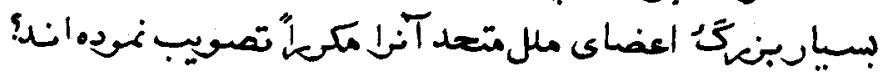

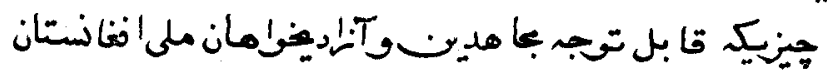
است اينستكه حالوقت آنست كم بنامخداونا موبس ملىبصوت

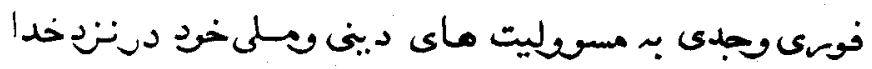

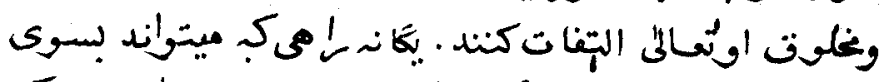

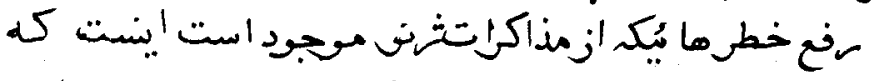

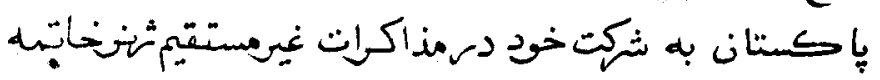

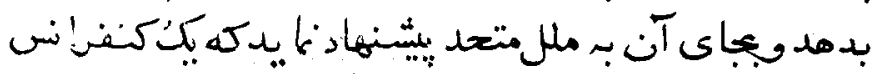

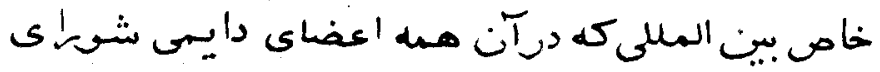

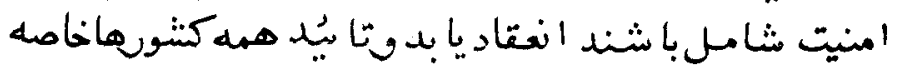

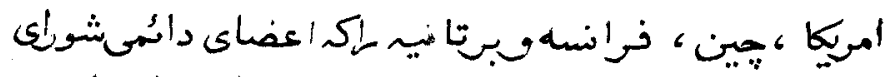

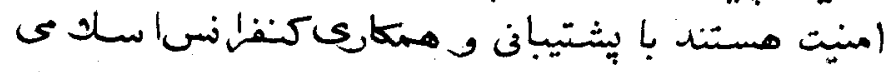

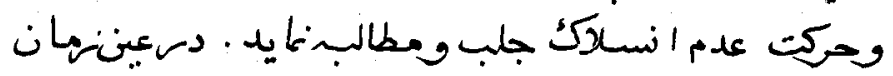

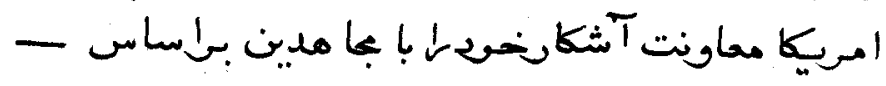

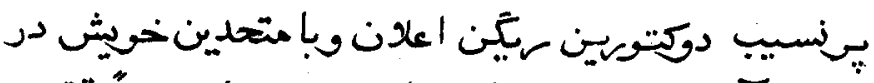

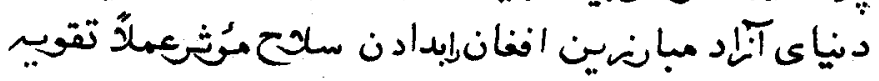




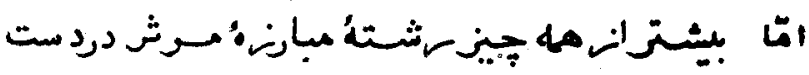

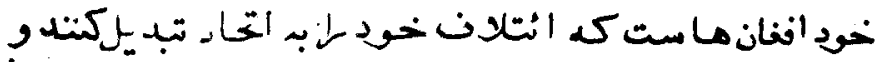

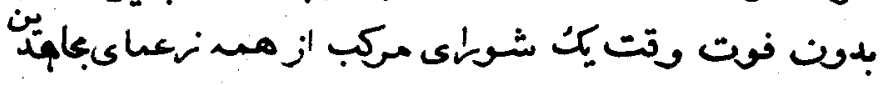

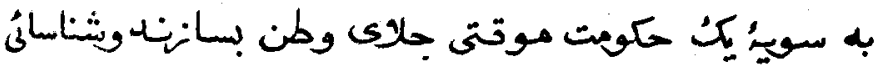

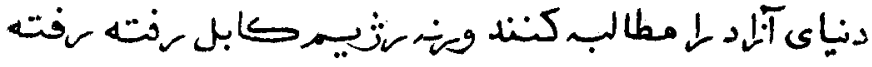

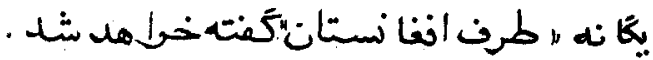

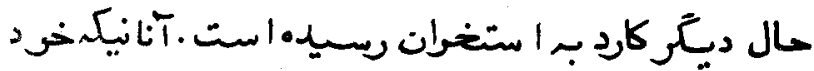

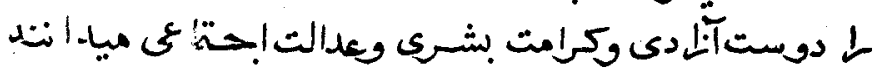

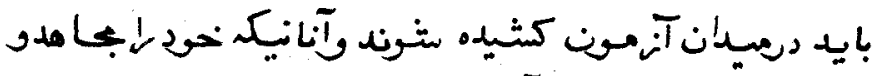

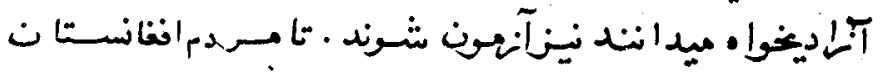

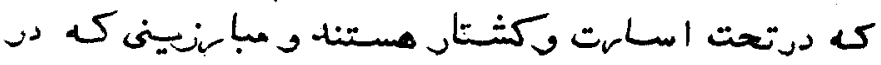

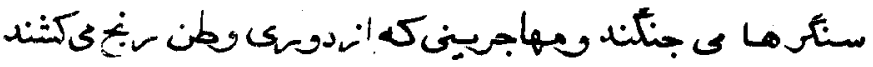

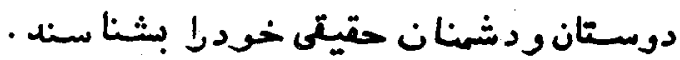

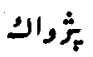

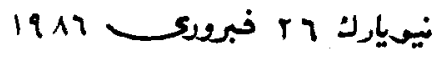

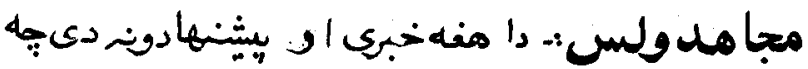

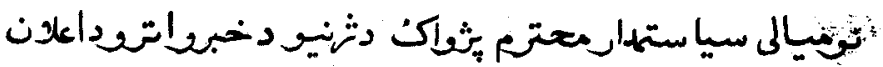

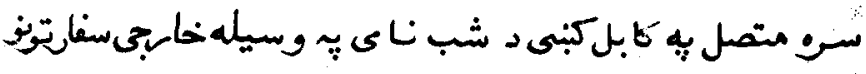

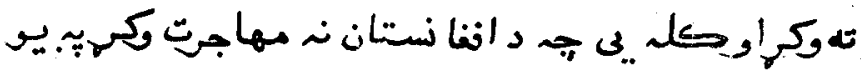

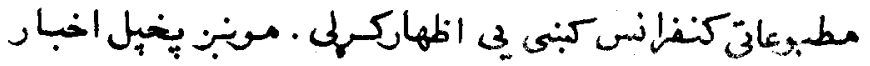




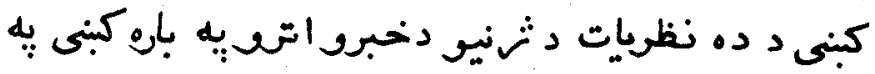

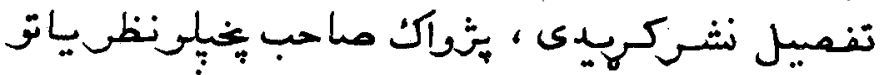

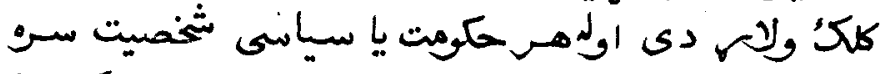

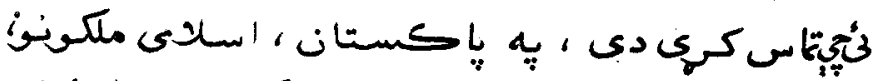

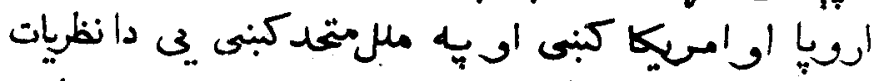

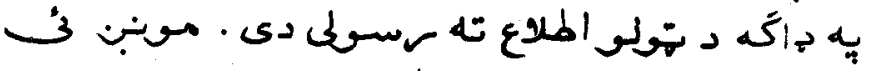

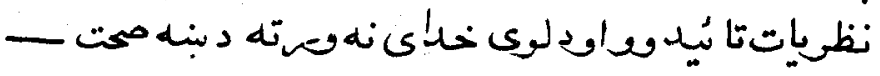

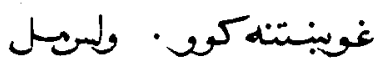

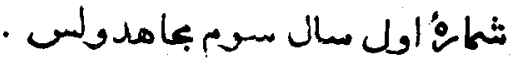
$1170 / 1 / 1$ 


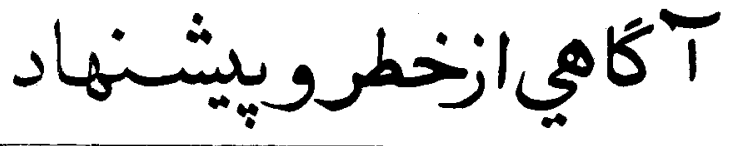

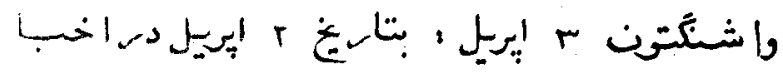

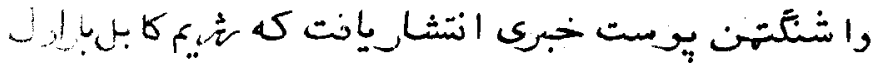

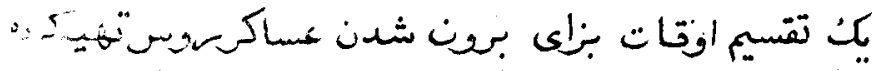

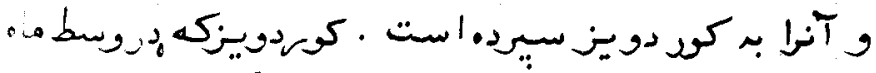

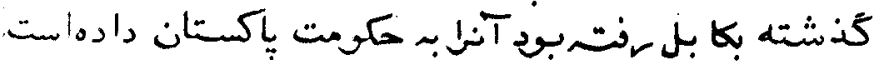

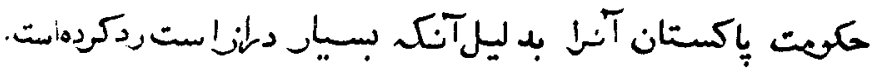

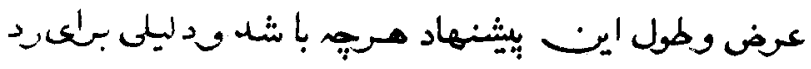

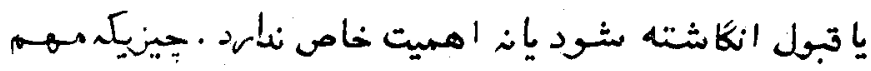

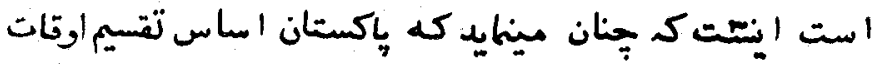

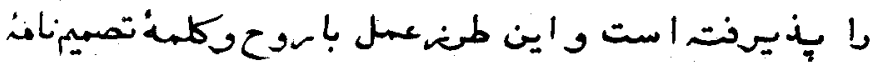

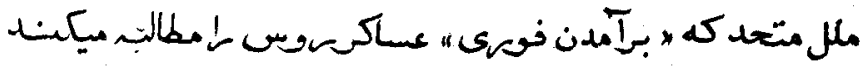




\section{مغا لفت راظع داضرد .}

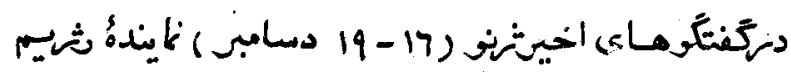

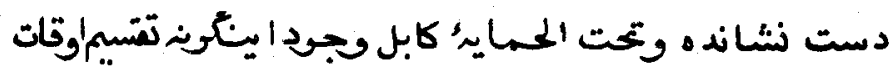

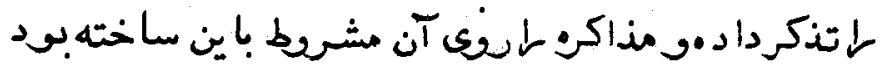

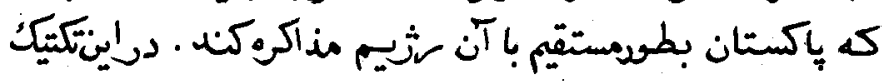

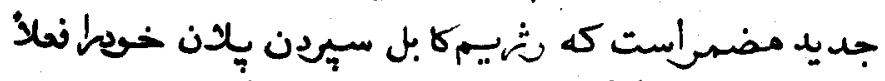

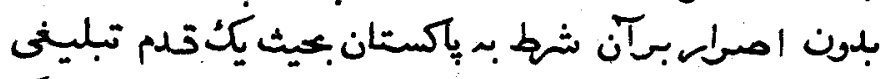

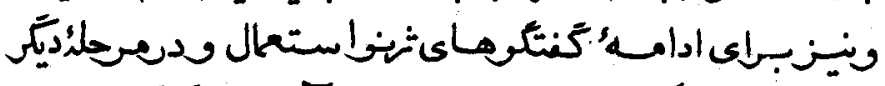

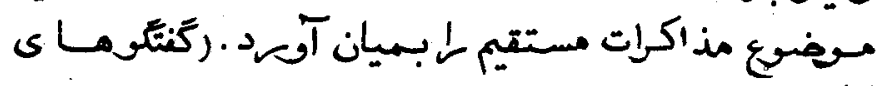

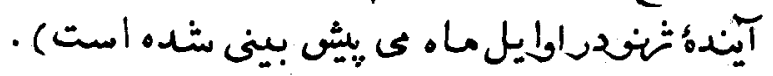

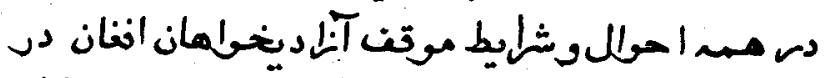

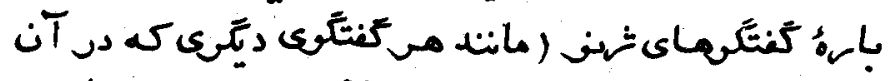

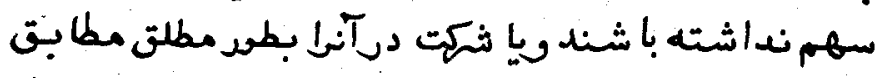

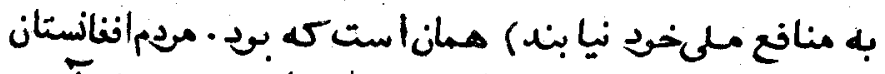

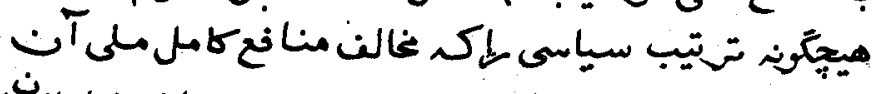

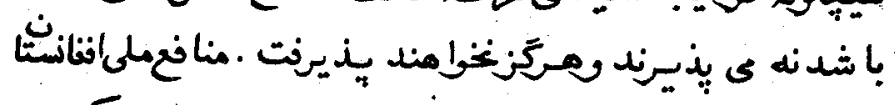

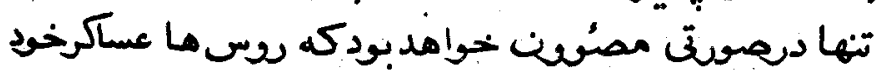

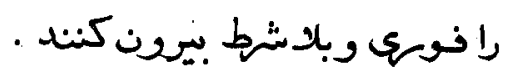

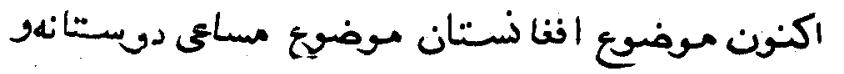

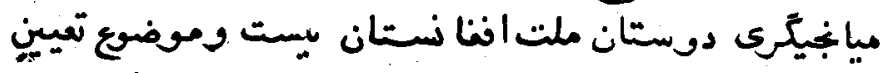

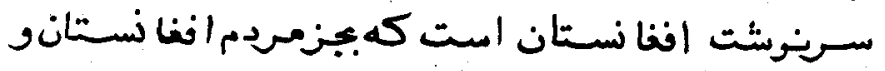




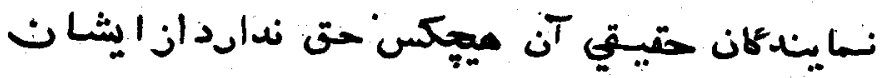

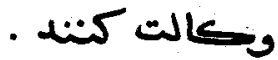

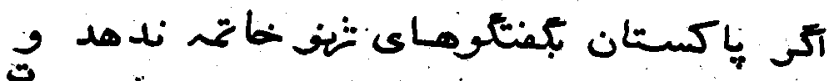

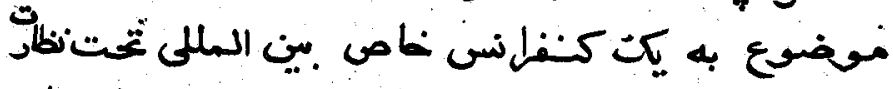

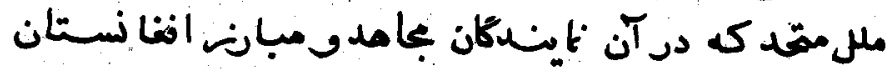

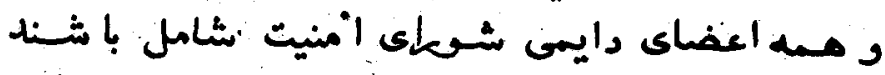

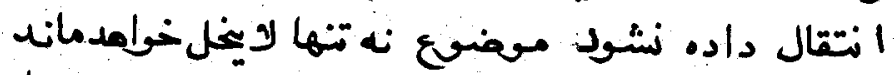

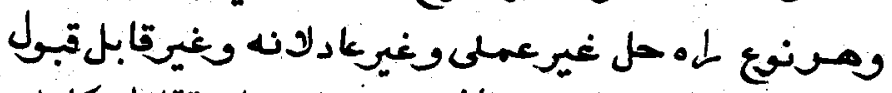

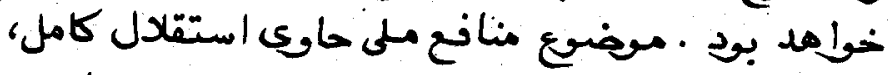

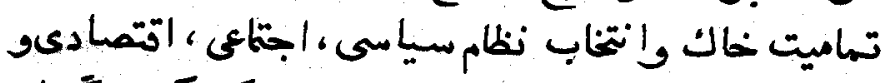

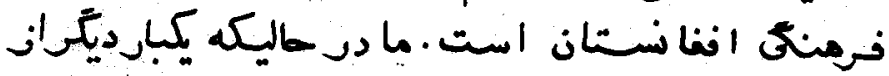

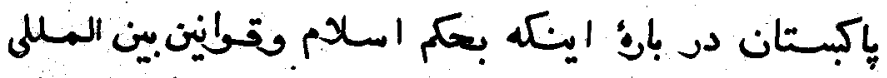

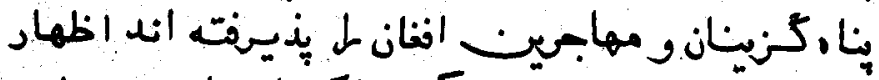

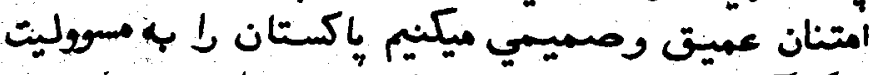

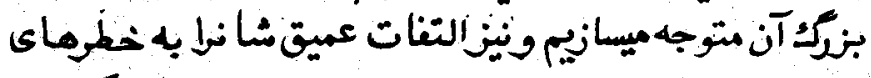

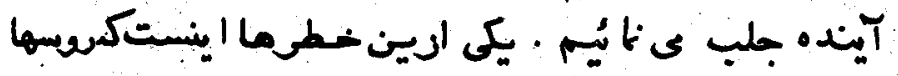

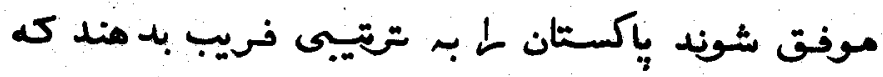

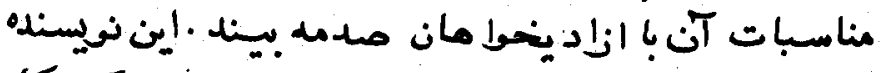

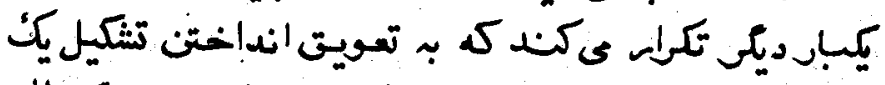

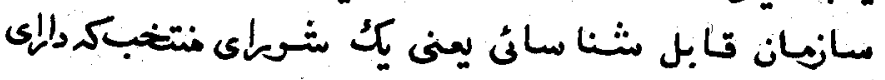

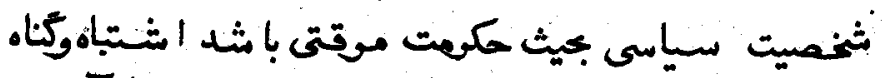

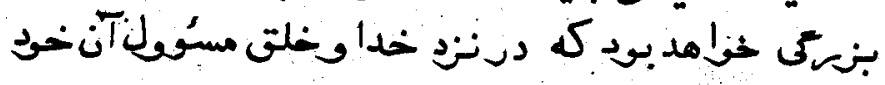


ry

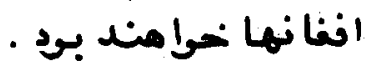

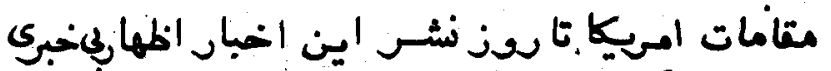

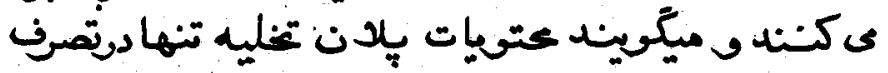

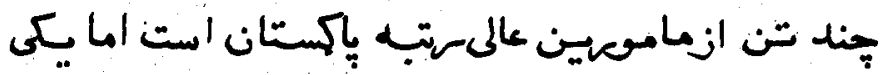

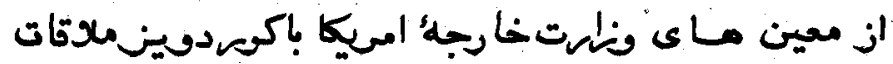

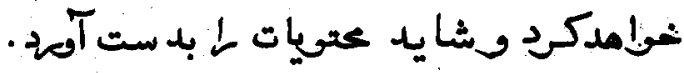

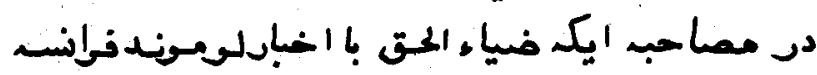

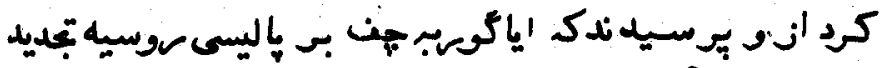

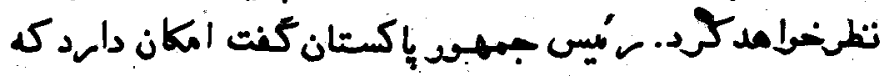

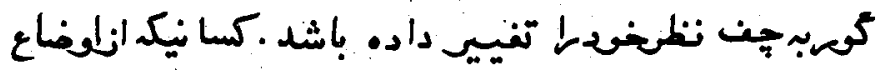

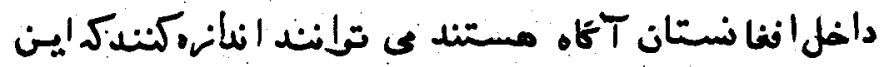

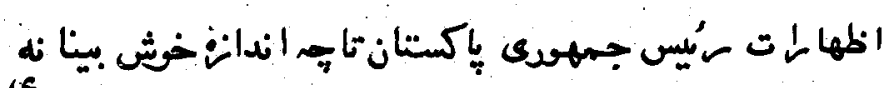

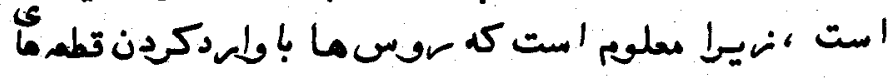

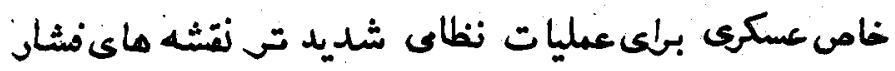

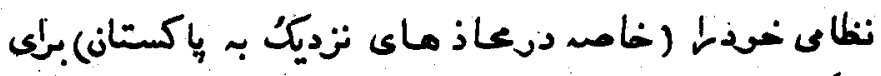

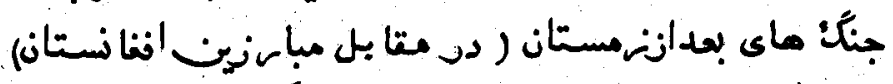

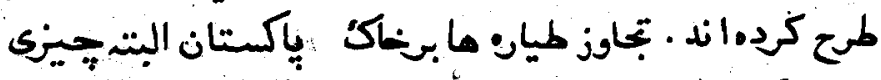

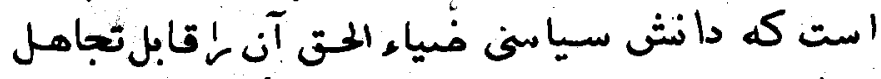

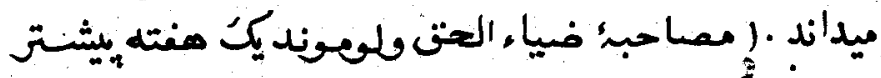

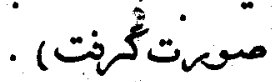

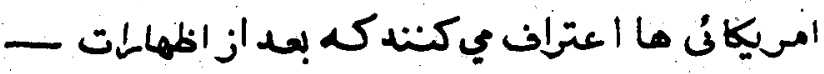


Y.?

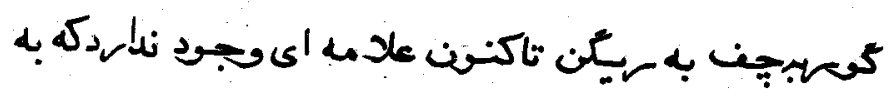

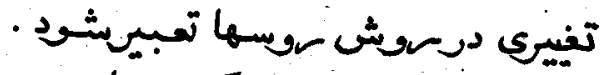

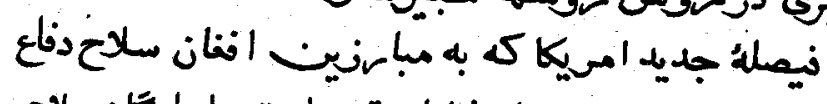

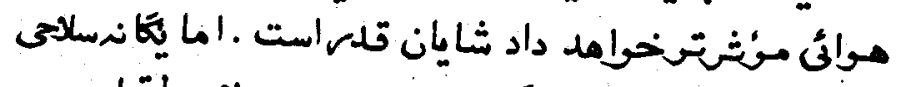

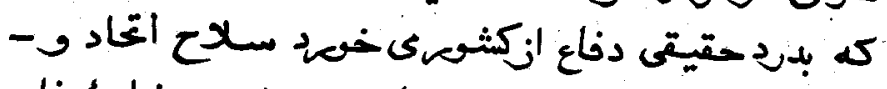

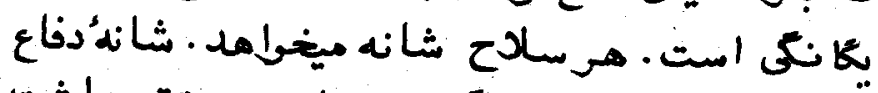

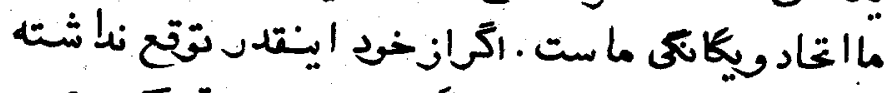

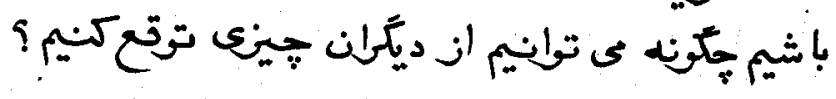

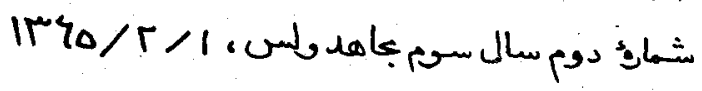




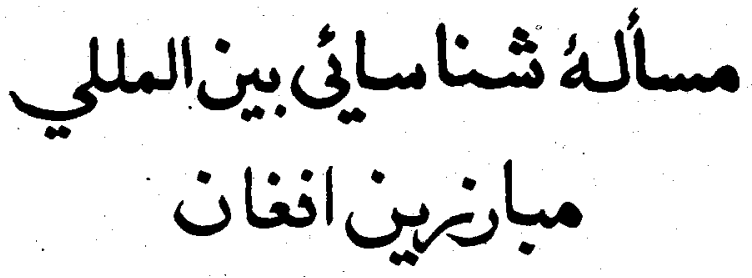

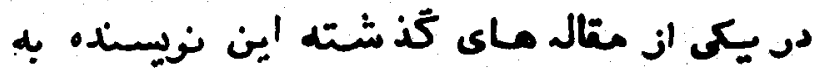

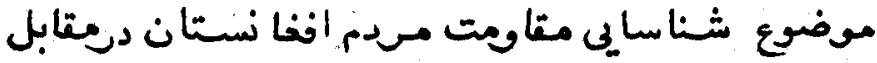

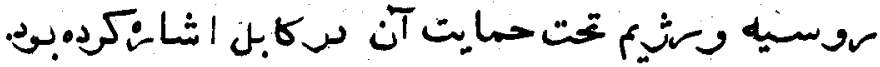

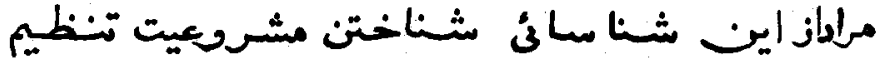

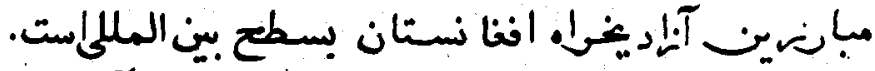

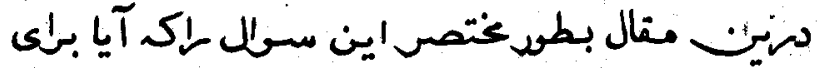

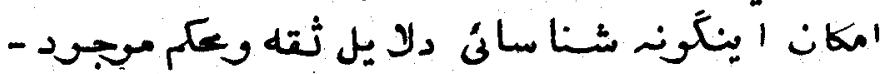

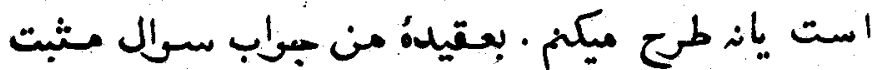

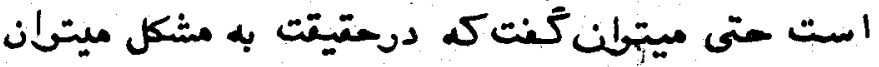

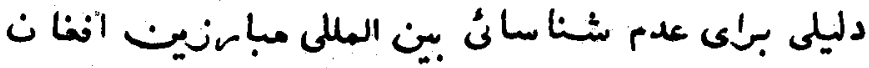




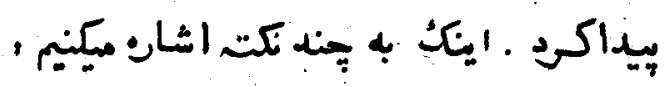

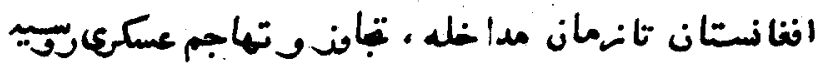

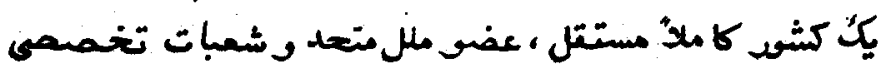

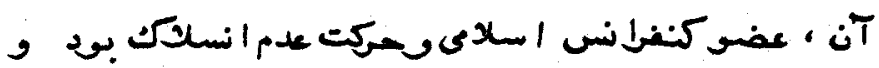

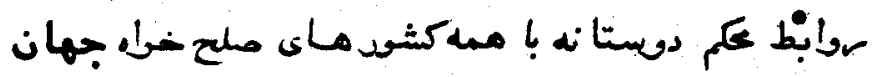

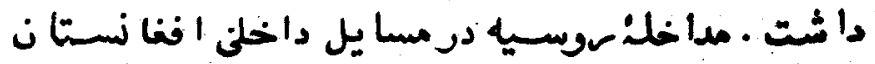

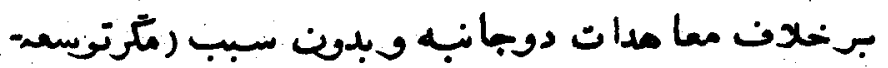

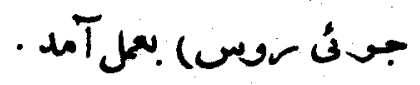

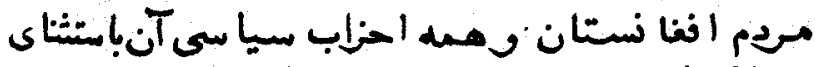

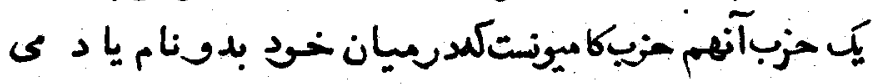

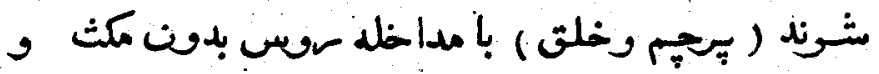

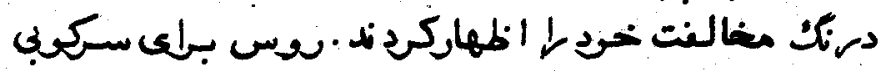

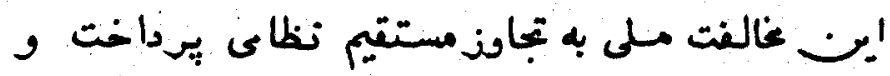

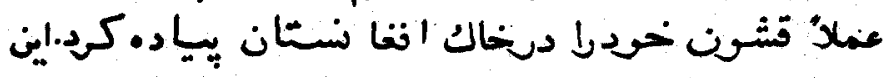

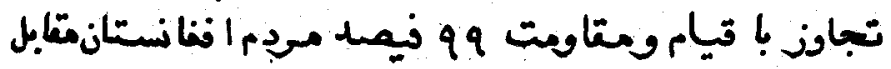

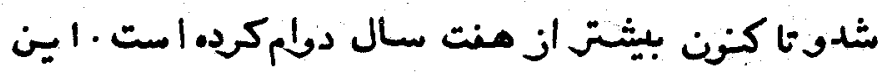

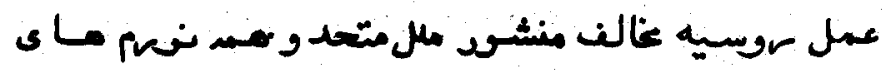

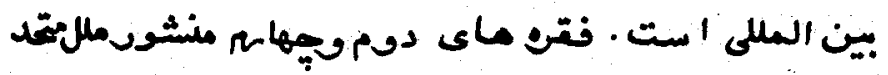

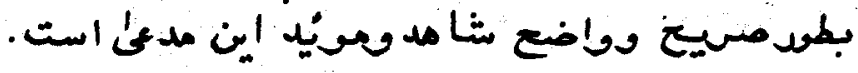

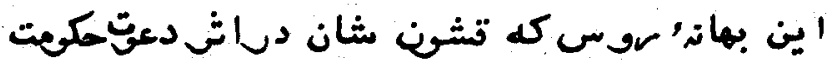

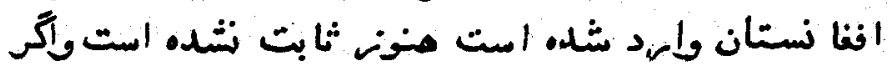




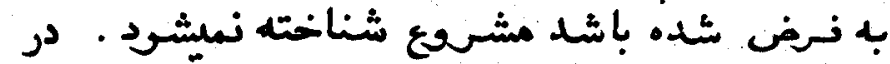

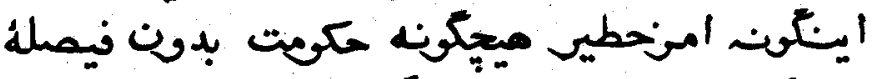

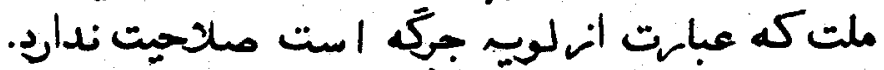

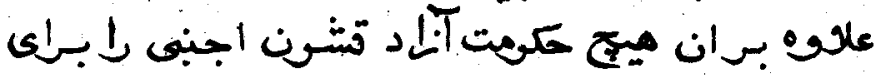

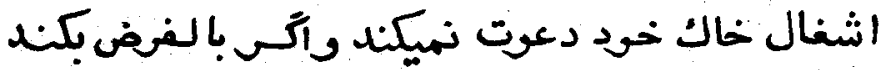

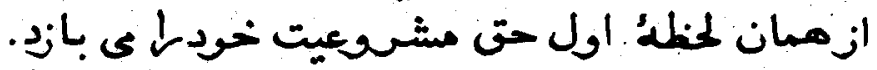

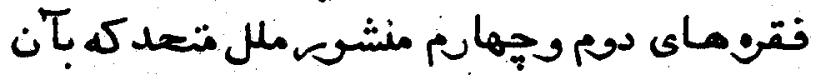

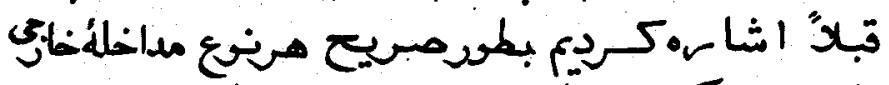

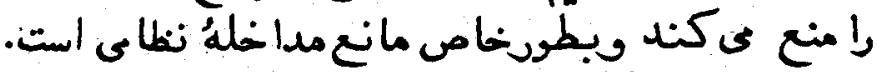

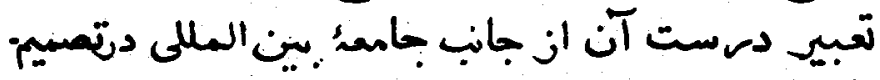

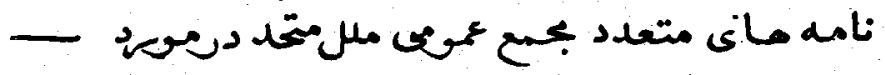

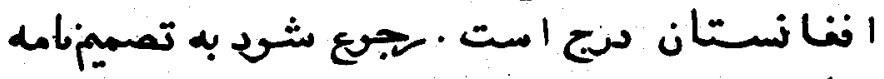

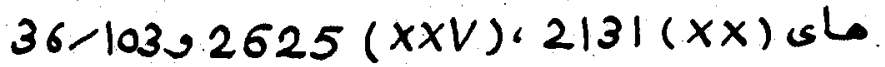

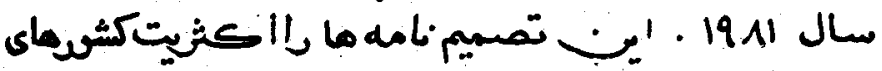

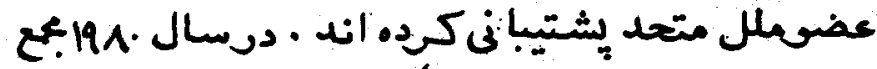

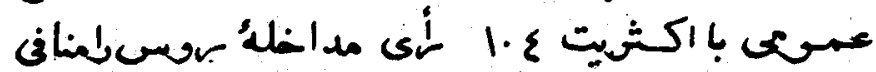

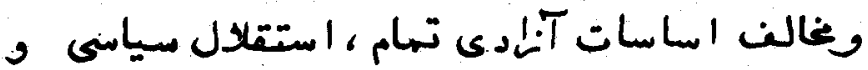

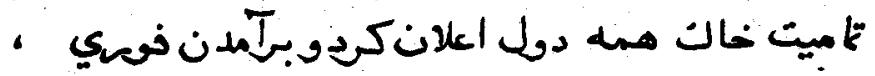

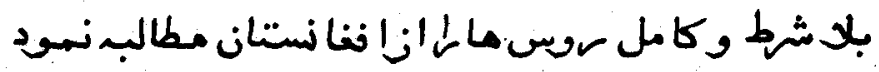

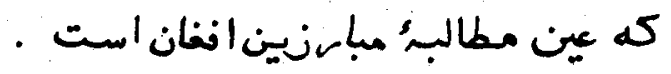

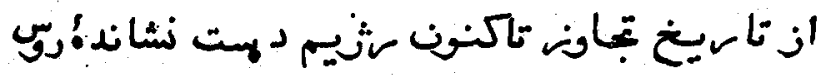




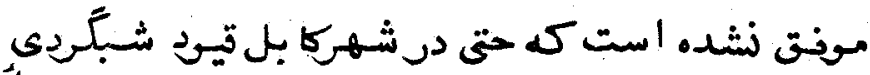

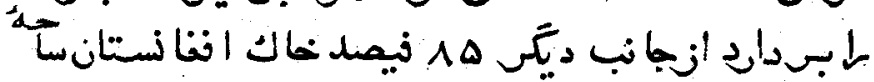

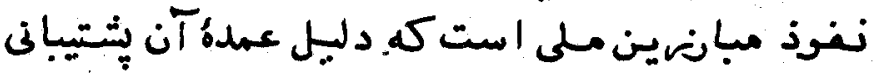

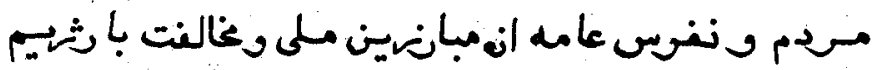

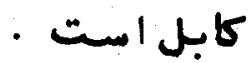

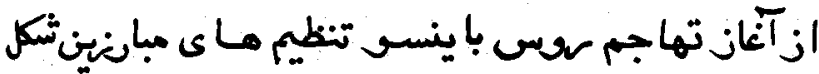

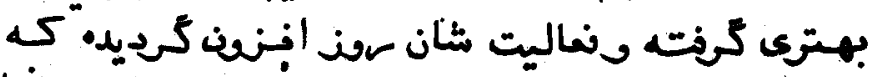

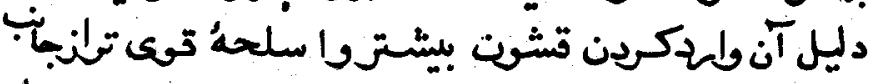

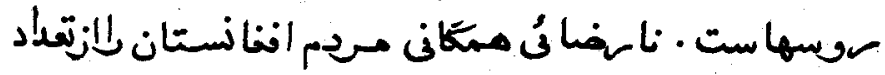

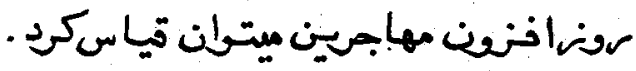

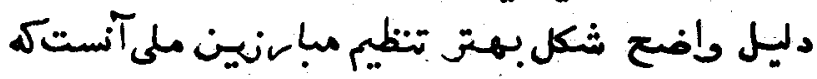

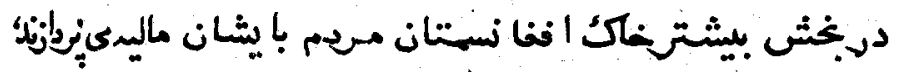

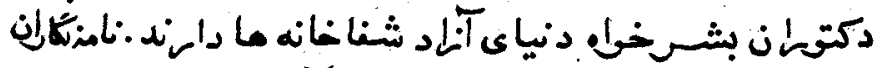

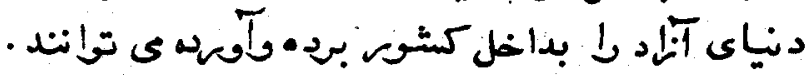

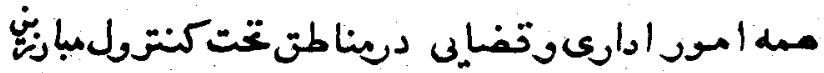

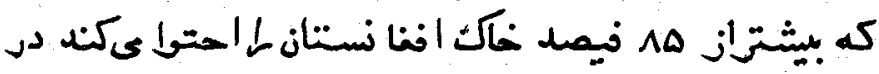

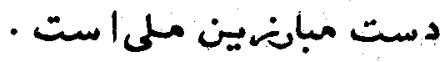

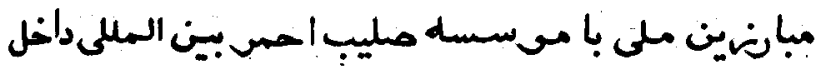

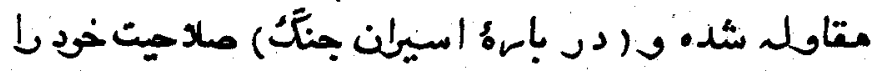

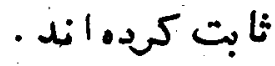
نسايندكان مبانهين آنا ديخها دربعامع بين المللى لـ. 


\section{r.9}

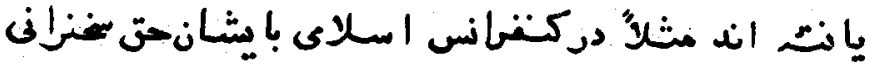
داده شده است .

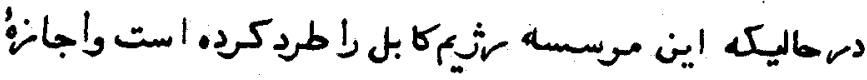

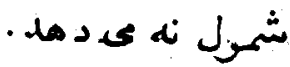

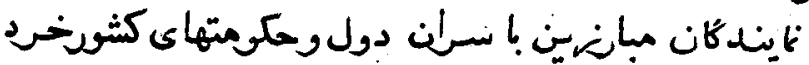

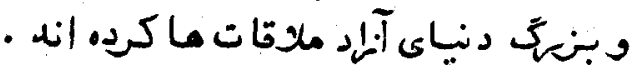

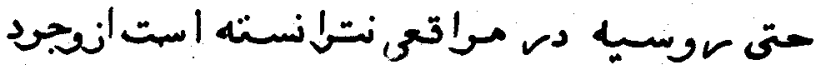

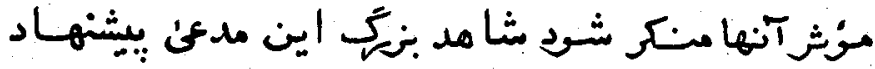

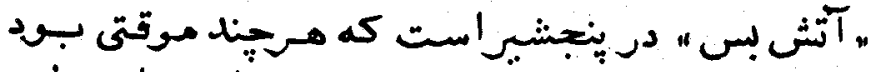

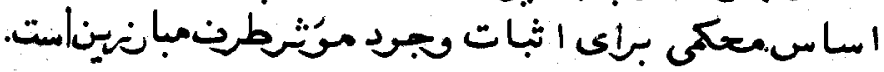

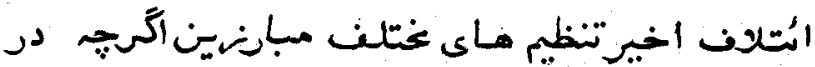

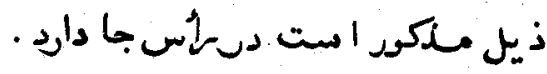

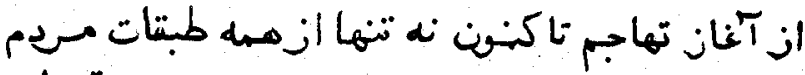

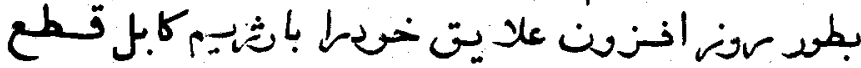

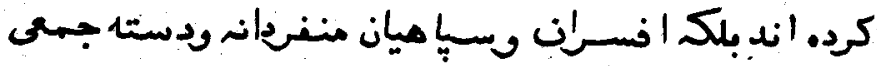

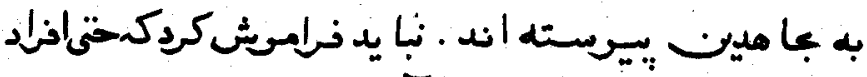

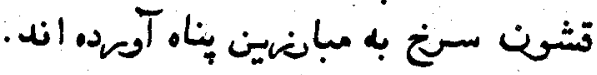

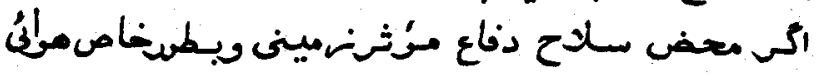

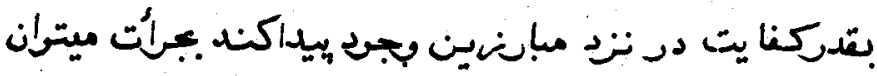

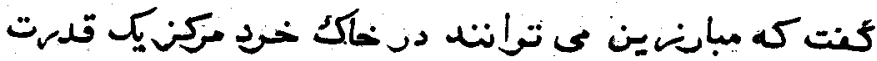

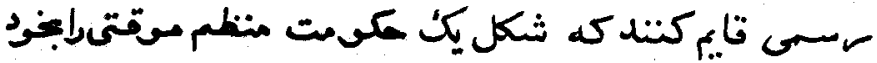




\section{ri.}

بكيرد . - مان

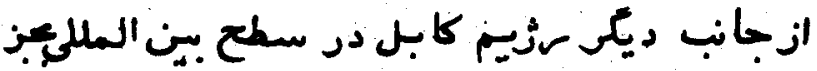

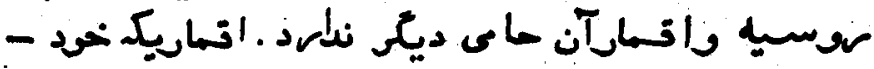

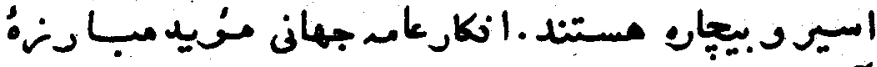

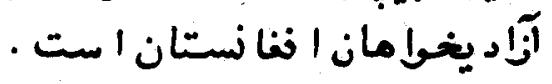

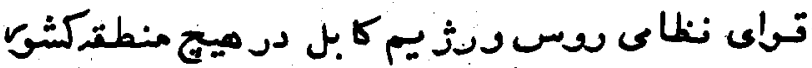

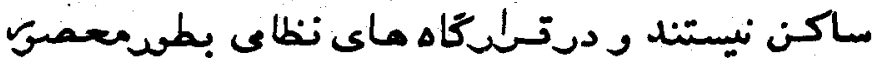

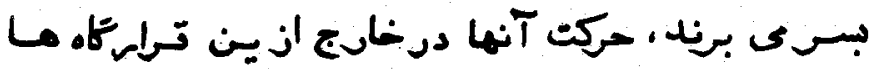

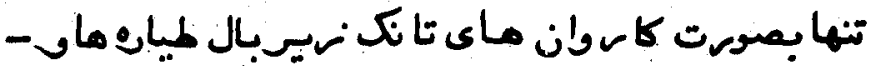

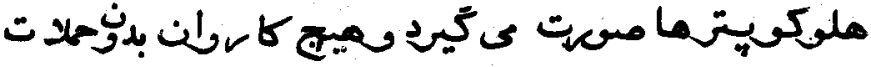

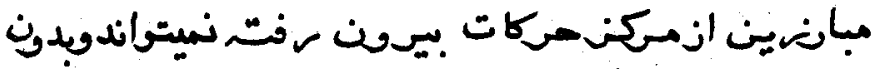

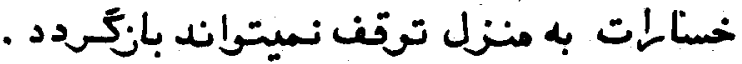

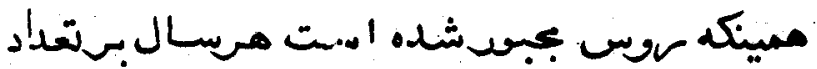

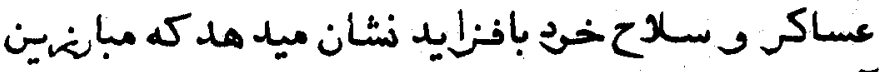

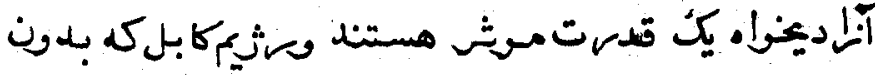

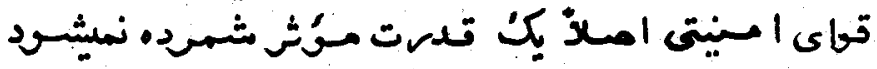

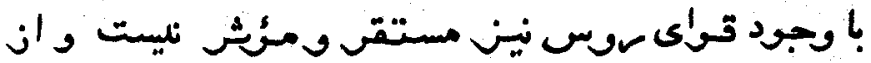

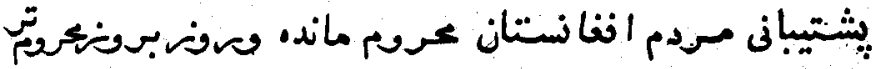

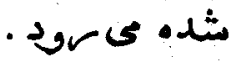

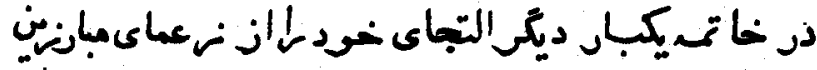

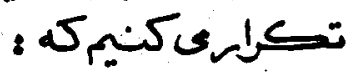




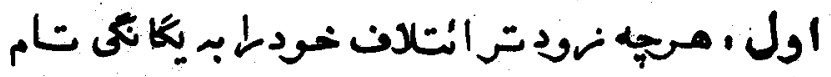

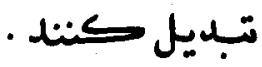

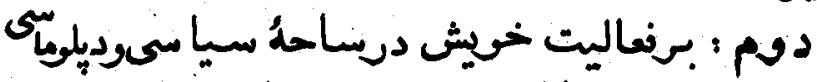

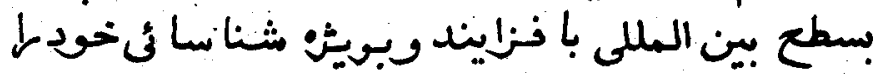

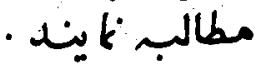

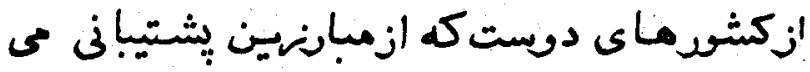

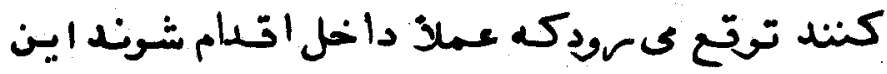

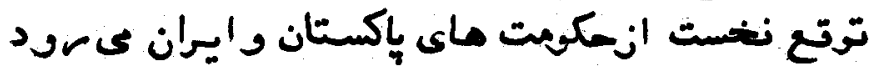

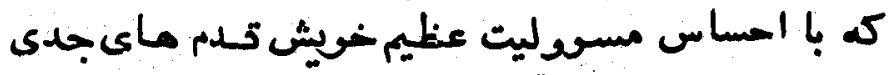

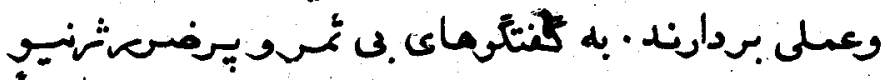

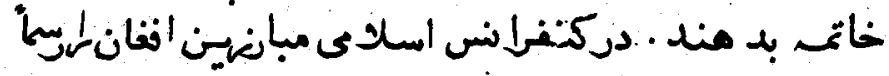

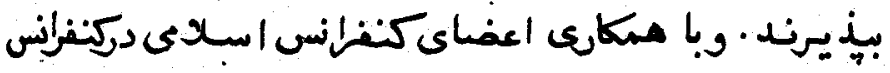

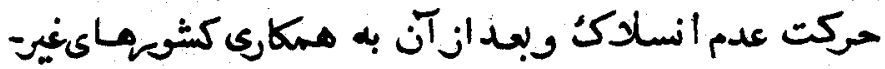

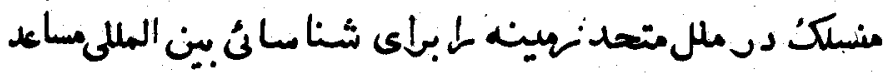
نسانمند.

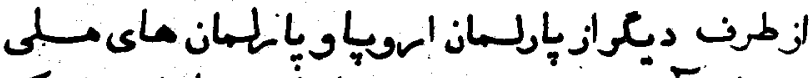

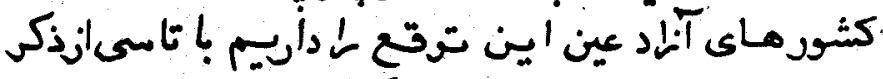

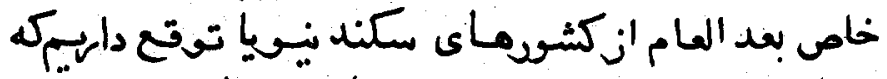

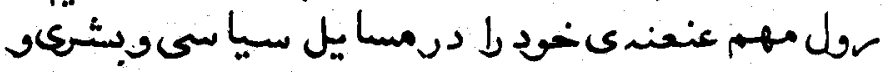

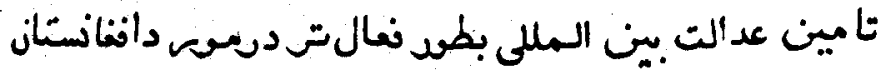

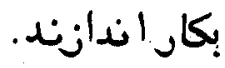




\section{VIr}

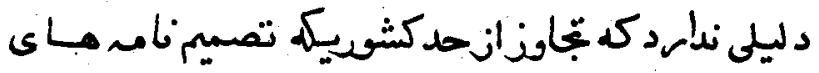

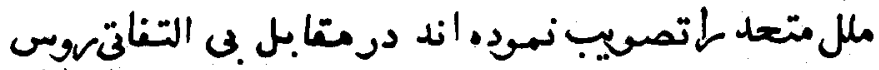

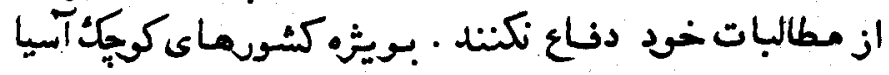

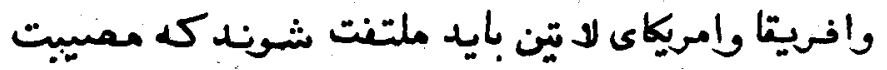

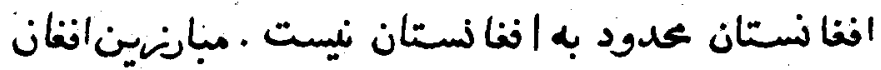

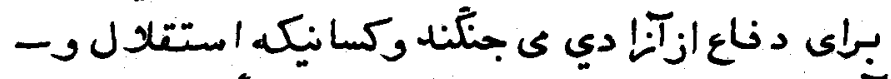

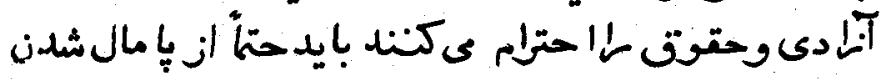

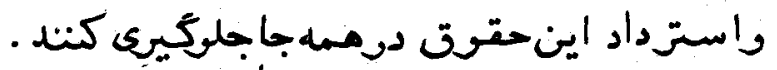
ومن الله التوفيتَ

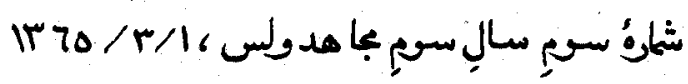




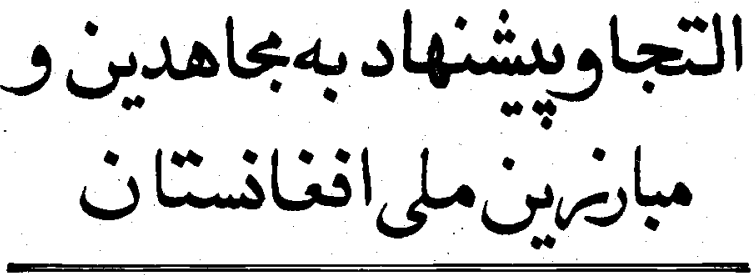

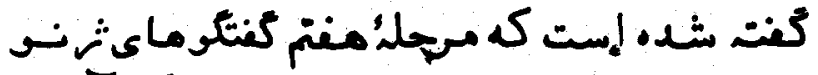

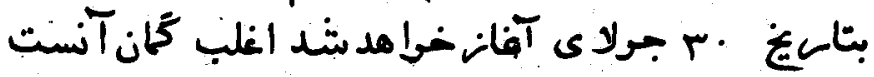

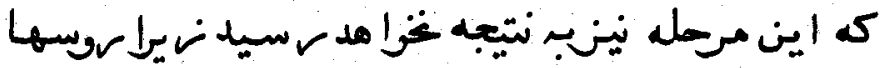

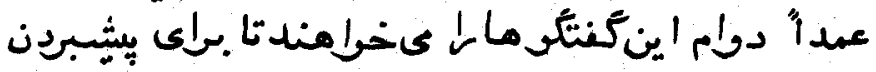

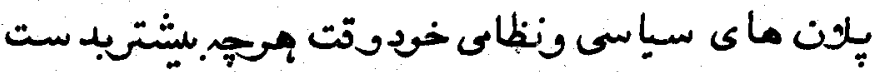

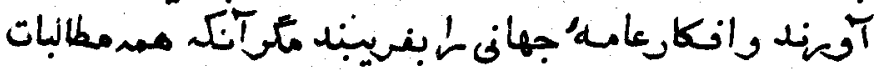

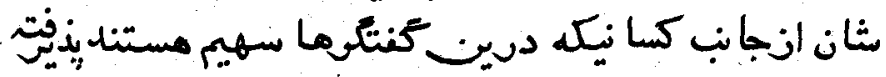

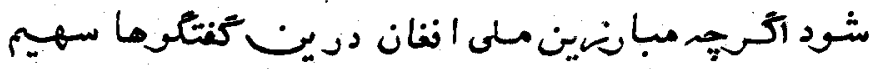

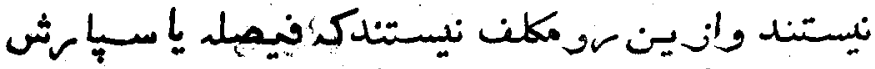

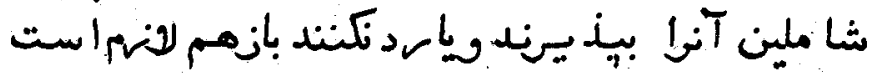


$T K$

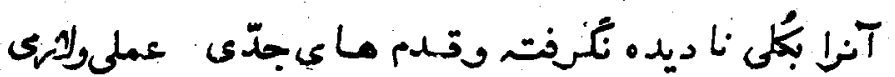

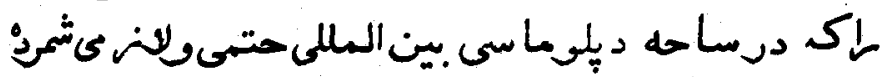

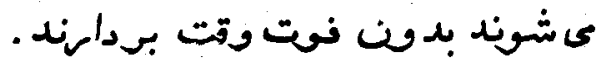

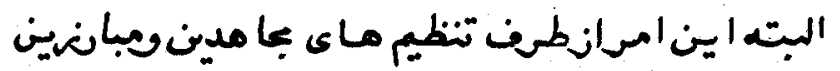

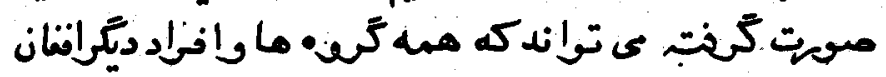

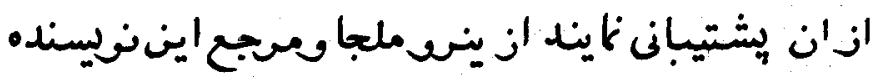

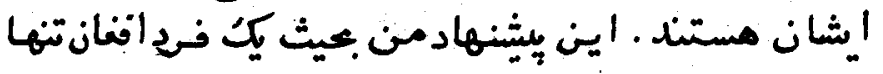

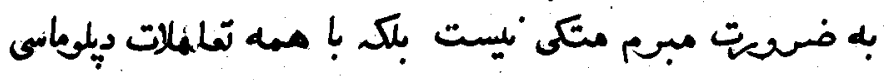

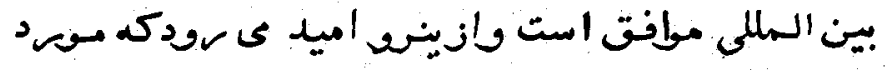

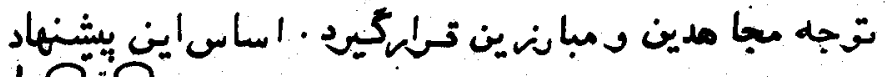

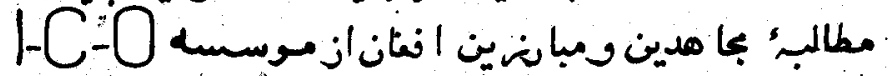
(Islamic Constance Organization.)

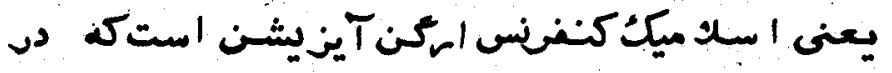

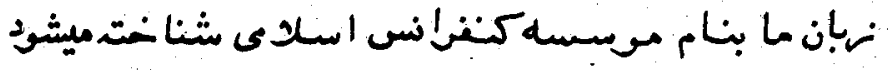

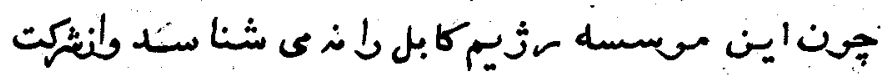

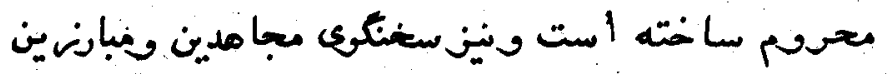

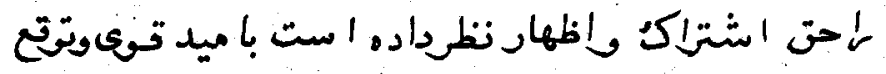

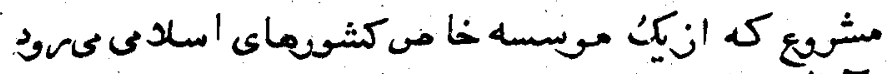

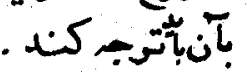

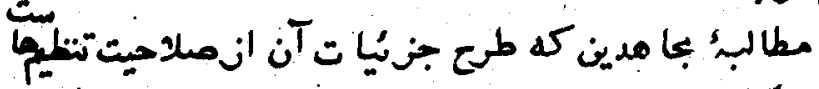

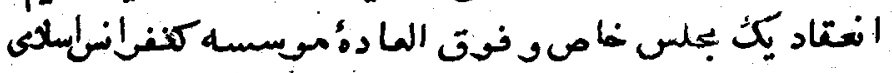


710

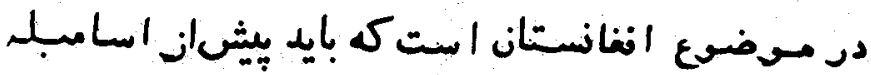

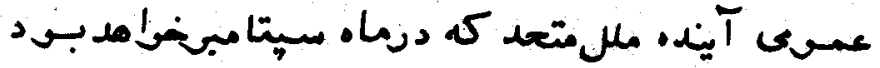

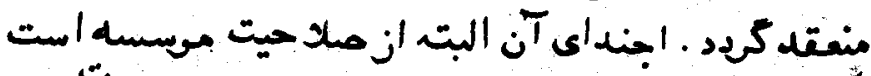

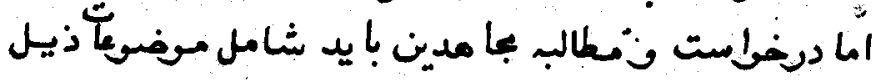
بإ.

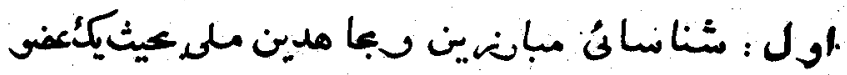

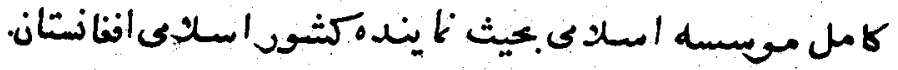

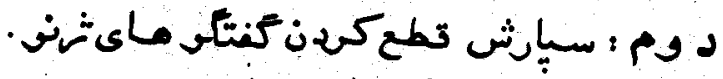

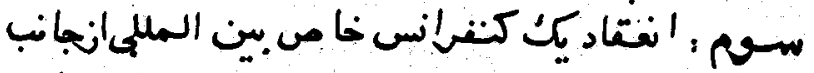

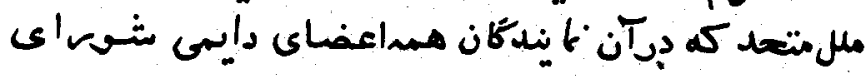

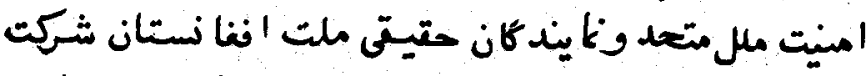

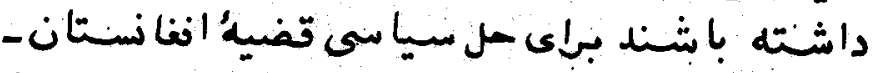

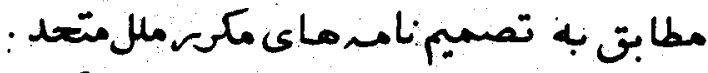

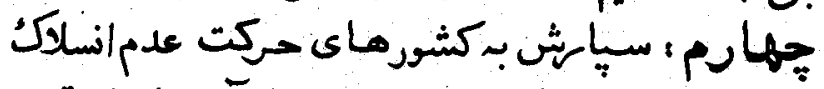

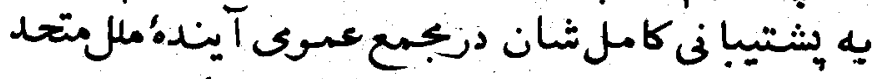

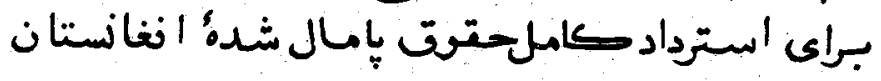

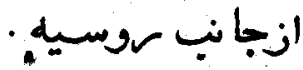
اين نويسندة درين متال به اين اختصار اكتناميكند

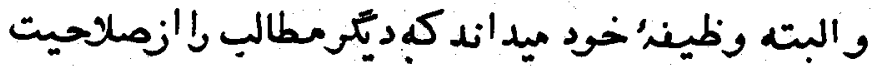

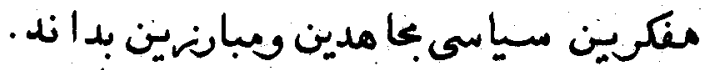

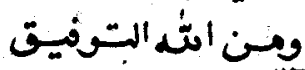

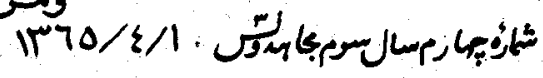




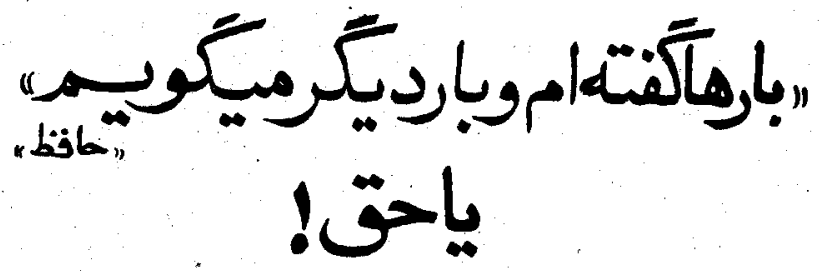

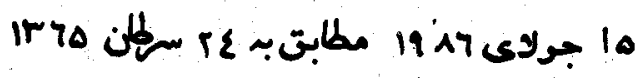

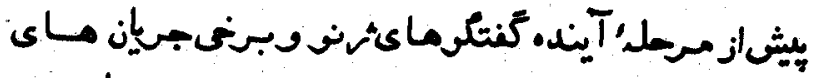

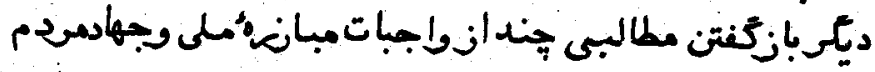

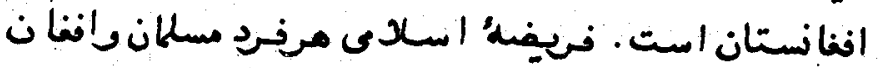

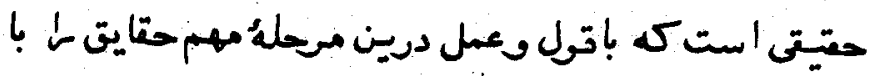

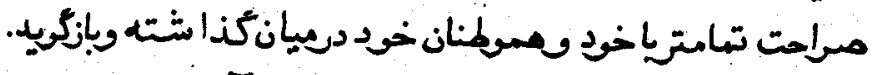

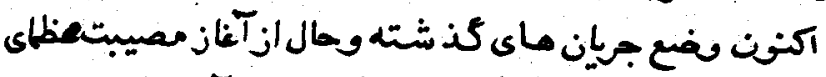

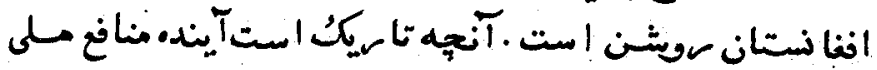

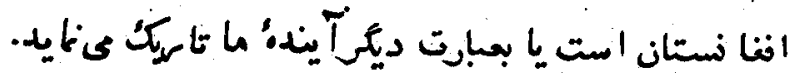

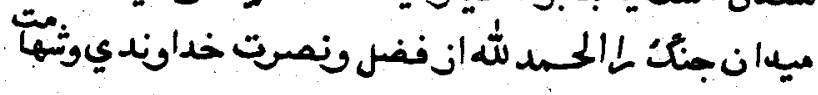




\section{riv}

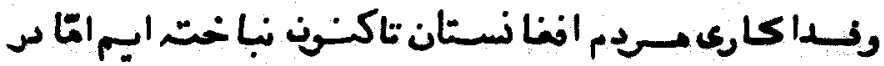

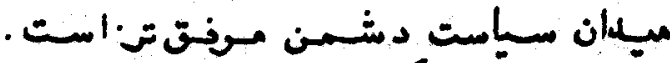

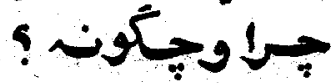

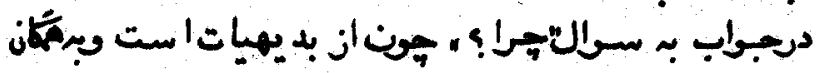

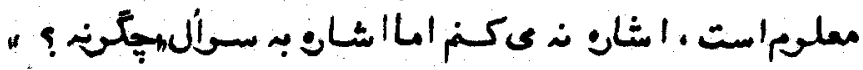

لעنه ' مست.

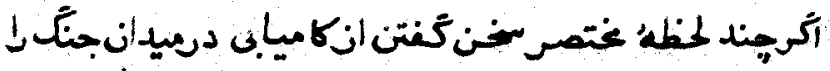

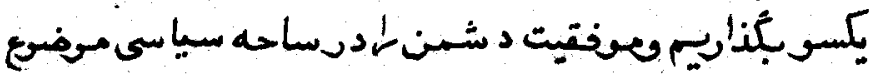

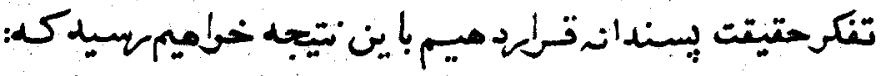

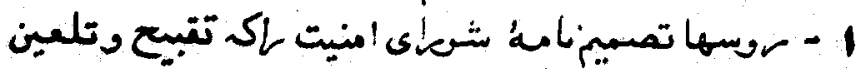

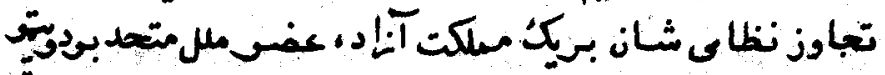

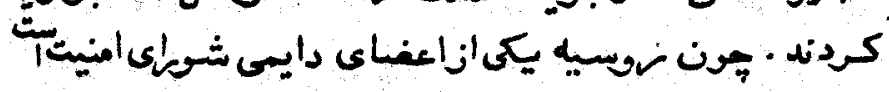

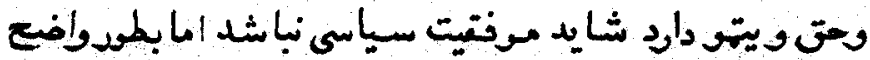

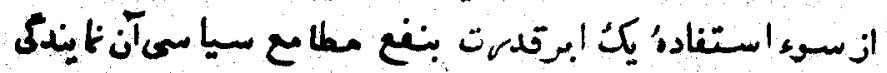

م.

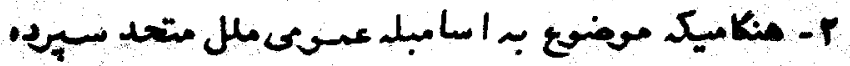

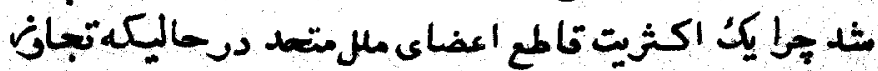

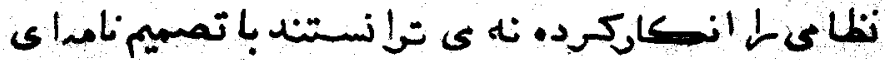

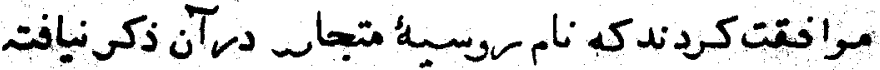

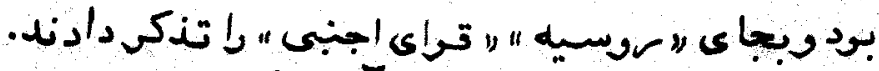

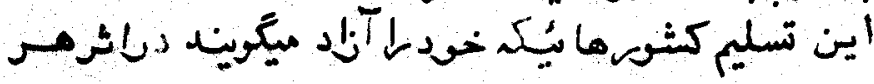




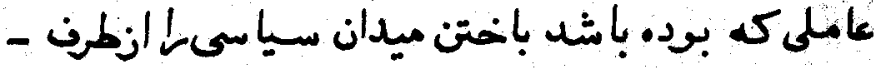

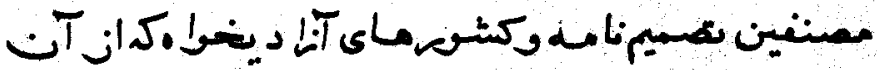

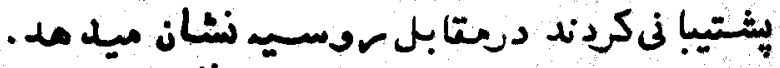

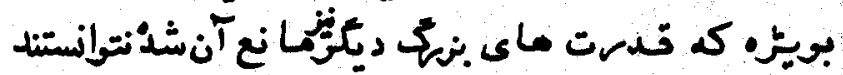

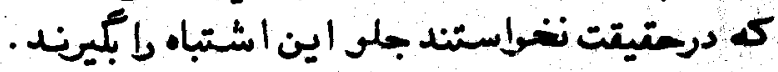

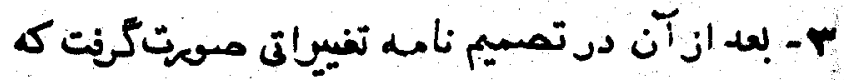

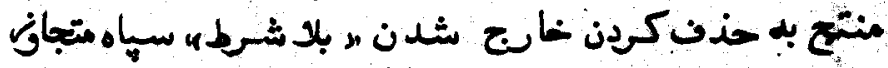

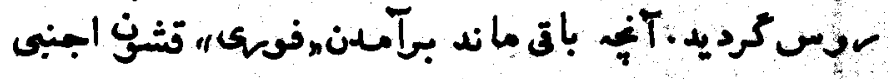
بو

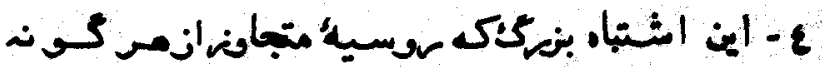

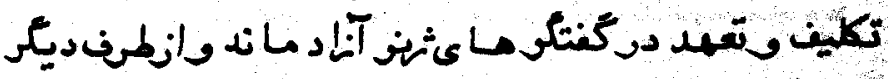

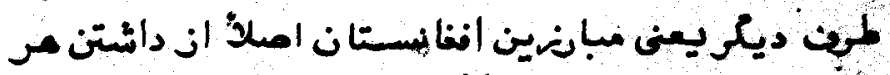

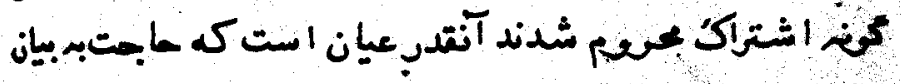
نان

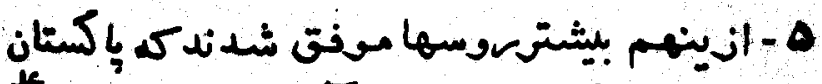

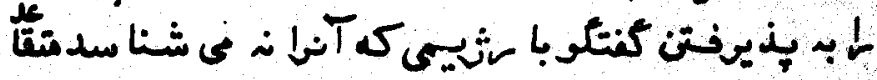

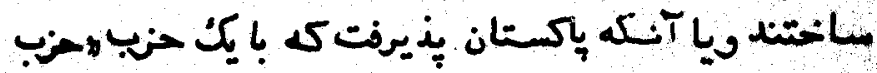

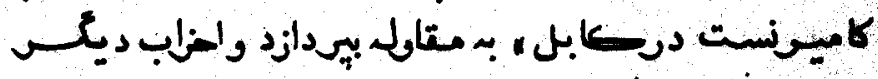

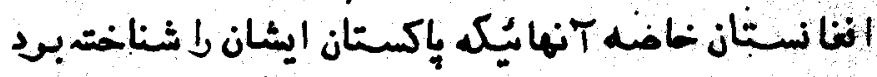

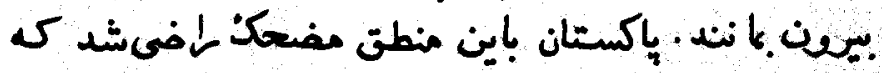

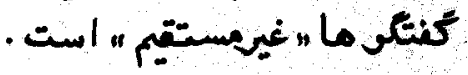




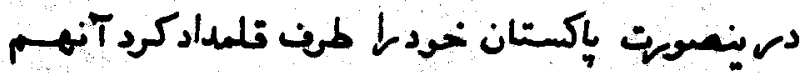

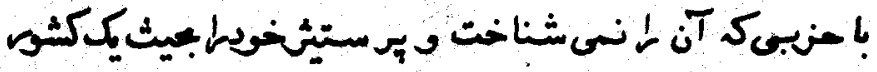

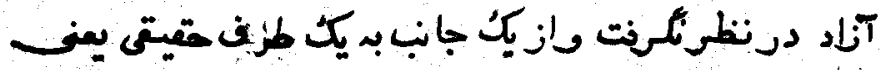

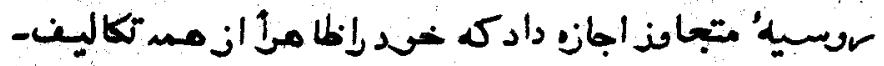

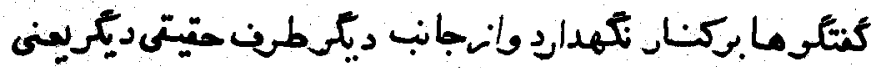

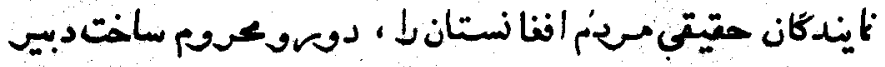

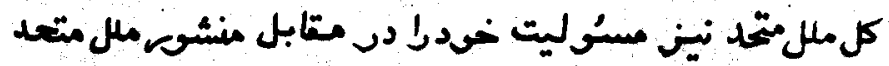

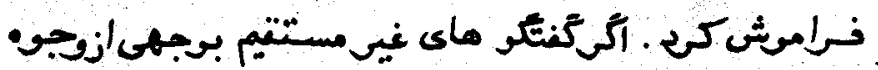

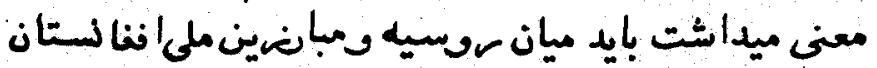

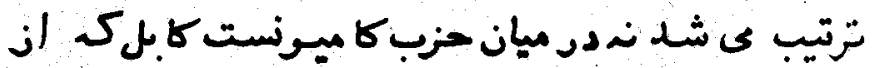

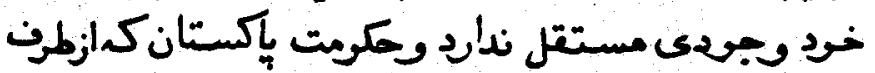

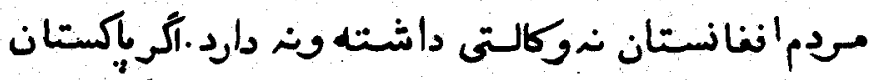

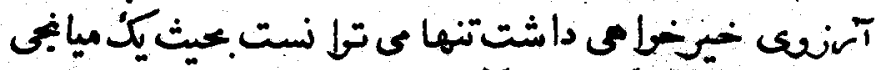

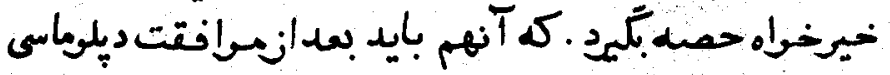

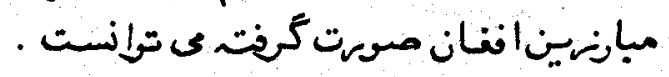

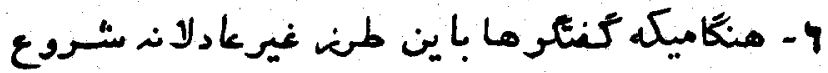

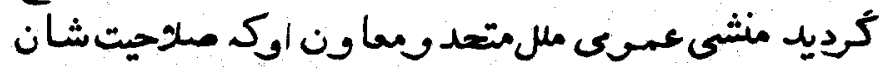

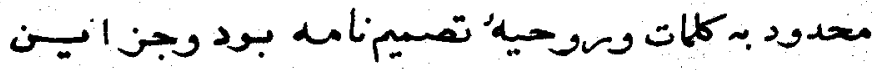

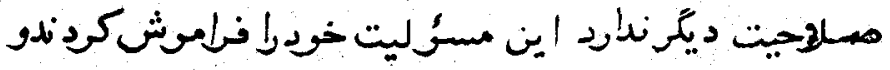

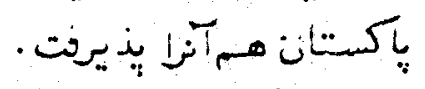

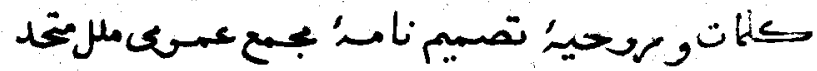


rr.

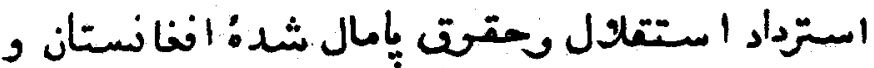

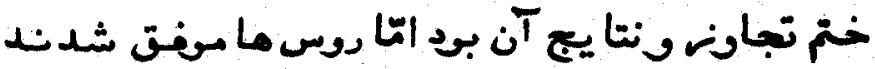

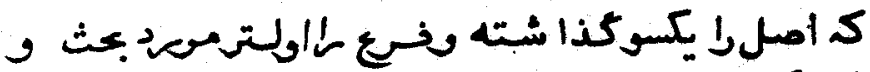

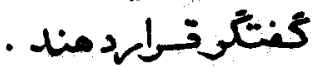

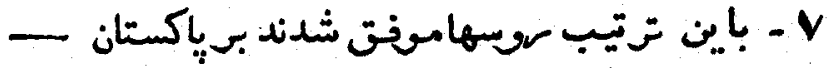

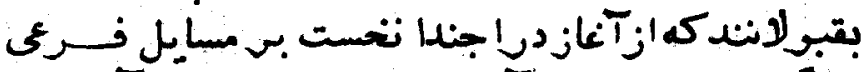

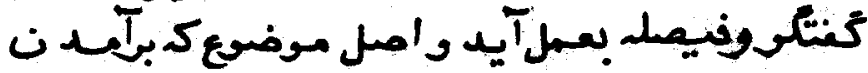

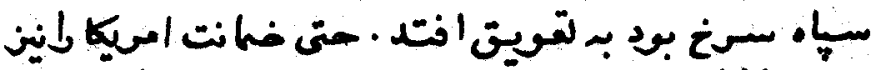

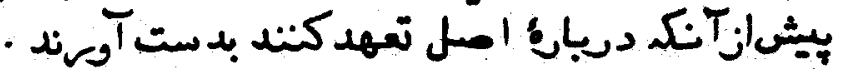

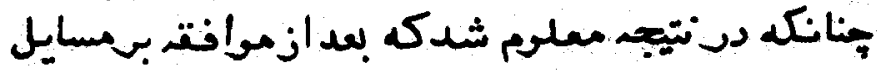

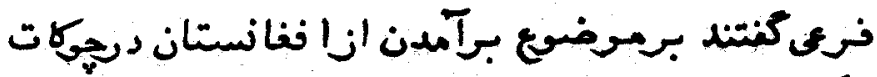

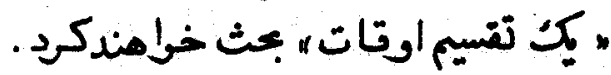

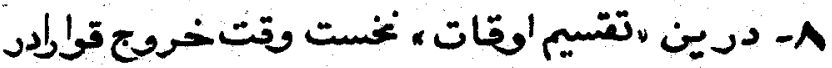

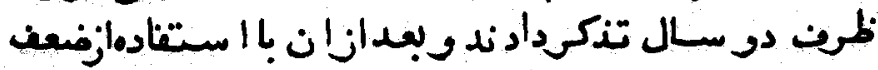

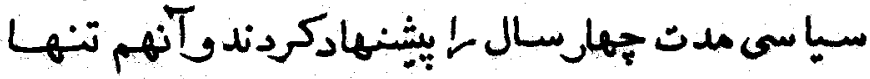

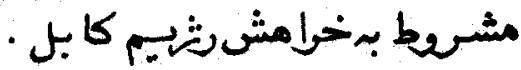

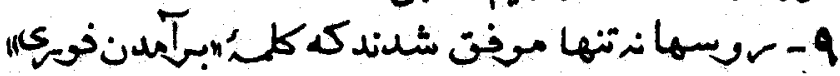

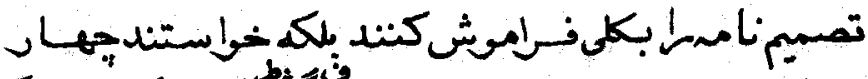

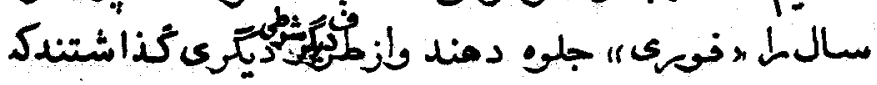

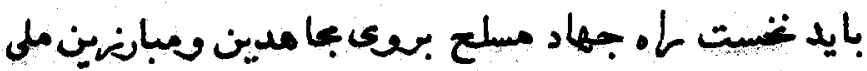




\section{rrI}

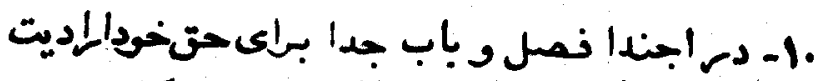

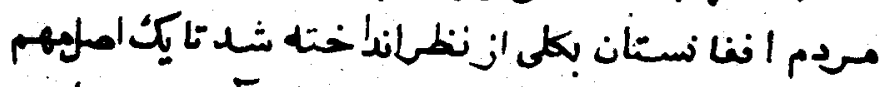

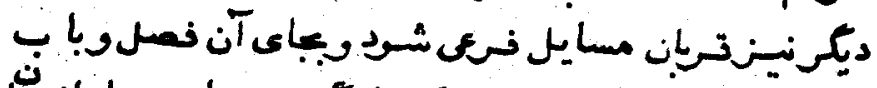

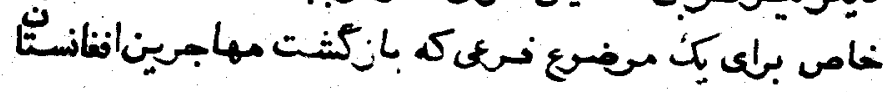

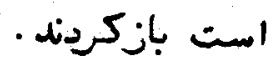

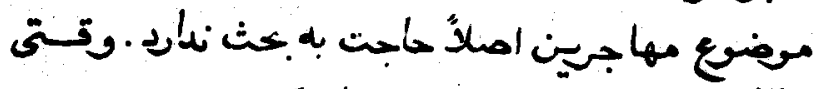

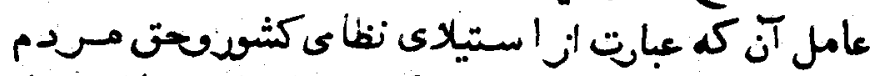

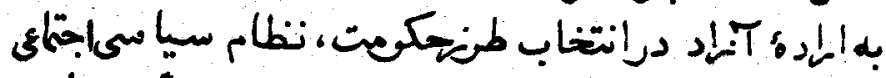

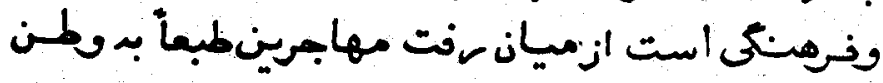

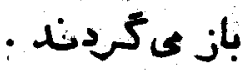

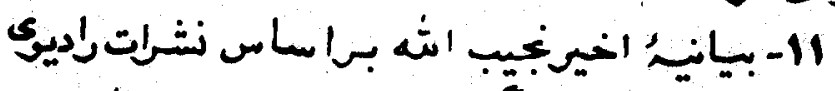

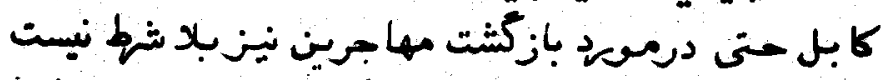

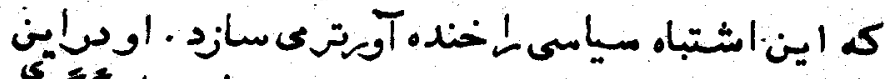

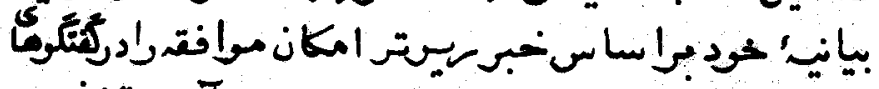

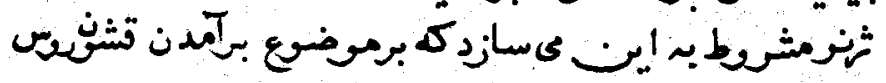

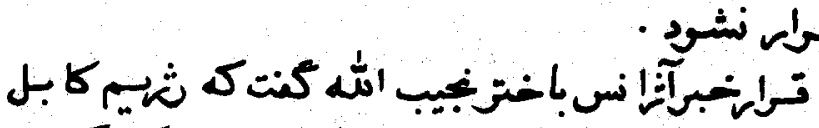

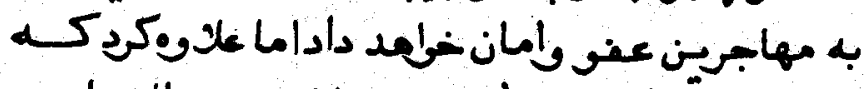

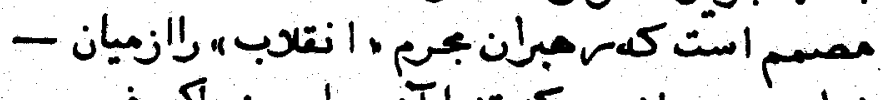

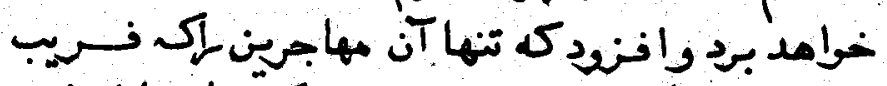

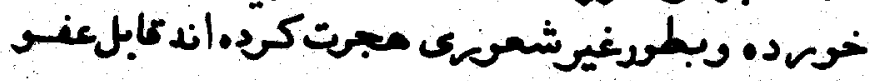




\section{rFr}

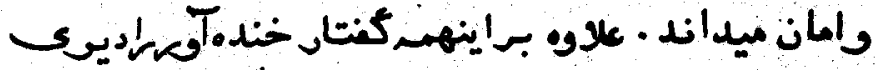

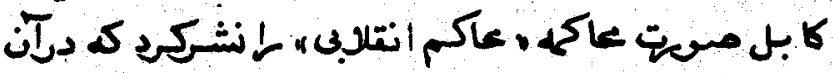

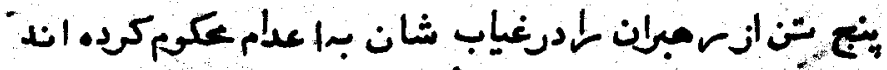

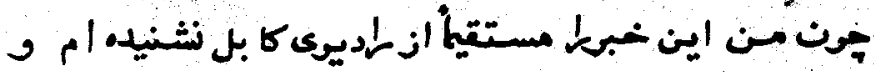

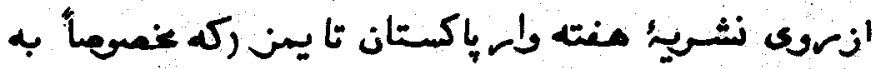

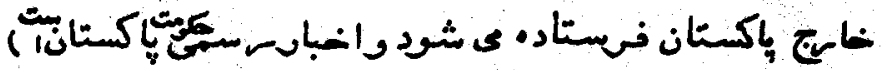

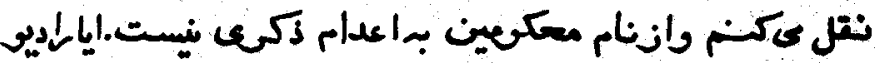

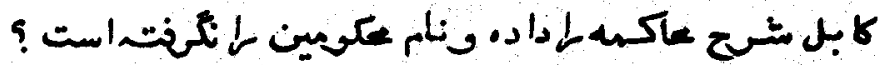

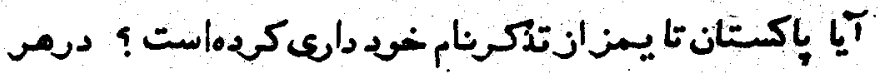

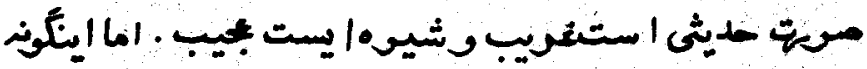

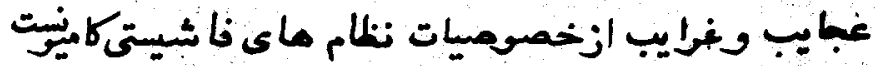

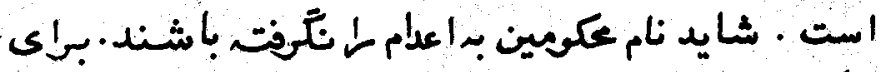

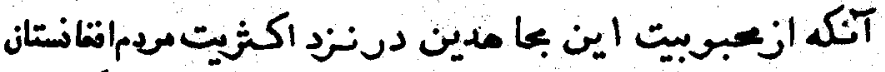

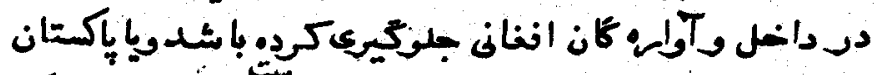

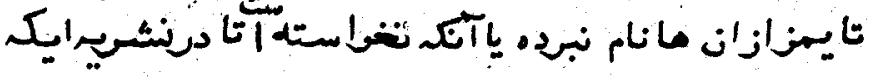

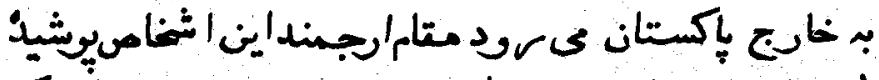

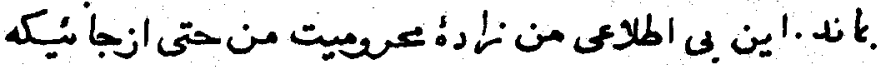

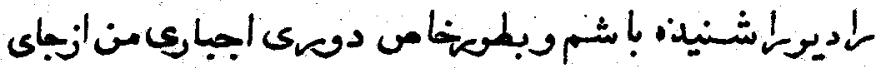

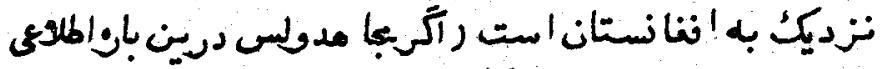

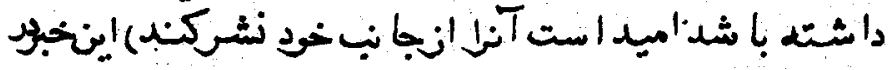
THE PAKISTAN TIMS OVERSEAS WEEKIY JUNE,29,1986 


\section{rir}

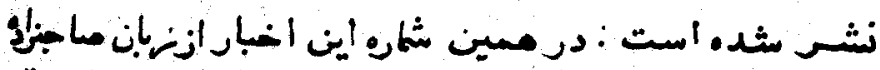

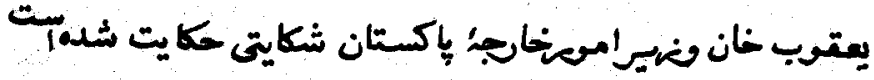

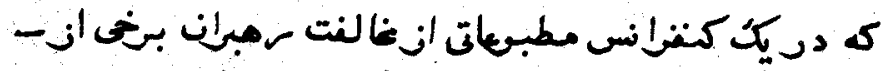

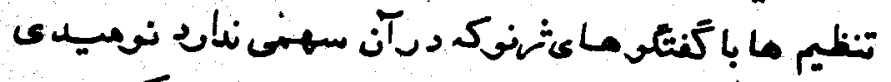

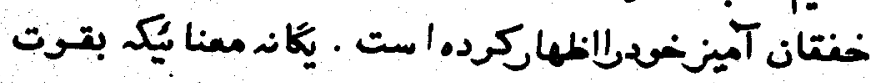

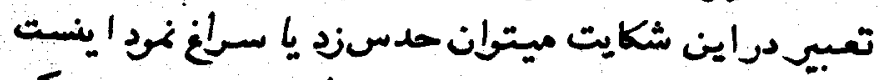

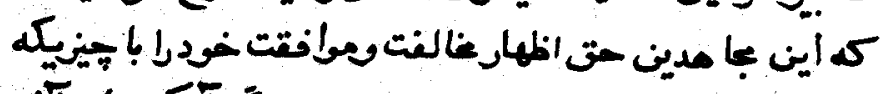

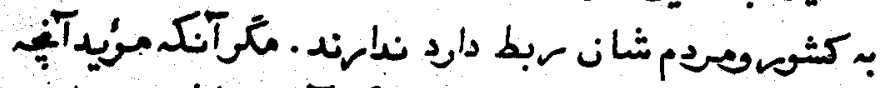

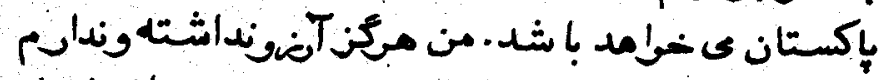

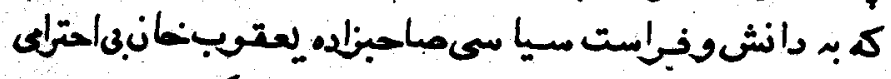

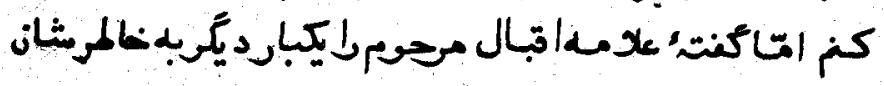

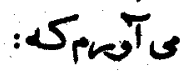

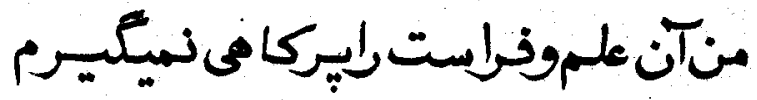

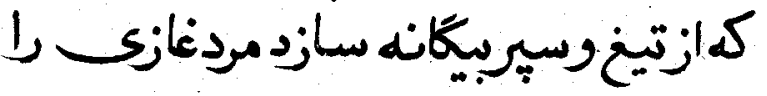

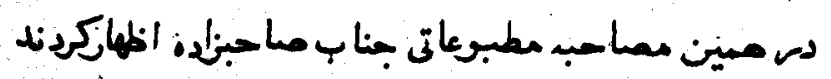

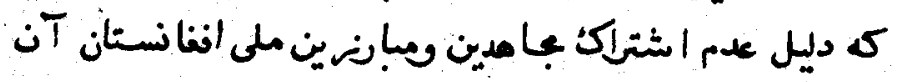

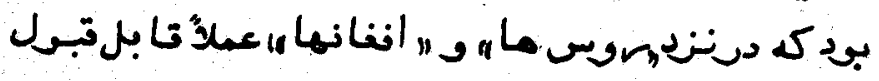

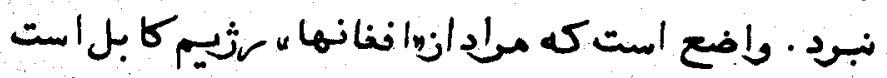

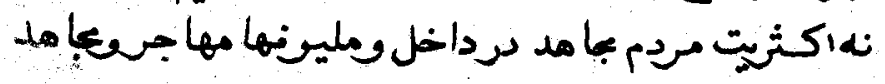




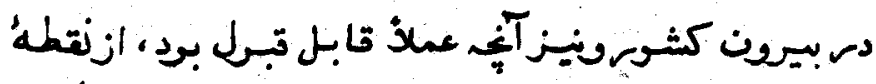

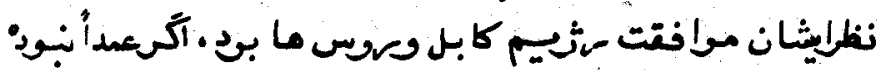

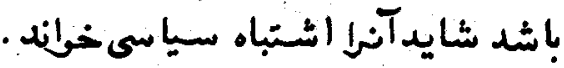

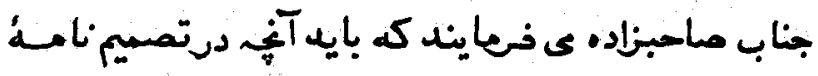

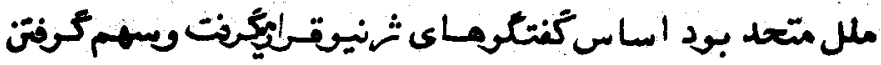

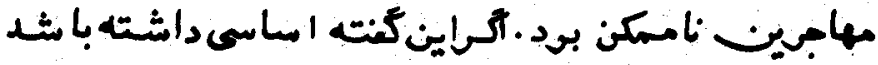

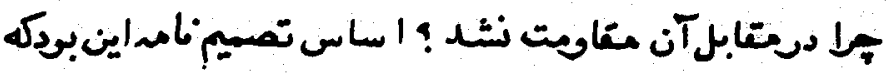

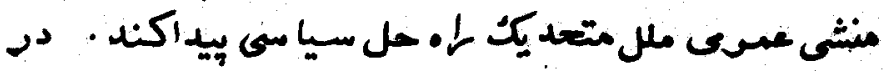

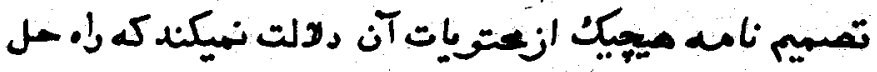

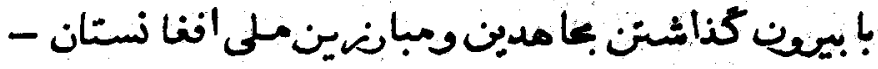

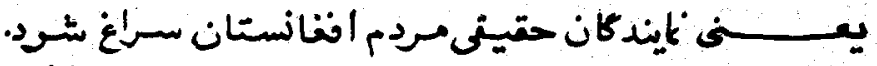

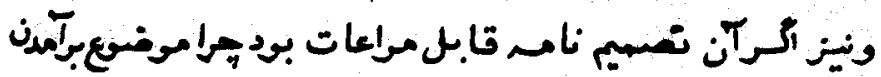

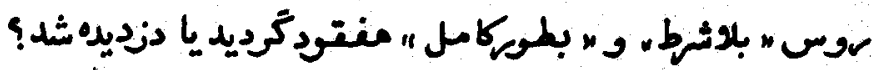

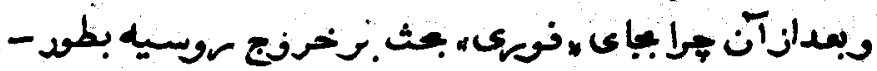

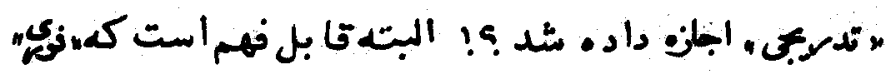

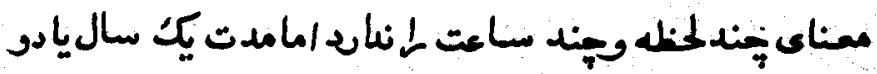

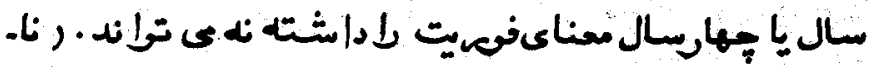

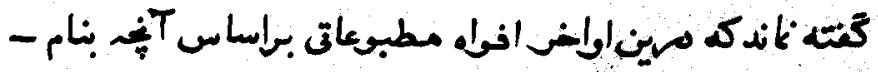

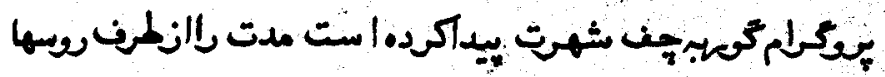

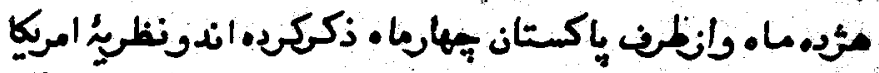

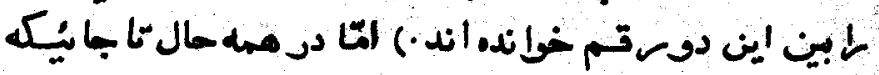




\section{rro}

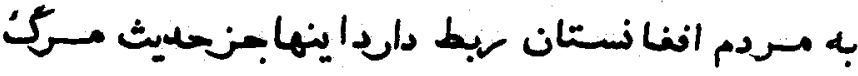

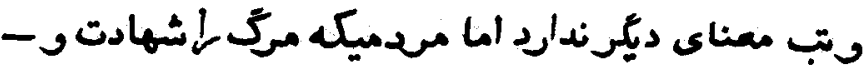

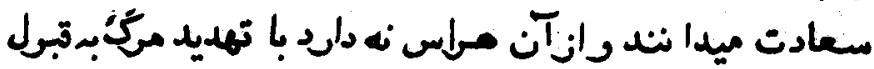

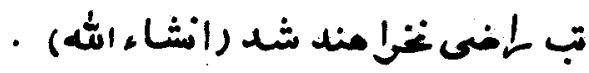

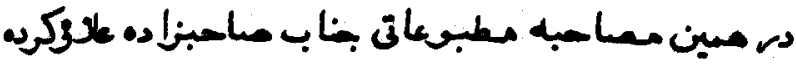

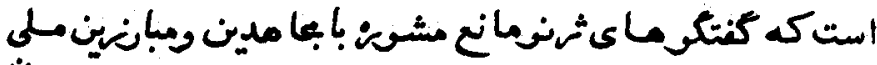

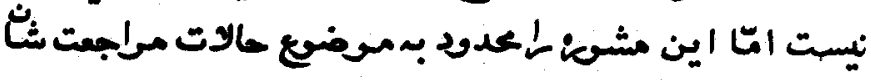

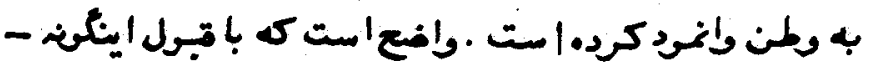

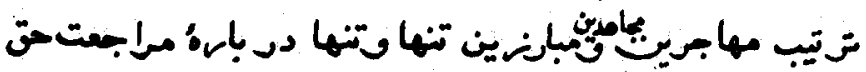

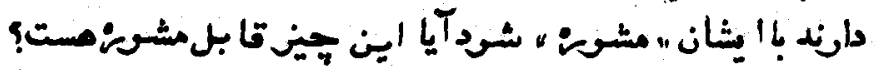

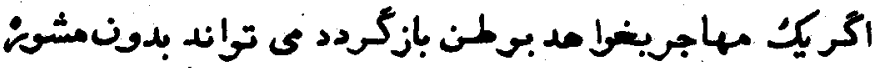

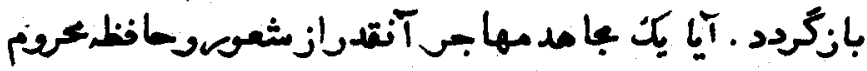

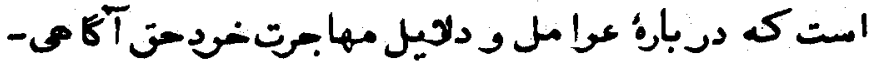

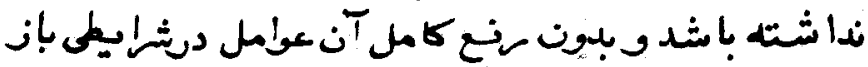

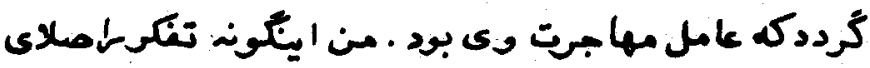

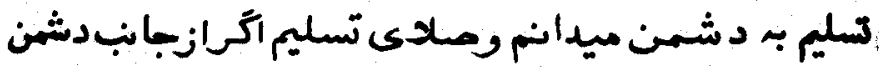

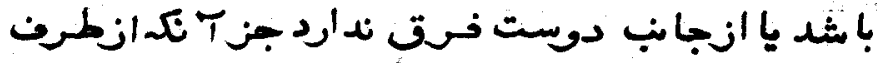

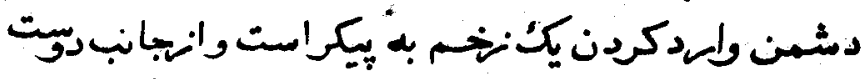

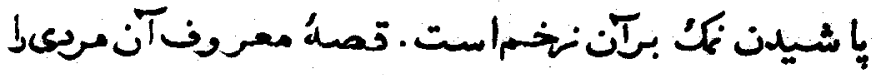

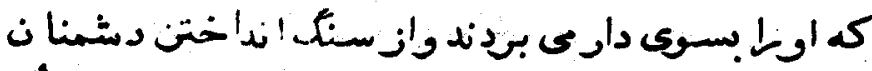

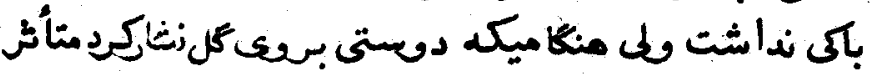




\section{MT}

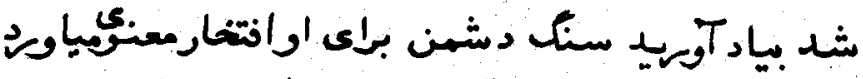

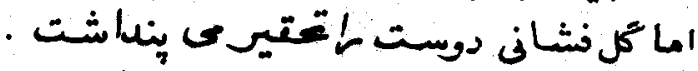

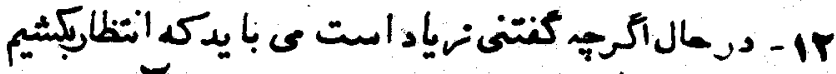

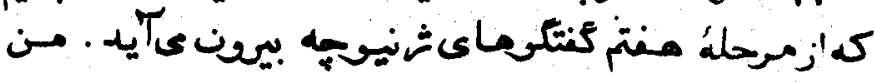

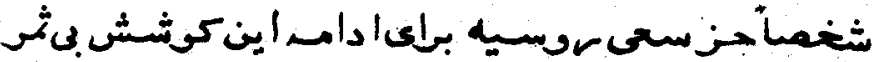

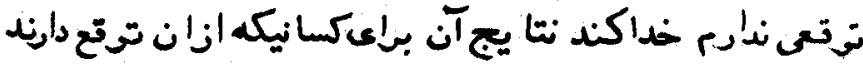

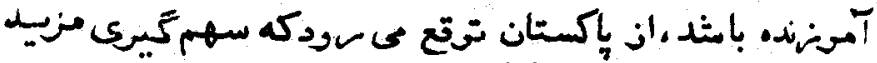

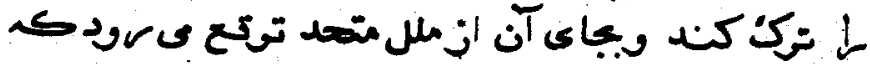

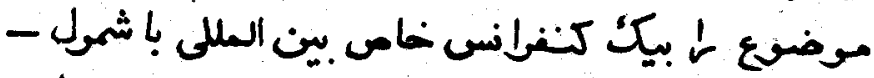

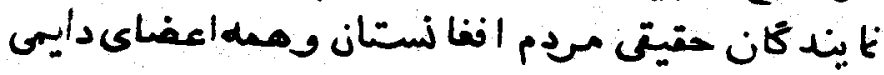

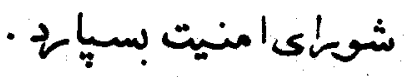

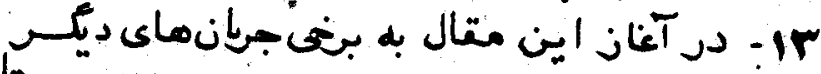

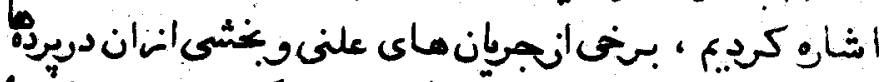

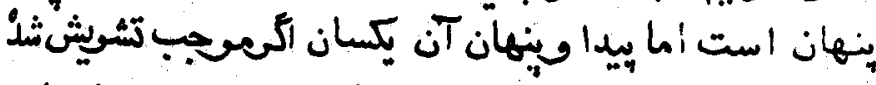

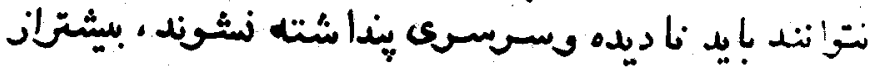

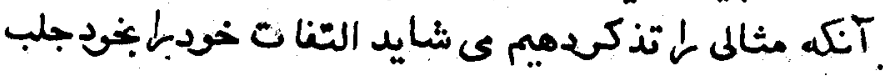

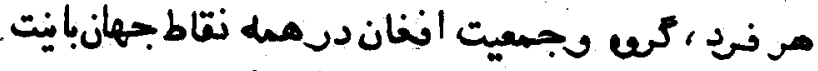

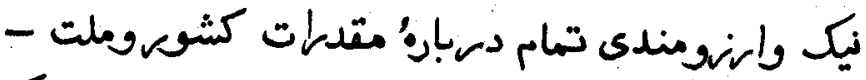

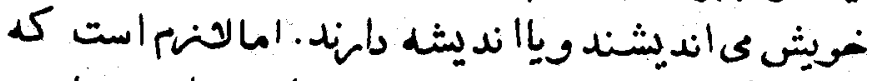

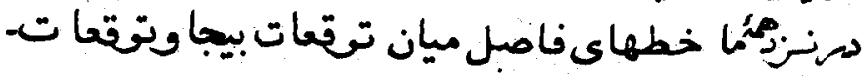




\section{rrV}

مبنى برتغكركثيده شـود. ومعناى دمست خهئ بينى

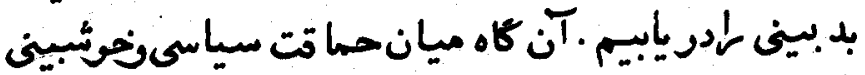

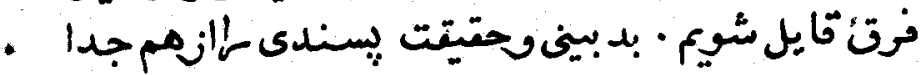

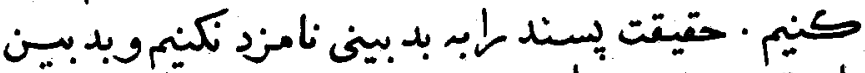

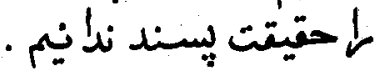

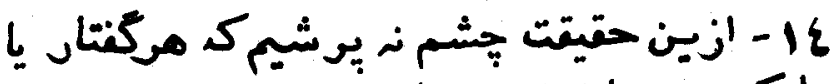

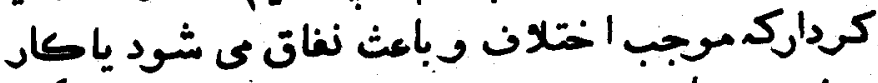

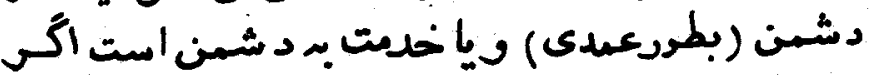

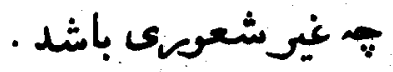

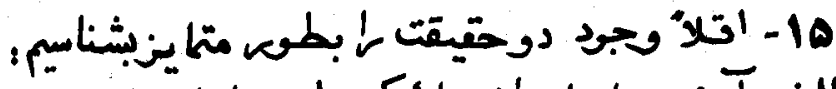

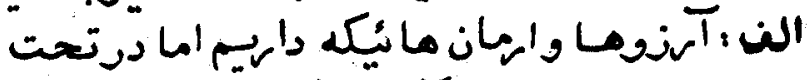

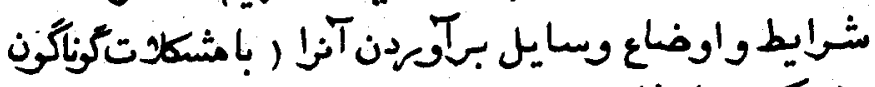

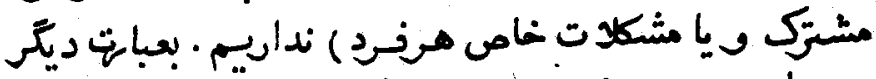

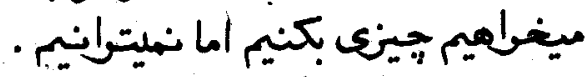

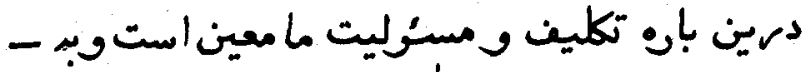

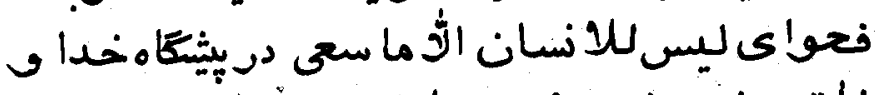

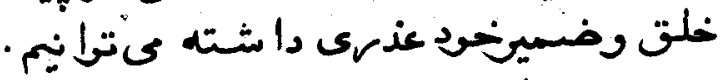

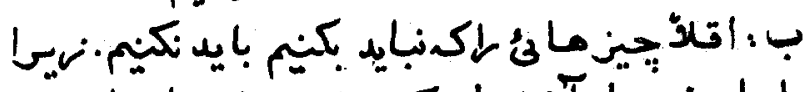

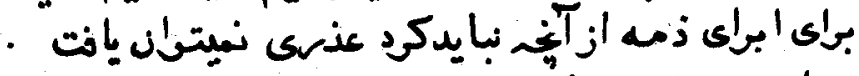

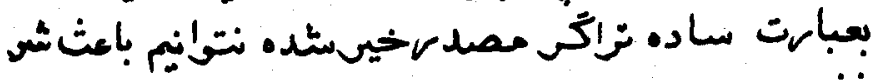
نَتْبِم 


\section{TrA}

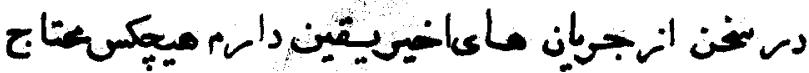

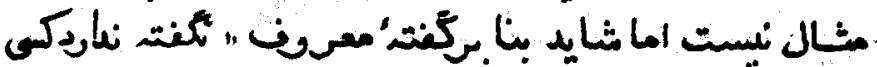

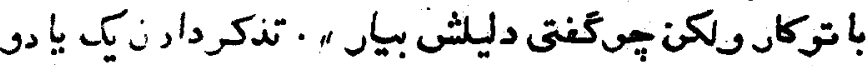

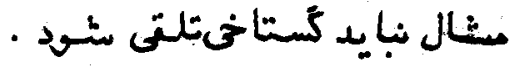

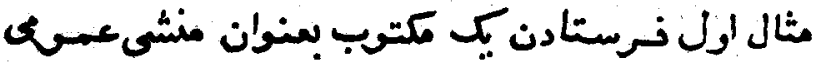

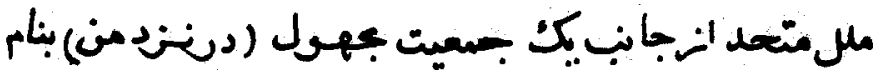

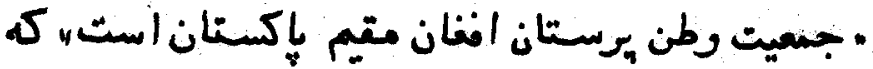

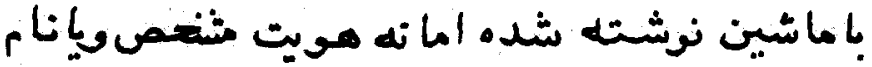

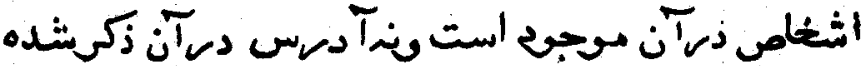

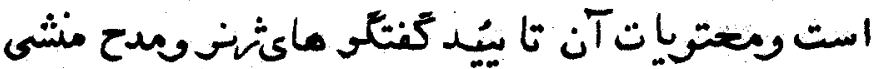

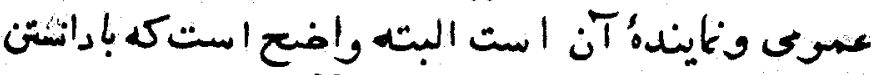

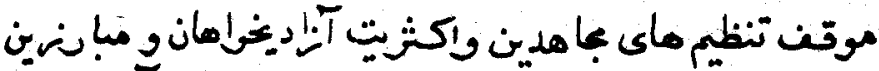

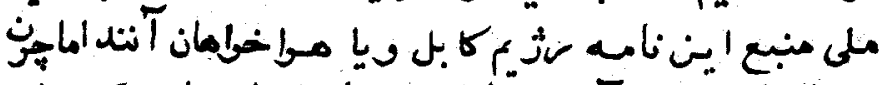

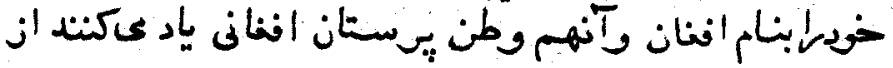

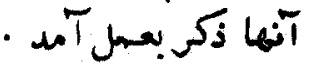

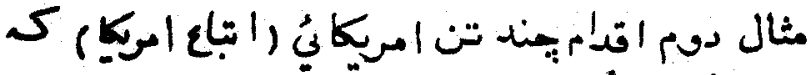

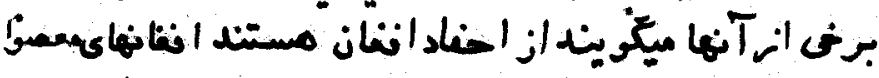

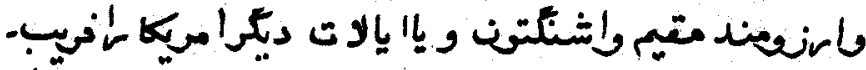

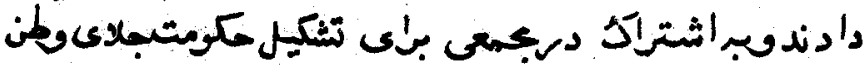

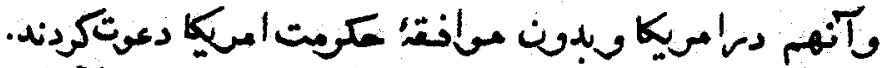

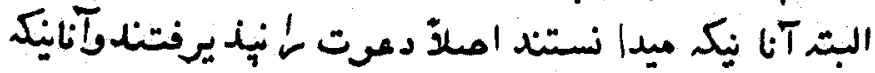




\section{rrq}

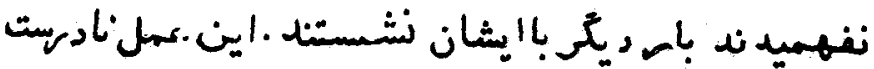

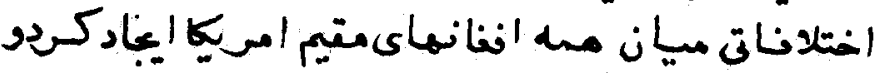

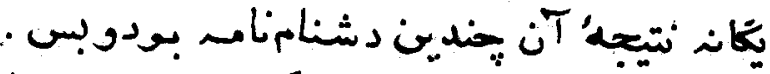

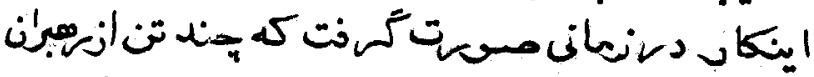

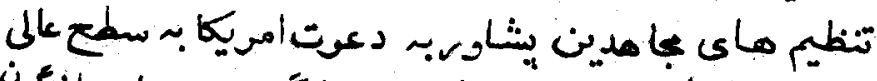

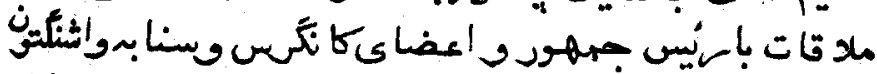

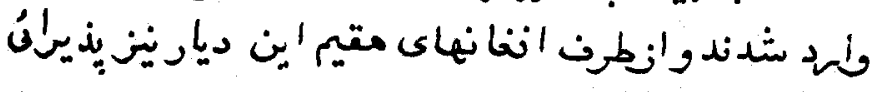

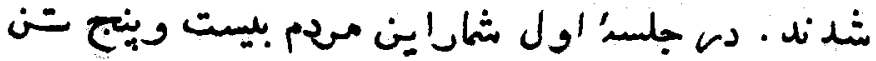

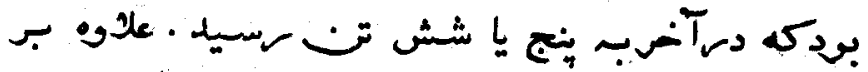

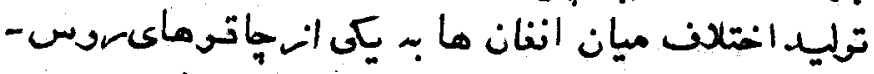

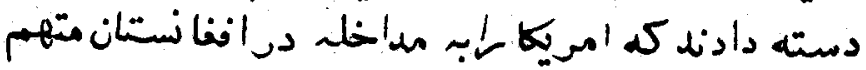

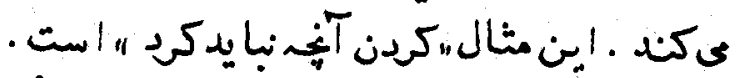

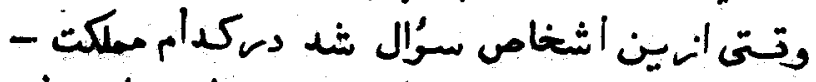

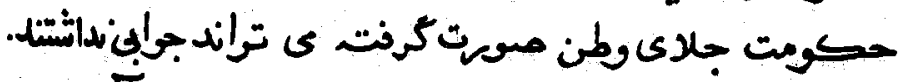

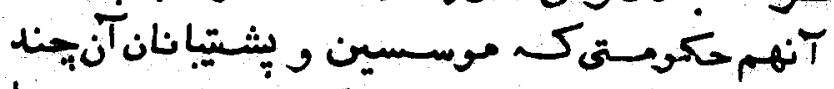

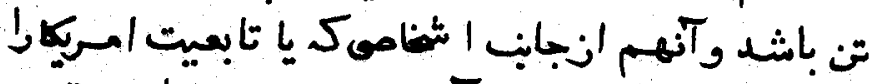

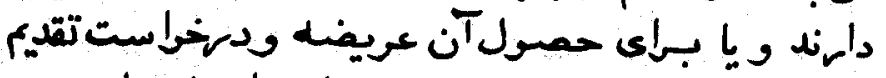

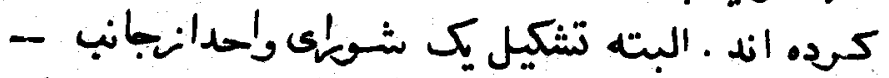

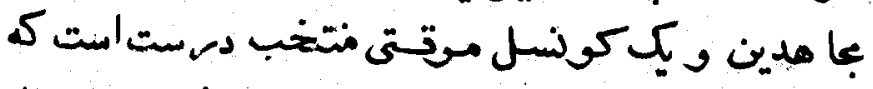

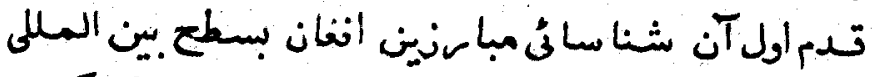

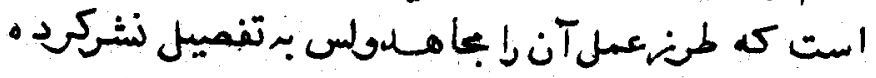




\section{rr.}

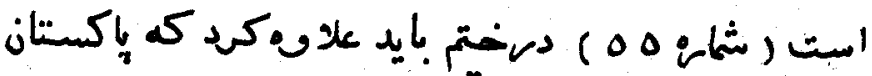

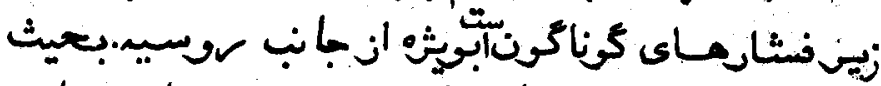

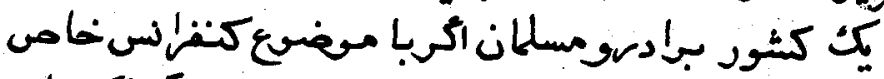

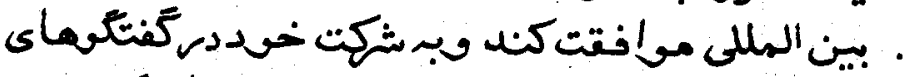

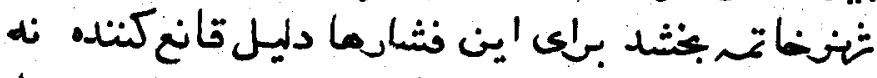

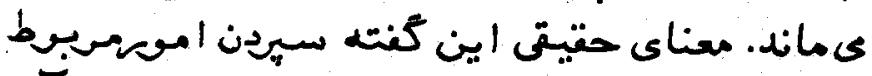

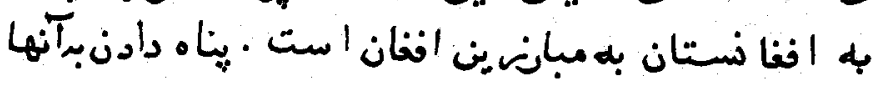

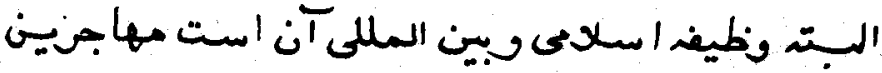

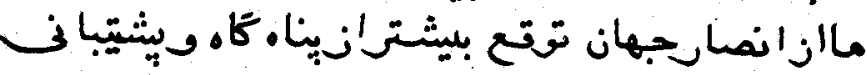

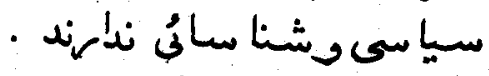

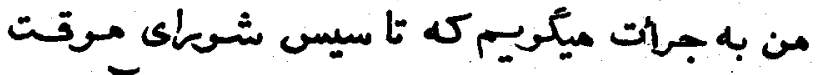

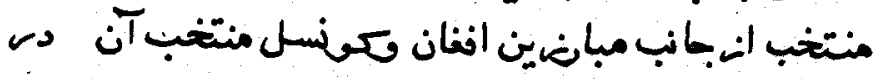

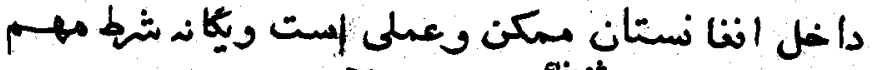

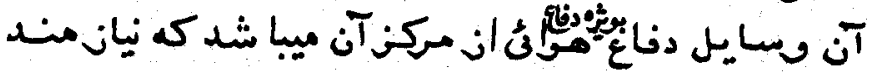

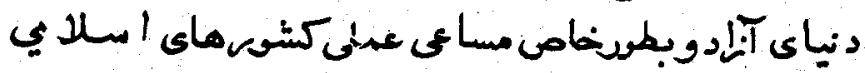

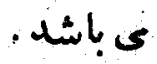

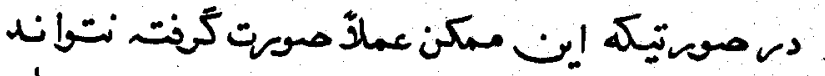

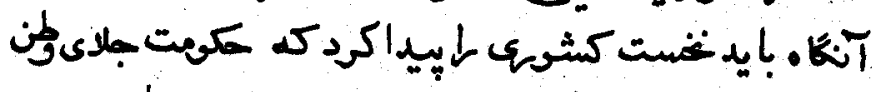

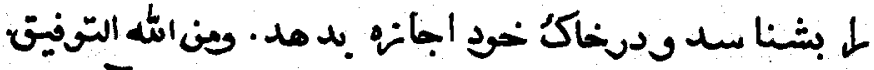

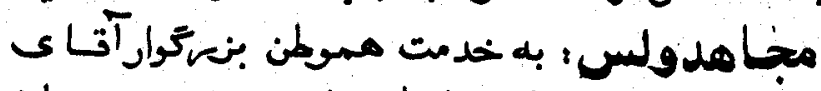

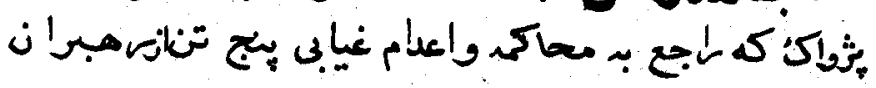




\section{TrI}

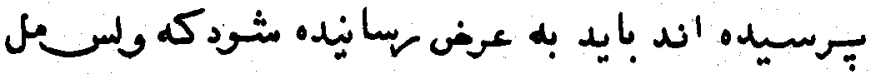

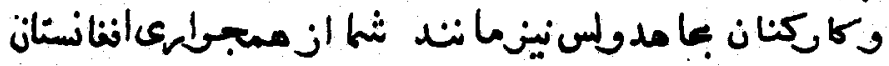

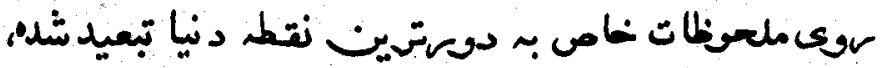

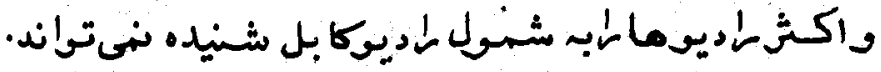

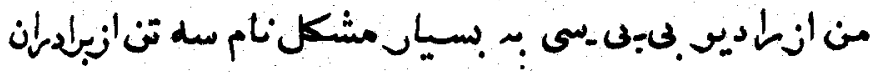

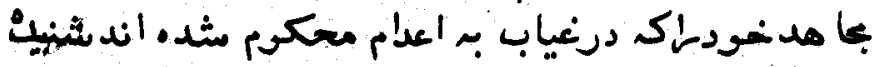

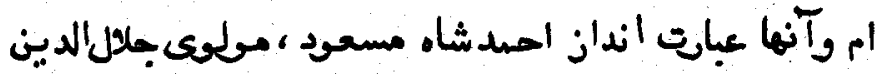

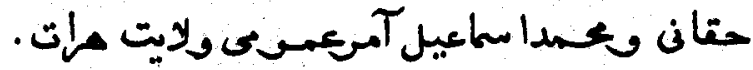

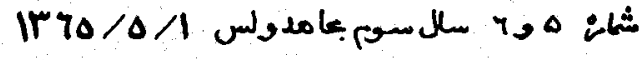

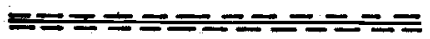




$$
\begin{aligned}
& \text { ازتثِّواكبهولسمل } \\
& \text { منغآته شرط بلاغ استبا توميكويم } \\
& \text { توخواه ازبخنم يندكيرخواه مـلال }
\end{aligned}
$$

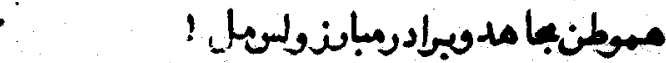

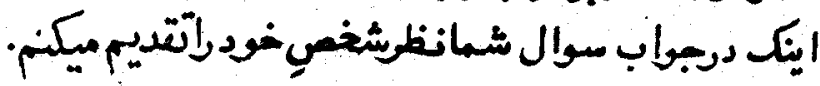

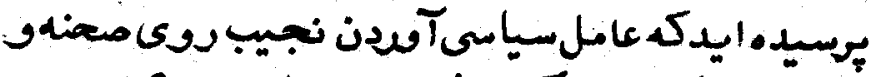

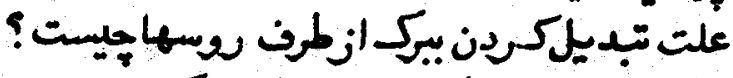

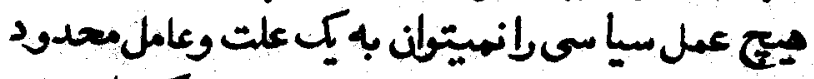

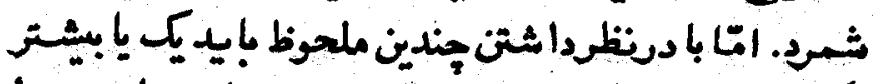

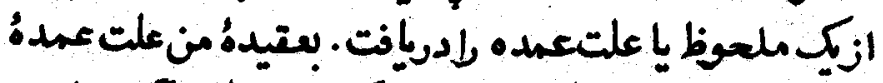

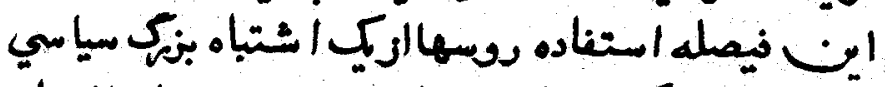

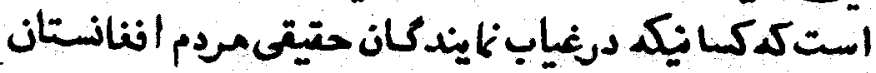

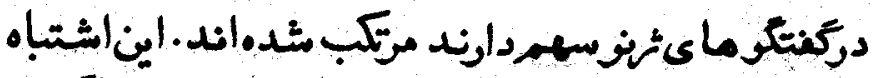

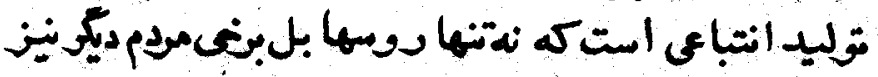




\section{rrr}

آن راتكرفت أند ـ ارتكاب إين اشتباه به أصطلاح سرستري

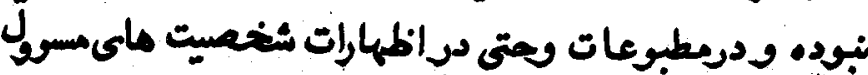
تَكراروبرآن اصراريثده اتيت.

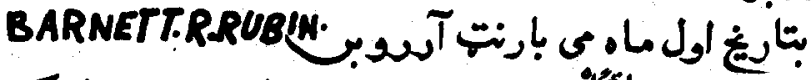

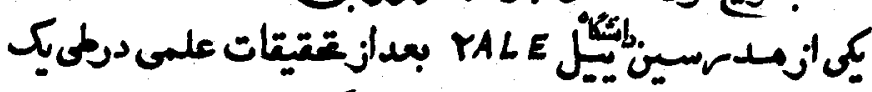

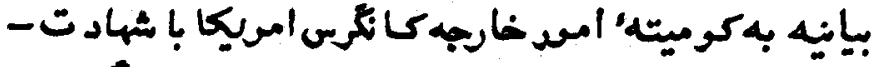

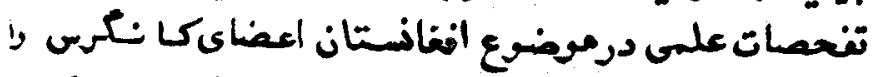

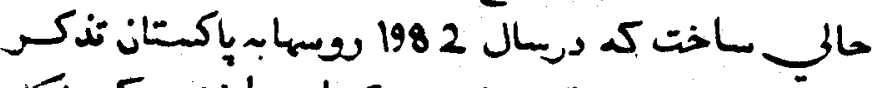

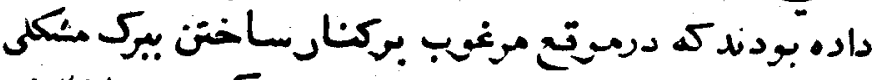

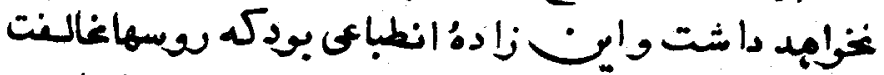

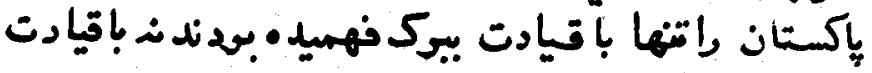

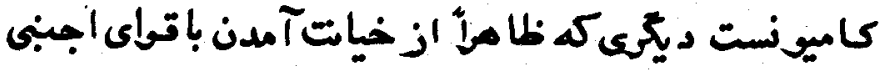

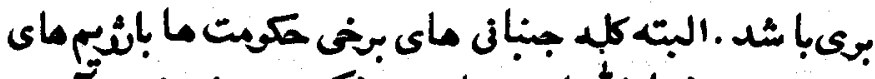

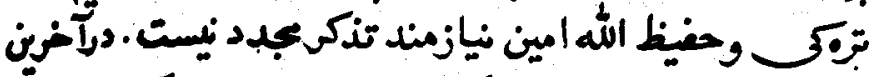

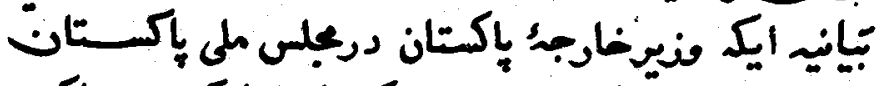

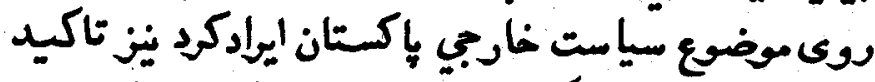

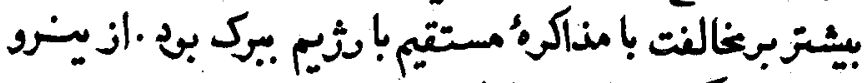

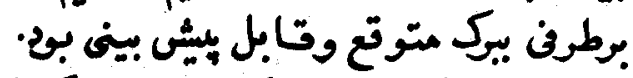

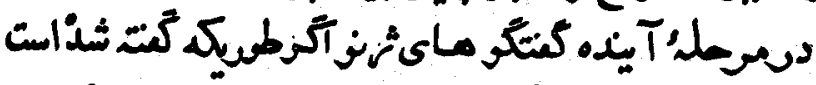

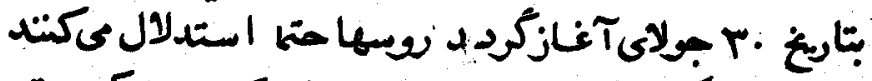

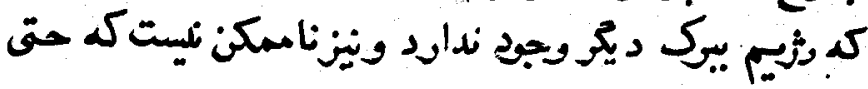


Prg

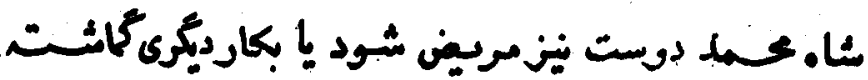

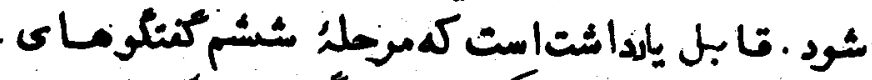

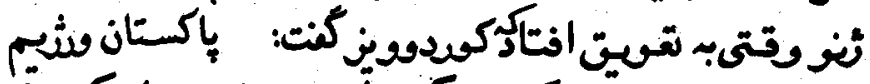

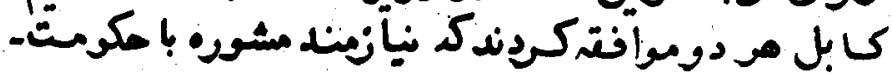

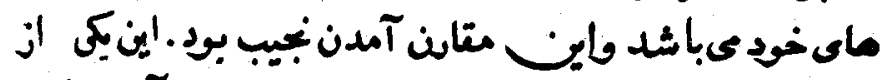

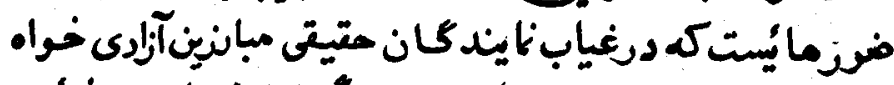

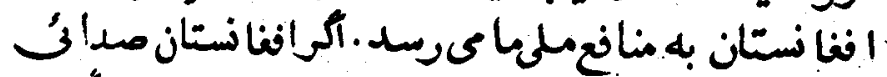

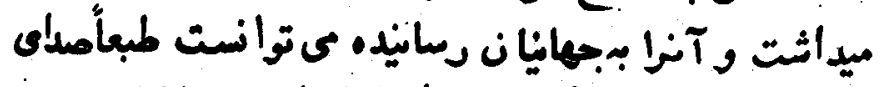

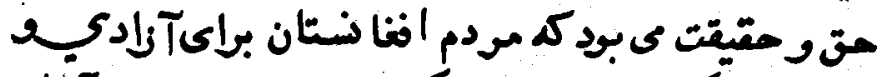

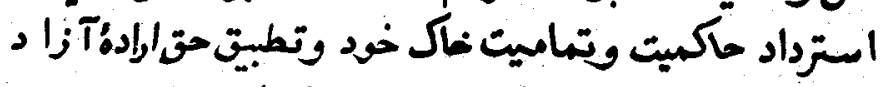

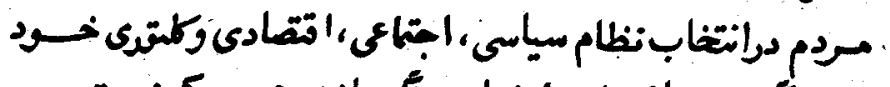

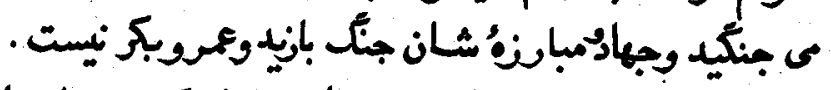

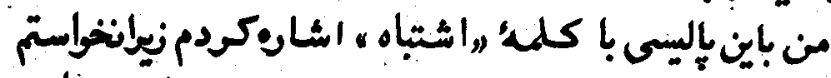

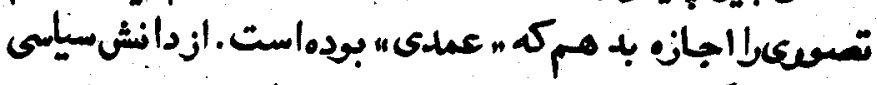

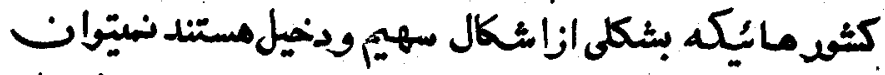

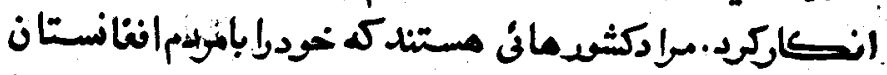

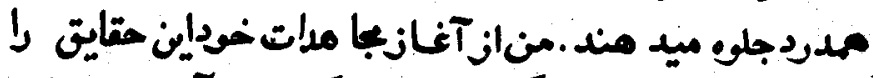

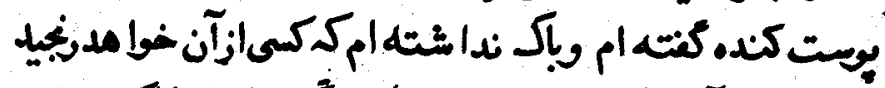

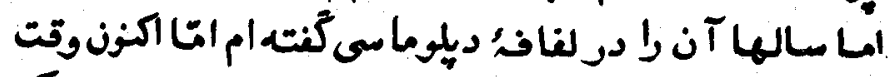

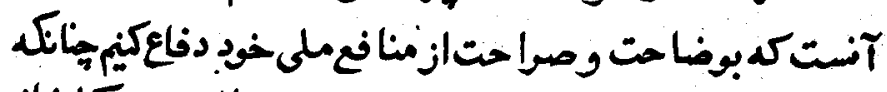

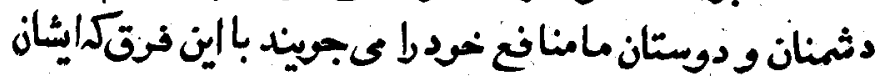




\section{rTs}

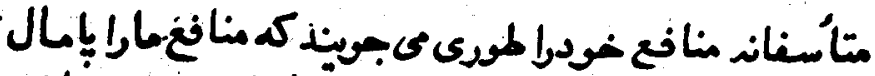

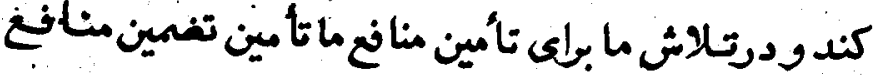

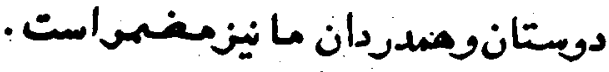

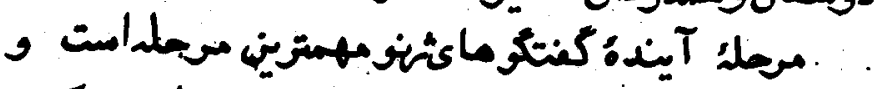

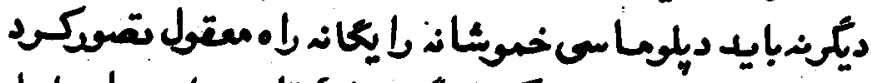

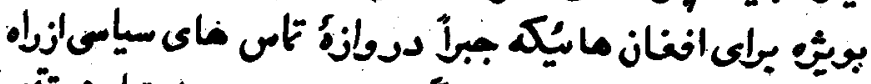

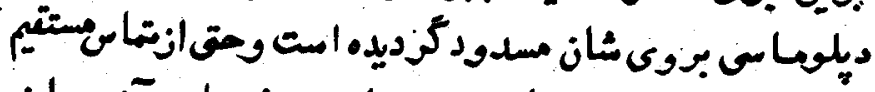

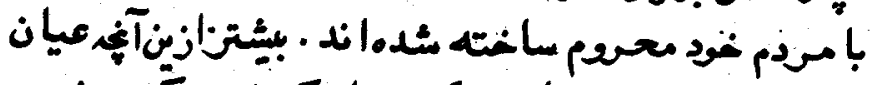

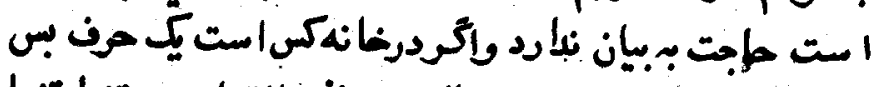

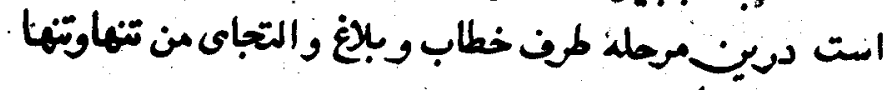
انتانهاى با مد ومبان مسندن.

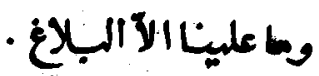

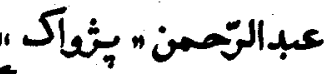

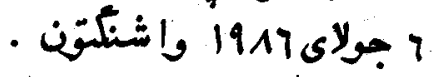

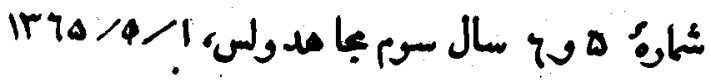




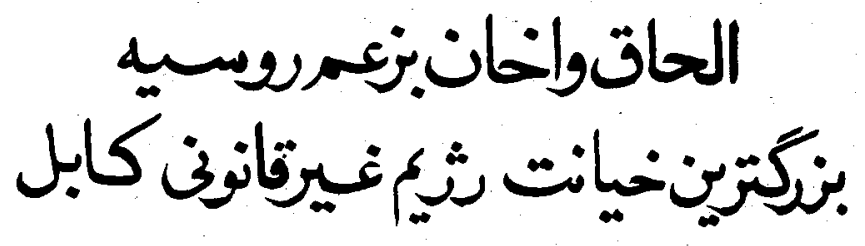

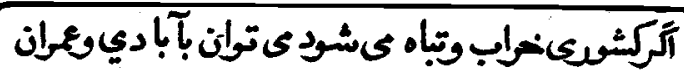

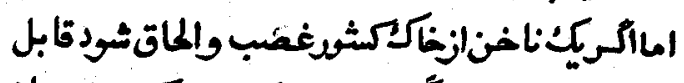

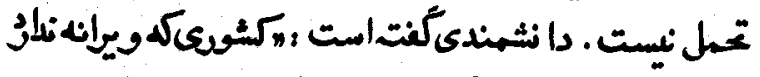

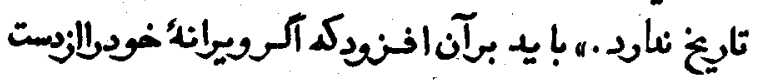

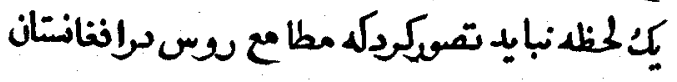

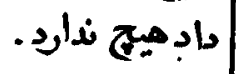

$$
\text { كبه وإخان محدودخوإمدماند . }
$$

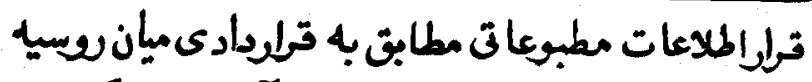

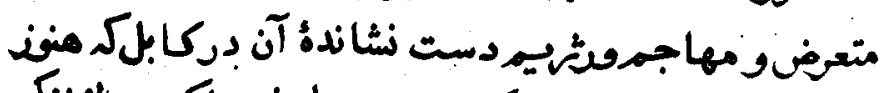

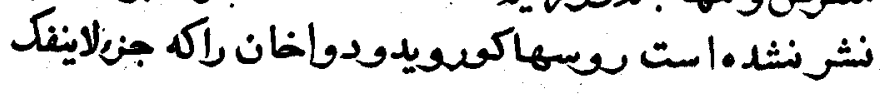




\section{rrv}

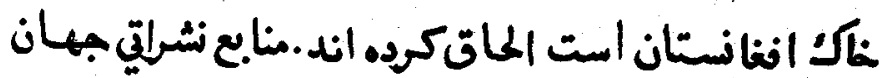

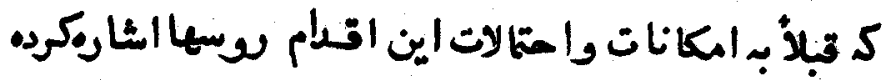

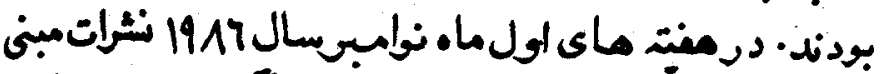

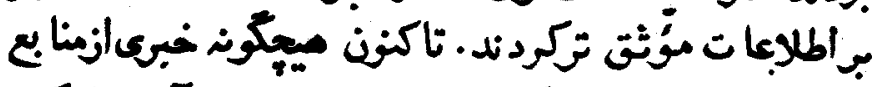

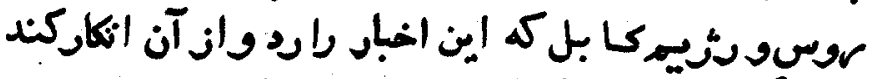

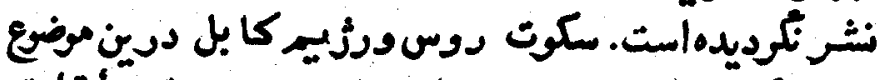

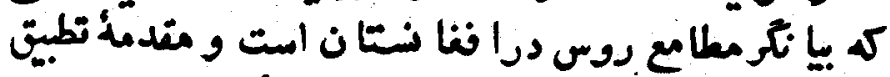

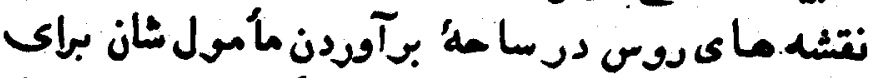

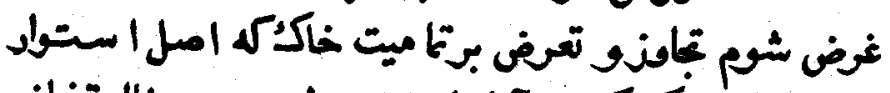

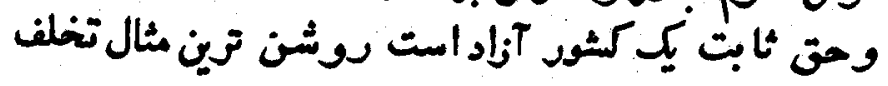

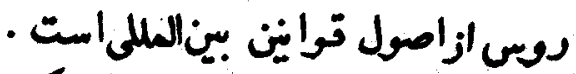

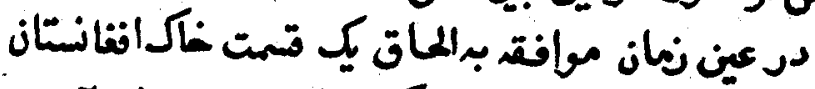

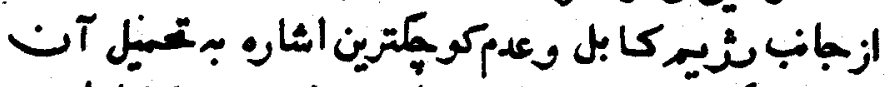

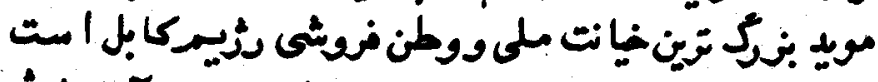

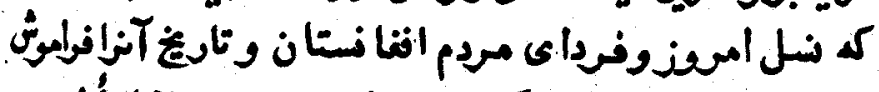

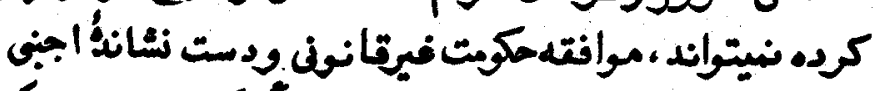

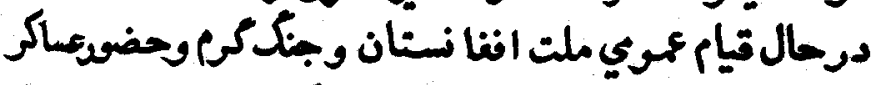

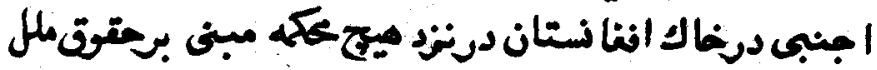

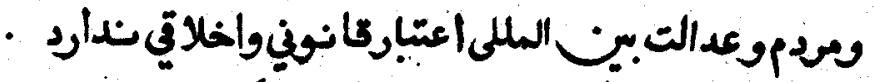

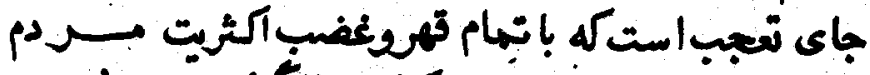

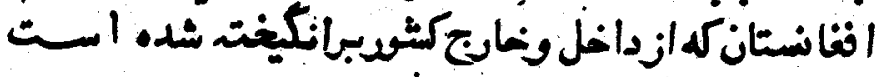




\section{YrA}

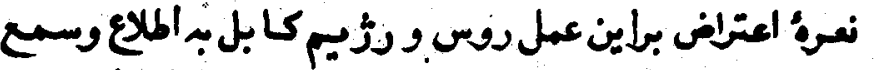

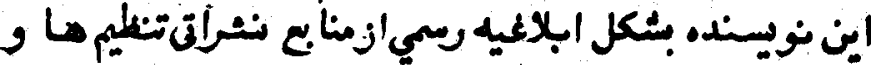

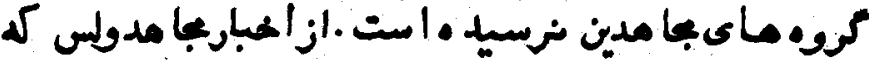

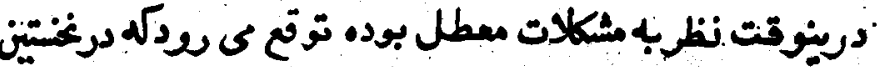

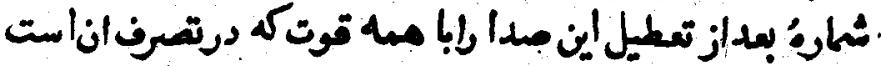

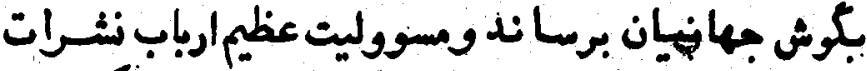

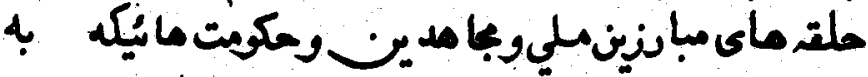

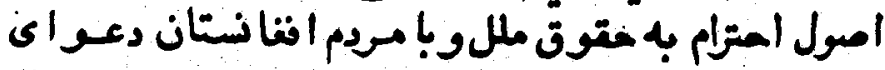

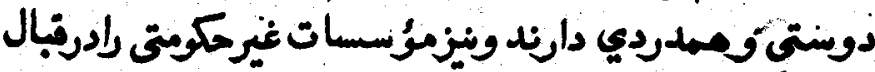

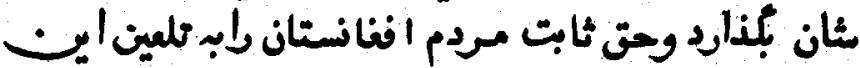

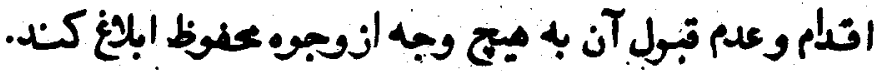

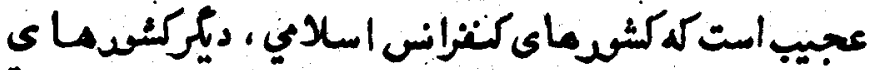

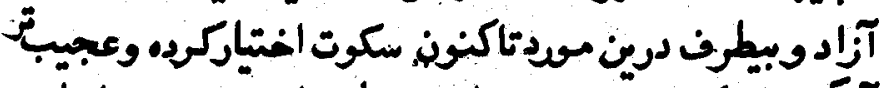

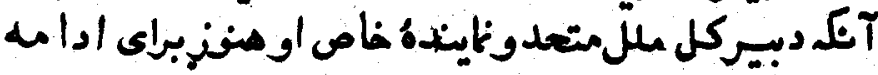

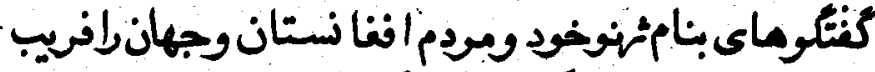

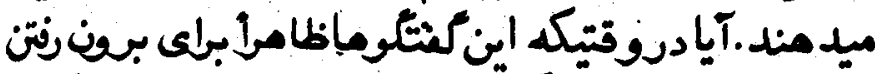

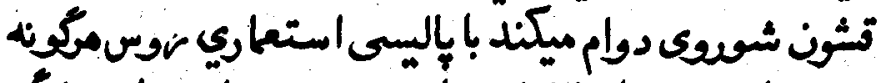

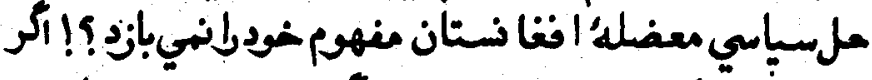

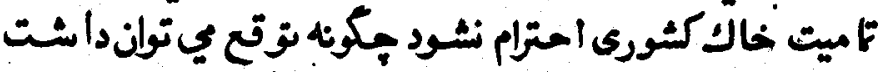

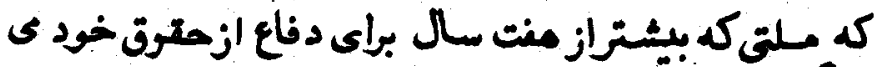

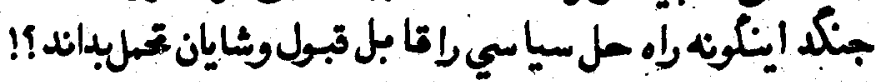




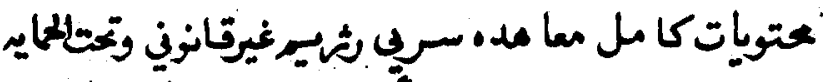

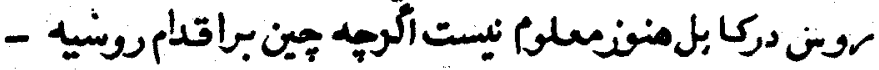

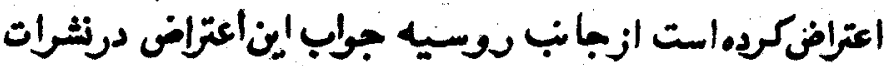

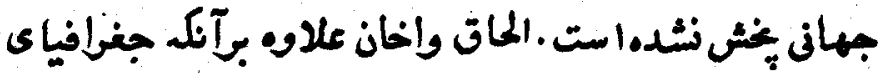

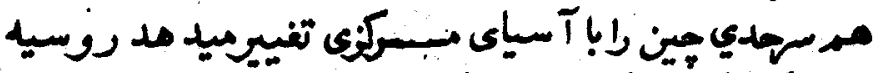

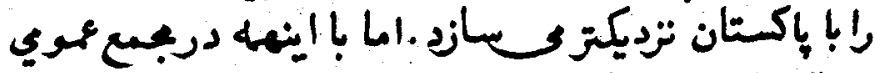

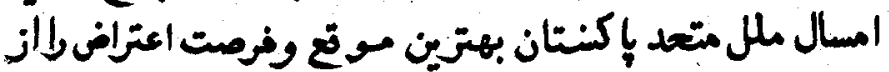

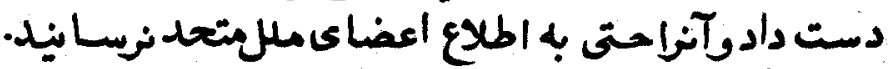

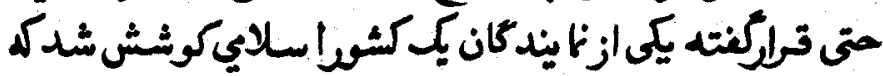

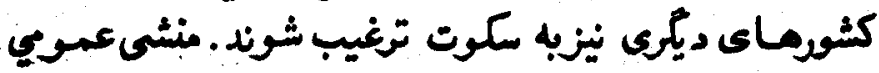

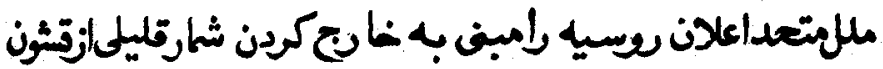

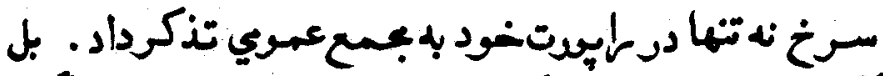

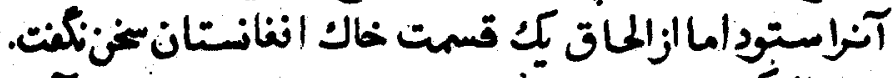

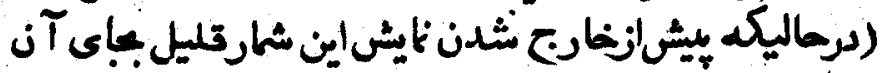

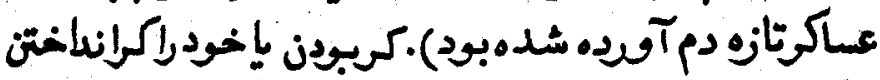

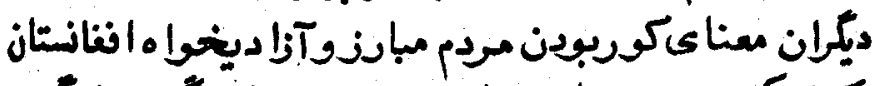

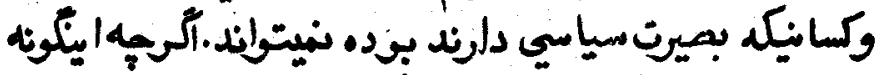

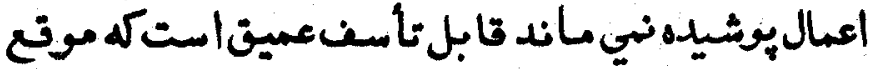

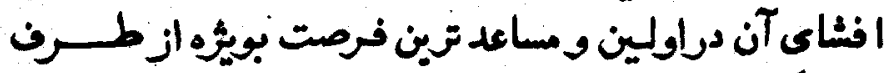

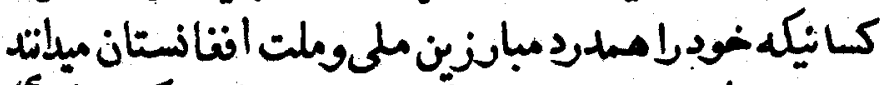

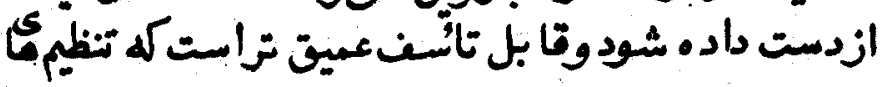




\section{TF.}

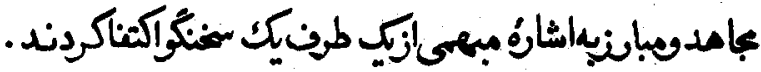

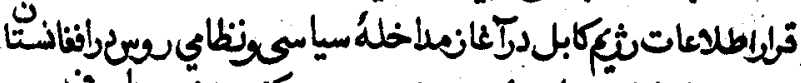

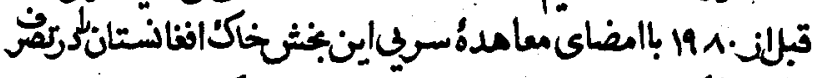

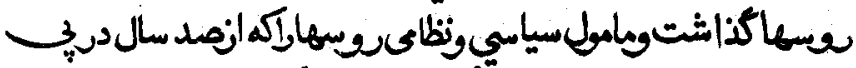

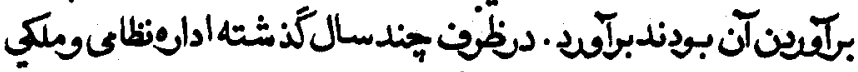

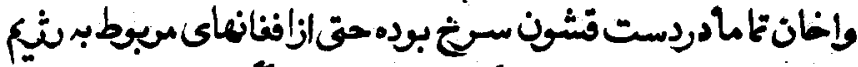

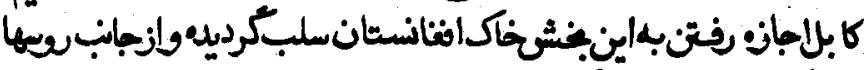

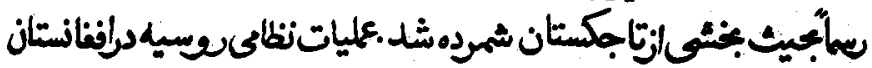

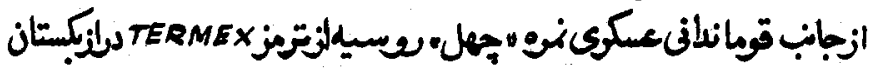

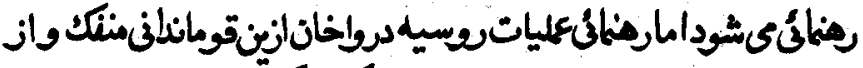

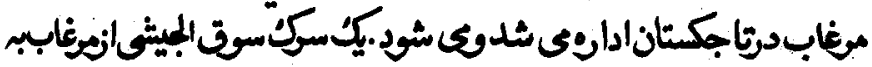

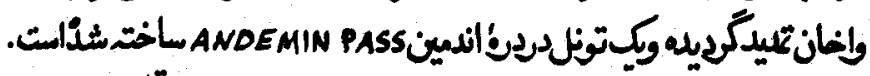

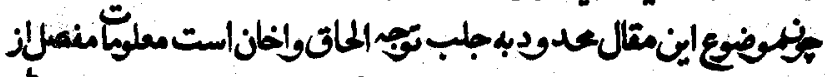

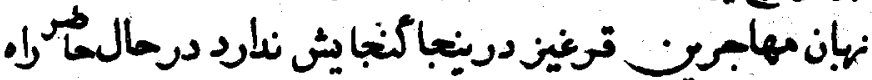

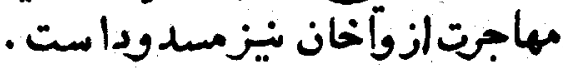

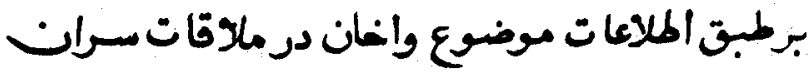

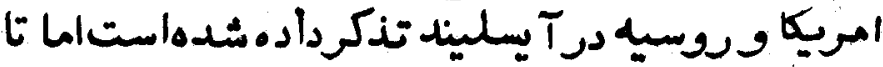

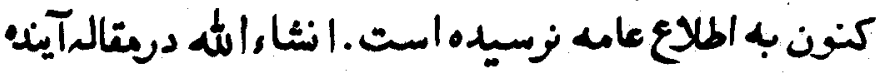

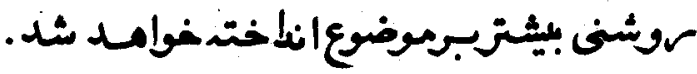

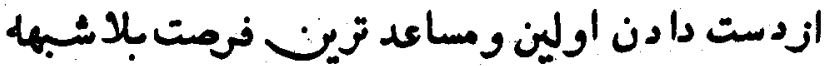

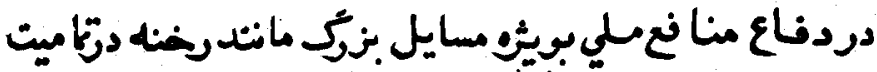

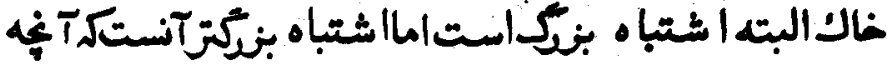




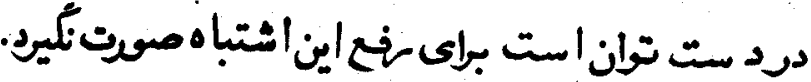

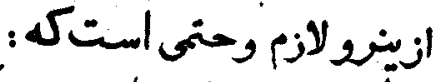

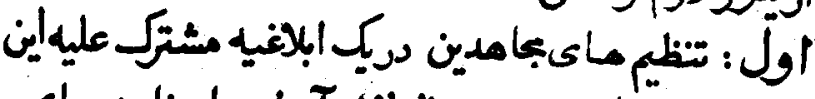

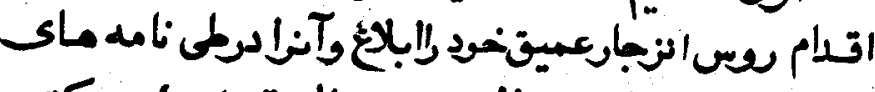

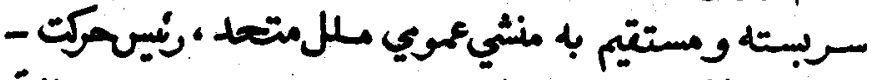

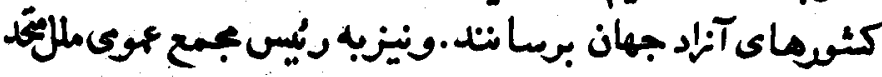

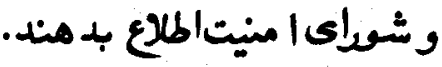

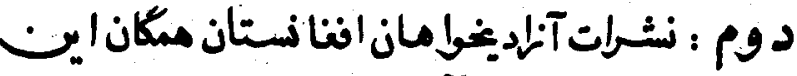

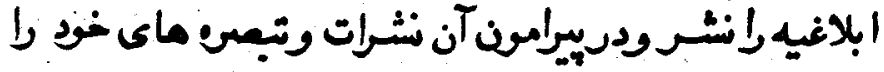

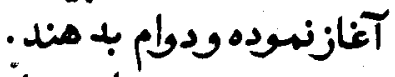

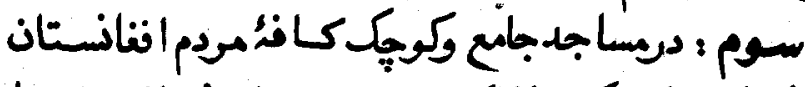

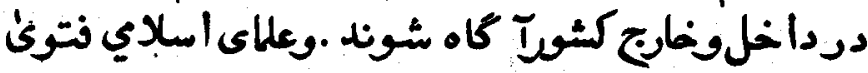

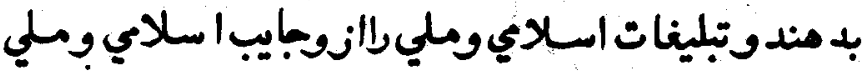

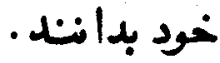

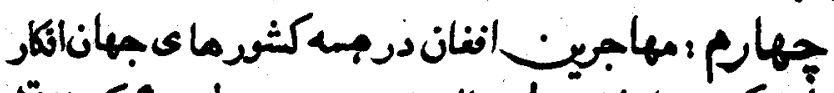

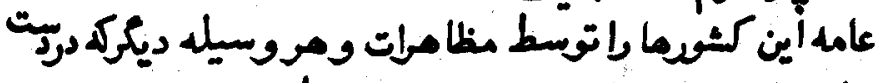

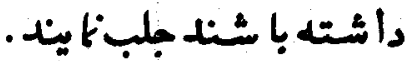

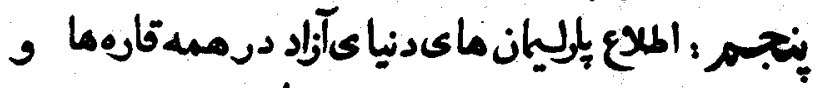

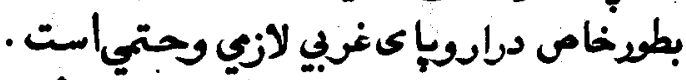

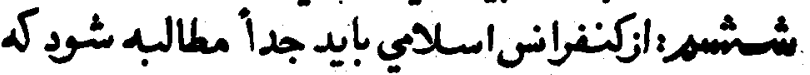

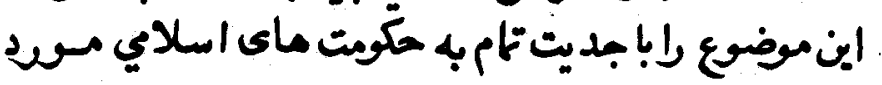




\section{rat}

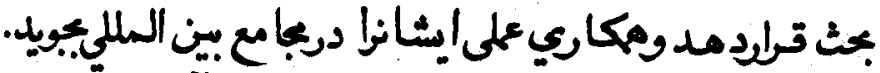

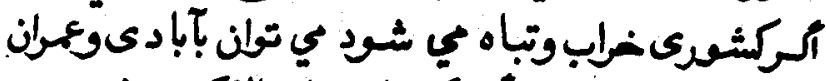

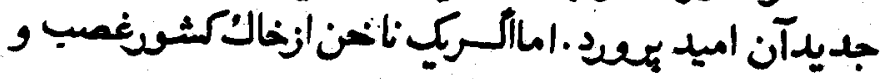

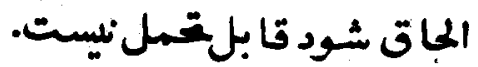

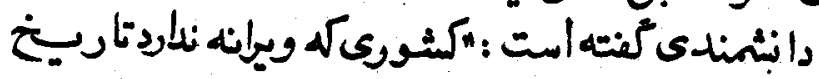

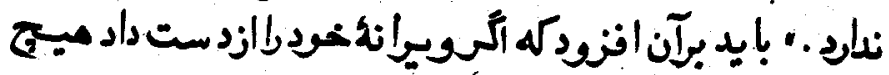

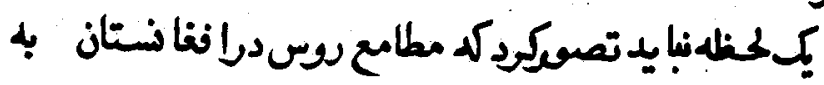
ن مارد. وإخان محاود خوامدماند.

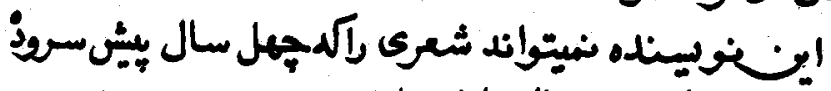

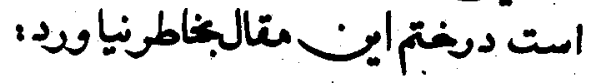

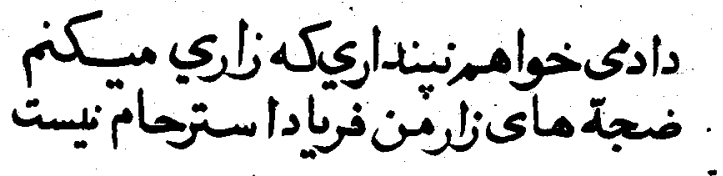

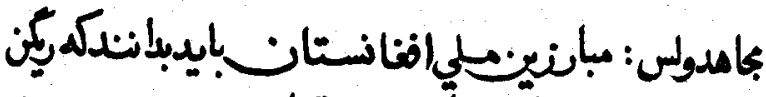

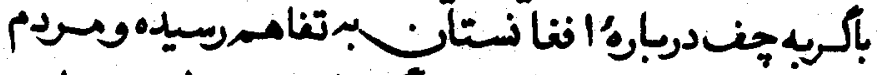

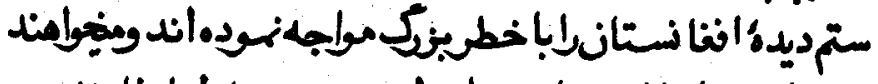

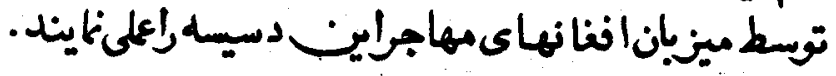
وماعليناالاوالبلاغن

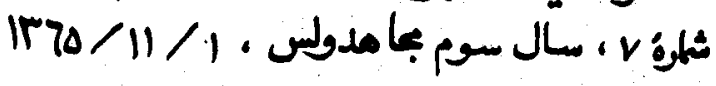




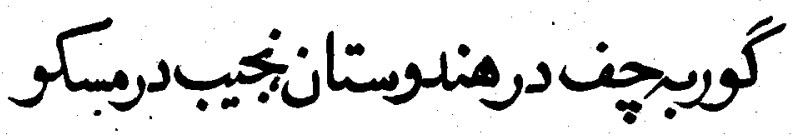

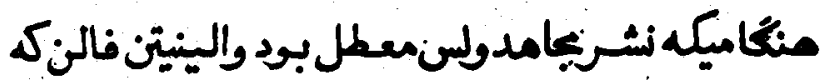

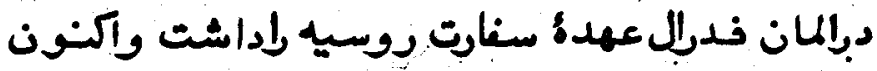

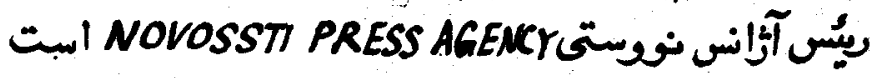

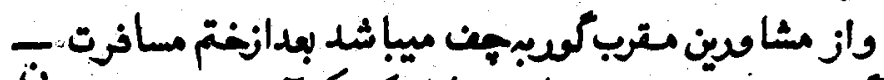

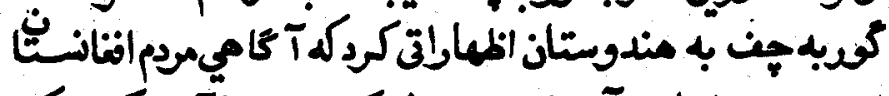

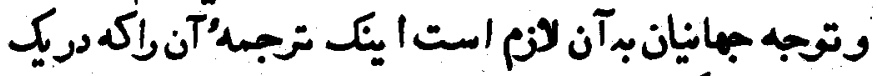

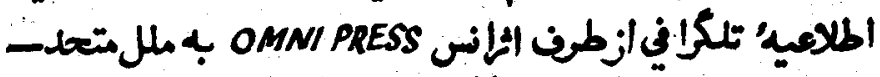

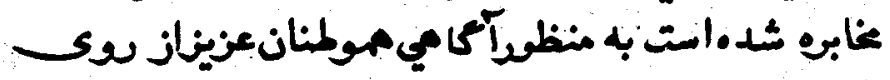

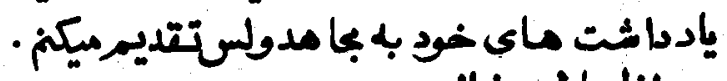

$$
\text { إنهاراتنالن مائن }
$$

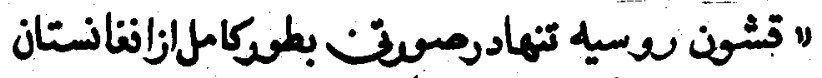

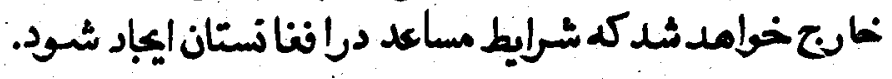


TLE

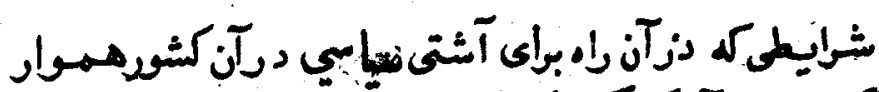

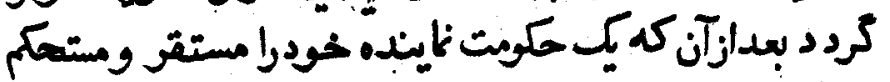

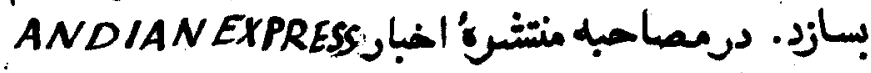

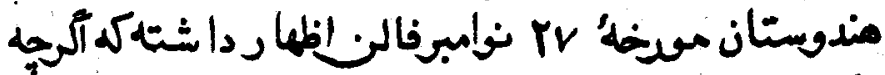

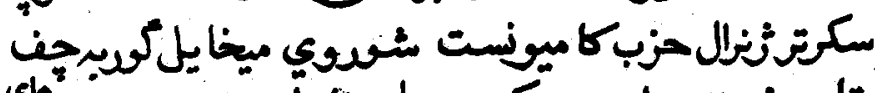

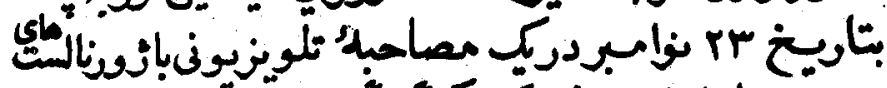

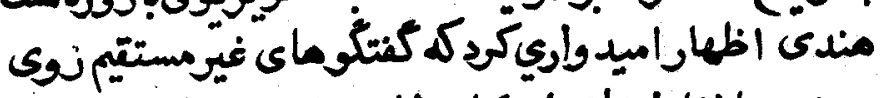

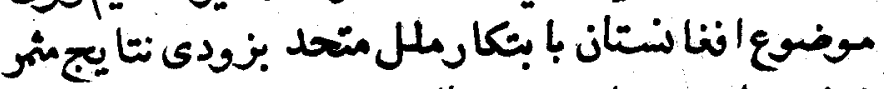

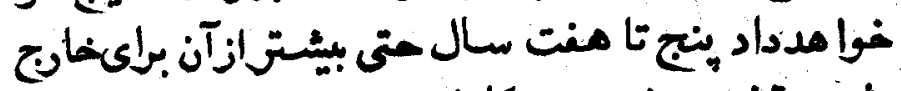

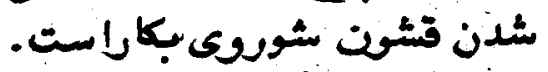

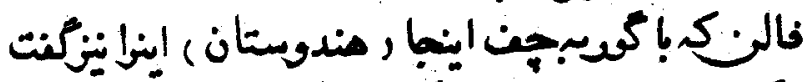

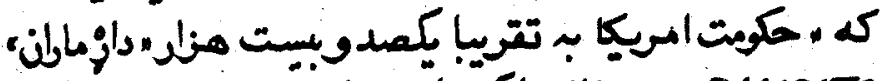

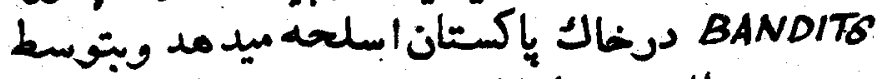

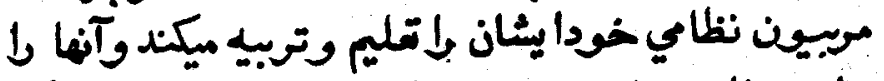

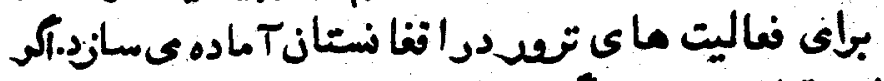

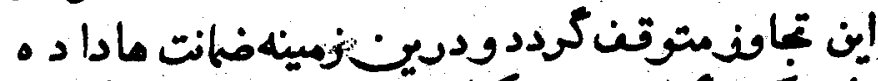

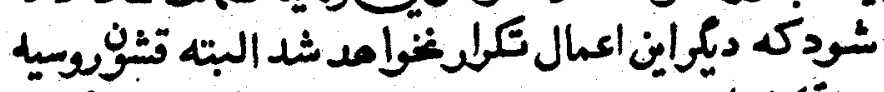

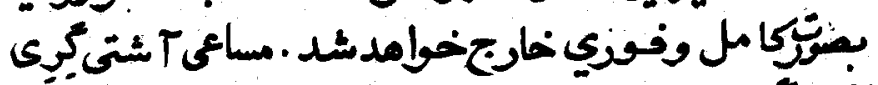

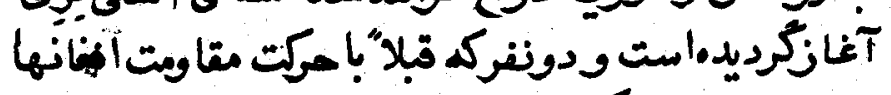

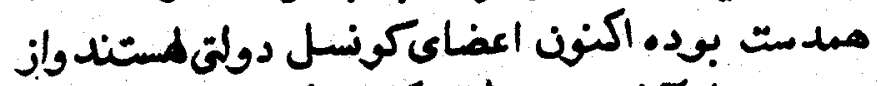

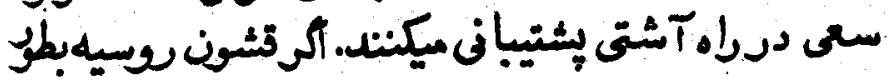




\section{ro}

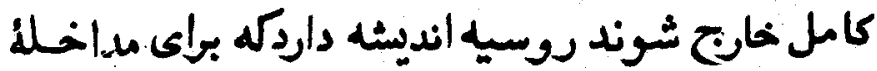

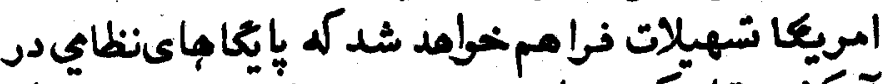

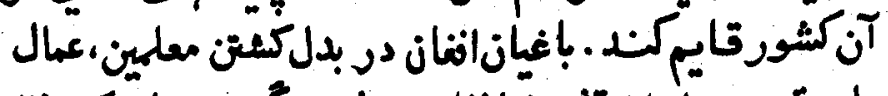

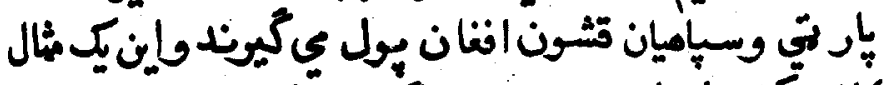

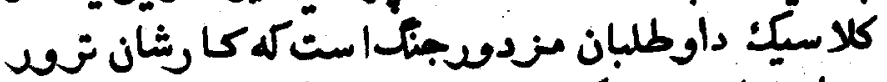

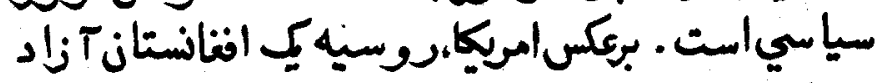

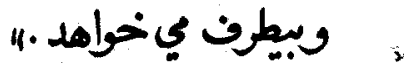

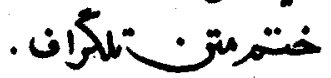

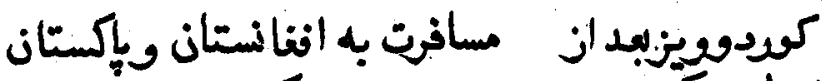

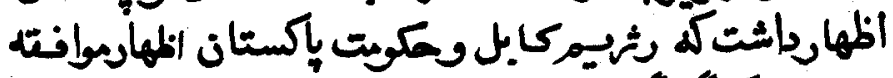

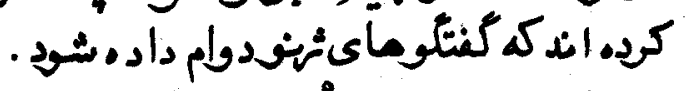

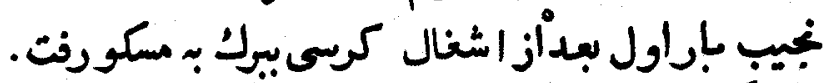

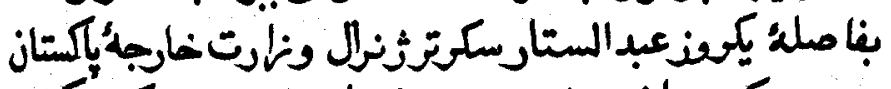

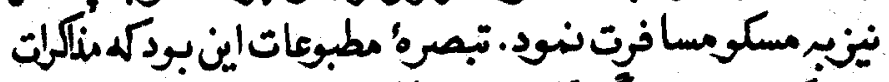

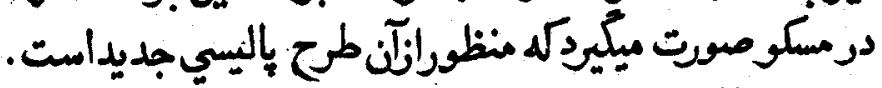

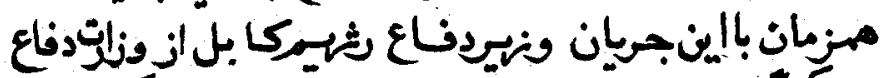

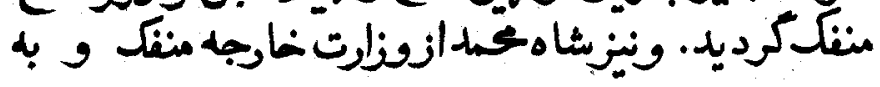

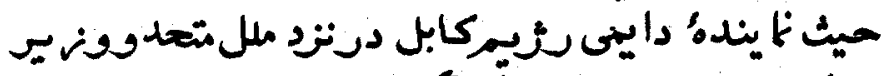

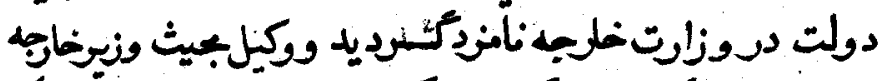

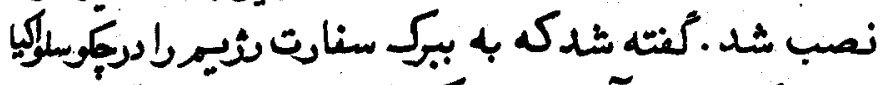

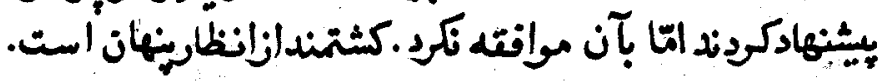




\section{YEY}

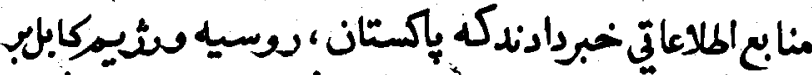

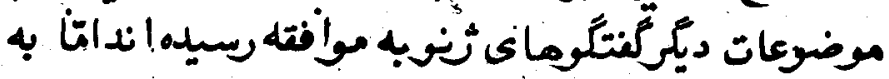

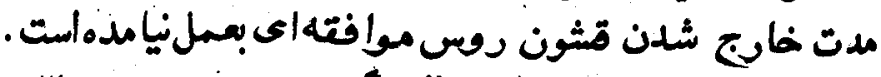

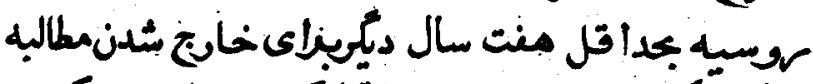

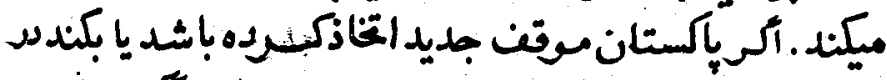

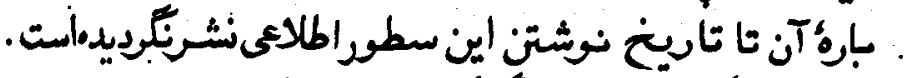

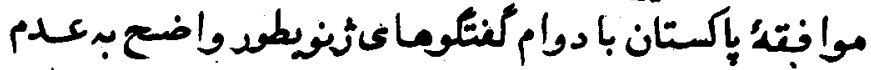

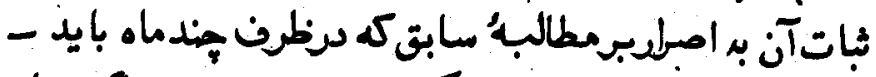

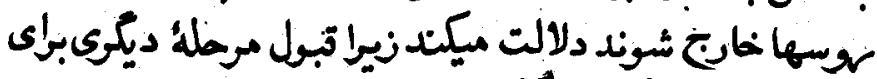

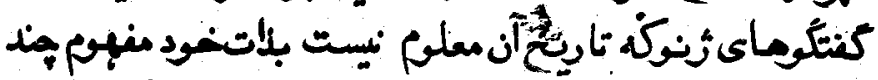

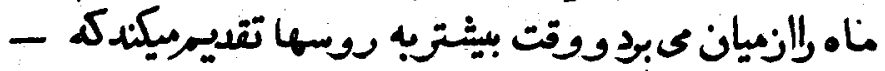

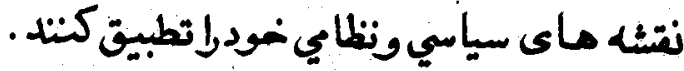

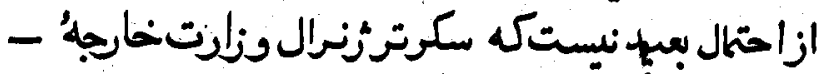

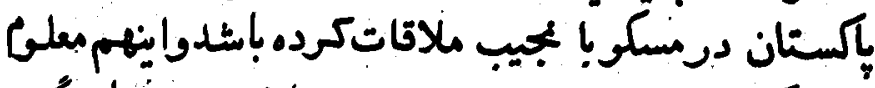

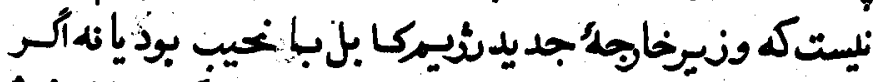

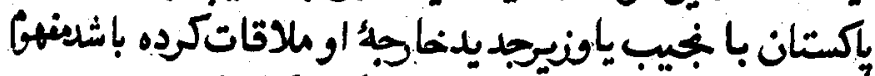

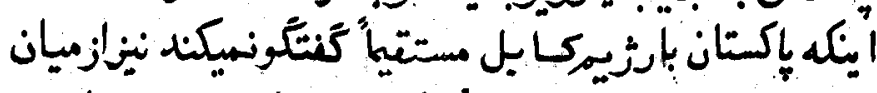

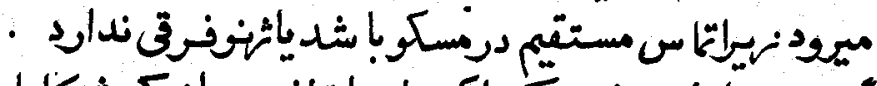

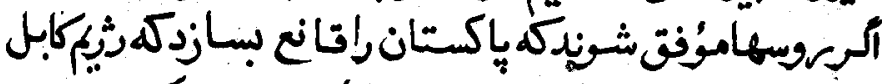

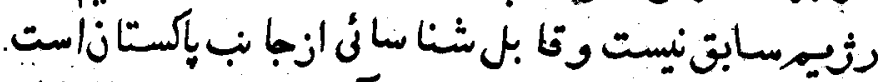

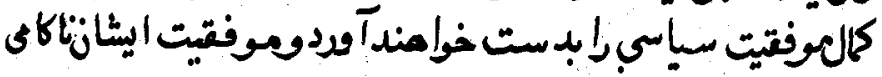




\section{YEV}

$$
\text { مطبت إكستاناست . }
$$

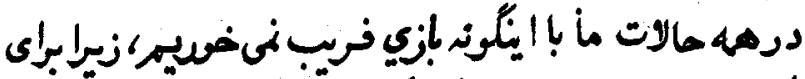

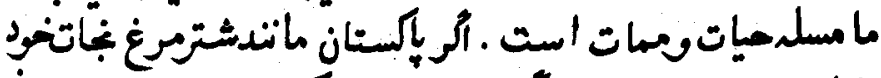

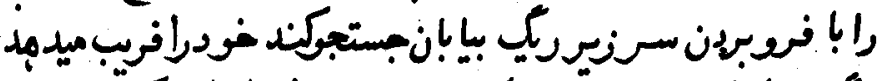

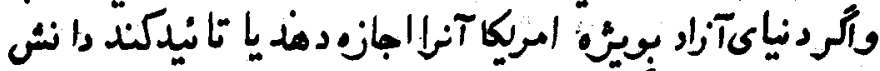

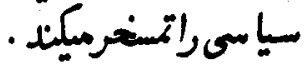

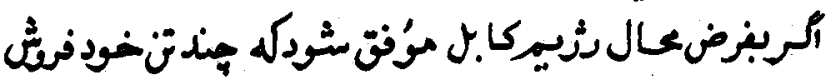

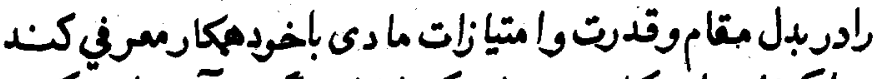

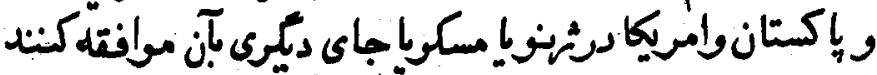

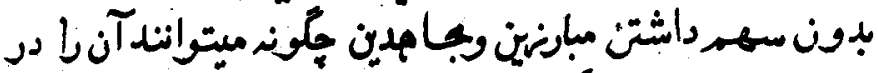

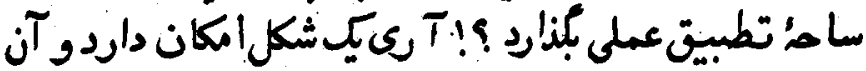

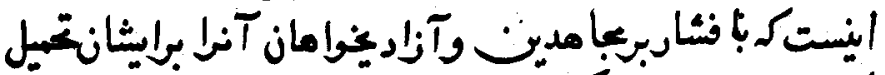

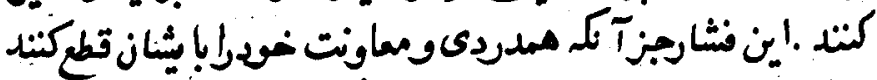

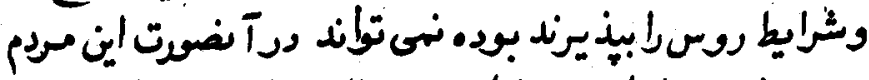

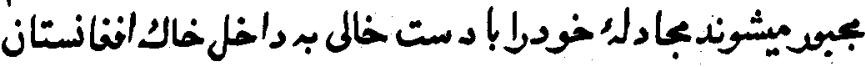

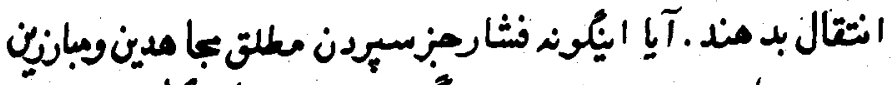

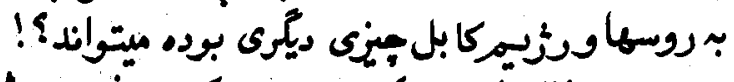

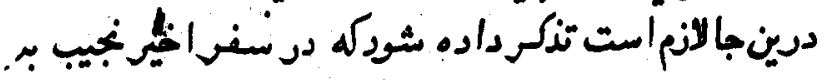

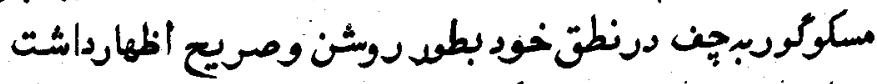

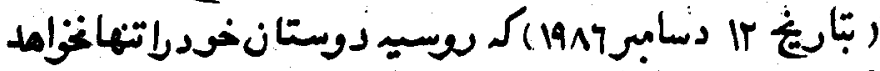

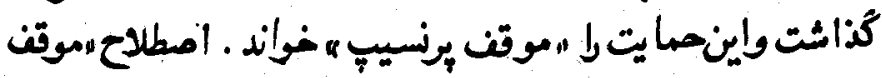




\section{reA}

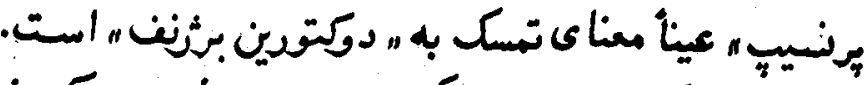

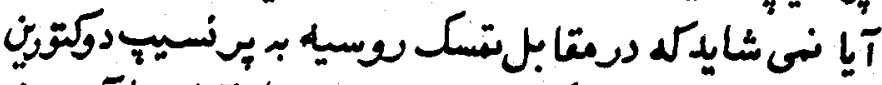

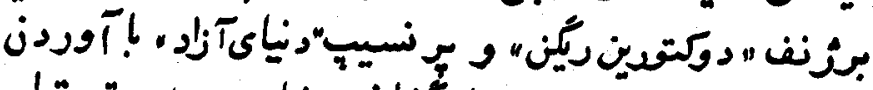

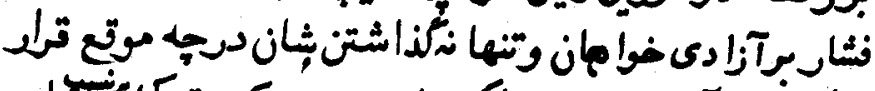

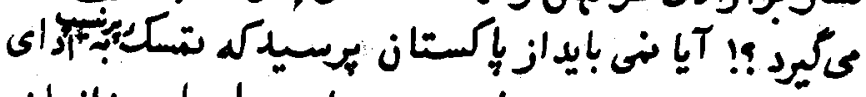

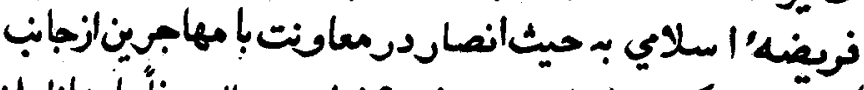

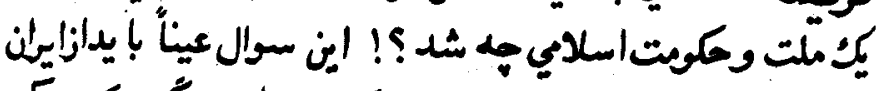

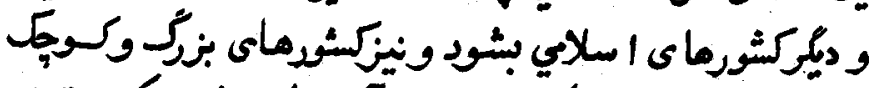

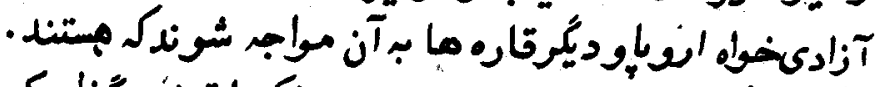

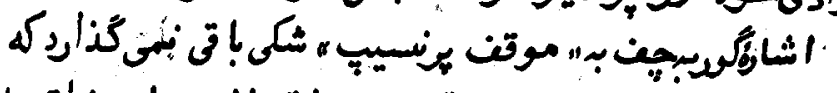

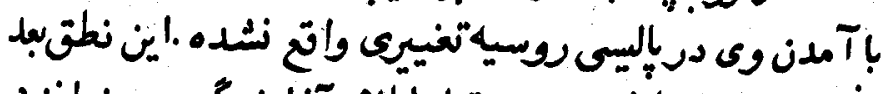

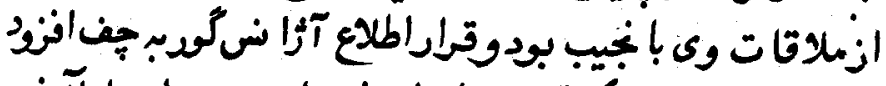

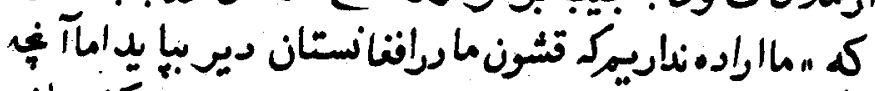

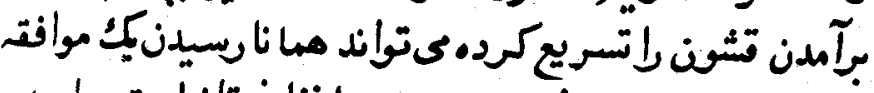

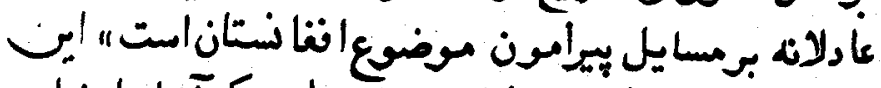

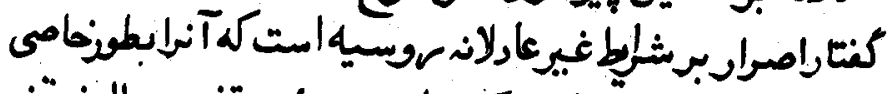

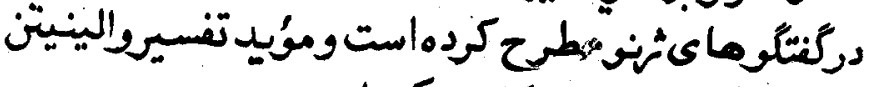

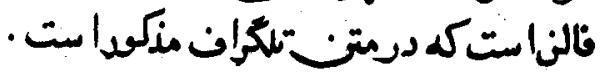

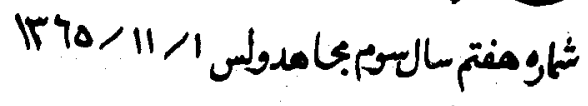



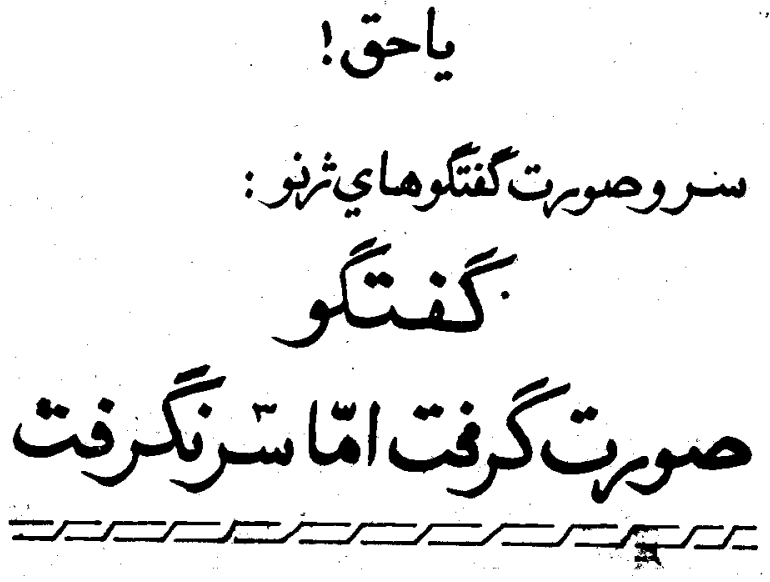

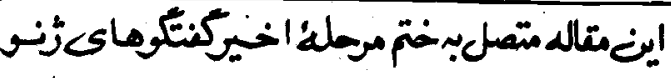

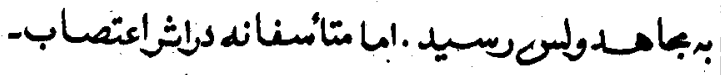

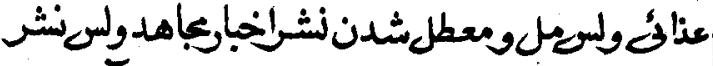

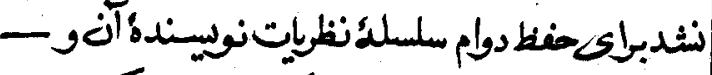

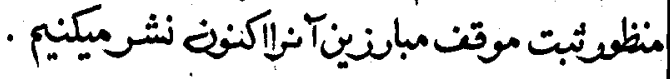

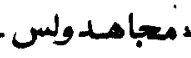

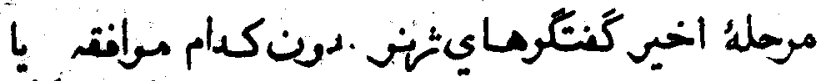

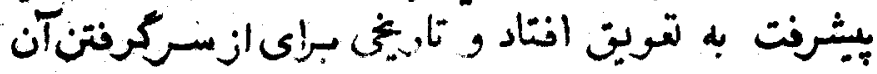


ro.

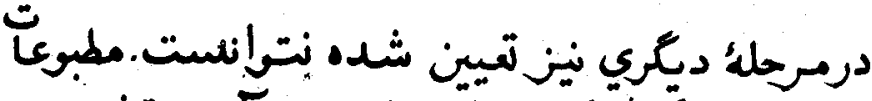

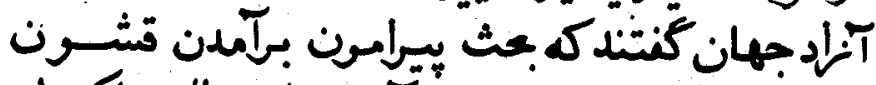

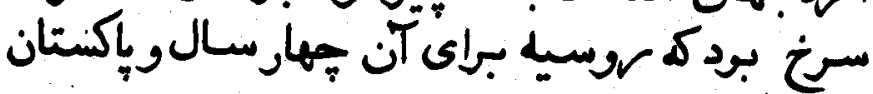

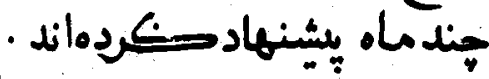

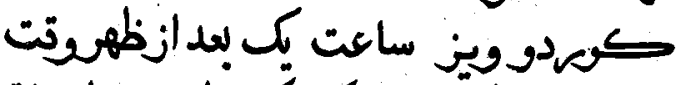

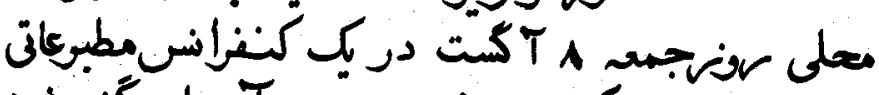

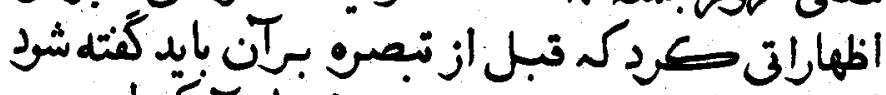

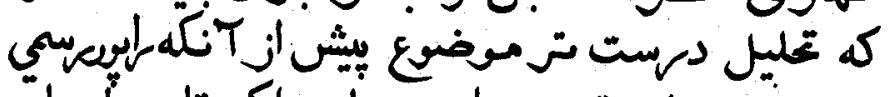

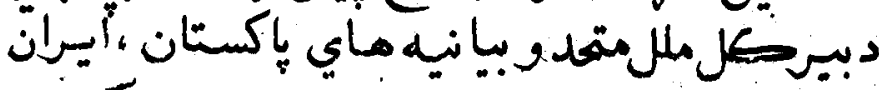

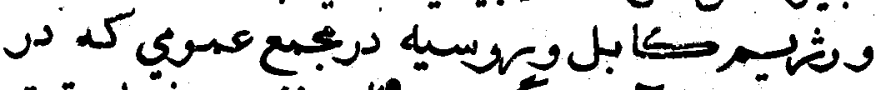

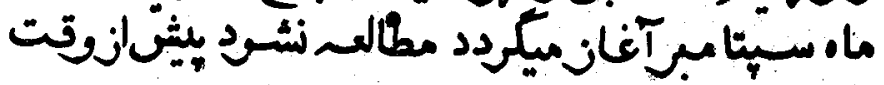

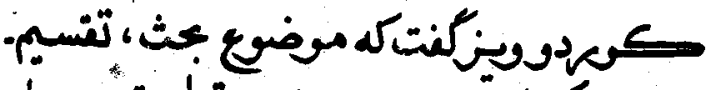

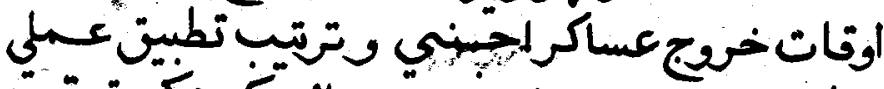

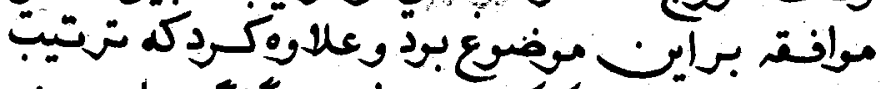

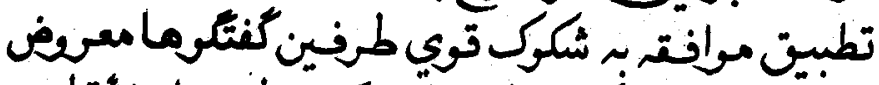

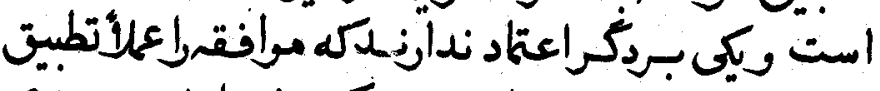

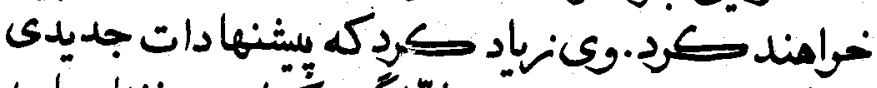

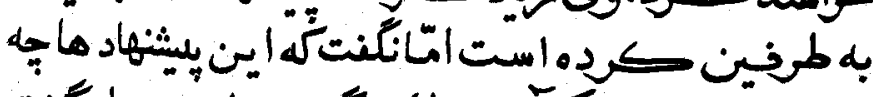

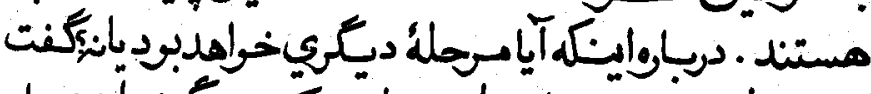

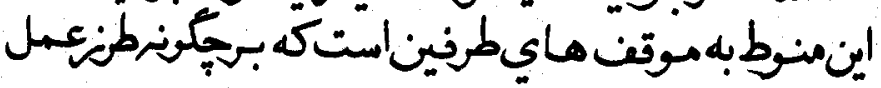




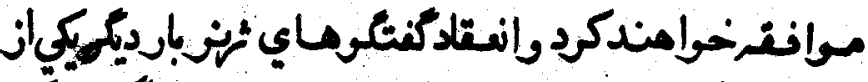

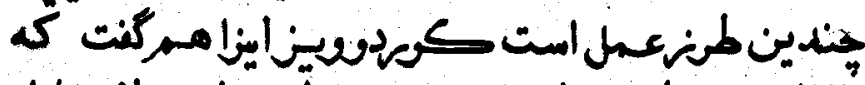

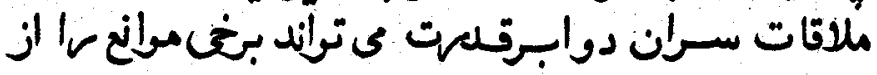

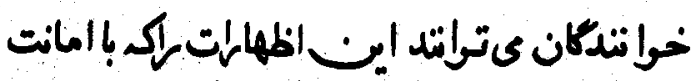

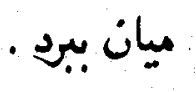

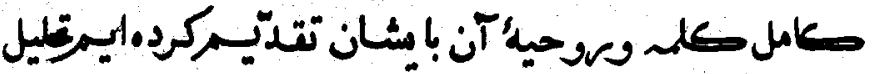

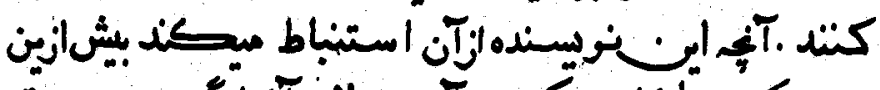

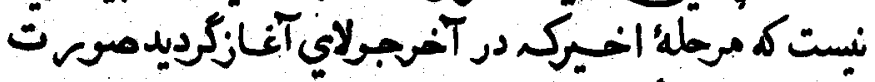

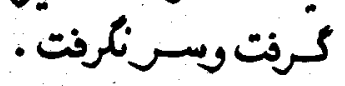

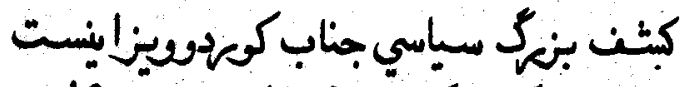

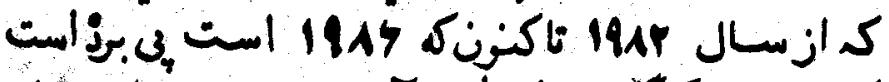

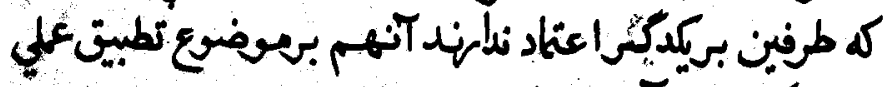

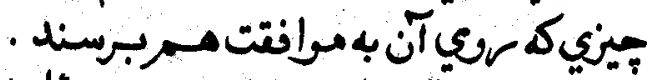
حالا جلب التنات بعيند مسئل لإنهم است :

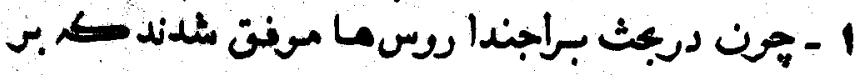

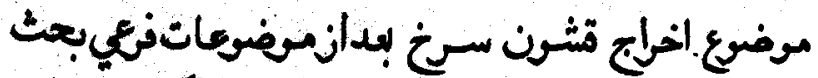

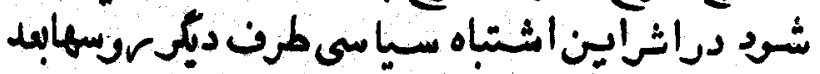

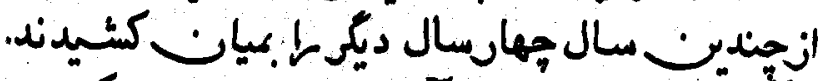

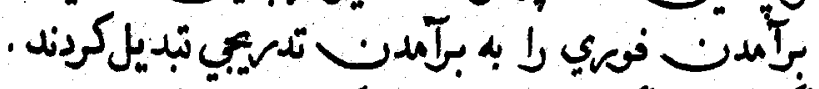

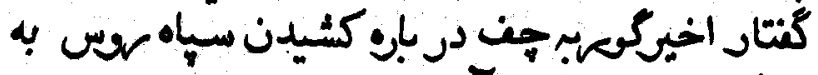

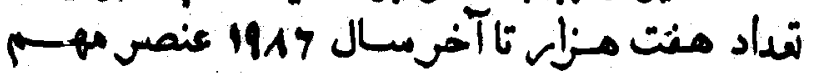




\section{ror}

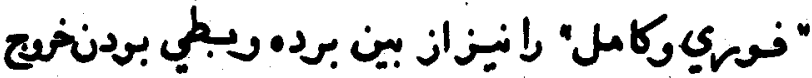

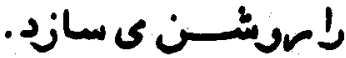

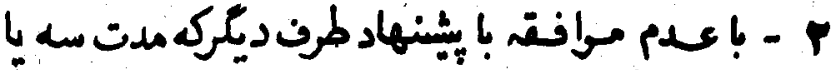

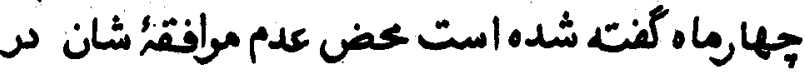

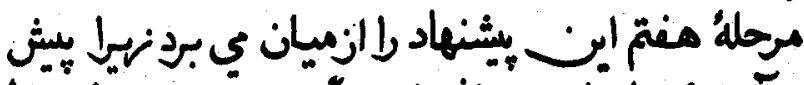

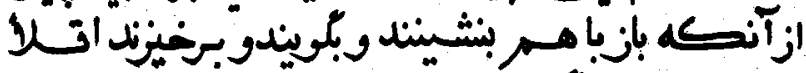

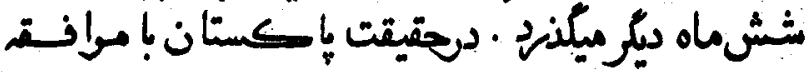

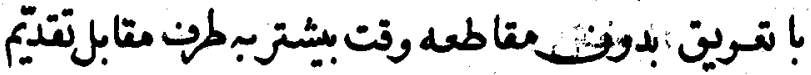

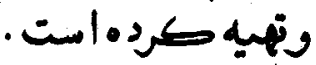

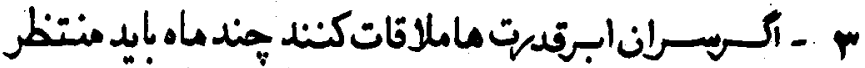

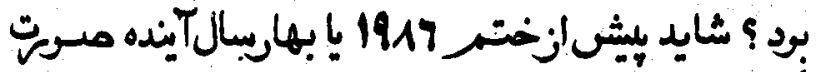

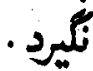

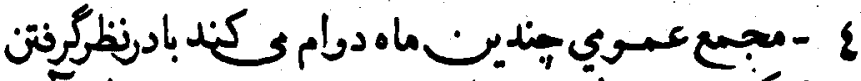

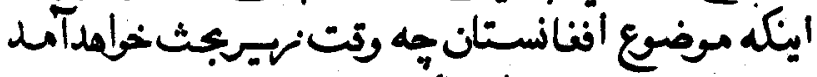

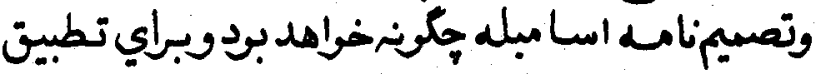

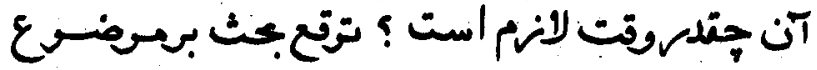

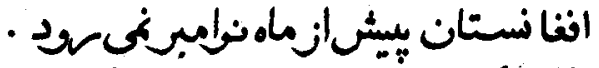

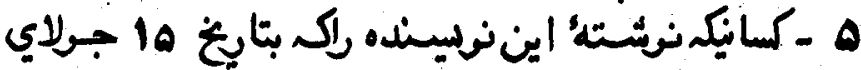

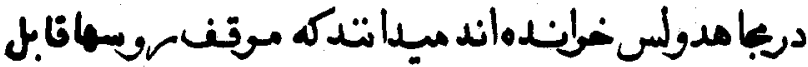

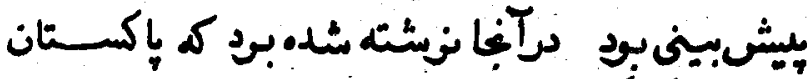

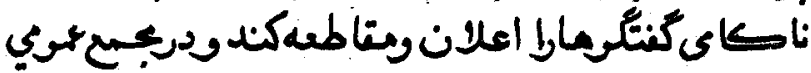




\section{Yor}

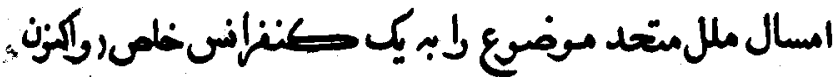

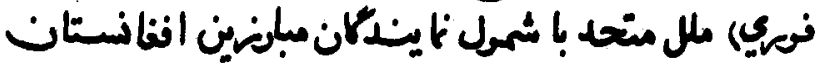

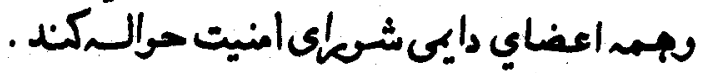

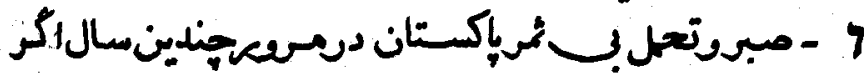

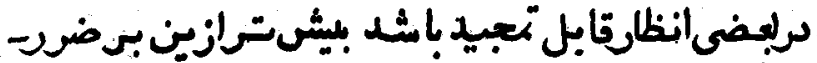

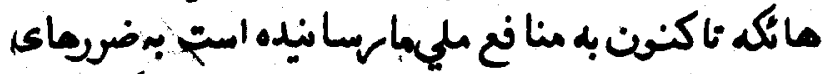

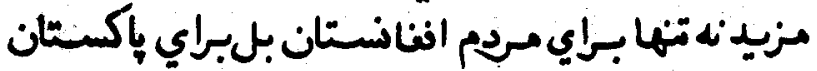

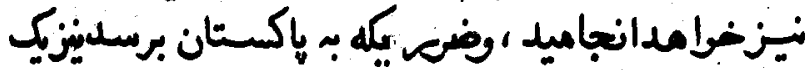

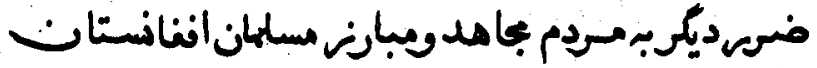

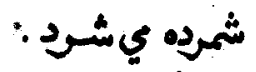

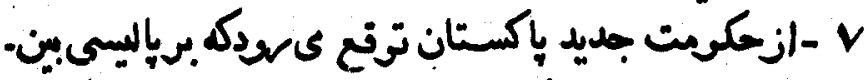

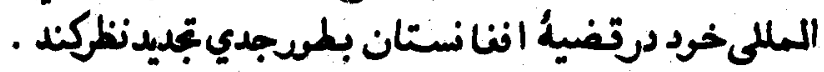

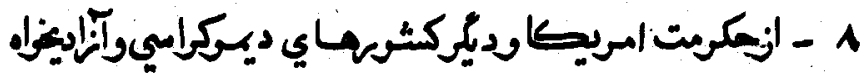

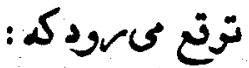

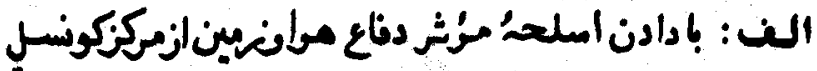

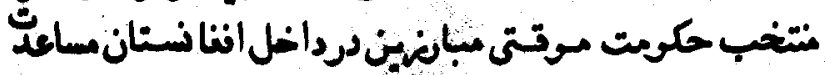

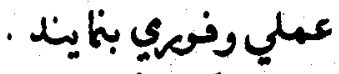

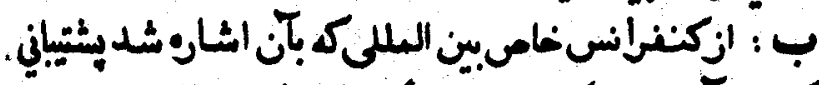

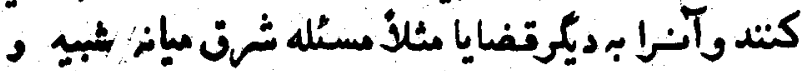

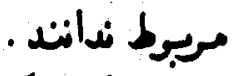

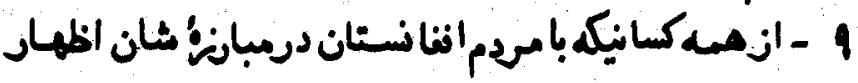




\section{Yos}

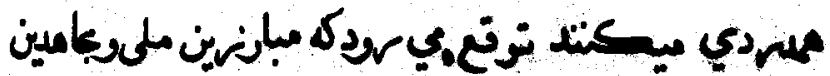

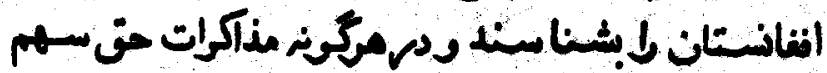

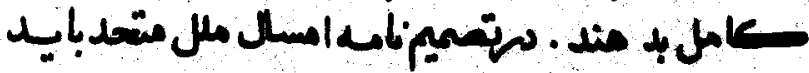

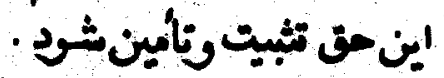

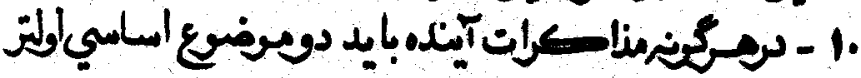

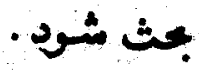

اله: احسيج تشرن سهن بصمت فويكامل

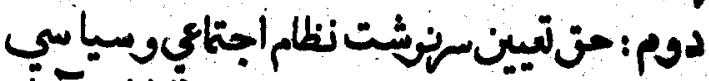
.

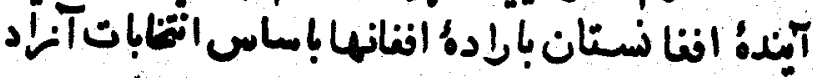

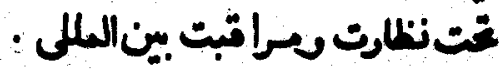

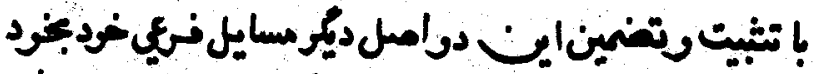

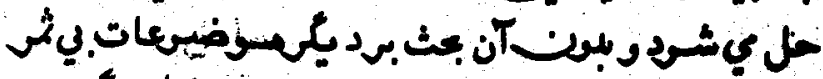

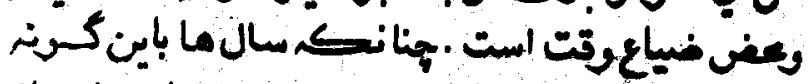

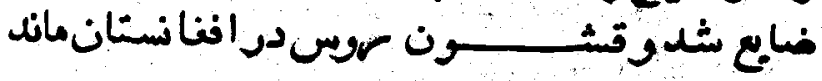

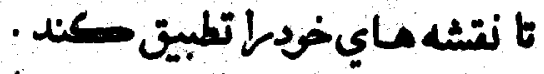

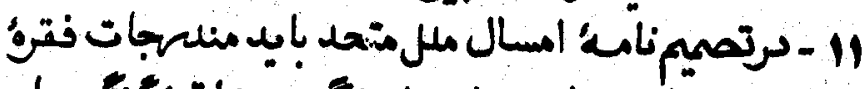

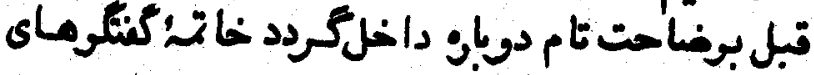

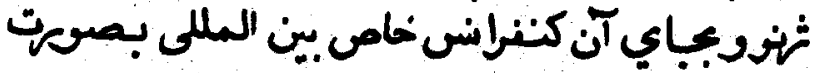

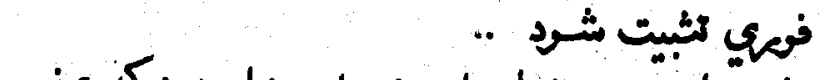

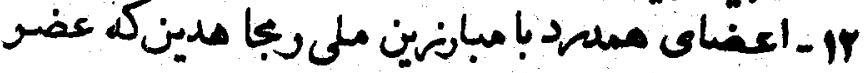




\section{YOS}

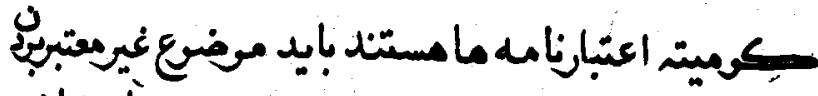

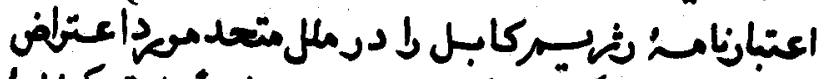

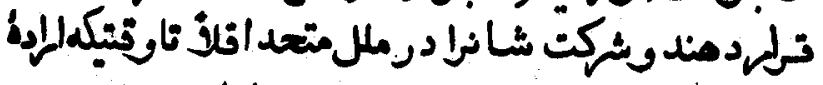

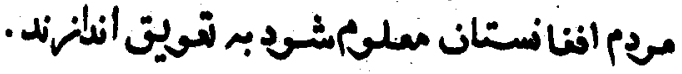

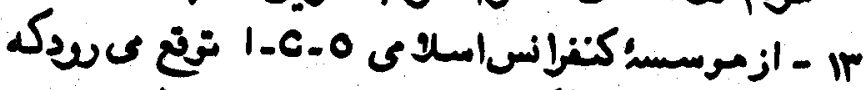

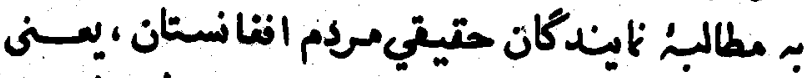

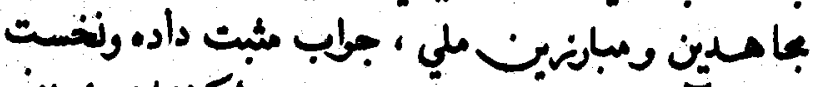

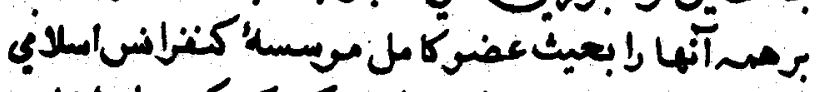

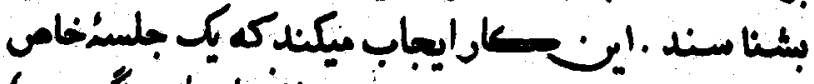

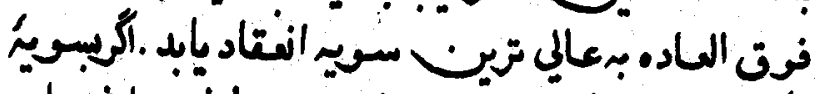

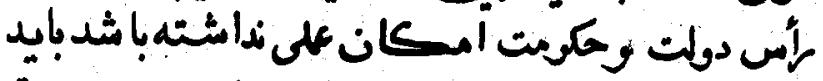

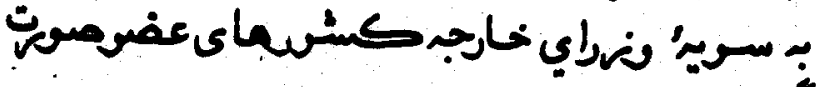

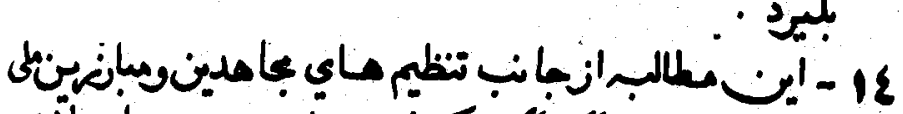

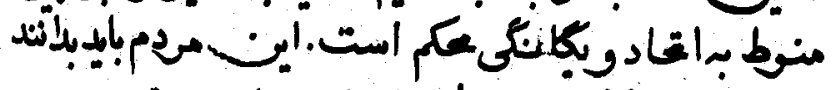

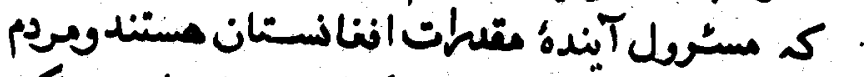

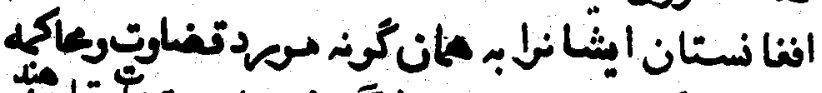

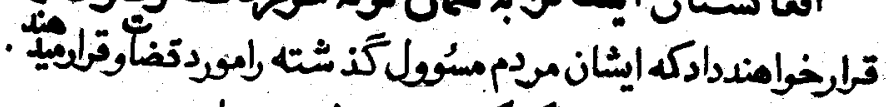

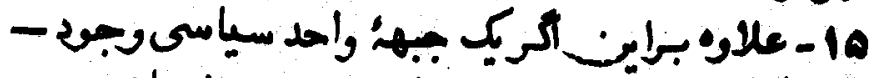

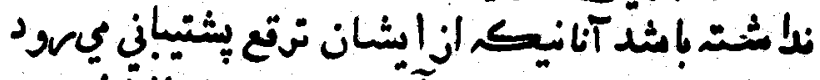

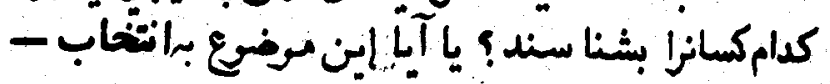




\section{YoY}

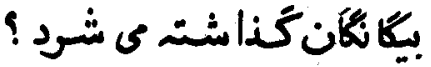

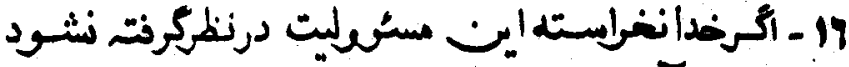

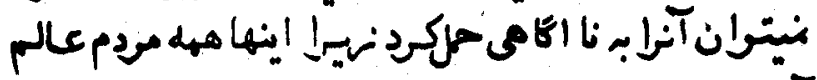

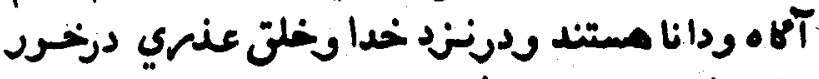

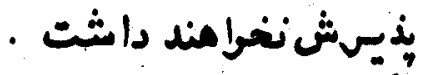

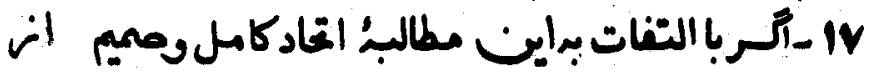

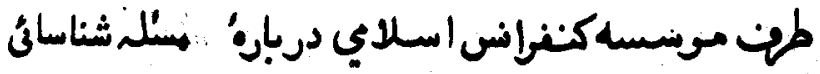

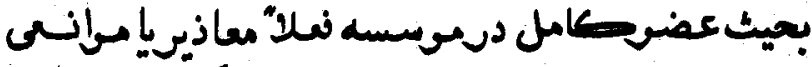

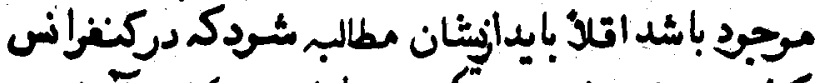

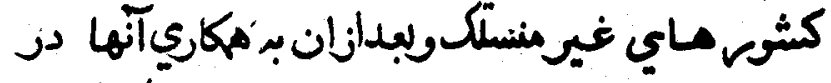

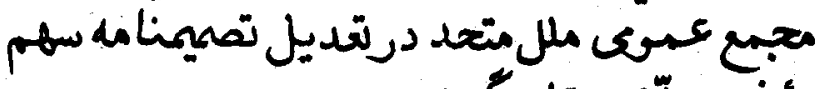

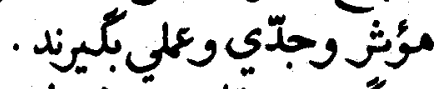

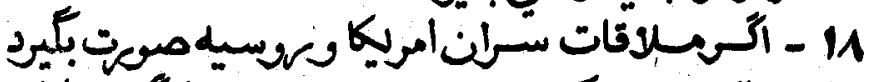

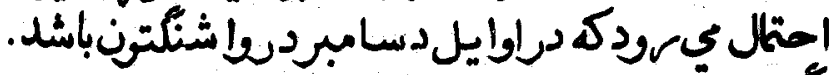

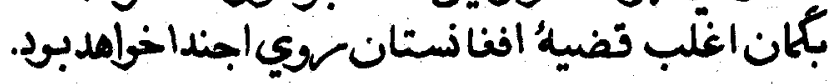

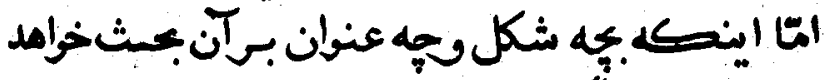

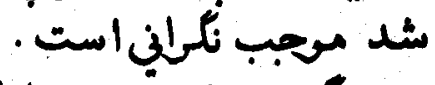

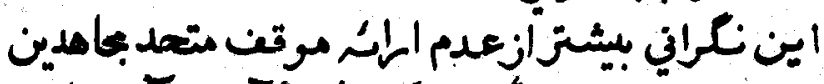

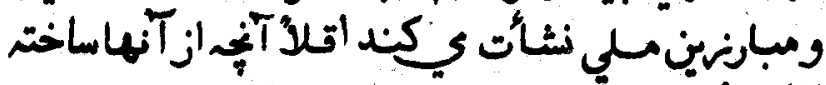

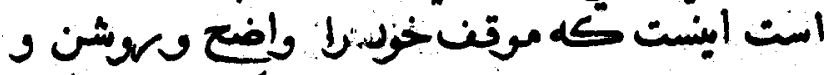

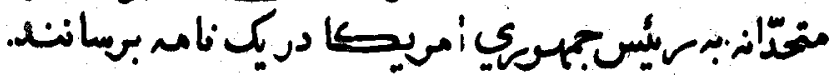




\section{YOV}

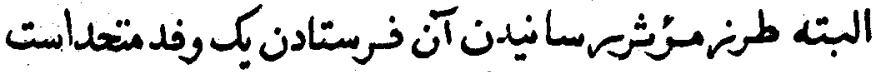

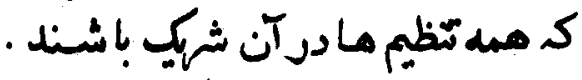

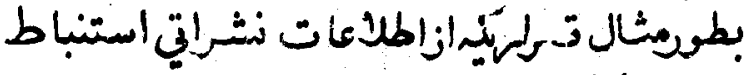

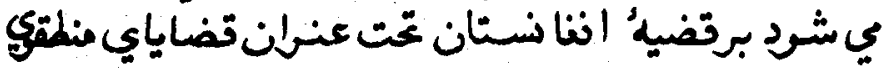

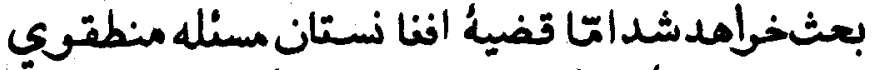

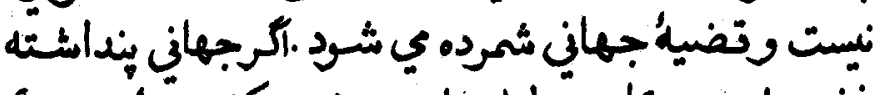

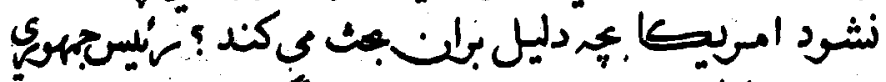

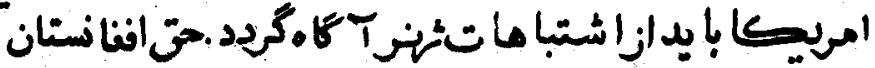

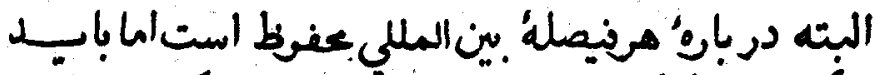

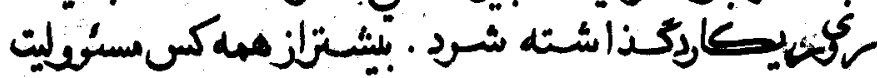

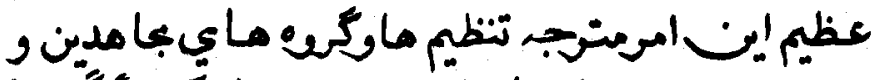

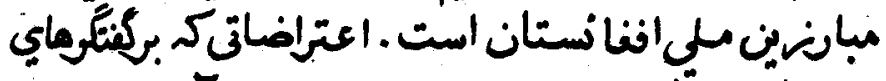

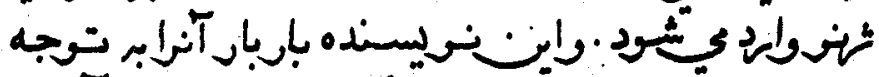

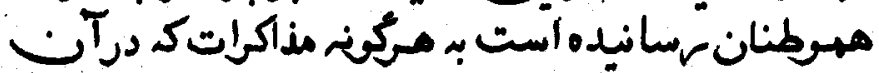

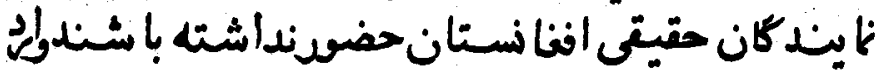

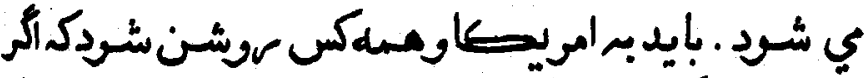

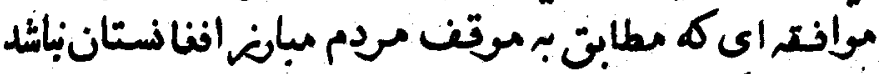

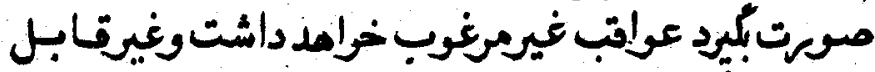

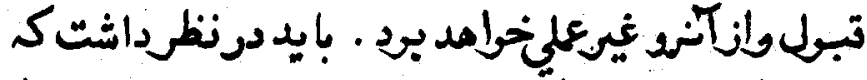

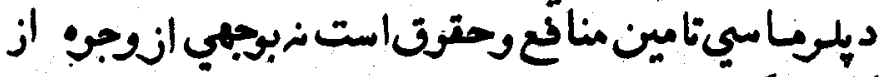
آك كن شئن

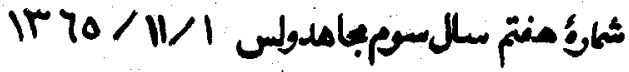




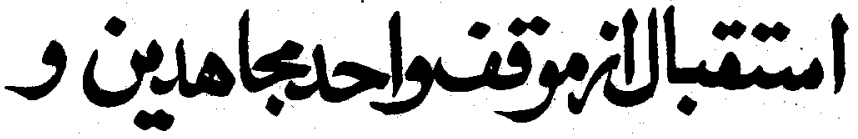 مبارئينمي}

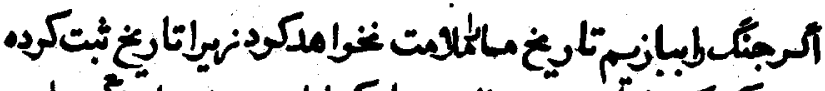

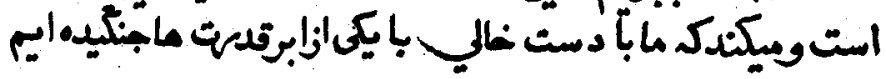

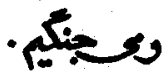

مراذازملامت تائيخ ملامث نسل آيندة انغانتان است .

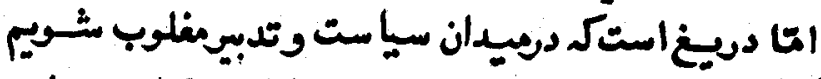

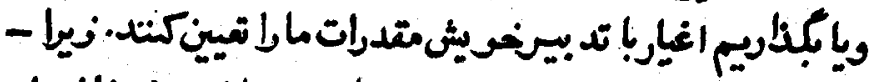

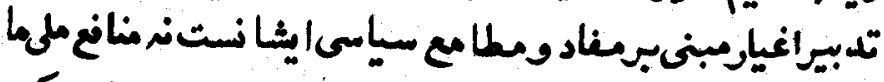

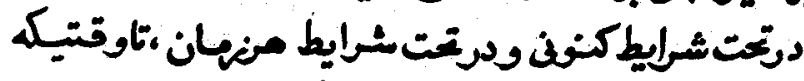

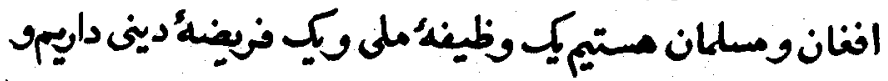




\section{Yo9}

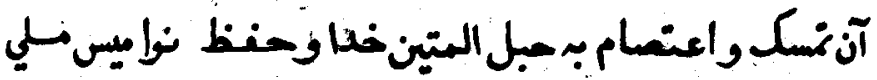

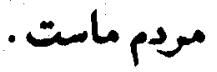
مركس ازين راه مسربكثدنمسلمان حتيقى ونهافنان باغيرت

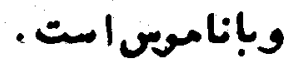

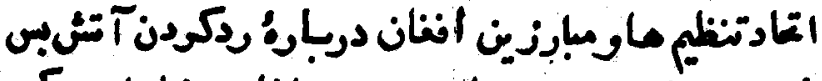

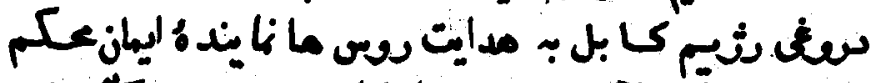

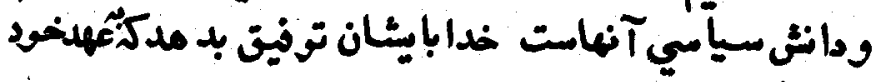
إخوفو مـردم استواربا نتد.

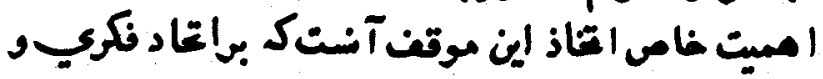

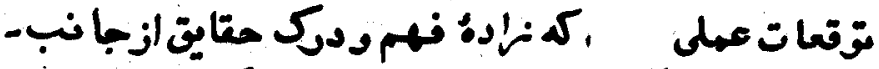

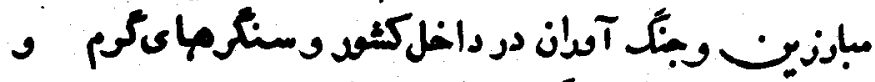

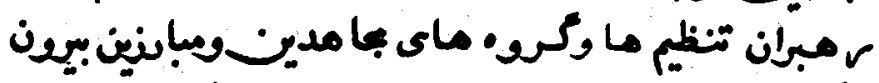

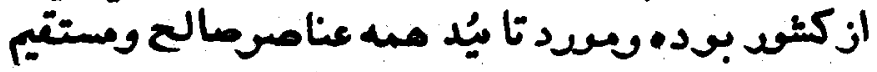

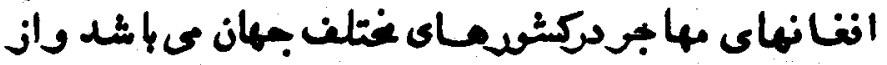

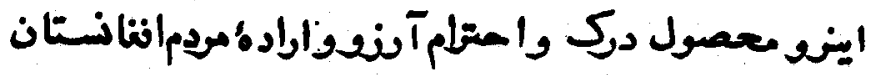

است .

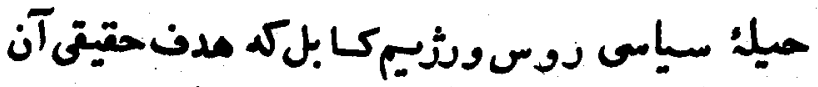

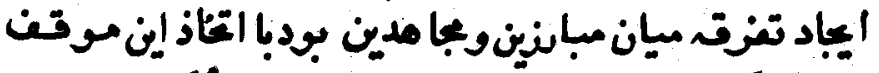

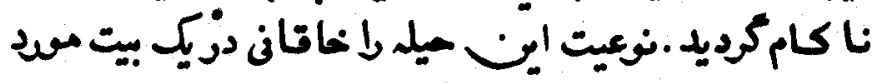

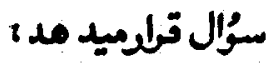

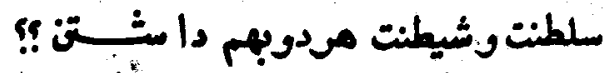

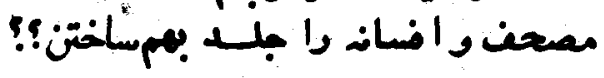




\section{r.}

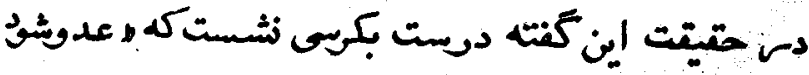

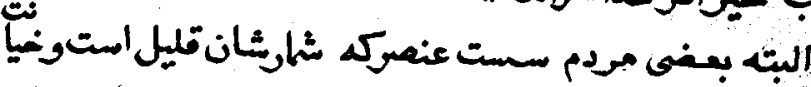

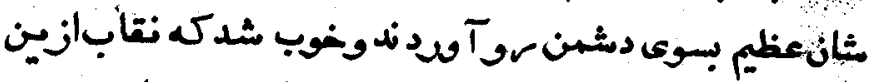

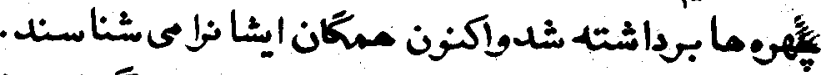

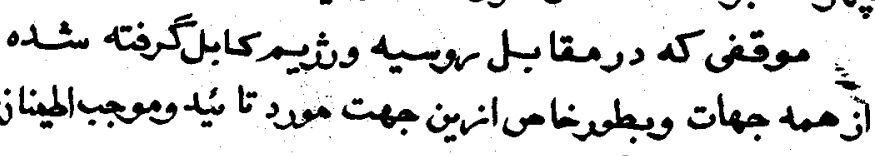

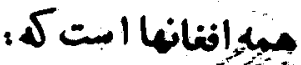

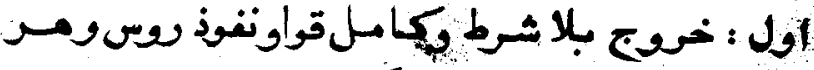

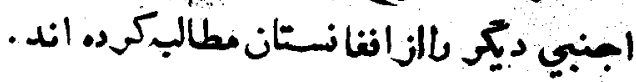

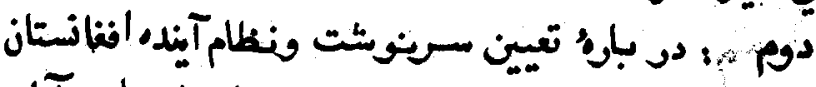

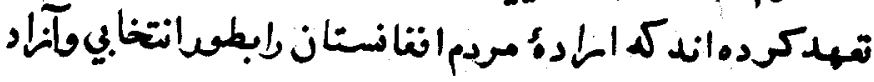

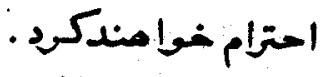

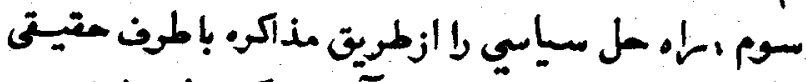

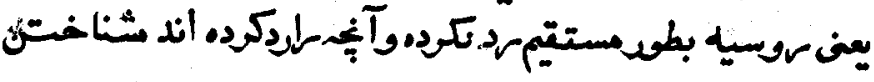

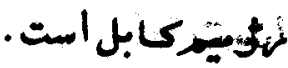

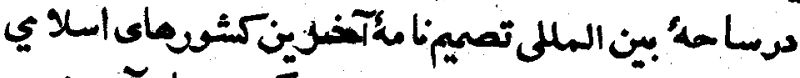

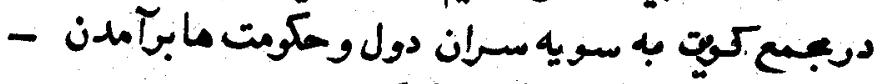

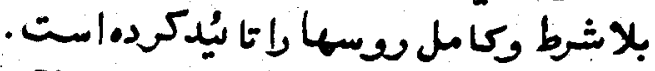

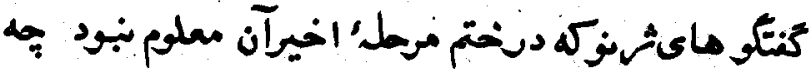

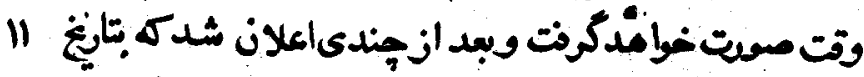




\section{หา}

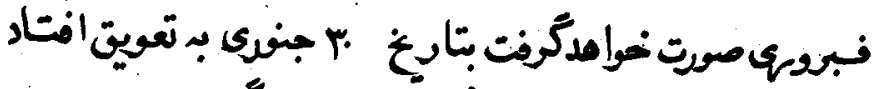

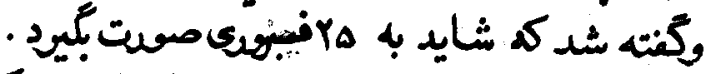

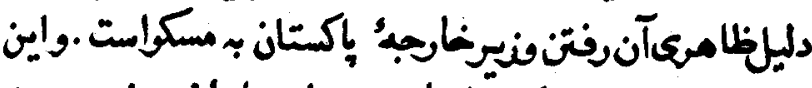

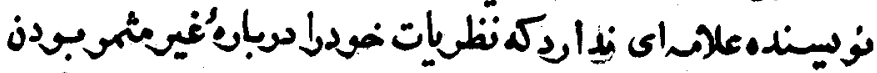

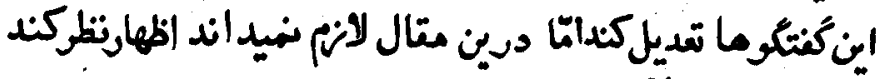

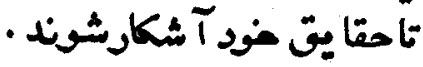

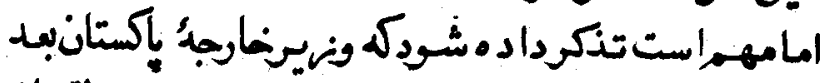

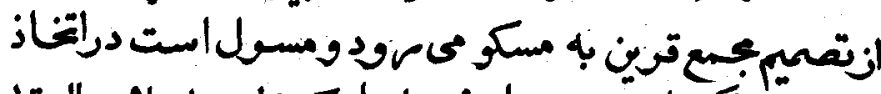

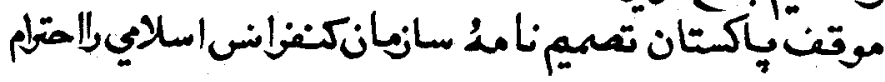
كند .

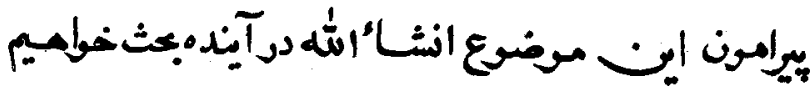
اس بمنورى كرد .

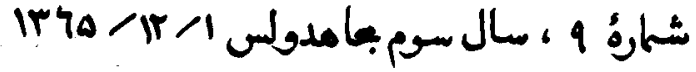

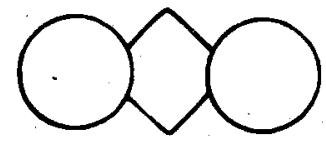




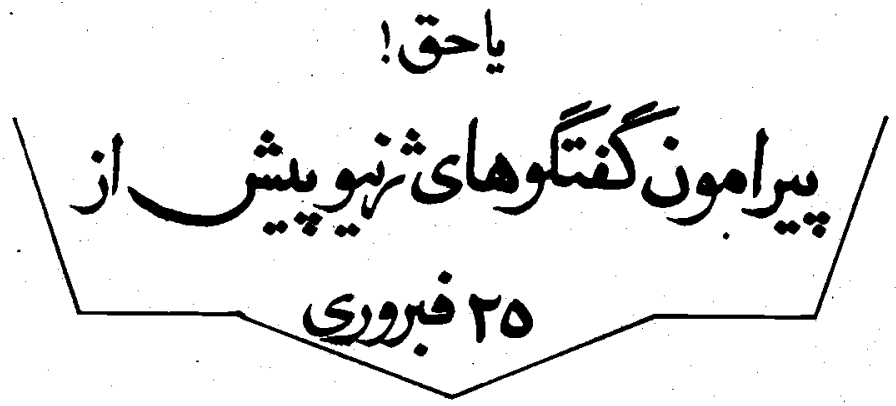

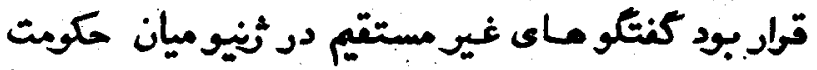

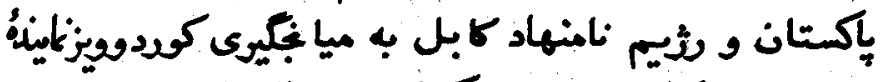

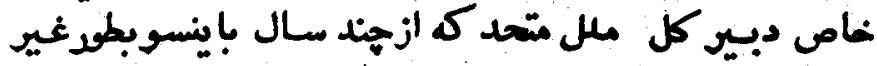

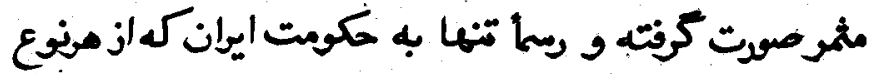

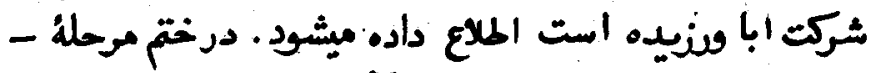

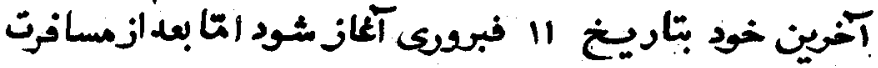

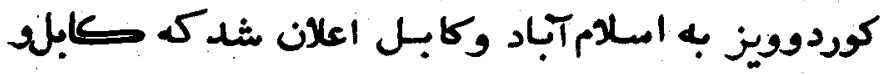

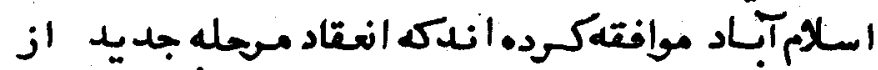

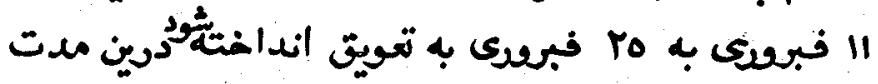

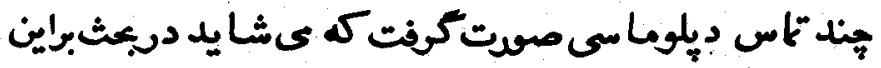




\section{ז}

متال بعضى آن را تثكى داد .

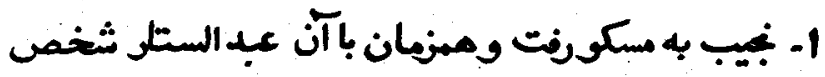

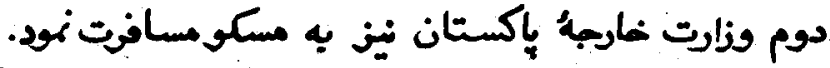

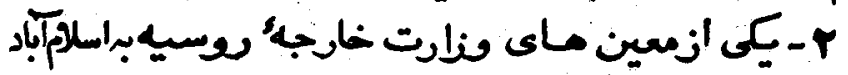

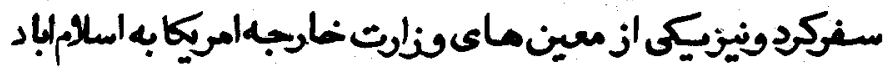

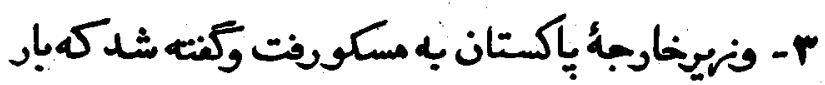

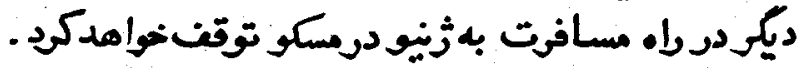

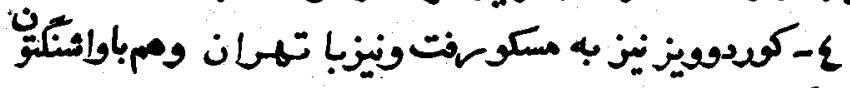
.

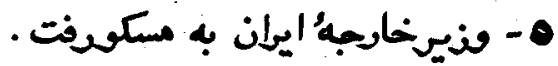

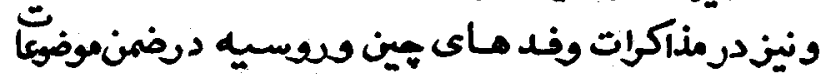
موبوط به مساسل خود شان نسبت به موضوع افنأ نستان تنكأت

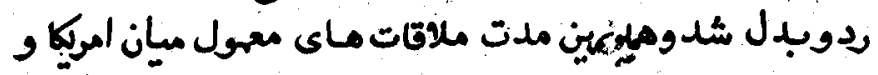

$$
\text { موبسه دوامكرد. }
$$

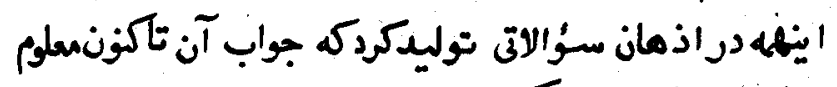
نست اعنى معلوم نعتك :

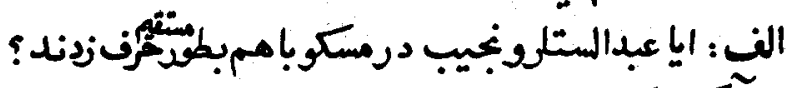

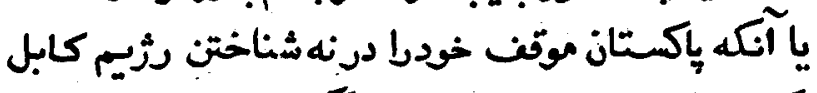

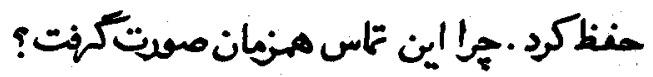

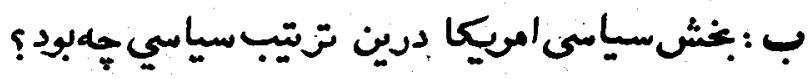




\section{r7}

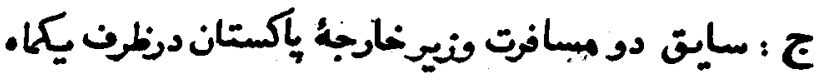

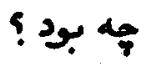

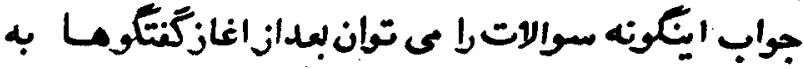

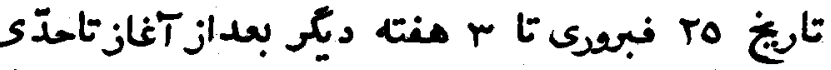
حدس ند.

آكى به اوضاع دد ساحه سياسىوديلوماسى تويجه شود

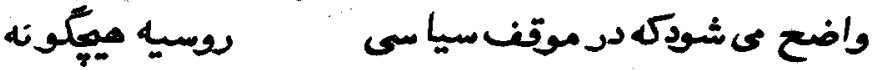

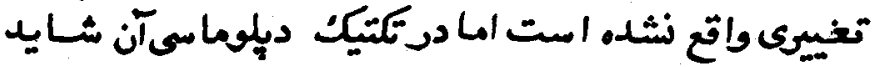

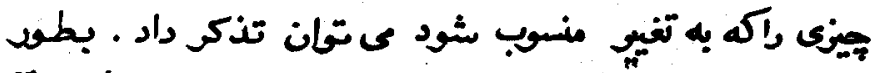

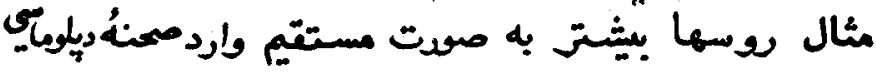
شُده اند. مصال

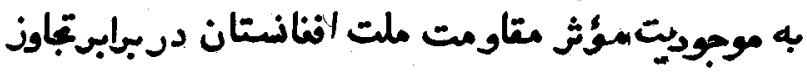

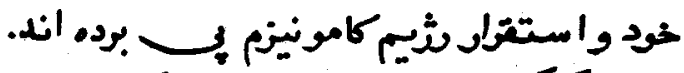

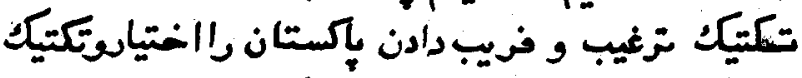

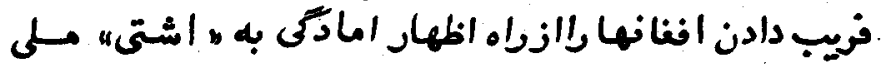

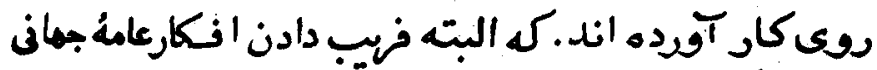

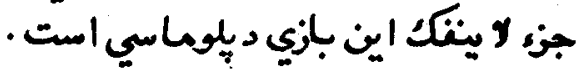

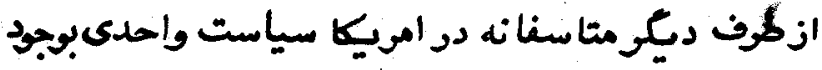

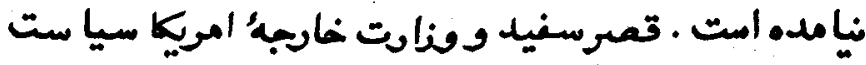

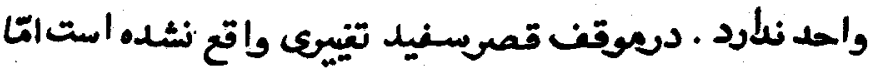

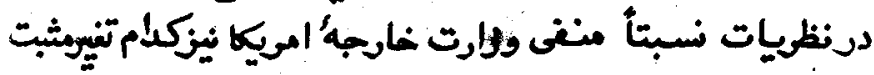




\section{rio}

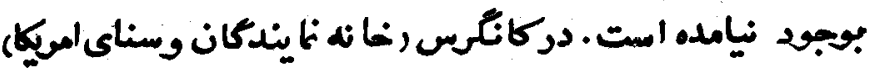

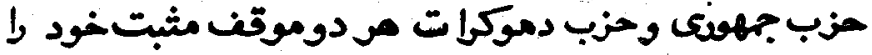

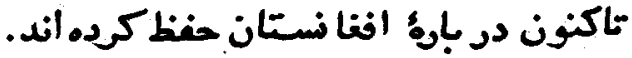

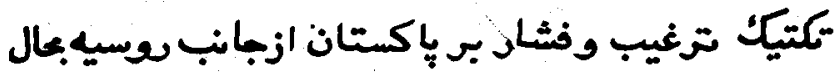

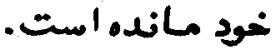

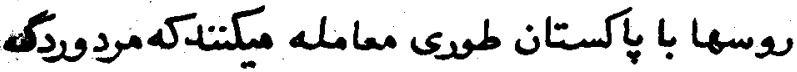

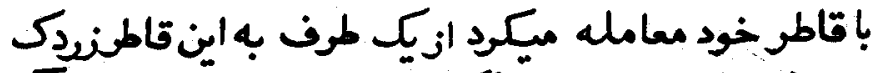

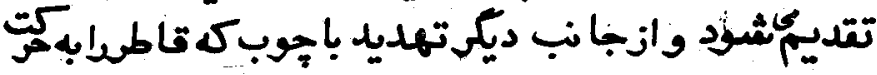

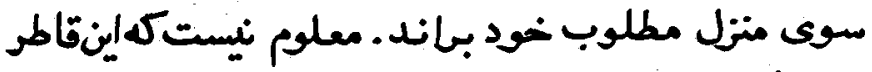

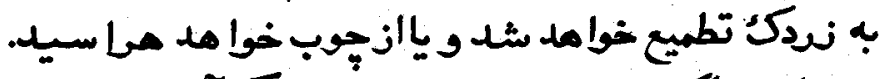

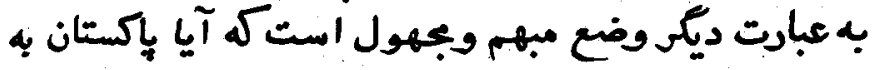

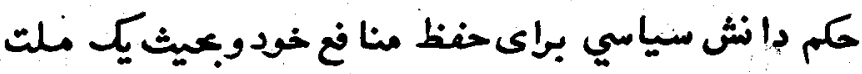

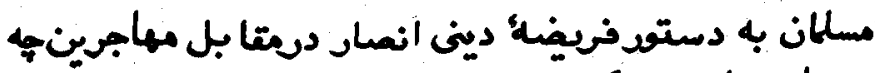

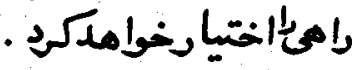

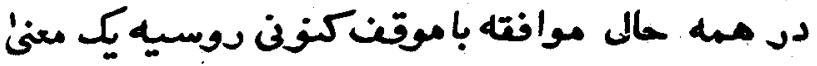

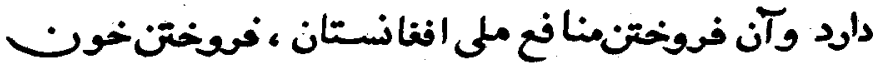

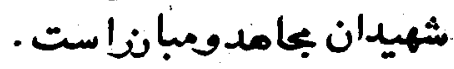

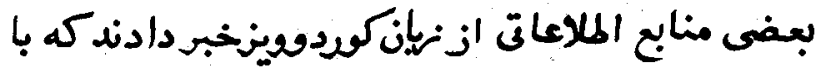

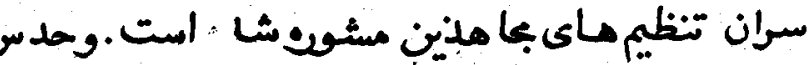

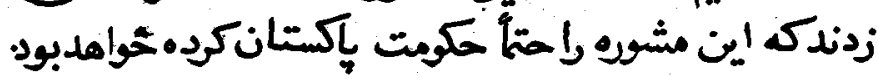

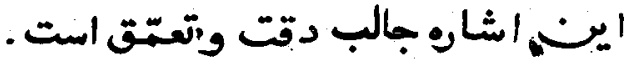




\section{צר}

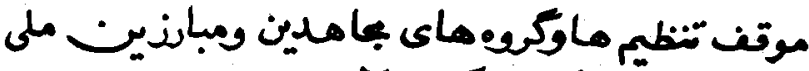

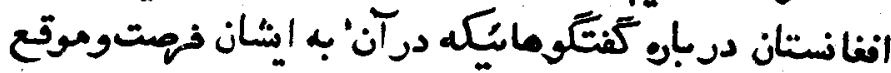

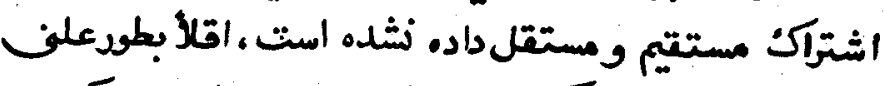

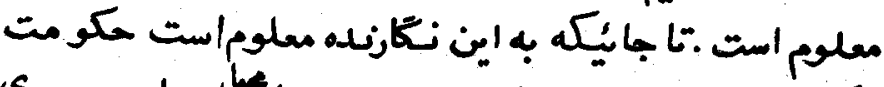

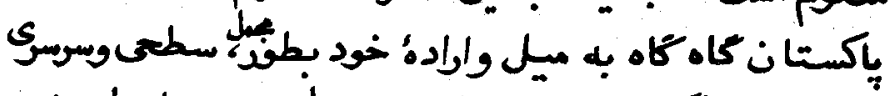

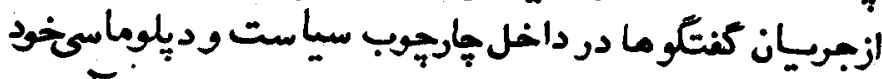

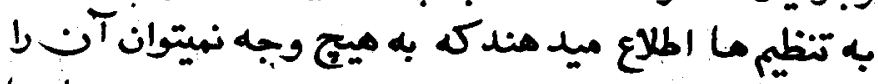

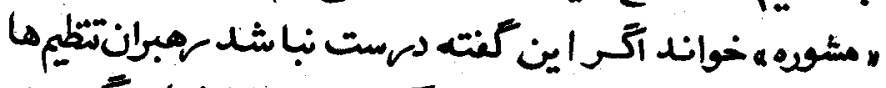

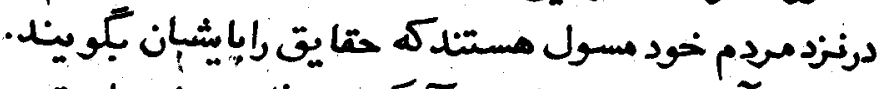

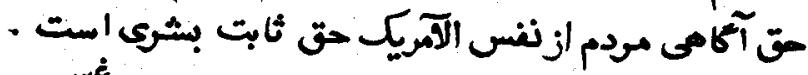

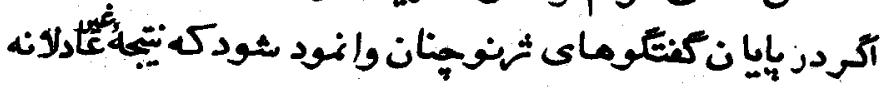

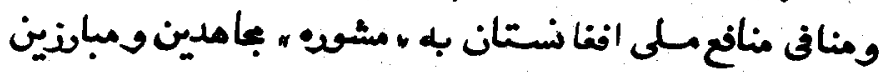

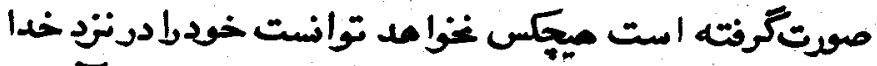

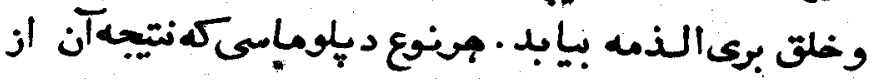

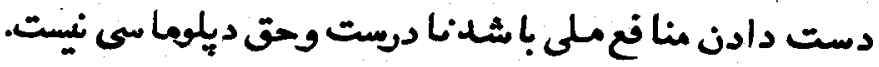

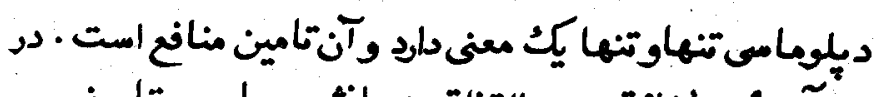

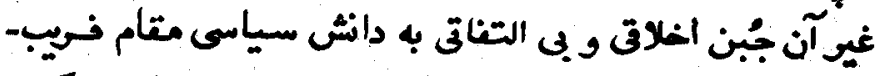

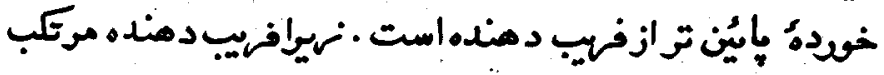

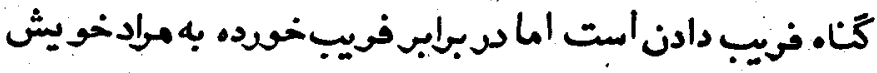

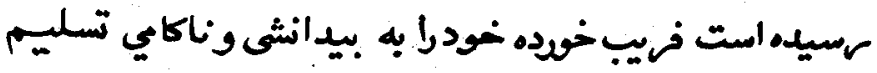

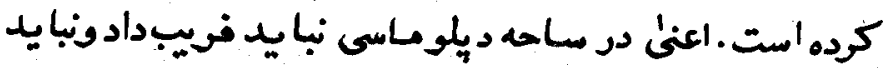




\section{TTV}

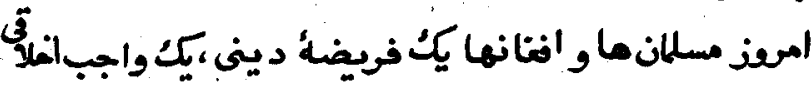

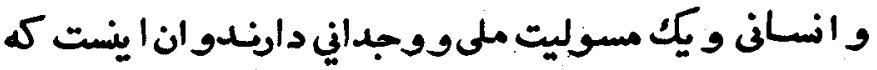

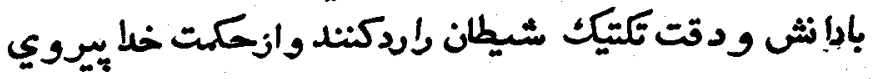
كند.

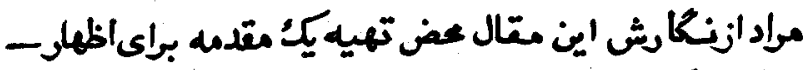

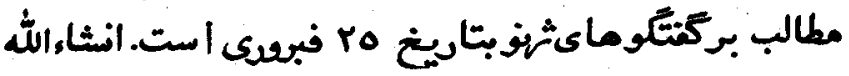

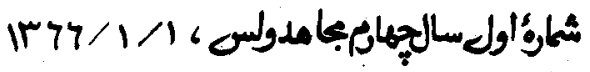

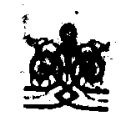




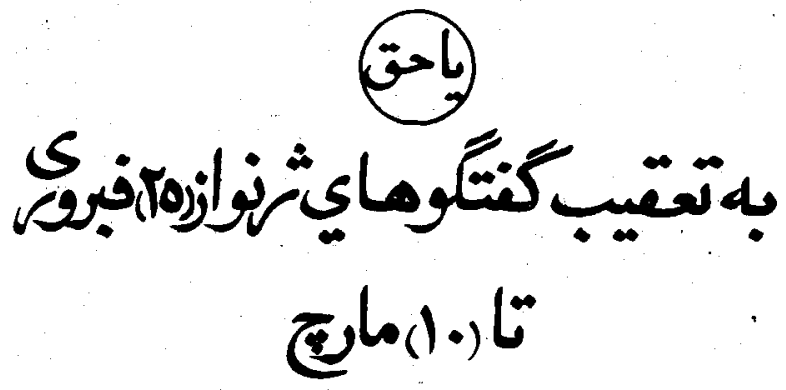

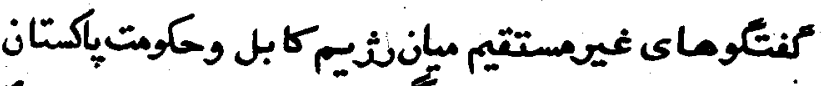

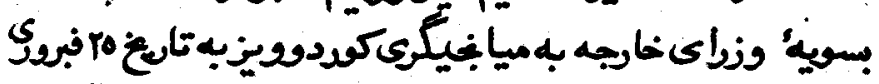

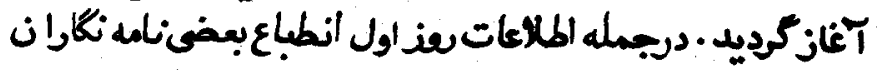

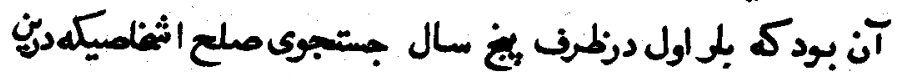

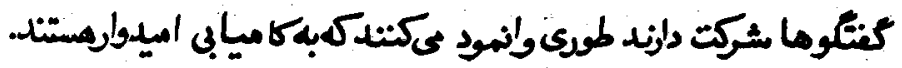

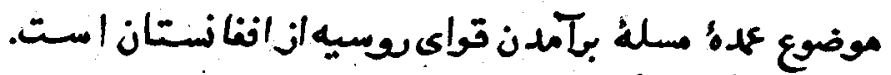

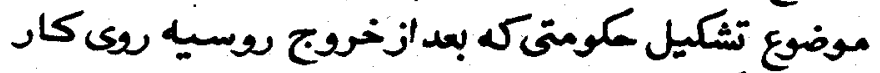

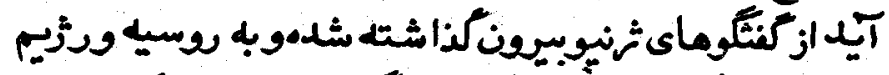

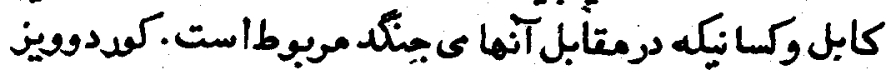




\section{Y79}

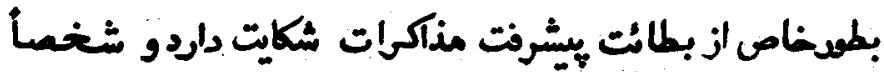

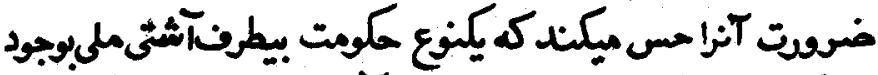

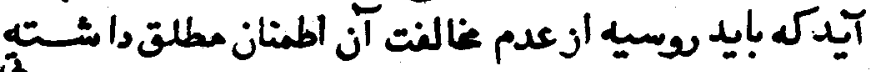
3

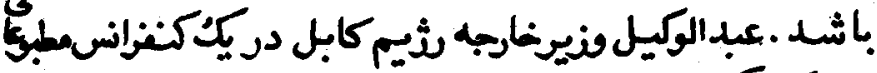

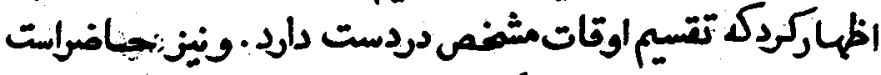

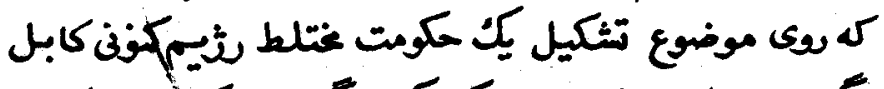

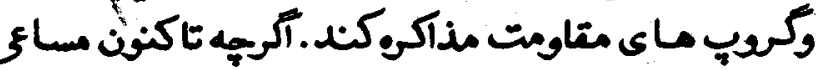

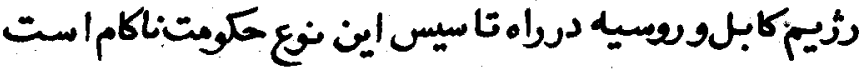

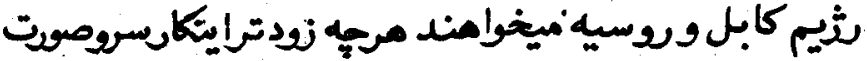

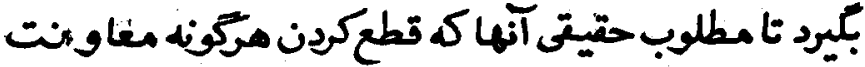

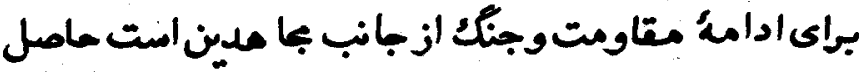

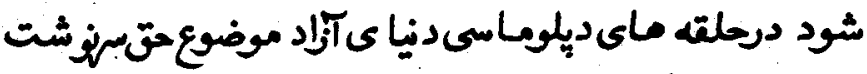

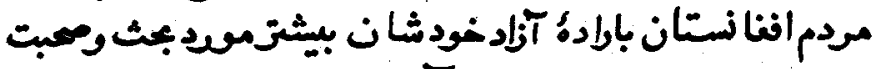

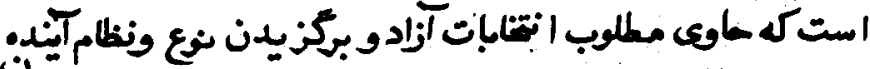

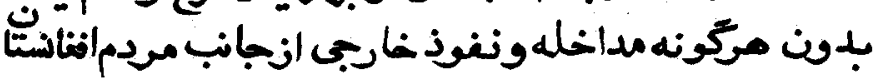

- 1

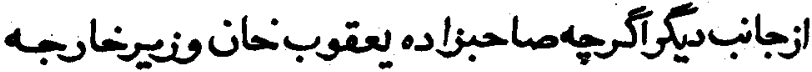

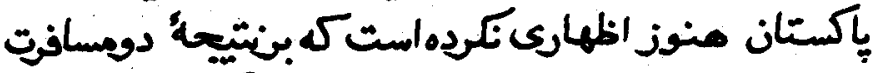

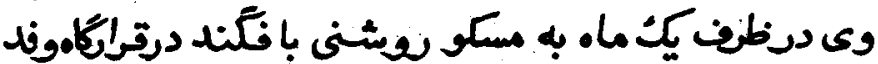

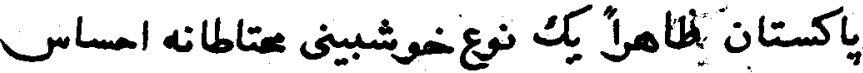




\section{TV.}

در مسكو فرقى دو موقف روسيه اعلان نشنفه است.مست

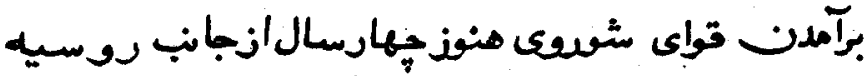

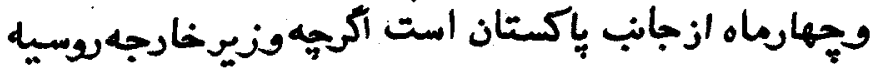

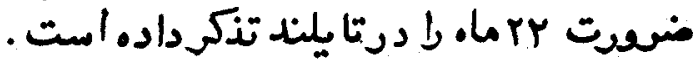

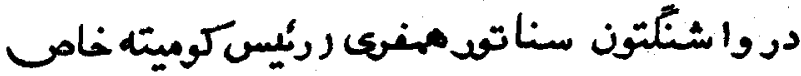

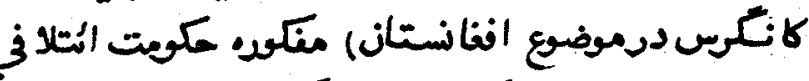

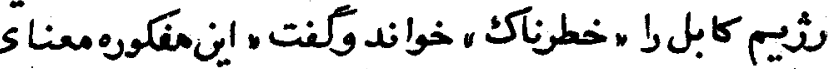

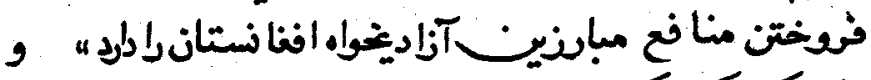

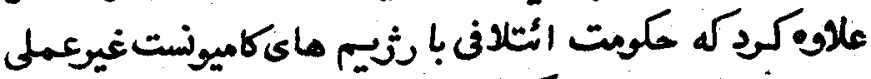

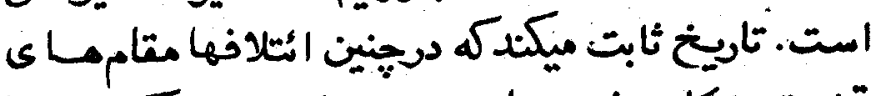

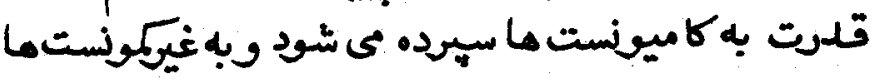

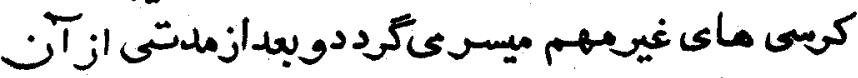

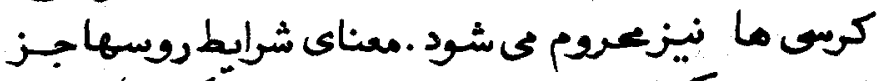

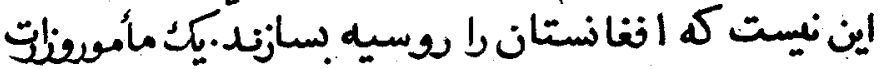

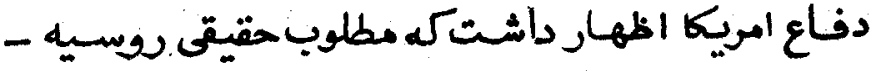

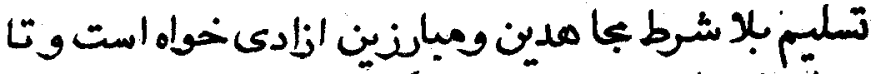

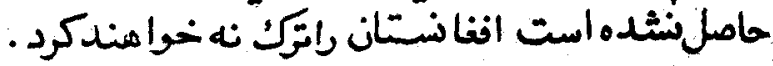

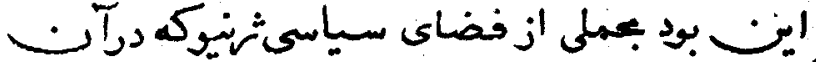

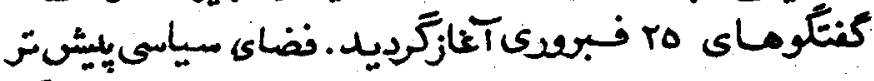

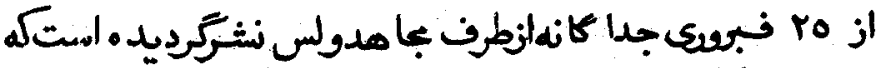

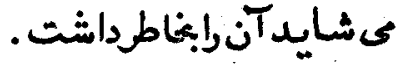




\section{TVI}

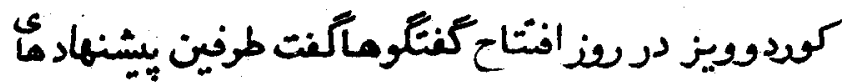

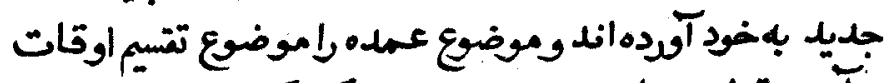

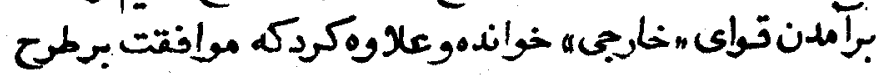

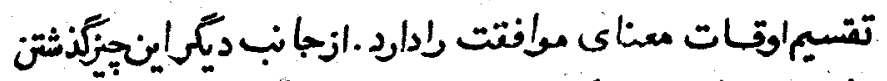

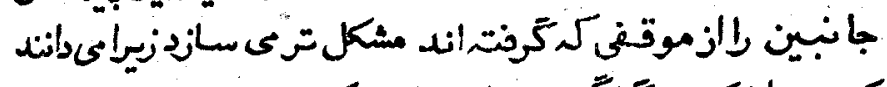

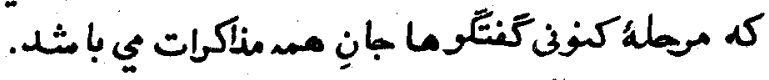

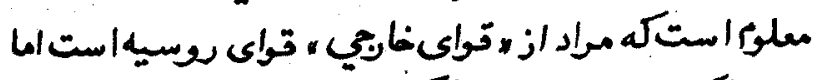

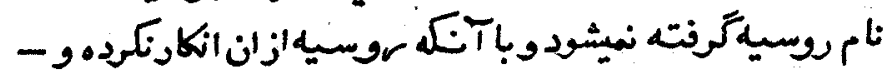

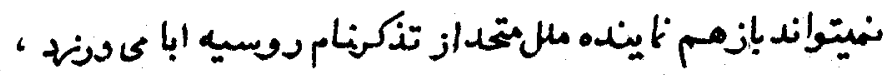

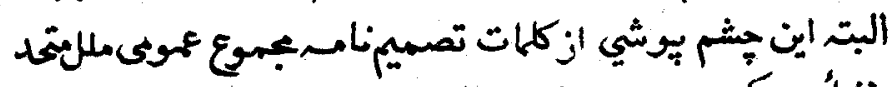

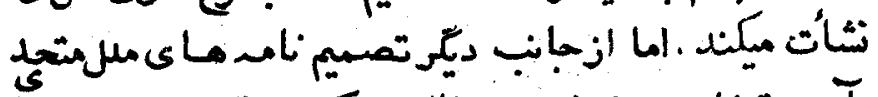

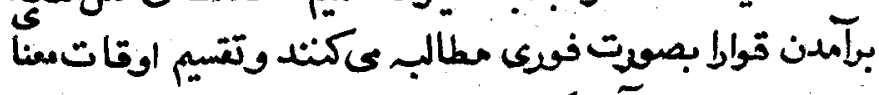

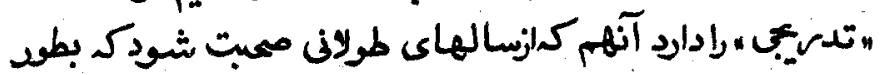

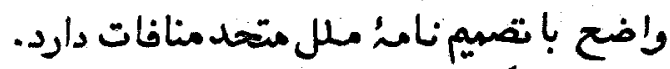

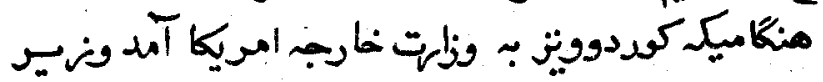

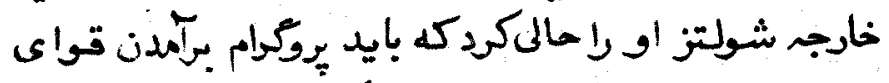

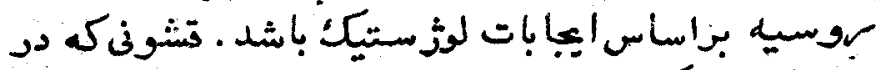

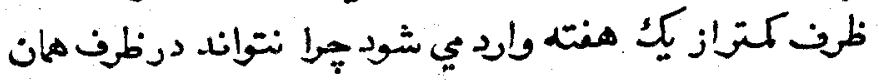

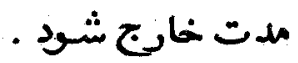

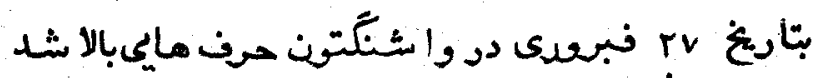

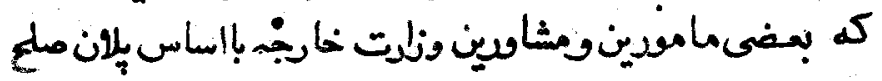




\section{YYY}

وآثتى ششـوروي اطلهارغالفت نمسكمند وآنما مُمدابمكاتات

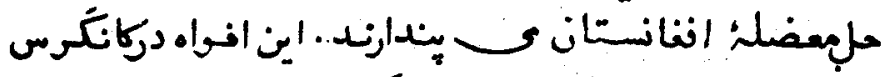

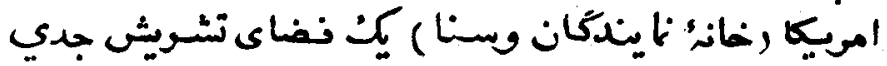

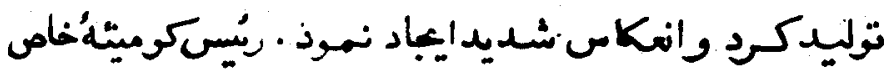

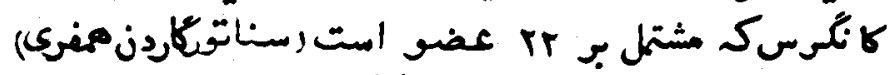

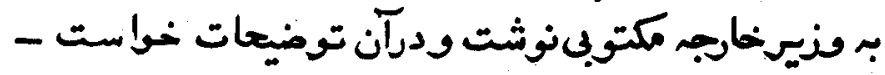

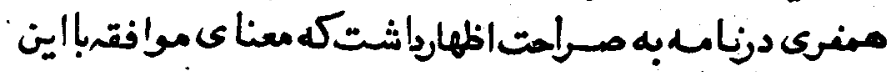

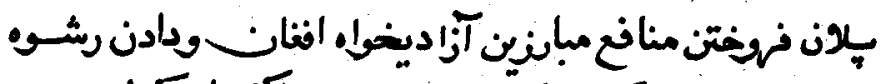

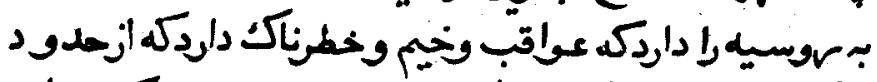

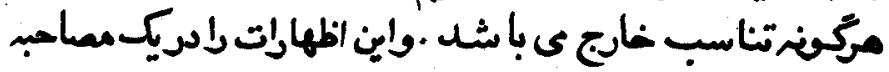

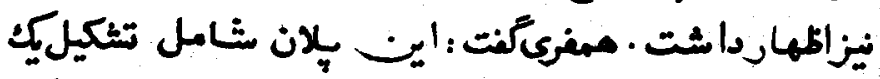

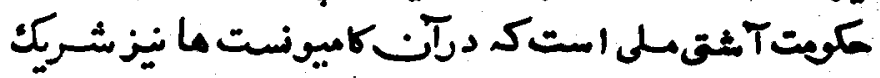

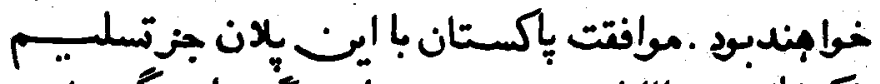

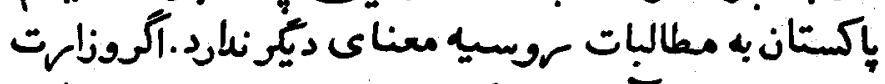

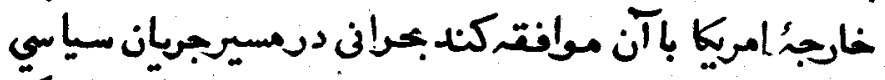

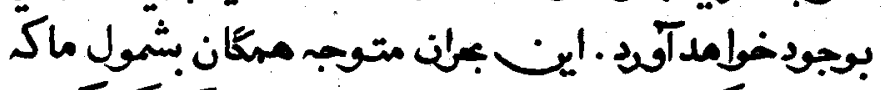

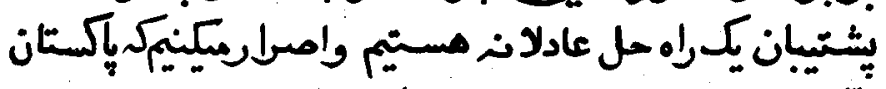

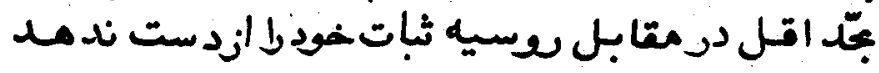

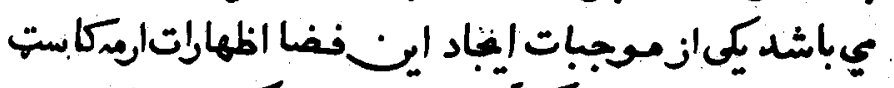

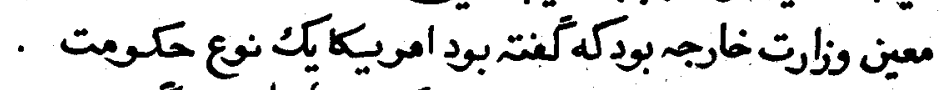

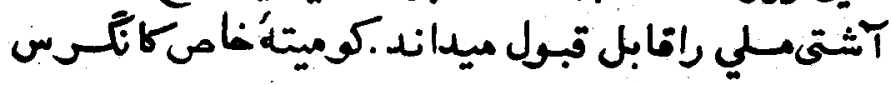


rrr

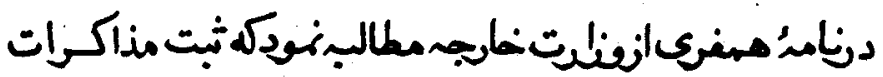

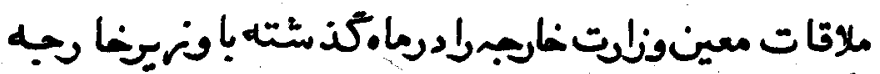

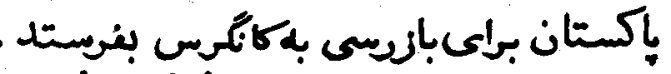

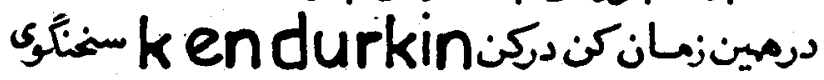

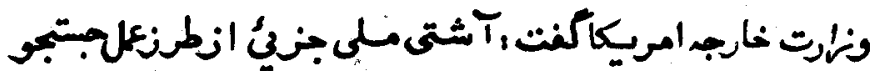

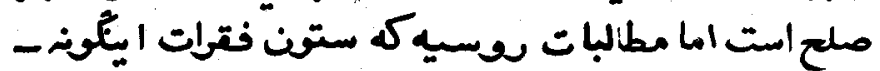

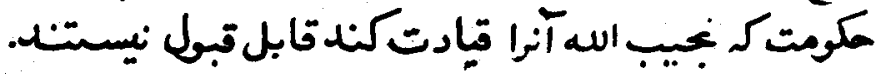

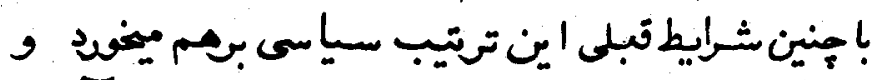

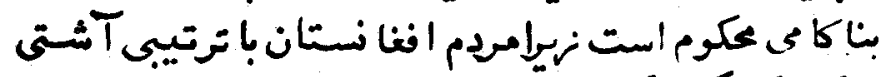

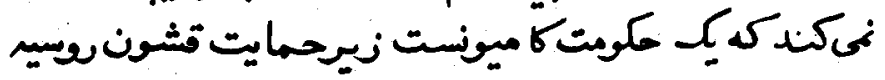
باقىباند .

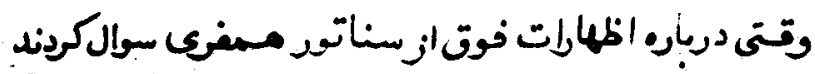

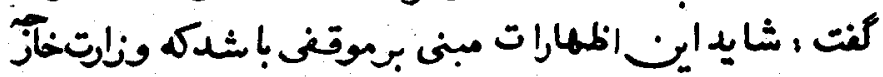

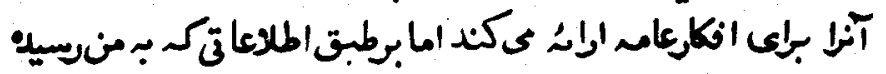

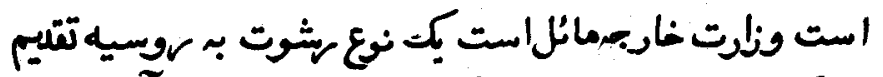

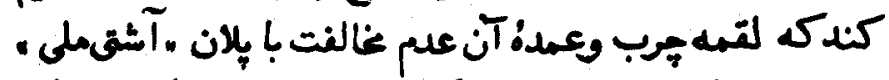

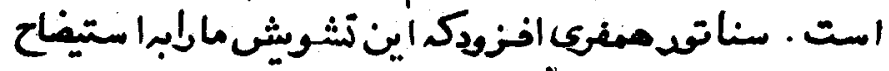

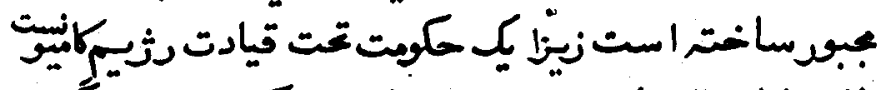

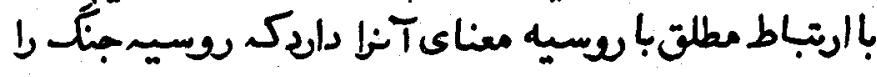

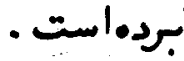
ازجانب ديكردرميان افواه نوى روشن وزاتِ خارجي 


\section{YY์}

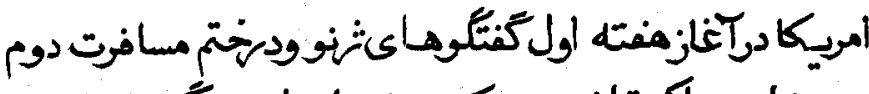

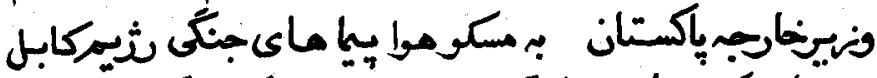

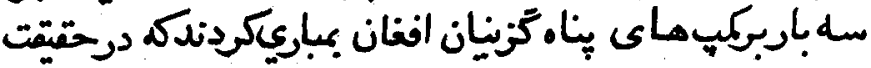

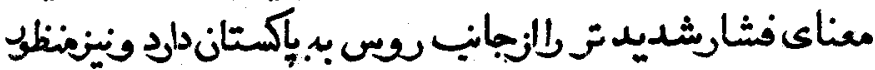

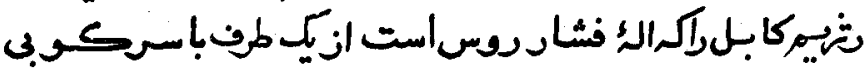

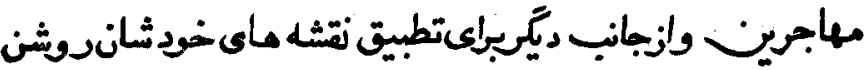

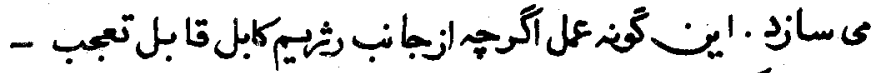

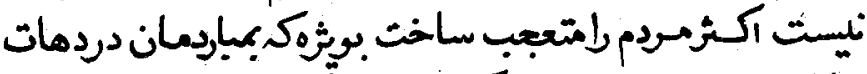

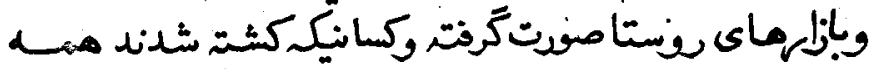

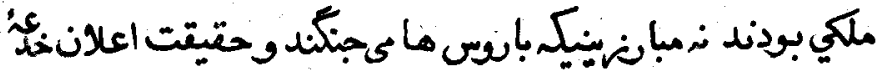

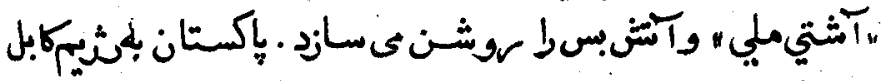

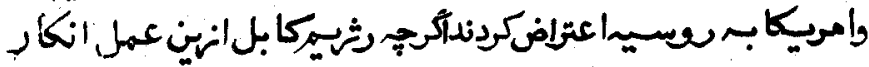

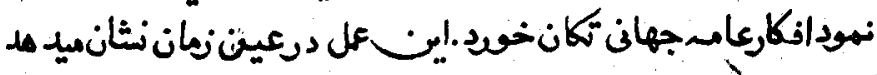

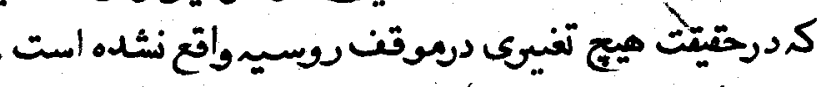

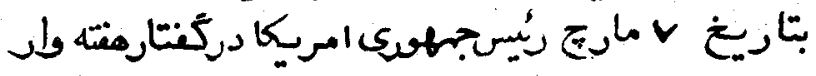

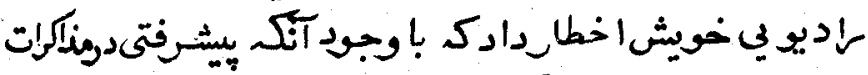

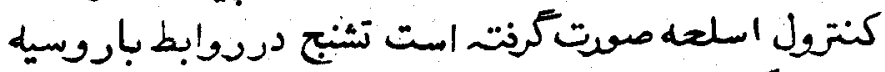

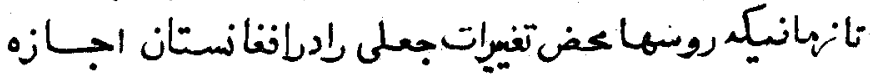

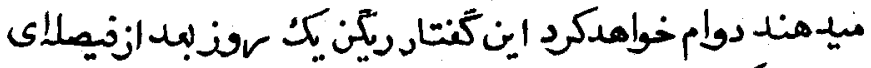

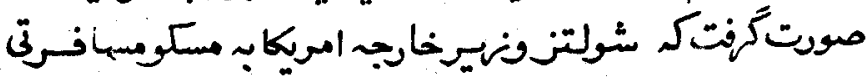

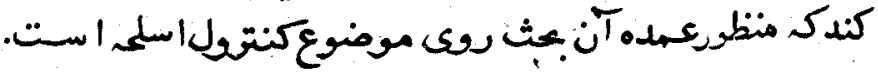




\section{Tro}

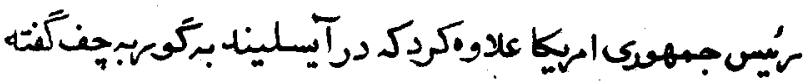

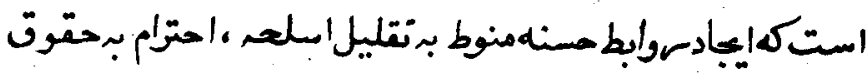

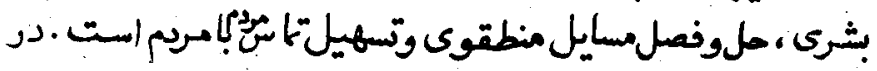

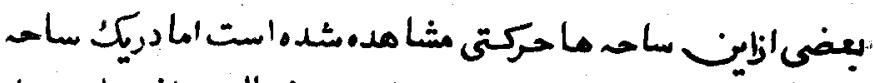

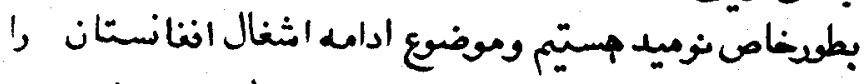

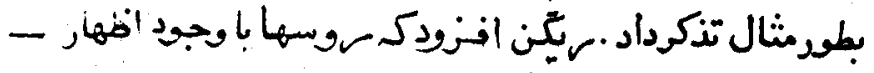

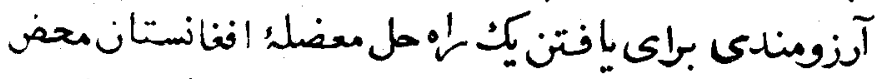

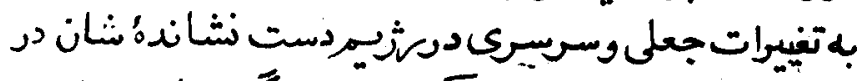

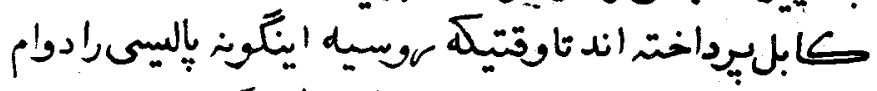

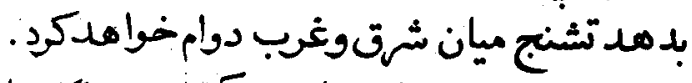

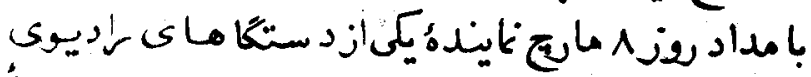

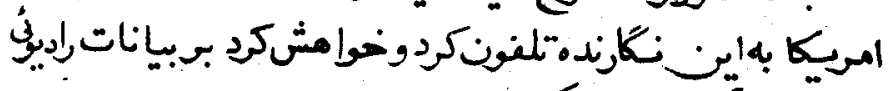

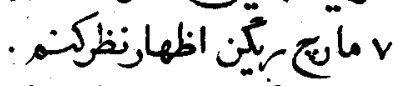

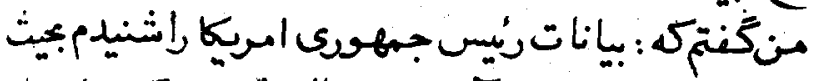

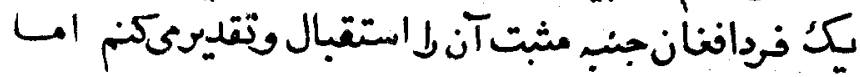

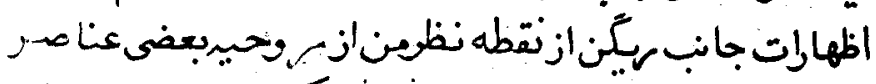

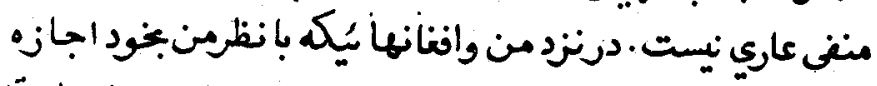

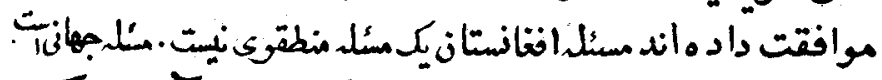

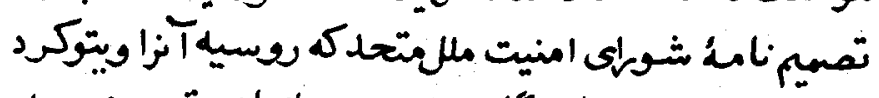

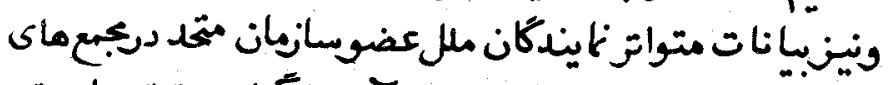

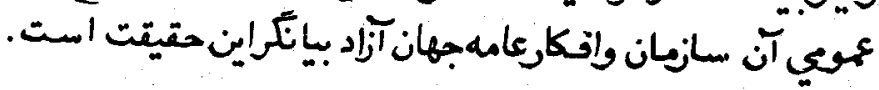




\section{PV7}

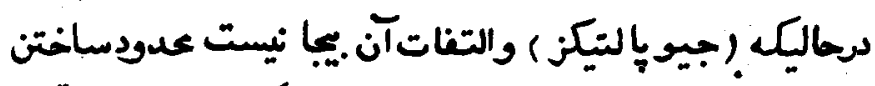

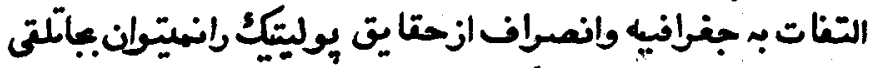

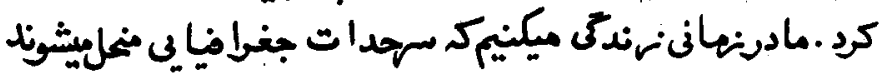

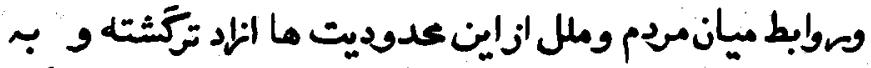

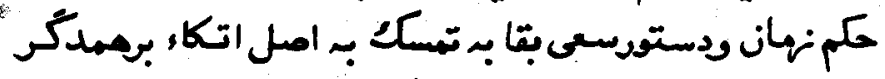
Inter depand ence

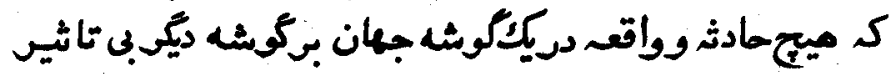

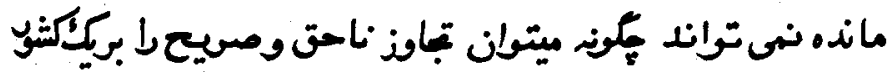

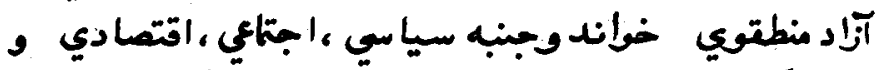

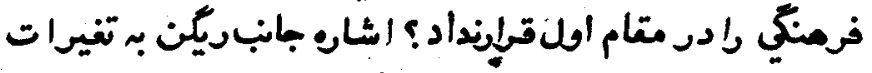

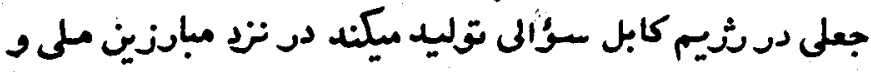

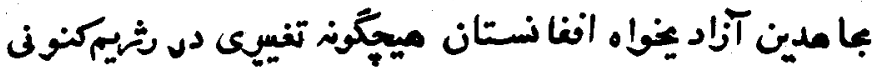

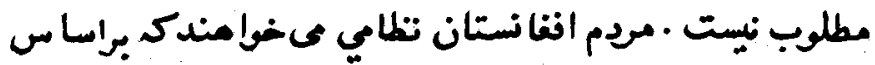

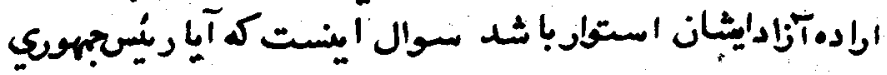

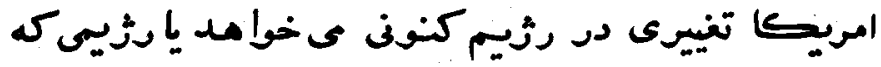

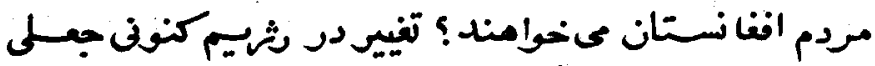

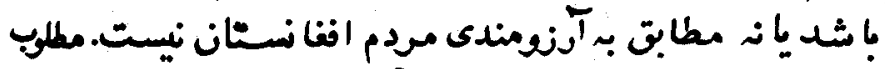

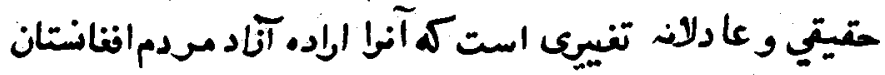

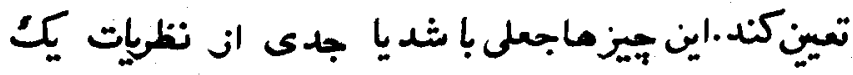

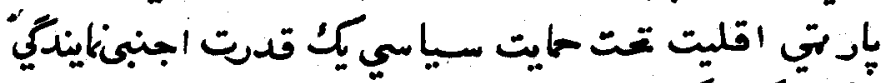

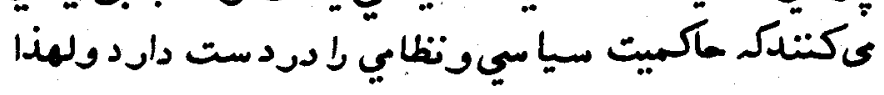




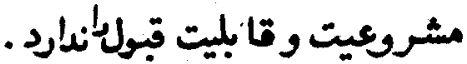

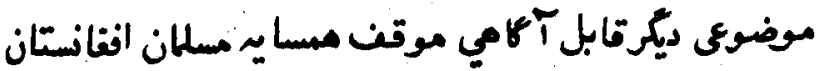

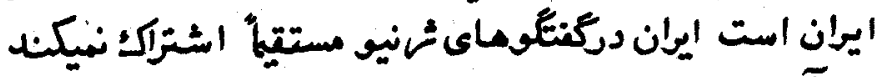

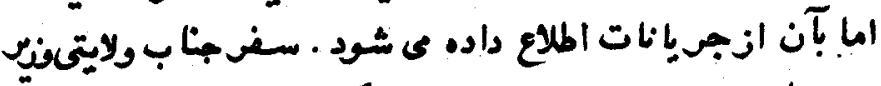

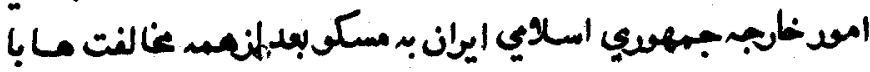

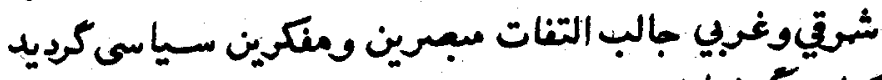

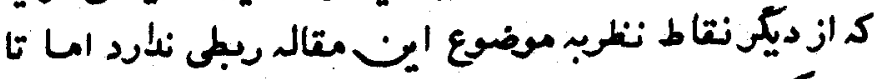

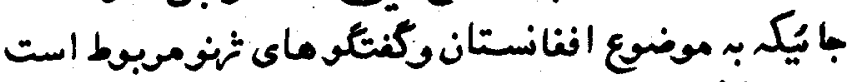

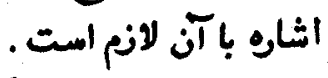
بناب ولايتى طفيك متوقع ع رنت دربسكو ر بنابراطهارات

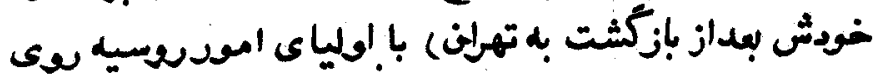

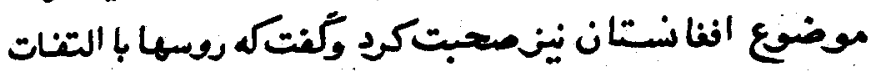

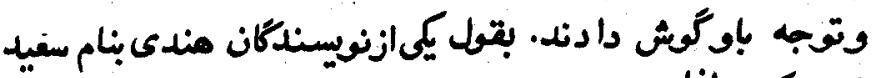

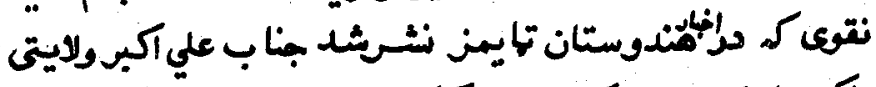

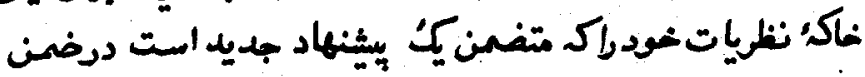

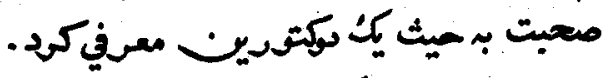

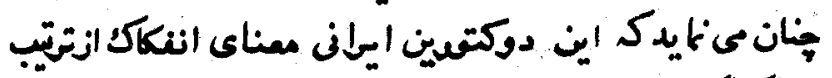

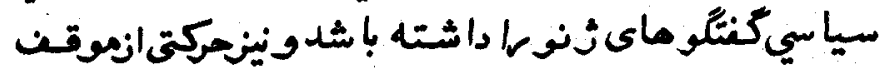

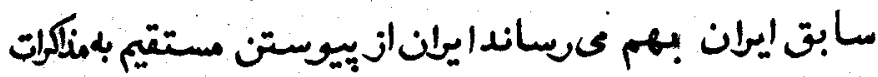

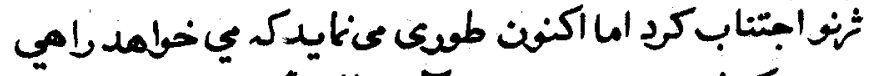

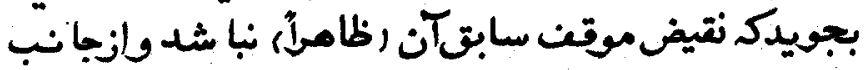




\section{TV}

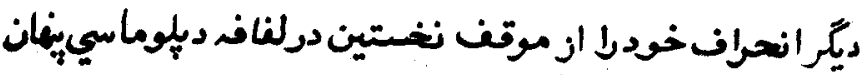

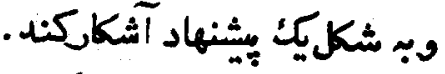

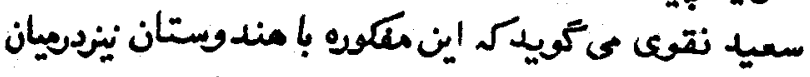

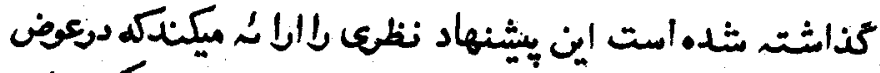

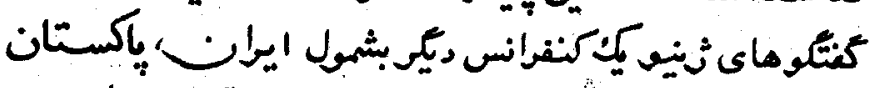

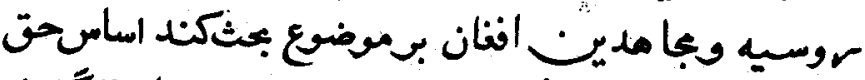

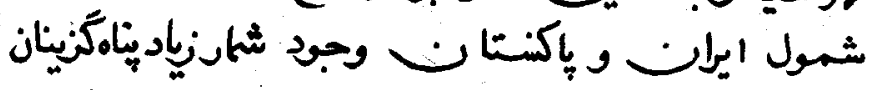

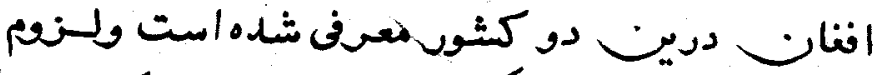

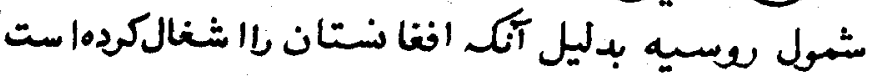

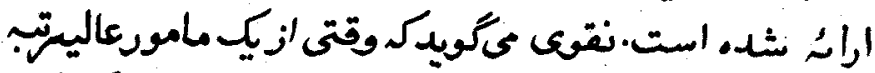

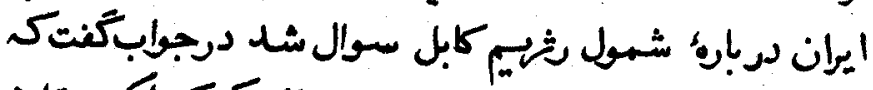

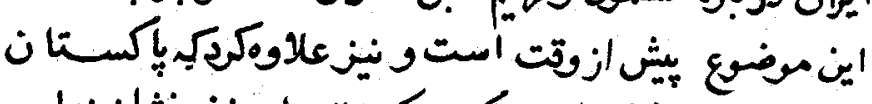

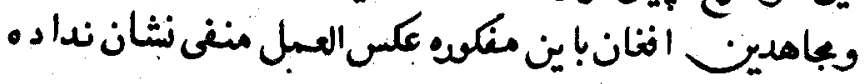
اند.

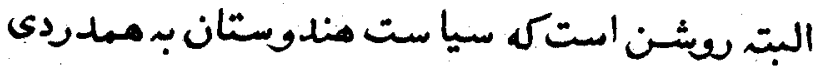

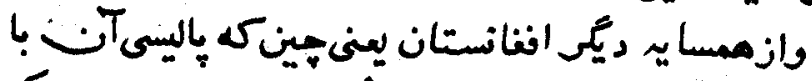

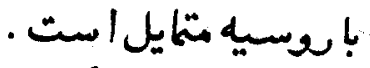

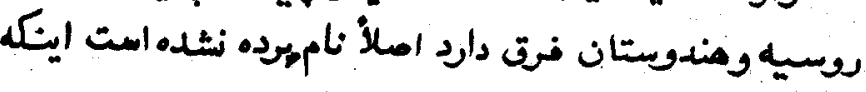

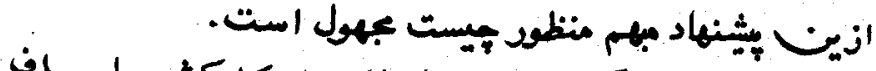

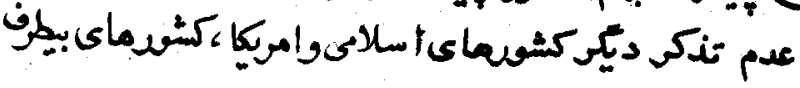
ود نياى آزاد اين إبهام كى أنزايد. 


\section{rvq}

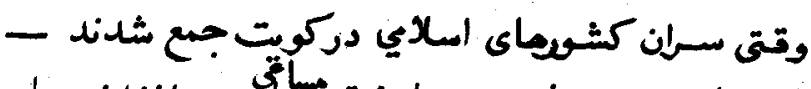

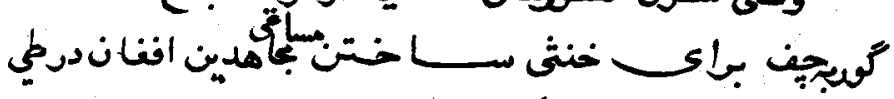

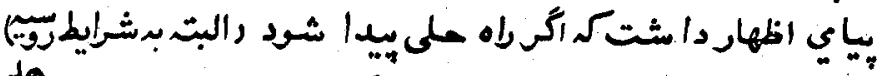

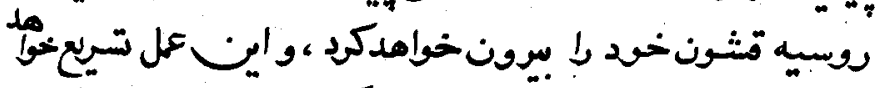

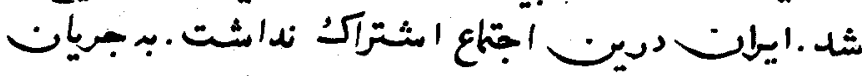

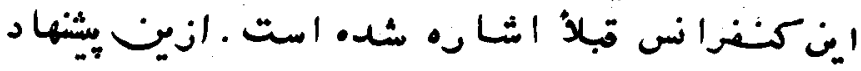

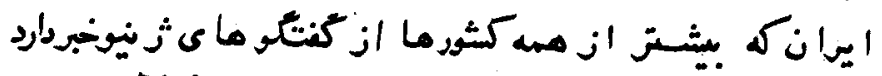

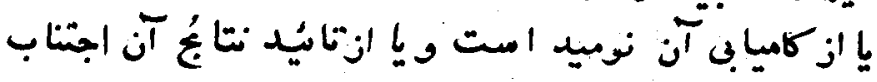
ي كن.

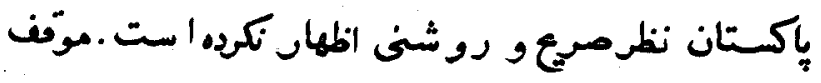

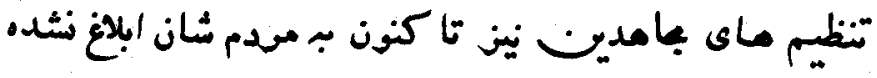

امتب المبر

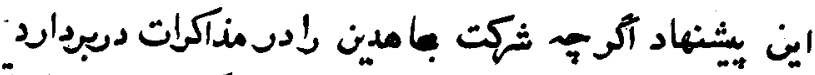

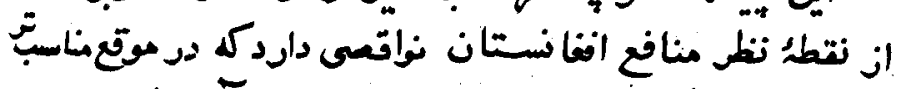

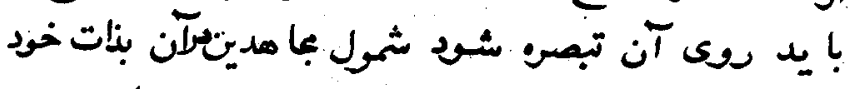

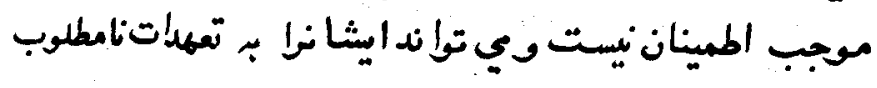

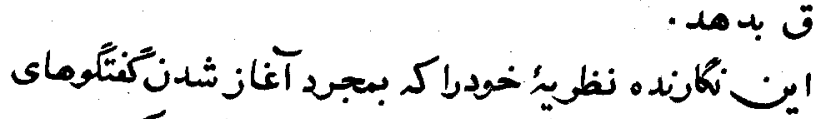

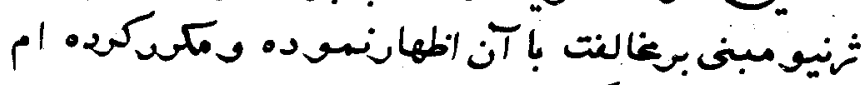

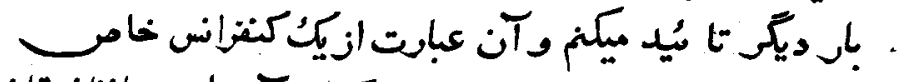

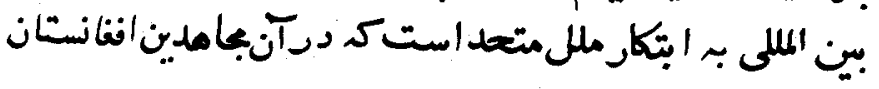




\section{rA.}

برنى ازكشوماى اسلاي بيرن و مسه اعضاى داسئى

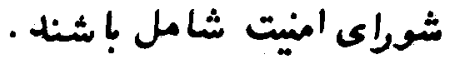

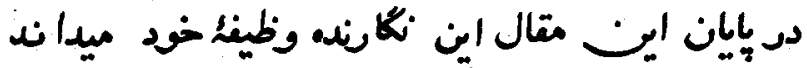

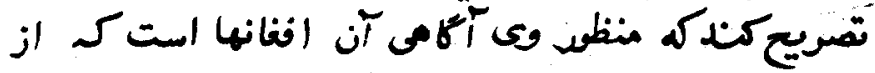

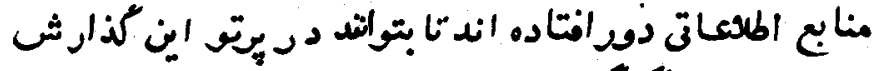

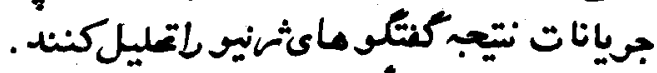

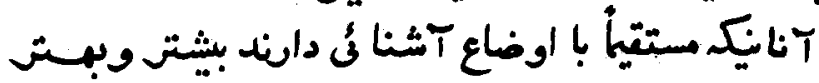

$$
\text { ازين نويسنده آثا م دار ند . }
$$

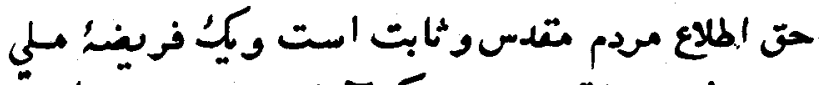

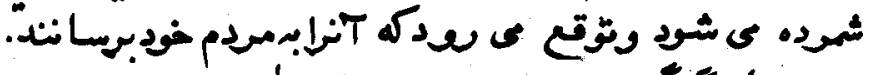

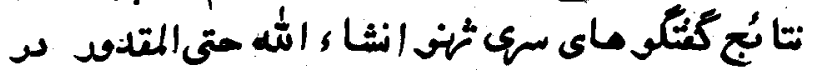

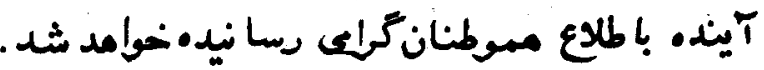

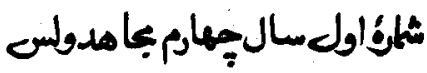

$$
\text { ir } 77 / 1
$$

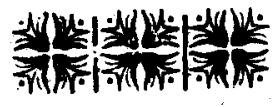




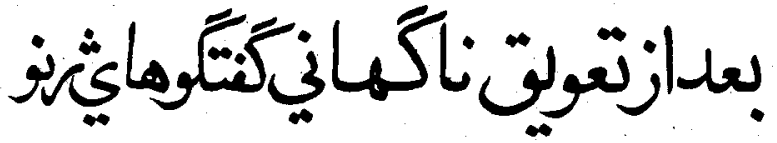

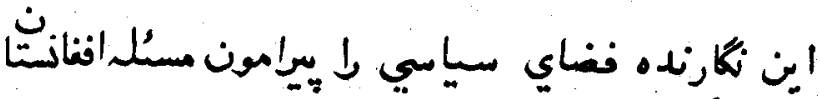

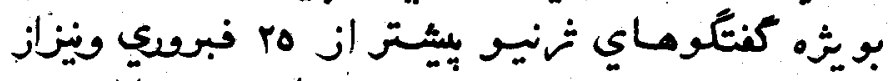

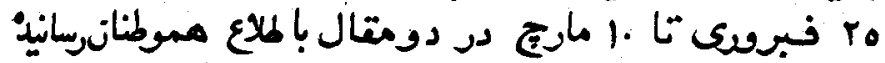

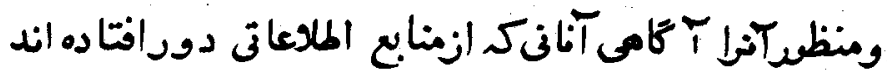

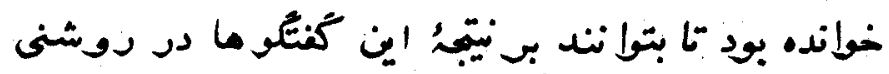

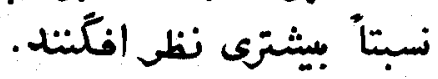

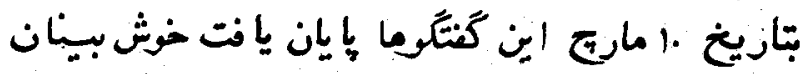

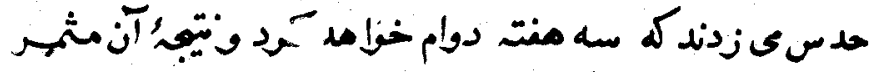

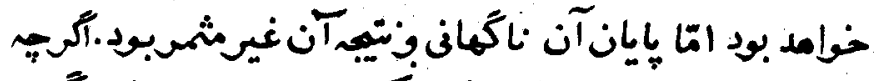

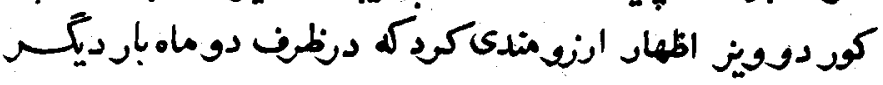




\section{YAY}

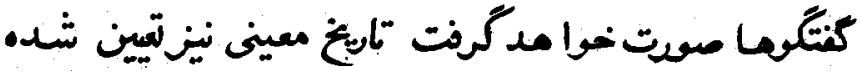

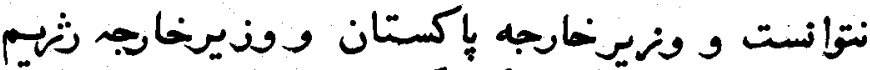

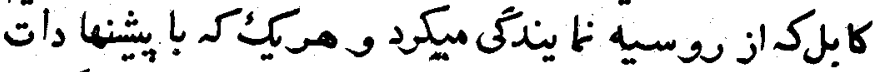

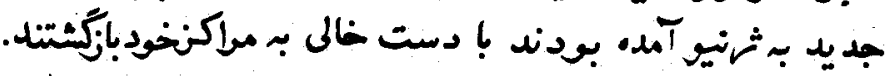

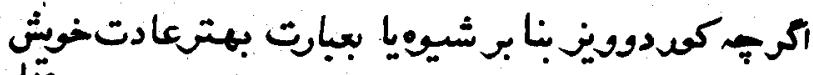

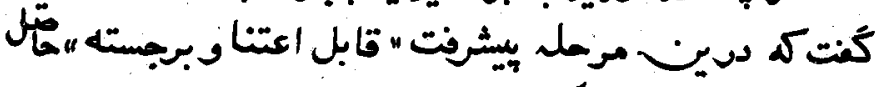

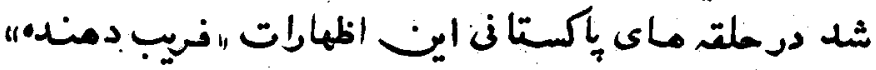

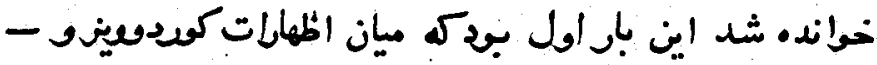

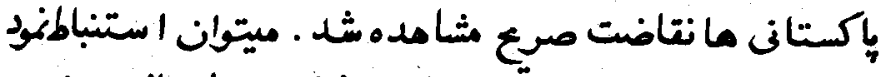

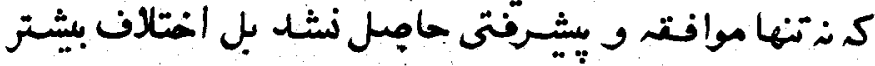

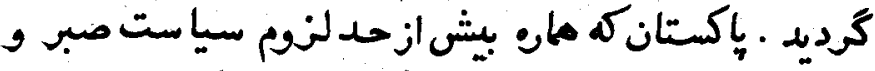

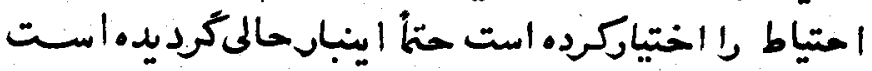

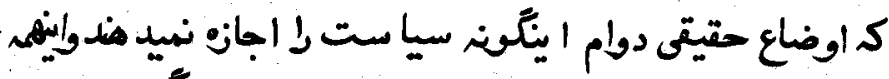

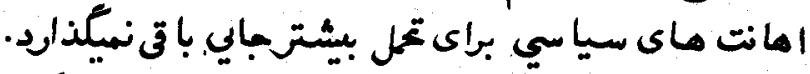

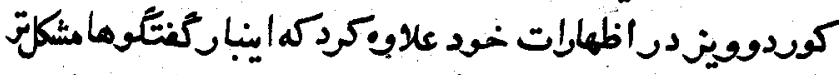

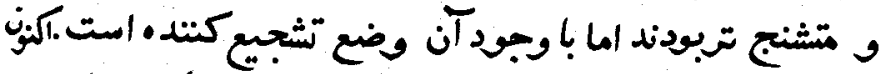

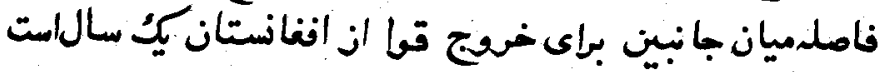

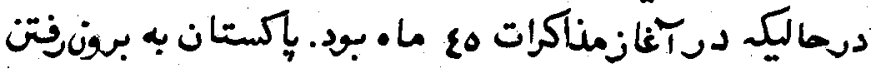

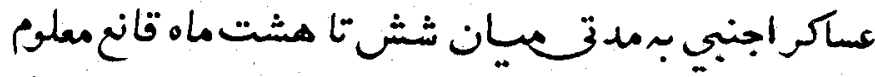

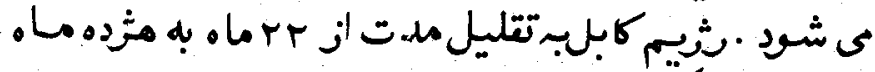

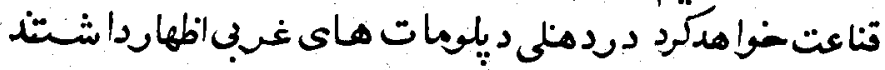




\section{rar}

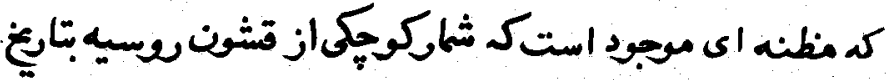

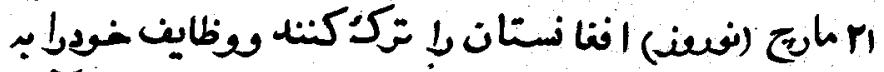

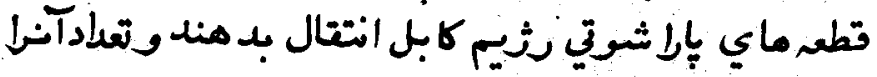

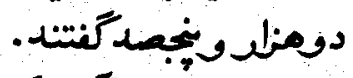

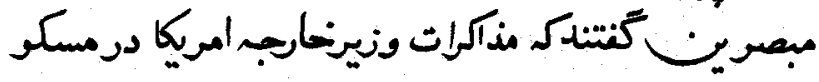

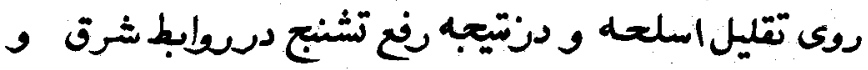

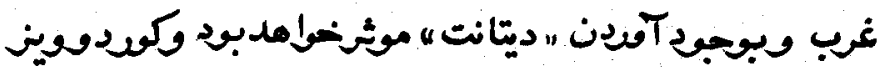

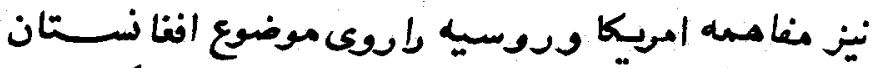

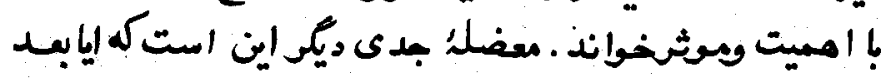

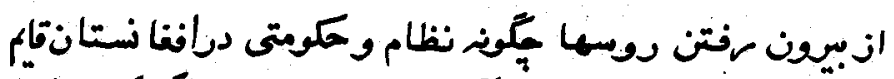

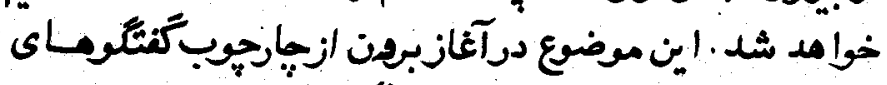

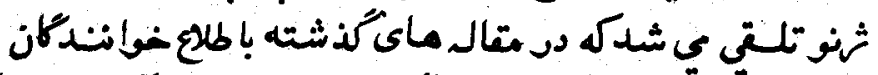

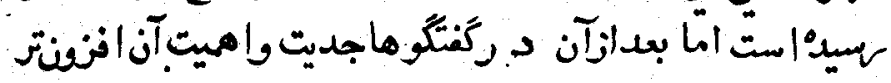

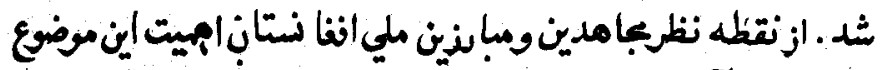

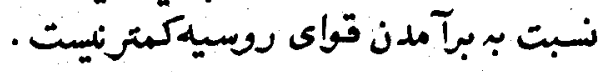

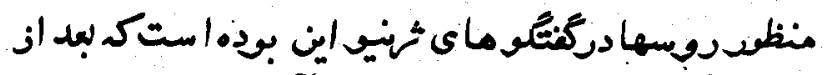

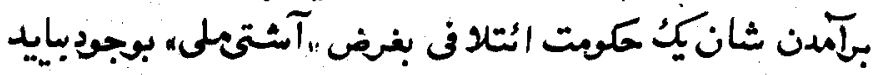

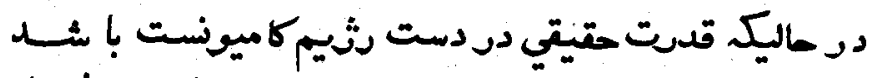

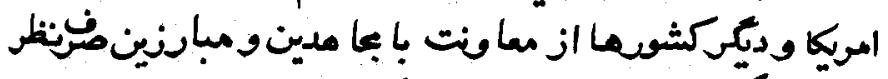

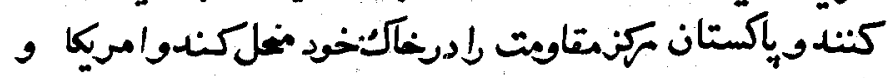

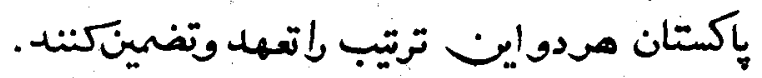




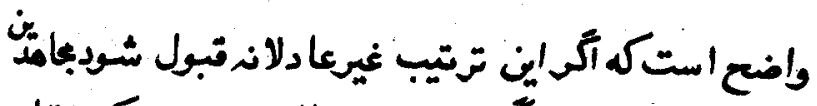

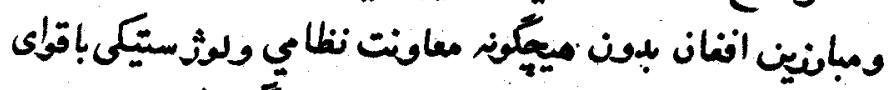

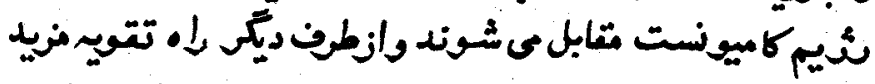

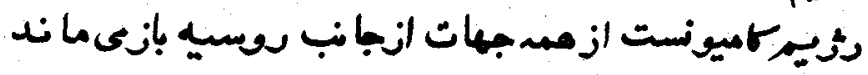

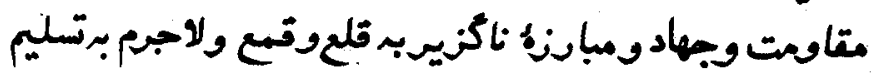

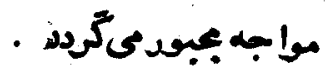

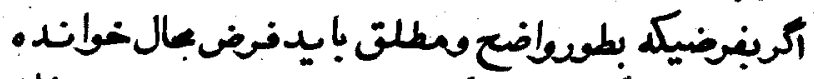

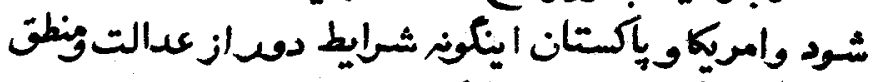

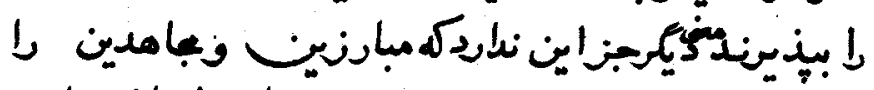

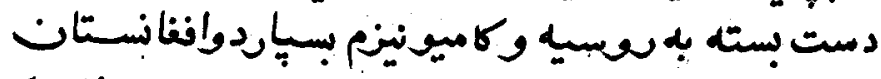

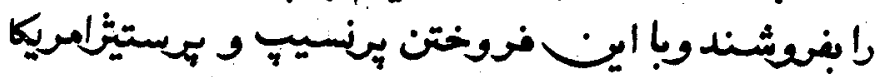

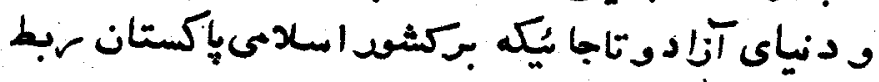

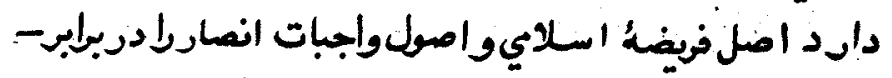

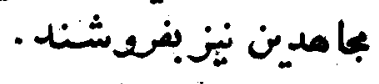

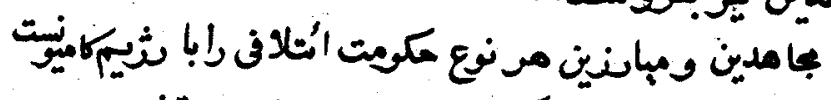

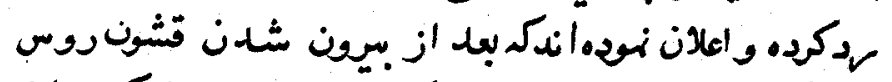

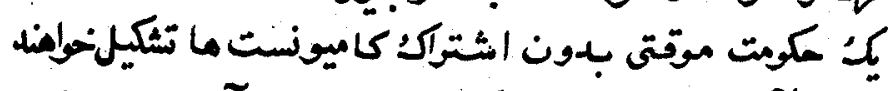

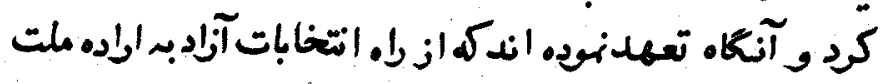

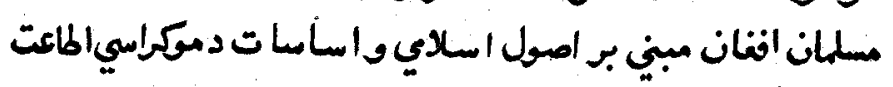

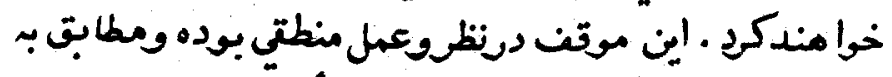

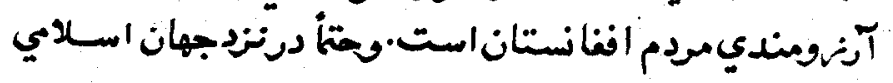




\section{rao}

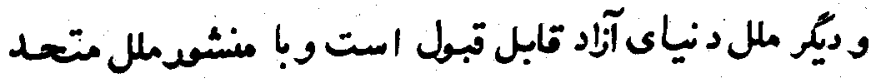

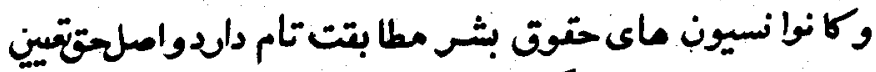

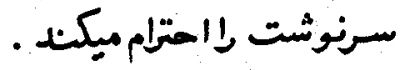

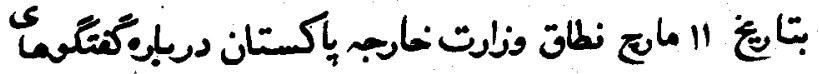

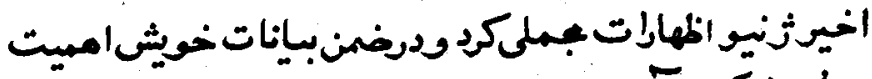

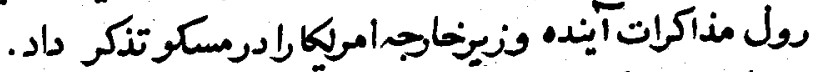

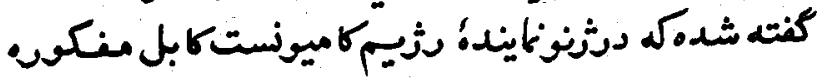

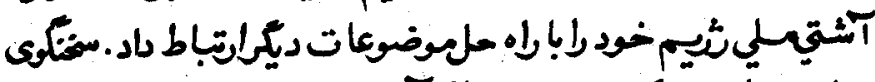

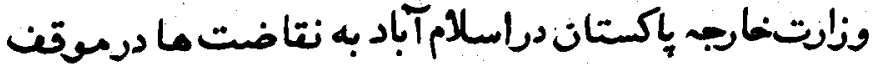

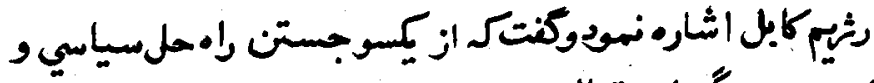

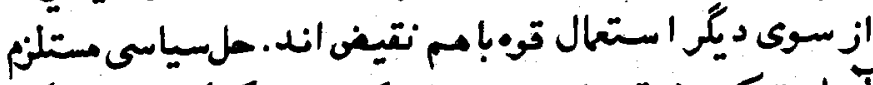

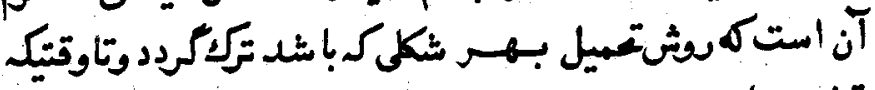

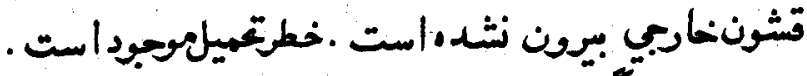

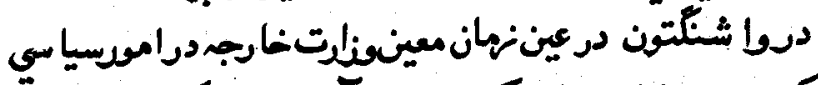

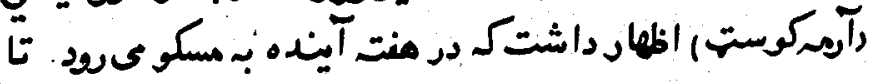

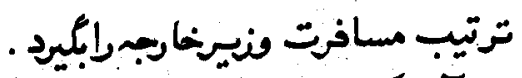

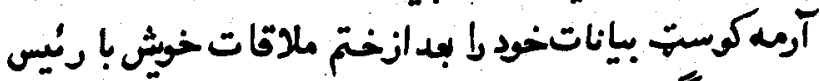

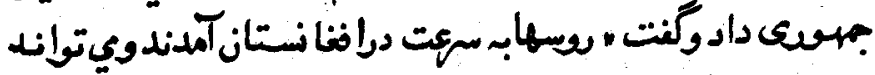

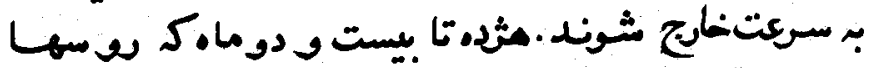

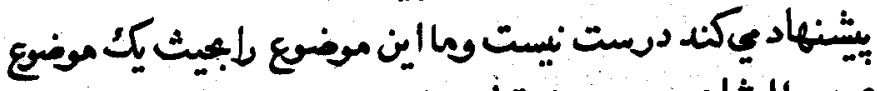
عهده باريثان مود بحث ترأرخواميم داد . 


\section{YAY}

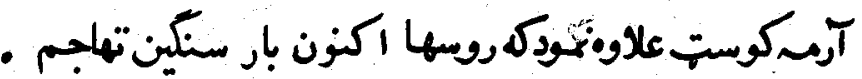

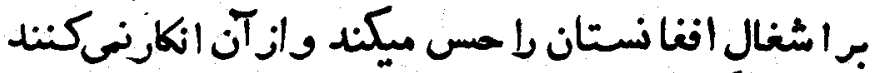

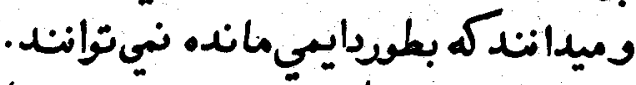

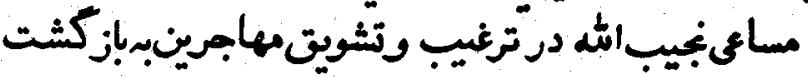

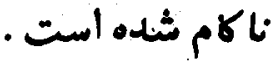

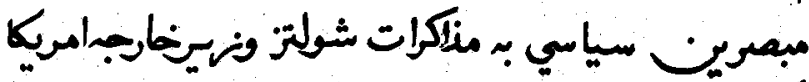

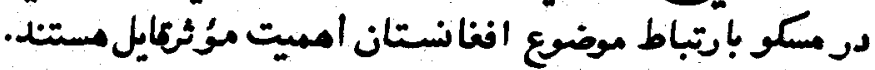

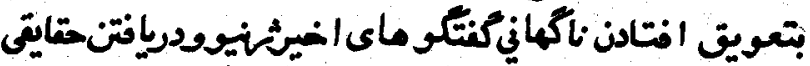

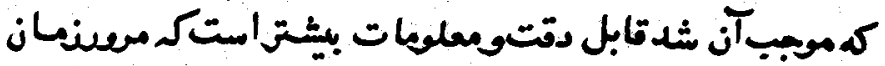

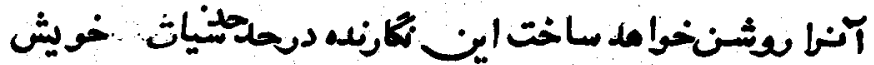

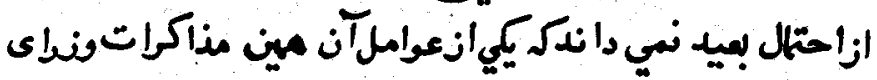

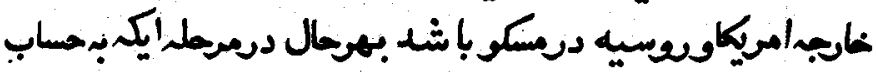

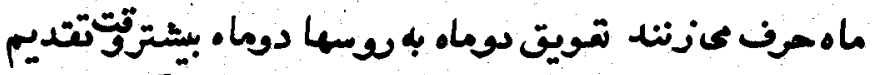

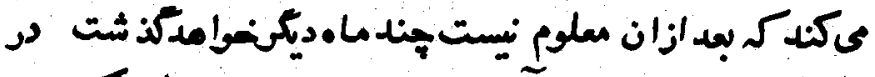

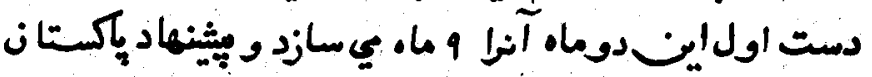

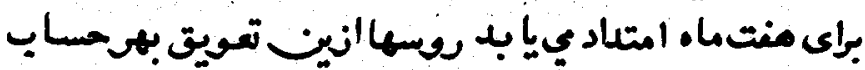

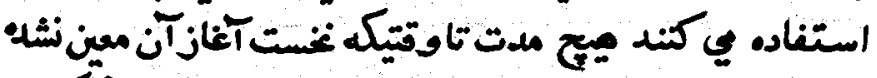

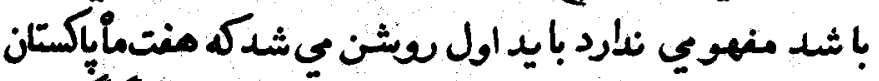

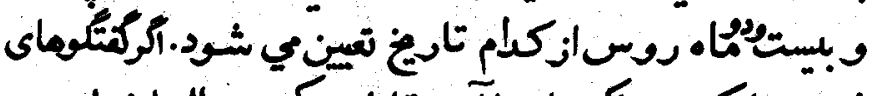

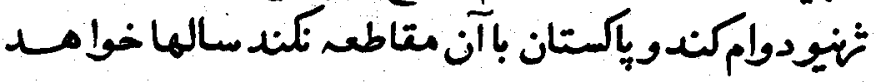

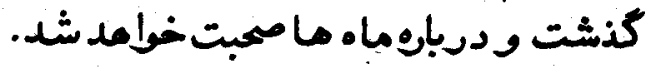




\section{YAY}

جونجريان نعلى جنين است موتع استفادهازوتت بايدتها

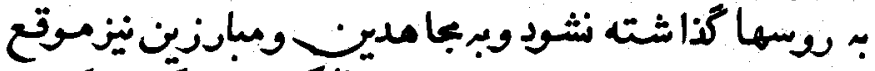

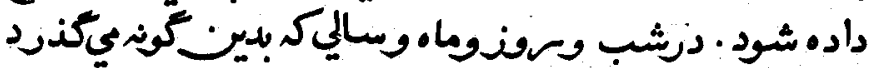

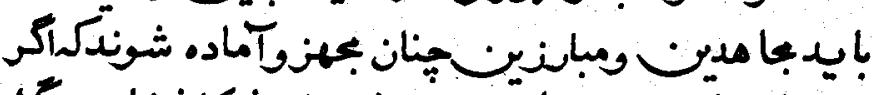

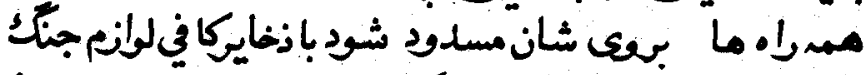

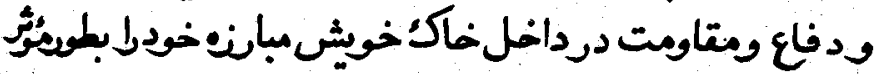

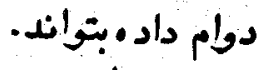

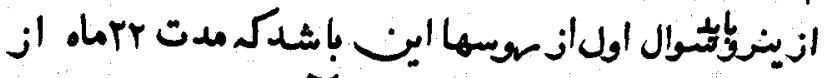

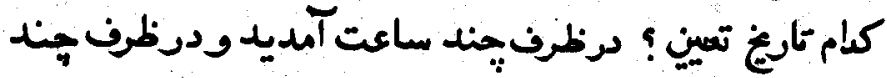

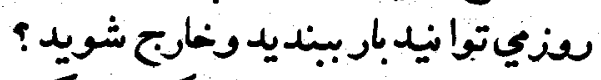

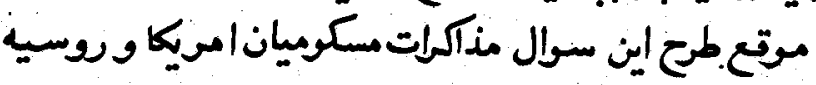

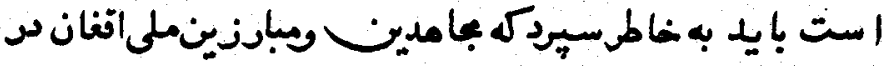

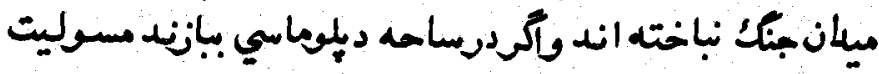

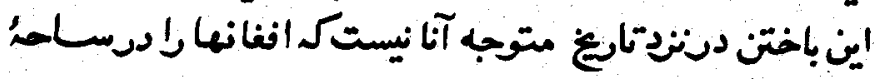

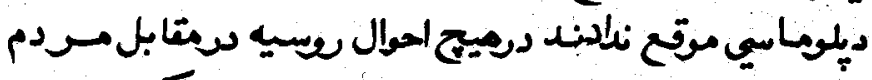

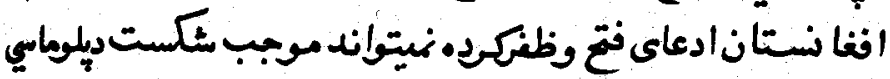

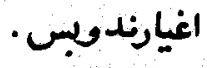

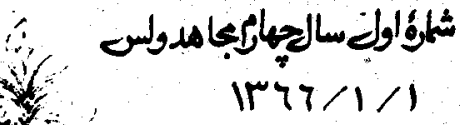




\section{ياحق!

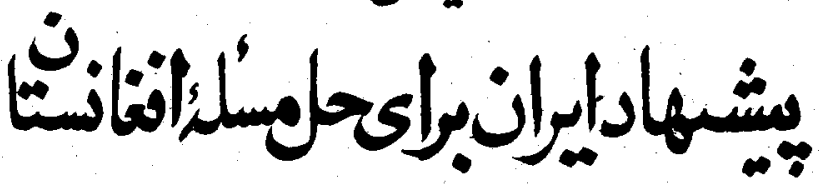

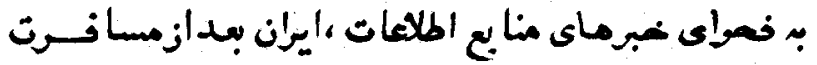

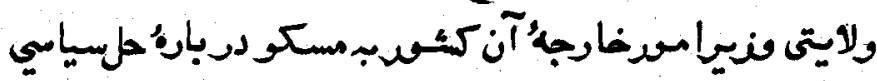

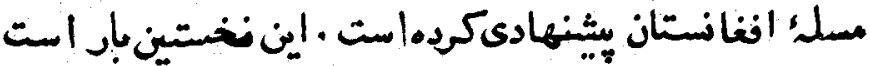

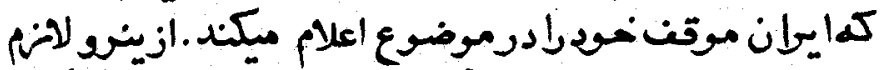

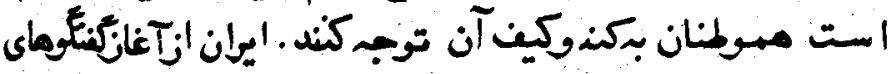

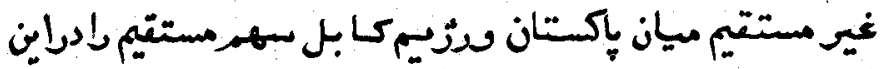

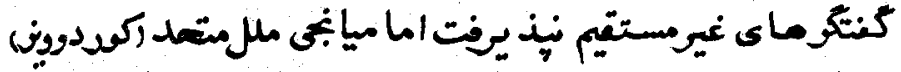

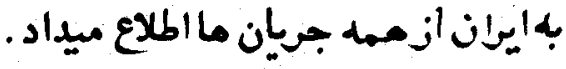

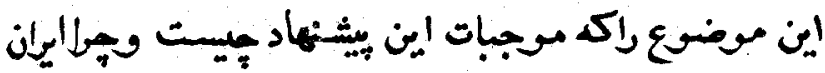

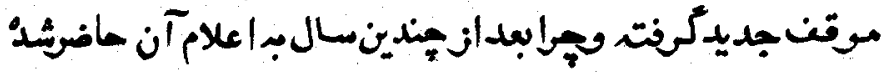

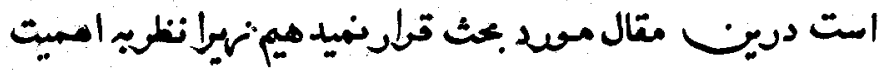




\section{YA9}

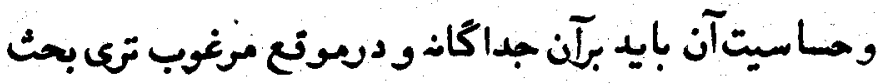

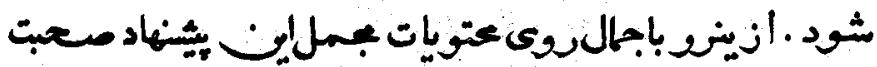
ميكنيم.

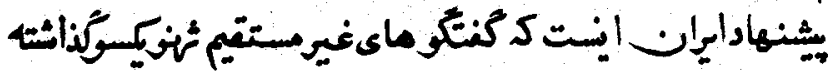

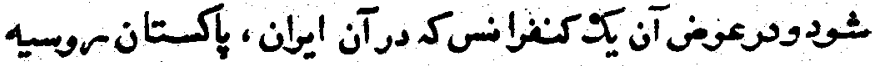

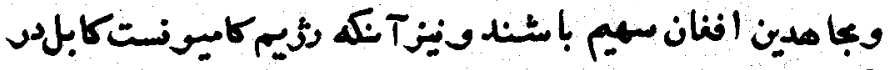

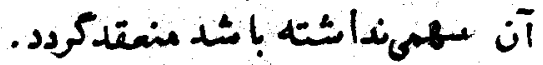

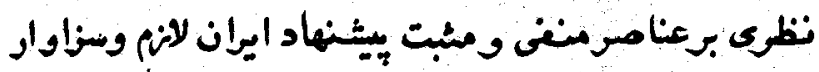

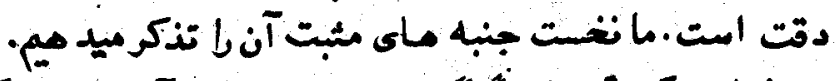

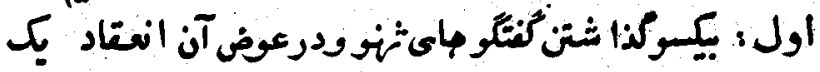

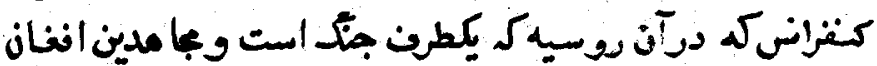

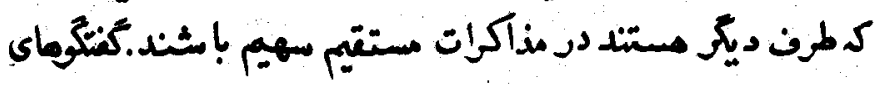

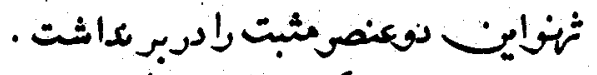

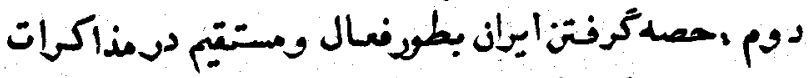

$$
\begin{aligned}
& \text { اين لامـم ميتوان يك عنصرمشبت تلفي كرد . }
\end{aligned}
$$

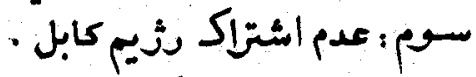

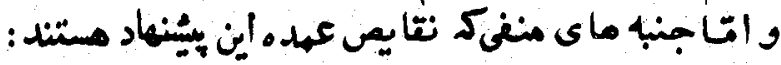

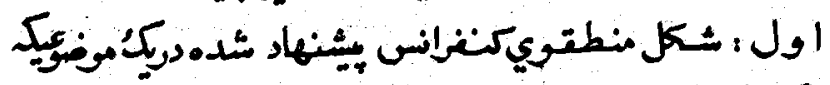

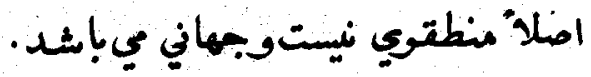

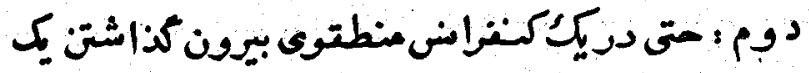

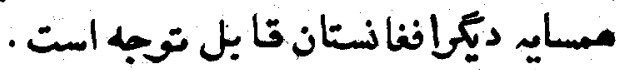




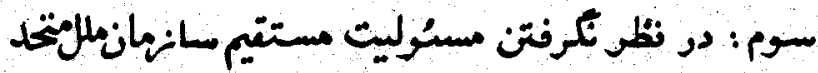

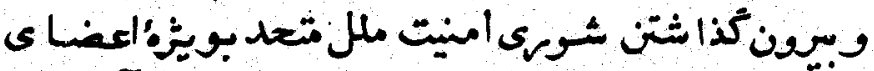

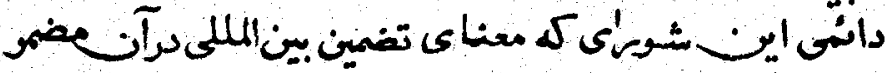
ابست

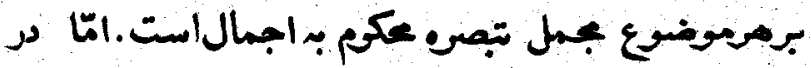

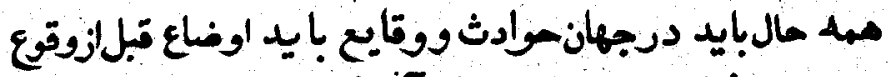

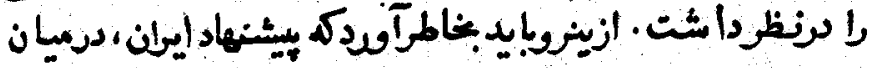

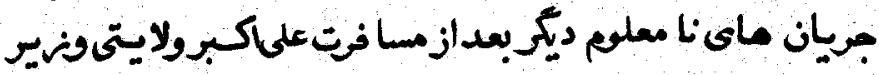
خارجهُ ايران بـ مسكوود ملنى اعلامكتديد.

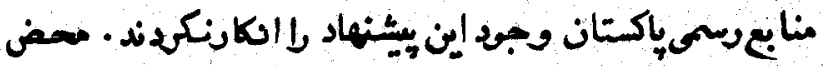

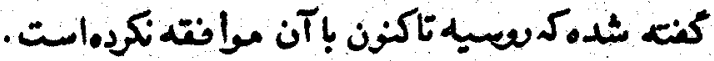

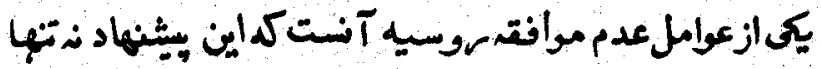

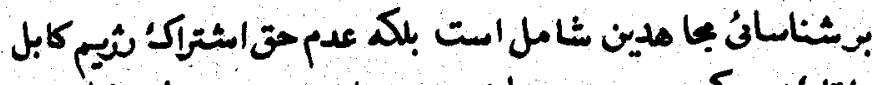

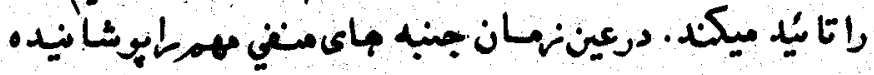

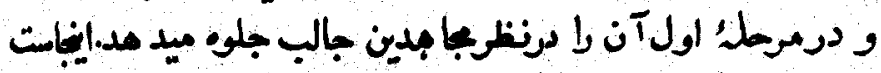

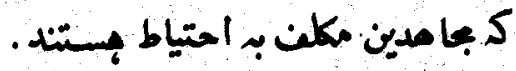

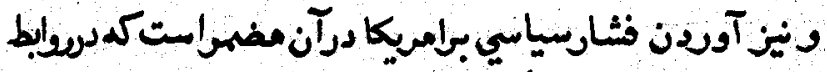

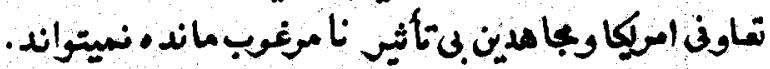

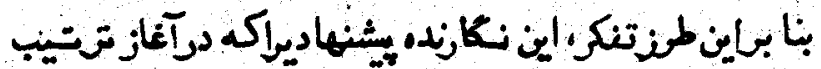

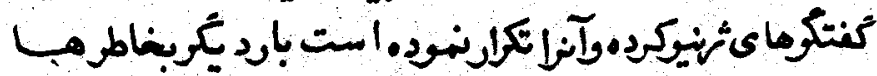
ي بيارد. 


\section{र91}

روابط امريكا با با مدين عمدودبرأمريكا نيست وبرروابط

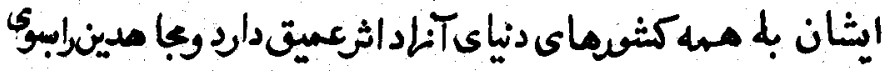

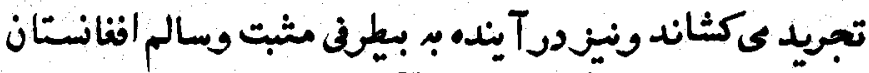

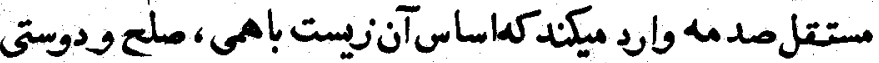

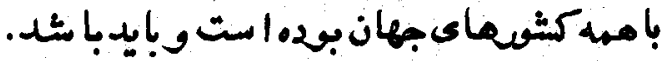

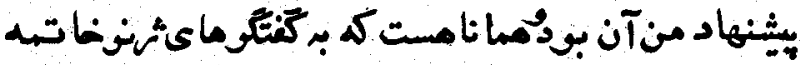

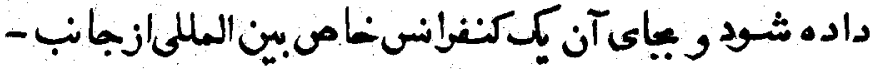

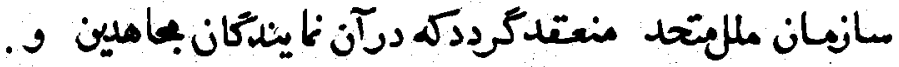

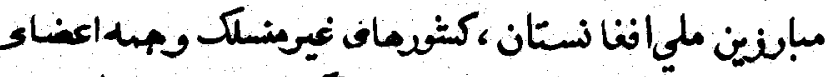

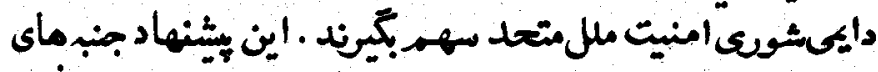

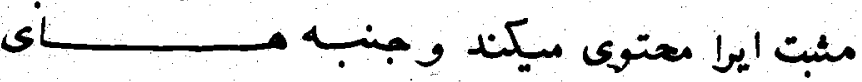

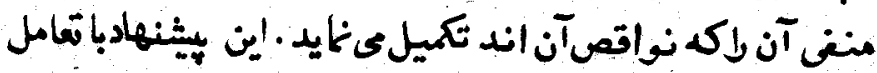

$$
\text { ملل متعد تثإنتكسامل دارد. }
$$

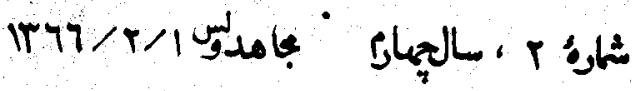




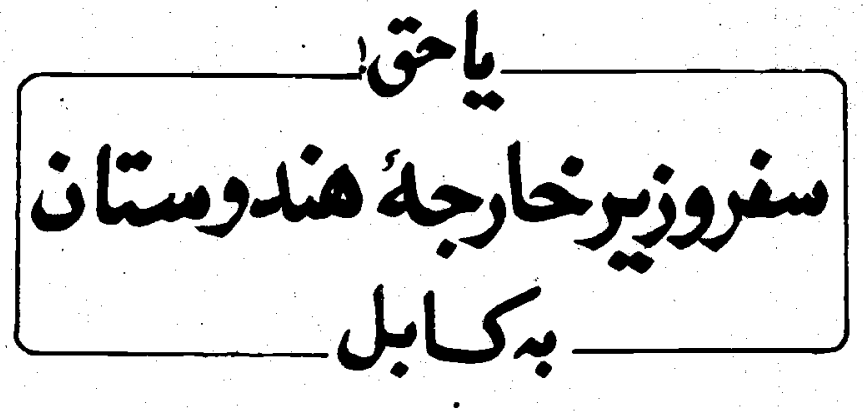

درتحتيق حتيقت بِندانئمتايق تاريخ مياسى ، درميـان

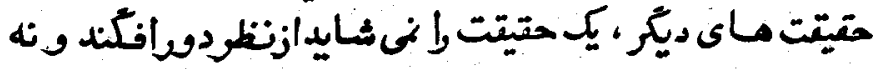

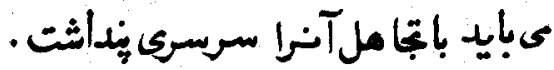

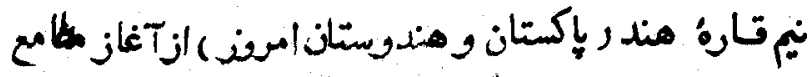

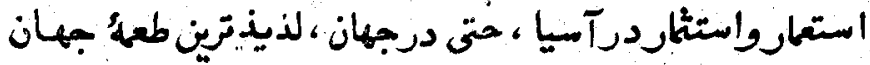

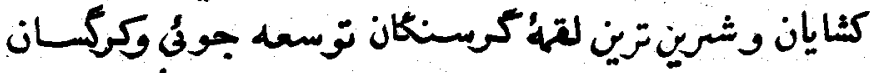

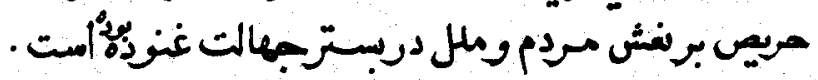

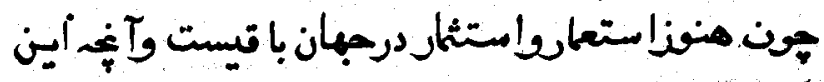

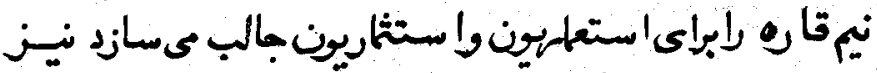

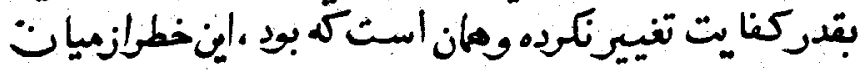




\section{4}

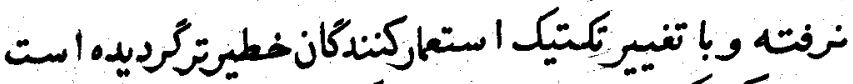

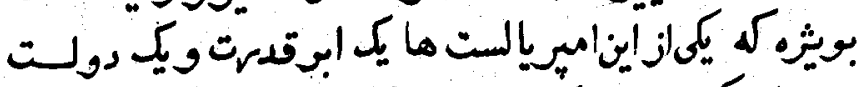

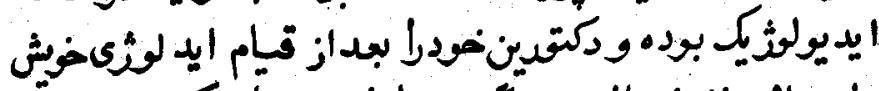

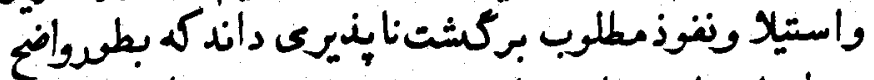

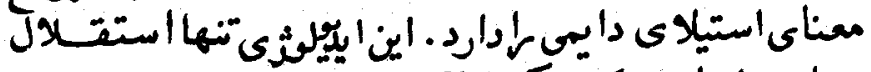

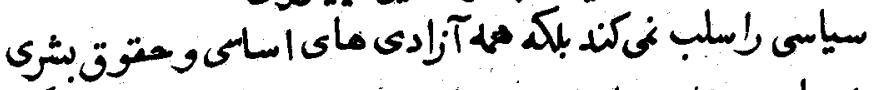

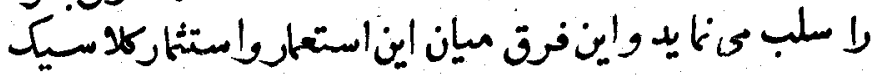

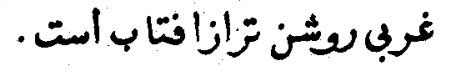

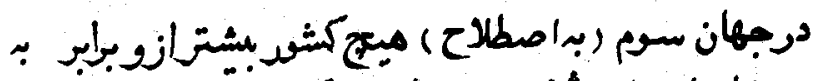

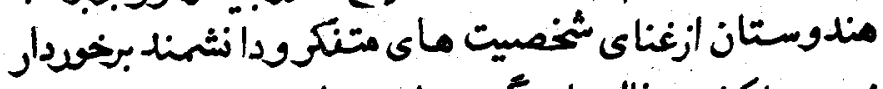

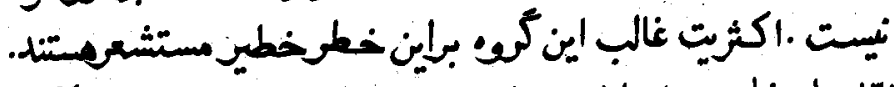

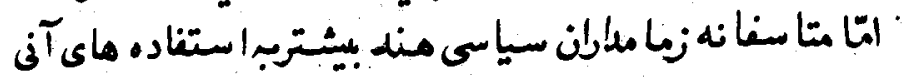

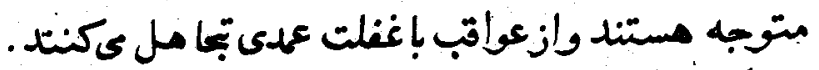

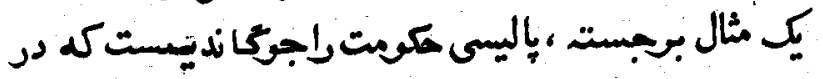

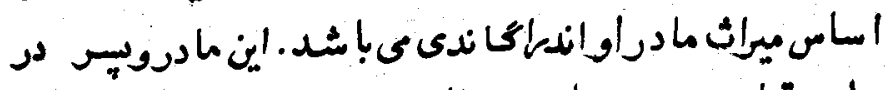

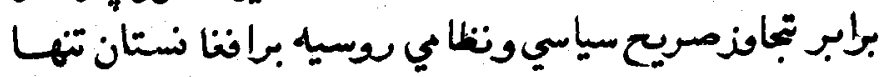

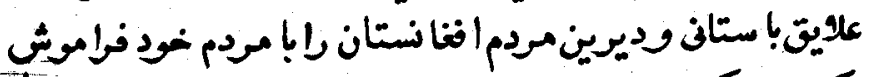

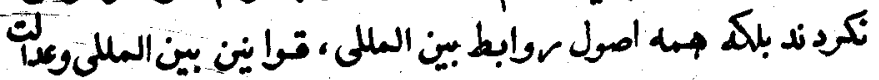

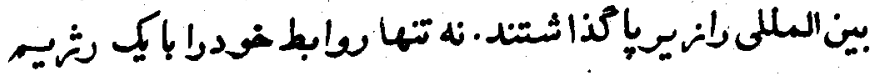

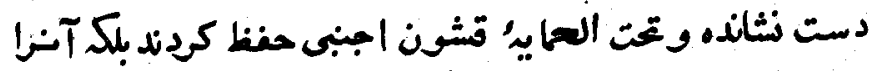

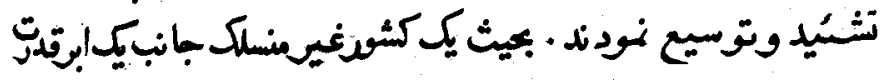




\section{raz}

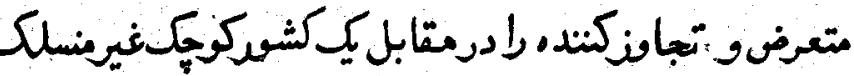

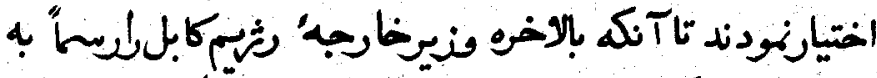

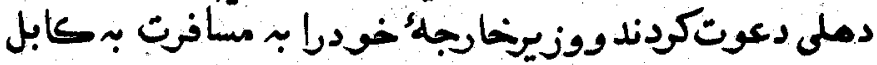
ماموريفودند.

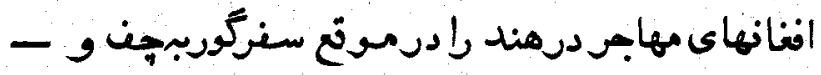

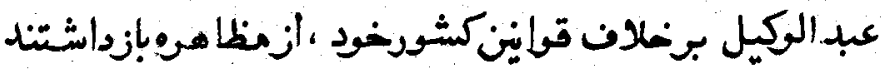

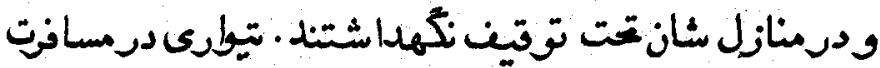

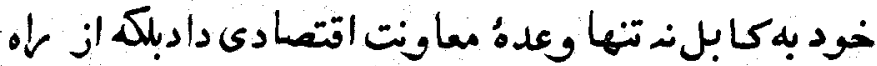

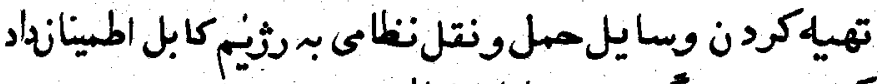

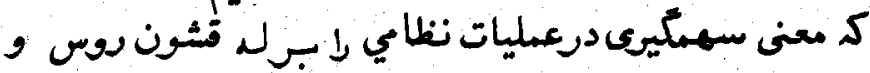

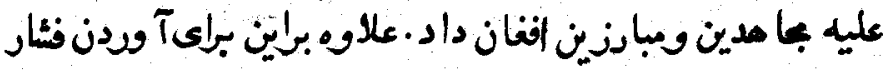

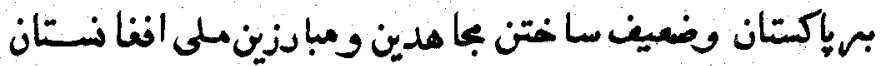

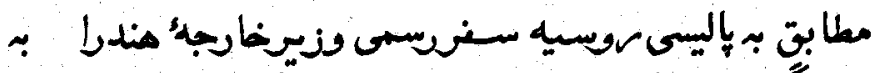

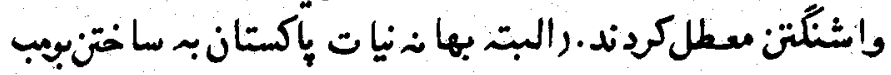

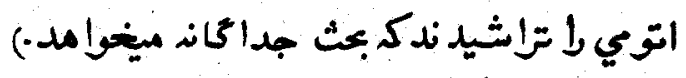

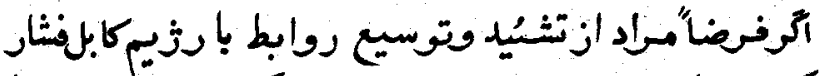

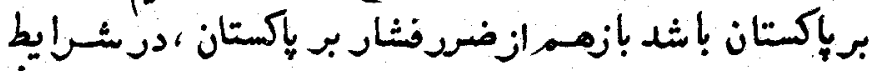

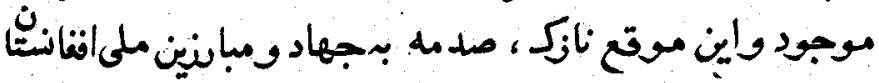

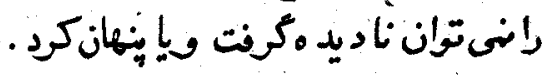

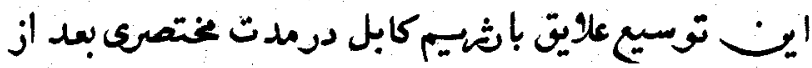

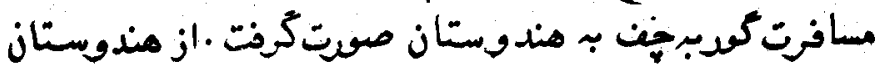




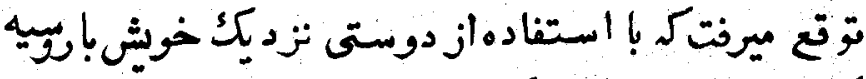

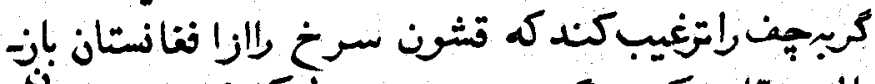

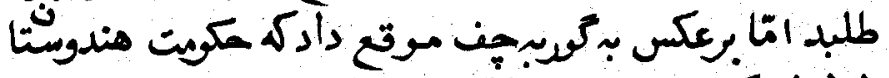

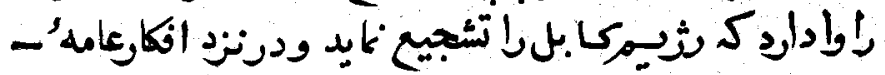

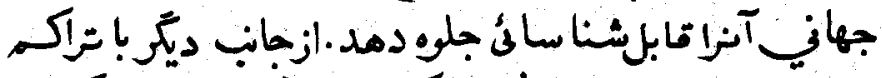

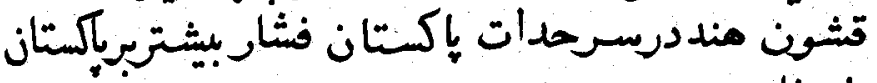

$$
\text { وارد نايد. }
$$

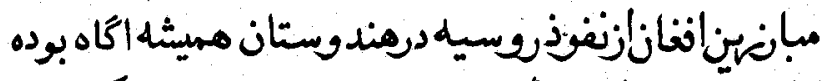

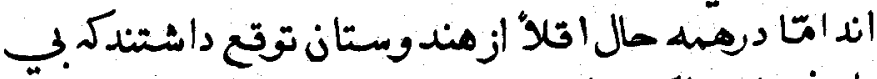

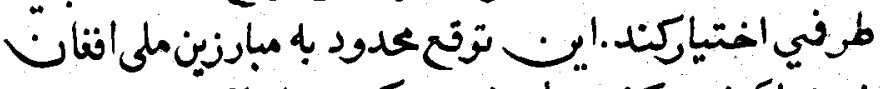

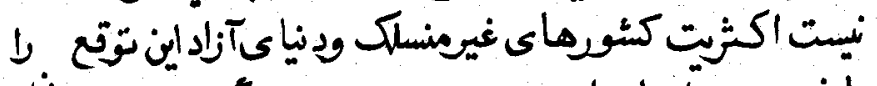

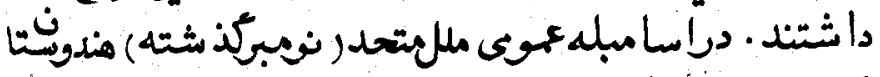

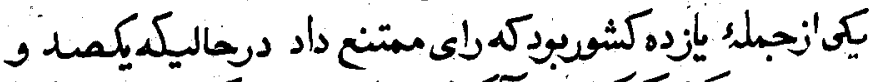

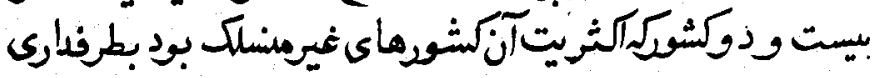

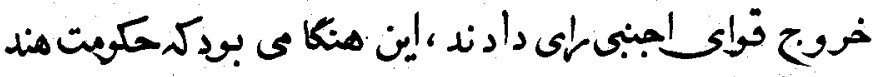

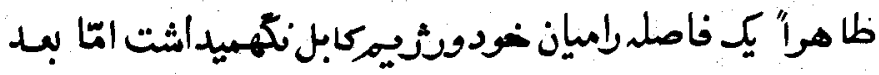

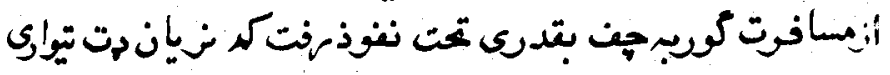

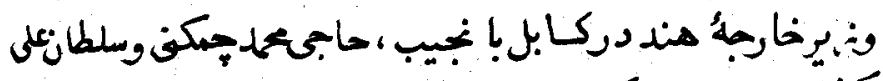

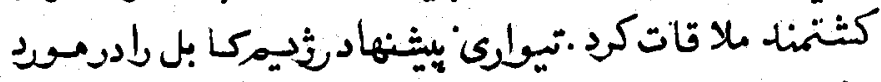

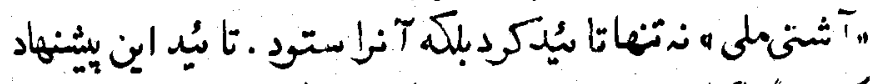

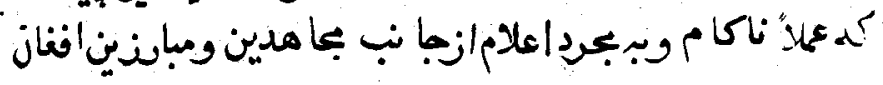


TAT

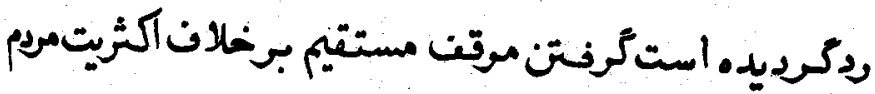

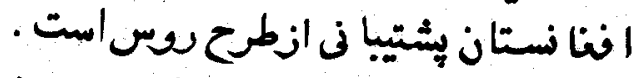

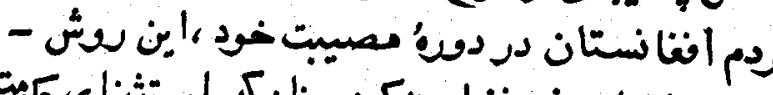

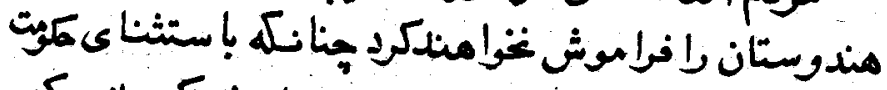

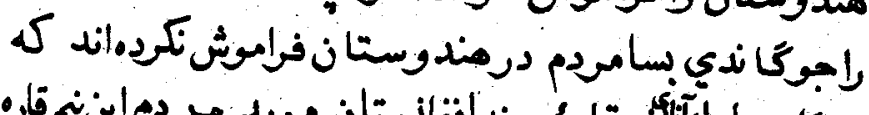

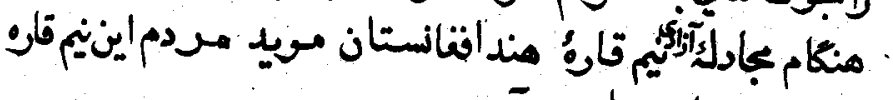

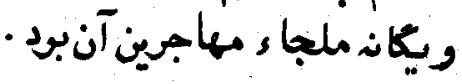

شارُ سوم،سالجهارمبكامدولس $1 r 7 \pi / r / 1$ 


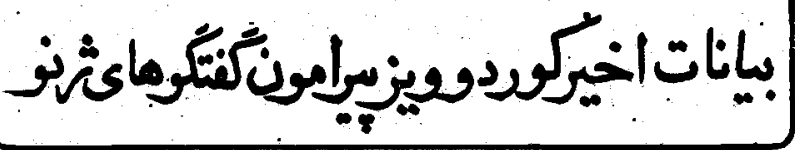

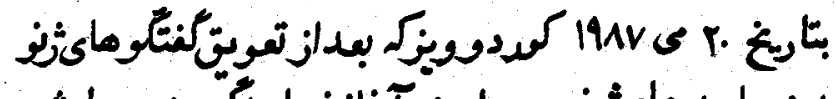

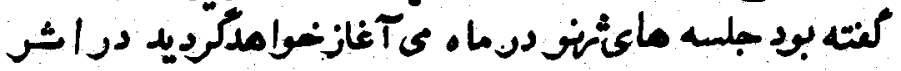

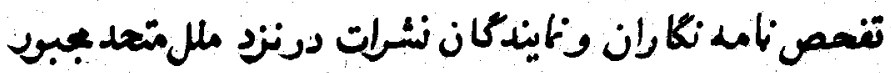

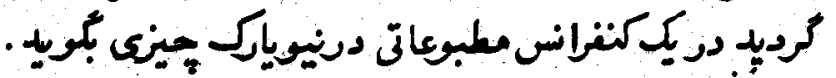

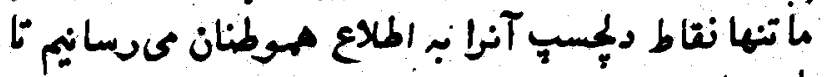

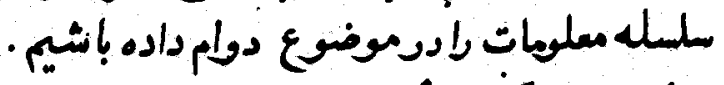

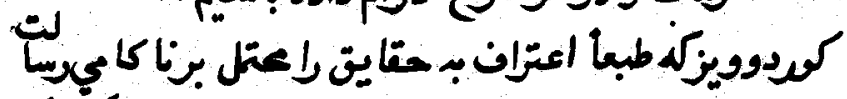

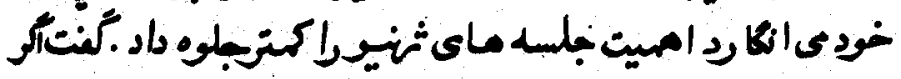

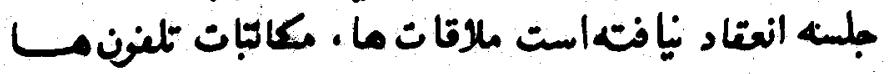

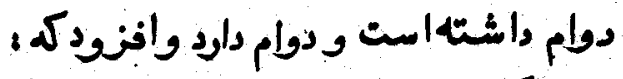

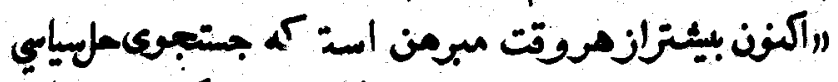

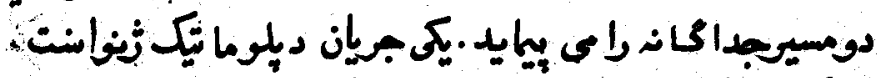

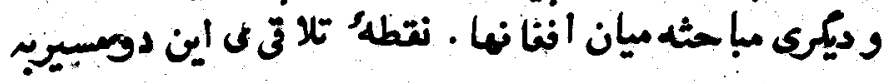




\section{หqu}

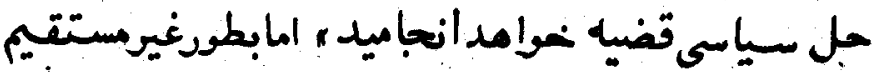

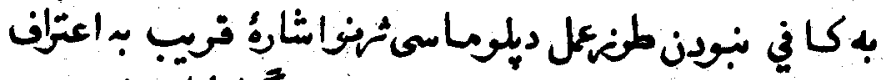

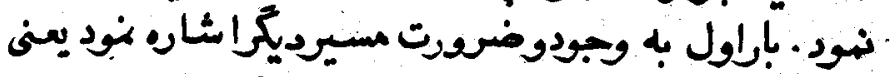

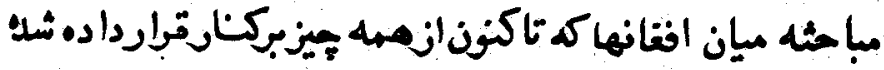
بودند.

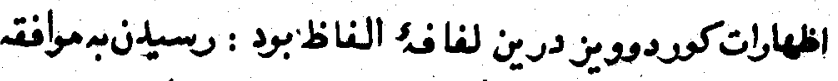

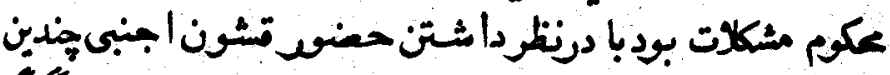

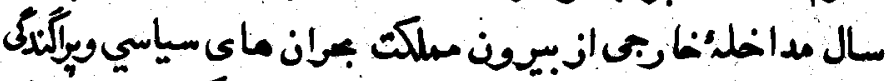

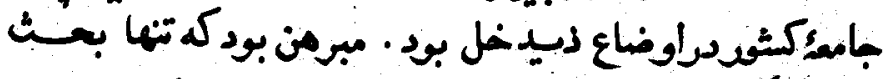

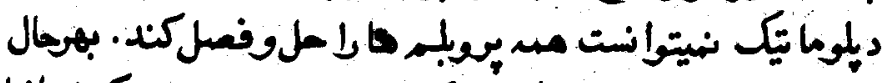

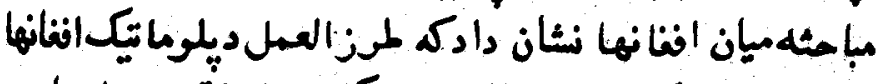

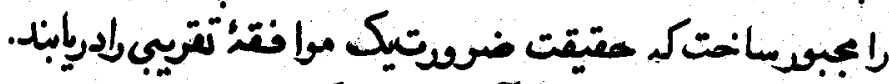

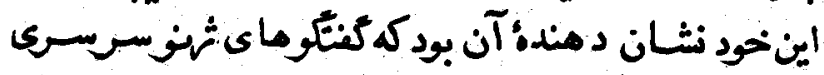

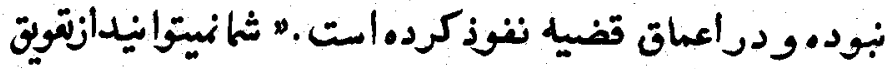

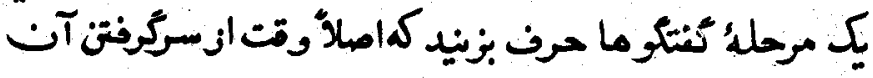

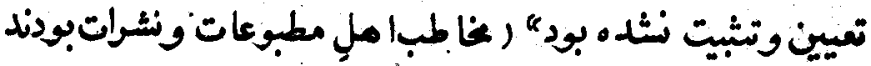

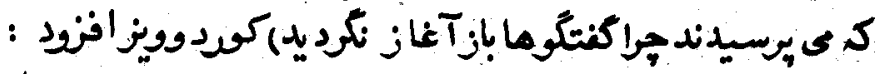

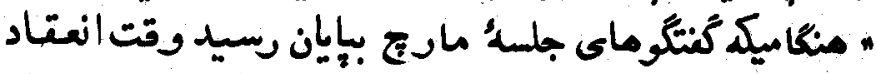

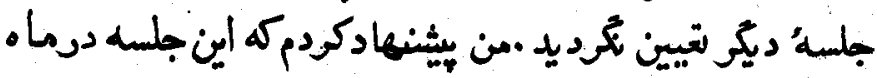

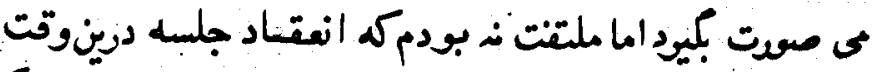

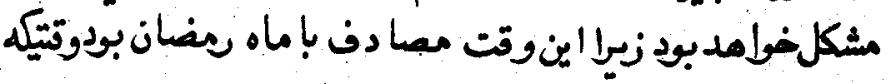




\section{Y99}

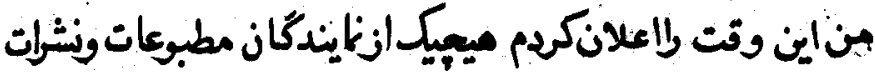

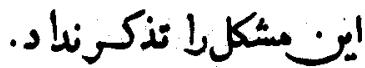

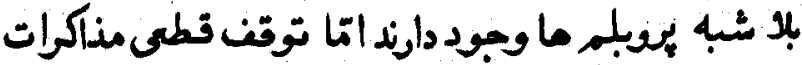

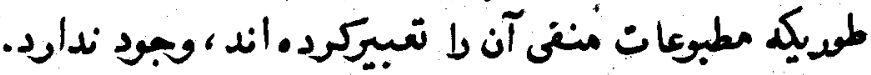

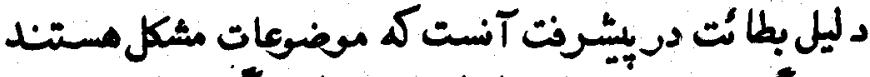

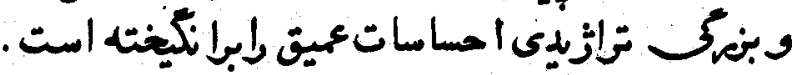

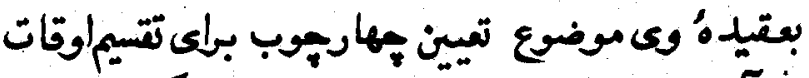

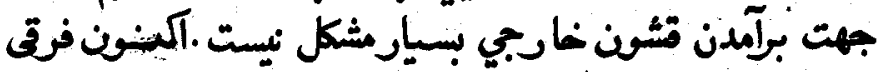

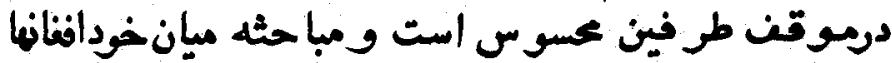

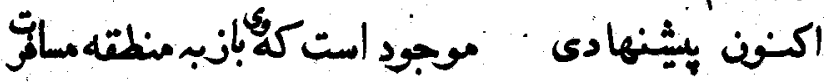

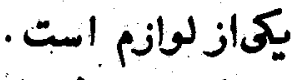

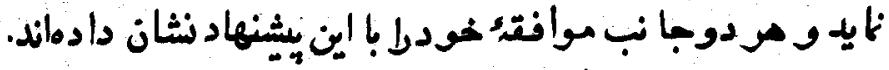

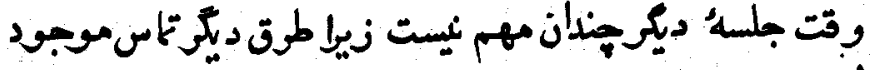
است .

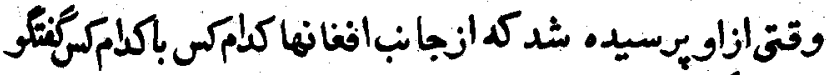

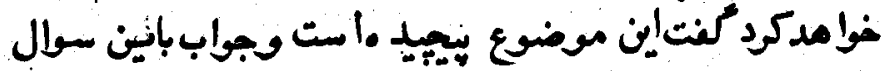

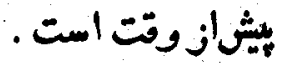

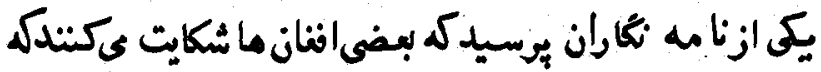

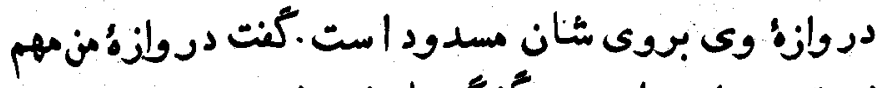

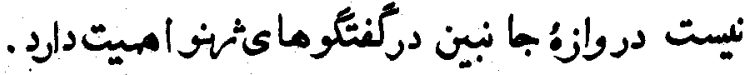

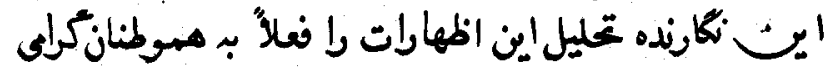




$$
r_{.}
$$

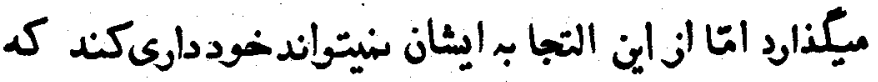

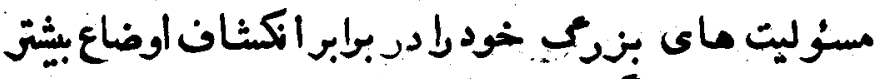
ازيـــر درنظليكيرند.

ثماروُ ع ، سالجعانمبامدولس |rqu/z/1<smiles>C1CC2CCC1C2</smiles> 


\section{ياحتى}

\section{اخططاريه رهـبان}

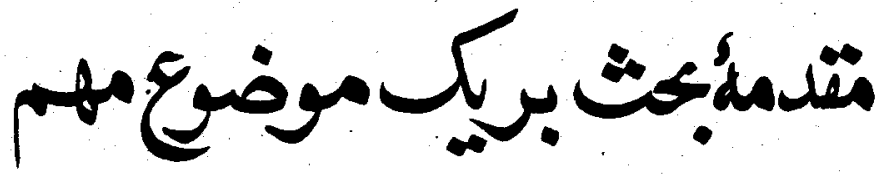

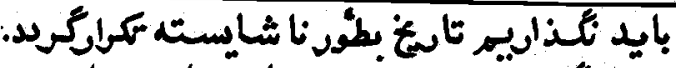

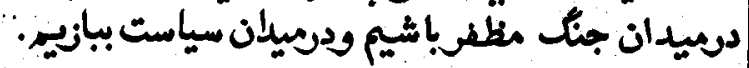

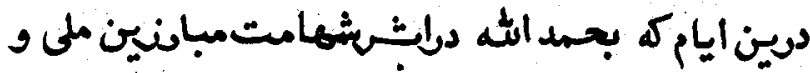

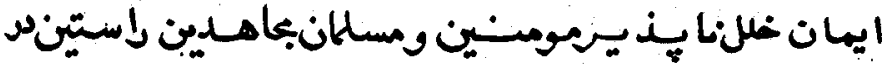

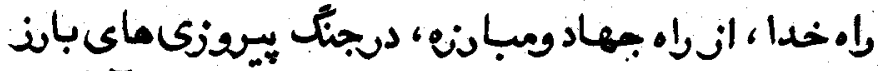

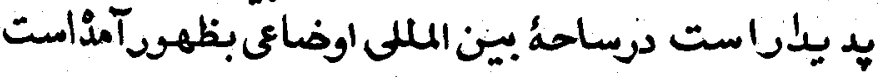

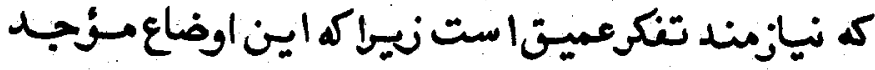

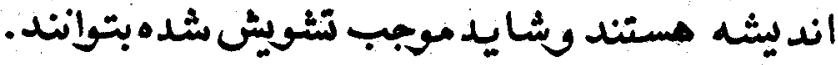

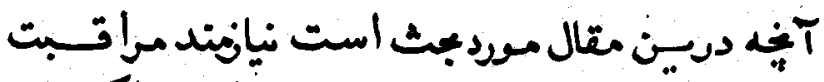

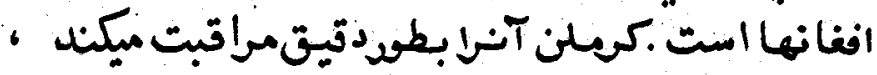




\section{r.T}

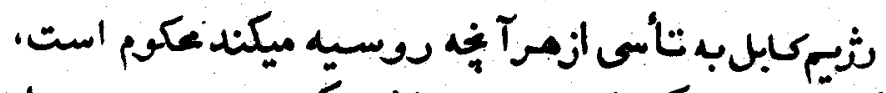

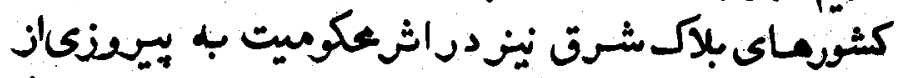

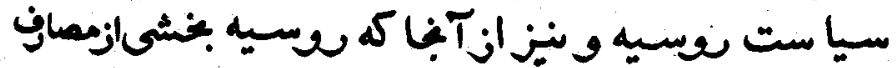

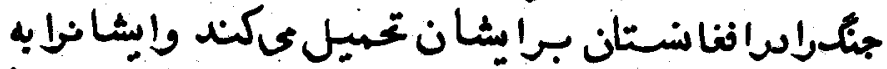

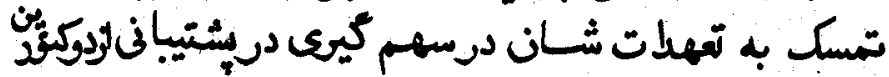

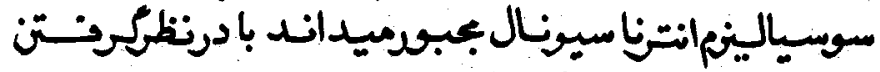

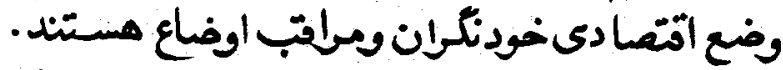

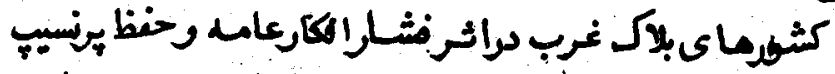

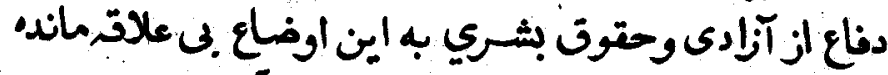

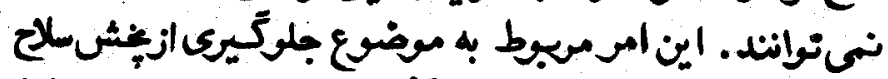

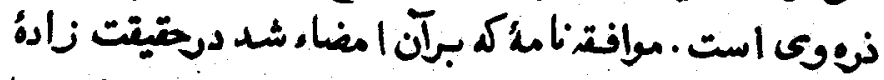

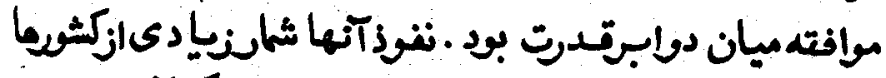

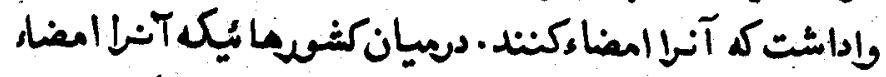

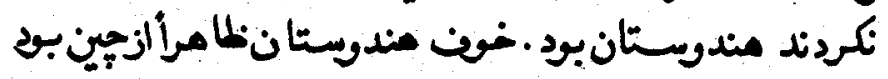

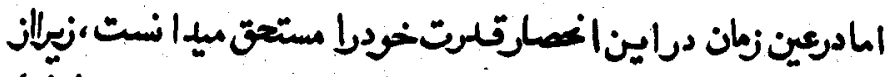

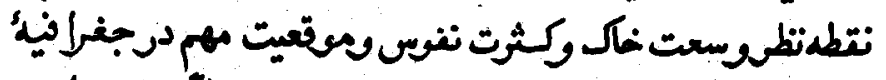

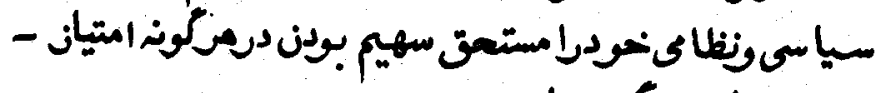
تمبرت ماى بندك ميداند .

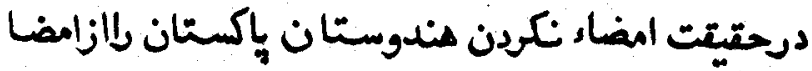

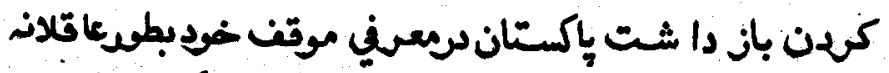

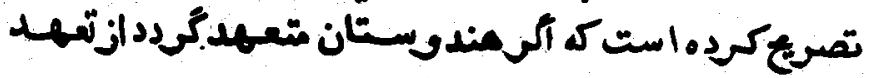




\section{$r \cdot r$}

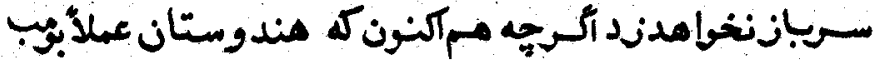

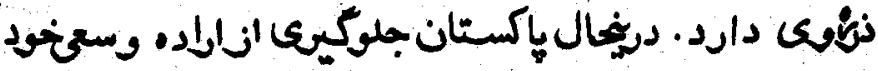

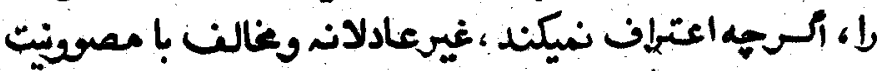

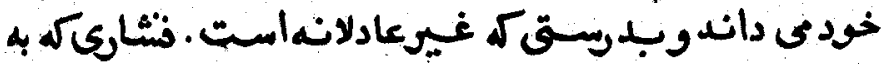

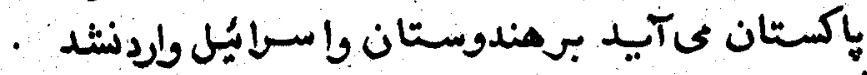

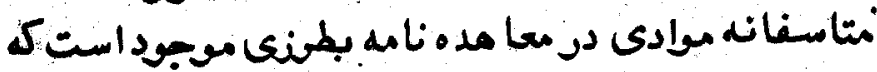

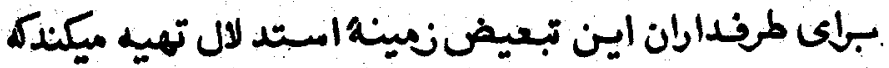

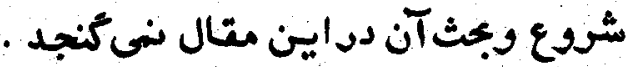

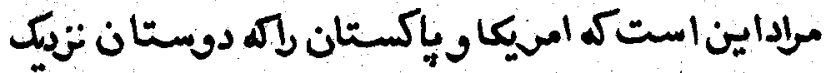

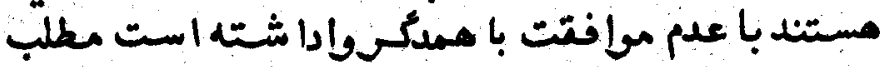

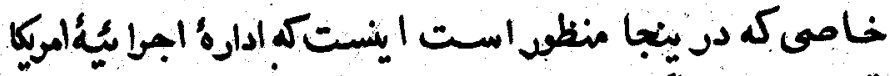

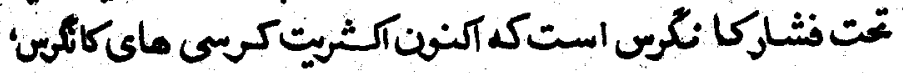

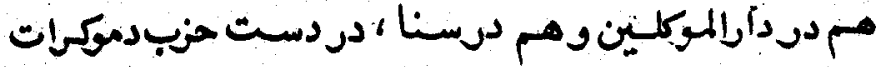

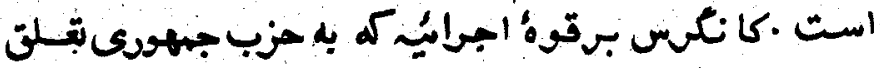

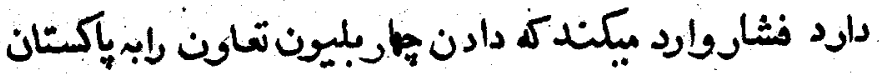

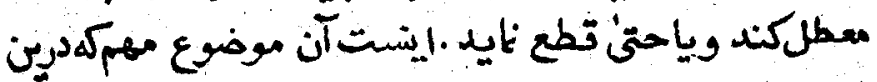

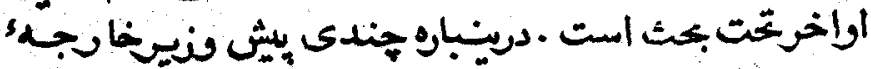

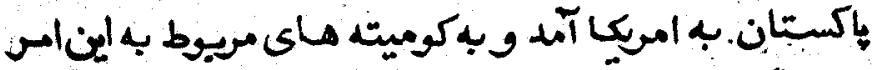

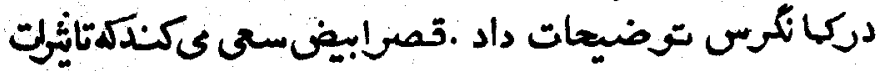

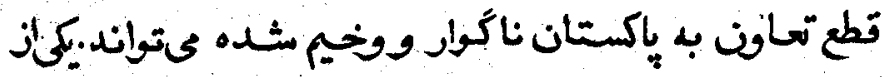

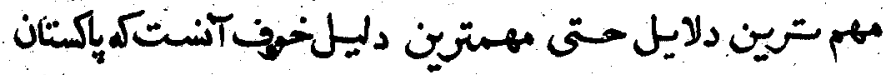




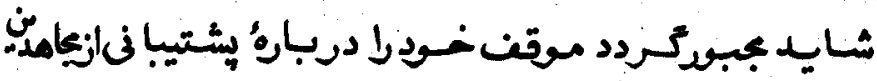

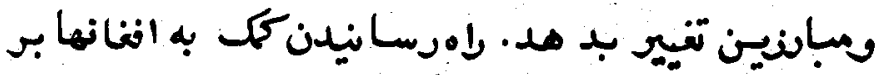

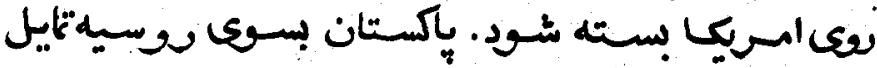

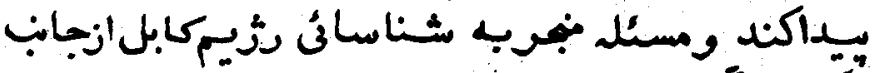

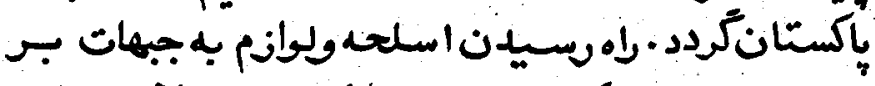

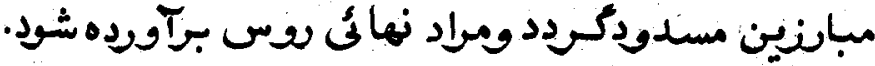

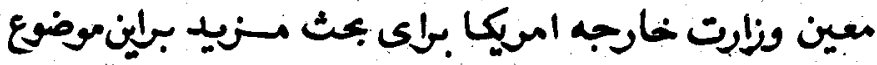

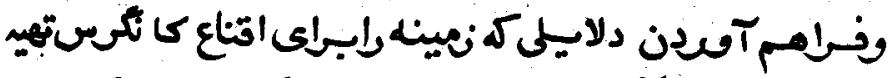

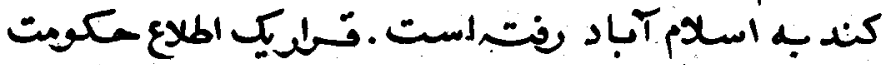

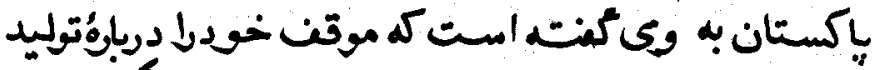

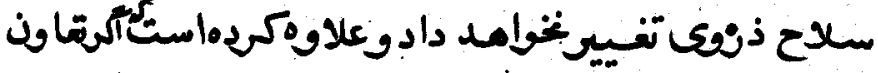

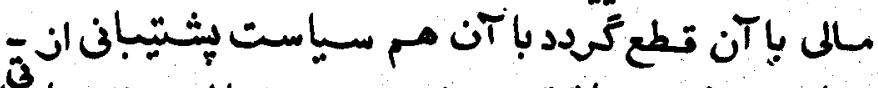

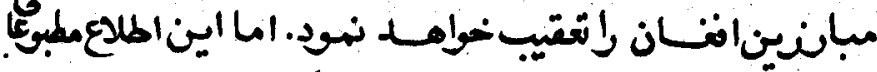

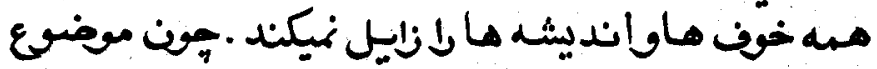

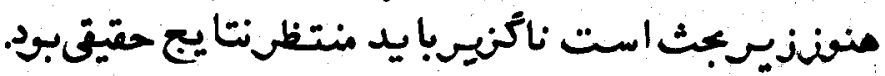

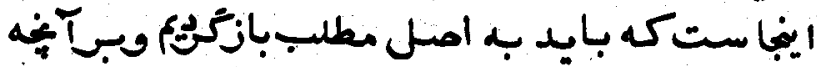

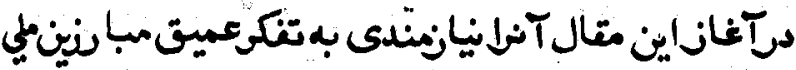

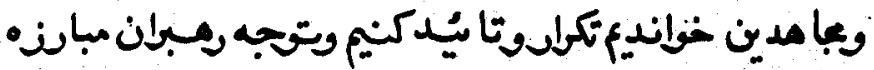

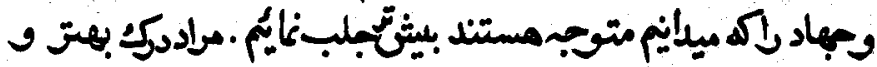

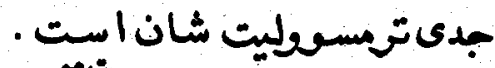

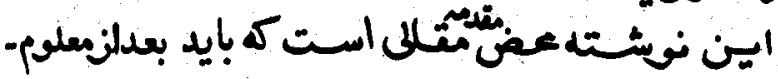


P.D

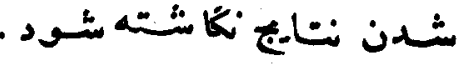

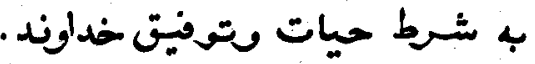

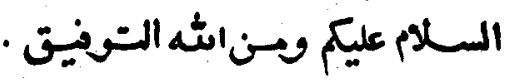

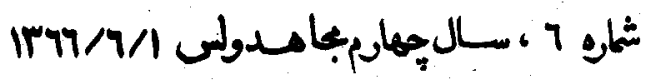




\section{ياحت:

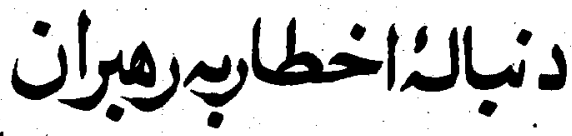

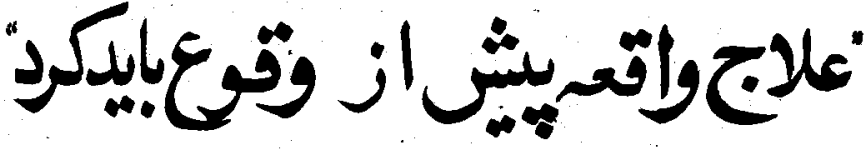

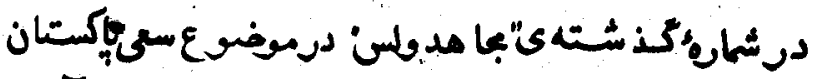

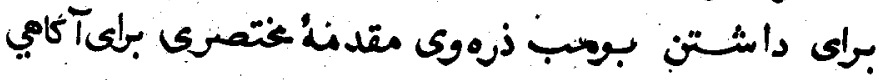

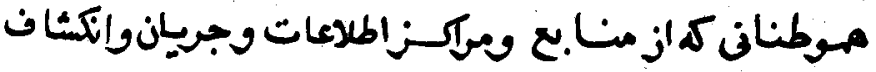

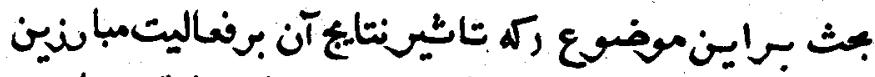

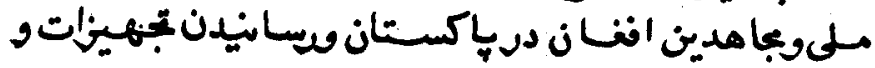

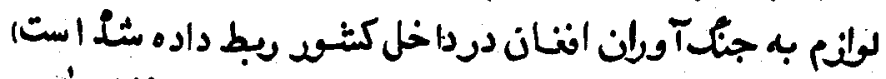

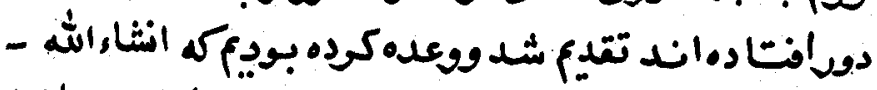

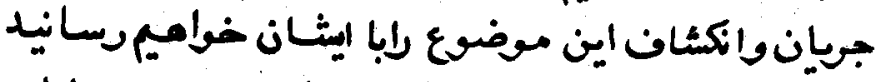

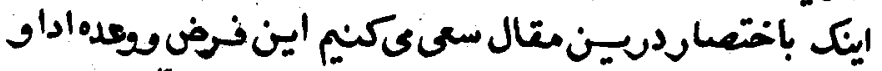

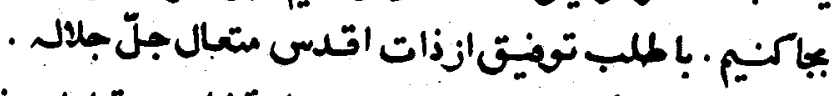

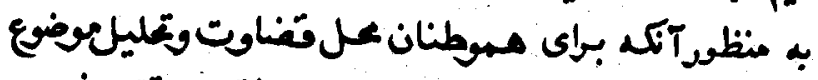

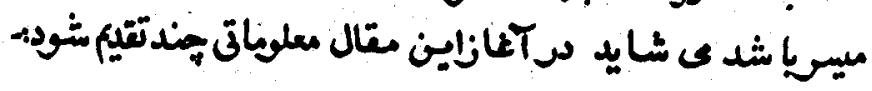




\section{P.V}

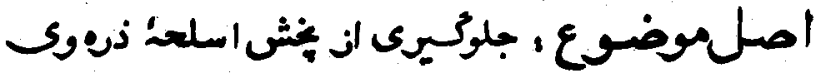

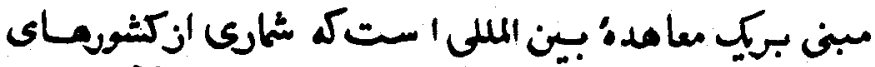

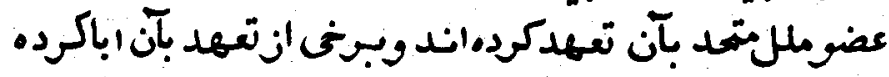

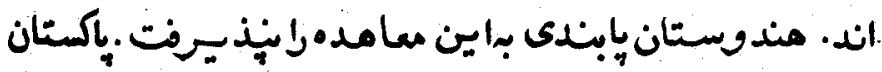

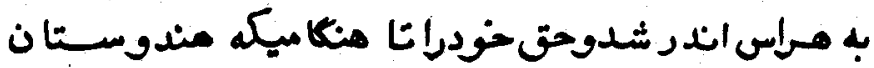

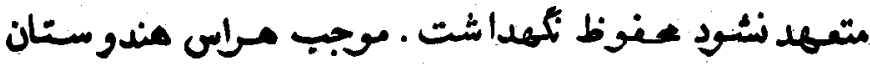

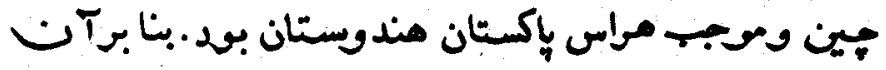

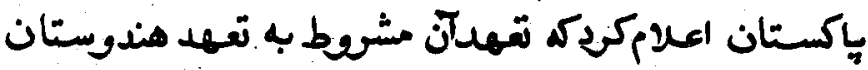

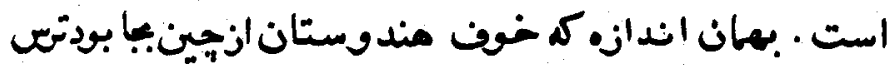

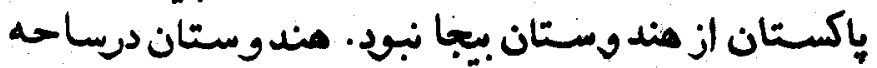

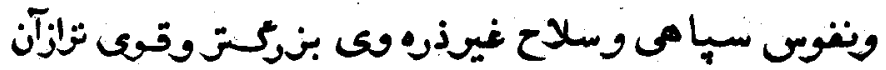

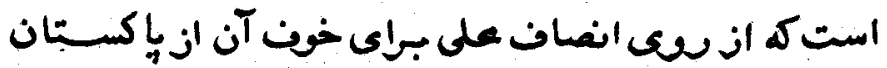

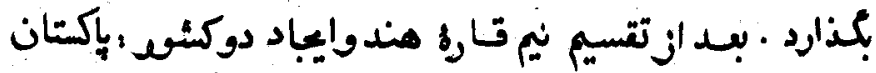

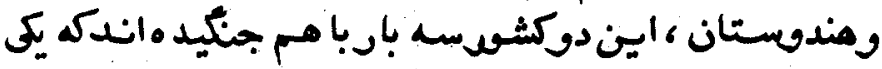

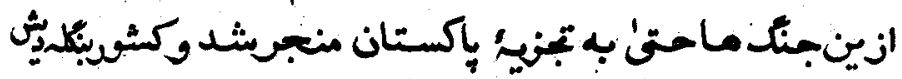

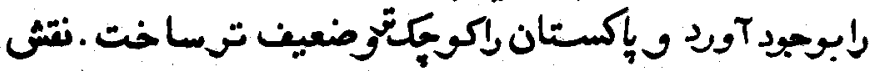

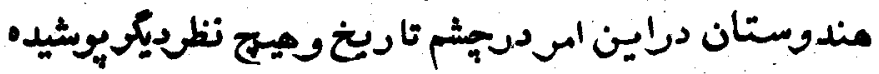

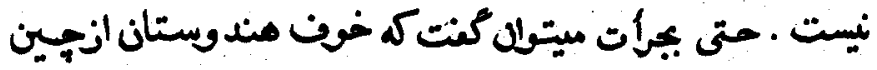

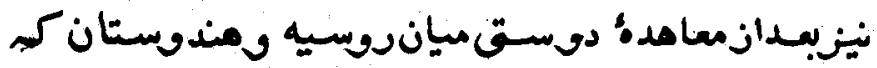

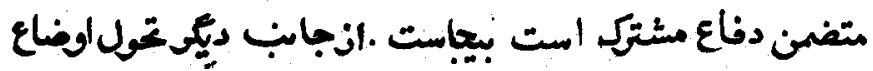

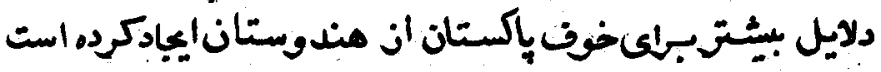




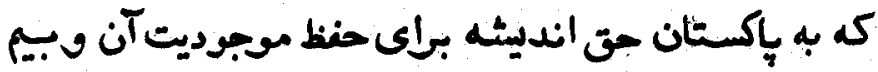

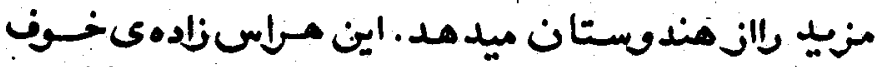

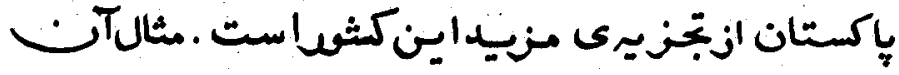

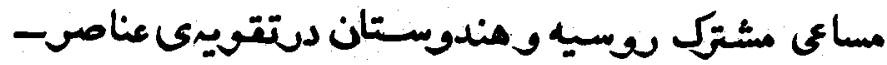

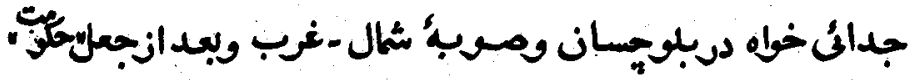

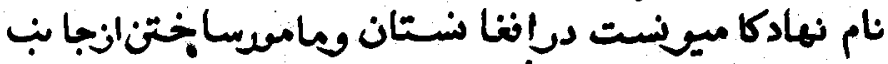

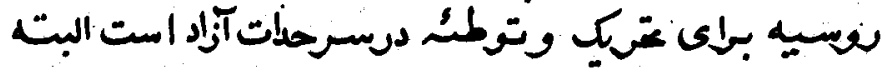

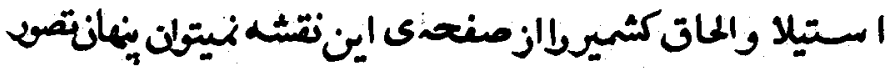
كرو .

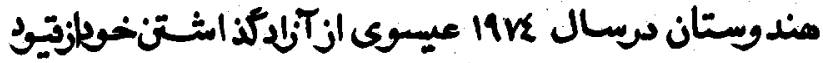

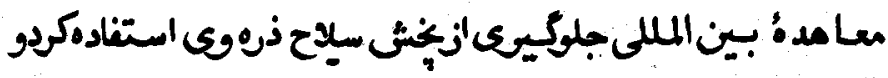

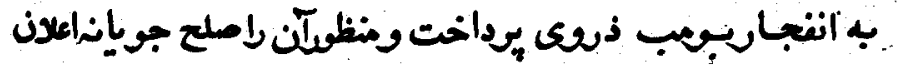

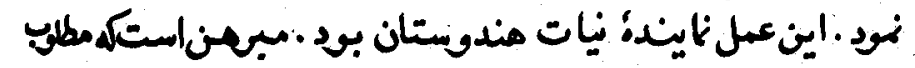

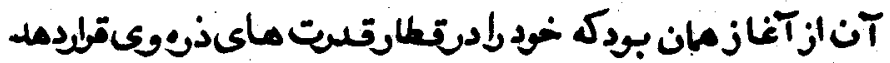

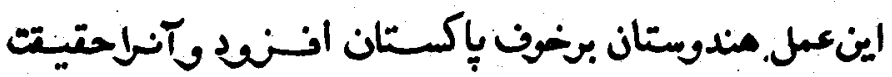

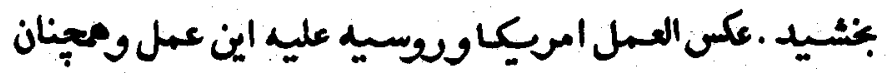

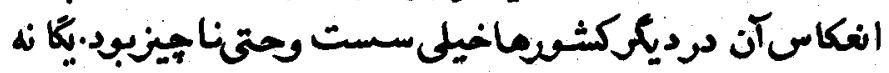

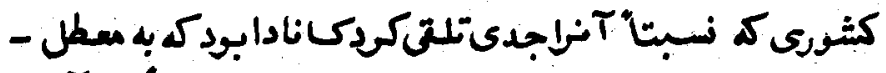

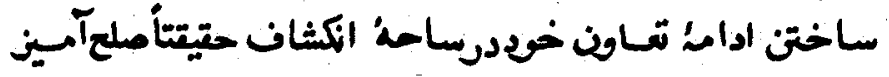

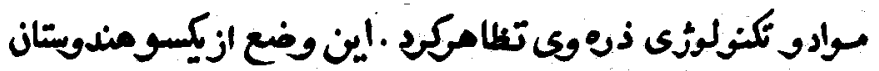

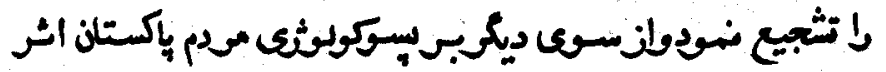




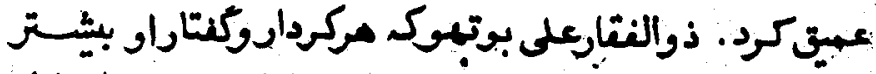

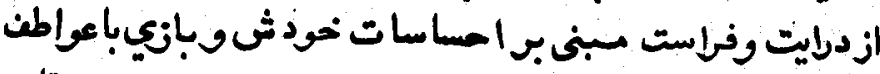

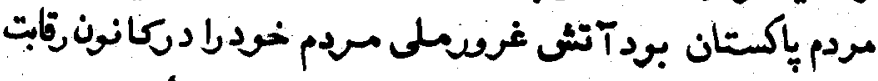

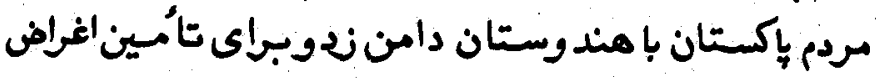

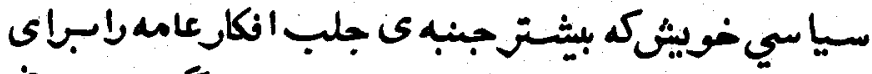

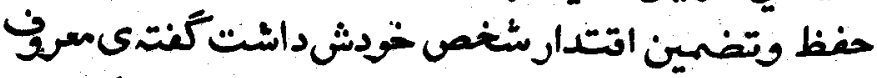

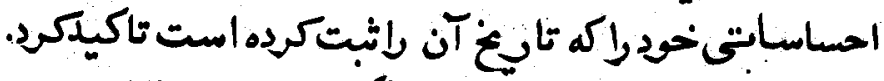

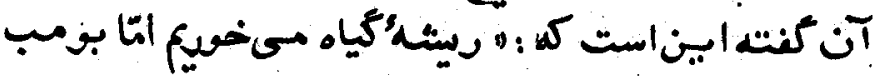

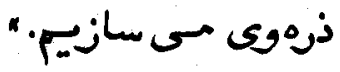

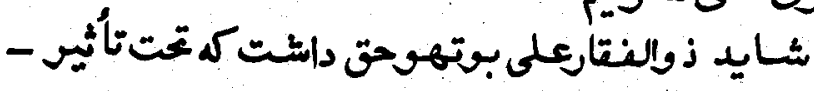

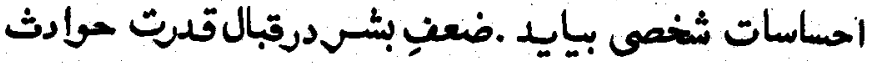

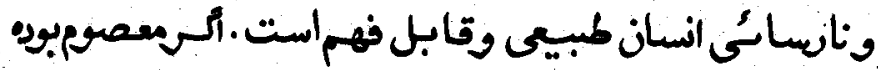

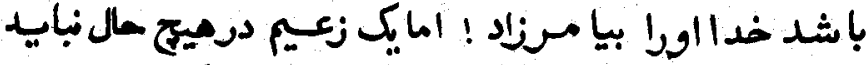

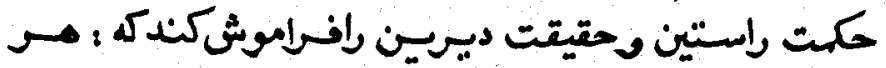

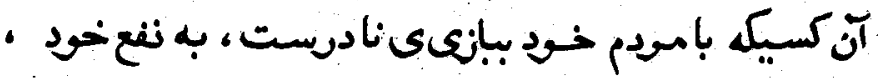

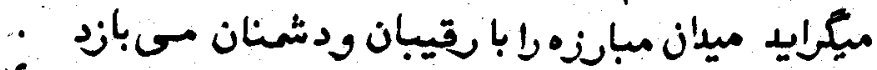

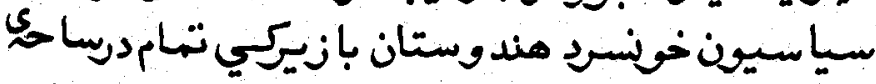

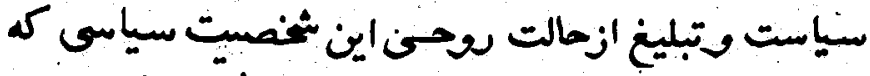

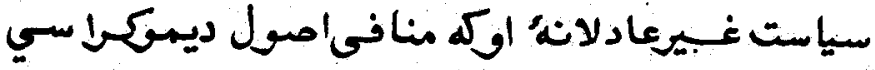

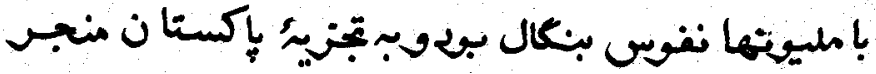
كرديد استفادهكدند. 


\section{r.}

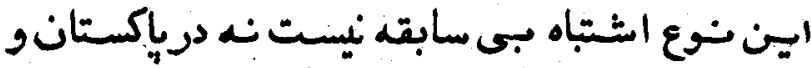

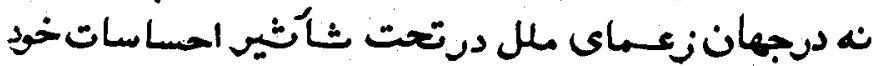

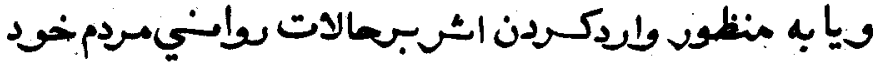

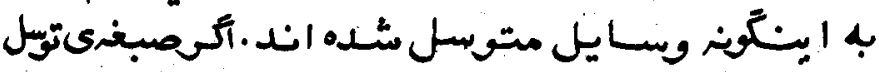

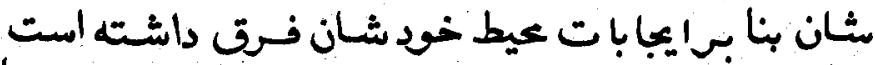

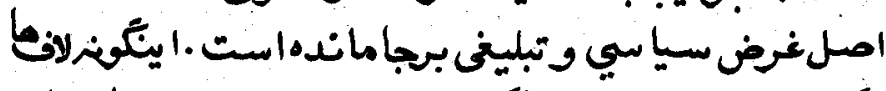

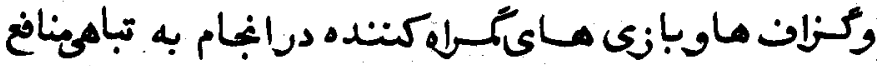

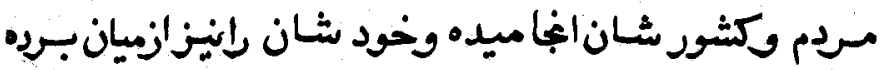
است مترد

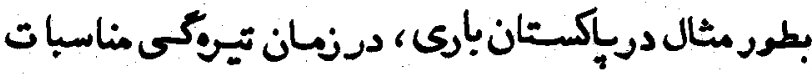

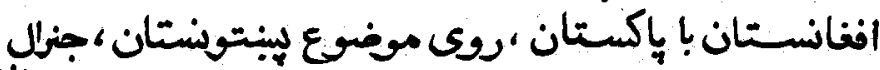

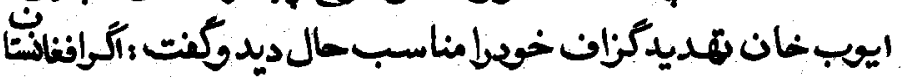

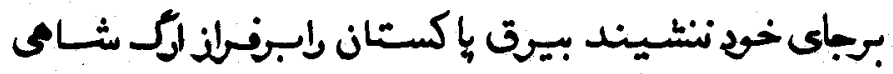

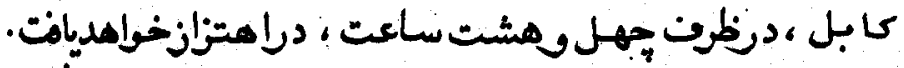

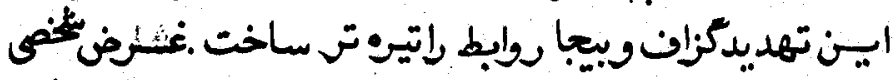

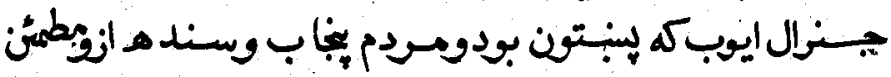

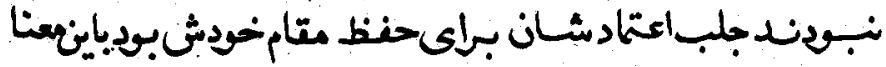

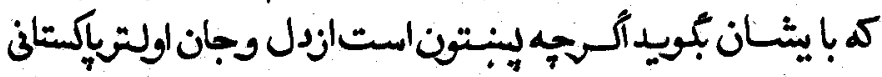

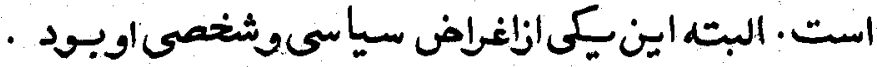

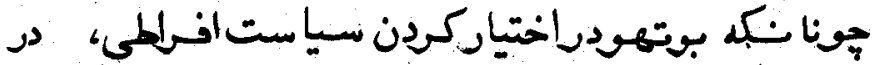

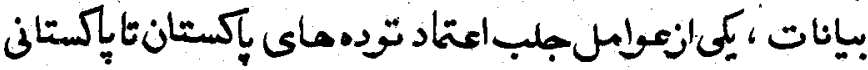




\section{rII}

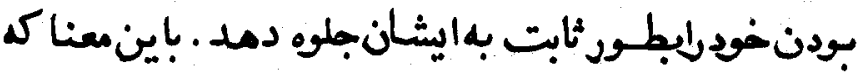

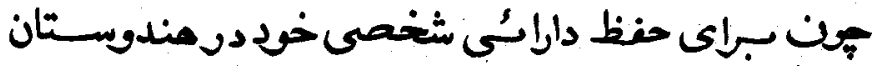

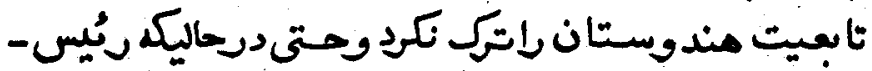

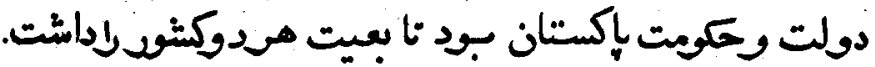

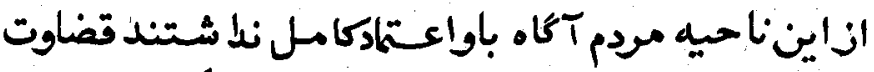

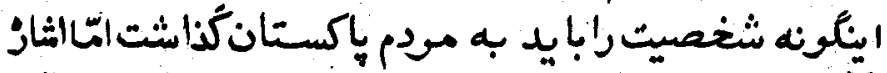

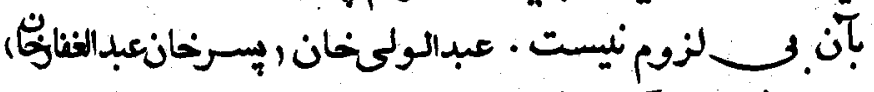

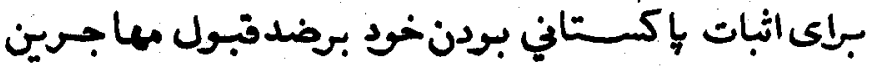

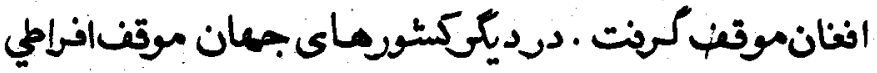

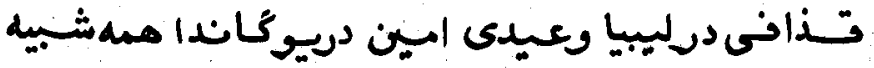

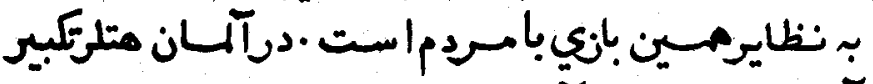

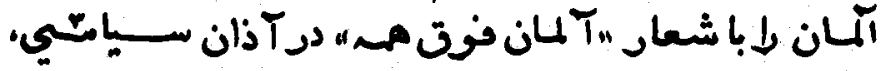

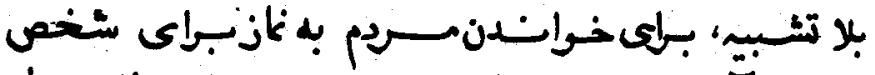

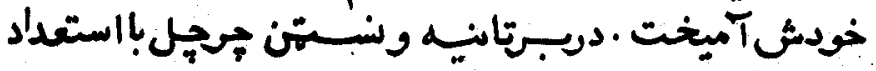

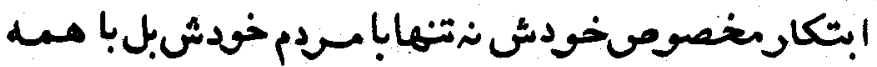

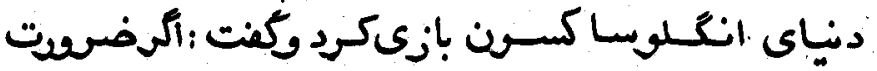

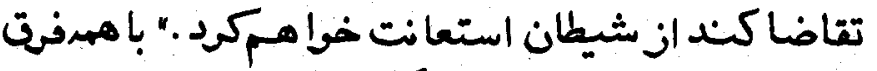

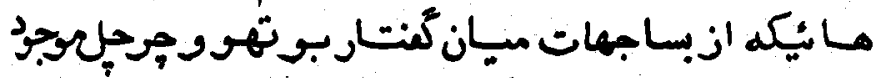

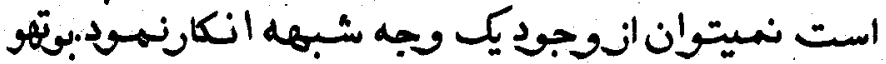

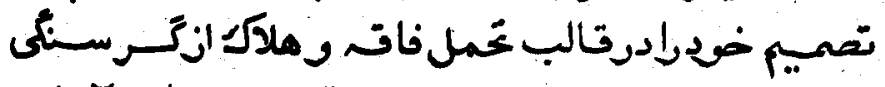

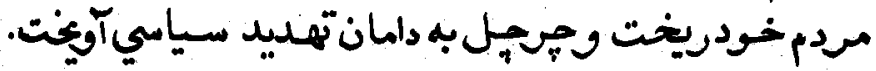




\section{rIr}

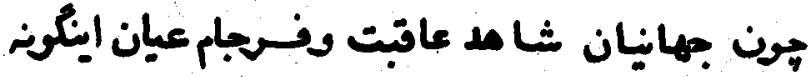

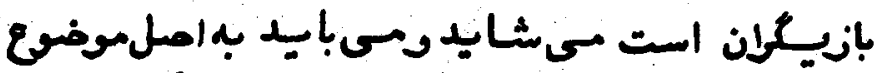

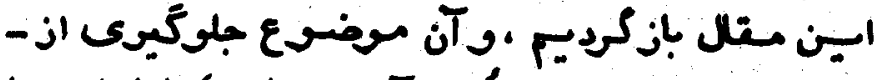

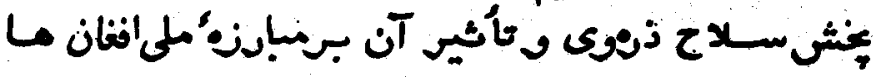

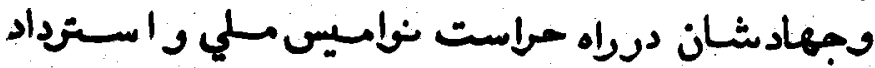

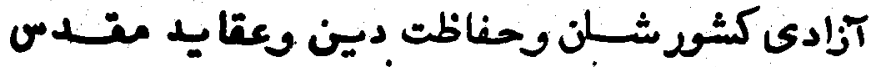

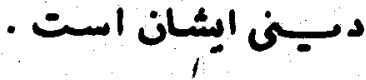

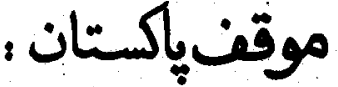

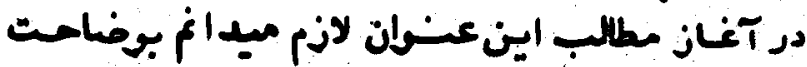

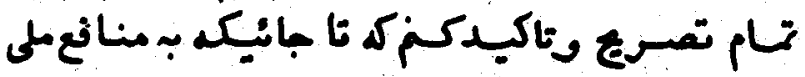

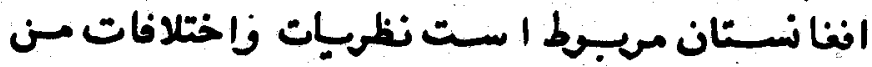

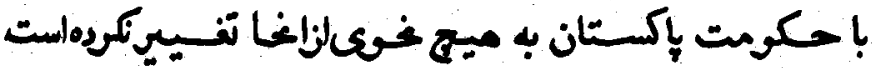

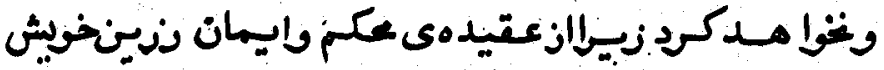

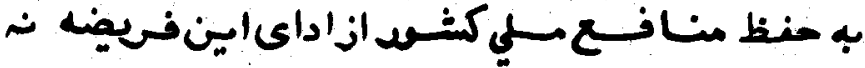

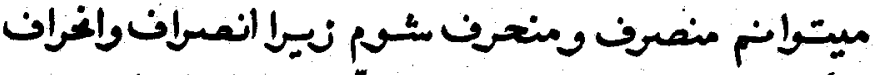

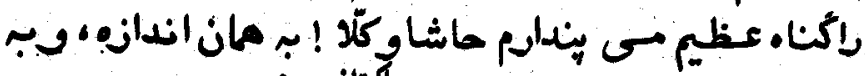

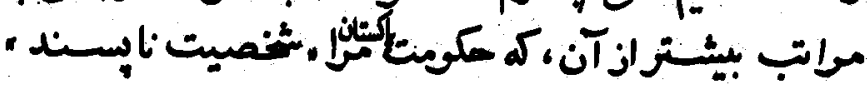

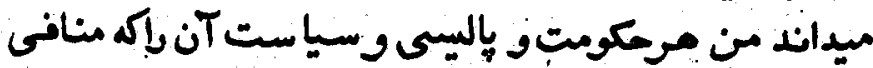

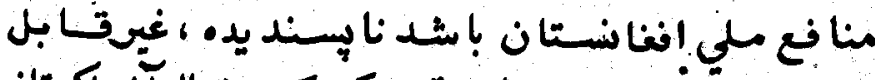

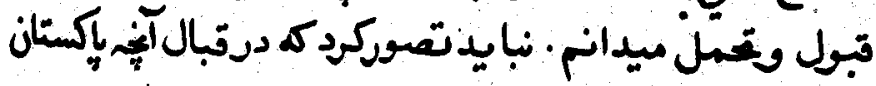




\section{rir}

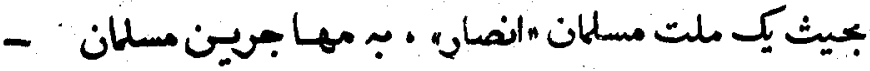

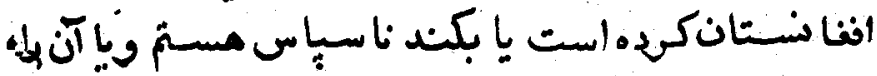

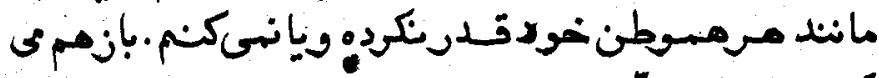

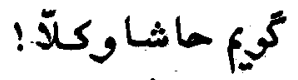

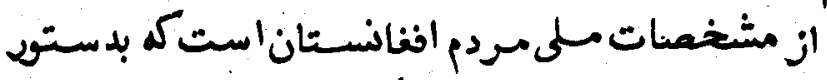

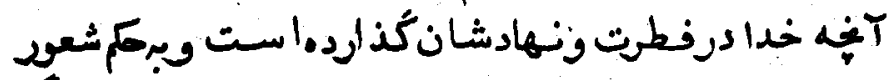

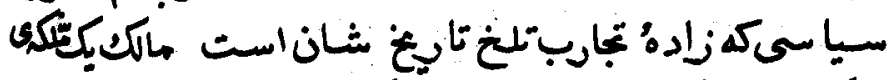

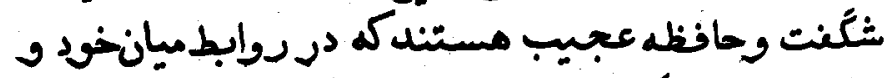

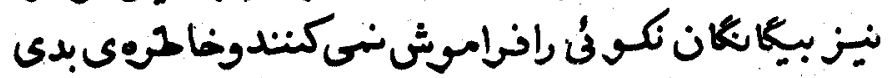

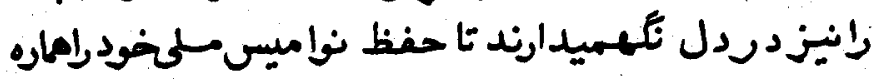

$$
\text { مراتبت مكرده بترانتد. }
$$

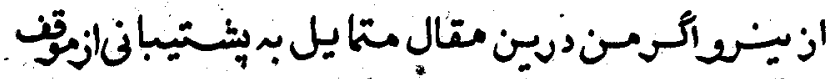

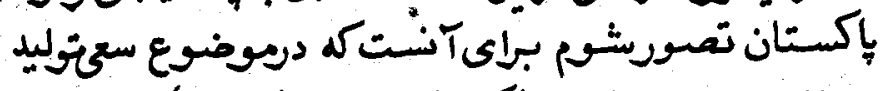

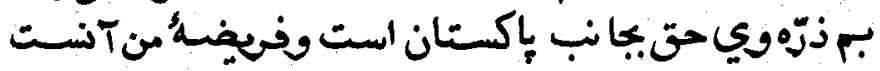

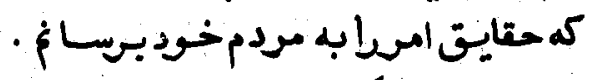

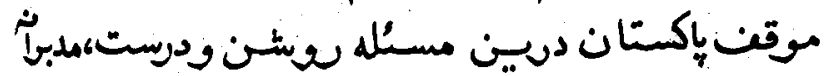

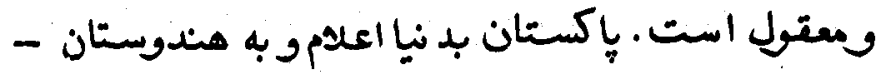

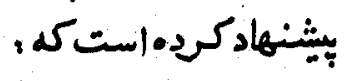

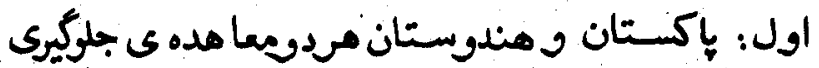

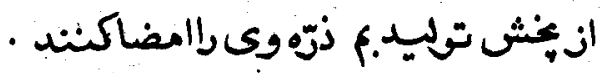

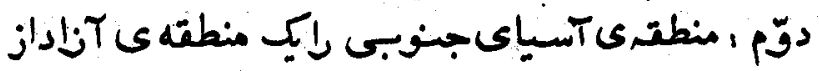




\section{rí}

\section{سـلاح ذرّه وى اعلان كنتد.}

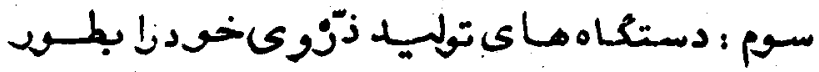

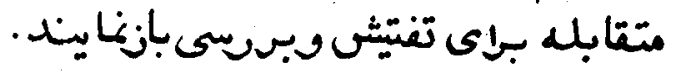

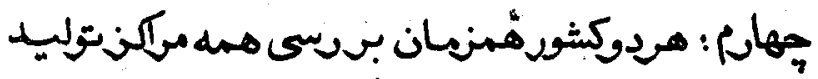

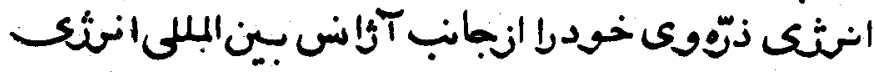

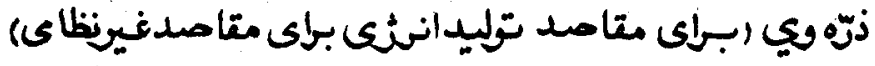

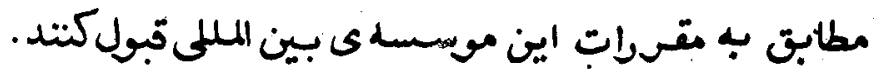

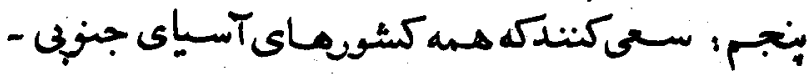

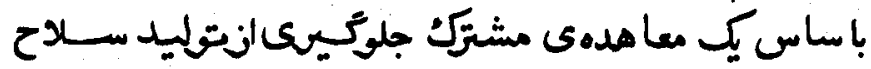

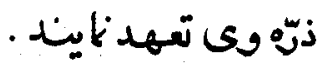

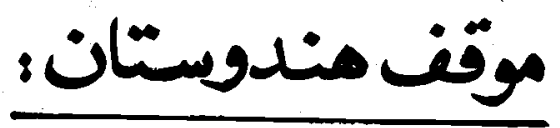

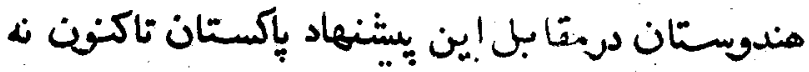

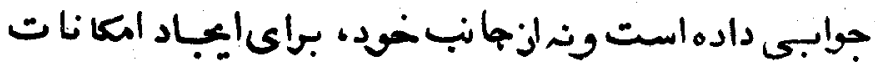

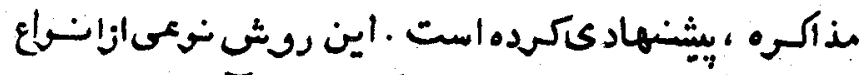

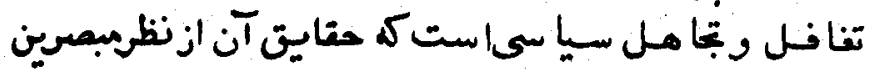

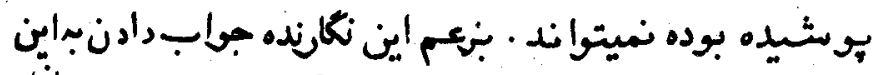

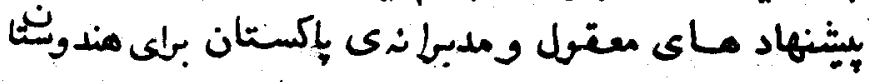

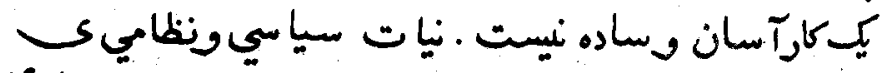

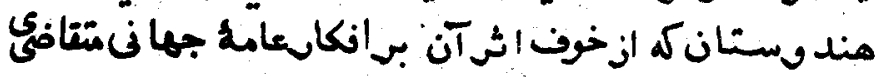




\section{Mo}

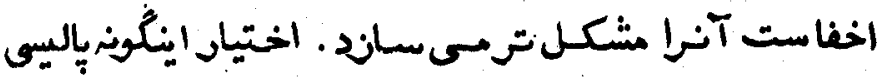

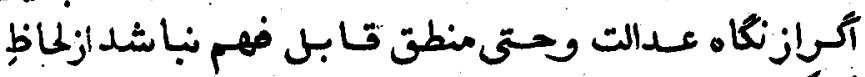

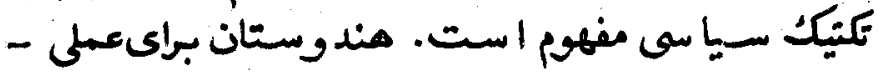

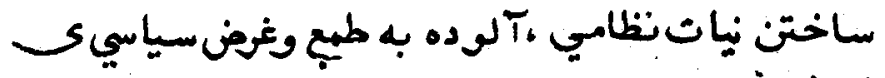

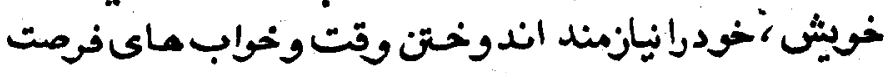

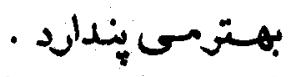

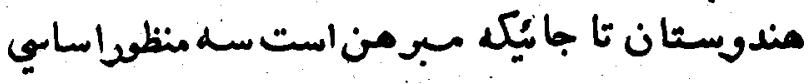

$$
\text { دارد : }
$$

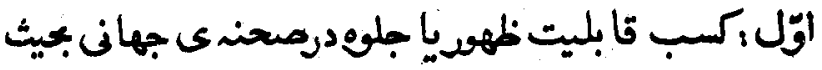

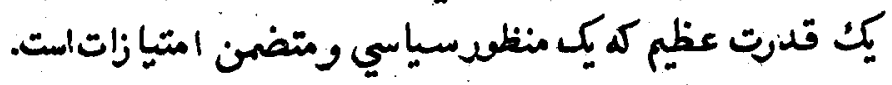

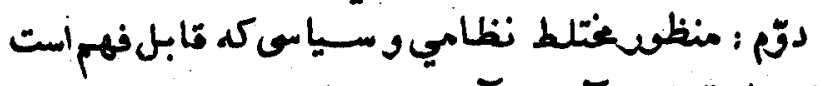

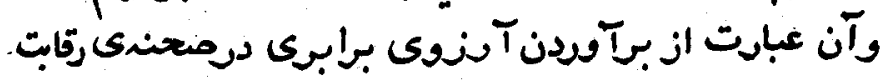

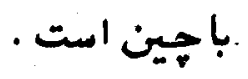

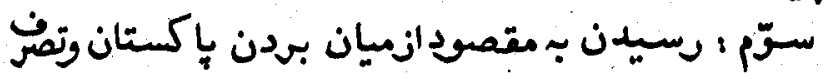

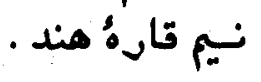

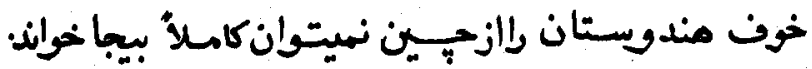

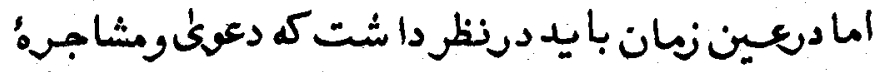

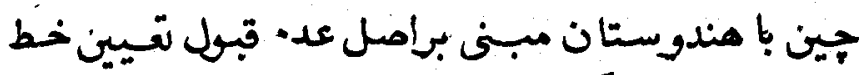

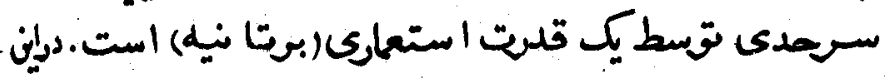

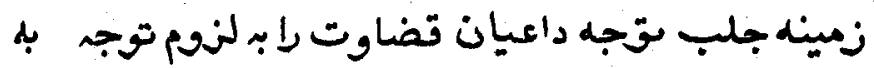

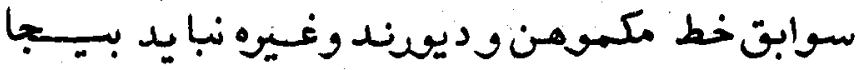




\section{PIT}

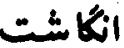

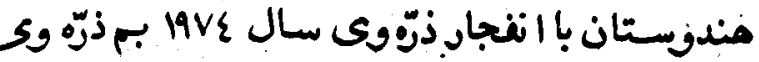

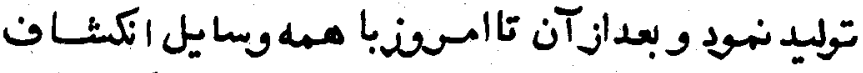

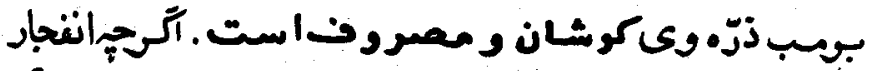

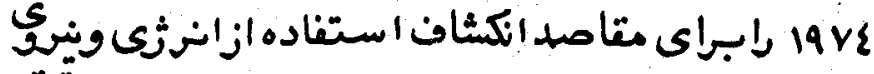

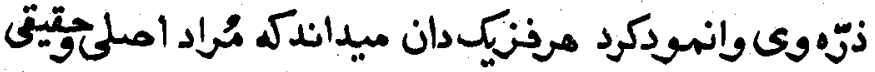

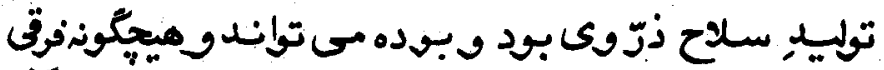

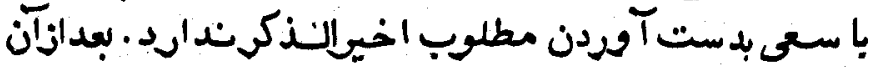

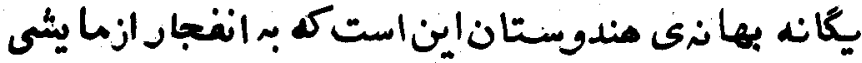

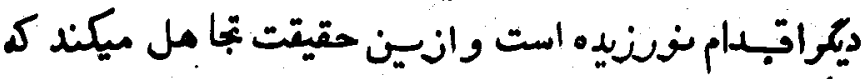

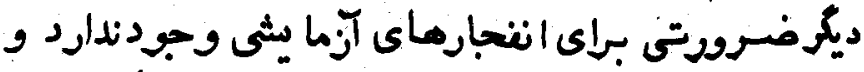

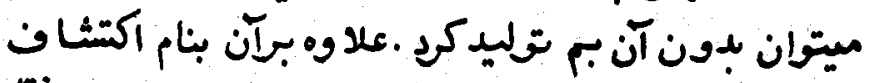

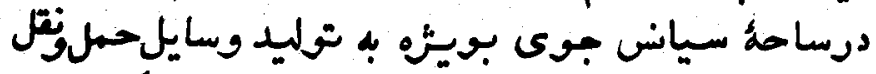

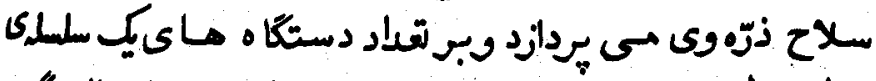

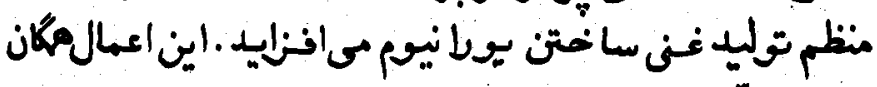

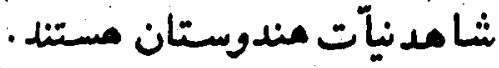

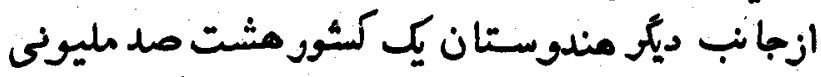

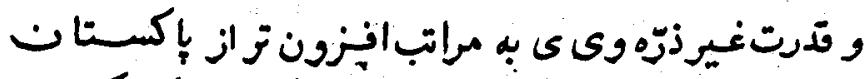

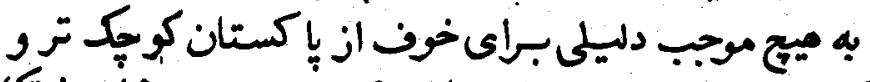

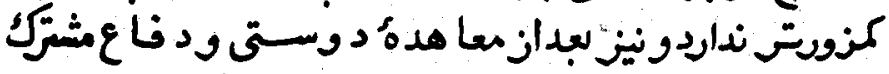

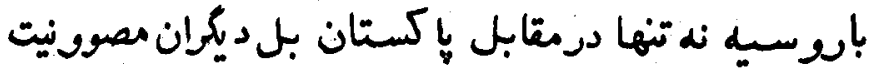




\section{YIV}

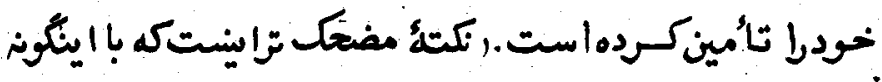

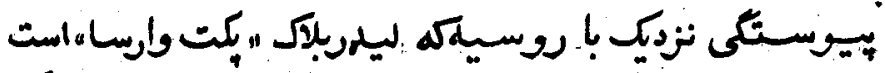

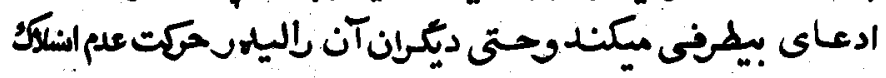

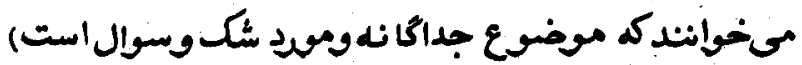

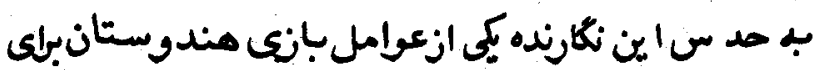

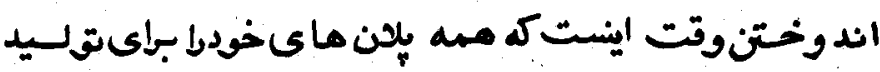

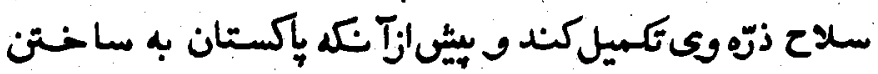

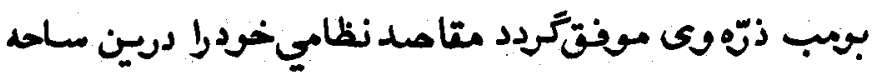

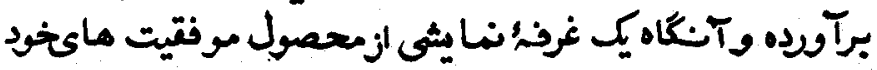

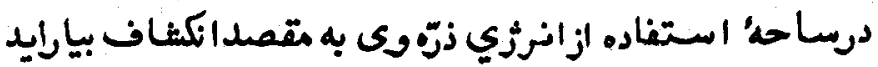

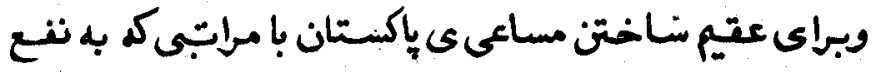

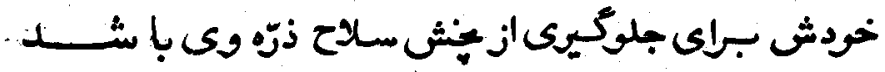

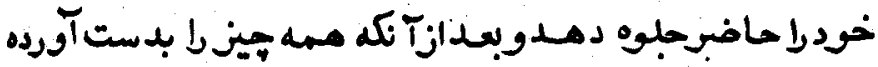

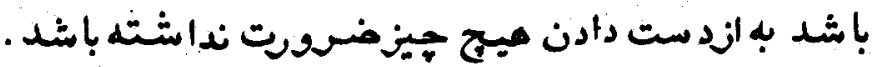

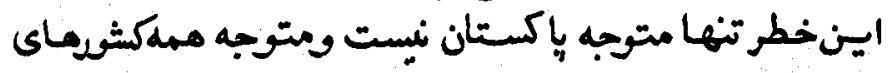

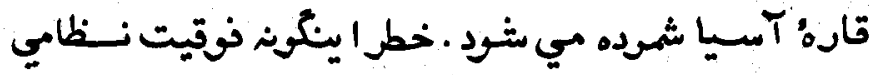

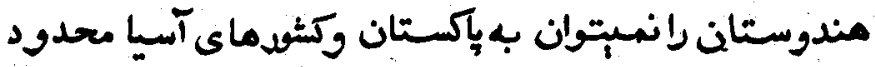

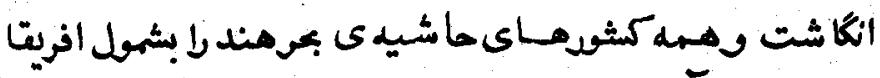

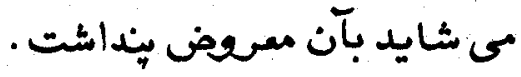

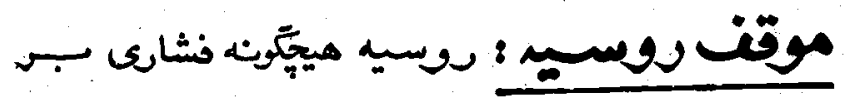




\section{TM}

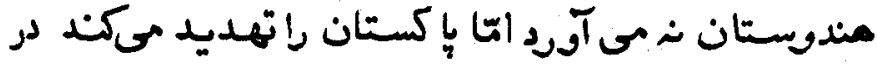

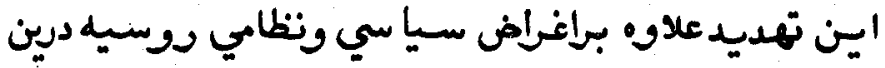

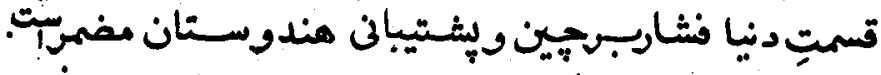

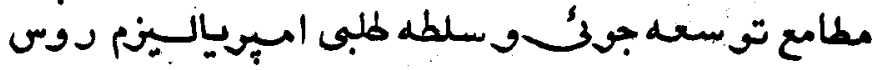

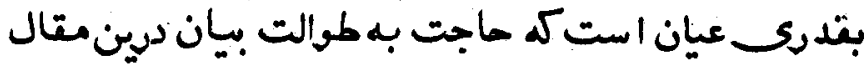

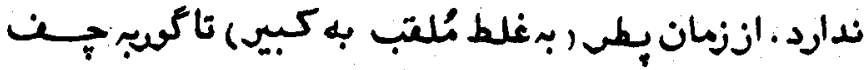

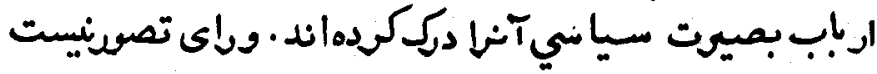

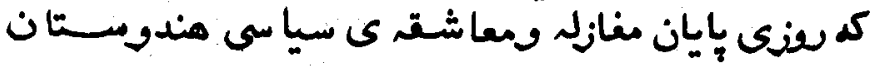

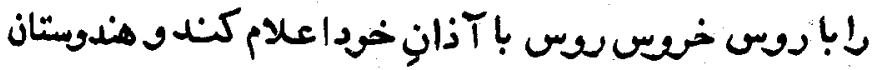

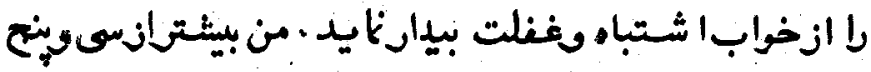
سال بيثي درغنيلى كنته بوحم : .

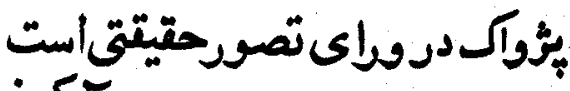

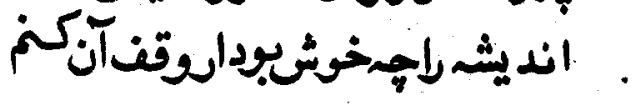

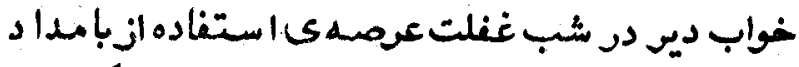

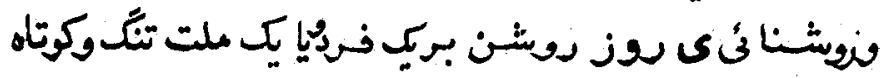
مي سازد · مئس

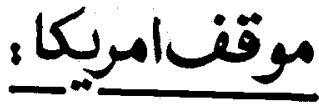

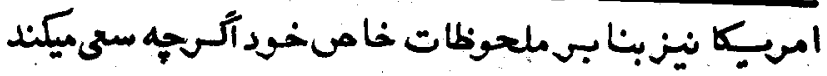




\section{P19}

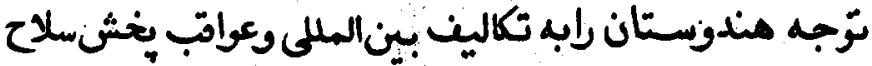

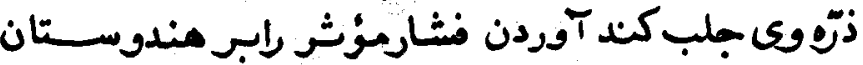

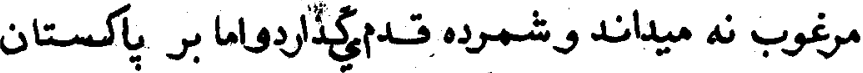

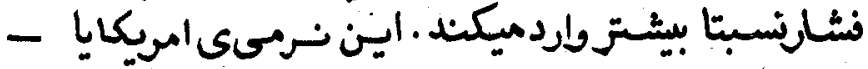

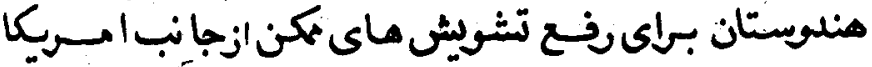

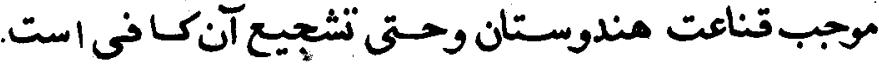

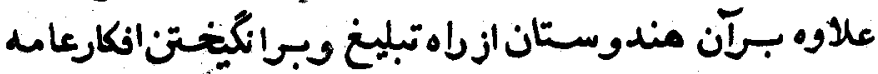

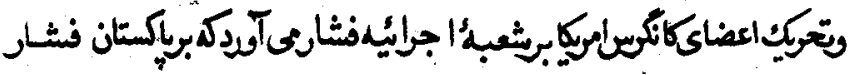

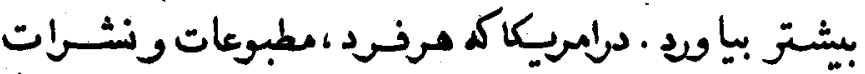

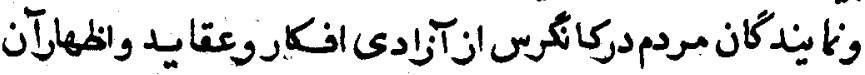

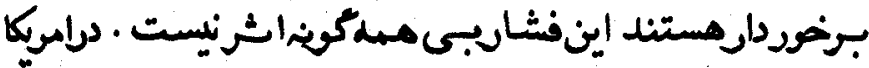

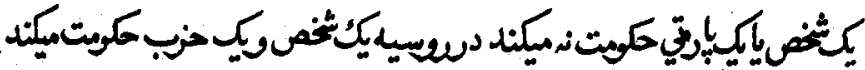

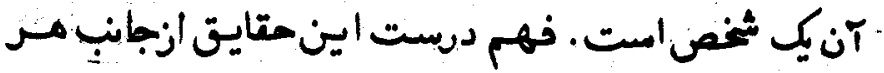

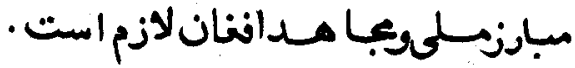

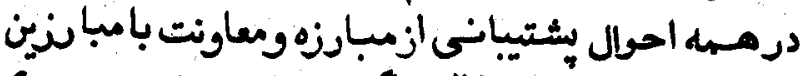

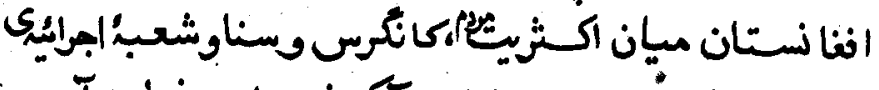

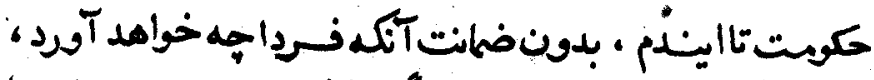

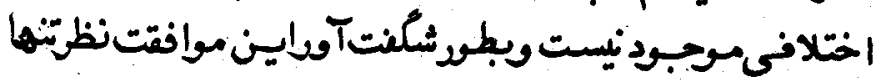

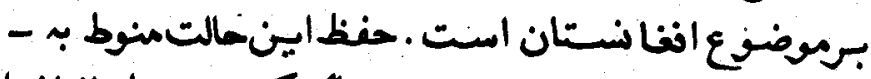

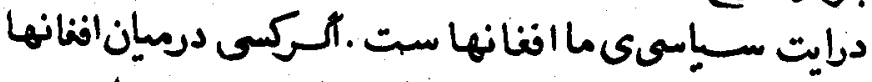

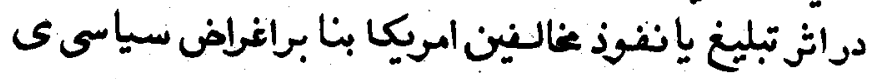




\section{rr.}

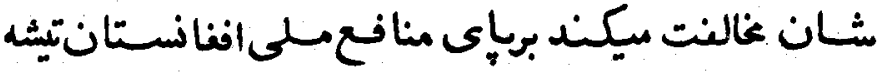

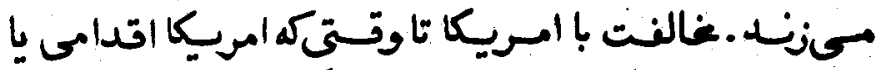

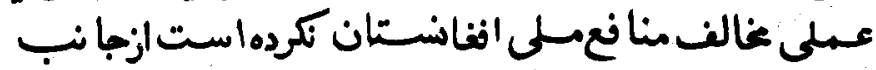

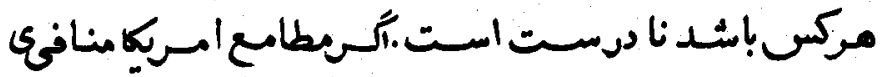

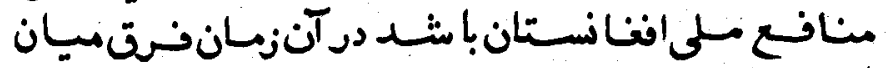

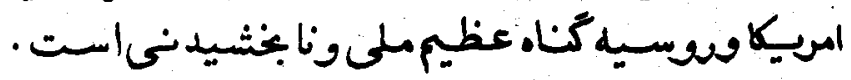

\section{عكس العهل آخينين ياكتنان :}

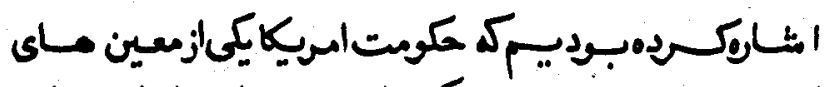

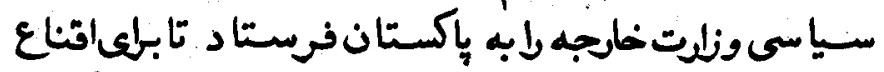

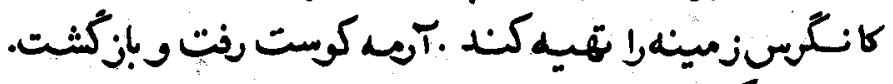

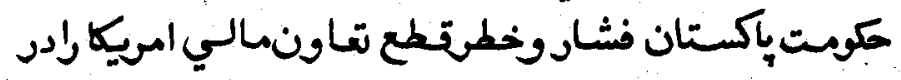

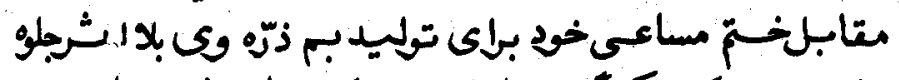

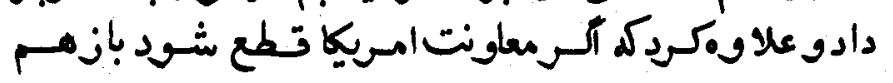

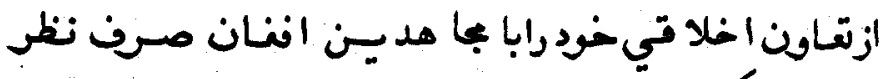

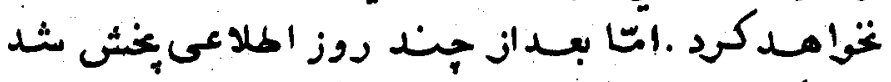

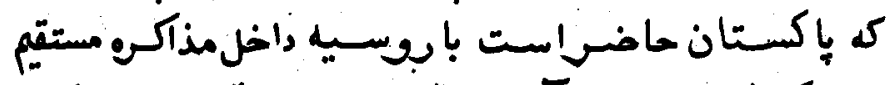

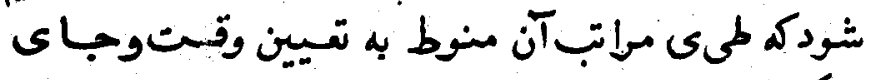

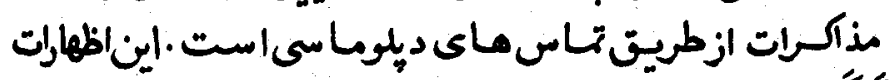

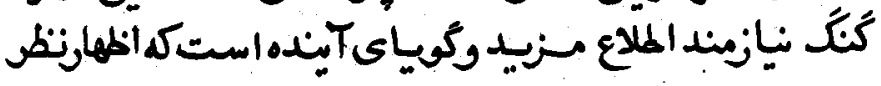




\section{YrI}

. بـ آن بيّ از وقت است .

\section{موضوعبوبذزّروياسلايي:}

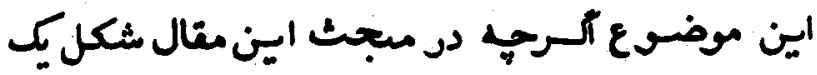

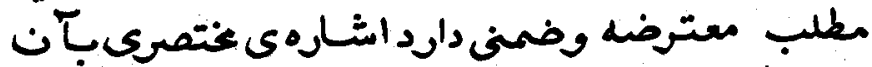

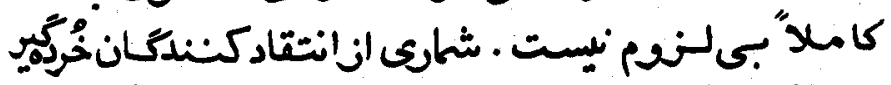

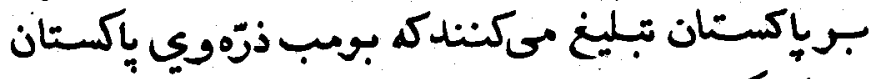

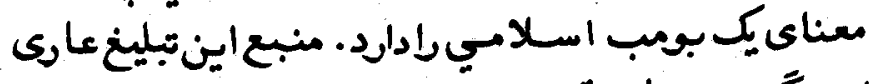

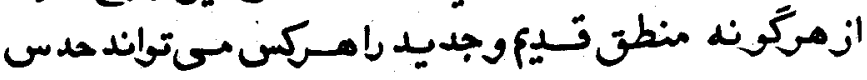

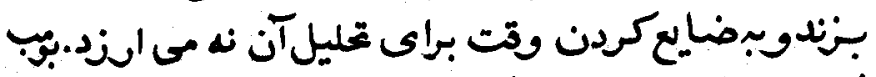

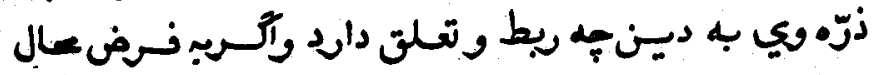

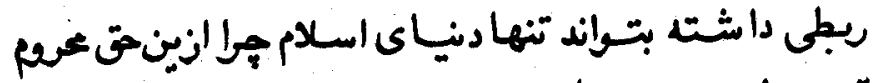

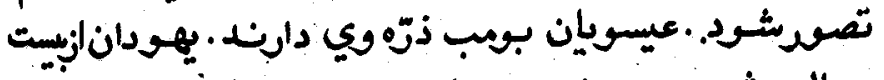

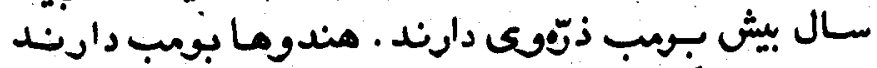

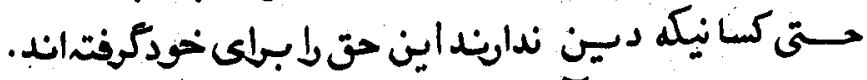

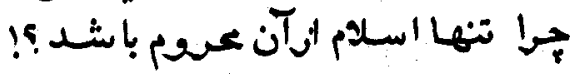

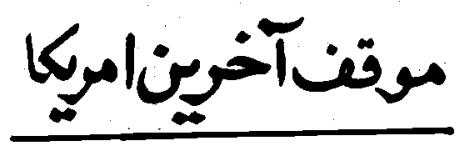

امروز اول سـتا بـر است باحستال غالبكاتكيسامسيكا 


\section{rir}

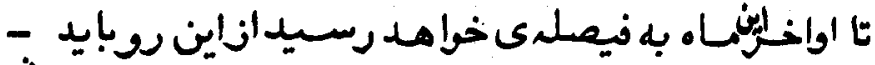

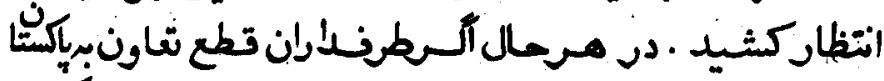

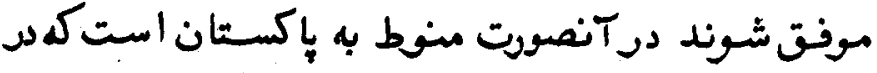

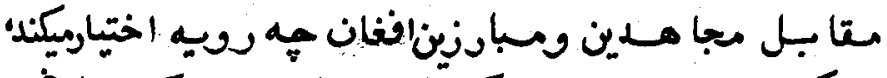

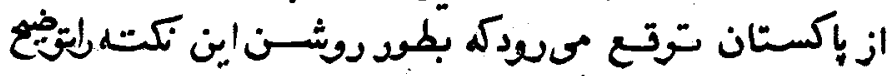

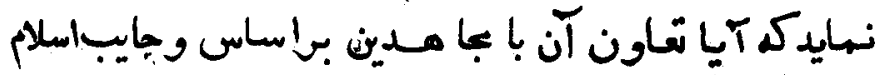
است يا به منظود جلب مساونت امريكالدين متدس اسـلام

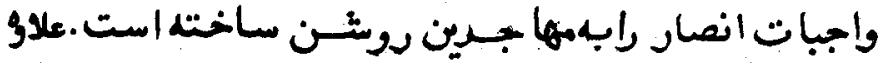

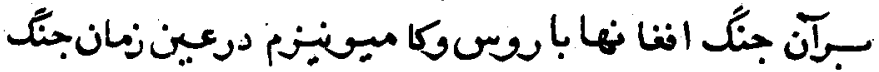

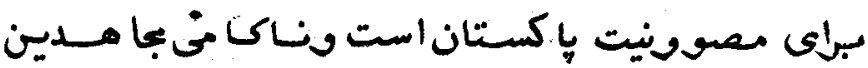

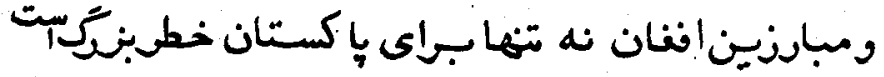

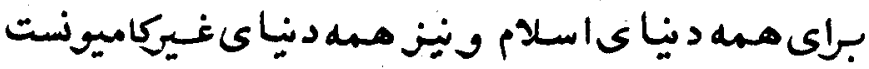

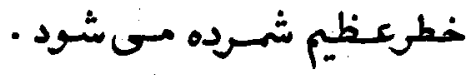

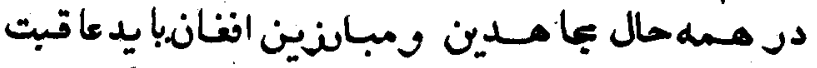

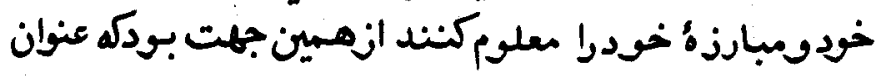

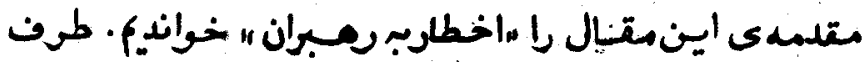

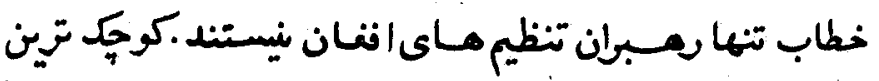

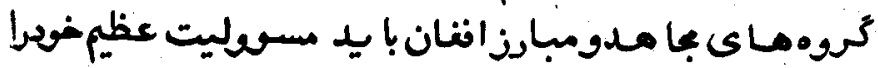

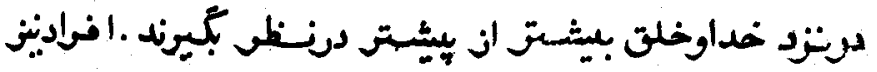

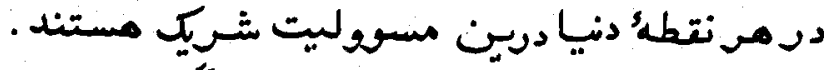

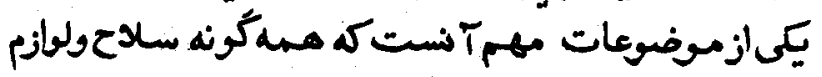




\section{rrr}

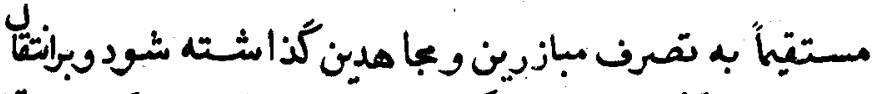

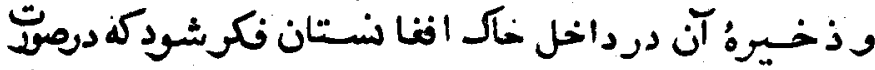

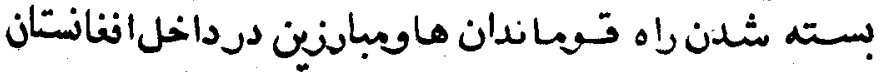

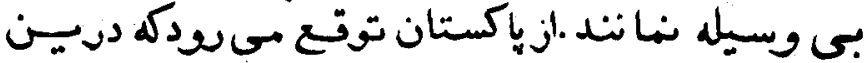

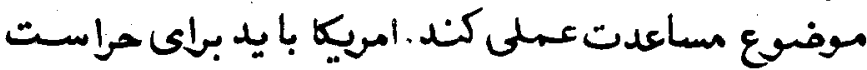

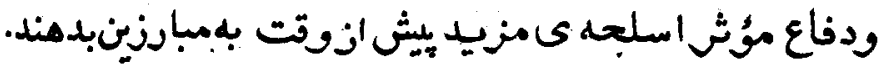

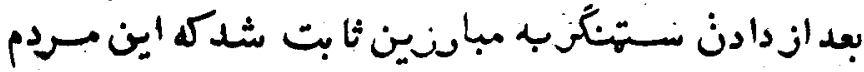

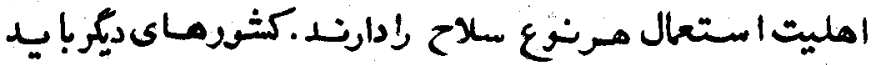

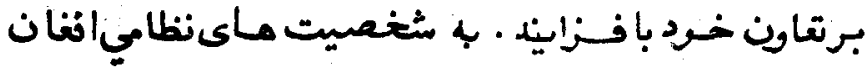

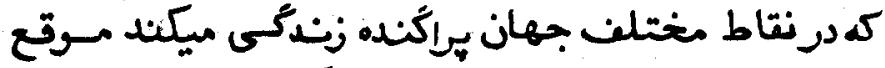

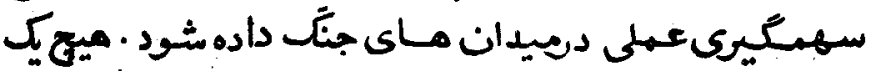

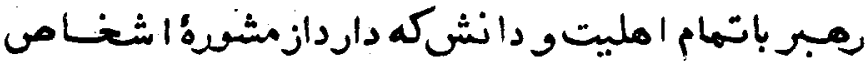

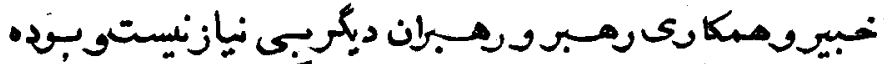

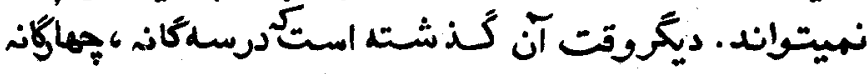

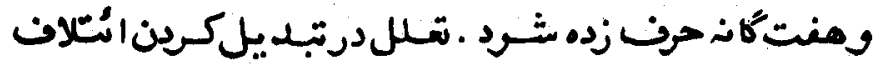

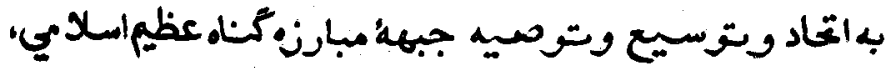

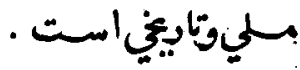

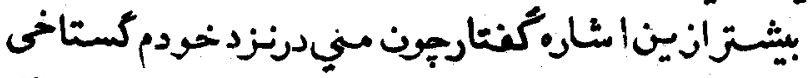

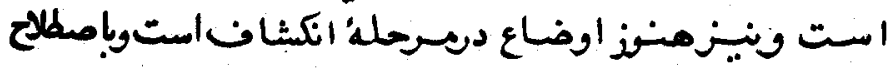

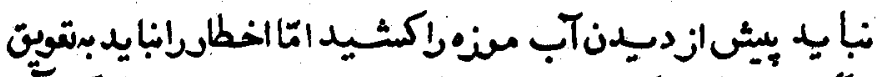

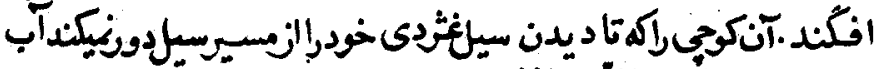

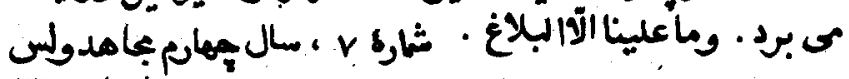
I 


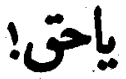

$$
\begin{aligned}
& \text { بلتقتيب الكلاعاتمثدماتى } \\
& \text { جيانماىمبيوطبافغانستان درباحئ } \\
& \text { بسينالملحهى } \\
& \text { موفضوعتعارنامريكابه بـآستان : }
\end{aligned}
$$

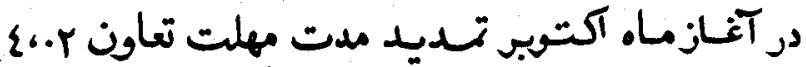

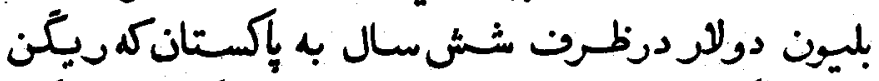

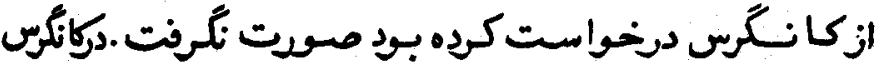

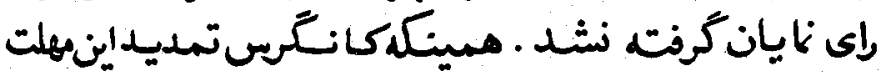

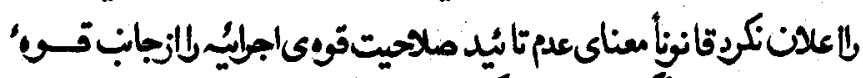

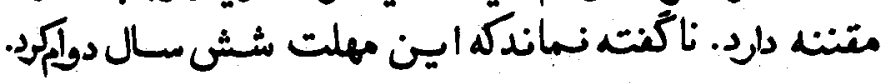




\section{rTo}

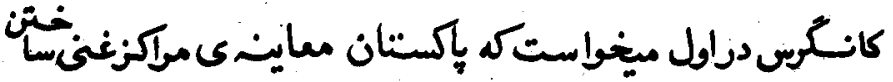

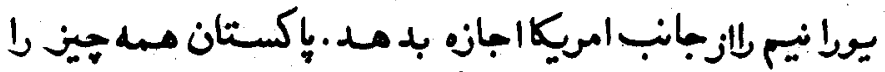

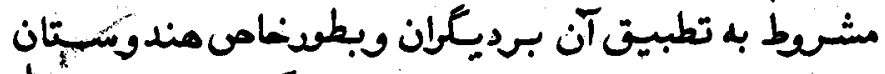

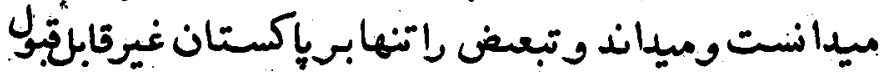

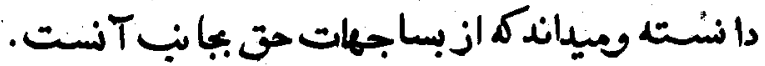

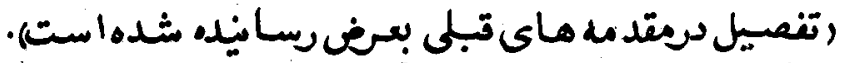

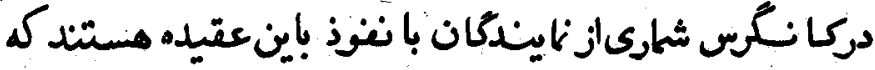

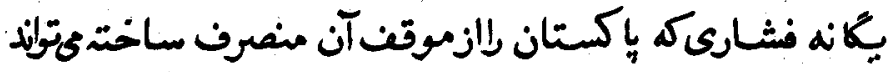

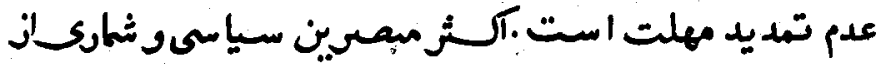

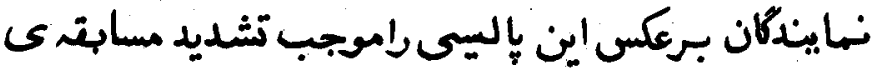

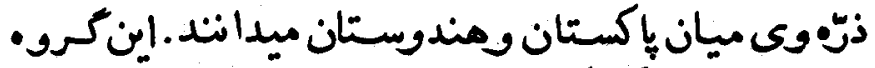

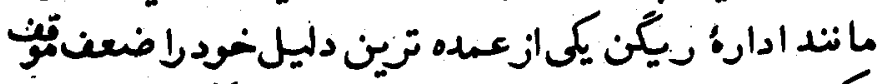

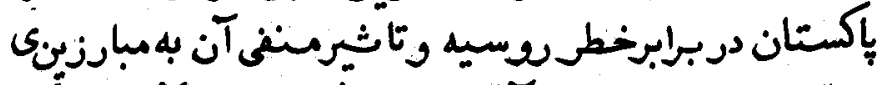

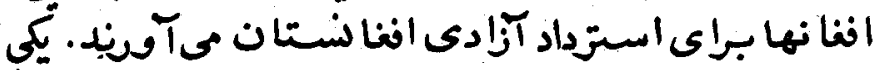

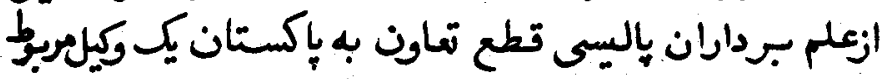

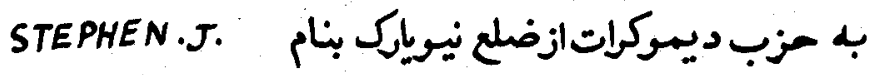
SOLA Z

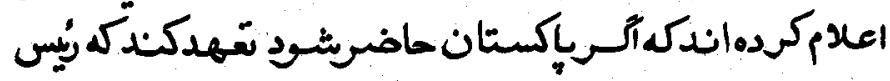

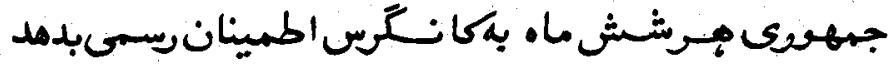

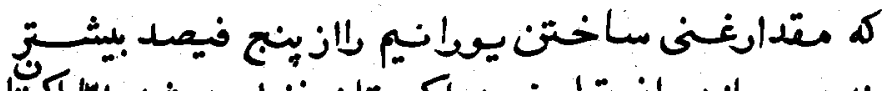

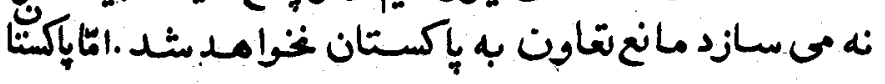




\section{rry}

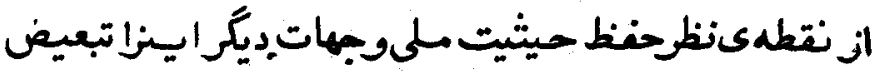

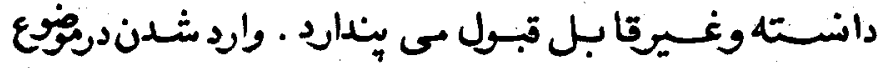

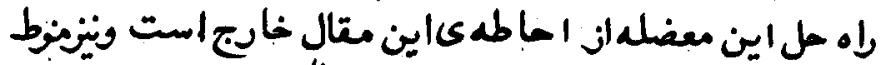

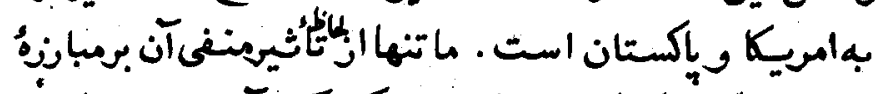

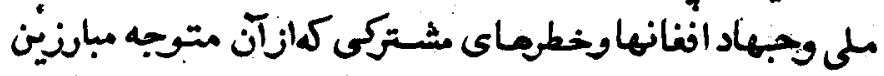

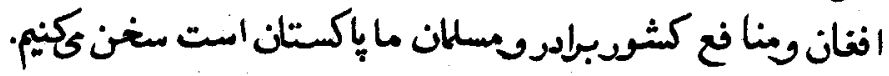

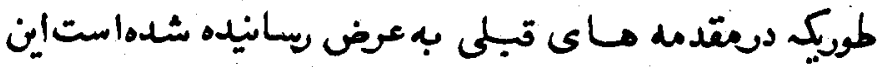

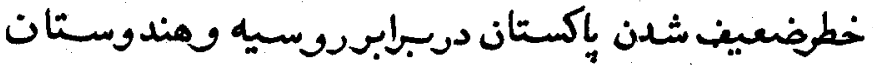

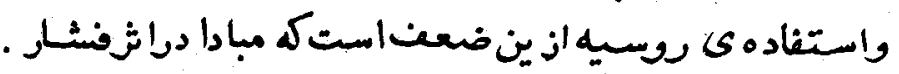

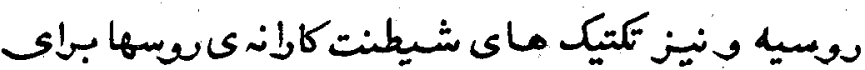

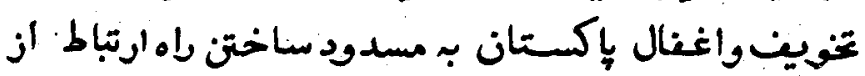

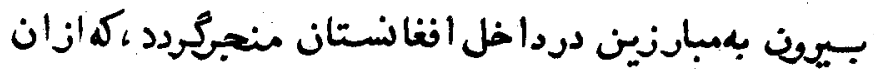

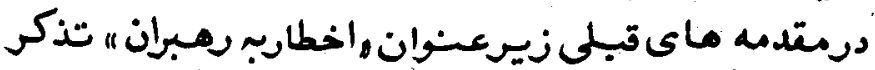

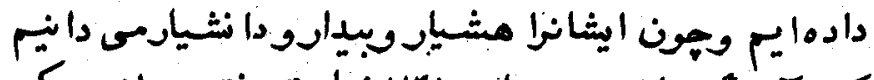

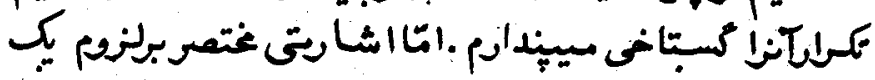

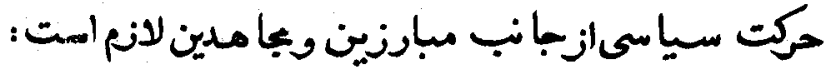

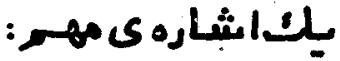

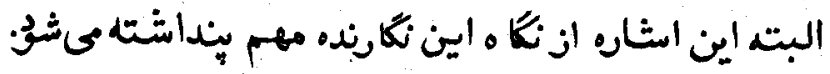

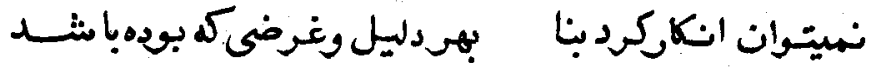

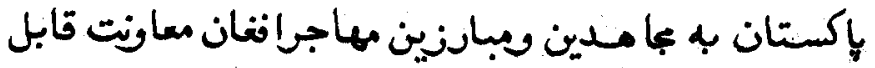

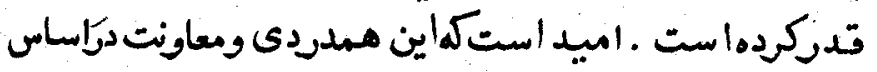




\section{MrV}

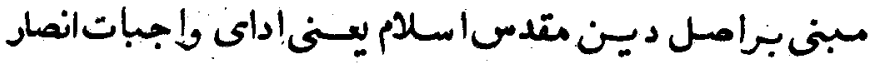

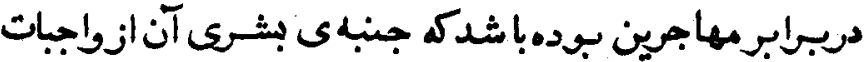

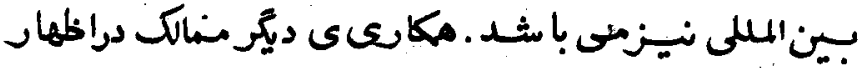

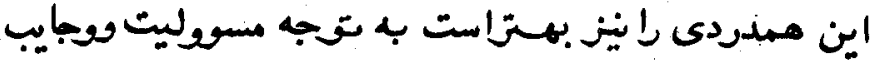

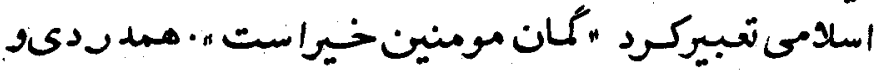

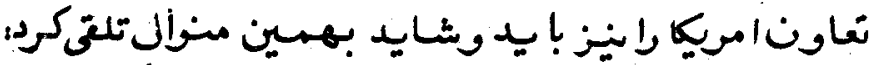

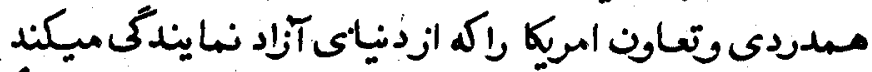

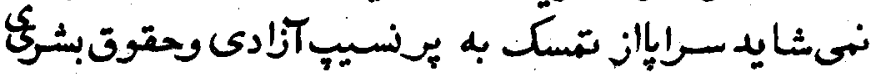

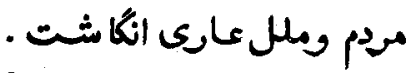

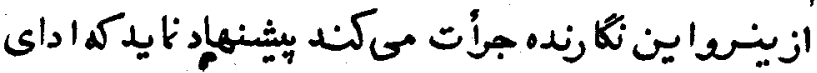

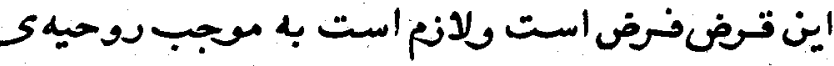

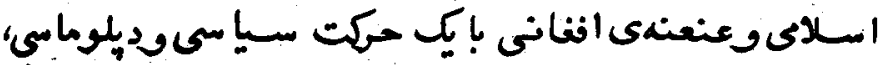

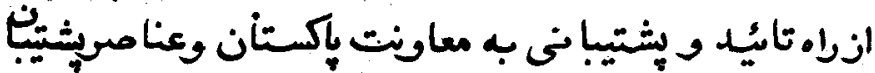

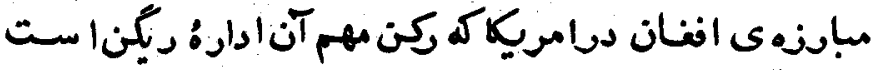

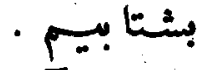

$$
\begin{aligned}
& \text { ج } \\
& \text { درمسلح'اول بدينتوني : }
\end{aligned}
$$

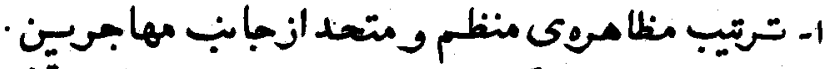

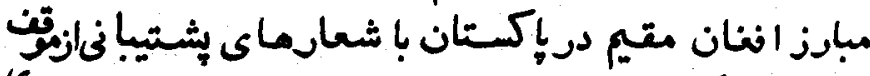

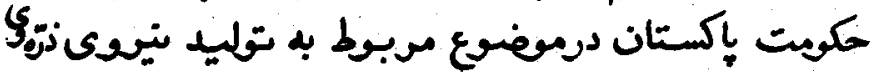

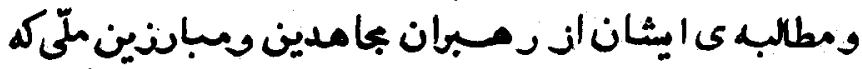




\section{rrA}

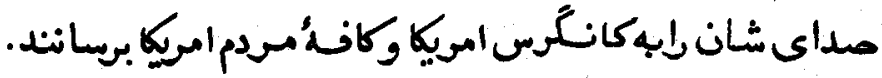

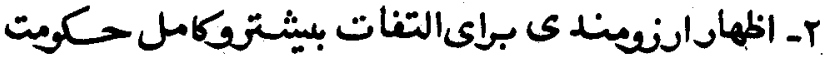

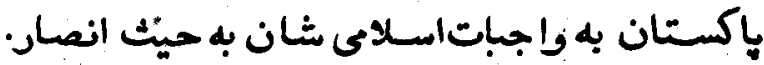

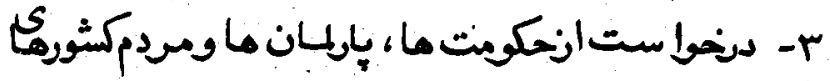

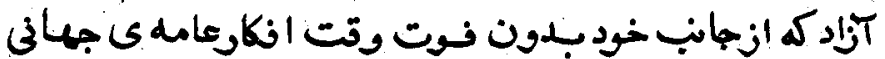

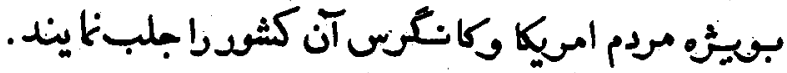

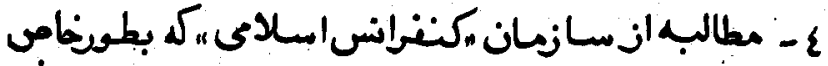

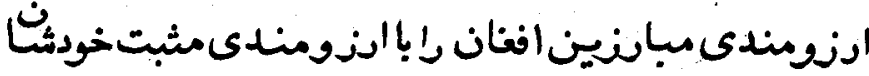

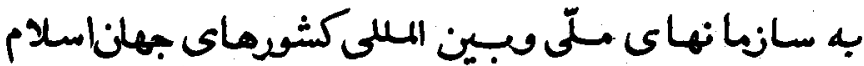

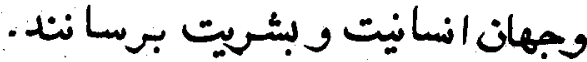

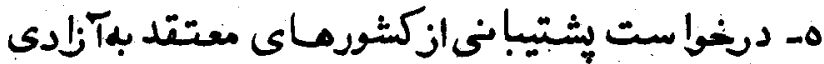

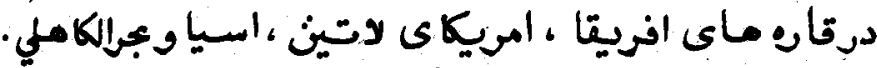

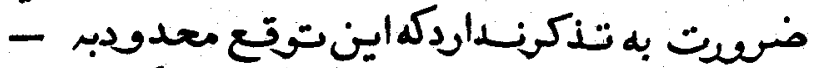

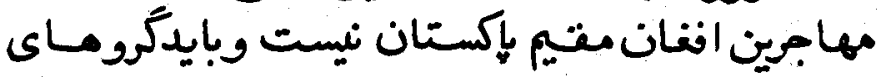

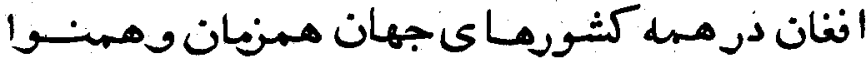

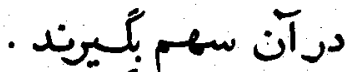

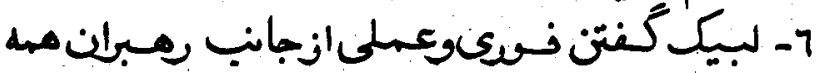
تنظم ها بطوقتتحد باين ارنومندى ومطالبات مردم

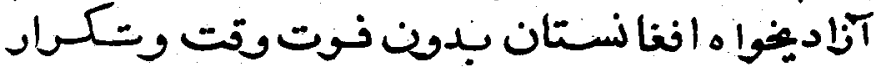

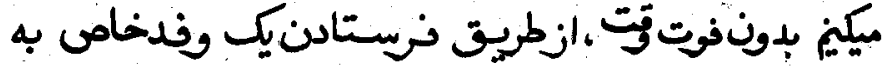

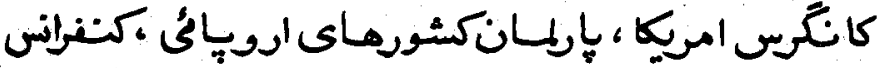




\section{rrq}

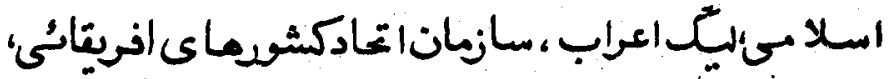

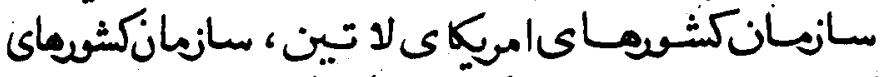

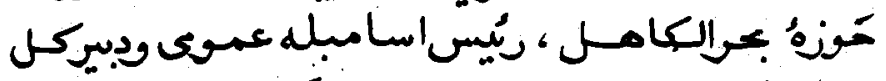

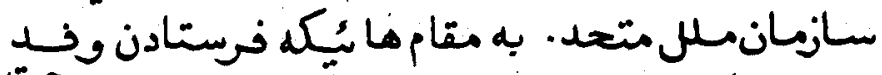

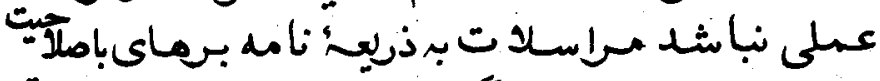

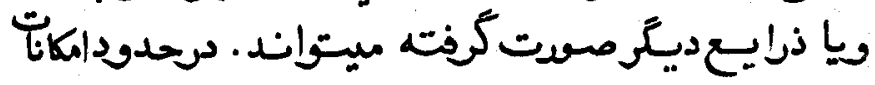

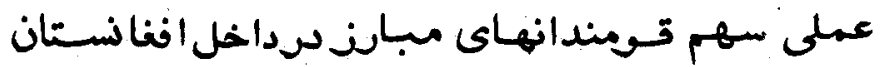

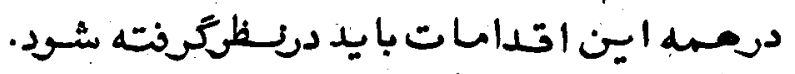

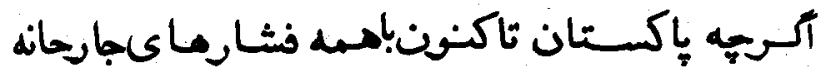

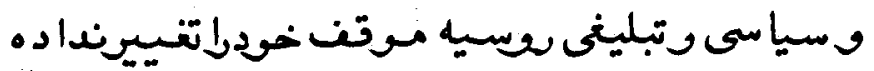

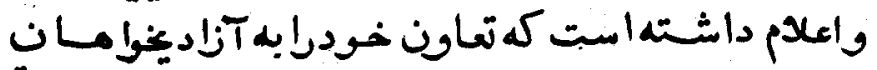

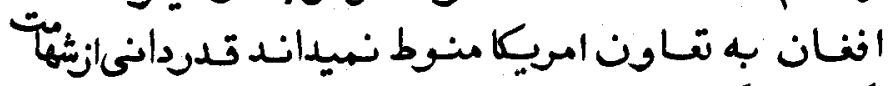

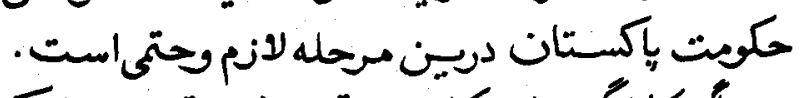

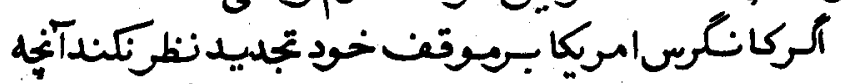

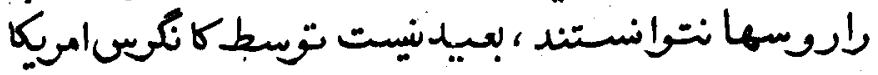

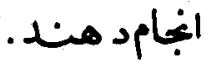

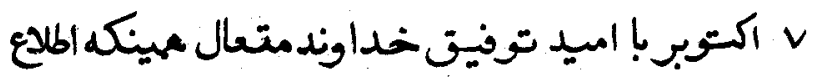

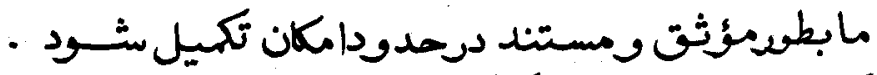

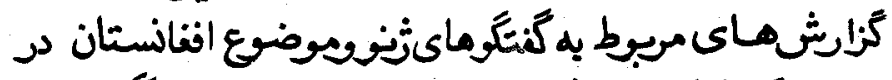

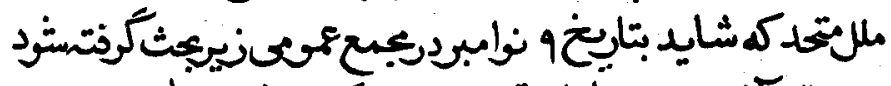

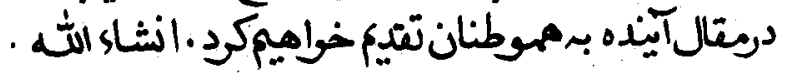

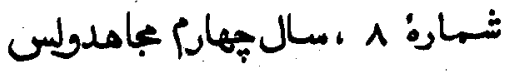




\section{ياحقن:}

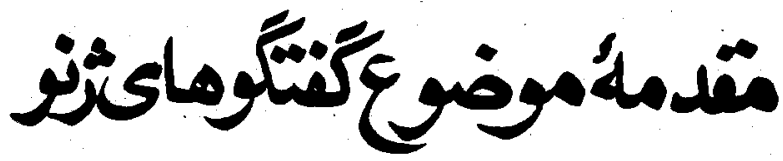
وبحثبرقضيهىجنئكانفانوروس

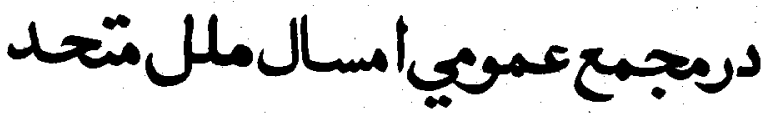

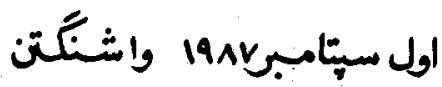

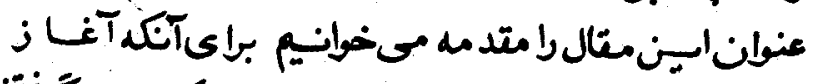

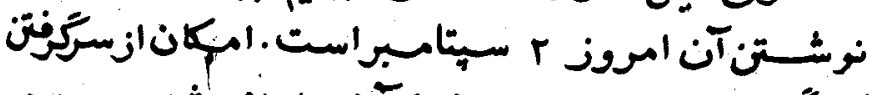

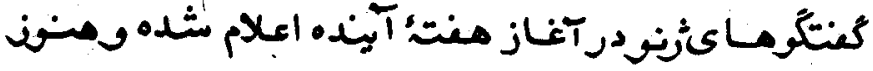

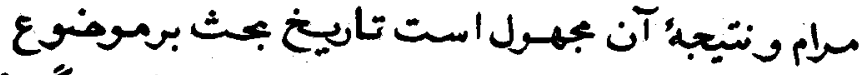

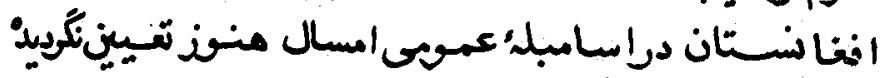

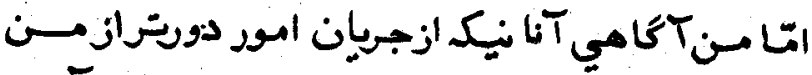

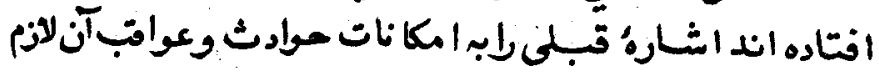




\section{rr}

مى دانم

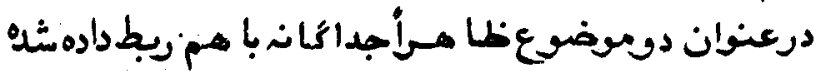

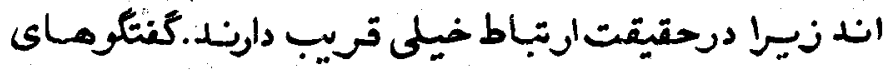

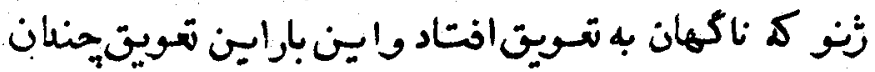

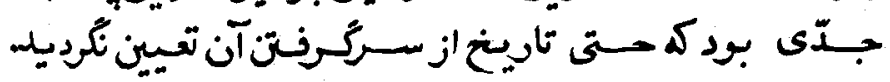

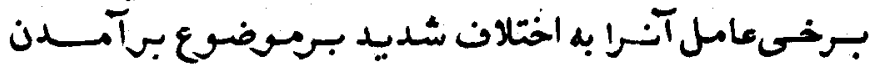

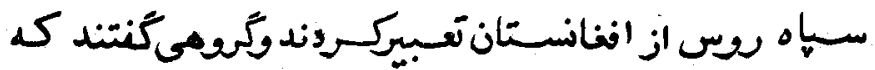

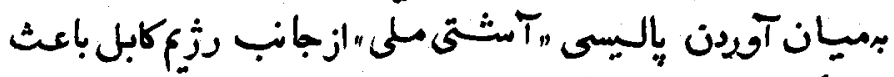

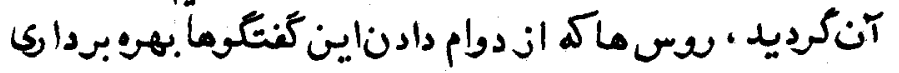

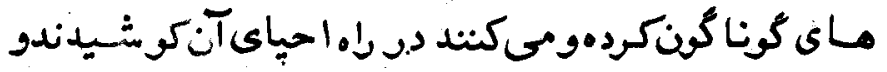

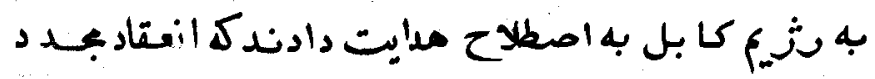

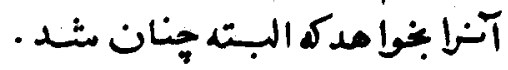

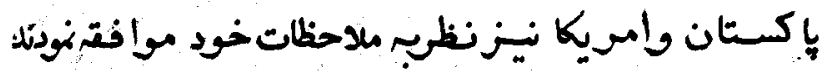

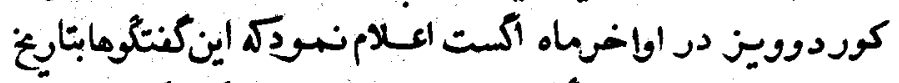

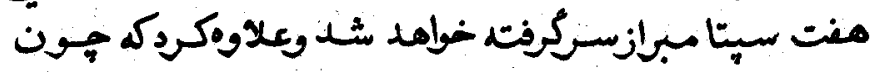

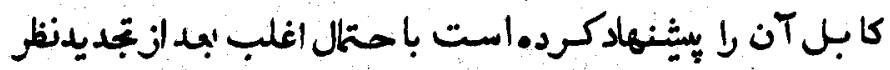

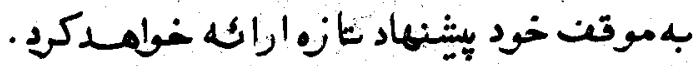

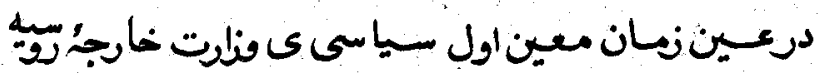

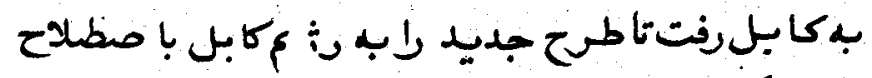

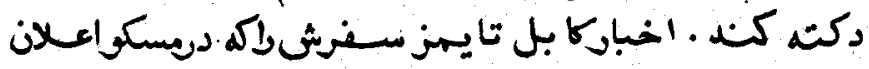

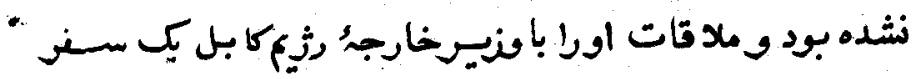




\section{TrT}

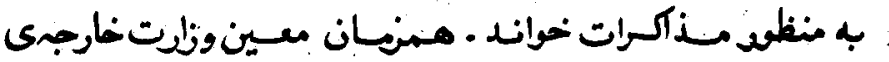

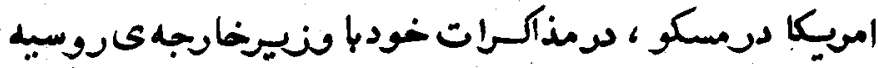

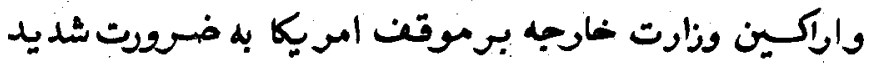

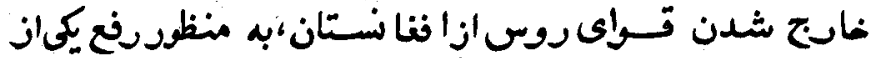

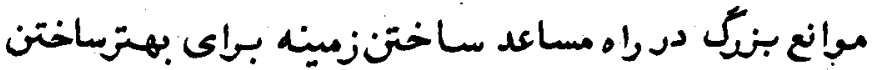

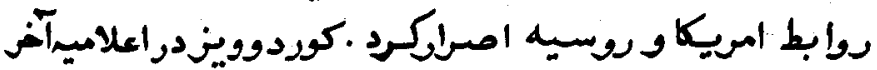

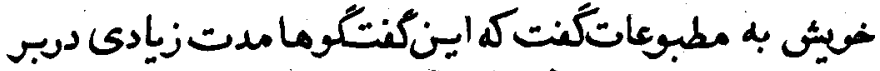

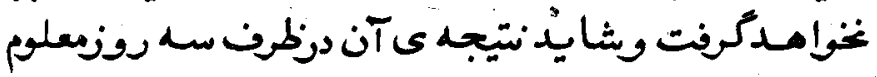

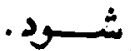

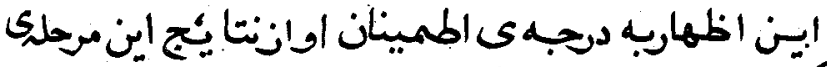

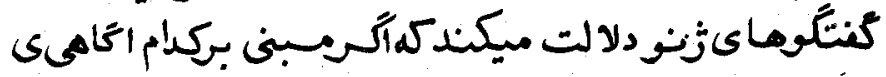

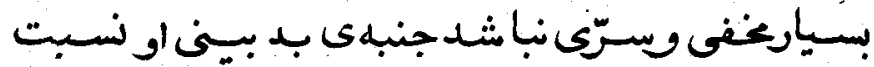

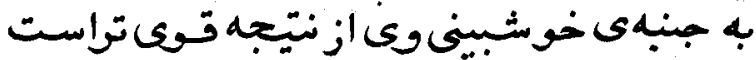

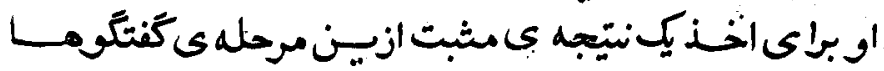

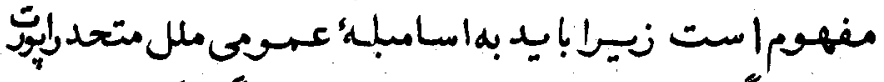

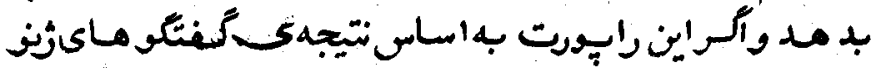

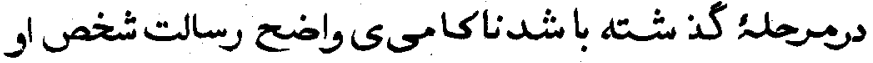

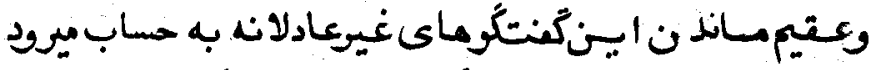

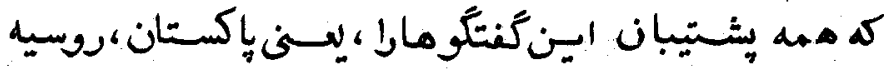

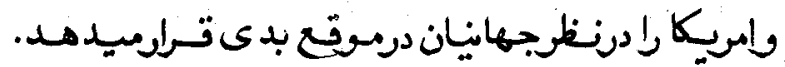

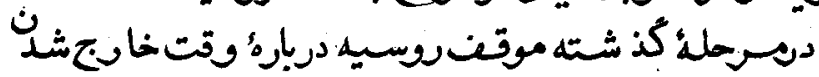




\section{rrr}

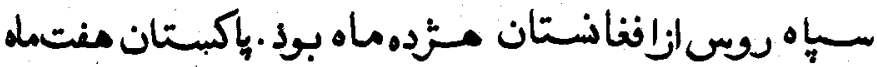

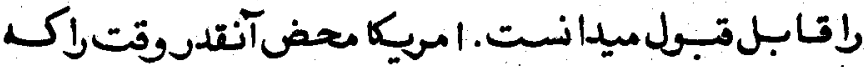

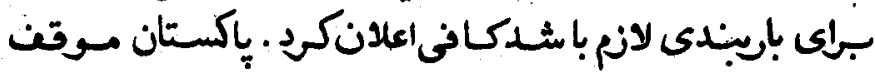

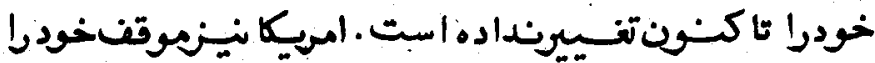

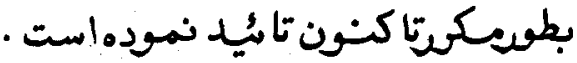

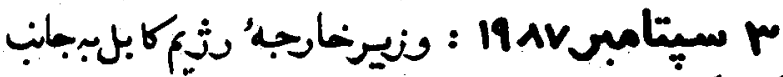

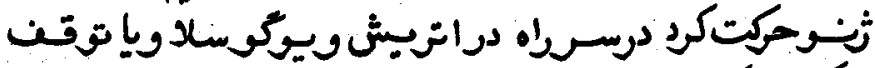

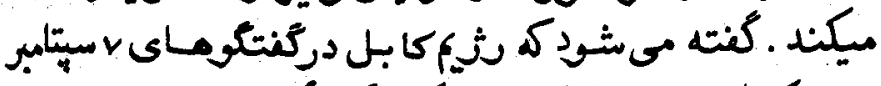

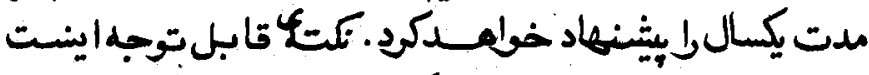

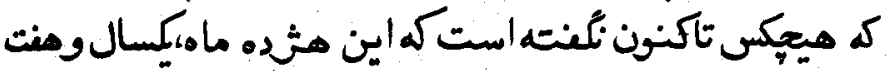

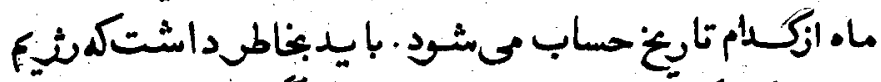

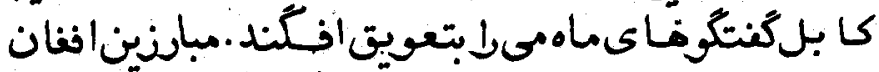

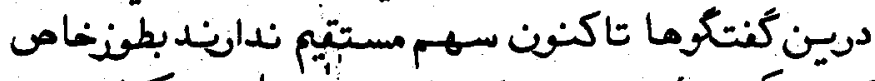

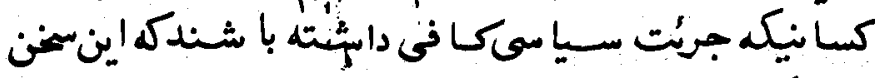

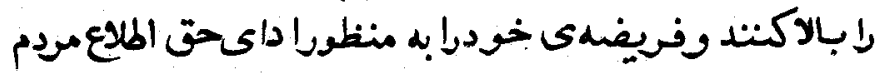

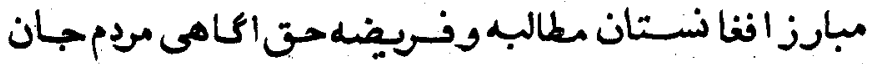

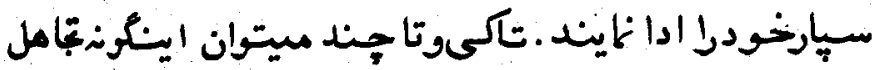

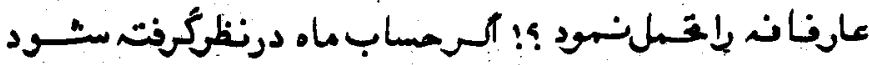

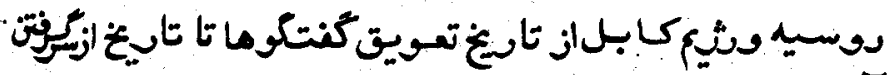

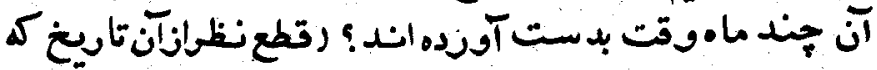

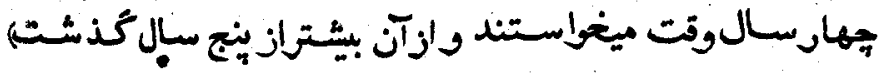




\section{rtg}

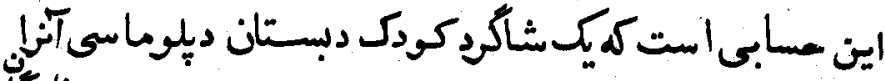

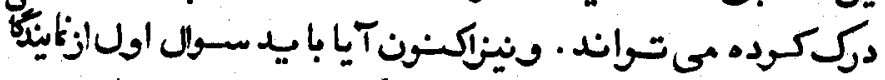

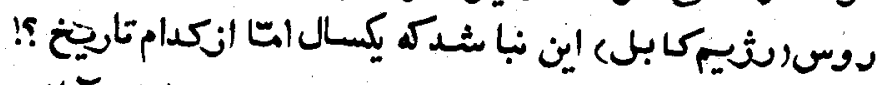

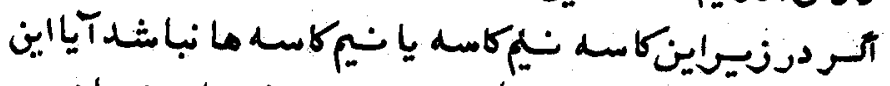

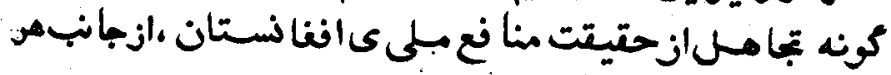

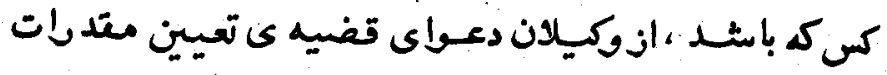

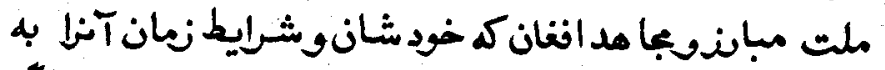

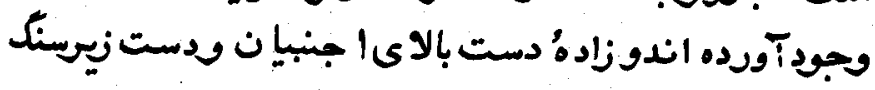

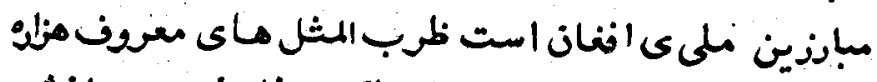

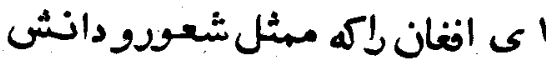

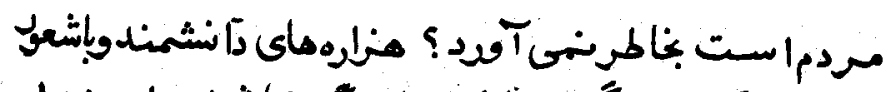

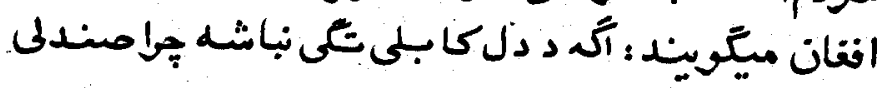

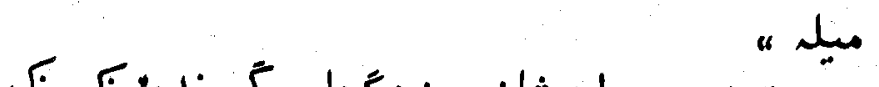

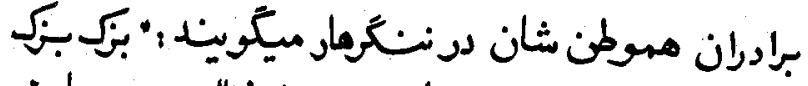

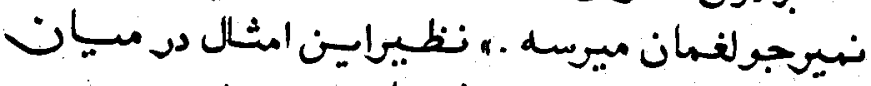

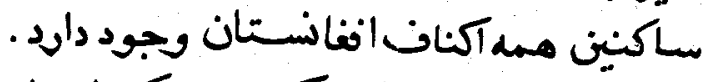

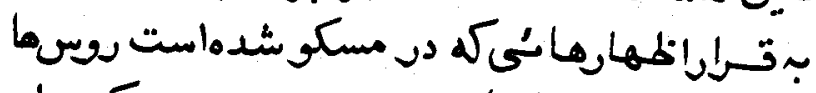

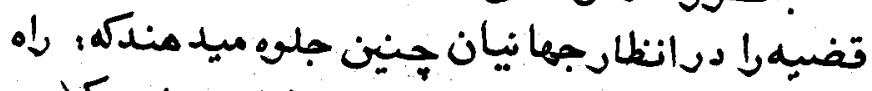

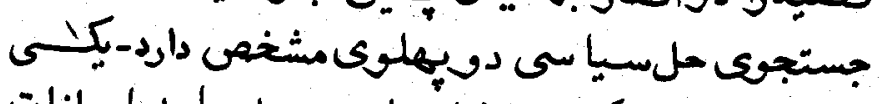

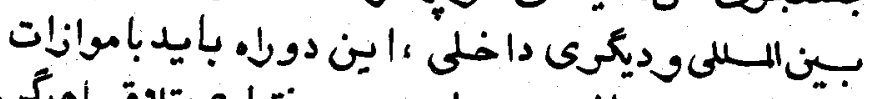

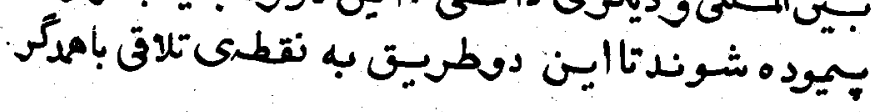




\section{rro}

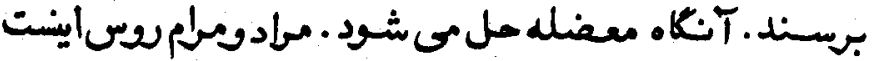

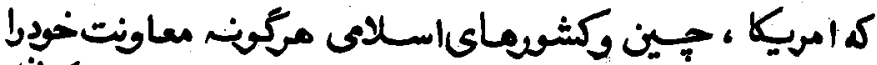

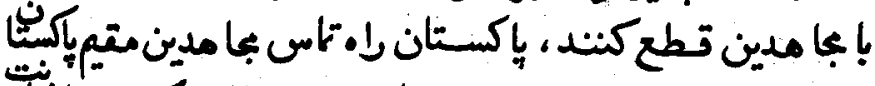

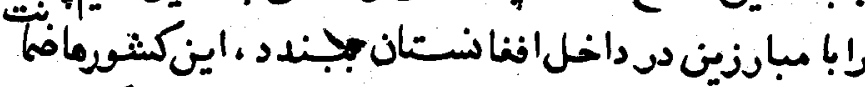

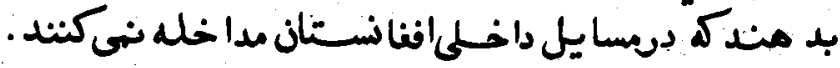

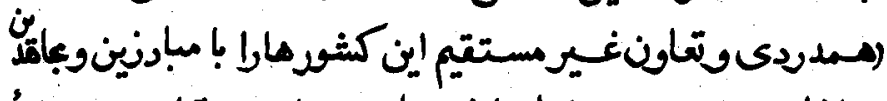

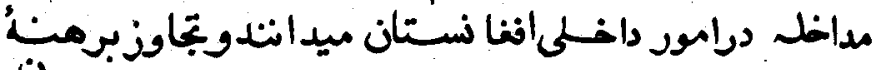

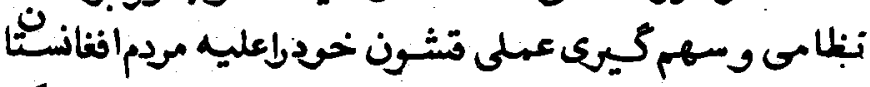

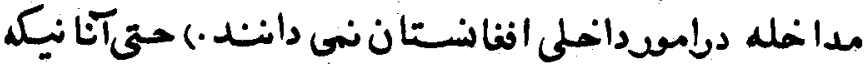

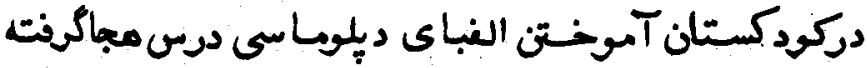

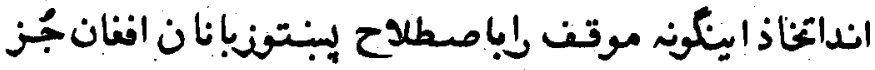

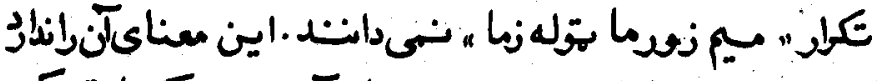

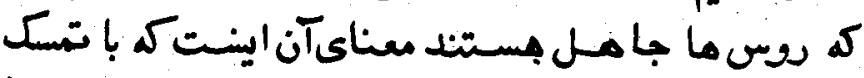

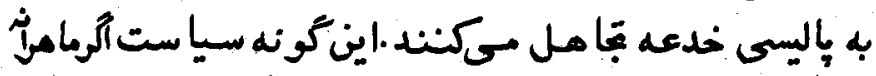

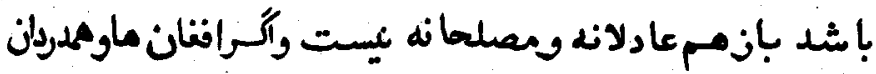

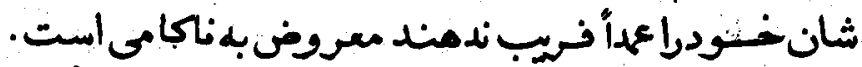

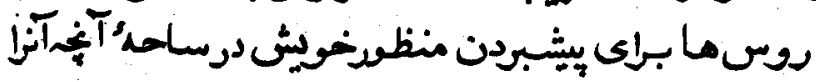

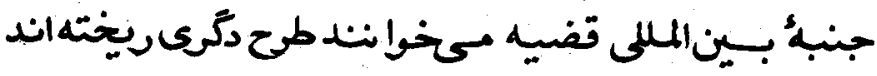

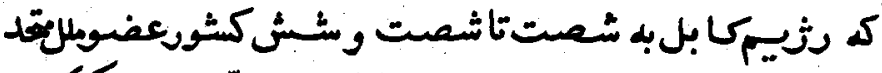

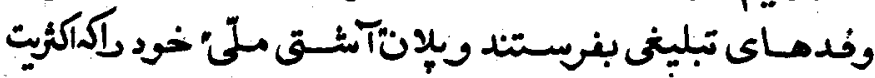

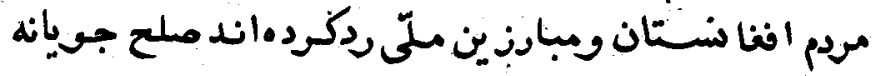


rry

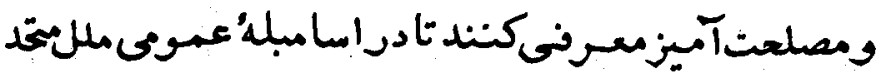

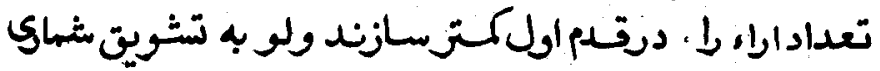

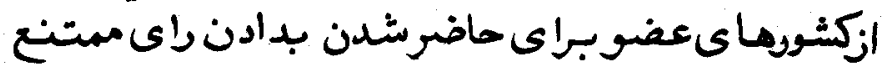

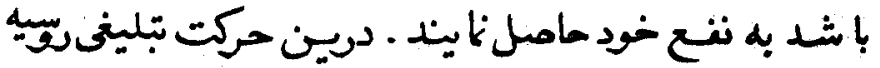

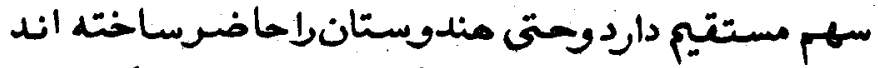

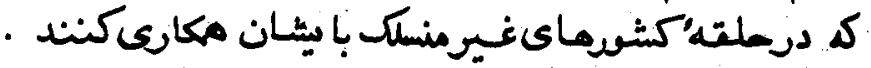

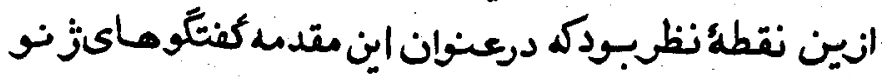

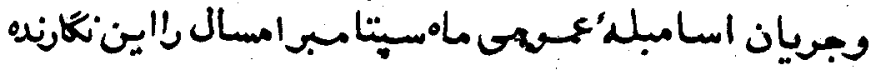

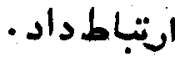

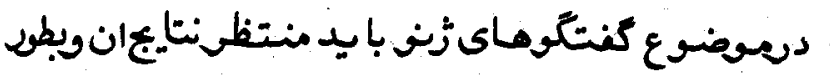

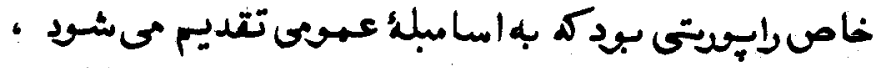

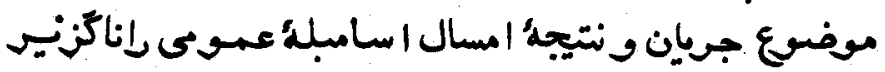

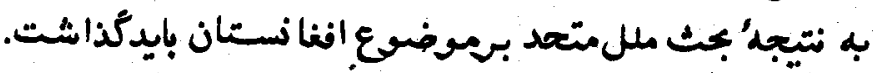

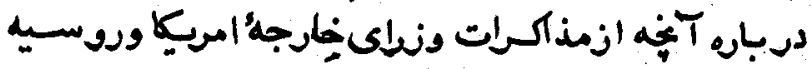

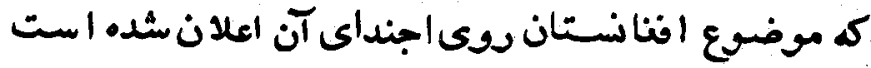

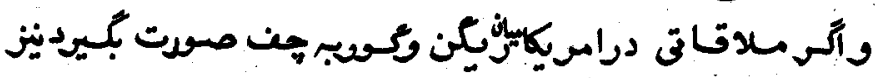

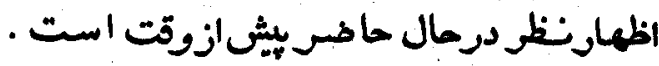

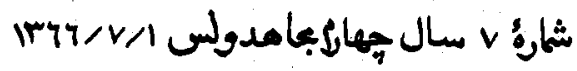




\section{6}

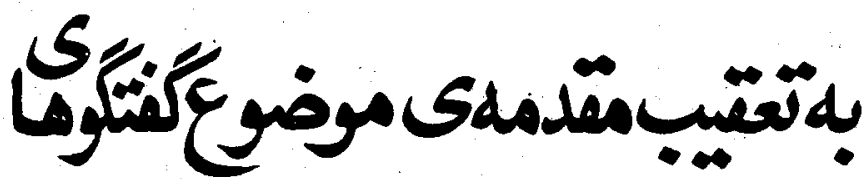
ثزلو

1411

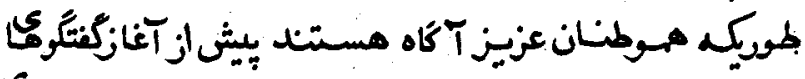

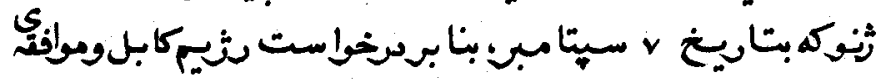

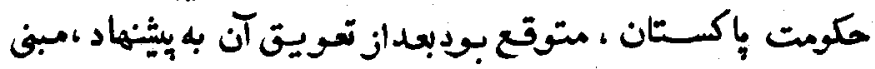

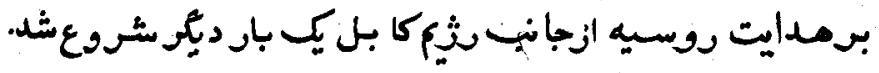

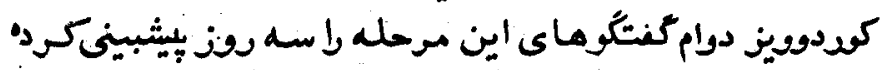

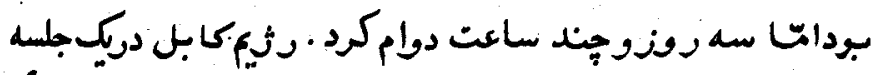

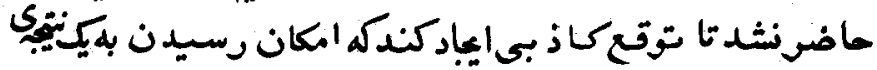

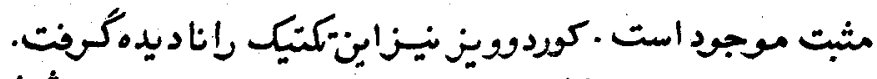

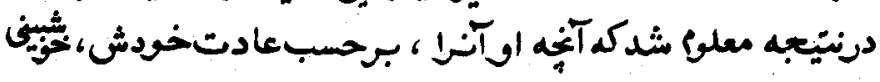

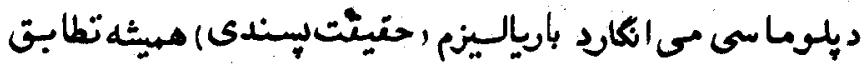




\section{rrA}

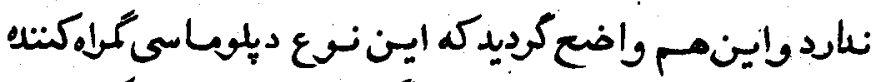

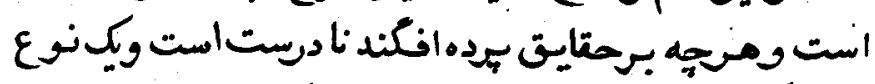

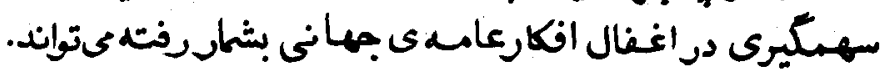

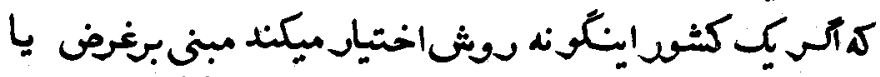

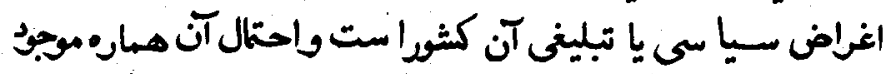

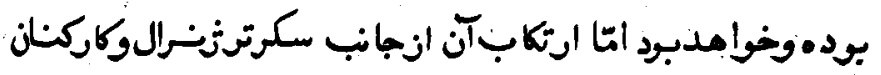

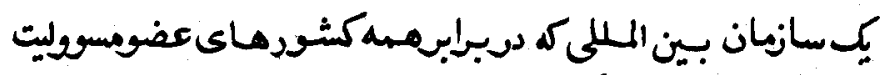

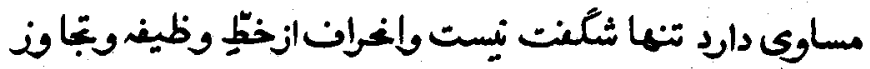

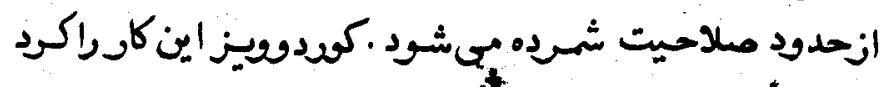

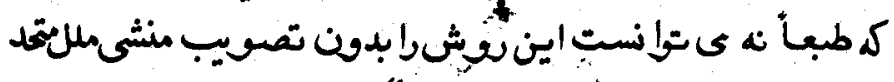

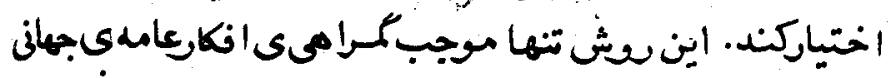

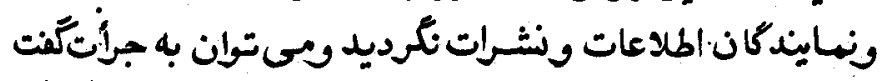

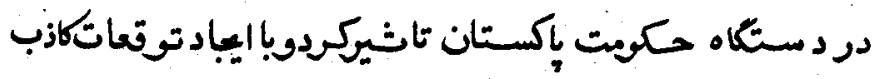

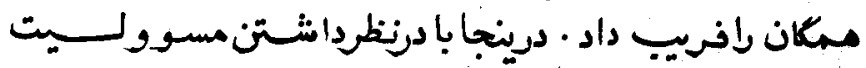

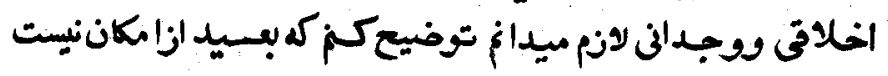

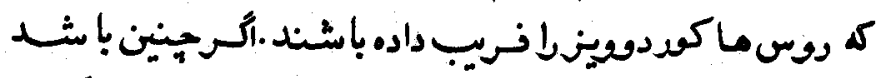

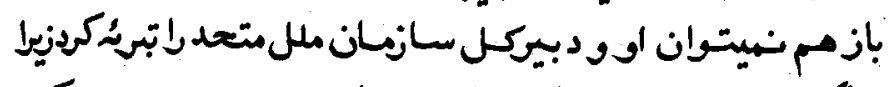

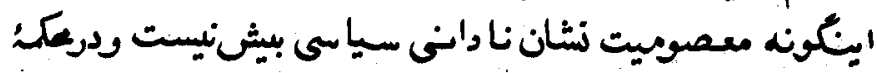

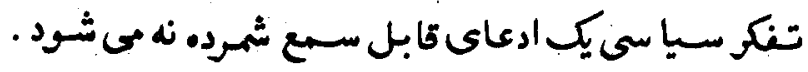

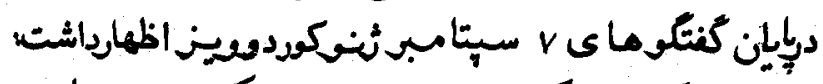

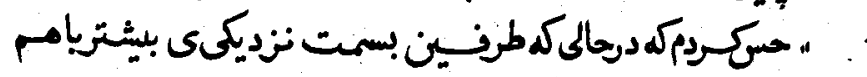




\section{rra}

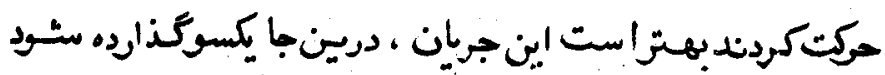

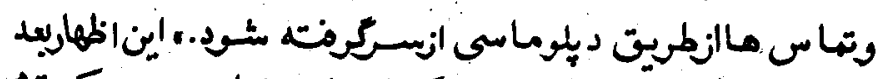

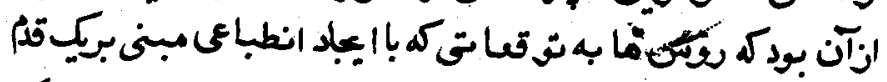

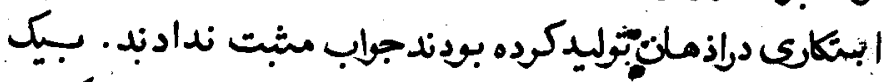

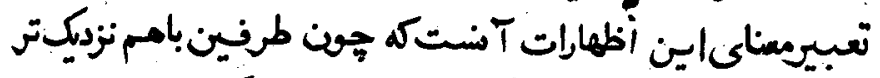

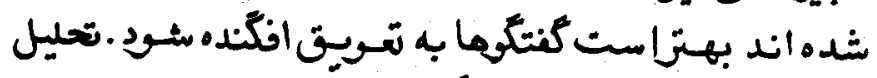

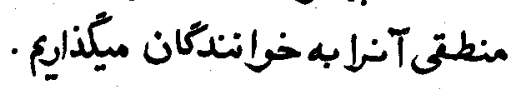

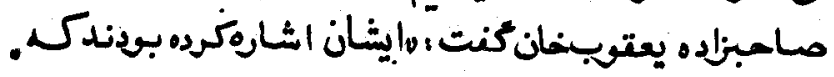

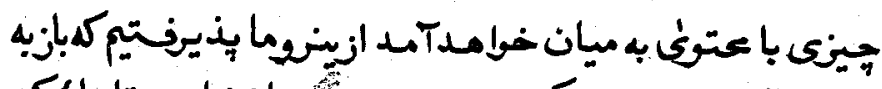

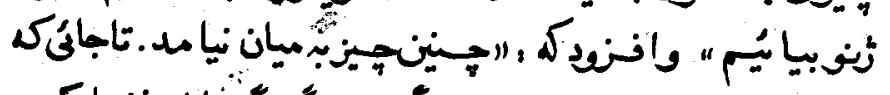

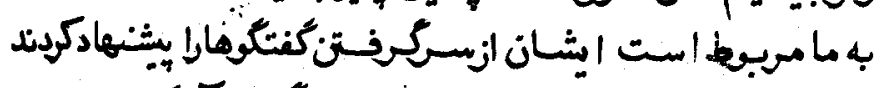

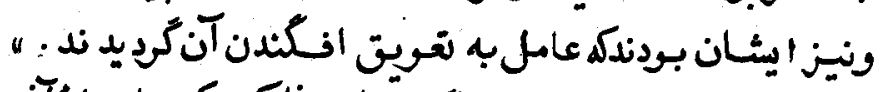

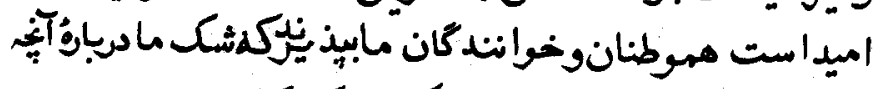

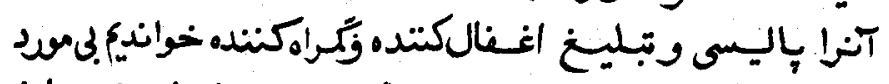

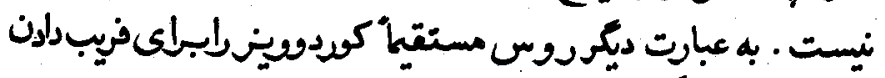

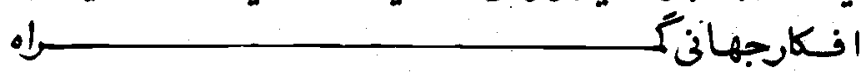

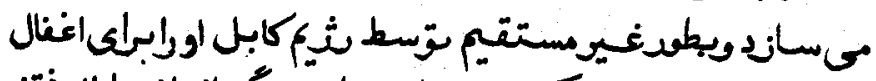

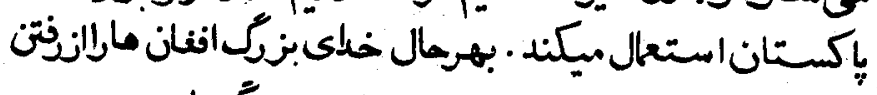

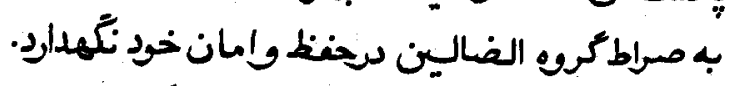

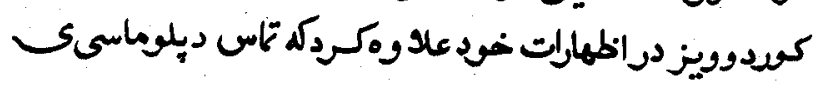




\section{rq.}

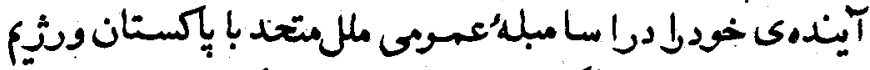

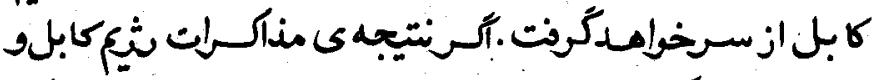

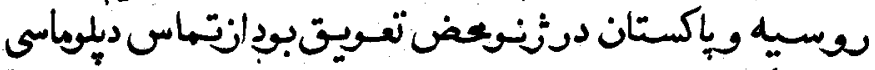

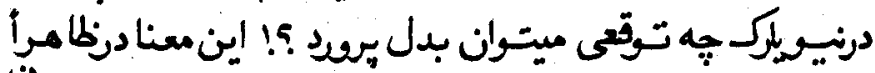

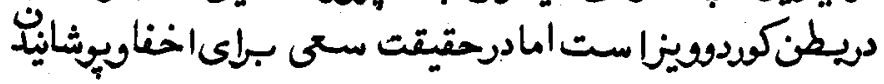

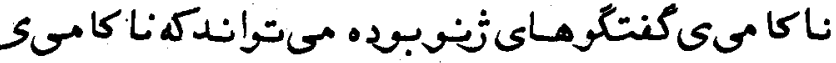

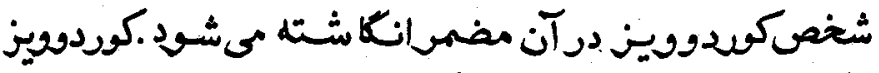

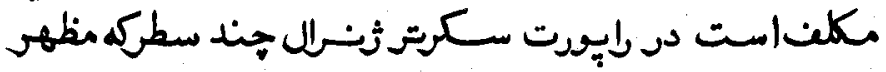

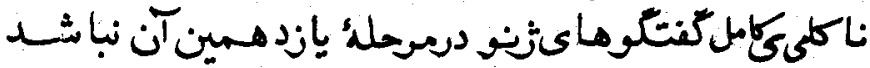

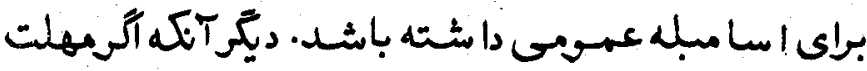

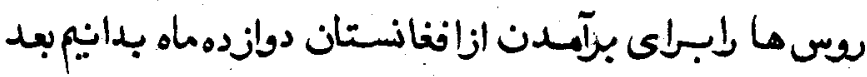

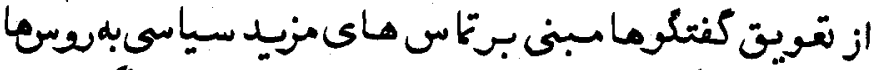

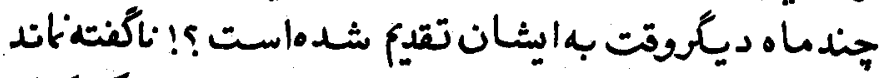

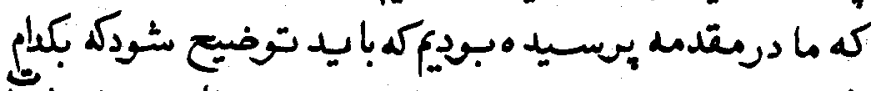

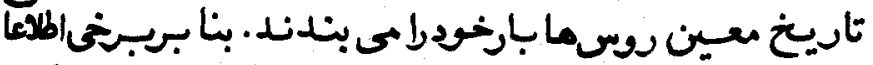

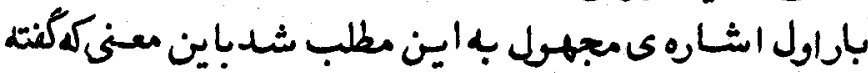

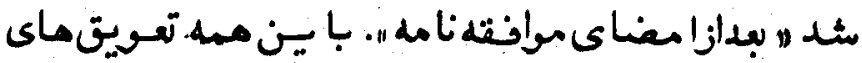

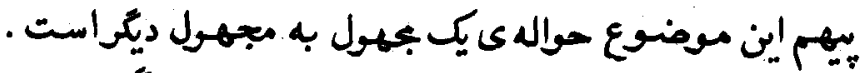

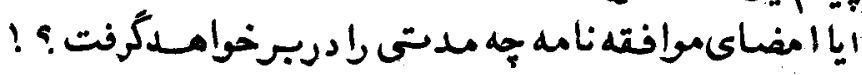

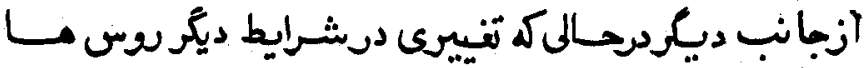

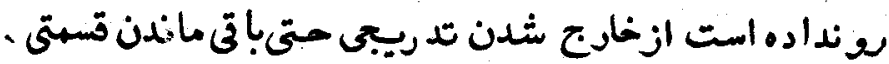


ازتشثون روس سغن مىرود.

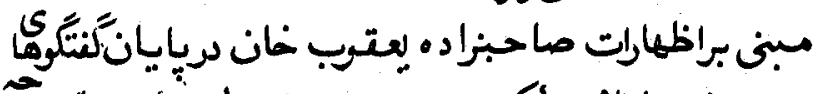

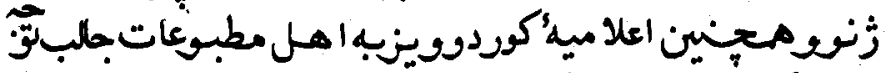

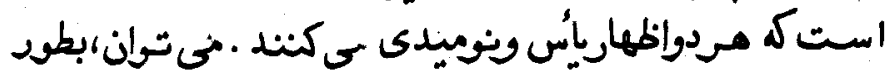

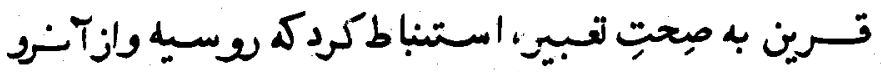

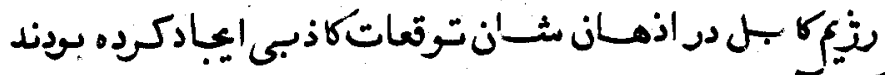

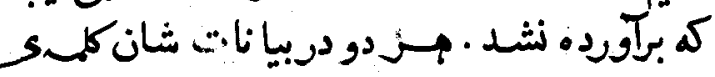

ل disapporntment

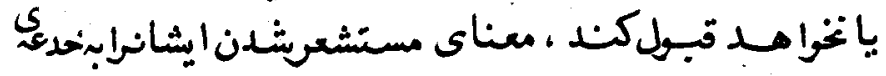

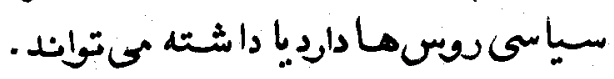

IV

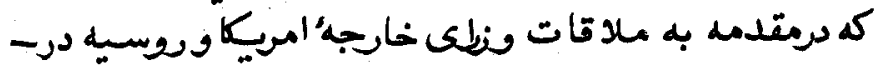

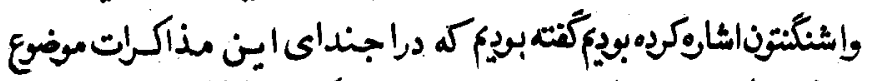

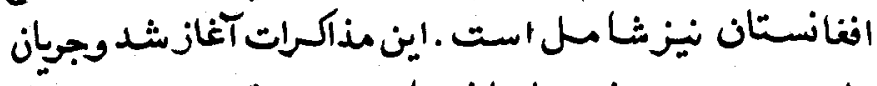

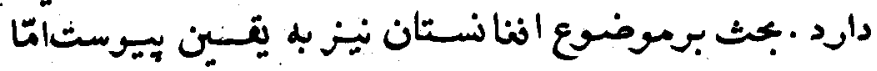

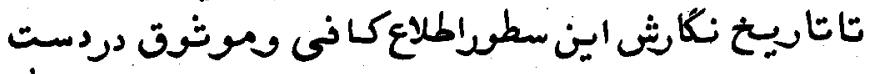

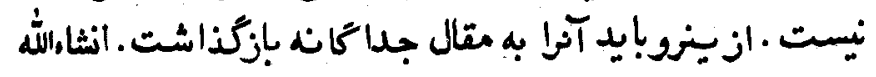

شـسازة 1 • مالجهارم بجا هدولس

|r|1 

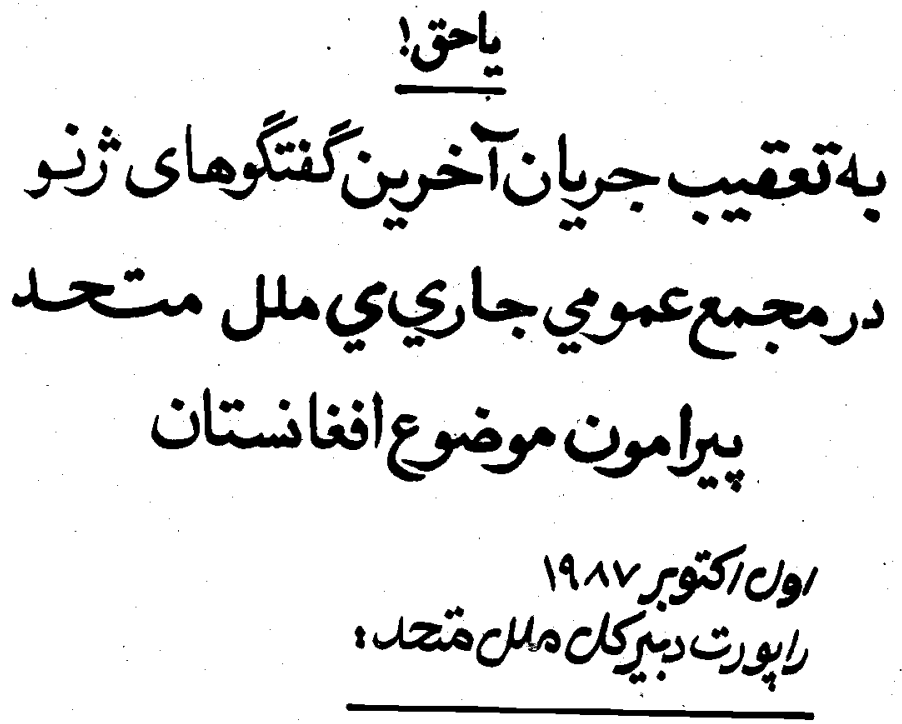

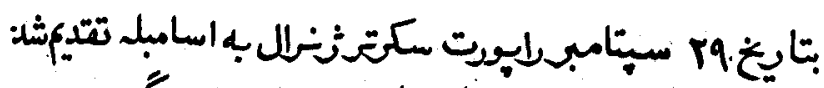

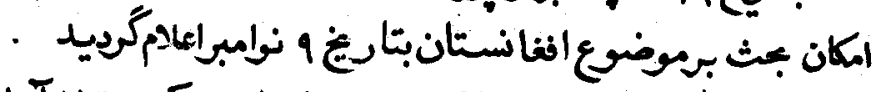

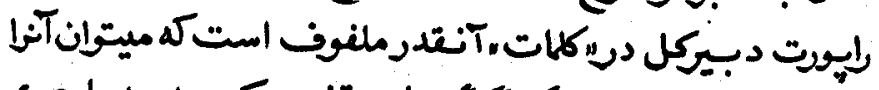

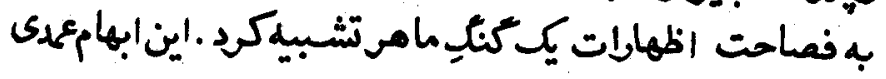

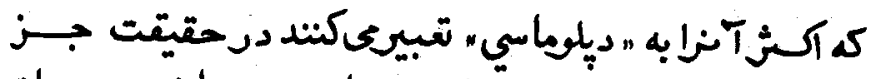

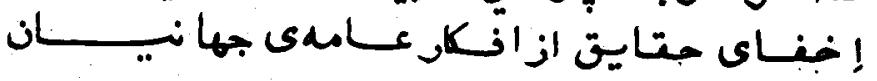




\section{TET}

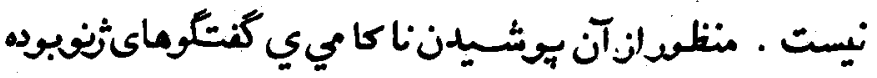

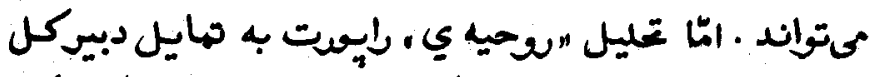

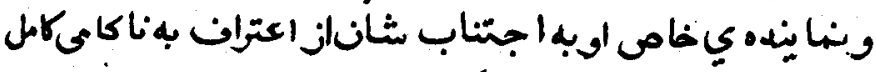

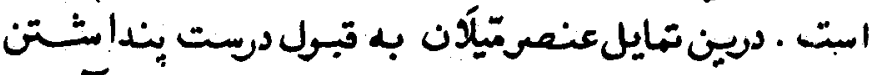

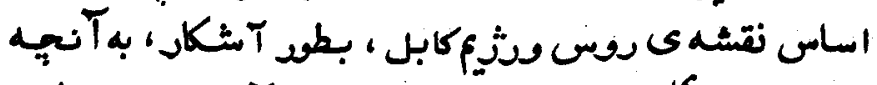

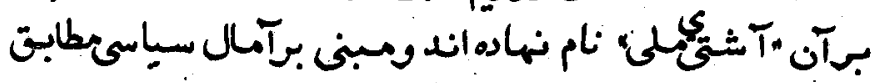

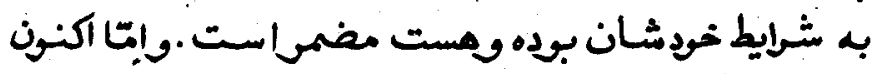

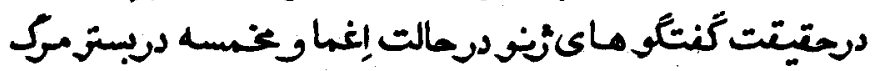

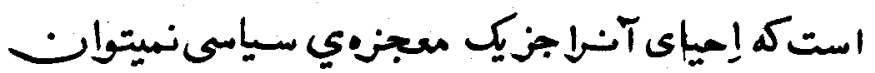

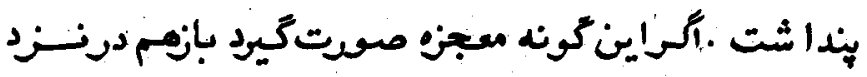

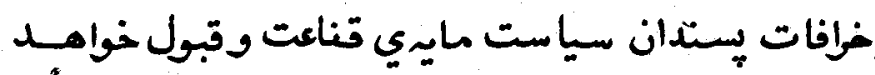

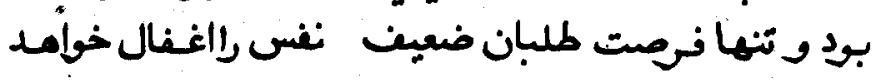

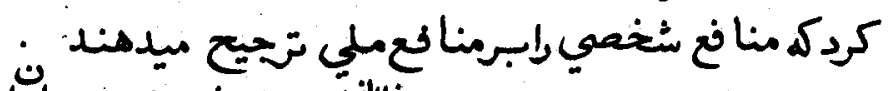

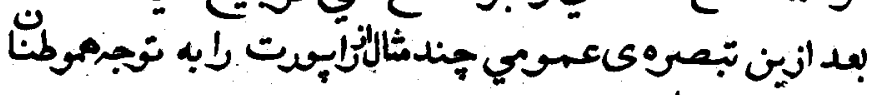

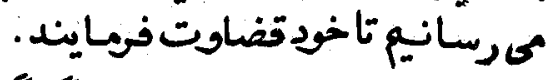

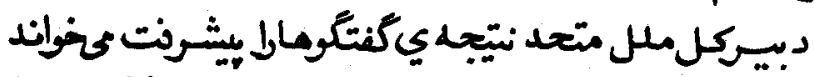

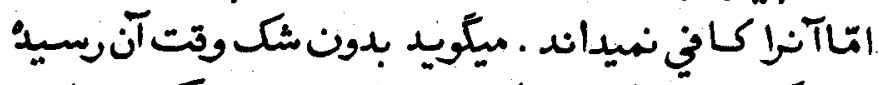

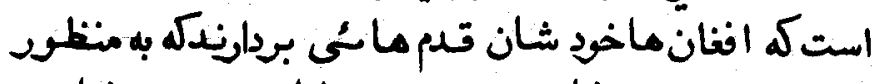

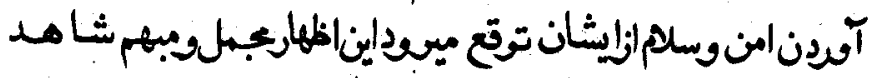

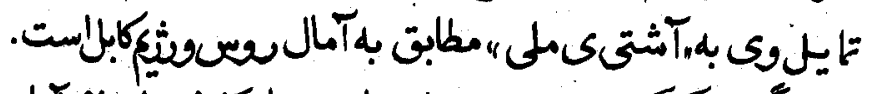

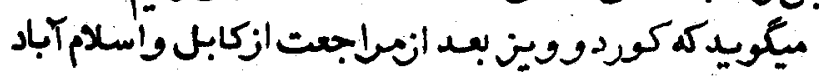




\section{ris}

باوكفت كم امكانات موا فقت رادربارهى تطبيقنقشهى طرح

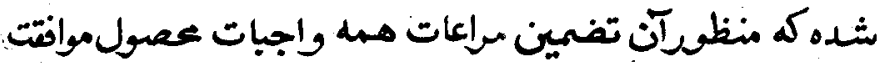

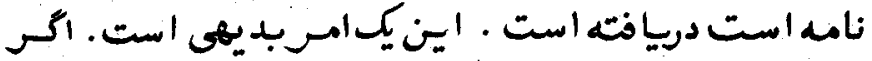

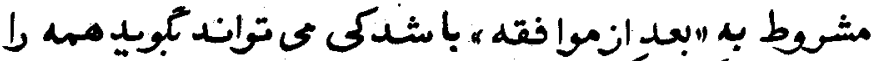

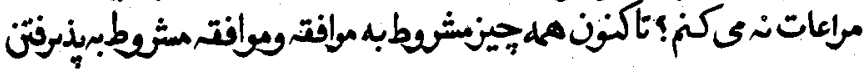
مترايط روي است . رومهاودست نشاندمّان شثان تا مر

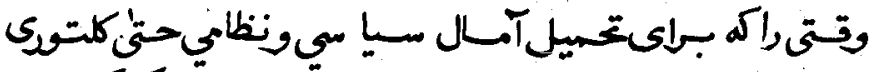

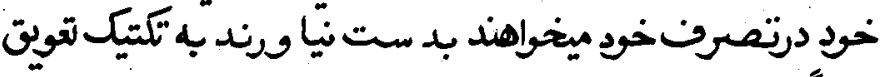

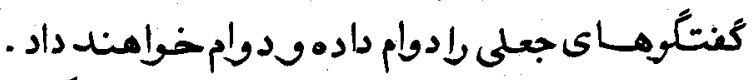

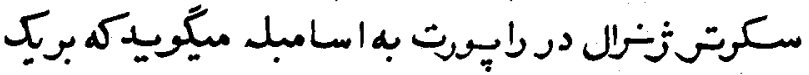

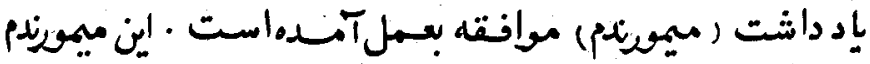

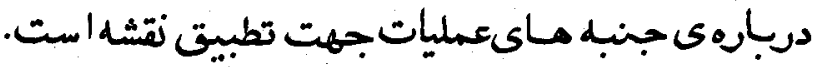

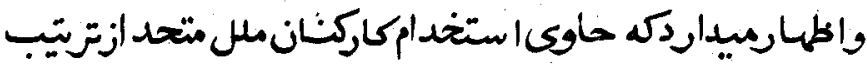

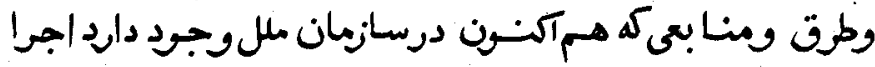

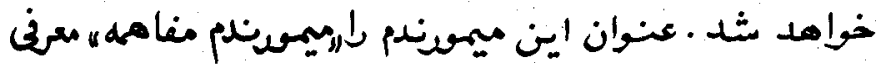

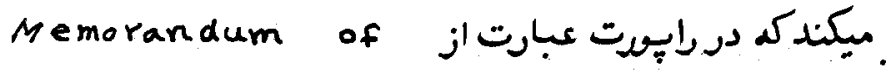
understanding

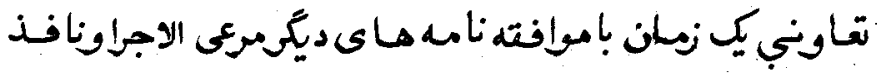

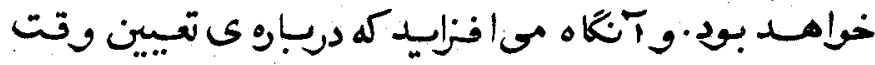

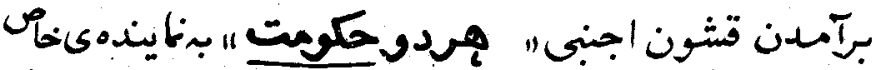

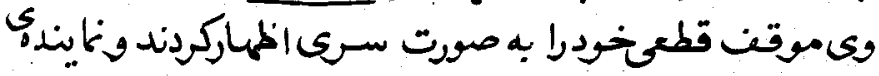




\section{ro}

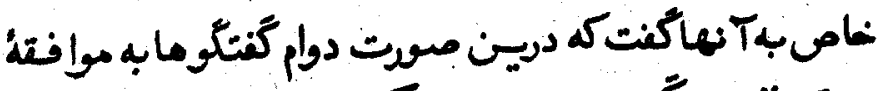

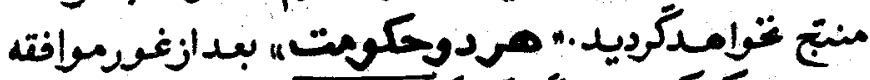

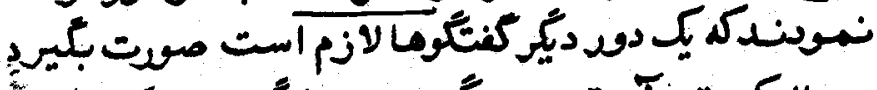

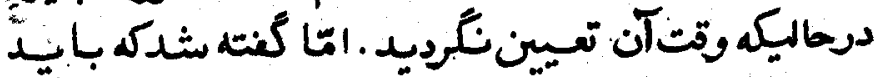

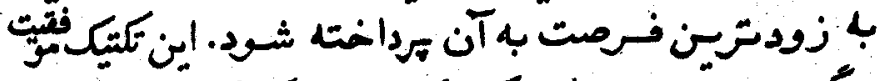

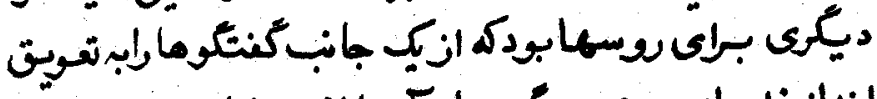

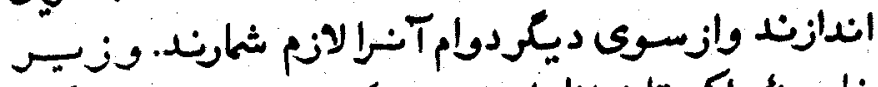

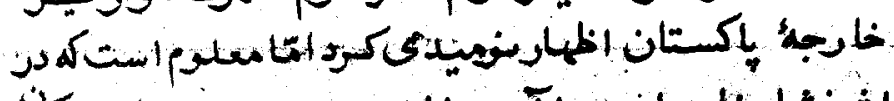

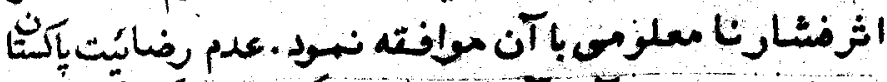

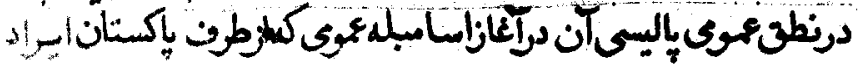

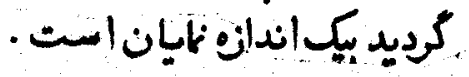

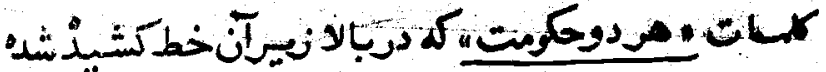

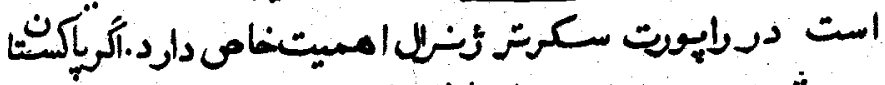

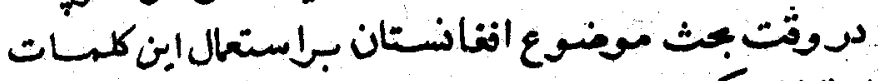

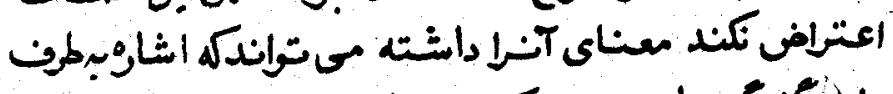

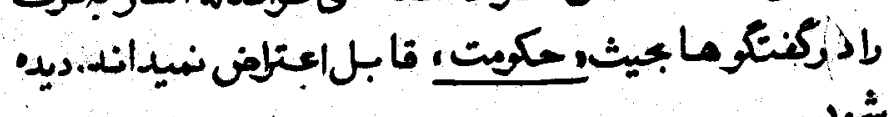

$$
\text { شود. }
$$

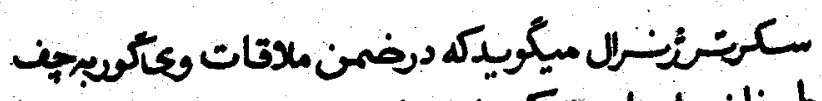

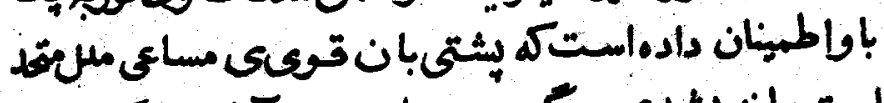

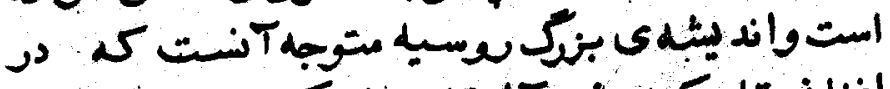

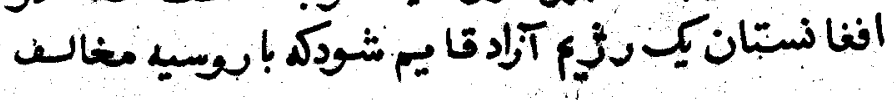




\section{P\{7}

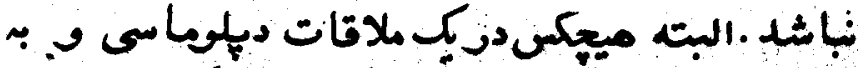

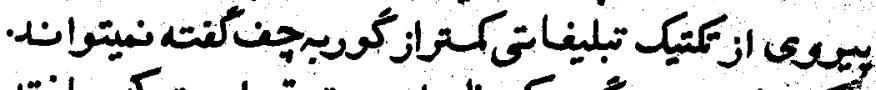

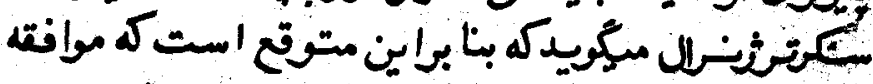

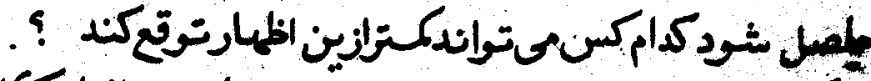

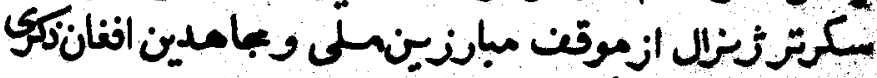

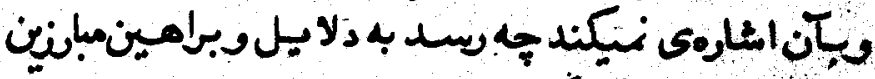

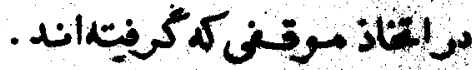

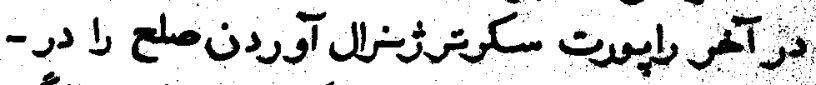

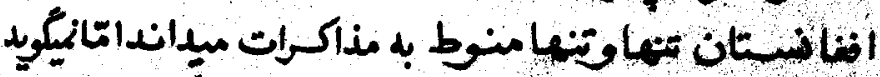

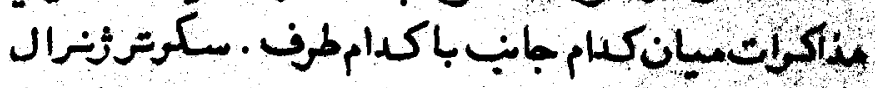

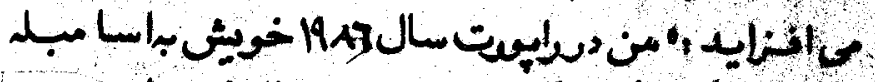

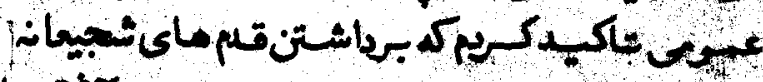

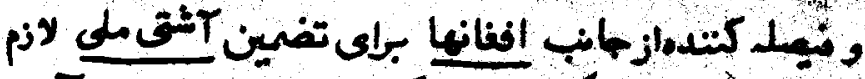

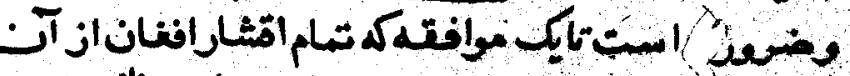
-

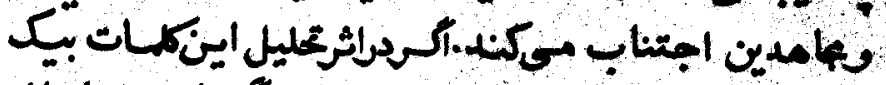

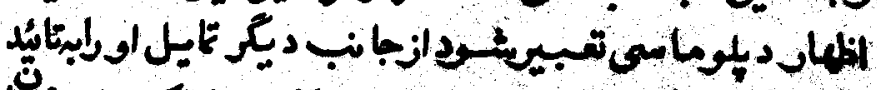
هـ .T

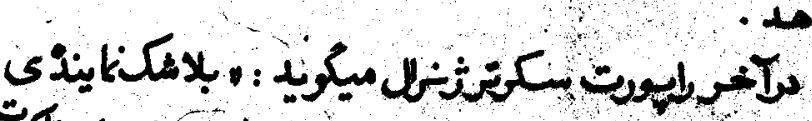

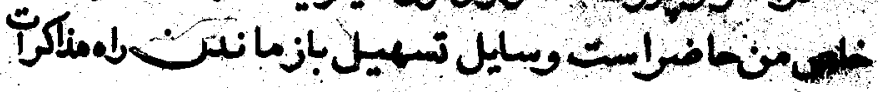




\section{TEV}

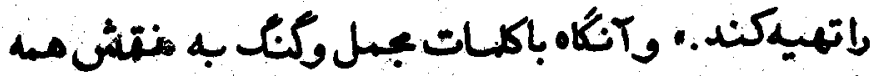

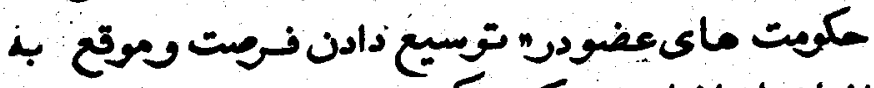

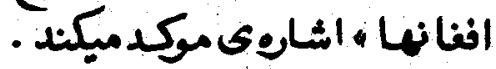

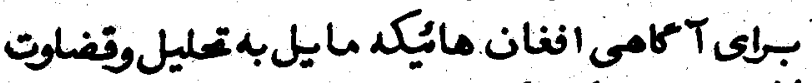

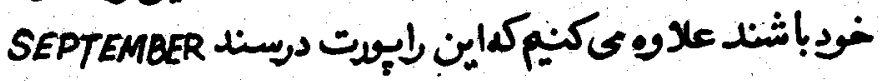
A/42/600,S/19160, 29

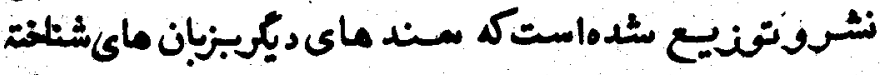

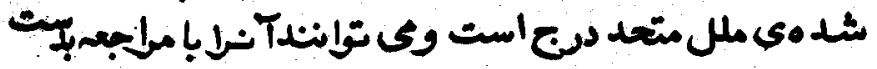

$$
\text { Tوندا }
$$

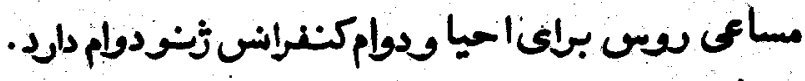

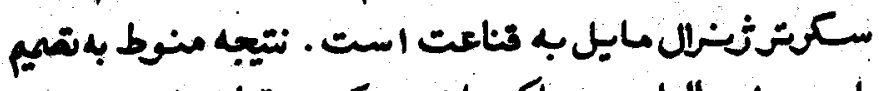

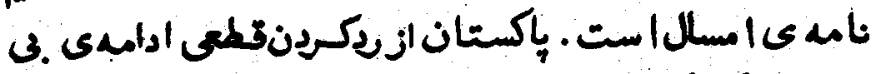

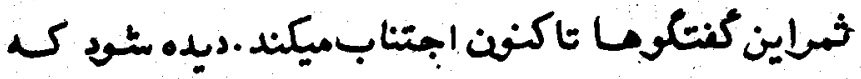

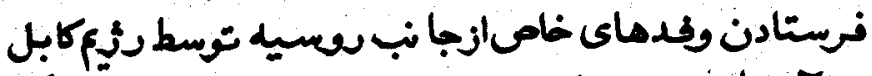

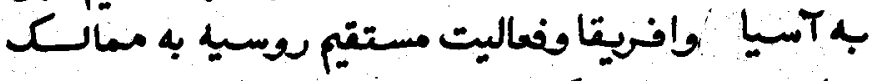

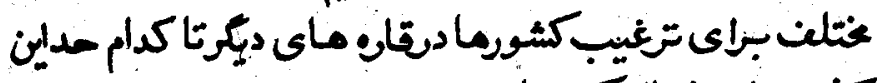

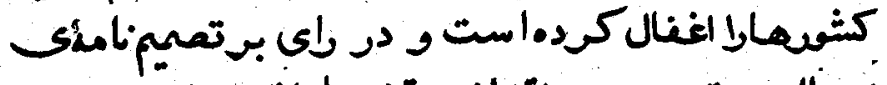

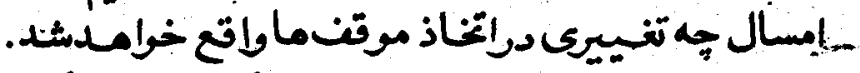

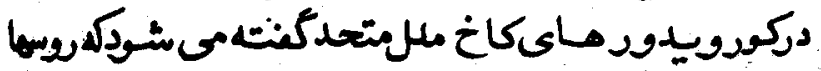

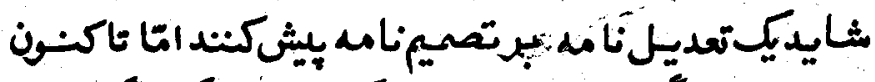

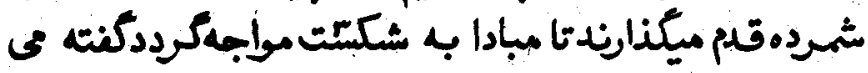




\section{ren}

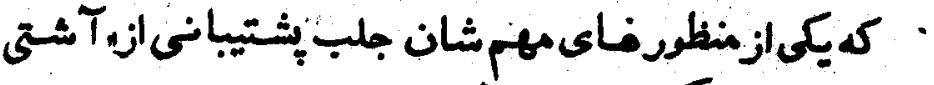

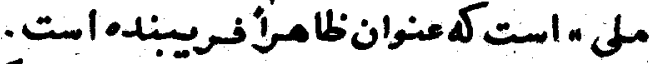

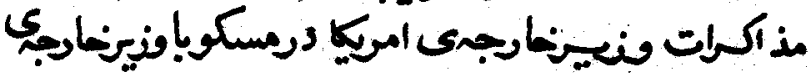

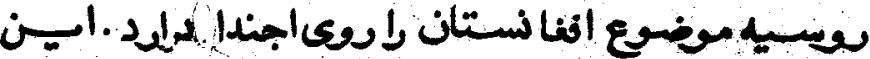

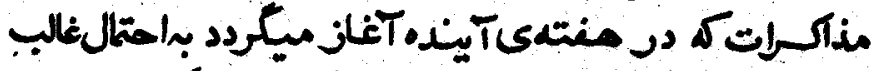

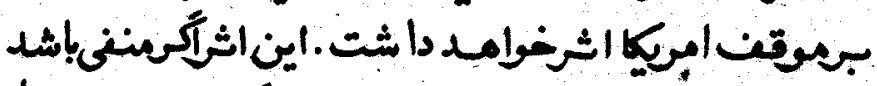

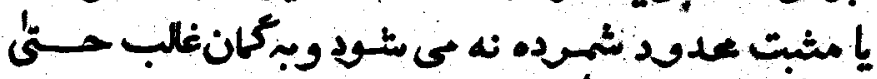

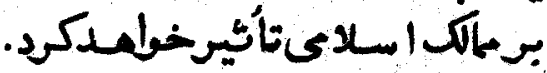

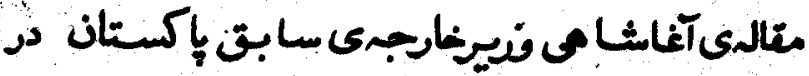

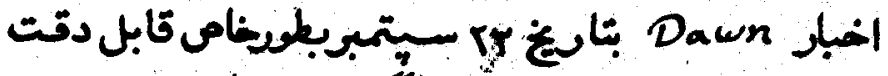

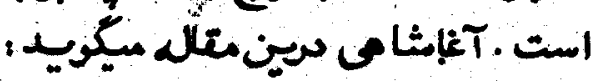

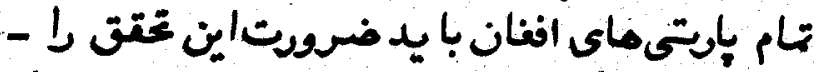

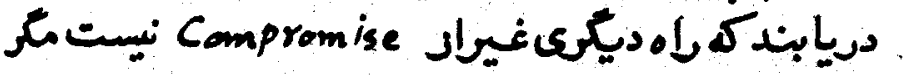

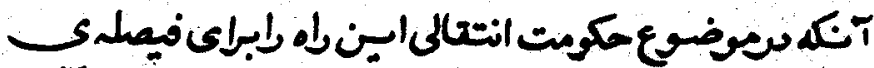

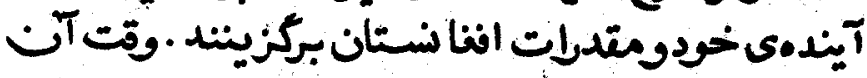

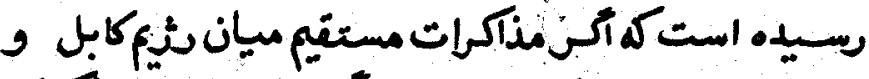

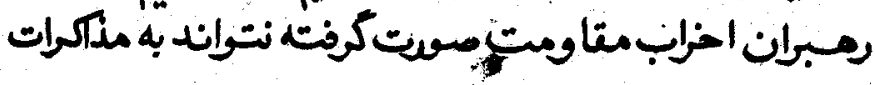

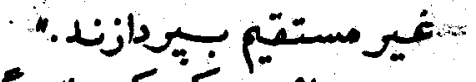

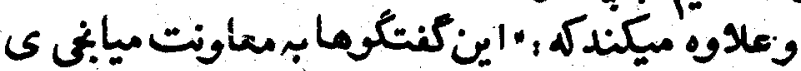

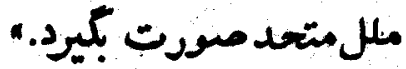

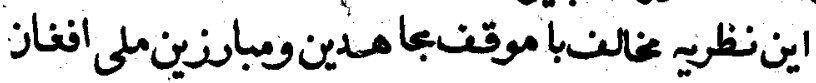


raq

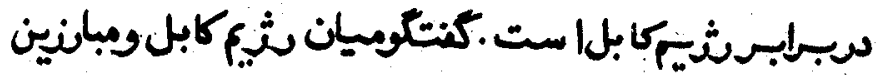

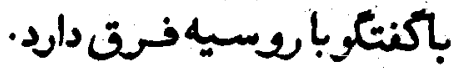

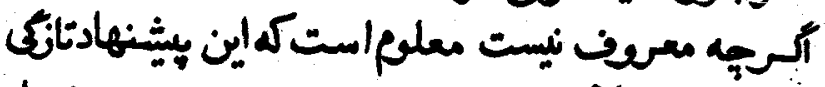

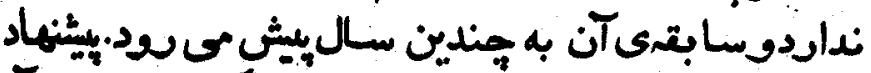

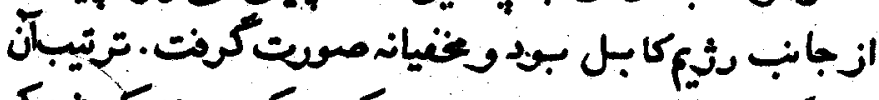

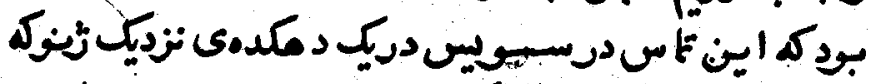

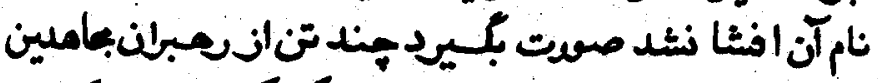

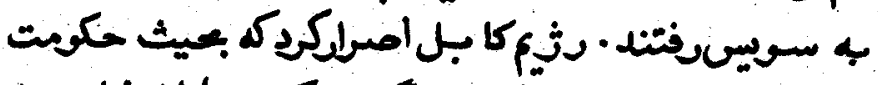

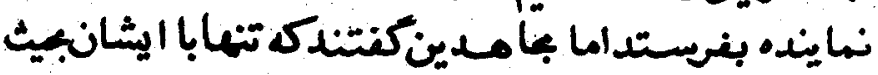

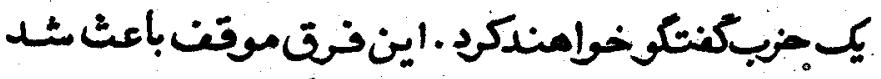

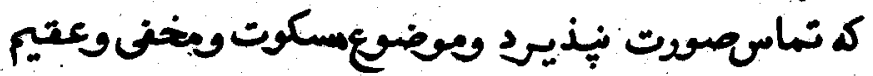

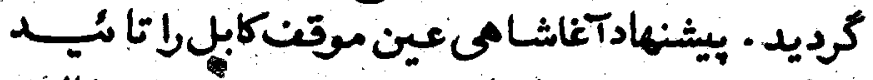

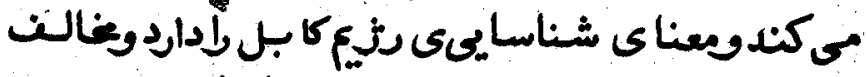

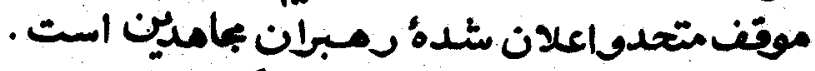

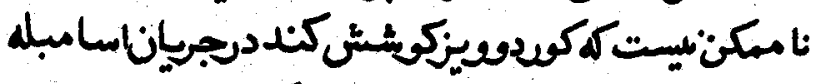

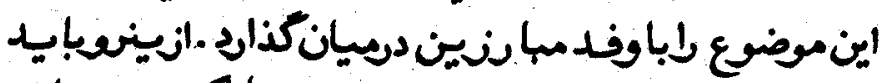

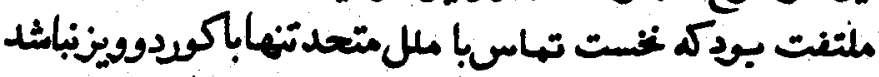

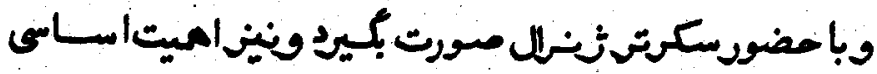

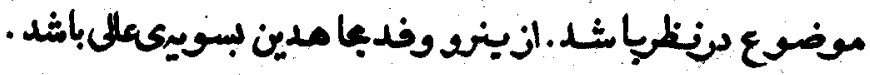

شمارة 9 سال بهارم بامدولسم

$1574 / 9 / 1$ 


\section{ياحتّ! \\ ثمامون موضوعانظانتمان دراسامبلئ rأ ملل متعد}

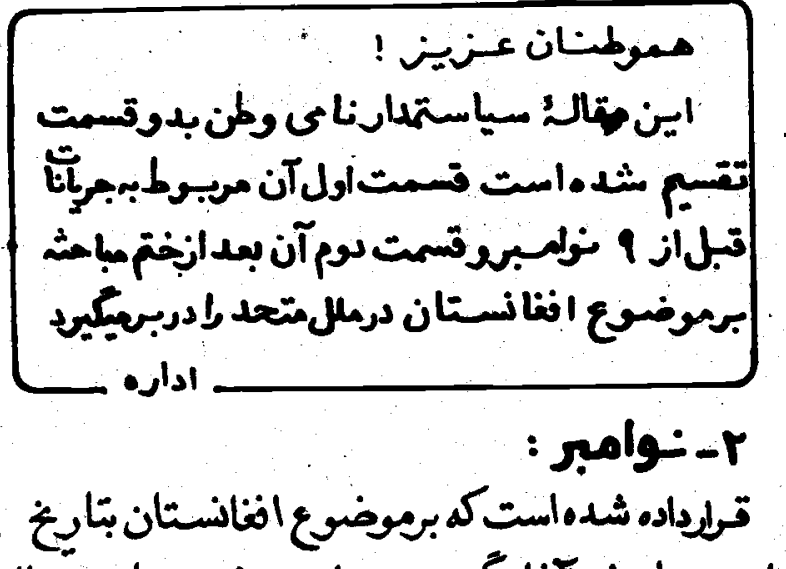

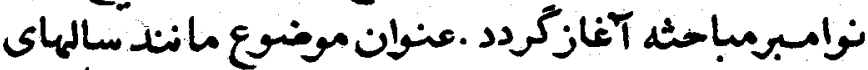

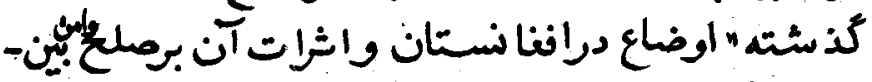

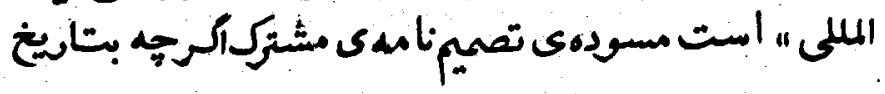




\section{rol}

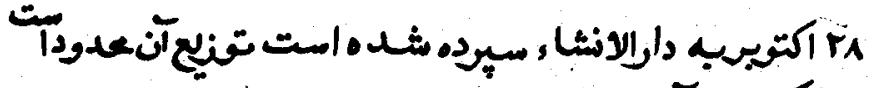

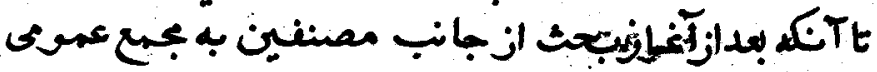
معرنى

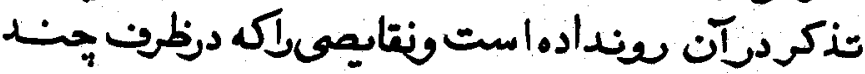

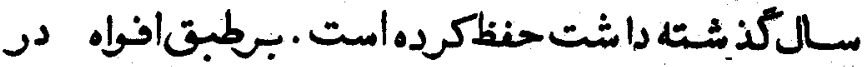

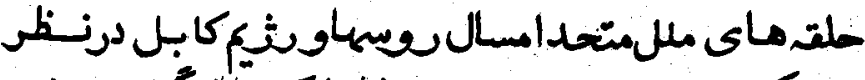

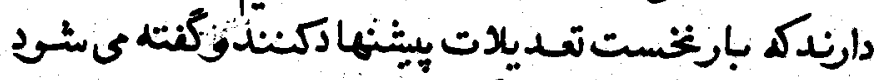

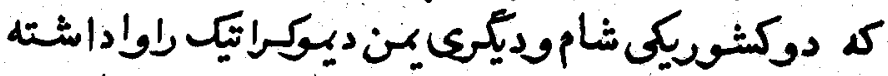

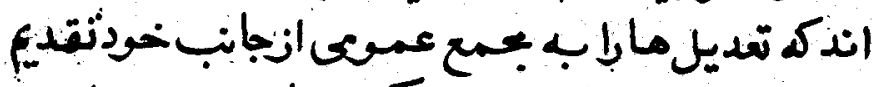

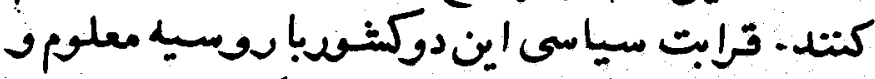

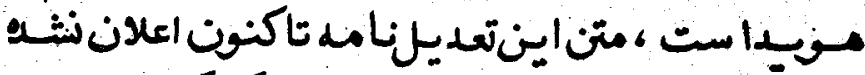

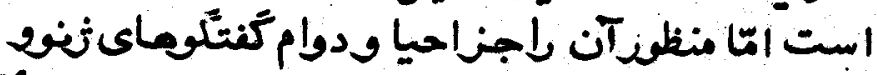

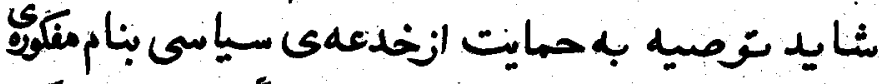

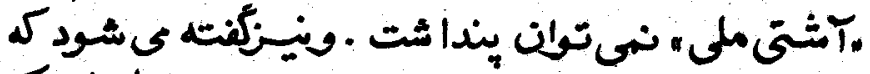

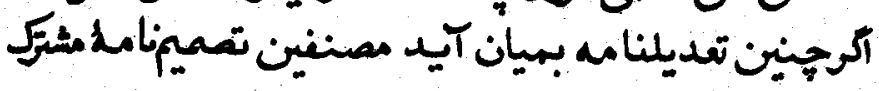
SubAmondment IAmondment

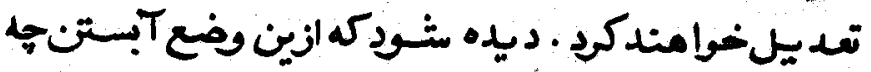

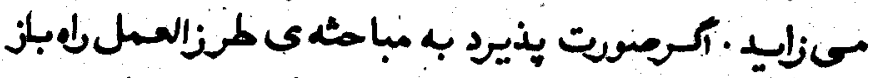

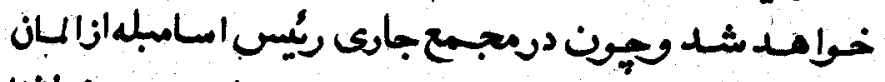

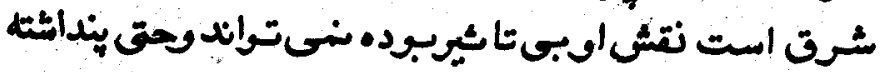

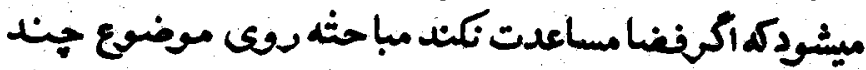




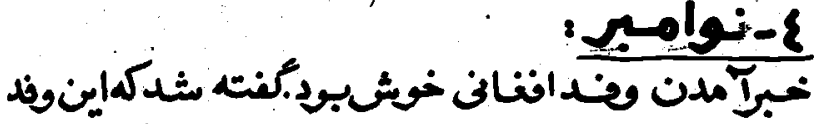

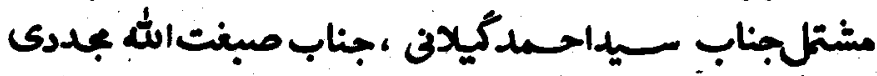

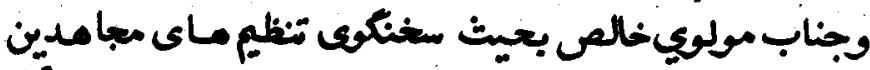

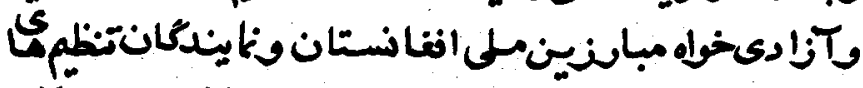

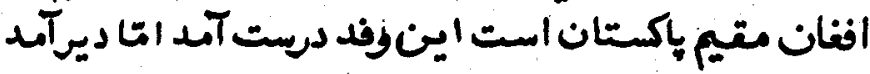

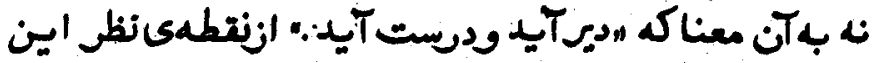

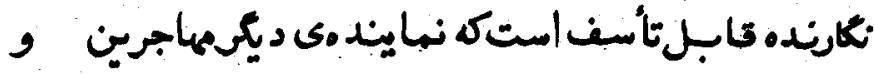

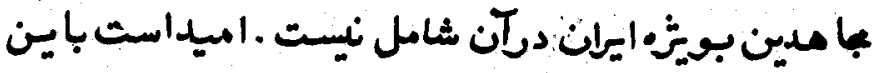

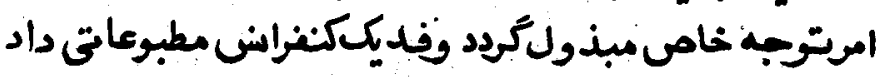

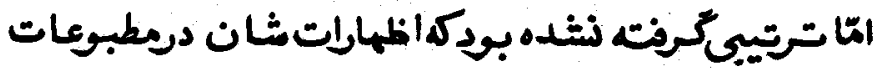

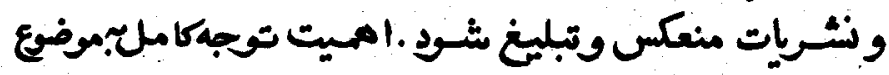
رإبط عامه Public Relation

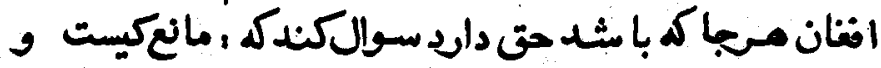

$$
\begin{aligned}
& \text { عايق جبيت ؟ }
\end{aligned}
$$

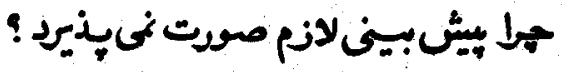

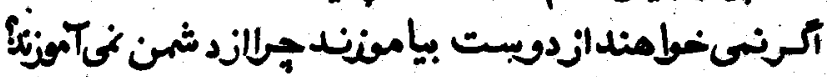

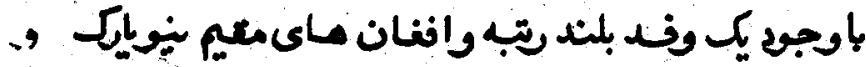

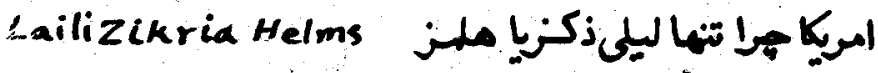

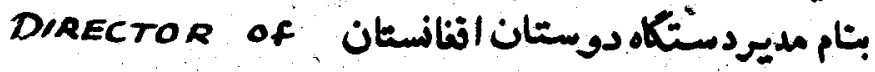




\section{ror}

if

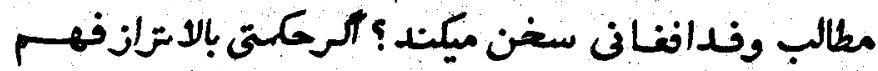

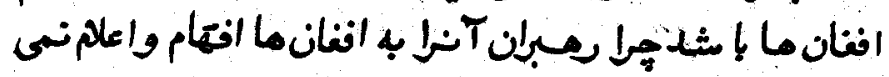

$$
\text { كنبل }
$$

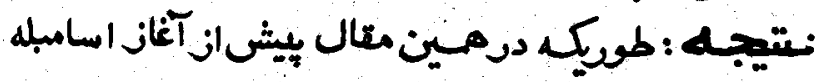

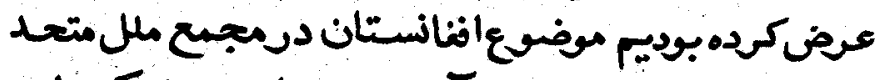

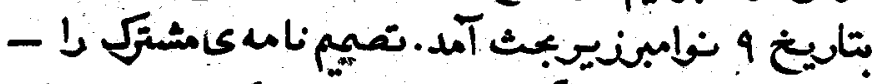

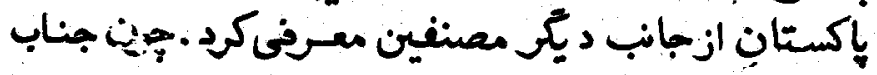

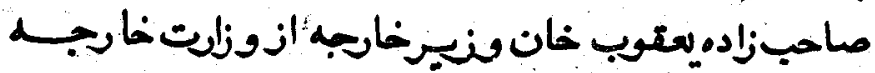

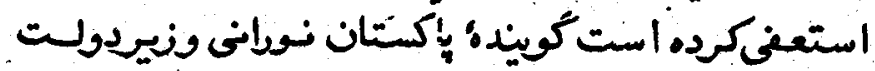

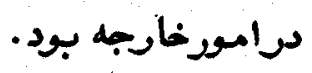

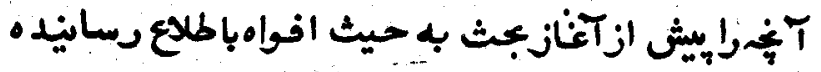

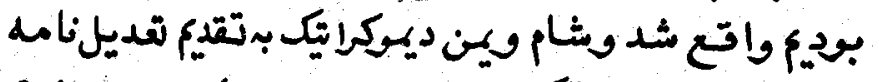

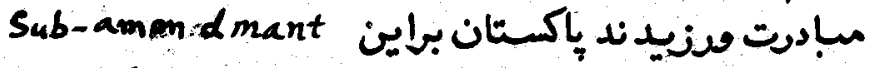

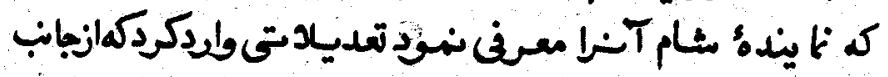

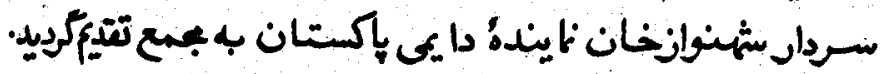

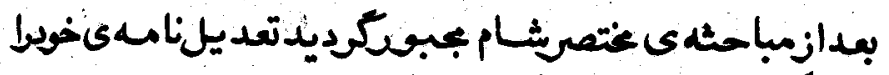

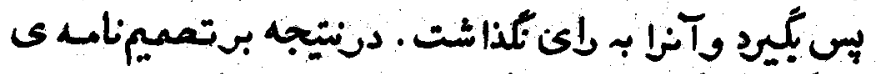

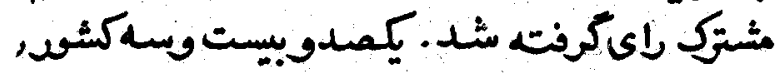

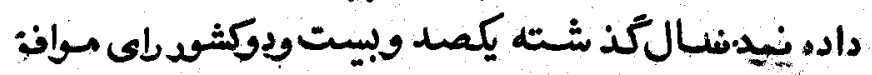




\section{rop}

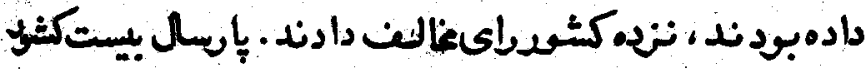

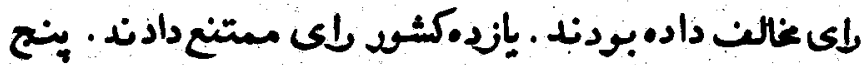

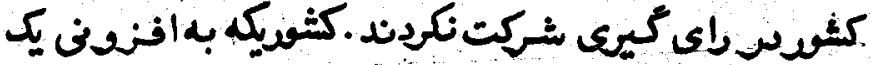

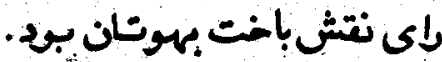

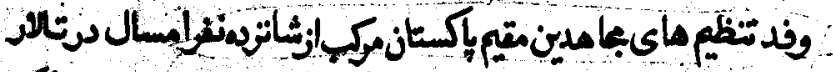

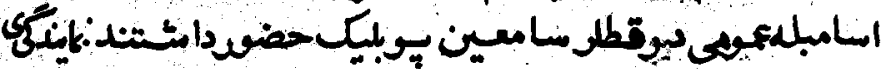

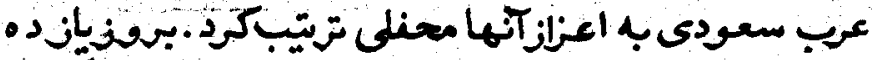

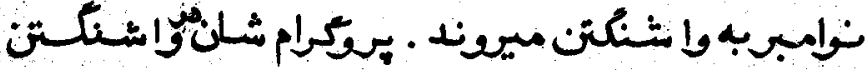

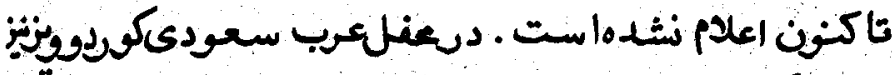

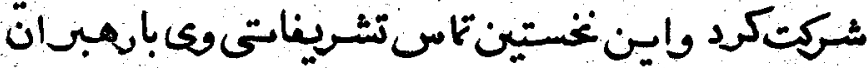

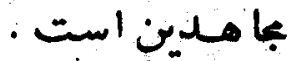

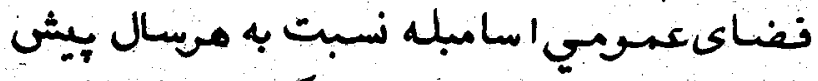

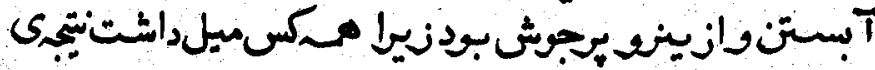

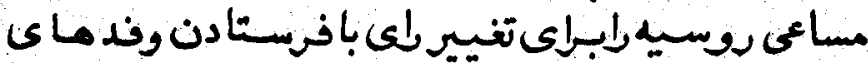

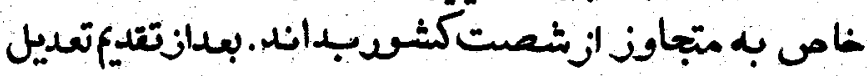

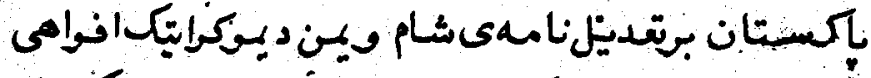

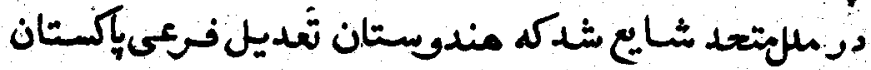

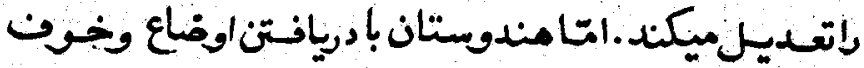
إنشكست مزيد عملفة اتدلم تكرد .

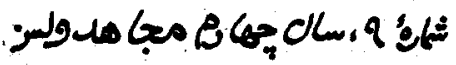

$$
\text { ir } 74 / 9 / 1
$$




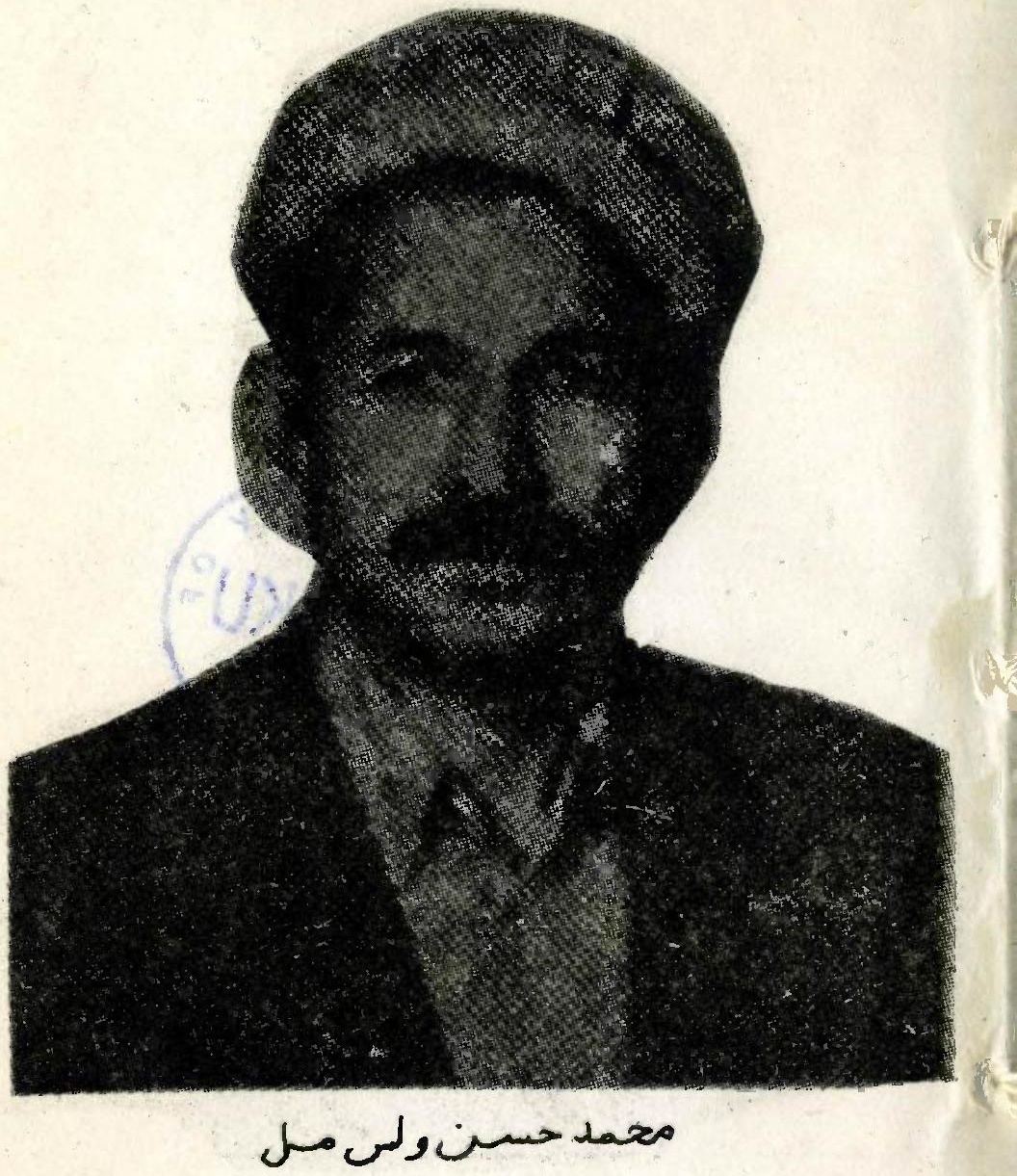




\section{Geneva Talks}

\section{Collection Of Assays Written}

by

A. R. PAZ W AK

\section{Compiler : M. H. Wolasmal}

Publisher: Afghan Mujahid Information Center 